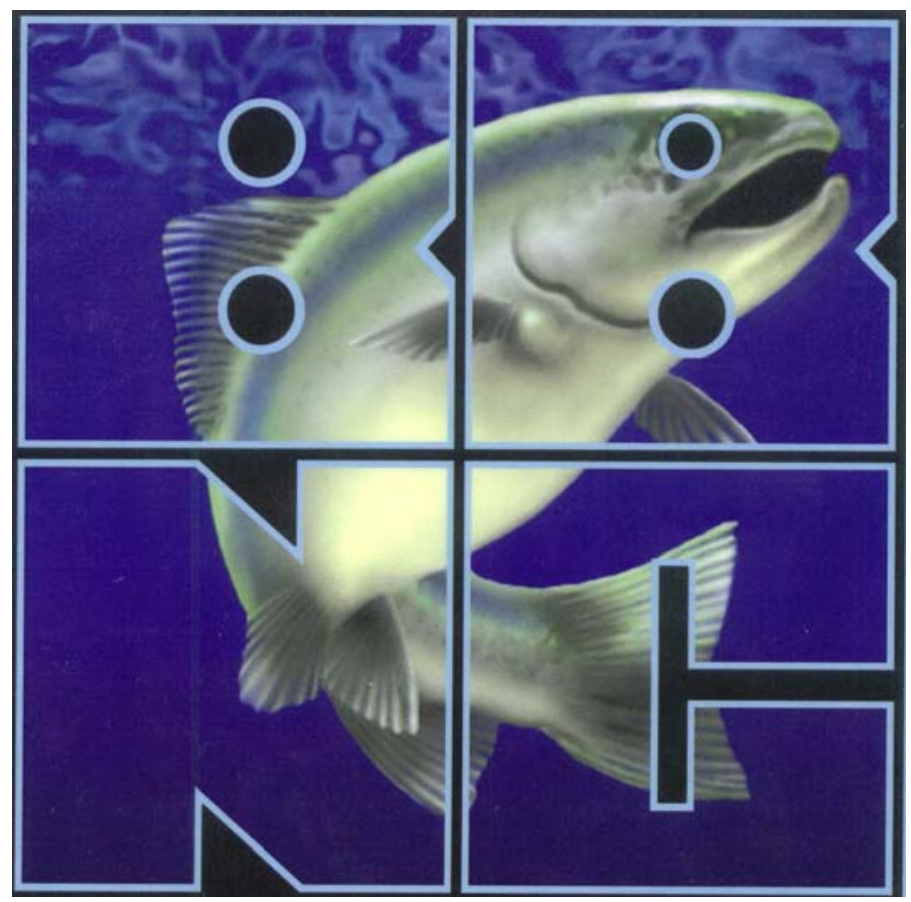

Final Project Report

\title{
Bristol Bay Native Corporation Wind and Hydroelectric Feasibility Study
}

Grant Number DE-FG36-03G013023, A000

Submitted to:

U.S. Department of Energy, Golden, Colorado, Field Office Tribal Energy Program

March 31, 2007

Bristol Bay Native Corporation

111 W. $16^{\text {th }}$ Avenue, Suite 400

Anchorage, Alaska 99501 


\section{Table of Contents}

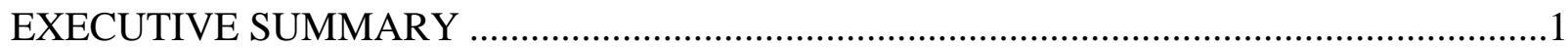

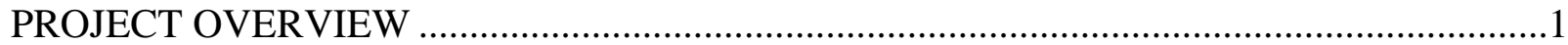

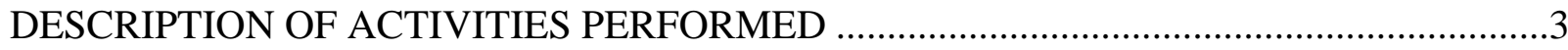

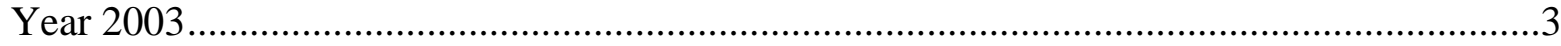

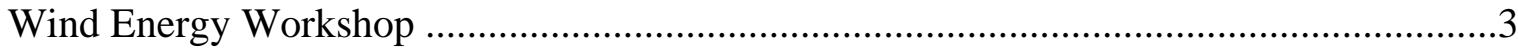

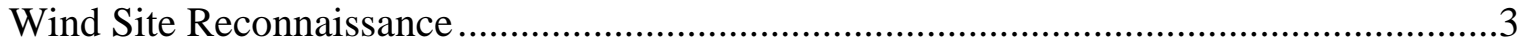

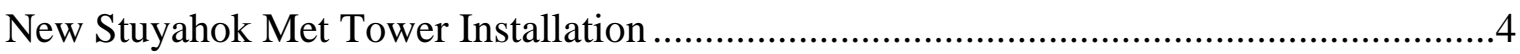

Tribal Energy Program (TEP) Review Meeting and Wind Energy

Applications and Training (WEATS) ........................................................................

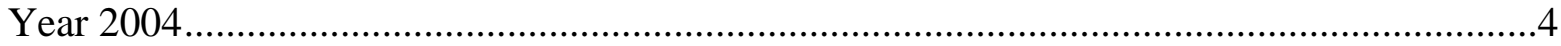

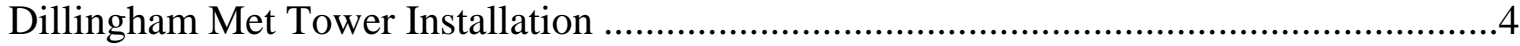

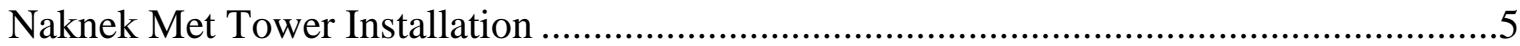

Kokhanok Met Tower Installation ...............................................................................

Alaska Peninsula Reconnaissance Flight ...................................................................

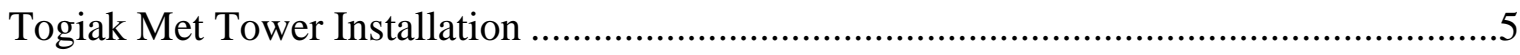

Chignik Lagoon and Perryville Met Tower Installations .............................................6

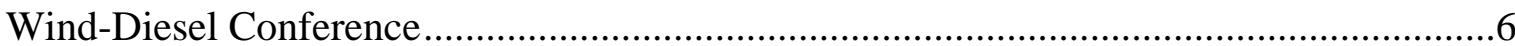

Tribal Energy Program Review Meeting.................................................................6

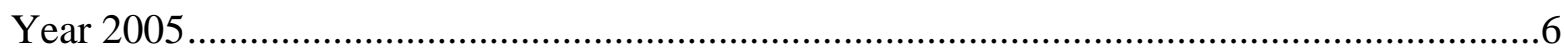

Clark’s Point Met Tower Installation .........................................................................6

New Stuyahok Met Tower Removal..........................................................................

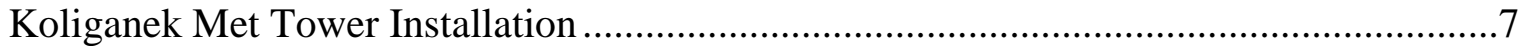

Dillingham - Kanakanak Met Tower Removal ...........................................................

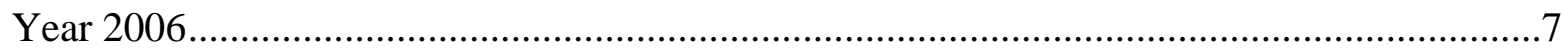

Naknek Electric Association Board Presentation .........................................................

Nushagak Electric Cooperative Board Presentation .....................................................

NEC, NEA, and Kokhanok Grant Proposals .................................................................

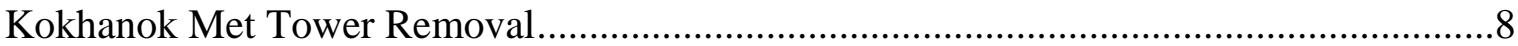

Clark’s Point and Koliganek Met Tower Removals .......................................................8

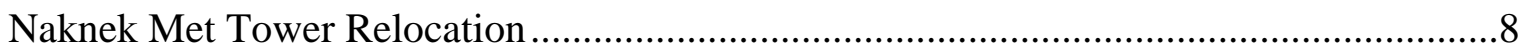

Tribal Energy Program Review Meeting....................................................................9 
Manokotak Site Preparation..................................................................................

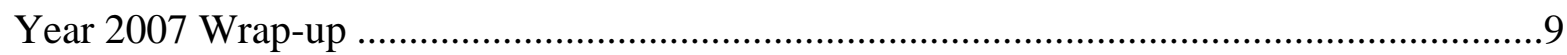

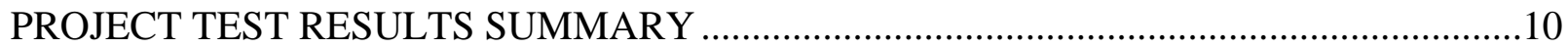

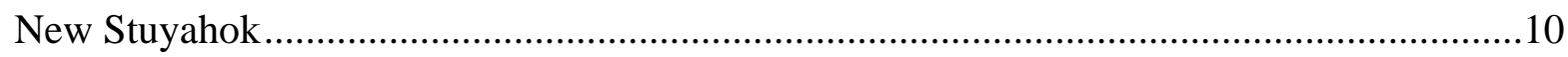

Dillingham Kanakanak ...........................................................................................12

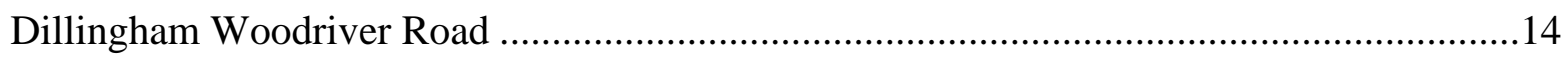

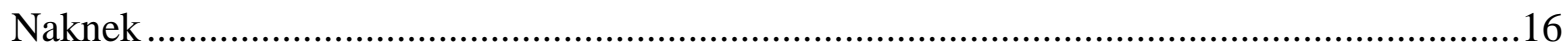

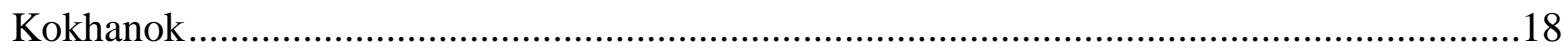

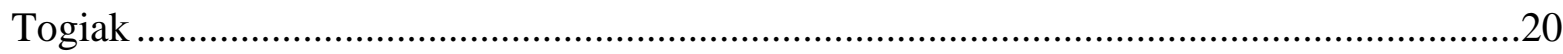

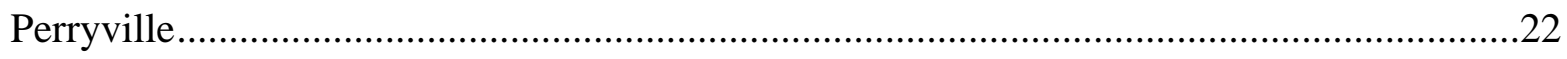

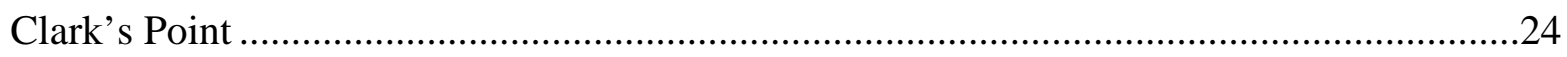

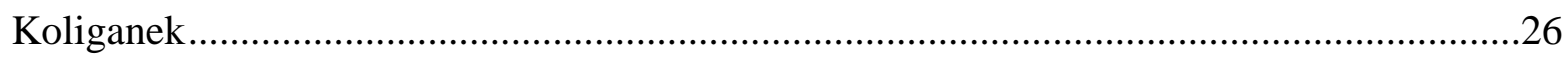

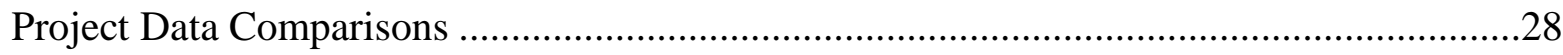

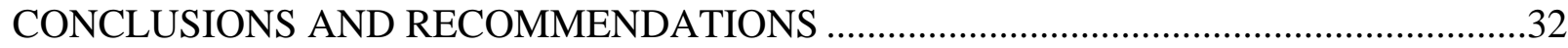

\section{Tables}

Table 1 New Stuyahok Summary Data..................................................................11

Table 2 Dillingham - Kanakanak Summary Data ....................................................13

Table 3 Dillingham - Woodriver Summary Data ........................................................15

Table 4 Naknek Summary Data ..........................................................................17

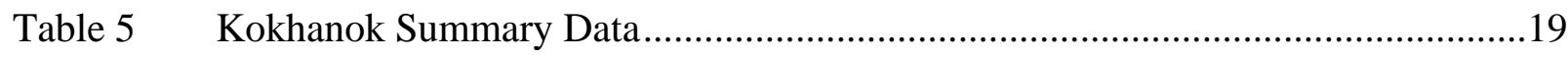

Table 6 Togiak Summary Data ................................................................................21

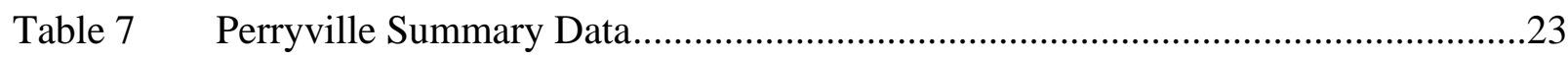

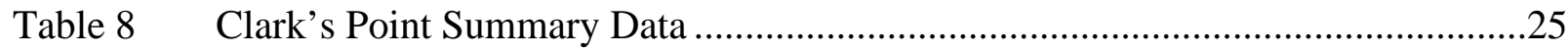

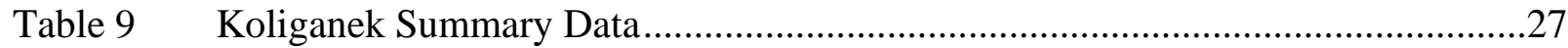

Table 10 50-meter Wind Power Density Site Comparison...............................................29

Table 11 30-meter Wind Power Density Site Comparison ...............................................30

Table 12 30-meter Average Annual Wind Speed Comparison..........................................31 


\section{Figures}

Figure $1 \quad$ Bristol Bay Regional Map of Alaska ................................................................

Figure $2 \quad$ Bristol Bay Village Map .............................................................................

Figure 3 New Stuyahok Seasonal Wind Speed Profile ......................................................12

Figure $4 \quad$ New Stuyahok Wind Power Density Rose .............................................................12

Figure 5 Dillingham - Kanakanak Seasonal Wind Speed Profile.......................................14

Figure 6 Dillingham - Kanakanak Wind Power Density Rose...........................................14

Figure $7 \quad$ Dillingham - Woodriver Seasonal Wind Speed Profile .......................................15

Figure 8 Dillingham - Woodriver Wind Power Density Rose ............................................16

Figure $9 \quad$ Naknek Seasonal Wind Speed Profile ..................................................................17

Figure $10 \quad$ Naknek Wind Power Density Rose......................................................................18

Figure 11 Kokhanok Seasonal Wind Speed Profile ………………….................................19

Figure 12 Kokhanok Wind Power Density Rose …………………………………….........20

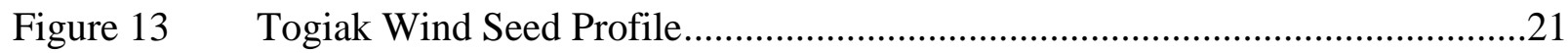

Figure 14 Togiak Wind Power Density Rose...................................................................2

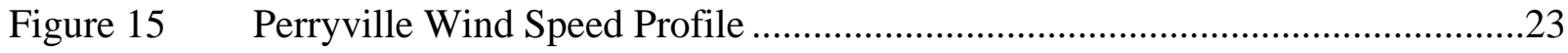

Figure 16 Perryville Wind Power Density Rose ………………….....................................24

Figure 17 Clark’s Point Wind Speed Profile........................................................................25

Figure 18 Clark’s Point Wind Power Density Rose.............................................................26

Figure 19 Koliganek Wind Speed Profile …………………….........................................27

Figure $20 \quad$ Koliganek Wind Power Density Rose ...............................................................28

\section{Appendices}

Appendix A Alaska Wind Resource Report: New Stuyahok

Appendix B Alaska Wind Resource Report: Dillingham - Kanakanak

Appendix C Alaska Wind Resource Report: Dillingham - Woodriver

Appendix D Alaska Wind Resource Report: Naknek

Appendix E Alaska Wind Resource Report: Kokhanok

Appendix F Alaska Wind Resource Report: Togiak

Appendix G Alaska Wind Resource Report: Perryville

Appendix H Alaska Wind Resource Report: Clark’s Point

Appendix I Alaska Wind Resource Report: Koliganek 


\section{Acronyms and Abbreviations}

$\begin{array}{ll}\text { AEA } & \text { Alaska Energy Authority } \\ \text { AVEC } & \text { Alaska Village Electric Cooperative } \\ \text { BBNA } & \text { Bristol Bay Native Association } \\ \text { BBNC } & \text { Bristol Bay Native Corporation } \\ \text { DOE } & \text { U.S. Department of Energy } \\ \text { ETS } & \text { Enterprise Technology Services } \\ \text { met tower } & \text { meteorological tower } \\ \text { NEA } & \text { Naknek Electric Association } \\ \text { NEC } & \text { Nushagak Electric Cooperative } \\ \text { NRG } & \text { NRG Systems, Inc. } \\ \text { NREL } & \text { National Renewable Energy Laboratory } \\ \text { NWTC } & \text { National Wind Technology Center } \\ \text { TEP } & \text { Tribal Energy Program } \\ \text { WEATS } & \text { Wind Energy Applications and Training }\end{array}$




\section{EXECUTIVE SUMMARY}

The Bristol Bay Native Corporation (BBNC) grant project focused on conducting nine wind resource studies in eight communities in the Bristol Bay region of southwest Alaska and was administered as a collaborative effort between BBNC, the Alaska Energy Authority, Alaska Village Electric Cooperative, Nushagak Electric Cooperative (NEC), Naknek Electric Association (NEA), and several individual village utilities in the region. BBNC's technical contact and the project manager for this study was Douglas Vaught, P.E., of V3 Energy, LLC, in Eagle River, Alaska.

The Bristol Bay region of Alaska (Figure 1) is comprised of 29 communities ranging in size from the hub community of Dillingham with a population of approximately 3,000 people, to a few Native Alaska villages that have a few tens of residents. Communities chosen for inclusion in this project were Dillingham, Naknek, Togiak, New Stuyahok, Kokhanok, Perryville, Clark's Point, and Koliganek. Selection criteria for conduction of wind resource assessments in these communities included population and commercial activity, utility interest, predicted Class 3 or better wind resource, absence of other sources of renewable energy, and geographical coverage of the region.

\section{Figure 1 Bristol Bay Regional Map of Alaska}

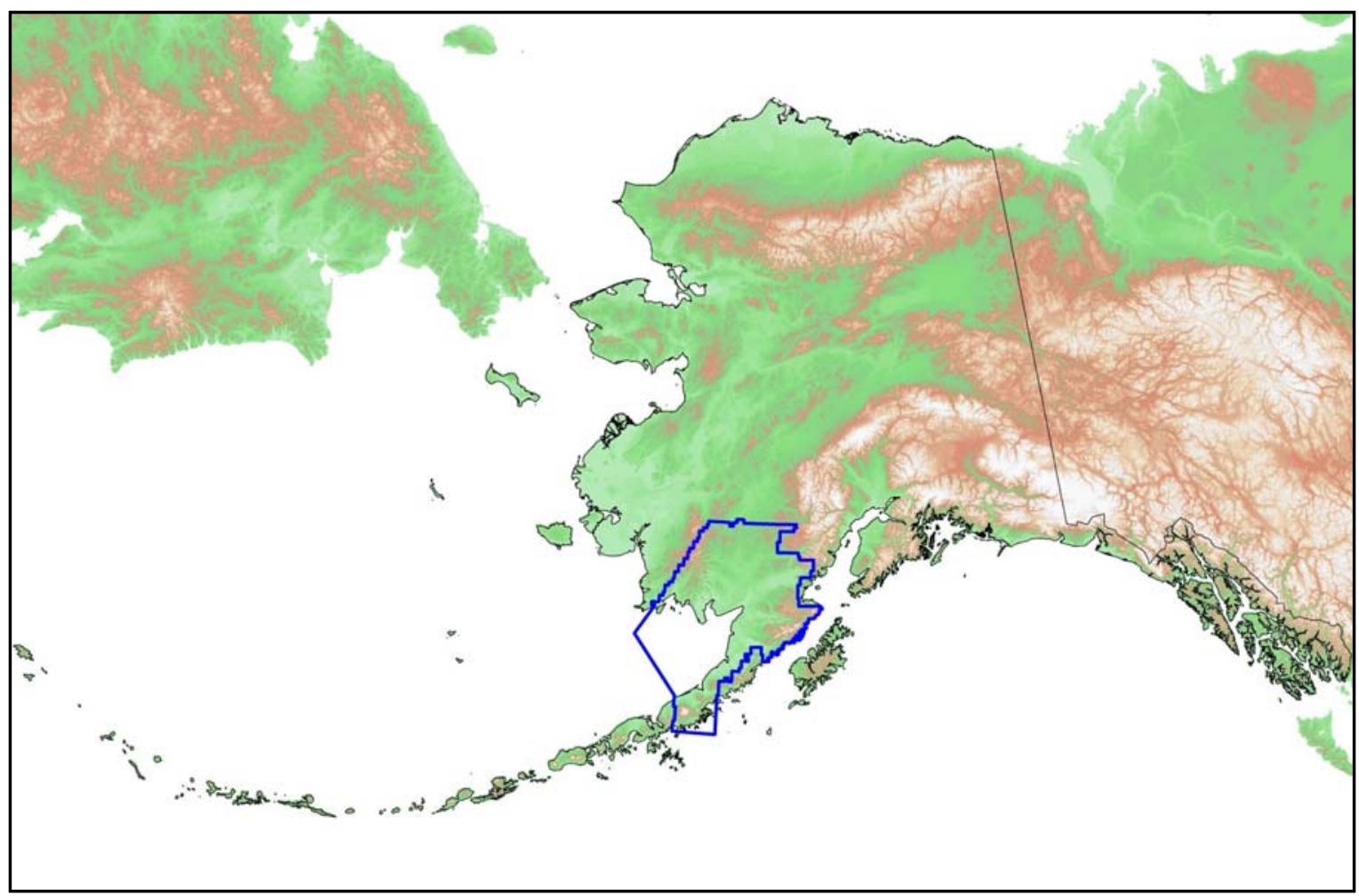


Beginning with the first meteorological tower installation in October 2003, wind resource studies were completed at all sites with at least one year, and as much as two and a half years, of data. In general, the study results are very promising for wind power development in the region with Class 6 winds measured in Kokhanok; Class 4 winds in New Stuyahok, Clark’s Point, and Koliganek; Class 3 winds in Dillingham, Naknek, and Togiak; and Class 2 winds in Perryville. Measured annual average wind speeds and wind power densities at the 30 meter level varied from a high of 7.87 meters per second and 702 watts per square meter in Kokhanok (Class 6 winds), to a low of 4.60 meters per second and 185 watts per square meter in Perryville (Class 2 winds). 


\section{PROJECT OVERVIEW}

This project was defined primarily by the installation of meteorological towers (met towers) and/or sensors on existing tower structures, and collection and analysis of wind data to support local utilities with wind power development efforts. Although there are 29 villages in the Bristol Bay region, we did not have the time, money, nor did we deem it necessary to attempt to instrument and study wind resources in each village. Instead we decided to focus on the two larger hub communities, Dillingham and Naknek, and then on smaller villages selected with consideration given to geographic spread, utility interest, potential for developable wind power, and community request (Figure 2).

\section{Figure 2 Bristol Bay Village Map}

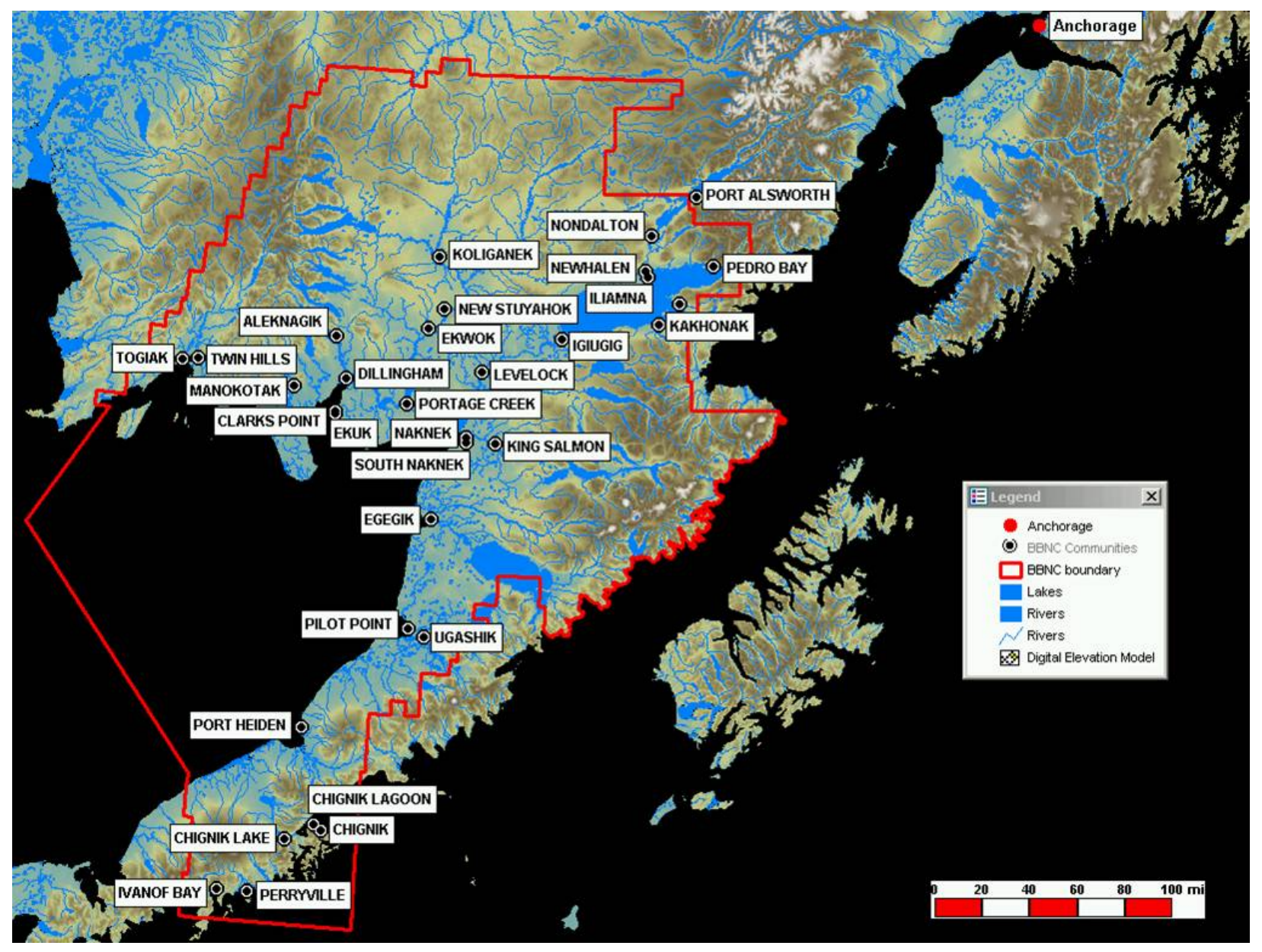

Because the U.S. Department of Energy (DOE) grant funds were insufficient to purchase transport and erect met towers for all nine communities (ten sites) eventually completed under this project, we accepted offers of collaboration from the Alaska Energy Authority (AEA) and Alaska Village Electric Cooperative (AVEC) to pool resources and money to enable more fieldwork to be accomplished than would have been possible had we stayed on our own. So, in a general sense, AEA purchased the met towers, paid for transportation from the manufacturer to Anchorage and on to the communities, and in some cases provided a state employee to assist 
with erection and dismantling efforts. AVEC provided labor assistance, personnel expenses and transport costs for equipment to its two villages within the region, while Bristol Bay Native Corporation (BBNC) provided project management, supervisory labor during field activities, and data management and analysis. The data activities and report formats were coordinated with the larger State of Alaska wind program efforts of AEA.

This project's objective, installation of met towers in several or more communities with a focus toward wind resource data collection and analysis, is different from the early project intent. When initially proposed, our thought had been more of a survey of renewable energy possibilities and a compilation of completed work for every village and community in the region. At the request of DOE and prior to award of the grant, we revised the objective of the grant to focus on the village of Perryville. The leadership of Perryville had expressed interest in alternative energy. Because of the village's location on the Alaska Peninsula, we thought it was a good candidate site for a project that would consist of a met tower installation and data study, preliminary wind-diesel system design, and financial study to support a business plan. However, after project award, but before commencing project activities, BBNC was approached by AEA with the proposal for a multi-village met tower installation effort as described above. Part of the AEA's rationale for their proposal was to maximize field effort and minimize paper studies; in other words, AEA felt that the Bristol Bay region, and Alaska in general, needed solid, highquality wind resource studies and this need far outweighed the need for another cost study. We agreed that this proposal had significant merit and decided we would like to refocus the project one last time along these lines. This new focus was discussed with DOE and the National Renewable Energy Laboratory (NREL), and approved for the project.

Understanding the change of objectives of this project helps explain why the title of our project, Bristol Bay Native Corporation Wind and Hydroelectric Feasibility Study, does not accurately describe the work we eventually accomplished. A wind and hydroelectric feasibility project was the objective of the original proposal, but as mentioned, the objective subsequently changed twice: first to a renewable energy feasibility and business plan project for the Native Village of Perryville, and lastly to a multi-village wind resource assessment effort in collaboration with AEA and AVEC. A better description of the final version of our project would have been "Bristol Bay Regional Wind Resource Assessment”, but the original title was never changed and hence has remained.

Besides the collaboration and labor and funding assistance from AEA and AVEC (for New Stuyahok and Togiak), BBNC hired Douglas Vaught, P.E., of V3 Energy, LLC, in Eagle River, Alaska, to manage the project, install and remove the met towers, and perform the data collection and data analysis tasks. Mr. Vaught, in part, appreciates the considerable assistance and technical advice of Mr. Reuben Loewen and Ms. Mia Devine of the AEA. BBNC also appreciates the assistance and contributory labor, equipment, supplies, and planning activities of Nushagak Electric Cooperative (NEC), Naknek Electric Association (NEA), and the villageowned utilities in Perryville, Kokhanok, Clark’s Point, and Koliganek. 


\section{DESCRIPTION OF ACTIVITIES PERFORMED}

This grant project lasted much longer than originally anticipated. It was awarded in September 2003 and originally planned to be complete in December 2004, although the original completion date had been based on an earlier award date. Because of the change of project objectives to a multi-village wind resource assessment and the time requirements necessary to accomplish so much work over a large geographic area, two 1-year extensions were requested and approved, resulting in a project end date of December 2006.

In an effort to describe what happened and when, a chronological summary is presented below to note significant project field events. In addition to those events noted below, data collection and analysis were ongoing efforts throughout the project. Because village wind power is a small niche market, at the beginning of the project there was no analysis software package geared toward small wind. The large and well-known software tools were too expensive and unnecessarily sophisticated for village power applications; through experience we found that analysis using Microsoft ${ }^{\circledR}$ Excel worked, but was tedious and difficult to standardize among all the sites. The solution to our problem came with the development and release of the Windographer Software Program by Tom Lambert, owner of Mistaya Engineering, Inc., in Calgary, Alberta, Canada. We have used the Windographer software for the past two years from the very first release to the latest version with its quite comprehensive capabilities. All analyses and graphics in the Wind Resource Reports in the appendices were produced with the use of Windographer.

\section{YEAR 2003}

\section{Wind Energy Workshop}

Several significant project activities occurred immediately after BBNC was awarded the grant in September 2003. First was project funding support for and attendance at a Wind Energy Workshop in Dillingham in early October 2003. This workshop was sponsored by AEA as a kick-off to the State's wind resource assessment project (with which BBNC had recently decided to collaborate). Participants included a large number of Alaskans involved with rural utilities and representatives from NREL and their consultants, equipment suppliers, regional organizations and interested citizens. This two-day project, held at the community Fire Hall and Bristol Bay Native Association (BBNA) property consisted of a number of lectures and presentations on many aspects of rural wind power, and during the final day included a demonstration sensor assembly and mounting, datalogger installation, and erection and lowering of one of AEA's new 30-meter NRG Systems, Inc., (NRG) met towers on the BBNA land.

\section{Wind Site Reconnaissance}

The workshop was followed immediately by a charter reconnaissance flight to investigate potential wind power/met tower locations in the Dillingham area, and in the village of Togiak. Togiak is an AVEC village and AVEC had expressed a desire to install a met tower as soon as possible to begin collecting data to support a possible wind-diesel power plant design that they are considering. This flight included Doug Vaught; John Wade; NREL's wind consultant from Portland, Oregon; Karen Kronner, an avian specialist from Pendleton, Oregon; and three AVEC 
employees - Brent Petrie, Eric Marchegiani, and Marie Becker. A number of potential met tower locations were selected as good possibilities for wind power development.

\section{New Stuyahok Met Tower Installation}

The day after the reconnaissance flight, Doug Vaught, Eli Reich of Global Energy Concepts of Seattle, and Eric Marchegiani and Marie Becker of AVEC, traveled to New Stuyahok (the second AVEC village in the region) with the 30-meter NRG met tower used for the demonstration in the Wind Energy Workshop and the intent to install it at a site previously selected and approved by AVEC as a possible site for wind turbine installation during a power plant upgrade project being planned. With the assistance of a power plant operator and a few interested residents and school students, the tower was erected in a one-day effort and began collecting data for the project's first field effort.

\section{Tribal Energy Program (TEP) Review Meeting and Wind Energy Applications and Training (WEATS)}

In mid-October Doug Vaught of V3 Energy, LLC, and April Ferguson of BBNC attended the week-long TEP Review Meeting in Colorado where they presented our planned project. In late October, Mr. Vaught returned to Colorado to attend the five-day Wind Energy Application and Training (WEATS) at the National Wind Technology Center (NWTC) in Boulder, Colorado. WEATS was a great introduction not only to the basics of wind energy and wind resource testing, but also a very worthwhile tour of the NWTC and also provided a great opportunity to spend time with NREL staff discussing how best to proceed with the wind analysis project.

\section{YEAR 2004}

\section{Dillingham Met Tower Installation}

The first field effort of the year occurred in April when Doug Vaught traveled to Dillingham for two days to erect a 30-meter met tower (owned by the AEA wind energy program) on Choggiung Ltd. (a local Native corporation) land near the Kanakanak Hospital. BBNC paid Choggiung Ltd. a nominal fee for this purpose. This site was selected during the previous October reconnaissance flight because of the relatively open nature of the terrain in an otherwise heavily forested community, easy road access, proximity to power lines, and uncomplicated land ownership. Mr. Vaught was assisted by James Thames, the NEC Operations Manager, and several of his line crew. Because of the excellent assistance of NEC, this installation occurred very quickly.

The following day, Mr. Vaught worked with Mr. Thames and a line crewman to install anemometers and a wind vane on the approximately 130-foot-tall State of Alaska Department of Administration Enterprise Technology Services (ETS) communications tower on a prominent knoll on Woodriver Road. A memorandum of understanding was signed between the State of Alaska, ETS, and BBNC to install our meteorological monitoring equipment on their tower. Although a lattice tower of this nature is not an ideal measurement platform by any means, the State made it available to BBNC and NEC, and we elected to install sensors and monitor at this site. The alternative would have been no monitoring at this location, as a second met tower was 
not available in Dillingham at the time. The labor and expense assistance from NEC were a welcome contribution to this project and were not charged to the grant.

\section{Naknek Met Tower Installation}

In mid-July Doug Vaught traveled to Naknek for two days to install an AEA-provided 30-meter met tower at a site near the borough landfill. This site was one of two in Naknek identified as desirable for potential wind power development by meteorologist John Wade and Larry Flowers of NREL in October 2003. The landfill site is situated on a hill with excellent wind exposure in all directions, but particularly to the northeast which is the direction of winter prevailing winds. Mel Coghill, NEA's Operations Manager, and several of his crew provided vehicles and equipment and assisted with the tower installation. As with NEC in Dillingham, the NEA labor and expenses were a welcome contribution to this project and were not charged to the grant.

\section{Kokhanok Met Tower Installation}

In mid-August Doug Vaught traveled to Kokhanok on the south shore of Lake Iliamna to install another AEA-provided 30-meter met tower. Site selection for Kokhanok had begun earlier in the summer with reviews of Alaska Department of Community and Economic Development maps and discussions with village representatives. A site of superior potential was chosen. It is located near the end of a natural spit of land that juts north into the Lake. This is the location of the former village airstrip, which was moved a number of years ago to a calmer location because of strong winds on the spit. Indications from local residents were that it is frequently very windy at the site and too windy for any future residential or commercial use. The local plant operator and his assistant assisted Mr. Vaught with the tower installation.

\section{Alaska Peninsula Reconnaissance Flight}

In early August, Doug Vaught accompanied Reuben Loewen, AEA wind program manager, and meteorologist John Wade on a reconnaissance flight to the Alaska Peninsula to scout wind development locations. The villages of Port Heiden, Chignik Bay, and Chignik Lagoon were investigated. This flight was paid for by the AEA as part of their efforts to develop wind power in rural Alaska. While on the ground in Port Heiden, Doug, Reuben, and John assisted Scott Anderson of Port Heiden with a non-functional datalogger mounted on a 10 kilowatt Bergey turbine that the community had installed. At that time, AEA was interested in installing a fullscale wind-diesel system in Port Heiden; however, that plan has been postponed indefinitely.

Note: At one point it was our intent to add the analysis of wind resources in Port Heiden to our project, but because AEA was working so closely with the community and writing their own wind resource assessment, we decided that it would be redundant. AEA's Port Heiden analysis is available on AEA's wind program website.

\section{Togiak Met Tower Installation}

In late August, Doug Vaught traveled to Togiak and, with the assistance of the power plant operator and a local man hired for this effort, installed the 30-meter NRG tall tower in Togiak that had been stored at the power plant since the previous autumn. Because Togiak is an AVEC community, AVEC and AEA (owner of the met tower) paid most of the expenses for this tower 
installation. Togiak is an important and relatively large Bristol Bay region village, and BBNC supported plans to development wind power there in an effort to lower electrical costs and help spur economic development.

\section{Chignik Lagoon and Perryville Met Tower Installations}

In early October Doug Vaught, traveled with Reuben Loewen, AEA's Wind Energy Program Manager, to the lower Alaska Peninsula to install wind sensors in Chignik Lagoon and a met tower in Perryville. In Chignik Lagoon, an anemometer, wind vane, and temperature sensor were installed on an existing 60-foot tower that supports an out-of-commission Jacobs wind turbine installed approximately 20 years ago. This turbine is on private land and landowner permission was obtained.

The following day, Doug Vaught and Reuben Loewen flew with an NRG 30-meter tower package on a chartered flight from King Salmon to Perryville. Perryville is an isolated but picturesque native village on the south shore of the Alaska Peninsula. Two men from the community assisted with the installation of the tower on a village-owned site just inland of the shoreline barrier sand dunes and near the village power plant.

\section{Wind-Diesel Conference}

Doug Vaught and Tiel Smith, BBNC’s Land and Resources Manager, attended the NRELsponsored International Wind-Diesel conference in Girdwood, Alaska, September 28 through October 2, 2004. Tiel Smith attended only the Girdwood workshop portion; however, Doug Vaught also participated in a conference field trip on October 1 and 2 to inspect and observe wind-diesel power systems in St. Paul, Kotzebue, and Selawik, Alaska. The trip included an overnight stay in Kotzebue.

\section{Tribal Energy Program Review Meeting}

In mid-October, Tiel Smith and Doug Vaught attended the Tribal Energy Program Review Meeting in Golden, Colorado. Tiel and Doug presented a progress report of the BBNC renewable energy grant project to the meeting attendees.

\section{YEAR 2005}

\section{Clark’s Point Met Tower Installation}

In early July, Doug Vaught traveled with Mia Devine, the AEA assistant program manager, and two AEA summer university student interns, Hannah Manser from the University of Alaska Anchorage and Zachary Adam from the University of Washington, to Clark's Point to for a day and a half visit to install an AEA-owned 30-meter met tower (note that AEA also paid for transport of the tower to Clark's Point) on a site near a bluff overlooking Bristol Bay. The site was chosen because it is relatively near the power plant and existing power lines; it is on property controlled by the city, but it is not too close to existing homes and is reasonably far from the airport. 


\section{New Stuyahok Met Tower Removal}

After the Clark’s Point met tower installation, Doug, Mia, Hannah, and Zach flew to New Stuyahok for the night. On the following day, with the assistance of the local power plant operator, they lowered the 30-meter met tower that had been collecting data since October 2003 and packaged it for transport.

\section{Koliganek Met Tower Installation}

Following removal of the New Stuyahok met tower, an aircraft was chartered at AEA's expense, as part of their wind-monitoring program, to fly the tower and Doug to Koliganek. Mia, Hannah, and Zach flew to Koliganek on scheduled flights via Dillingham. The initial selected site in Koliganek proved to be unsatisfactory because of the presence of permafrost soils which had not been anticipated, and for which appropriate anchors had not been purchased. After discussion with a village council representative, an alternate site on an abandoned airstrip was selected. This new site is clearly superior in that the soils are stable and future wind power development would be relatively easy with respect to better access and easier foundation issues.

\section{Dillingham - Kanakanak Met Tower Removal}

In early October, Doug Vaught returned to Dillingham to remove the met tower installed in April 2005. He was assisted once again by James Thames, NEC's Operations Manager, and a member of his crew. Because the met tower is owned by AEA, arrangements were made to transport it by air freight to Anchorage for use elsewhere in the State.

\section{YEAR 2006}

\section{Naknek Electric Association Board Presentation}

In late January, Doug Vaught and Reuben Loewen of AEA traveled to Naknek to present a synopsis of the wind resource data collected in Naknek since July 2004 and a general discussion of the wind power development process to the NEA board of directors. The presentation was during NEA's monthly board meeting. There was strong board interest in the possibility of wind power for the utility, given the high and increasing cost of diesel fuel in the region.

\section{Nushagak Electric Cooperative Board Presentation}

As he had done in Naknek the previous month, Doug Vaught traveled to Dillingham in late February to present a synopsis of Dillingham's wind resource and information regarding wind power development to the NEC board of directors. The presentation was during the monthly board meeting, but in this case the audience also included several local residents and a reporter for KDLG, Dillingham's public radio affiliate. After the presentation, Doug was interviewed by the KDLG reporter and that interview was broadcast statewide on the following day on the Alaska Public Radio Network. 


\section{NEC, NEA, and Kokhanok Grant Proposals}

During February and March, Doug Vaught assisted NEA, NEC, and Kokhanok Village Council Utility with preparing the wind resource assessments and other information for grant proposals in response to Requests for Proposal offered by the AEA for rural communities in Alaska to develop wind power. The purpose of the grant was to lessen rural Alaska's dependence on fossil fuel for electric power generation. In the case of Kokhanok, this proposal was written with the assistance of Dennis Meiners of Powercorp Alaska, LLC. Tom Hawkins, Tiel Smith, and April Ferguson of BBNC also assisted with this effort by working with individuals in the communities to obtain and organize information needed for the grant applications. Although AEA awarded their grant to a community not in the Bristol Bay region, this effort helped the three utilities plan for eventual wind power projects.

\section{Kokhanok Met Tower Removal}

In mid-June, Doug Vaught traveled to Kokhanok with Reuben Loewen of AEA and Dennis Meiners of Powercorp Alaska, LLC, to remove the met tower installed two years previous and return it to Anchorage. They were assisted by the power plant operator and another man from the village. Dennis accompanied Doug and Reuben at his expense in order to get a better understanding of Kokhanok's layout and electrical power infrastructure, and the logistical issues involved should a wind-diesel power project involving Powercorp ever be constructed in Kokhanok.

\section{Clark's Point and Koliganek Met Tower Removals}

In early July, Doug Vaught traveled with Mia Devine of AEA to Clark’s Point and Koliganek to remove the met towers installed the previous July and return them to Anchorage via Dillingham. Also during this trip, Doug and Mia removed the datalogger from the State ETS tower on Woodriver Road in Dillingham; NEC personnel later removed the anemometers and wind vane from the tower.

\section{Naknek Met Tower Relocation}

In mid-July, Doug Vaught traveled to Naknek to relocate the 30-meter met tower installed at the borough landfill two years prior. Despite its proximity to existing power lines and its location between the major load centers of Naknek and King Salmon, NEA decided that the landfill location was not really a desirable site for a wind power project. Apparently, the borough has intentions to expand the landfill toward the direction of the met tower placement. A less significant issue was the problems associated with large numbers of brown bears in the area and their attraction to the landfill; this was seen as an undesirable nuisance issue for construction and operation of wind turbines.

Instead of considering the second site selected by John Wade and Larry Flowers in 2003 (later deemed by NEA as too close to a small aircraft airfield), NEA preferred to move the met tower to their new preferred wind power project location closer to Naknek itself, and also closer to Naknek Bay where the winds are perceived to be stronger. Doug Vaught was assisted with this two-day effort to move the met tower by a NEA line crew. With the termination of this grant 
project, NEA has accepted responsibility for data analysis and the eventual removal of the met tower from this site.

\section{Tribal Energy Program Review Meeting}

In October, Tiel Smith and Doug Vaught attended the Tribal Energy Program Review Meeting in Golden, Colorado. Tiel and Doug presented their final progress report to DOE and other tribal participants of the BBNC renewable energy grant project.

\section{Manokotak Site Preparation}

The leadership in the village of Manokotak, approximately midway between Dillingham and Togiak but not connected by road to either, had expressed strong interest throughout the grant project for a wind resource assessment, but the constraints of money, time, and met tower availability prevented it. To assist Manokotak, BBNC helped the village select and permit a site for a met tower in late autumn. At BBNC's expense this spring or summer, our intention is to erect a met tower in Manokotak and conduct a wind resource study for them.

\section{YEAR 2007 WRAP-UP}

A few field-related tasks were not fully complete at the end of the grant project period in December 31, 2006. These tasks include the met tower in Togiak, the met tower in Perryville, and the datalogger and instrumentation in Chignik Lagoon. AVEC has stated that they plan to remove the Togiak met tower in spring and make it available for use in Manokotak. The met tower in Perryville is still in place and the instrumentation in Chignik Lagoon is still attached to the old, inoperative Jacobs wind turbine. This situation will be discussed with AEA and it is anticipated that they will arrange for removal of this equipment in Perryville and Chignik Lagoon using their wind program funds. 


\section{PROJECT TEST RESULTS SUMMARY}

Dillingham is the largest community in the Bristol Bay region, with approximately 2,300 residents. It, along with Naknek/King Salmon, are hub communities with a concentration of industry and services not typically found in the smaller outlying villages. Our intent at the beginning of this project was to concentrate initially on Dillingham and Naknek with the philosophy that helping to solve the problems of high energy costs in the Bristol Bay hub communities would have a ripple effect that would indirectly benefit the smaller villages as well. With this in mind, early on in the project we worked with NEC in Dillingham and NEA in Naknek to identify sites and secure permits and landowner permission to install met towers.

Once the Dillingham and Naknek met towers were installed and wind resource studies started, we devoted more attention to planning which villages in the region we wanted to concentrate on. The AVEC villages of New Stuyahok and Togiak were pre-selected in a sense that before this grant was even awarded, AVEC had expressed the desire for AEA to install State met towers in the two villages. After award of this grant and the initiation of the collaboration model of work, New Stuyahok and Togiak were an immediate focus of attention.

The other villages eventually chosen for wind resource studies were, for the most part, selected in 2004 by a combination of geographic representation, anticipated likelihood of a developable wind resource, and expression of community interest. Several communities in the Bristol Bay region already had wind resource studies completed or underway either by an interest group in the case of Sustainable Energy Coalition for the Alaska Peninsula for Port Heiden and Pilot Station, or Chignik which was pursuing grant funding for a met tower through another agency. For one group of three villages in the region - Iliamna, Nondalton, and Newhalen - a combination of a low predicted wind resource and reliance on a very good hydroelectric power supply led us to look elsewhere for villages to conduct wind resource assessments. Eventually we installed met towers or instrumentation and conducted wind resource studies in the nonAVEC villages of Kokhanok, Perryville, Chignik Lagoon, Clark's Point, and Koliganek. The wind study efforts were successful in all locations, except Chignik Lagoon where a loss of contact with the responsible person in the village and then eventual recovery of a damaged and unreadable data card resulted in essentially no recoverable data from this site.

In all, eight communities representing nine separate wind resource studies were successfully completed in this project. Chignik Lagoon was not successfully studied and will not be presented in the discussion below. For all nine studies, in addition to the summary information presented in this section, separate full reports are included in the appendices. These full reports are also available online on the Alaska Energy Program wind resource website at http://www.akenergyauthority.org/programwindresourcedata.html. Below is summary information for the nine wind resource studies completed for this project, listed in order of data start date.

\section{NEW STUYAHOK}

A met tower, erected in October 2003 on village corporation property near the airport, was the first one installed in the Bristol Bay region for this project. The met tower was removed in July 
2005 and erected in the upriver village of Koliganek as a continuation of the grant wind resource study project.

The wind resource report for New Stuyahok indicates a low Class 4 wind resource at 50 meters, although as explained in the report, the 50-meter wind power density is high compared to the 30meter wind power density and likely due to the high wind shear measured at the particular site. If another met tower were to be installed in New Stuyahok, but in a location less affected by trees and other ground clutter, it is predicted that a lower wind shear would be measured and hence Class 3 winds at 50 meters would be calculated.

AVEC, the electrical utility for New Stuyahok, is at present in the design and planning stage of a new bulk fuel and power plant upgrade project. The desire and intent of AVEC is to incorporate wind power into the New Stuyahok power system with a medium to high penetration wind-diesel hybrid system. The Wind Resource Report completed for New Stuyahok was forwarded to AVEC and will be used to support the design effort. Specific wind turbines have not yet been selected, although, AVEC has installed Northern Power Systems Northwind 100 turbines in other communities and has been pleased with their performance.

Notable wind resource information, including a wind speed profile and annual wind density rose (Figures 3 and 4), from the New Stuyahok, Alaska Wind Resource Report (see Appendix A), is presented below in Table 1.

Table 1 New Stuyahok Summary Data

$\begin{array}{ll}\text { Wind power class } & \text { Class } 4 \text { - Good } \\ \text { Wind speed annual average (30 meters) } & 5.46 \mathrm{~m} / \mathrm{s} \\ \text { Maximum wind gust } & 33.6 \mathrm{~m} / \mathrm{s} \text {, November } \mathbf{2 0 0 4} \\ \text { Mean wind power density (50 meters) } & 414 \mathrm{~W} / \mathrm{m}^{2} \text { (calculated*) } \\ \text { Mean wind power density (30 meters) } & 232 \mathrm{~W} / \mathrm{m}^{2} \text { (measured) } \\ \text { Weibull distribution parameters } & \mathrm{k}=1.76, \mathrm{c}=6.29 \mathrm{~m} / \mathrm{s} \\ \text { Roughness Class } & 4.39 \mathrm{~m} \text { (suburban) } \\ \text { Power law exponent } & 0.382 \text { (high wind shear) } \\ \text { Turbulence Intensity } & 0.151 \text { (moderate to high) } \\ \text { Data start date } & \text { October 10, 2003 } \\ \text { Data end date } & \text { July } 7,2005\end{array}$

*Wind power density at 50 meters is likely an overestimate due to a high measured power law exponent 
Figure 3 New Stuyahok Seasonal Wind Speed Profile

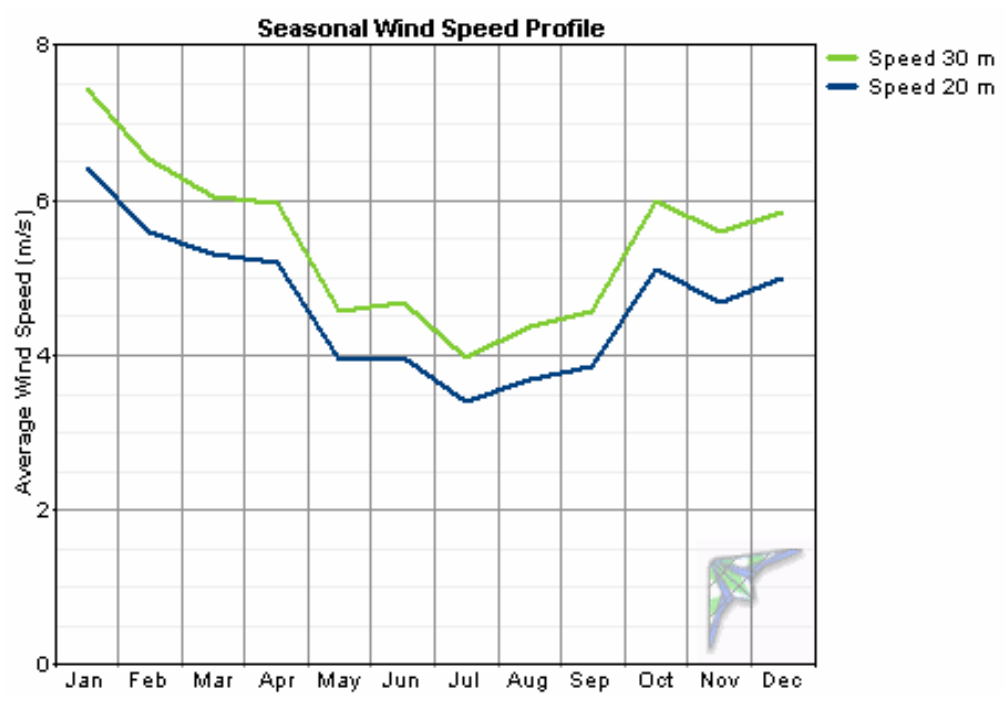

Figure 4 New Stuyahok Wind Power Density Rose

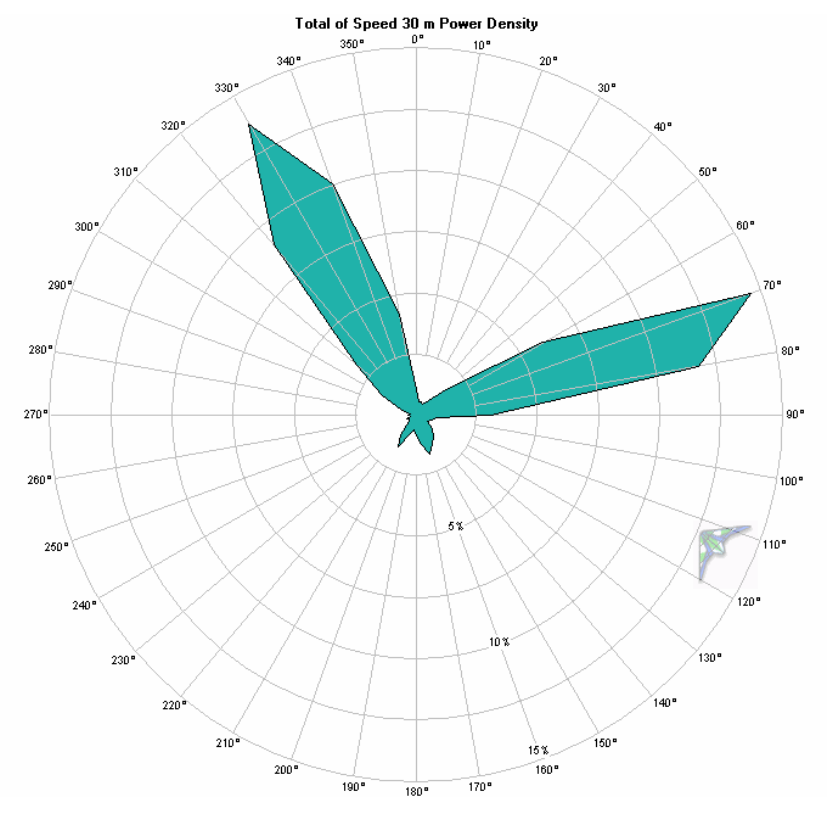

\section{DILLINGHAM - KANAKANAK}

The measured wind resource at the Dillingham Kanakanak site showed good potential for wind energy development with a high Class 3 wind power density and good turbulence behavior. Should wind power be developed in Dillingham, this site presents easy road access, nearby power infrastructure, is well away from the airport, and the owner is enthusiastic about wind development. Potential land area at this site available for turbine installations is relatively large, so it is reasonable that a more open location than the site chosen for the met tower can be found. The relatively high wind shear measured at the site is likely due to the nearby forest margin that undoubtedly negatively impacted the 20-meter anemometer on the met tower. 
The wind power density at the Kanakanak site in Dillingham is about average, compared to other study sites in the Bristol Bay Region. But, because Dillingham is the largest community in the region and given the high cost of energy and the associated high cost of business in Dillingham, the potential benefit of wind power is greater than in smaller communities with stronger wind resources. If wind power is developed in the future, care must be exercised to find the most suitable site free that will be free of upwind ground obstructions and place turbines on high towers to maximize the available wind resource.

At this time, however, the board of NEC, Dillingham's electric utility company, has elected to not consider wind power for any part of its near-term energy needs. This consideration may change, of course, should the price of diesel fuel increase or other potential alternative sources of power prove to be infeasible.

Notable wind resource information, including a wind speed profile and annual wind density rose (Figures 5 and 6), from the Dillingham, Alaska Wind Resource Report - Kanakanak site (see Appendix B), is presented below in Table 2.

Table 2 Dillingham - Kanakanak Summary Data

\author{
Wind power class \\ Wind speed annual average (30 meters) \\ Maximum wind gust \\ Mean wind power density (50 meters) \\ Mean wind power density (30 meters) \\ Weibull distribution parameters \\ Roughness Class \\ Power law exponent \\ Turbulence Intensity \\ Data start date \\ End data date
}

Class 3 - Fair

$5.78 \mathrm{~m} / \mathrm{s}$

30.9 m/s, April 2005

$374 \mathrm{~W} / \mathrm{m}^{2}$ (calculated)

$230 \mathrm{~W} / \mathrm{m}^{2}$ (measured)

$k=2.01, c=6.29 \mathrm{~m} / \mathrm{s}$

3.66 (forest)

0.286 (high wind shear)

0.124 (moderate)

April 23, 2004

October 5, 2005 
Figure 5 Dillingham - Kanakanak Seasonal Wind Speed Profile

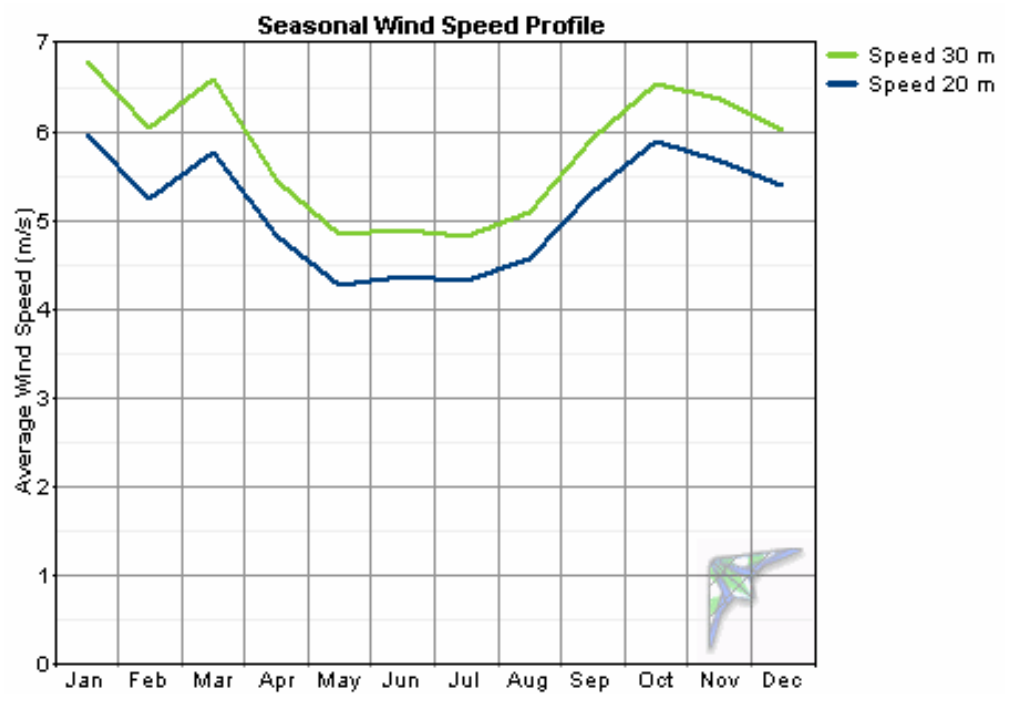

Figure 6 Dillingham - Kanakanak Wind Power Density Rose

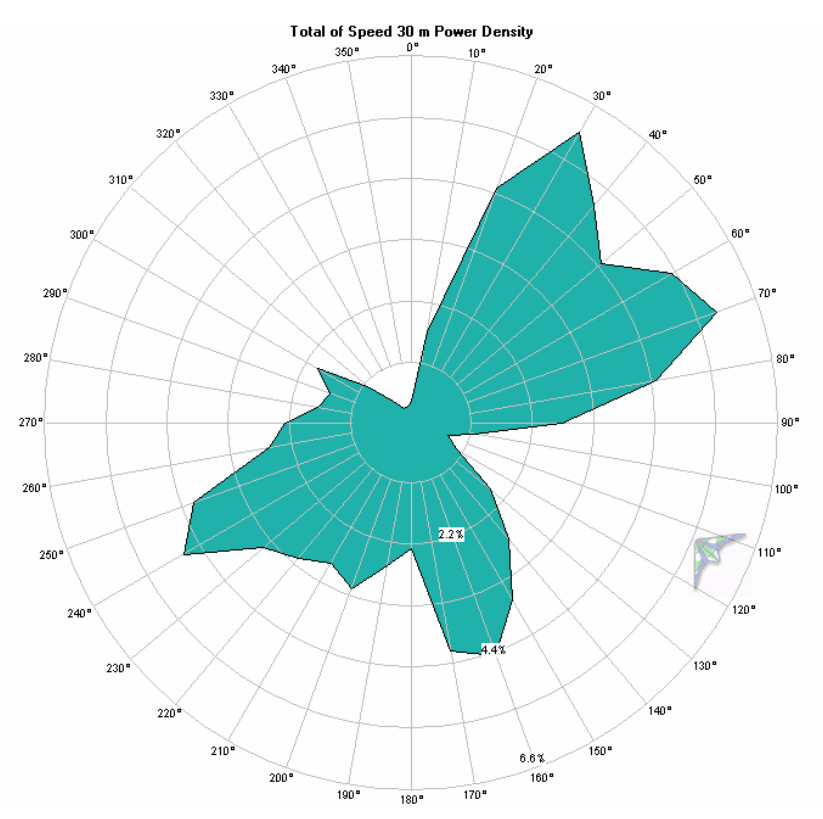

\section{DILLINGHAM - WOODRIVER ROAD}

The measured wind resource at the Dillingham Woodriver Road site also showed good potential for wind energy development with a high Class 3 wind power density and good turbulence behavior. As at the Kanakanak site, and compared to other sites in the Bristol Bay Region, the wind power density at the Woodriver Road site in Dillingham is about average.

Should wind power be developed in Dillingham, this site, similar to the Kanakanak site, also presents easy road access and nearby power infrastructure, but it is closer to the airport and land ownership questions have not yet been researched. Potential land area at this site available for 
turbine installations is not especially large, but there is sufficient room for a few larger turbines. The relatively high wind shear measured at the site is likely due to the positioning of the anemometers on the tower and the lattice nature of the tower itself, as well the presence of trees nearby.

Notable wind resource information, including a wind speed profile and annual wind density rose (Figures 7and 8), from the Dillingham, Alaska Wind Resource Report - Woodriver Road site (see Appendix C), is presented below in Table 3.

\section{Table 3 Dillingham - Woodriver Summary Data}

Wind power class

Wind speed annual average (33 meters)

Wind speed annual average (30 meters)

Maximum wind gust

Mean wind power density (50 meters)

Mean wind power density (33 meters)

Mean wind power density (30 meters)

Weibull distribution parameters

Roughness Class

Power law exponent

Turbulence Intensity

Data start date

End data date
Class 3 - Fair

$5.99 \mathrm{~m} / \mathrm{s}$ (measured)

$5.88 \mathrm{~m} / \mathrm{s}$ (calculated)

$31.3 \mathrm{~m} / \mathrm{s}$, April 2005

$375 \mathrm{~W} / \mathrm{m}^{2}$ (calculated)

$289 \mathrm{~W} / \mathrm{m}^{2}$ (measured)

$272 \mathrm{~W} / \mathrm{m}^{2}$ (calculated)

$\mathrm{k}=1.85, \mathrm{c}=6.64 \mathrm{~m} / \mathrm{s}$

3.06 (forest)

0.235 (high wind shear)

0.110 (moderate)

April 22, 2004

July 13, 2006

Figure 7 Dillingham - Woodriver Seasonal Wind Speed Profile

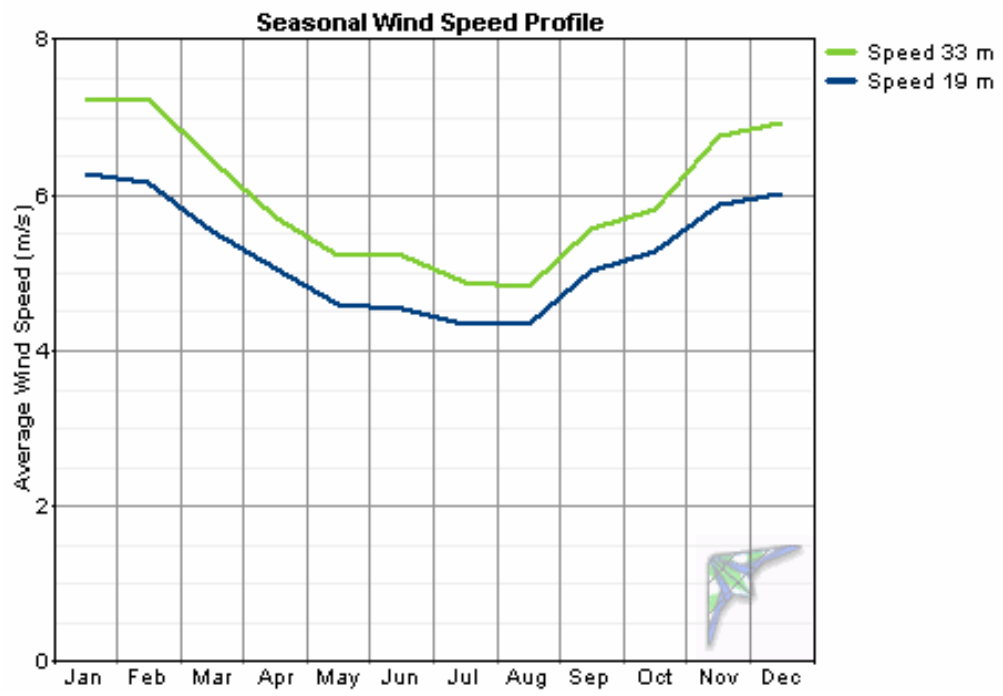




\section{Figure 8 Dillingham, Woodriver Wind Power Density Rose}

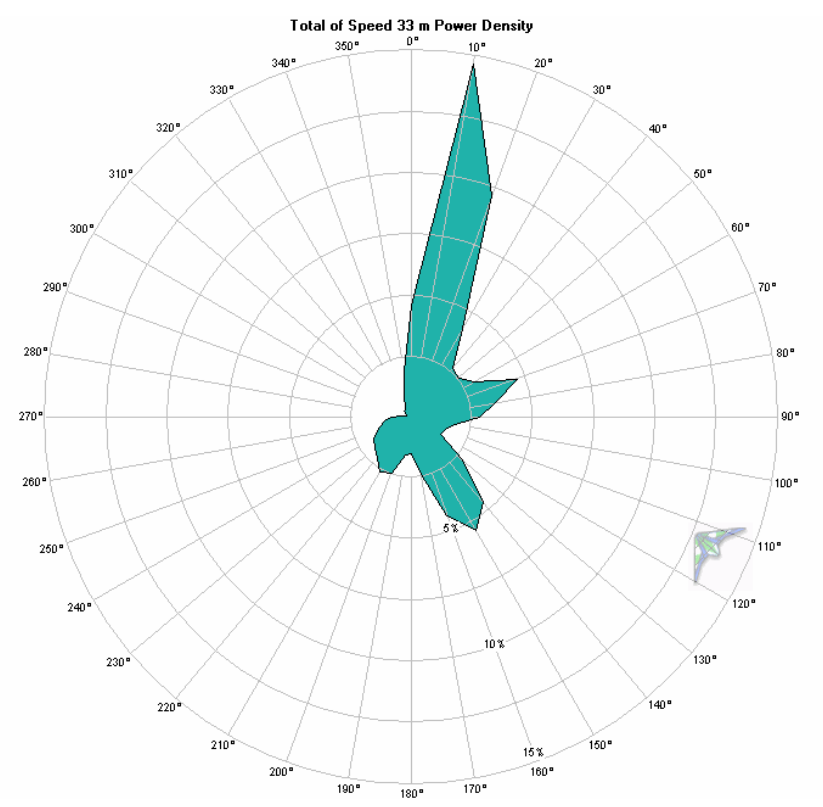

\section{NAKNEK}

The measured wind resource in Naknek showed good potential for wind energy development with a mid-to-high Class 3 wind power density and excellent turbulence behavior. The monitored site, near the borough landfill, does exhibit more wind shear than desirable, necessitating tall turbine towers, and, in other respects, may not be desirable to develop. However, there is plenty of similar terrain nearby that would be suitable for wind power development. In July 2006, the meteorological test tower was moved to a site closer to Naknek Bay, which may prove superior to the landfill site because of its better exposure to onshore winds. Early data recovery from the new site suggests that this will be the case.

NEA is keenly interested in developing sources of renewable energy to augment their diesel power system and view wind power as a strongly viable solution. Given the more open terrain and proximity to the bay, the new met tower site is now the designated wind power site in Naknek. NEA has initiated engineering and permitting work necessary for installation of wind turbines, should they decide to develop wind power in the near future.

Notable wind resource information, including a wind speed profile and annual wind density rose (Figures 9 and 10), from the Naknek, Alaska Wind Resource Report (see Appendix D), is presented below in Table 4. 


\section{Table 4 Naknek Summary Data}

Wind power class

Wind speed annual average (30 meters)

Maximum wind gust

Mean wind power density (50 meters)

Mean wind power density (50 meters)

Weibull distribution parameters

Roughness Class

Power law exponent

Turbulence Intensity (30 meters)

Data start date

Data end date
Class 3 - Fair

$6.22 \mathrm{~m} / \mathrm{s}$

$32.9 \mathrm{~m} / \mathrm{s}$, April 2005

$368 \mathrm{~W} / \mathrm{m}^{2}$

$301 \mathrm{~W} / \mathrm{m}^{2}$

$\mathrm{k}=1.99, \mathrm{c}=7.02 \mathrm{~m} / \mathrm{s}$

1.86 (few trees)

0.175 (moderate wind shear)

0.102 (excellent)

July 27,2004

July 19, 2006

Figure 9 Naknek Seasonal Wind Speed Profile

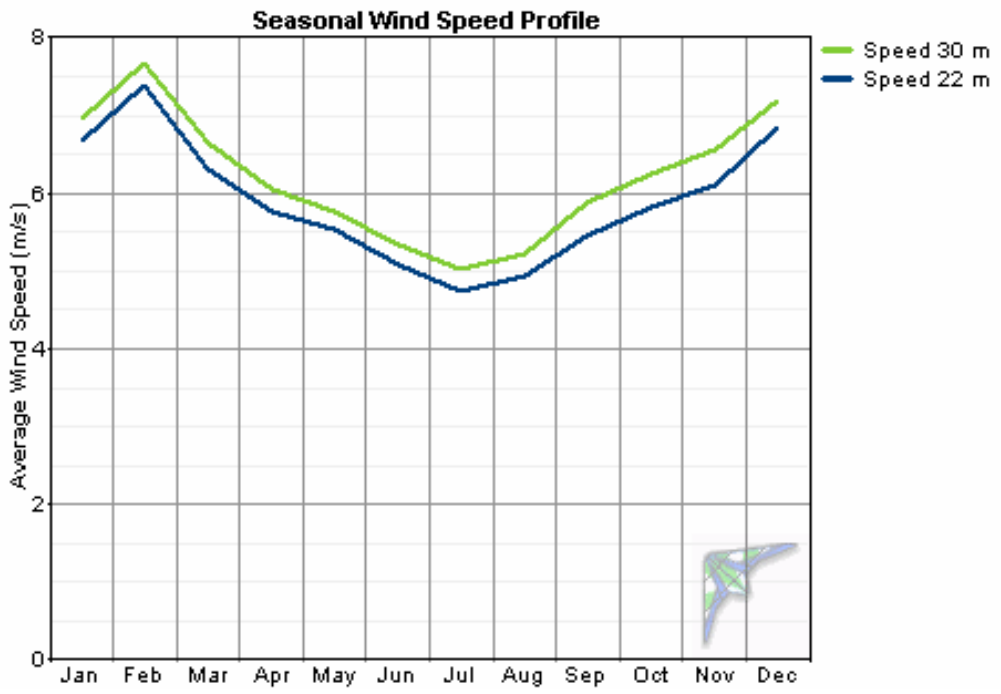




\section{Figure 10 Naknek Wind Power Density Rose}

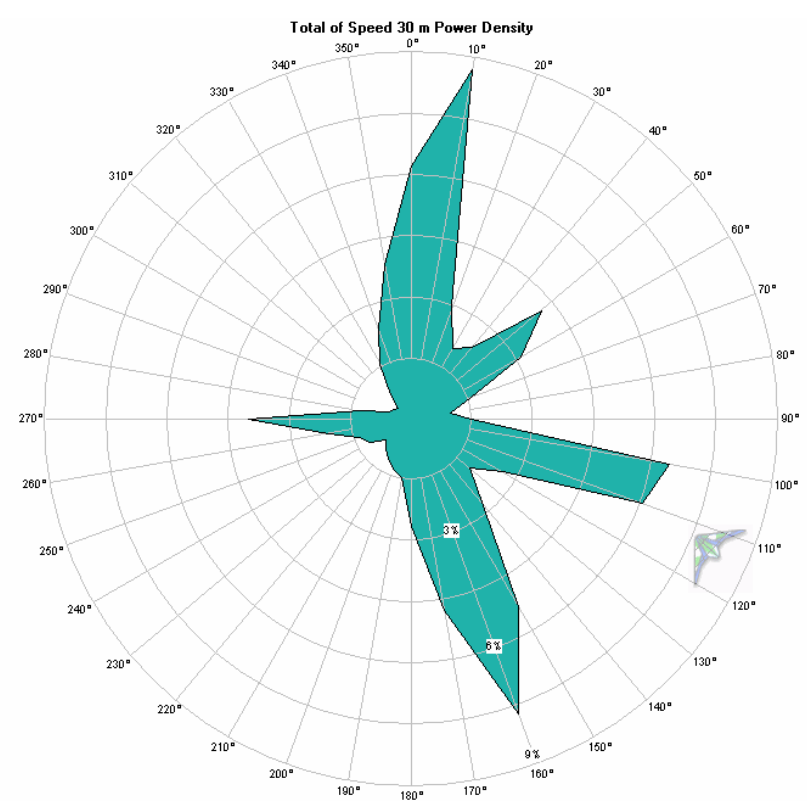

\section{KOKHANOK}

The wind resource in Kokhanok is superb by any measure - the winds are steady, smooth, low shear, highly directional, and high power class. The selected wind site, near the tip of the spit of land jutting into Lake Iliamna, is ideal for wind turbine installations as it is relatively far from the village, but near an existing overhead power line it is comprised of stable rocky soil and is in a location unlikely to be desired for other village uses (because of the wind). The truly great aspect about the wind resource in Kokhanok is that the strong winds at the prospective wind site are not felt so keenly in the village itself, because of topographic features and heavy forest that mute the winds considerably.

Kokhanok was recognized early in the data collection and analysis process as having outstanding potential for wind power development, and has been the focus of attention to obtain grant money to fund a wind-diesel system. Although the Kokhanok wind power proposal in response to an AEA Request for Proposals in February 2006 was not successful, Kokhanok's wind resources were recognized and in late 2006 the Alaska legislature appropriated approximately $\$ 150,000$ to Kokhanok to begin planning and design work for a wind power system. Active management of this funding was transferred from the Kokhanok Village Council to the Lake and Peninsula Borough, and at this writing an effort is underway to secure additional funding for a complete project. We anticipate actual construction of a wind power project in Kokhanok no later than summer 2008.

Notable wind resource information, including a wind speed profile and annual wind density rose (Figures 11 and 12), from the Kokhanok, Alaska Wind Resource Report (see Appendix E), is presented below in Table 5 . 


\section{Table 5 Kokhanok Summary Data}

Wind power class

Wind speed annual average (30 meters)

Maximum wind gust

Mean wind power density (50 meters)

Mean wind power density (30 meters)

Weibull distribution parameters

Roughness class

Power law exponent

Turbulence intensity

Data start date

Data end date
Class 6 - Outstanding

$7.84 \mathrm{~m} / \mathrm{s}$

$40.1 \mathrm{~m} / \mathrm{s}$ (November 2004)

$763 \mathrm{~W} / \mathrm{m}^{2}$ (calculated)

$690 \mathrm{~W} / \mathrm{m}^{2}$ (measured)

$\mathrm{k}=1.64, \mathrm{c}=8.77 \mathrm{~m} / \mathrm{s}$

0.00 (smooth)

0.0725 (very low wind shear)

0.0985 (low)

August 12, 2004

June 14, 2006

Figure 11 Kokhanok Seasonal Wind Speed Profile

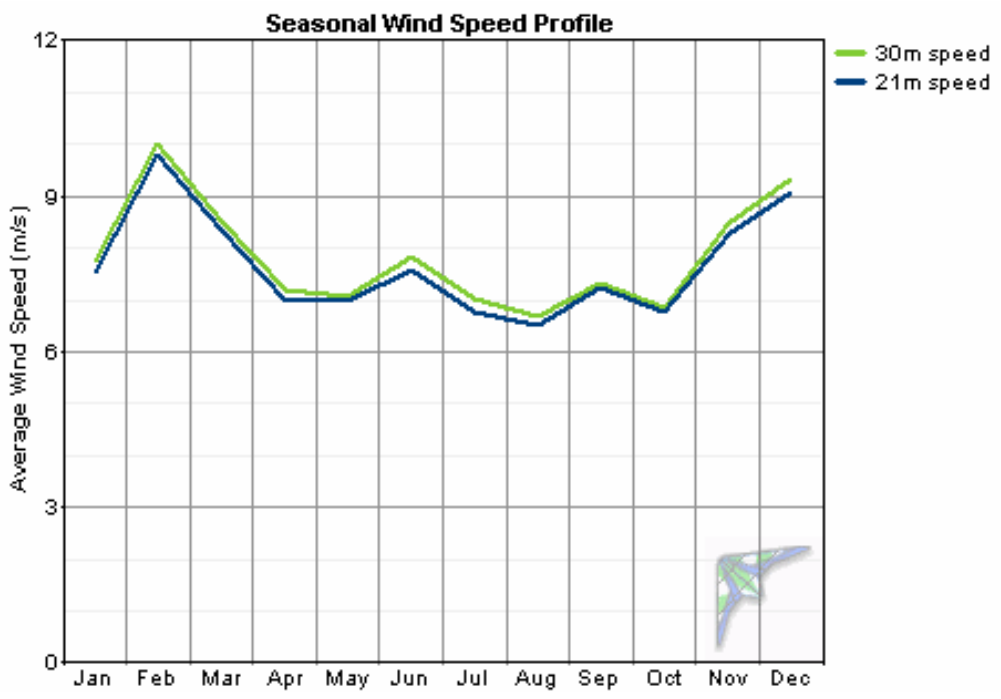




\section{Figure 12 Kokhanok Wind Power Density Rose}

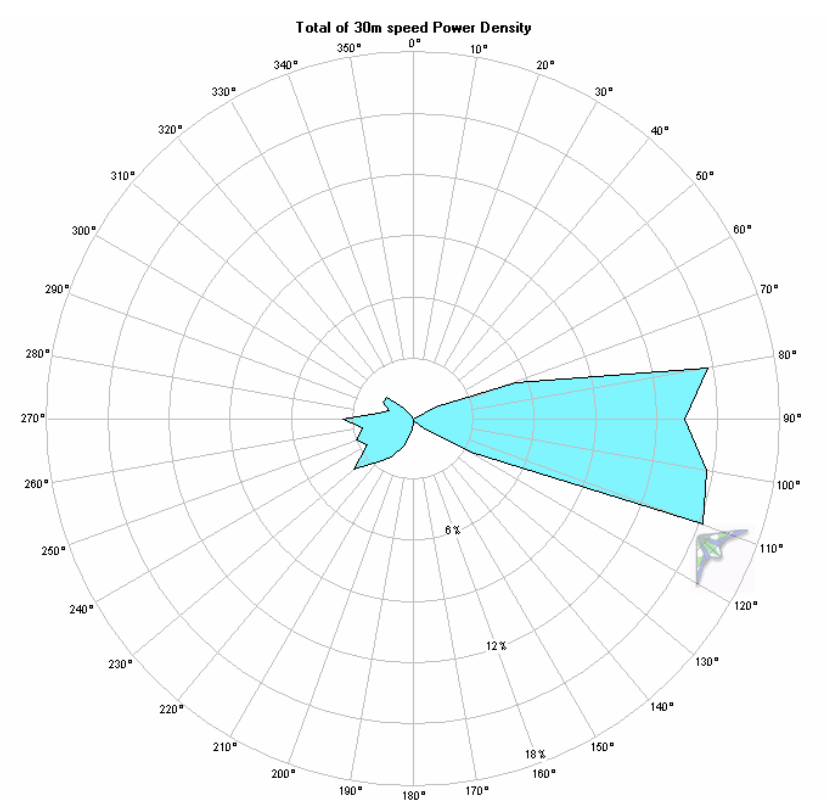

\section{TOGIAK}

A met tower was installed in Togiak in September 2004. The original plan had been to install the tower immediately after the Dillingham Wind Energy Workshop in October 2003, as was the met tower in New Stuyahok, but time constraints and weather forced a delay until the following summer. The intent was to erect the Togiak met tower in May, but the site selected during the previous October's reconnaissance trip proved to be unacceptable due to land ownership issues, construction of housing nearby, and relocation of the planned new power plant. A new site was selected, but the need for permits and other approval delayed the met tower installation until autumn. The Togiak met tower is still on site and will be removed by AVEC in summer 2007.

Notable wind resource information, including a wind speed profile and annual wind density rose (Figures 13 and 14), from the Togiak, Alaska Wind Resource Report (see Appendix F), is presented below in Table 6 . 


\section{Table 6 Togiak Summary Data}

Wind power class

Wind speed annual average (30 meters)

Maximum wind gust

Mean wind power density (50 meters)

Mean wind power density (30 meters)

Weibull distribution parameters

Roughness Class

Power law exponent

Turbulence Intensity

Data start date

Data end date
Class 3 - Fair

$5.68 \mathrm{~m} / \mathrm{s}$

$32.9 \mathrm{~m} / \mathrm{s}$ (April 2005)

$311 \mathrm{~W} / \mathrm{m}^{2}$ (calculated)

$256 \mathrm{~W} / \mathrm{m}^{2}$ (measured)

$\mathrm{k}=1.75, \mathrm{c}=6.40 \mathrm{~m} / \mathrm{s}$

1.11 (fallow field)

0.151 (moderate wind shear)

0.104 (low)

September 11, 2004

July 12, 2006

Figure 13 Togiak Wind Speed Profile

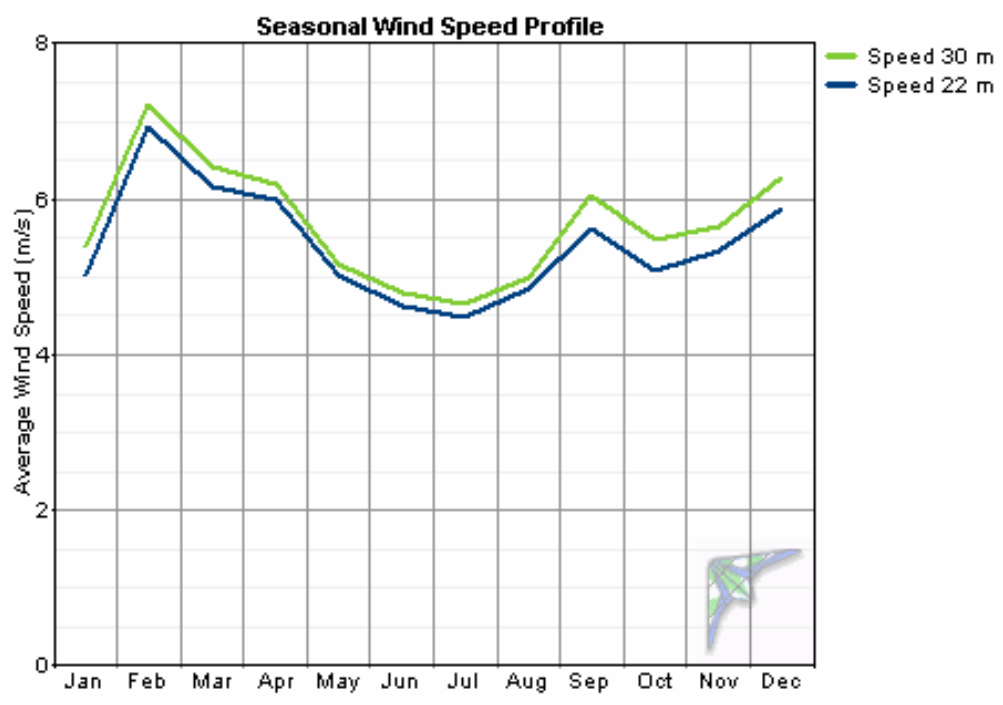




\section{Figure 14 Togiak Wind Power Density Rose}

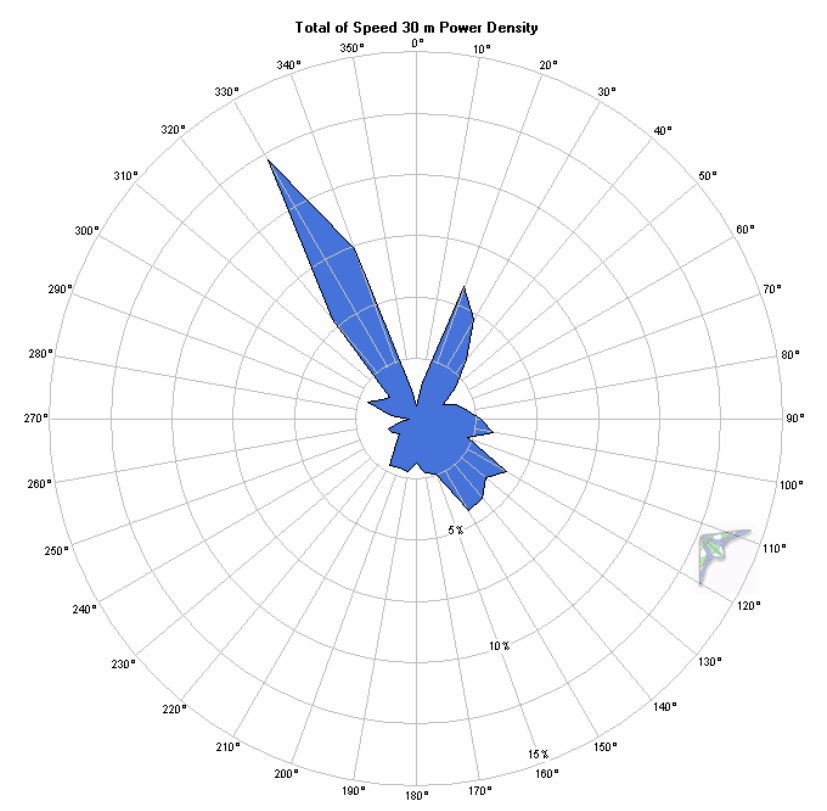

The Togiak test site is a Class 3 wind resource, and not as promising as we had hoped. One thought is that perhaps the met tower site is not the best site for wind power development in the village. The site, after an extensive effort with Togiak Natives Ltd., to select a suitable parcel, was selected because of uncomplicated ownership and accessibility issues. However, other, and likely superior, sites were not available for testing at the time because of complicated ownership issues.

The electrical utility in Togiak, AVEC, is presently in the design and planning stage of a new bulk fuel and power plant upgrade project. As in New Stuyahok, the desire and intent of AVEC is to incorporate wind power into the Togiak power system with a medium-to-high penetration wind-diesel hybrid system. The Wind Resource Report completed for Togiak was forwarded to AVEC, and has and will continue to be used to support the design effort. Given the test results, the desirability of the test site as an actual turbine location is still undetermined. There has been discussion and some planning to connect Togiak to the nearby non-AVEC village of Twin Hills by electrical intertie. Should this occur, AVEC is interested in measuring the wind resource on a prominent ridge, near Twin Hills, that they think may be a superior wind location than the present test site. Given the timeline of the decision of Twin Hills to join AVEC and a possible decision to build an intertie line across Togiak Bay, this new test site is not likely to be monitored until 2008.

\section{Perryville}

The wind resource study in Perryville defied expectations of measuring strong winds. It appears that local geographic features effectively shield the test site, and the nearby village, from the ferocious winds common to the southern Alaska Peninsula coast. With a measured wind power Class of 2 (marginal), Perryville does not appear at this time to be a promising location for village-scale wind power development, although, there is always the possibility of successful home-scale wind power development. This is unfortunate as the leadership of Perryville has 
been very aggressive in their desire to develop renewable energy, but wind power does not appear to be a good solution to their high energy cost problem.

Notable wind resource information, including a wind speed profile and annual wind density rose (Figures 15 and 16), from the Perryville, Alaska Wind Resource Report (see Appendix G), is presented below in Table 7.

\section{Table 7 Perryville Summary Data}

Wind power class

Wind speed annual average (30 meters)

Maximum wind gust

Mean wind power density (50 meters)

Mean wind power density (30 meters)

Wiebull distribution parameters

Roughness Class

Power law exponent

Turbulence intensity

Data start date

Most recent data date
Class 2 - Marginal

$4.60 \mathrm{~m} / \mathrm{s}$ (at 30 meters)

$24.4 \mathrm{~m} / \mathrm{s}$ (November 2004)

$240 \mathrm{~W} / \mathrm{m}^{2}$ (calculated)

$185 \mathrm{~W} / \mathrm{m}^{2}$ (measured)

$\mathrm{k}=1.36, \mathrm{c}=5.02 \mathrm{~m} / \mathrm{s}$

1.93 (few trees)

0.181 (moderate wind shear)

0.158 (moderate to high)

October 9, 2004

October 4, 2006

\section{Figure 15 Perryville Wind Speed Profile}

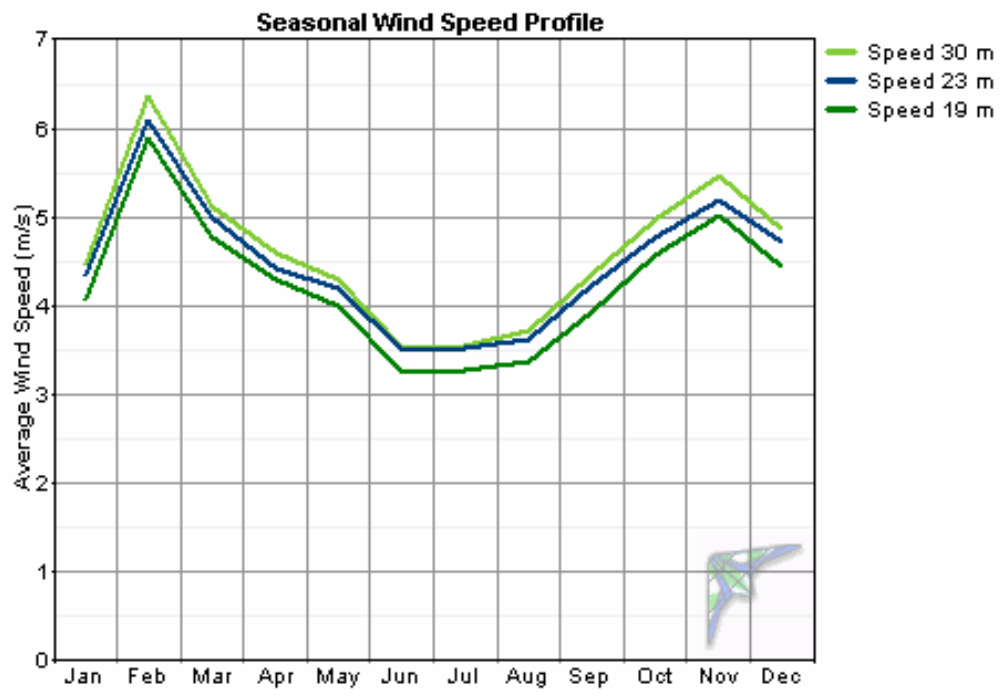


Figure 16 Perryville Wind Power Density Rose

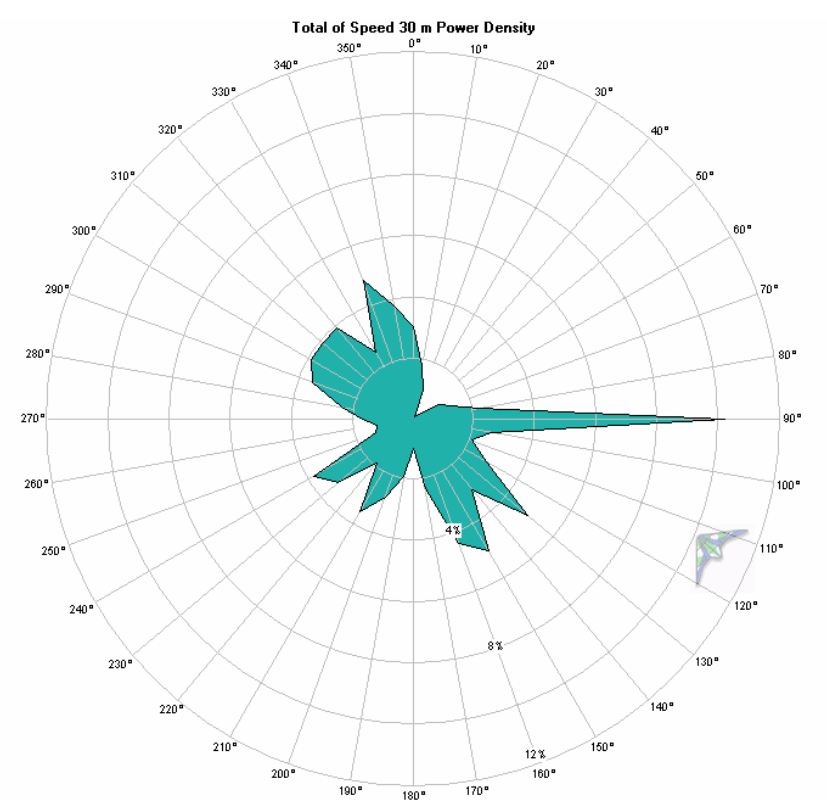

\section{ClarK's Point}

The wind resource study in Clark's Point indicates excellent potential for the development of wind power to augment the village's diesel engine power supply. One advantage for the village is the bluff where the meteorological test tower was located. This bluff is high and exposed and has superb exposure to onshore winds off the bay. A disadvantage for wind power development is the relative isolation and small population of Clark's Point. Clark's Point has a small, local utility that would likely need outside help and support to successfully initiate and construct a wind power project. It is hoped that this wind resource study will aid a future wind power development effort.

Notable wind resource information, including a wind speed profile and annual wind density rose (Figures 17 and 18), from the Clark's Point, Alaska Wind Resource Report (see Appendix H), is presented below in Table 8. 


\section{Table 8 Clark's Point Summary Data}

Wind power class (at 50 meters)

Wind speed annual average (30 meters)

Maximum wind gust

Mean wind power density (50 meters)

Mean wind power density (30 meters)

Wiebull distribution parameters

Roughness Class

Power law exponent

Turbulence Intensity

Data start date

Data end date
Class 4 - Good

$6.94 \mathrm{~m} / \mathrm{s}$

$34.8 \mathrm{~m} / \mathrm{s}$, October 2005

$491 \mathrm{~W} / \mathrm{m}^{2}$ (calculated)

$423 \mathrm{~W} / \mathrm{m}^{2}$ (measured)

$\mathrm{k}=2.01, \mathrm{c}=7.77 \mathrm{~m} / \mathrm{s}$

0.94 (fallow field)

0.143 (moderate wind shear)

0.095 (low)

July 6, 2005

July 12, 2006

Figure 17 Clark's Point Wind Speed Profile

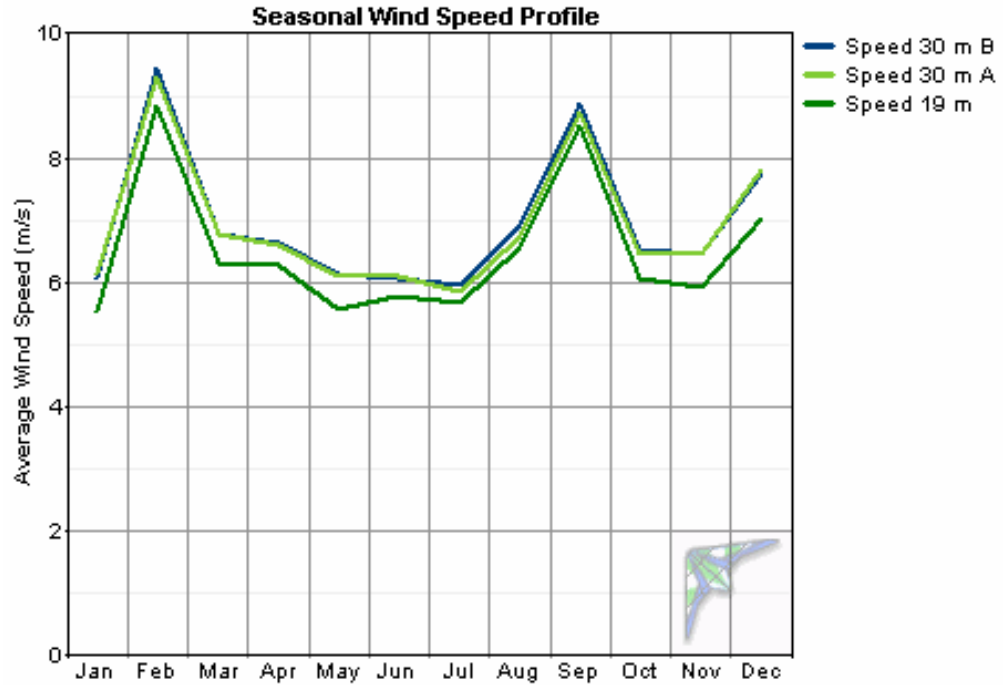




\section{Figure 18 Clark's Point Wind Power Density Rose}

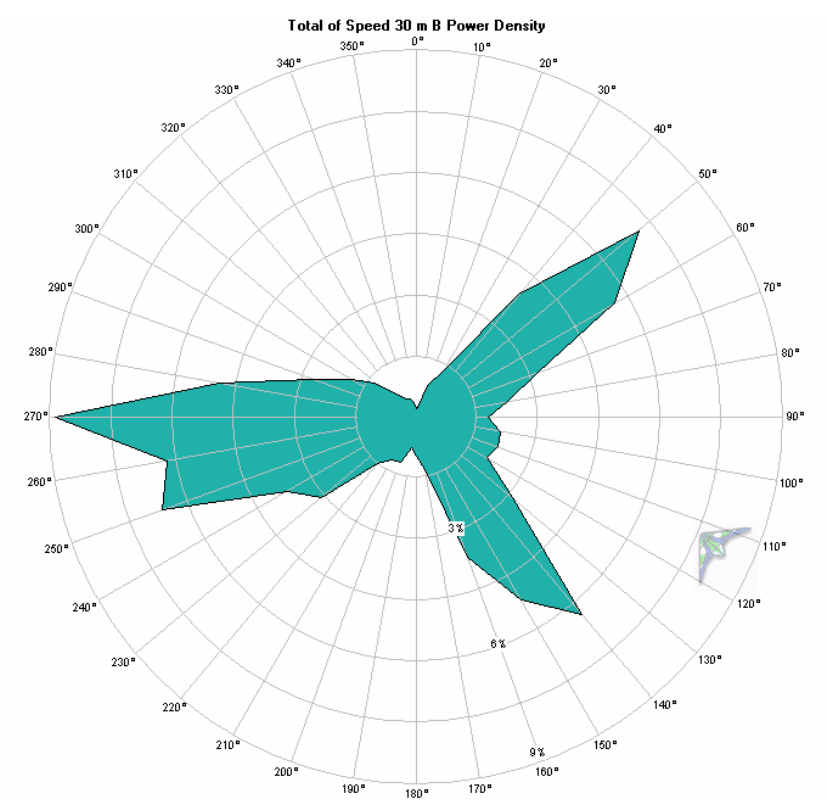

\section{KOLIGANEK}

The wind resource study in Koliganek indicates very good potential for the development of wind power to augment the village's diesel power supply. One excellent advantage for the village is the old airstrip where the meteorological test tower was located. Because the village and surrounding area is comprised of permafrost soils, construction of wind turbines on the old airstrip would significantly reduce construction costs. A disadvantage for village-scale wind power development is the relative isolation, small population, and small power load of Koliganek. Koliganek has a small, local utility that would likely need outside help and support to successfully initiate and construct a wind power project. It is hoped that this wind resource study will aid a future wind power development effort.

Notable wind resource information, including a wind speed profile and annual wind density rose (Figures 19 and 20), from the Koliganek, Alaska Wind Resource Report (see Appendix I), is presented below in Table 9 . 
Table 9 Koliganek Summary Data

Wind power class (at 50 meters)

Wind speed annual average (30 meters)

Maximum wind gust

Mean wind power density (50 meters)

Mean wind power density (30 meters)

Weibull distribution parameters

Roughness class

Power law exponent

Turbulence intensity

Data start date

Data end date
Class 4 - Good

$5.72 \mathrm{~m} / \mathrm{s}$

$36.5 \mathrm{~m} / \mathrm{s}$, December 2005

$404 \mathrm{~W} / \mathrm{m}^{2}$ (calculated)

$320 \mathrm{~W} / \mathrm{m}^{2}$ (measured)

$\mathrm{k}=1.60, \mathrm{c}=6.40 \mathrm{~m} / \mathrm{s}$

2.92 (many trees)

0.227 (high wind shear)

0.115 (moderate)

July 8,2005

July 13, 2006

Figure 19 Koliganek Wind Speed Profile

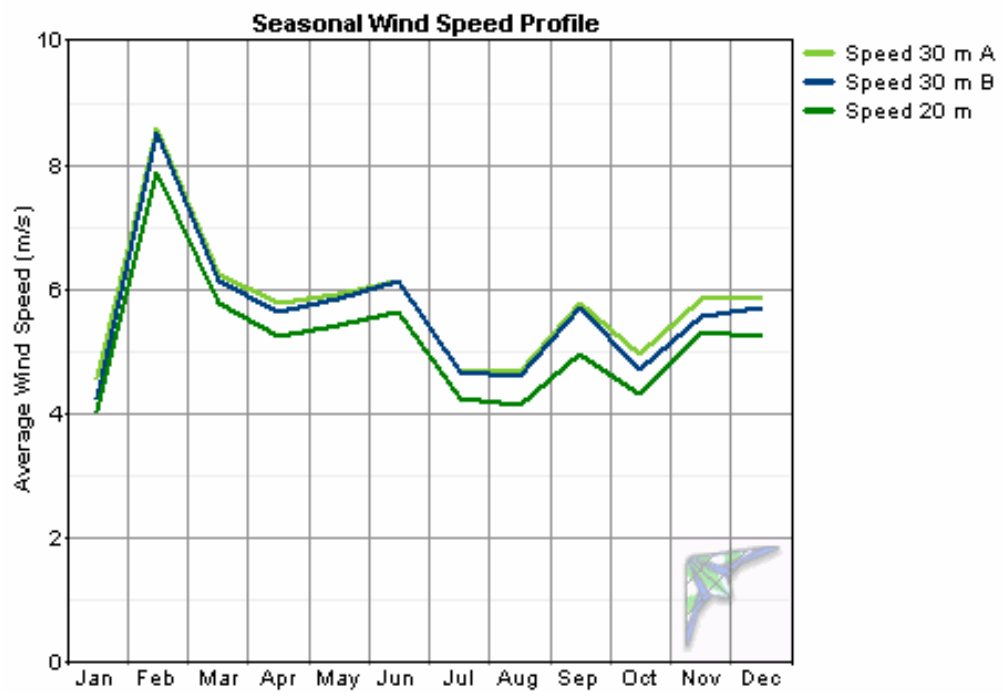




\section{Figure 20 Koliganek Wind Power Density Rose}

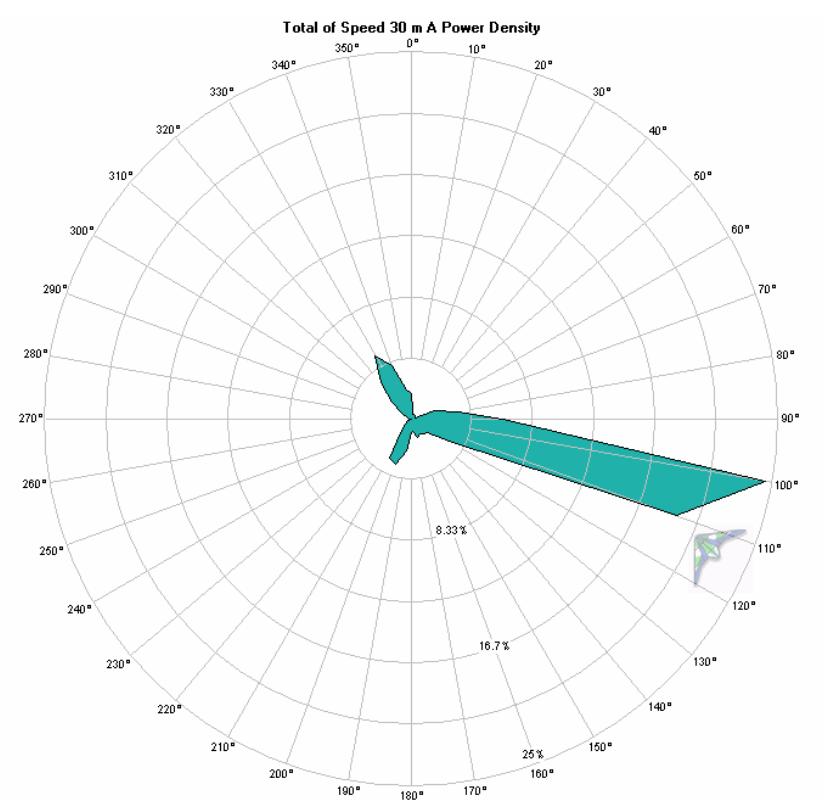

\section{Project Data Comparisons}

Comparing the project sites to each other would appear to be a reasonable way to summarize the nine separate studies, but we are including this comparison at the end of the results summary only as matter of interest. Because the wind resources were conducted in different communities, except for the two in Dillingham, comparing sites is not of much interest to people in the individual communities, nor to the local utilities, or a private project developer. The particular wind power project opportunities and challenges in each community are individual enough to render inter-village comparisons of marginal use.

Still, comparisons are interesting and may potentially be useful information. Below are two comparison tables: Table 10 orders the sites by wind power density at 50 meters, which in all cases estimates were calculated by the Windographer software program and Table 11 orders the sites by wind power density measured at 30 meters. The 50 -meter wind power density is useful as 50 meters is the normative height for classification of wind class, and is broadly used throughout the wind industry in North America and Europe as a common measure of wind power. 
Table 10 50-meter Wind Power Density Site Comparison

\begin{tabular}{|c|c|c|c|c|c|c|}
\hline & Site & $\begin{array}{c}\text { Wind } \\
\text { Power } \\
\text { Density } 50 \\
\text { meters, } \\
\text { W/m }\end{array}$ & $\begin{array}{c}\text { Wind } \\
\text { Power } \\
\text { Density } \\
30 \text { meters, } \\
\text { W/m } / \mathrm{m}^{2}\end{array}$ & $\begin{array}{c}\text { Average } \\
\text { Wind Speed } \\
30 \text { meters, } \\
\mathrm{m} / \mathrm{s}\end{array}$ & $\begin{array}{l}\text { Wind } \\
\text { Power } \\
\text { Class }\end{array}$ & $\begin{array}{l}\text { Wind Class } \\
\text { Description }\end{array}$ \\
\hline 1 & Kokhanok & 763 & 690 & 7.84 & 6 & Outstanding \\
\hline 2 & Clark's Point & 491 & 423 & 6.94 & 4 & Good \\
\hline 3 & New Stuyahok & 414 & 232 & 5.46 & 4 & Good \\
\hline 4 & Koliganek & 404 & 320 & 5.72 & 4 & Good \\
\hline 5 & Dillingham - Woodriver & 375 & 272 & 5.88 & 3 & Fair \\
\hline 6 & Dillingham - Kanakanak & 374 & 230 & 5.78 & 3 & Fair \\
\hline 7 & Naknek & 368 & 301 & 6.22 & 3 & Fair \\
\hline 8 & Togiak & 311 & 256 & 5.68 & 3 & Fair \\
\hline 9 & Perryville & 240 & 185 & 4.60 & 2 & Marginal \\
\hline
\end{tabular}

Note: Wind Power Class and description based on 50-meter wind power density data

Because all of the project met towers were 30 meters in height, all 50-meter wind power density data is calculated and therefore subject to error if the power law exponent calculation was compromised by unusual effects at the relatively low elevation of 20 meters, rather than would be true if anemometers were located at higher elevations closer to 50 meters. For this reason, the 30 wind power density is perhaps a better comparative tool and in one sense is a more reasonable measure of ranking the nine project sites to each other. Note that the site rankings change quite a bit between the two tables, but in both cases, Kokhanok is clearly the superior location for wind power development and Perryville the least. It is unfortunate that the Kokhanok test site is not closer to a larger population of people or an electrical transmission line, because the wind resources at the Kokhanok test site were so good that a wind power development would unquestionably be highly cost effective. 
Table 11 30-meter Wind Power Density Site Comparison

\begin{tabular}{|c|c|c|c|c|c|c|}
\hline & Community & $\begin{array}{c}\text { Wind } \\
\text { Power } \\
\text { Density } \\
30 \text { meters, } \\
\text { W/m }\end{array}$ & $\begin{array}{c}\text { Wind } \\
\text { Power } \\
\text { Density } \\
50 \text { meters, } \\
\text { W/m }\end{array}$ & $\begin{array}{c}\text { Average } \\
\text { Wind Speed } \\
30 \text { meters, } \\
\mathrm{m} / \mathrm{s}\end{array}$ & $\begin{array}{l}\text { Wind } \\
\text { Power } \\
\text { Class }\end{array}$ & $\begin{array}{l}\text { Wind Class } \\
\text { Description }\end{array}$ \\
\hline 1 & Kokhanok & 690 & 763 & 7.84 & 6 & Outstanding \\
\hline 2 & Clark's Point & 423 & 491 & 6.94 & 4 & Good \\
\hline 3 & Koliganek & 320 & 404 & 5.72 & 4 & Good \\
\hline 4 & Naknek & 301 & 368 & 6.22 & 3 & Fair \\
\hline 5 & Dillingham - Woodriver & 272 & 375 & 5.88 & 3 & Fair \\
\hline 6 & Togiak & 256 & 311 & 5.68 & 3 & Fair \\
\hline 7 & New Stuyahok & 232 & 414 & 5.46 & 4 & Good \\
\hline 8 & Dillingham - Kanakanak & 230 & 374 & 5.78 & 3 & Fair \\
\hline 9 & Perryville & 185 & 240 & 4.60 & 2 & Marginal \\
\hline
\end{tabular}

Note: Wind Power Class and description based on 50 meter wind power density data

Lastly, a final comparison of the sites by average wind speed at 30 meters is presented below in Table 12. Comparison of sites by wind speed can be somewhat misleading because of the nonlinear relationship between wind speed and wind power density - the different wind power densities that result from sits with equivalent average wind speeds can be understood with reference to the Weibull distribution - but again, it is a useful measure for an intuitive understanding of how one site compares against another. Note again that Kokhanok ranks first and Perryville ranks last by this alternate comparative measure. 


\section{Table 12 30-meter Average Annual Wind Speed Comparison}

\begin{tabular}{|c|c|c|c|c|c|c|}
\hline & Community & $\begin{array}{c}\text { Average } \\
\text { Wind Speed } \\
30 \text { meters, } \\
\mathrm{m} / \mathrm{s}\end{array}$ & $\begin{array}{c}\text { Wind } \\
\text { Power } \\
\text { Density } \\
30 \text { meters, } \\
\text { W/m } \mathrm{m}^{2}\end{array}$ & $\begin{array}{c}\text { Wind } \\
\text { Power } \\
\text { Density } \\
50 \text { meters, } \\
{\mathrm{W} / \mathrm{m}^{2}}^{2}\end{array}$ & $\begin{array}{l}\text { Wind } \\
\text { Power } \\
\text { Class }\end{array}$ & $\begin{array}{l}\text { Wind Class } \\
\text { Description }\end{array}$ \\
\hline 1 & Kokhanok & 7.84 & 690 & 763 & 6 & Outstanding \\
\hline 2 & Clark's Point & 6.94 & 423 & 491 & 4 & Good \\
\hline 3 & Naknek & 6.22 & 301 & 368 & 3 & Fair \\
\hline 4 & Dillingham - Woodriver & 5.88 & 272 & 375 & 3 & Fair \\
\hline 5 & Dillingham - Kanakanak & 5.78 & 230 & 374 & 3 & Fair \\
\hline 6 & Koliganek & 5.72 & 320 & 404 & 4 & Good \\
\hline 7 & Togiak & 5.68 & 256 & 311 & 3 & Fair \\
\hline 8 & New Stuyahok & 5.46 & 232 & 414 & 4 & Good \\
\hline 9 & Perryville & 4.60 & 185 & 240 & 2 & Marginal \\
\hline
\end{tabular}

Note: Wind Power Class and description based on 50 meter wind power density data 


\section{CONCLUSIONS AND RECOMMENDATIONS}

Despite the presence of wind resources that are well suited for wind power developed, the successful design and construction of wind turbines in rural Alaska communities is difficult and expensive. As with any construction project in rural Alaska, significant reasons are high transportation costs, lack of easy availability of heavy construction equipment, the high cost of fuel, and difficult permafrost soil conditions. The Bristol Bay region experiences these issues as well, but in some respects to a lesser degree than further north or inland in Alaska. Winter sea ice is less of a problem in Bristol Bay than elsewhere, and the region's proximity to Anchorage results in somewhat lower transportation costs than further north. Also, permafrost is discontinuous in much of the region, enabling more standard and hence less expensive foundation costs.

Our very early decision in this project to collaborate with AEA and AVEC in order to conduct as many wind resource studies as possible with the grant funds had a very pragmatic motivation: we wanted these studies to not be an end in themselves, but rather be just enough information for the utilities to decide whether or not they wish to develop wind power in their communities. If a utility does decide to develop wind power, it was our hope that the wind resource assessment reports would help the utility with the information they will need to properly locate wind turbines, select the best turbine for their needs, specify tower hub heights, and predict wind energy recovery and fuel displacement for economic planning and modeling.

With our project goal of supporting the construction of renewable energy projects in the Bristol Bay region, but playing a support role, BBNC considers our DOE grant project to be very successful. Already based on the outstanding wind resources proven by our wind resource study in the village, Kokhanok has received initial State grant funding for a wind power project and is working to secure the remaining money needed to move ahead with design and construction. AVEC has stated their strong intention to install wind turbines in New Stuyahok and would like to do so as well in Togiak, although, they may move the monitor to another more promising site before proceeding. NEA decided to fund a wind resource study as the second location, which will have obtained one year of data in July, and are actively planning for wind power to augment their diesel generator power system.

We hope that when one or two projects are successfully completed in the region, other communities will also want to develop wind power and will have a road map to follow so to speak. As the native corporation representing the entire Bristol Bay region, it is BBNC's plan to share information as best we can to support utilities and communities desiring to develop wind power. BBNC would like to once again thank the people at the DOE's Golden, Colorado Field Office, Tribal Energy Program, for awarding to us the funding for this project in 2003. Their help, along with the support and advice of the excellent people at the NREL in Golden and Boulder, Colorado, proved invaluable in our efforts. 


\section{APPENDICES}

Wind Resource Reports 


\section{Clark’s Point, Alaska Wind Resource Report}

Report written by: Douglas Vaught, P.E., V3 Energy, LLC

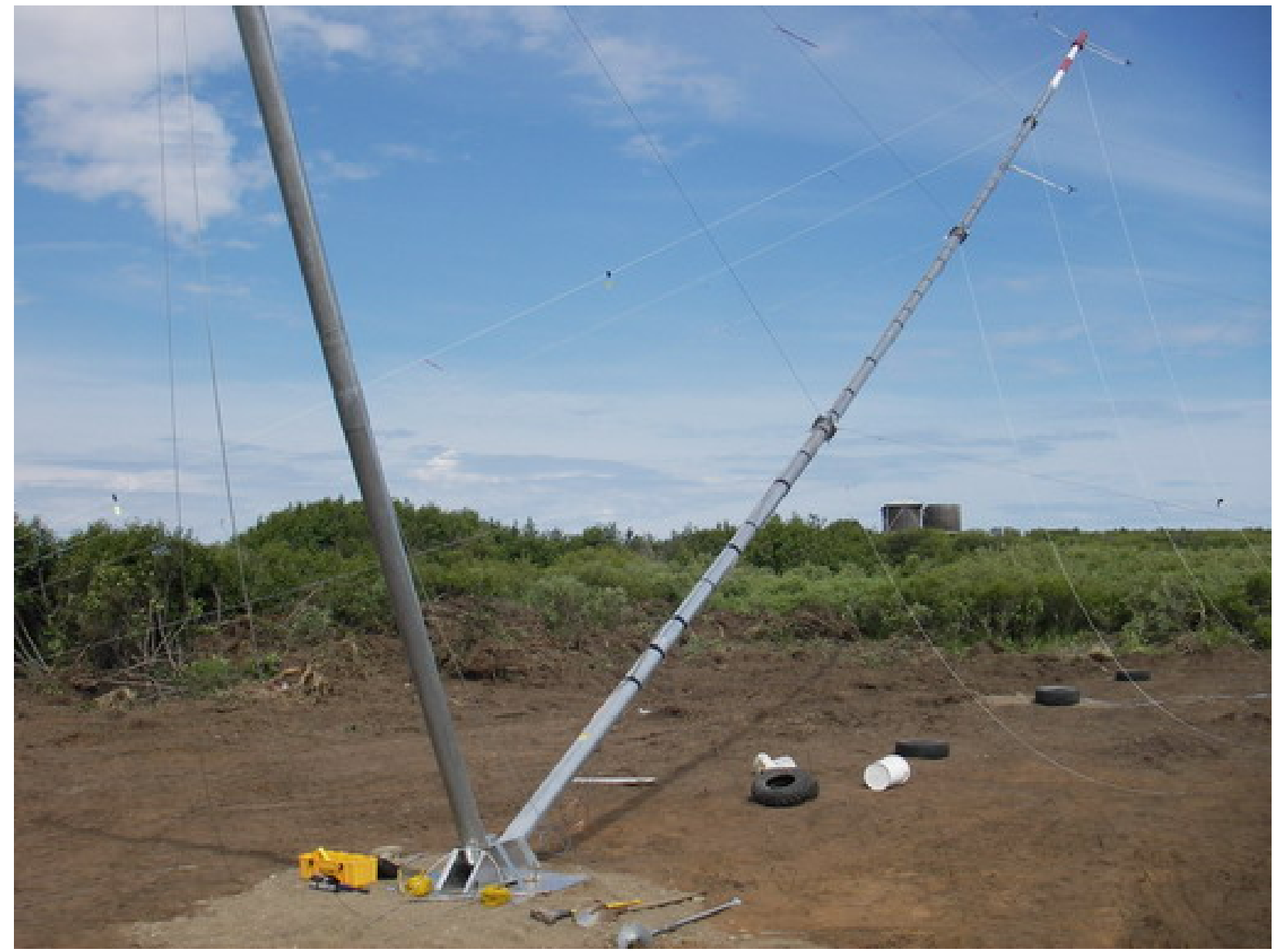

Photo ( Doug Vaught

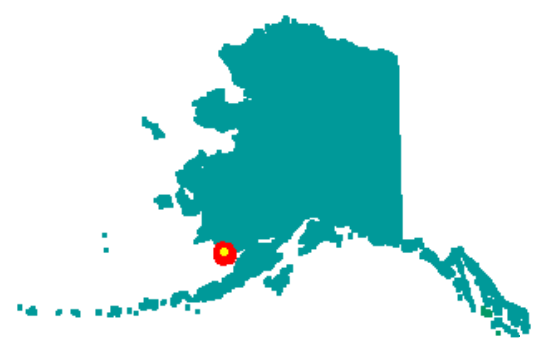

\section{Summary Information}

The wind resource study in Clark's Point indicates excellent potential for the development of wind power to augment the village's diesel engine power supply. One advantage for the village 
is the bluff where the meteorological test tower was located. This bluff is high and exposed and has superb exposure to onshore winds off the bay.

\title{
Meteorological Tower Data Synopsis
}

Wind power class (at 50 meters)

Wind speed annual average (30 meters)

Maximum wind gust (2 sec. Average)

Mean wind power density (50 meters)

Mean wind power density (30 meters)

Weibull distribution parameters

Roughness Class

Power law exponent

Turbulence Intensity

Data start date

Data end date
Class $4-$ Good

$6.94 \mathrm{~m} / \mathrm{s}$

$34.8 \mathrm{~m} / \mathrm{s}, 10 / 17 / 05$

$491 \mathrm{~W} / \mathrm{m}^{2}$ (calculated)

$423 \mathrm{~W} / \mathrm{m}^{2}$ (measured)

$\mathrm{k}=2.01, \mathrm{c}=7.77 \mathrm{~m} / \mathrm{s}$

0.94 (fallow field)

0.143 (moderate wind shear)

0.095 (low)

July 6, 2005

July 12, 2006

Community Profile

\author{
Current Population: 65 (2005 State Demographer est.) \\ Incorporation Type: 2nd Class City \\ Borough Located In: Unorganized \\ School District: Southwest Region Schools \\ Regional Native Corporation: Bristol Bay Native Corporation
}

\section{Location:}

Clark's Point is located on a spit on the northeastern shore of Nushagak Bay, 15 miles from Dillingham and 337 miles southwest of Anchorage. It lies at approximately $58.844170^{\circ}$ North Latitude and $158.550830^{\circ}$ West Longitude. (Sec. 25, T015S, R056W, Seward Meridian.) Clark's Point is located in the Bristol Bay Recording District. The area encompasses 3.1 sq. miles of land and 0.9 sq. miles of water.

\section{History:}

The point originally had an Eskimo name, "Saguyak," yet there is no evidence of a settlement at the site prior to the Nushagak Packing Company cannery, established in 1888. The community was named for John Clark, who was the manager of the Alaska Commercial Company store at Nushagak. Clark is reputed to have operated a saltery prior to the establishment of the cannery. In 1893 the cannery became a member of the Alaska Packers Association. In 1901 a two-line cannery was built. During World War II the canning operation ceased, and only salting was done at Clark's Point. The plant was shut down permanently by 1952, and the Alaska Packers Association used the facility as the headquarters for its fishing fleet. In 1929, a major flood occurred. The City was incorporated in 1971. The village has been plagued by severe erosion. A housing project in 1982 was constructed on high and safe ground on the bluff.

\section{Culture:}

The community was founded on fishing operations of non-Native settlers, although presently it is predominantly Yup'ik Eskimo. The population increases by about 300 in summer months due to the commercial fishery.

\section{Economy:}


The economic base in Clark's Point is primarily commercial fishing. Trident Seafoods operates an onshore facility. Sixteen residents hold commercial fishing permits. Everyone depends on subsistence to some extent, and travel over a great area if necessary. Salmon, smelt, moose, bear, rabbit, ptarmigan, duck and geese are utilized. Exchange relationships exist between nearby communities, for example, whitefish from Ekwok, New Stuyahok and Bethel are traded for smelt, and ling cod from Manokotak are traded for moose.

\section{Facilities:}

Spring-fed wells provide water to the community, treated with chlorine and fluoride. Nearly $80 \%$ of residents are connected to the piped water system; the remainder use individual wells. Approximately $40 \%$ of homes and the school -- those located on the bluff -- are served by a piped gravity sewage system. Residents below the bluff rely on septic tanks or pit privies. In all, 21 homes have piped water and sewer. The clinic and city offices use honeybuckets. Trident Seafoods supplies its own power, and the school has back-up generators.

\section{Transportation:}

Air transport is the primary method of reaching Clark's Point. Regular and charter flights are available from Dillingham. There is a State-owned 2,600' long by 70' wide gravel runway, and float planes land on Nushagak River. Freight is brought by barge to Dillingham, and then flown or lightered to the community. The only boat moorage is an undeveloped spit dock owned by the City; boats land on the beach. Trident Seafoods owns a private dock for fish processing. ATVs and snowmachines are the primary means of local transportation.

\section{Climate:}

Clark's Point is located in a climatic transition zone. The primary influence is maritime, although the arctic climate also affects the region. Average summer temperatures range from 37 to 66 degrees Fahrenheit. Average winter temperatures range from 4 to 30 degrees Fahrenheit. Annual precipitation is 20 to 26 inches, and annual snowfall is 82 inches. Fog and low clouds are common during winter months. The Nushagak Bay is ice-free from June through mid-November.

(Community profile information from State of Alaska Department of Commerce, Community, and Economic Development website, http://www.dced.state.ak.us/)

\section{Site Information and Location}

Site number

Site Description

Latitude/longitude

Site elevation

Datalogger type

Tower type
5046

On ocean side of bluff edge in the upper village area

N 58 $49.944^{\prime}$ W $158^{\circ} 33.389^{\prime}$

40 meters

NRG Symphonie

NRG 30-meter tall tower, $152 \mathrm{~mm}$ (6 in) diameter 
Clark’s Point, Alaska Wind Resource Report

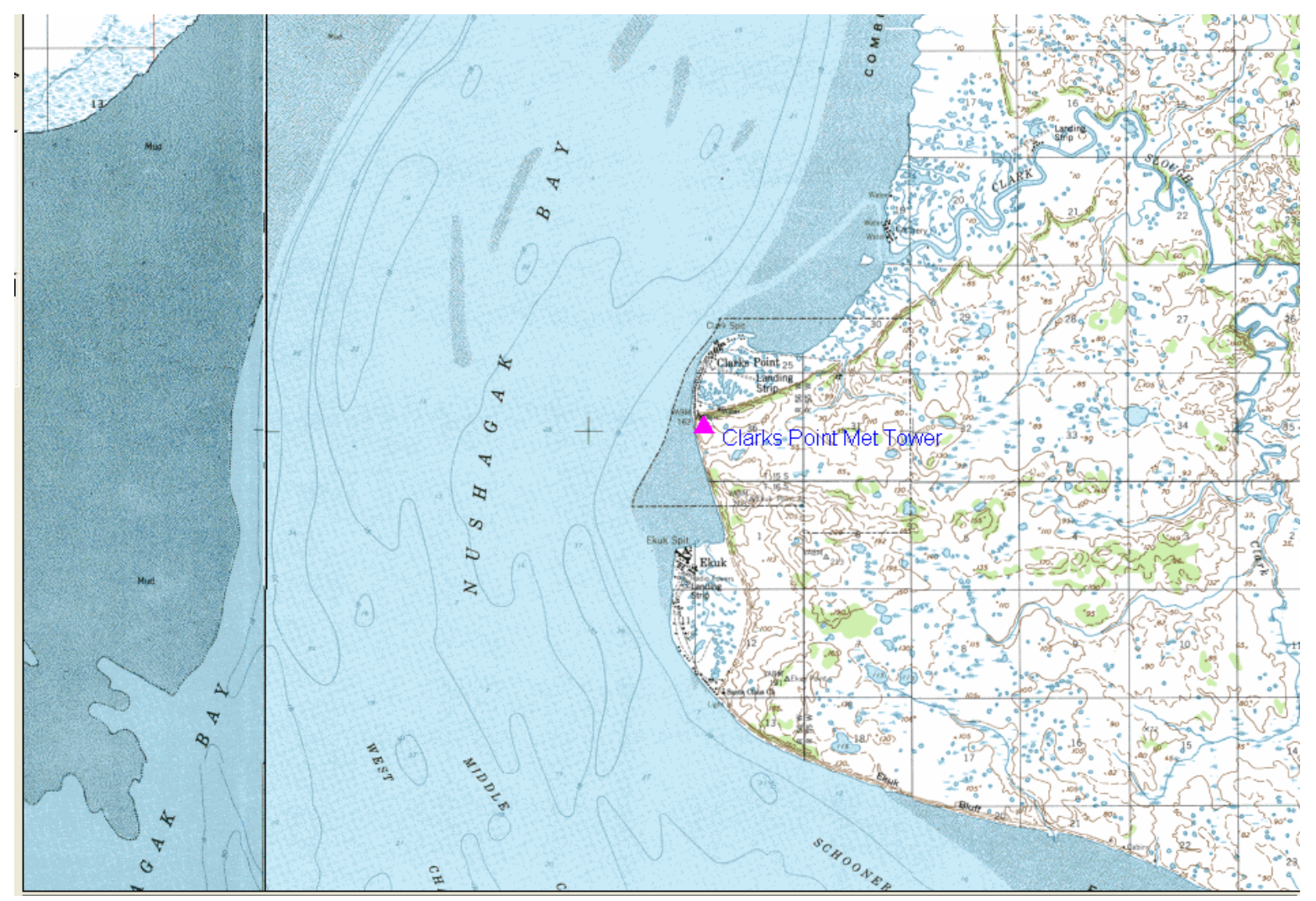

Tower Sensor Information

$\begin{array}{cl}\text { Channel } & \text { Sensor type } \\ 1 & \text { NRG \#40 anemometer } \\ 2 & \text { NRG \#40 anemometer } \\ 3 & \text { NRG \#40 anemometer } \\ 7 & \text { NRG \#200P wind vane } \\ 9 & \text { NRG \#110S Temp C }\end{array}$

$\begin{array}{crcc}\text { Height } & \text { Multiplier } & \text { Offset } & \text { Orientation } \\ 30 \mathrm{~m}(\mathrm{~A}) & 0.765 & 0.35 & \text { northeast } \\ 30 \mathrm{~m}(\mathrm{~B}) & 0.765 & 0.35 & \text { southwest } \\ 20 \mathrm{~m} & 0.765 & 0.35 & \text { northeast } \\ 30 \mathrm{~m} & 0.351 & 250 & \text { northeast } \\ 2 \mathrm{~m} & 0.136 & -86.383 & \text { N/A }\end{array}$




\section{Data Quality Control}

Data was filtered to remove presumed icing events that yield false zero wind speed data. Data that met the following criteria were filtered: wind speed $<1 \mathrm{~m} / \mathrm{s}$, wind speed standard deviation $=0$, and temperature $<3{ }^{\circ} \mathrm{C}$. Note that data recovery during the months of February through October was nearly $100 \%$, but during the months of November through January some data was filtered, with November being quite ice prone as far as data loss is concerned. Temperature data recovery was 100 percent, indicating full functioning of the temperature sensor. To make up for the lost icing data and to create a complete data set representative of all sensors fully functional, the removed icing data was synthesized with the data gap fill feature of the Windographer® wind analysis software. The gap-filled data set was used through the remainder of this wind resource report.

\begin{tabular}{|c|c|c|c|c|c|c|c|}
\hline & & \multicolumn{2}{|c|}{ Ch $130 \mathrm{~m}(\mathrm{~A})$} & \multicolumn{2}{|c|}{ Ch $230 \mathrm{~m}(\mathrm{~B})$} & \multicolumn{2}{|c|}{ Ch $320 \mathrm{~m}$} \\
\hline Year & Month & Records & $\begin{array}{l}\text { Recovery } \\
\text { Rate (\%) }\end{array}$ & Records & $\begin{array}{l}\text { Recovery } \\
\text { Rate }(\%)\end{array}$ & Records & $\begin{array}{l}\text { Recovery } \\
\text { Rate (\%) }\end{array}$ \\
\hline 2005 & Jul & 3,664 & 100 & 3,664 & 100 & 3,664 & 100 \\
\hline 2005 & Aug & 4,464 & 100 & 4,464 & 100 & 4,464 & 100 \\
\hline 2005 & Sep & 4,320 & 100 & 4,320 & 100 & 4,320 & 100 \\
\hline 2005 & Oct & 4,461 & 99.9 & 4,460 & 99.9 & 4,459 & 99.9 \\
\hline 2005 & Nov & 2,525 & 58.4 & 2,308 & 53.4 & 2,238 & 51.8 \\
\hline 2005 & Dec & 4,237 & 94.9 & 4,451 & 99.7 & 3,732 & 83.6 \\
\hline 2006 & Jan & 4,163 & 93.3 & 4,164 & 93.3 & 4,168 & 93.4 \\
\hline 2006 & Feb & 4,028 & 99.9 & 4,029 & 99.9 & 4,028 & 99.9 \\
\hline 2006 & Mar & 4,441 & 99.5 & 4,444 & 99.6 & 4,443 & 99.5 \\
\hline 2006 & Apr & 4,310 & 99.8 & 4,312 & 99.8 & 4,308 & 99.7 \\
\hline 2006 & May & 4,444 & 99.6 & 4,444 & 99.6 & 4,460 & 99.9 \\
\hline 2006 & Jun & 4,320 & 100 & 4,320 & 100 & 4,320 & 100 \\
\hline 2006 & Jul & 1,638 & 100 & 1,638 & 100 & 1,638 & 100 \\
\hline All data & & 51,015 & 95.5 & 51,018 & 95.5 & 50,242 & 94.1 \\
\hline & & \multicolumn{2}{|c|}{ Ch 7 vane } & \multicolumn{2}{|c|}{ Ch 9 temperature } & & \\
\hline Year & Month & Records & $\begin{array}{l}\text { Recovery } \\
\text { Rate (\%) }\end{array}$ & Records & $\begin{array}{l}\text { Recovery } \\
\text { Rate (\%) }\end{array}$ & & \\
\hline 2005 & Jul & 3,664 & 100 & 3,664 & 100 & & \\
\hline 2005 & Aug & 4,464 & 100 & 4,464 & 100 & & \\
\hline 2005 & Sep & 4,320 & 100 & 4,320 & 100 & & \\
\hline 2005 & Oct & 4,459 & 99.9 & 4,464 & 100 & & \\
\hline 2005 & Nov & 2,525 & 58.4 & 4,320 & 100 & & \\
\hline 2005 & Dec & 4,237 & 94.9 & 4,464 & 100 & & \\
\hline 2006 & Jan & 4,163 & 93.3 & 4,464 & 100 & & \\
\hline 2006 & Feb & 4,028 & 99.9 & 4,032 & 100 & & \\
\hline 2006 & Mar & 4,440 & 99.5 & 4,464 & 100 & & \\
\hline 2006 & Apr & 4,307 & 99.7 & 4,320 & 100 & & \\
\hline 2006 & May & 4,443 & 99.5 & 4,464 & 100 & & \\
\hline 2006 & Jun & 4,320 & 100 & 4,320 & 100 & & \\
\hline 2006 & Jul & 1,638 & 100 & 1,638 & 100 & & \\
\hline All data & & 51,008 & 95.5 & 53,398 & 100 & & \\
\hline
\end{tabular}




\section{Measured Wind Speeds}

The 30 meter (B) anemometer annual wind speed average for the reporting period is $6.94 \mathrm{~m} / \mathrm{s}$, the 30 meter (A) anemometer wind speed average is $6.88 \mathrm{~m} / \mathrm{s}$ and the 20 meter anemometer wind speed average is $6.47 \mathrm{~m} / \mathrm{s}$.

\begin{tabular}{|c|c|c|c|c|c|c|c|c|c|}
\hline \multirow[b]{3}{*}{ Month } & \multicolumn{5}{|c|}{30 m (B) speed } & \multirow{2}{*}{\multicolumn{2}{|c|}{$30 \mathrm{~m}(\mathrm{~A})$ speed }} & \multicolumn{2}{|c|}{$20 \mathrm{~m}$ speed } \\
\hline & & & Std. & Weibull & Weibull & & & & \\
\hline & $\begin{array}{l}\text { Mean } \\
(\mathrm{m} / \mathrm{s})\end{array}$ & $\begin{array}{l}\text { Max } \\
(\mathrm{m} / \mathrm{s})\end{array}$ & $\begin{array}{l}\text { Dev. } \\
(\mathrm{m} / \mathrm{s})\end{array}$ & k & $\begin{array}{c}c \\
(\mathrm{~m} / \mathrm{s})\end{array}$ & $\begin{array}{l}\text { Mean } \\
(\mathrm{m} / \mathrm{s})\end{array}$ & $\begin{array}{l}\operatorname{Max} \\
(\mathrm{m} / \mathrm{s})\end{array}$ & $\begin{array}{c}\text { Mean } \\
(\mathrm{m} / \mathrm{s})\end{array}$ & $\begin{array}{l}\operatorname{Max} \\
(\mathrm{m} / \mathrm{s})\end{array}$ \\
\hline Jan & 6.07 & 17.3 & 3.34 & 1.87 & 6.83 & 6.14 & 17.0 & 5.53 & 15.3 \\
\hline Feb & 9.45 & 24.6 & 4.60 & 2.18 & 10.68 & 9.30 & 24.0 & 8.84 & 23.2 \\
\hline Mar & 6.79 & 19.6 & 3.24 & 2.19 & 7.65 & 6.79 & 19.1 & 6.32 & 18.5 \\
\hline Apr & 6.65 & 19.2 & 3.40 & 2.06 & 7.51 & 6.61 & 18.7 & 6.27 & 19.6 \\
\hline May & 6.15 & 17.9 & 2.95 & 2.18 & 6.93 & 6.09 & 16.5 & 5.55 & 17.6 \\
\hline Jun & 6.06 & 21.9 & 3.41 & 1.88 & 6.84 & 6.09 & 21.3 & 5.77 & 20.6 \\
\hline Jul & 5.97 & 18.3 & 2.94 & 2.14 & 6.75 & 5.85 & 17.9 & 5.68 & 17.5 \\
\hline Aug & 6.93 & 25.5 & 4.47 & 1.66 & 7.80 & 6.74 & 25.8 & 6.58 & 25.0 \\
\hline Sep & 8.89 & 21.1 & 3.41 & 2.82 & 9.96 & 8.72 & 20.1 & 8.53 & 19.7 \\
\hline Oct & 6.54 & 25.5 & 3.85 & 1.80 & 7.38 & 6.47 & 25.2 & 6.06 & 25.3 \\
\hline Nov & 6.45 & 21.2 & 3.45 & 1.94 & 7.27 & 6.45 & 20.5 & 5.92 & 20.9 \\
\hline Dec & 7.74 & 19.0 & 3.43 & 2.40 & 8.73 & 7.81 & 20.9 & 7.04 & 18.7 \\
\hline Annua & 6.94 & 25.5 & 3.72 & 1.96 & 7.83 & 6.88 & 25.8 & 6.47 & 25.3 \\
\hline
\end{tabular}

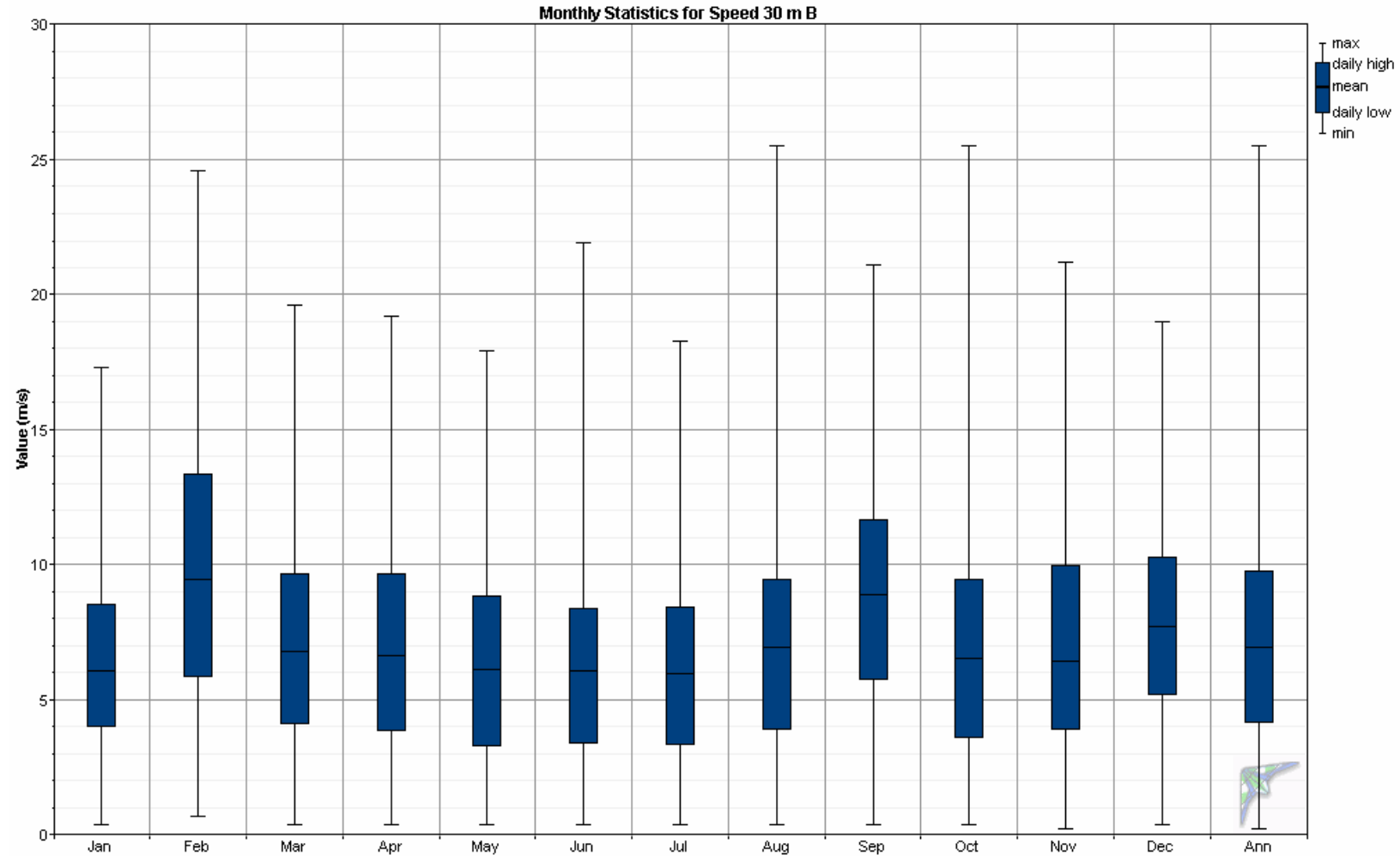

Daily Wind Profile 
The daily wind profile indicates that the lowest wind speeds of the day occur in the morning hours of 8 a.m. to $11 \mathrm{a}$ am. and the highest wind speeds of the day occur during the afternoon and evening hours of 5 p.m. to 9 p.m. The daily variation of wind speed is minimal on an annual basis, but as shown below, more pronounced on a monthly basis.
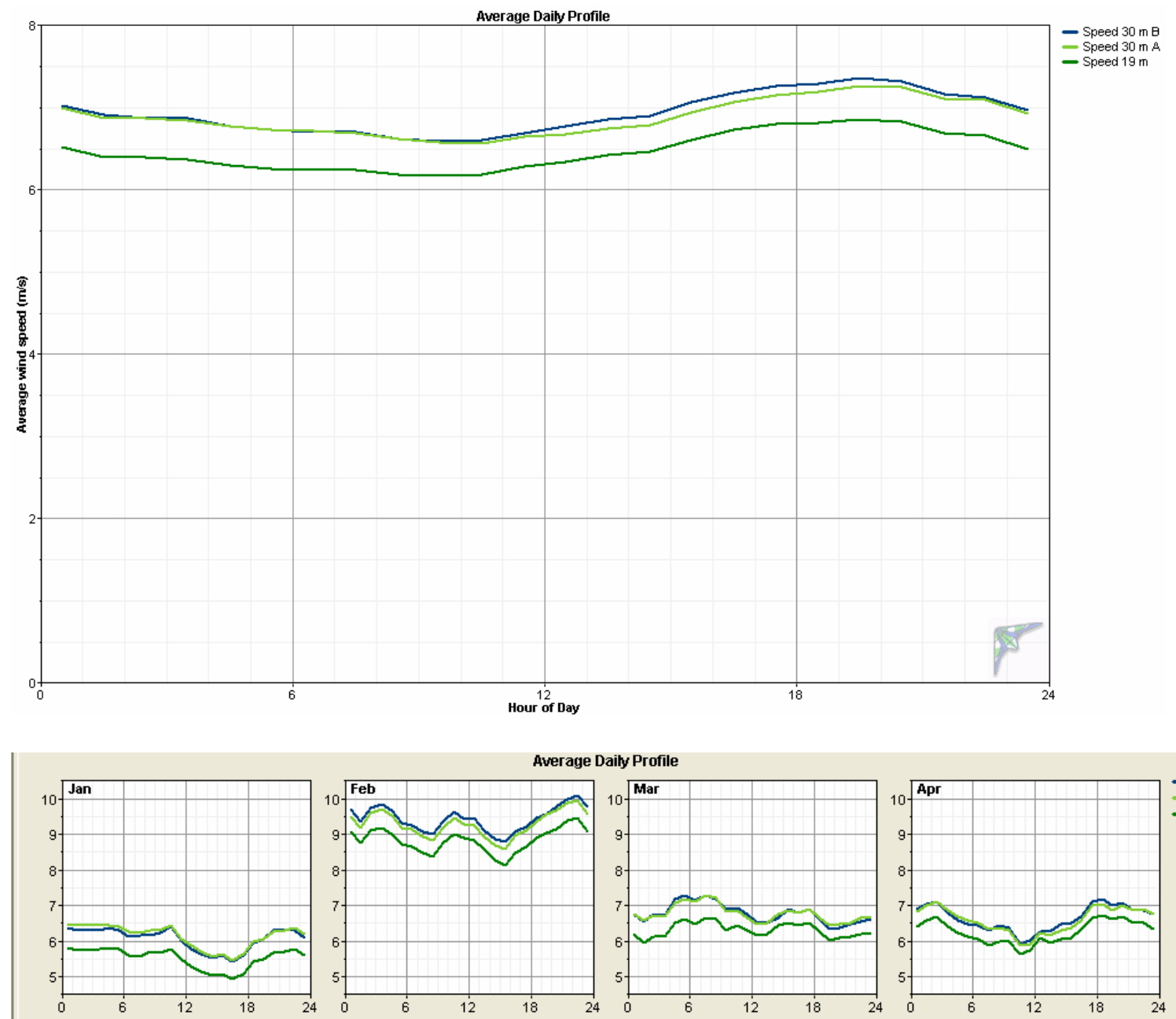

- Speed $30 \mathrm{mB}$ - Speed $30 \mathrm{~mA}$
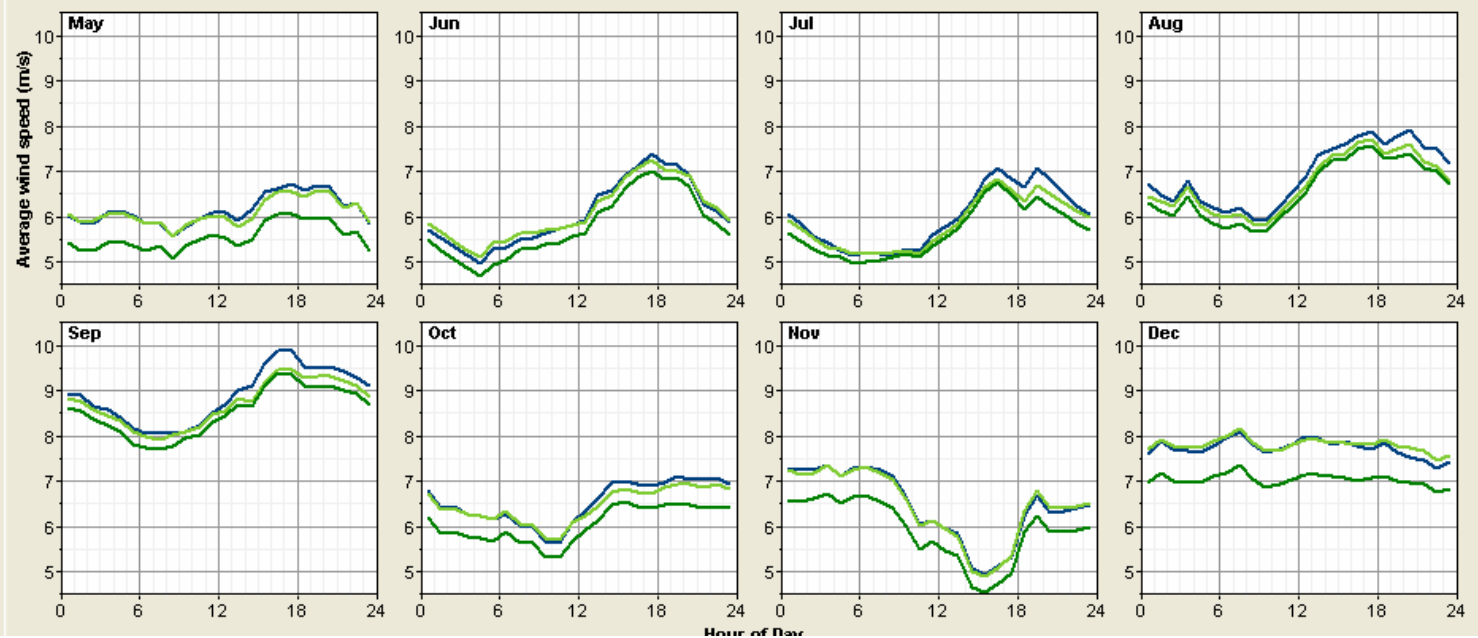


\section{Time Series of Wind Speed Monthly Averages}

Typically, Clark's Point's highest winds occur during the fall and winter months of September through March with the lowest winds during the spring-summer-autumn months of April through August. The unusually low winds measured in January 2006 were due to a persistent high pressure system over Alaska that month that yielded calm winds and extremely cold weather Statewide. Had the January winds been higher and more representative of a typical year, it is expected that the wind power average for this site would be higher, possibly in the low Class 5 range.

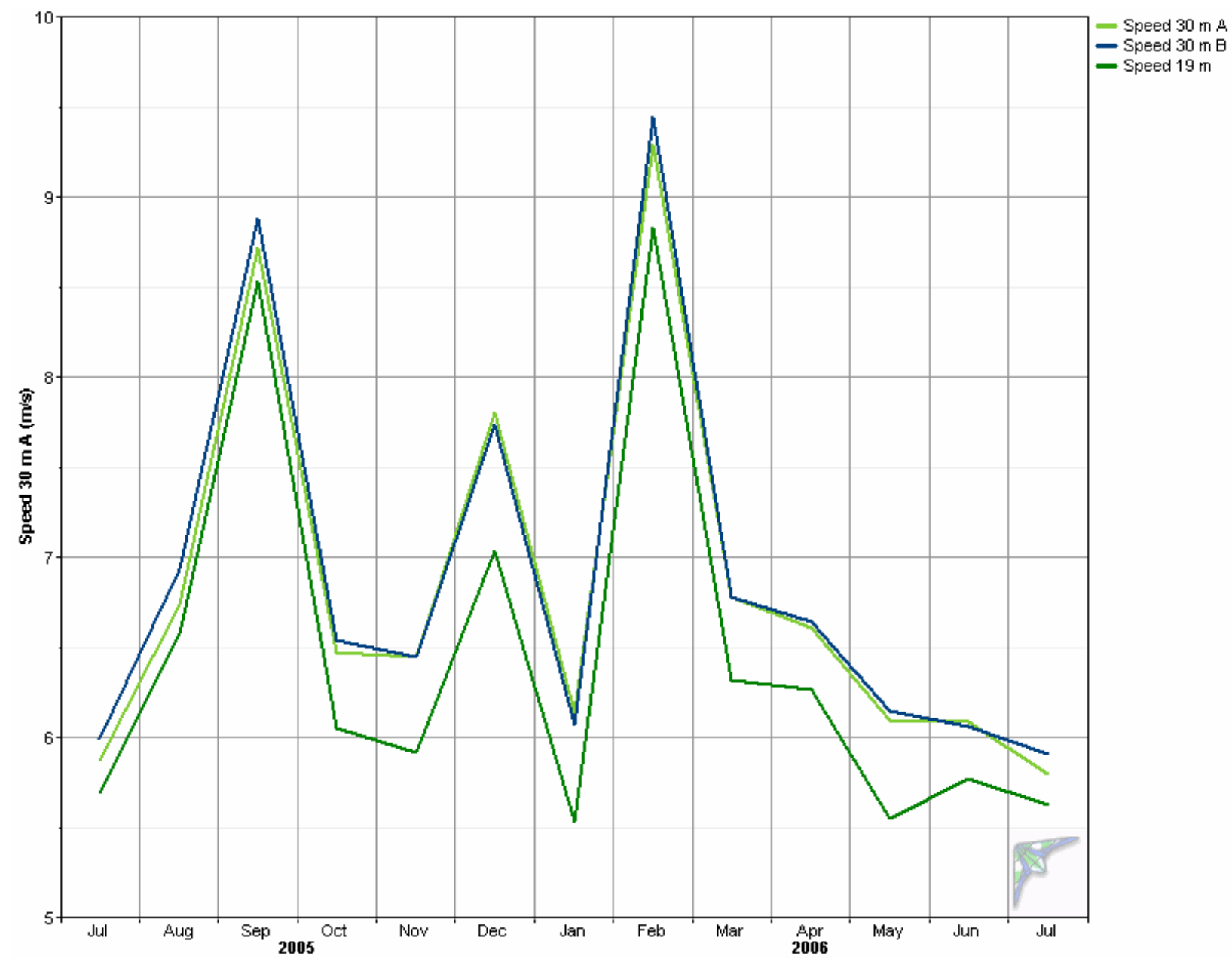




\section{Wind Shear Profile}

The power law exponent was calculated at 0.143 indicating moderate wind shear at the Clark's Point test site. The practical application of this data is that a higher turbine tower height is advantageous there will be an appreciable gain in wind speed/power recovery with additional height. A tower height/power recovery/construction cost tradeoff study is advisable.
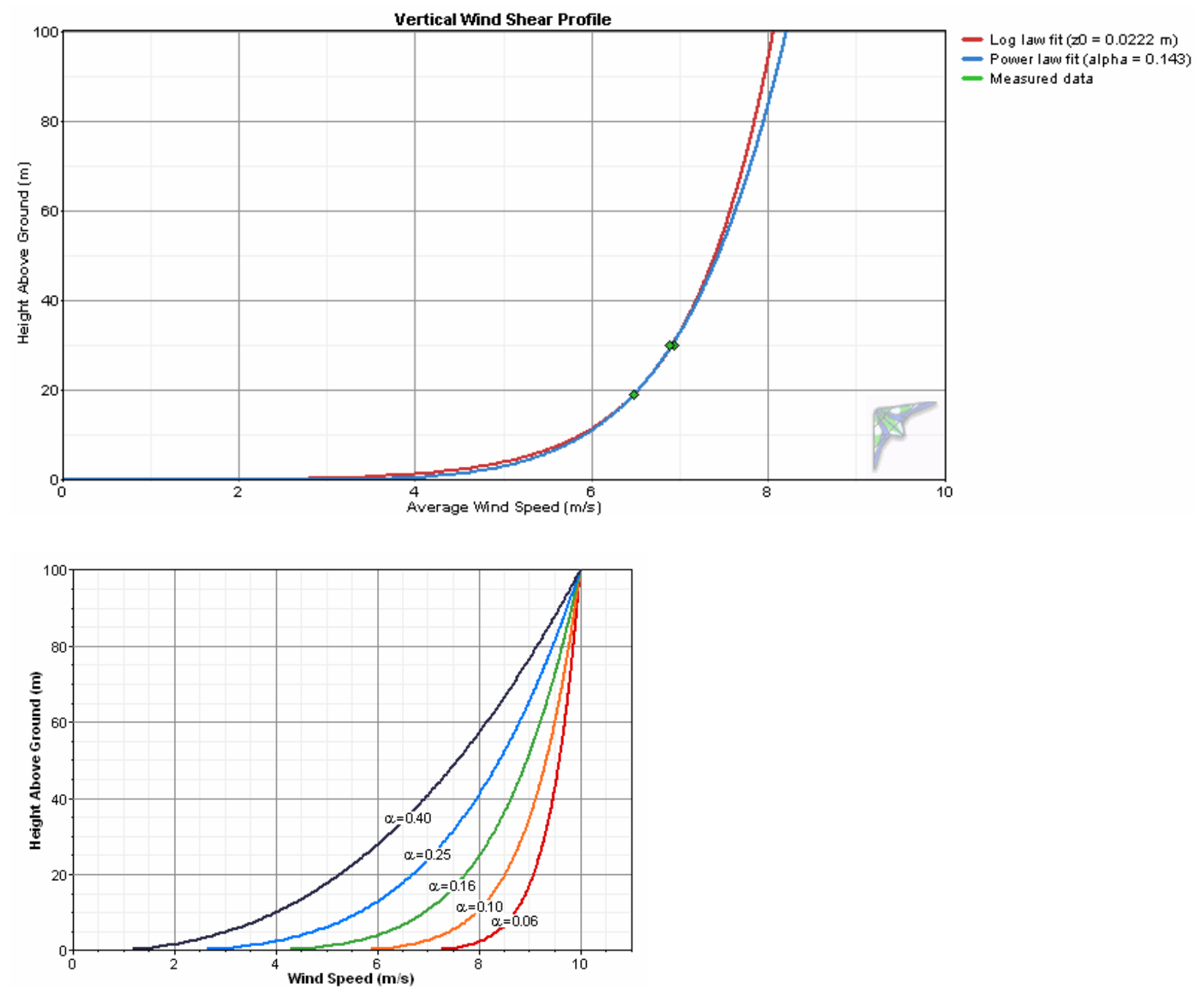
Clark’s Point, Alaska Wind Resource Report
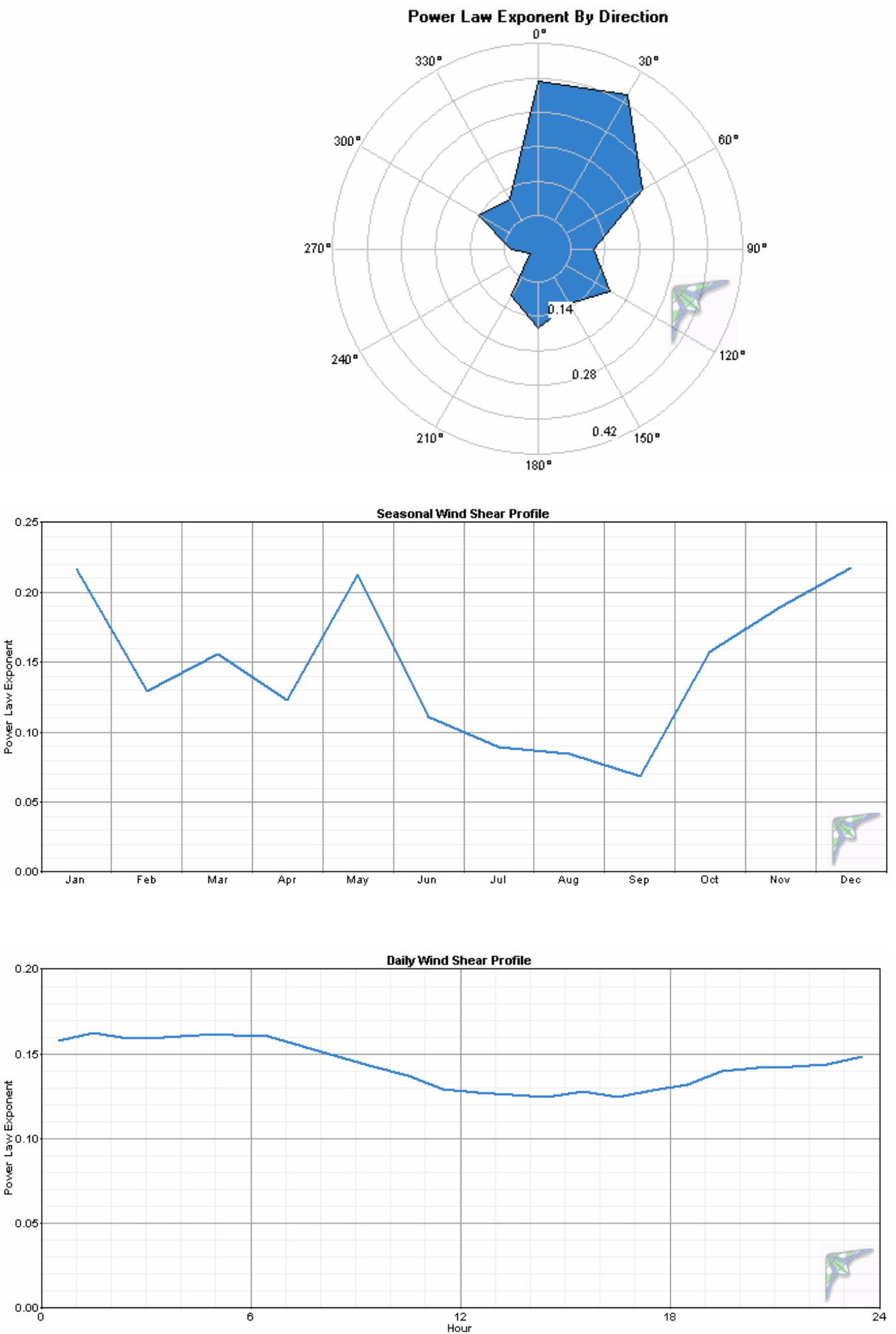


\section{Probability Distribution Function}

The probability distribution function provides a visual indication of measured wind speeds in one meter per second "bins". Note that most wind turbines do not begin to generate power until the wind speed at hub height reaches $4 \mathrm{~m} / \mathrm{s}$. The black line in the graph is a best fit Weibull distribution. At the 30 meter level, Weibull parameters are $\mathrm{k}=2.01$ (indicates a broad distribution of wind speeds) and c $=7.77 \mathrm{~m} / \mathrm{s}$ (a scale factor for the Weibull distribution). The PDF information is shown visually in another manner in the second graph, the cumulative distribution function.
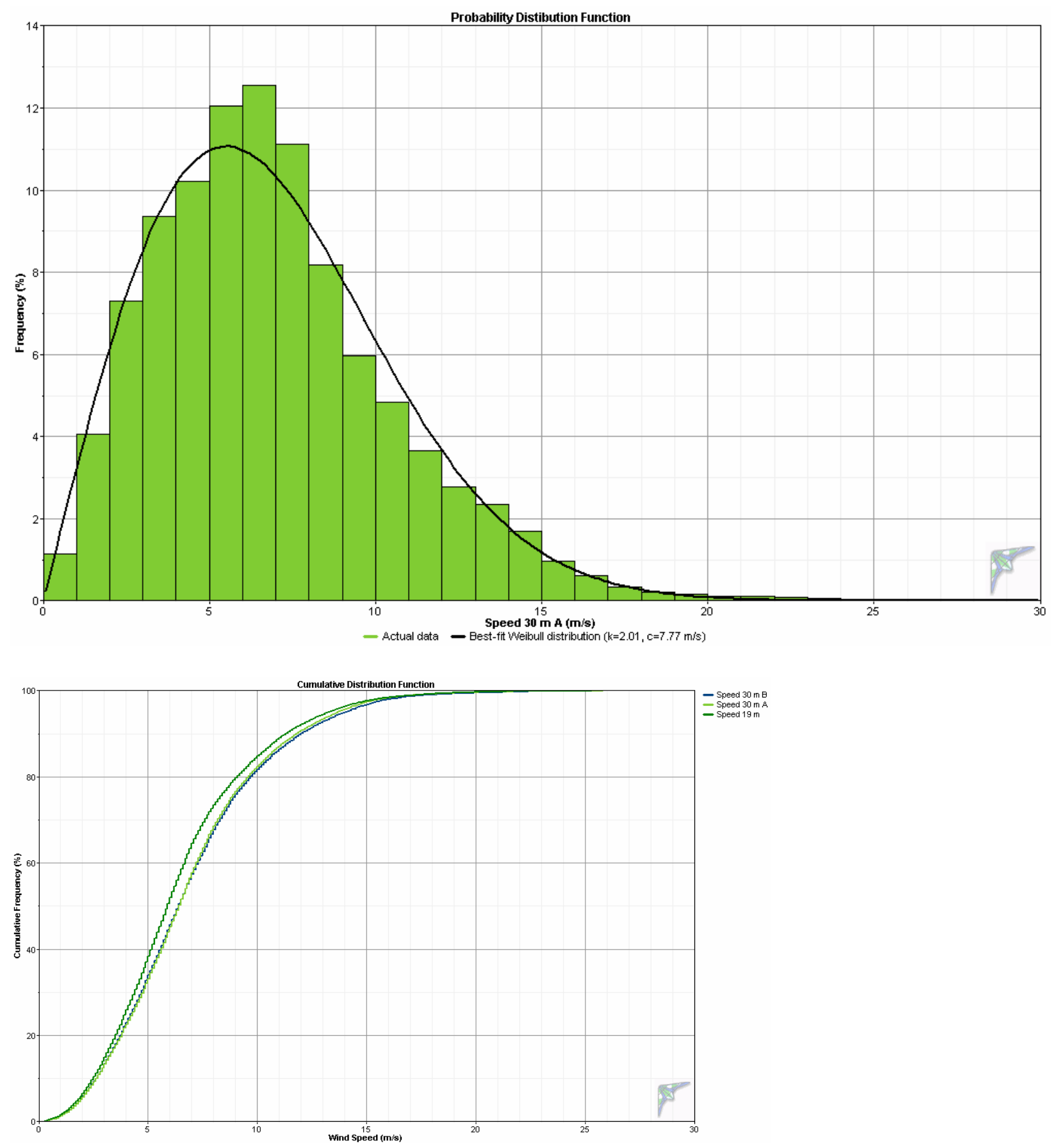


\section{Wind Roses}

Clark's Point winds are rather directional; the wind frequency rose indicates northeast and westerly wind. This observation is reinforced with reference to the power density rose below. Power producing winds are chiefly also northeast and west, although infrequent but powerful southeast winds characterize the wind power density rose. The practical application of this information is that a site should be selected with adequate freedom from ground interference in especially northeast, west and southeast directions and if more than one wind turbine is installed, the turbines should be adequately spaced apart to prevent downwind (from the power producing winds) interference problems between the turbines. The indication below of 23 percent calm winds is calculated with a $4 \mathrm{~m} / \mathrm{s}$ wind speed threshold, the typical cut-in speed of wind turbines.

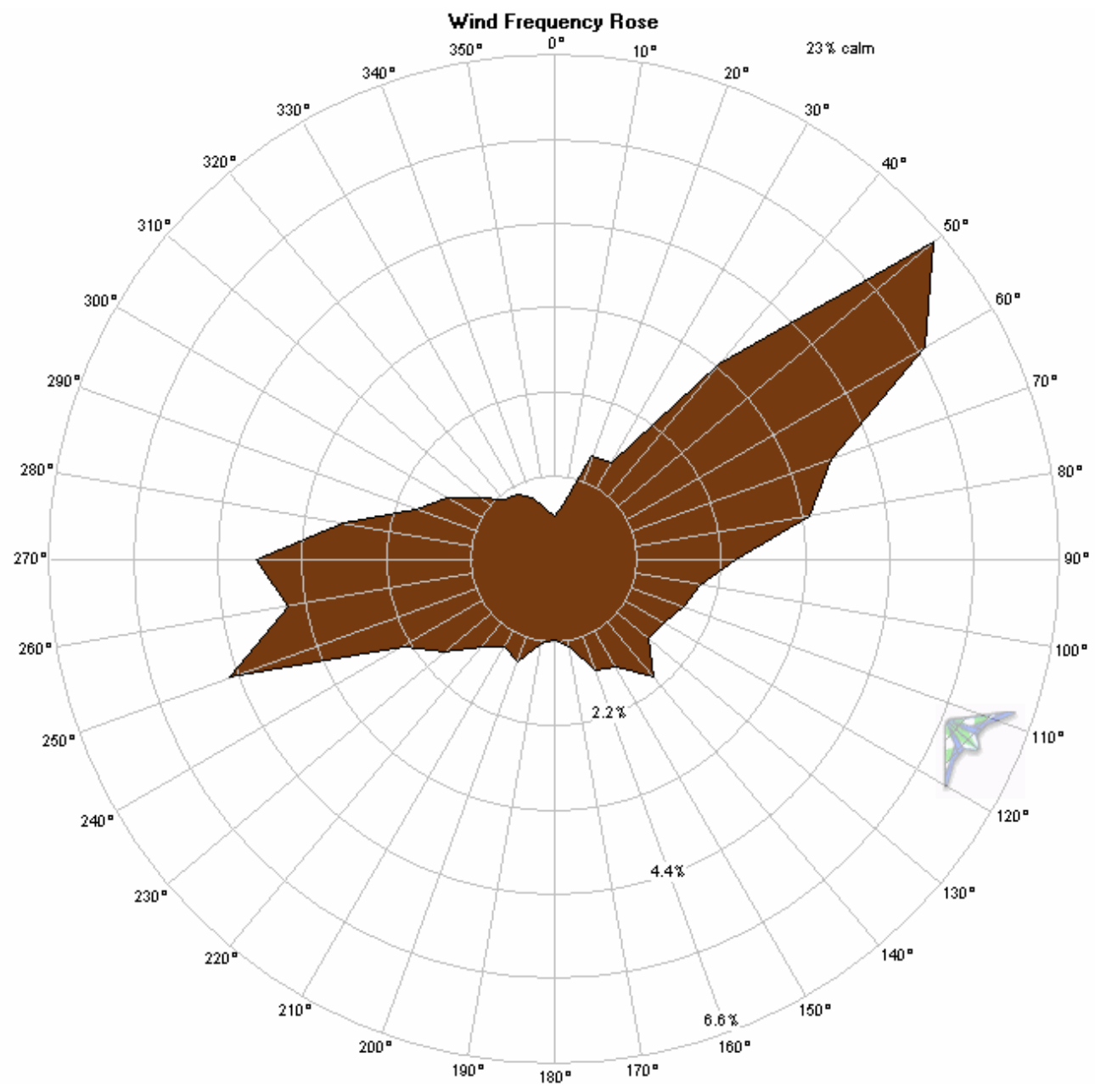


Clark’s Point, Alaska Wind Resource Report

Wind Power Density Rose (30 meters)

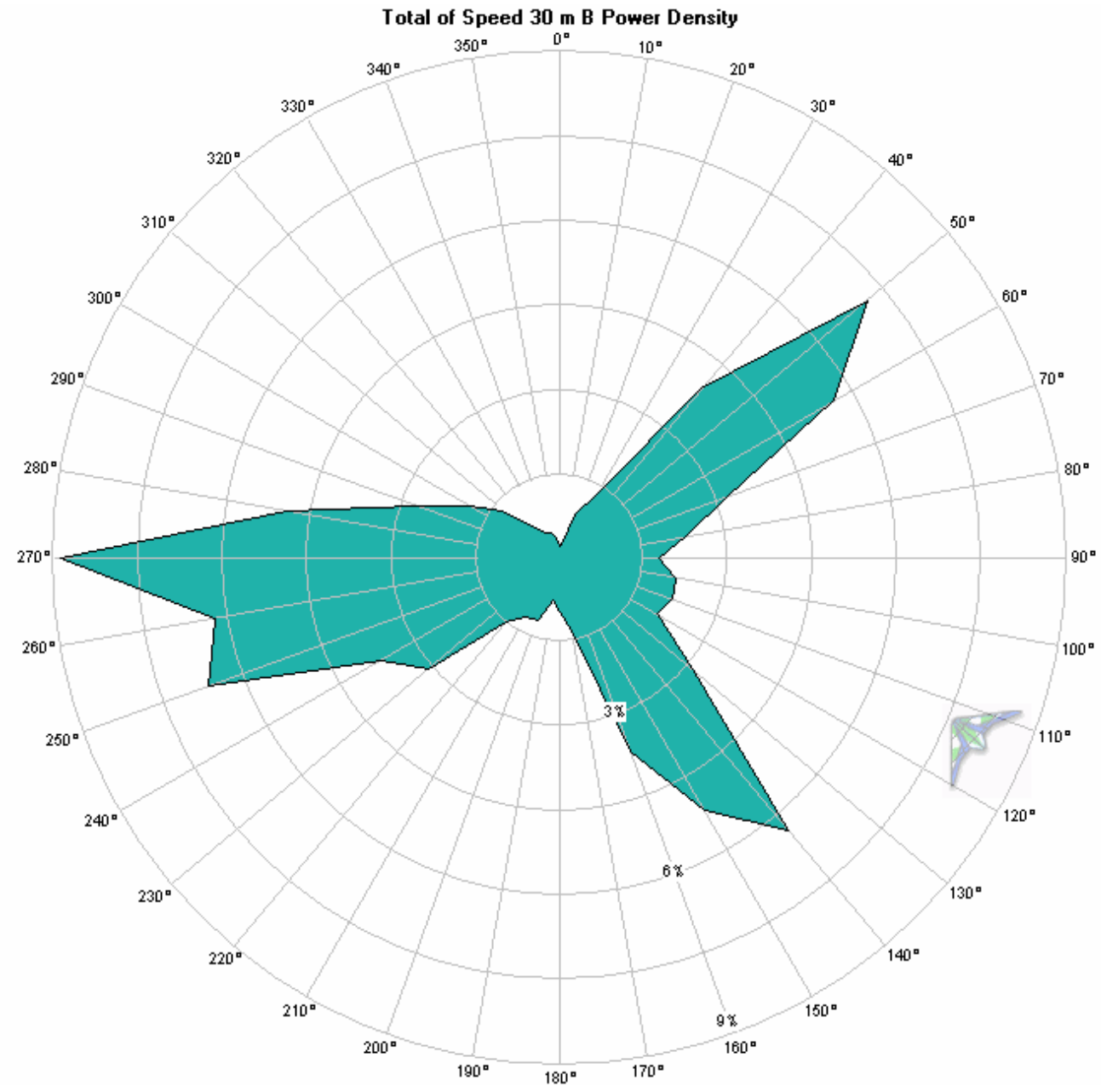

Wind Power Density Rose by Month (30 meters)

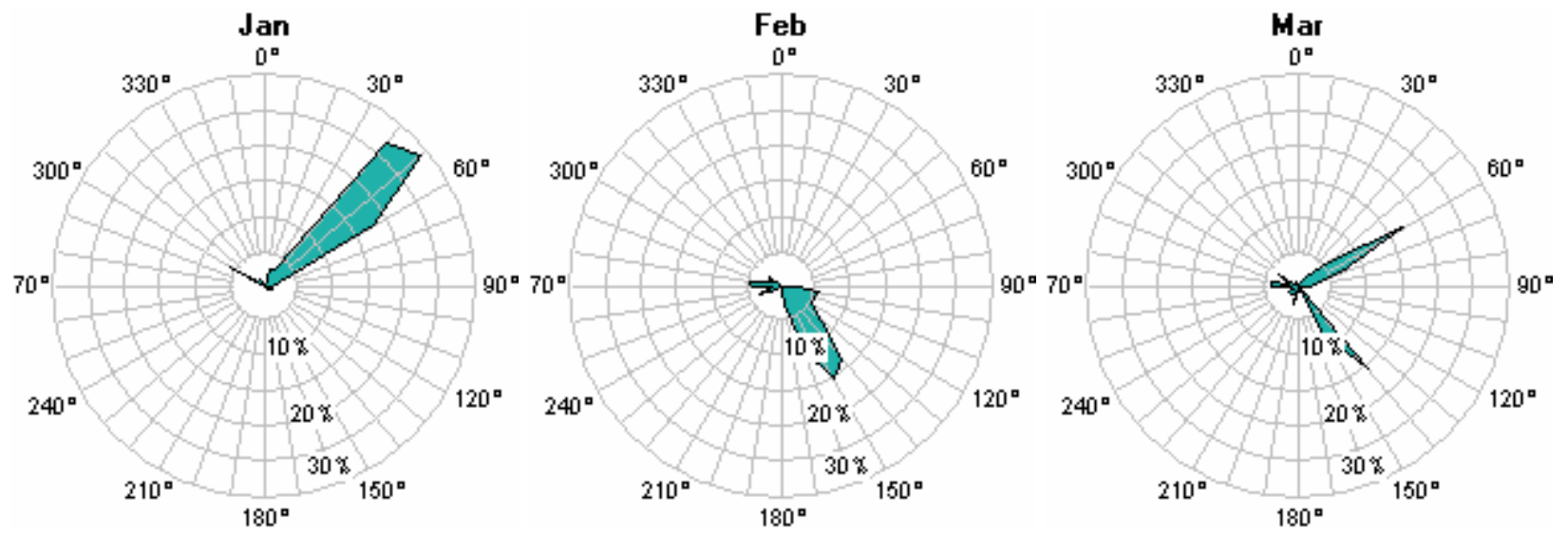




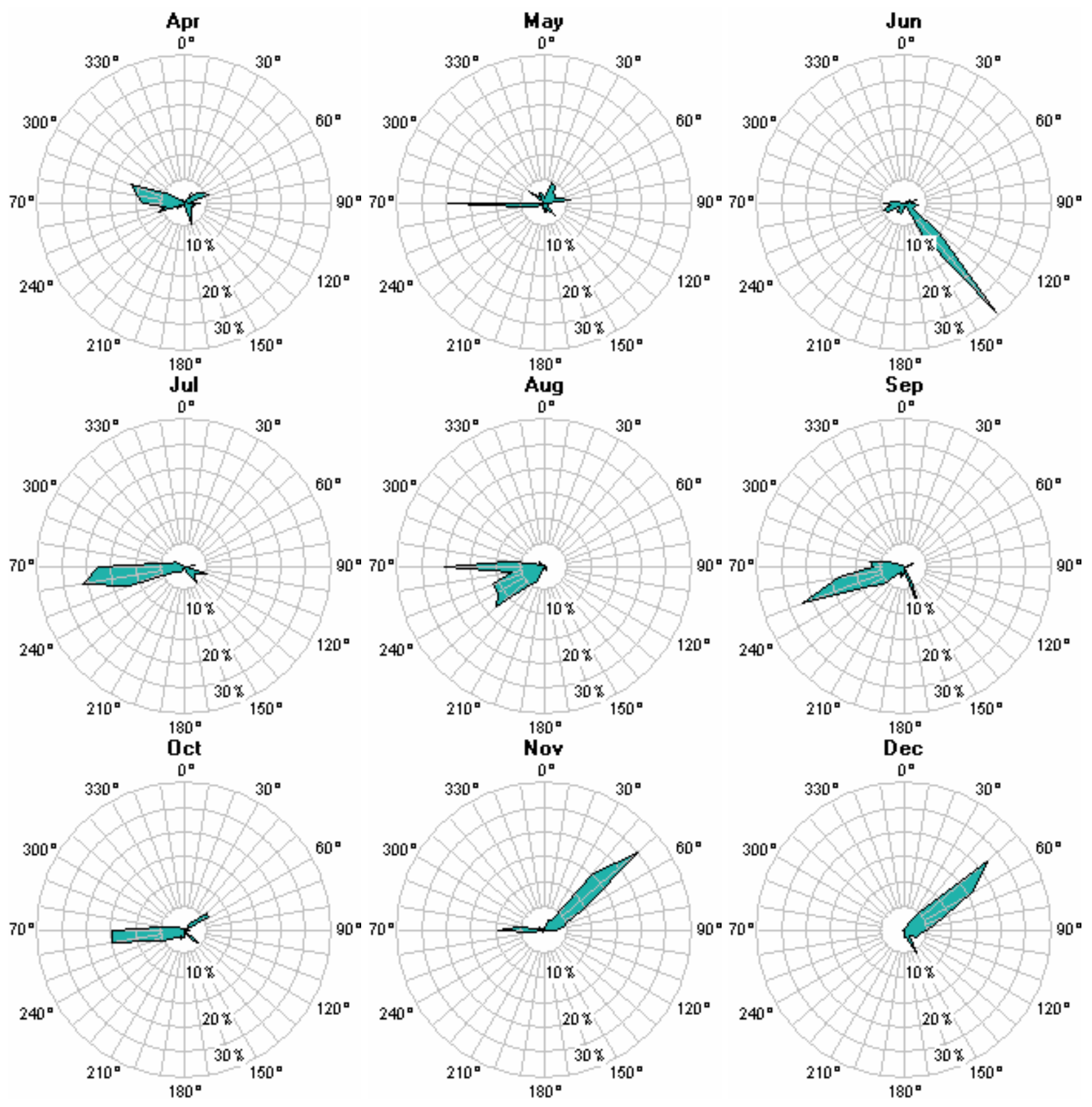




\section{Turbulence Intensity}

The turbulence intensity (TI) is acceptable for all wind direction, with a mean turbulence intensity of 0.0942 (30 meter A) and 0.0954 (30 meter B), indicating relatively smooth air. These TIs are calculated with a threshold wind speed of $4 \mathrm{~m} / \mathrm{s}$. The spike of relatively high turbulence to the north to northeast in both graphs may be due to the presence of two old water tanks located several hundred meters north of the met tower test site and heavy brush and higher terrain both north and northeast of the met tower location, but it is relatively unimportant at NNE is an infrequent wind direction.

30 meter (A) Turbulence Intensity

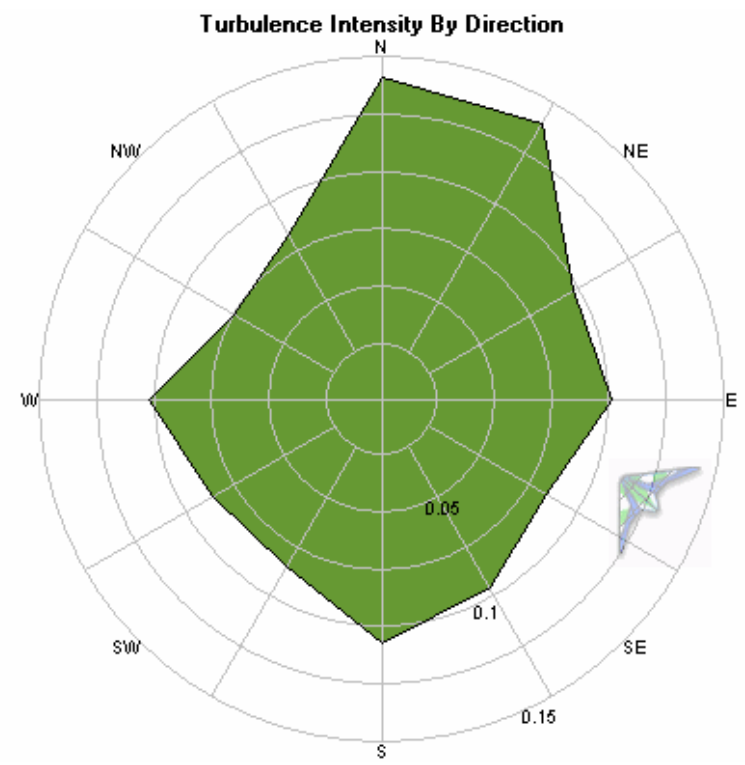

30 meter (B) Turbulence Intensity

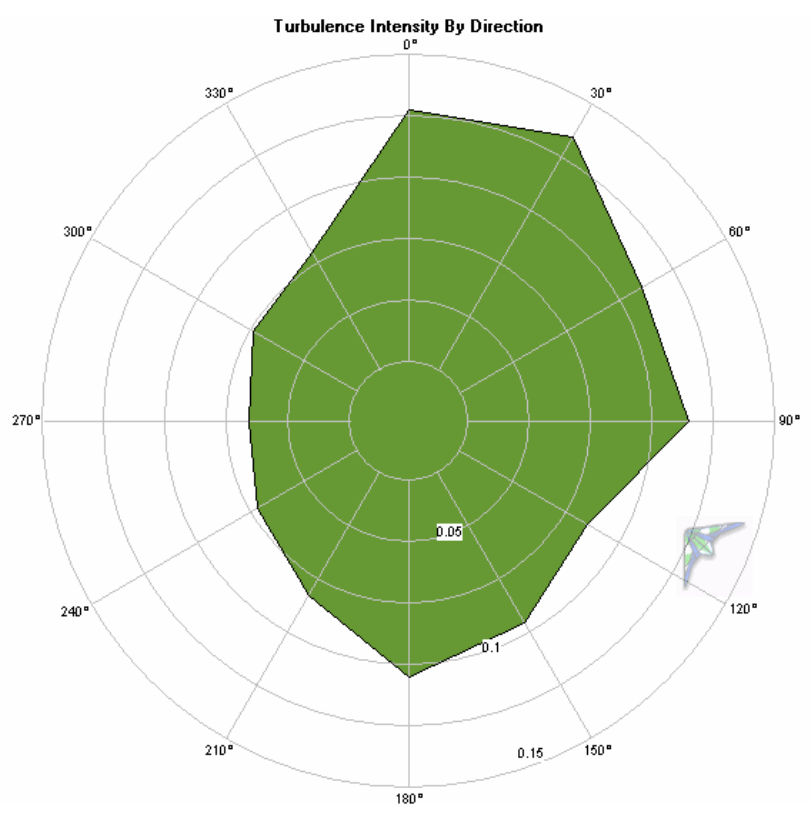


IEC Turbulence Intensity Standards

As indicated below, turbulence at the Clark's Point project test site is well below International Electrotechnical Commission (IEC) standards at all measured wind speeds and from all four quadrants of the wind rose. The somewhat high turbulence in the $315^{\circ}$ to $45^{\circ}$ sector is not so important as the wind rarely blows from this quadrant.
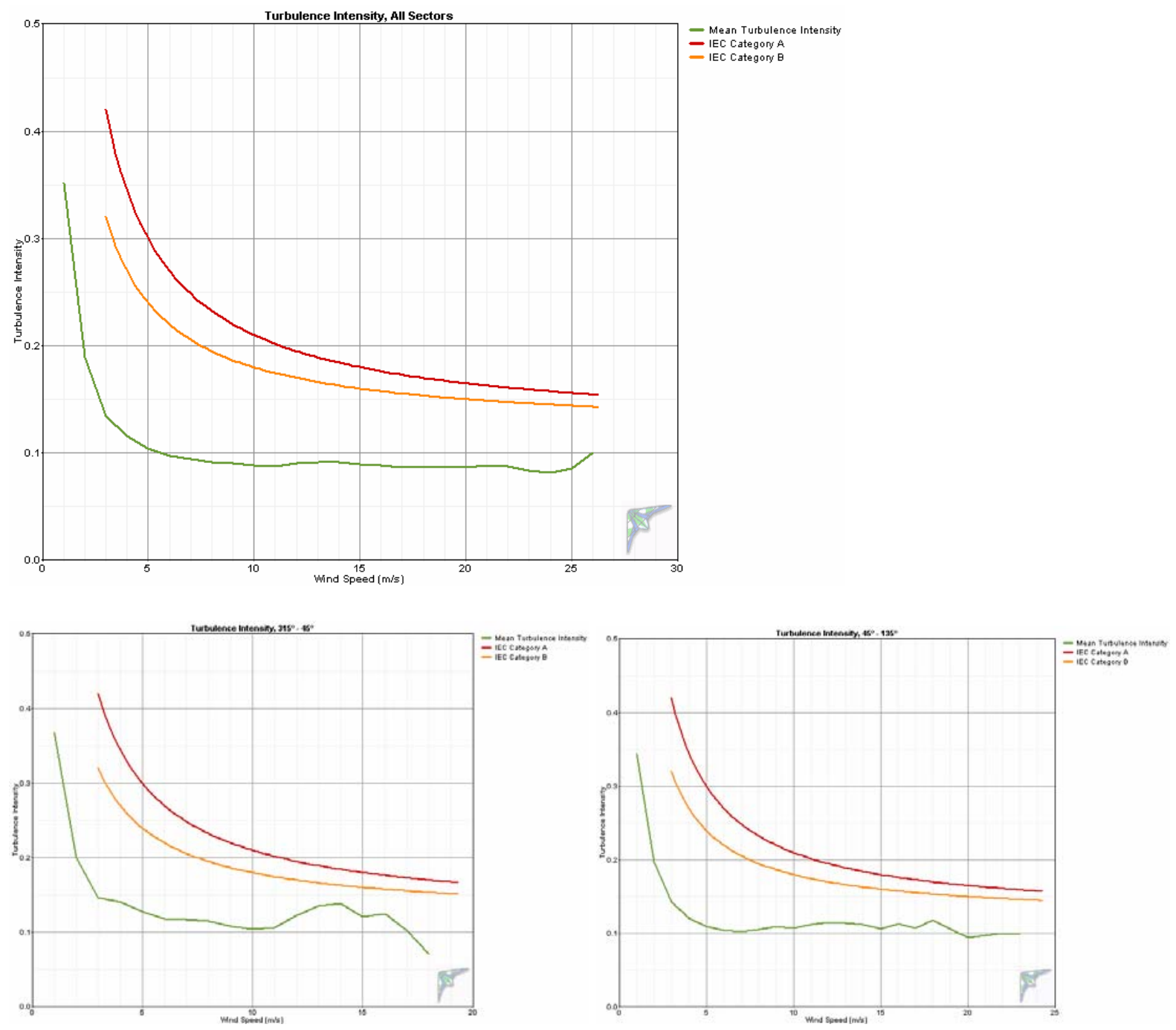
Clark’s Point, Alaska Wind Resource Report
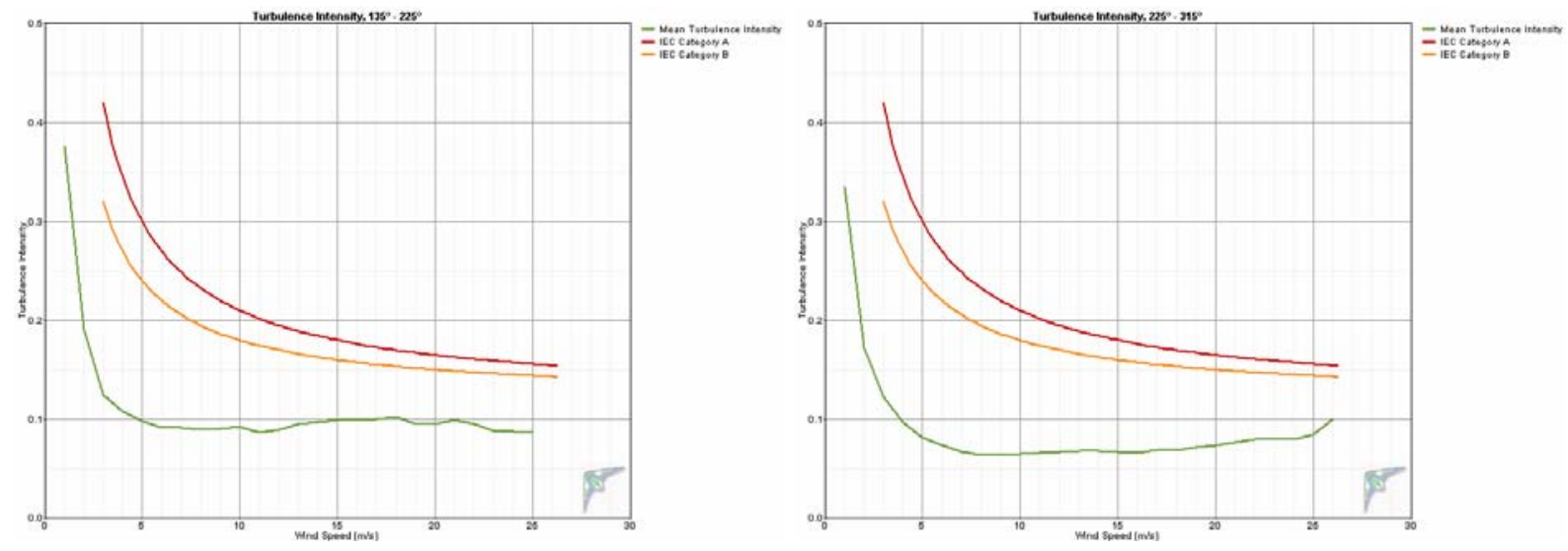

Turbulence Table

\begin{tabular}{cccccccc}
$\begin{array}{c}\text { Bin } \\
\text { Midpoint } \\
(\mathrm{m} / \mathrm{s})\end{array}$ & $\begin{array}{c}\text { Bin Endpoints } \\
\text { Lower } \\
(\mathrm{m} / \mathrm{s})\end{array}$ & $\begin{array}{c}\text { Upper } \\
(\mathrm{m} / \mathrm{s})\end{array}$ & $\begin{array}{c}\text { Records } \\
\text { In }\end{array}$ & $\begin{array}{c}\text { Sin } \\
\text { Bindard Devia- } \\
\text { tion } \\
\text { of Wind Speed } \\
(\mathrm{m} / \mathrm{s})\end{array}$ & $\begin{array}{c}\text { Mean } \\
\text { Turbulence } \\
\text { Intensity }\end{array}$ & $\begin{array}{c}\text { Standard Devia- } \\
\text { tion } \\
\text { of Turbulence } \\
\text { Intensity }\end{array}$ & $\begin{array}{c}\text { Characteristic } \\
\text { Turbulence } \\
\text { Intensity }\end{array}$ \\
\hline 1 & 0.5 & 1.5 & 1294 & 0.342 & 0.352 & 0.169 & 0.521 \\
2 & 1.5 & 2.5 & 3152 & 0.372 & 0.189 & 0.094 & 0.283 \\
3 & 2.5 & 3.5 & 4590 & 0.398 & 0.135 & 0.068 & 0.203 \\
4 & 3.5 & 4.5 & 5360 & 0.458 & 0.116 & 0.059 & 0.175 \\
5 & 4.5 & 5.5 & 6051 & 0.514 & 0.104 & 0.054 & 0.158 \\
6 & 5.5 & 6.5 & 6473 & 0.580 & 0.097 & 0.049 & 0.147 \\
7 & 6.5 & 7.5 & 5940 & 0.657 & 0.095 & 0.048 & 0.143 \\
8 & 7.5 & 8.5 & 5134 & 0.728 & 0.092 & 0.045 & 0.137 \\
9 & 8.5 & 9.5 & 3830 & 0.807 & 0.091 & 0.042 & 0.133 \\
10 & 9.5 & 10.5 & 2862 & 0.883 & 0.089 & 0.038 & 0.127 \\
11 & 10.5 & 11.5 & 2223 & 0.958 & 0.088 & 0.038 & 0.126 \\
12 & 11.5 & 12.5 & 1759 & 1.085 & 0.091 & 0.036 & 0.127 \\
13 & 12.5 & 13.5 & 1358 & 1.188 & 0.092 & 0.034 & 0.126 \\
14 & 13.5 & 14.5 & 1064 & 1.269 & 0.091 & 0.032 & 0.123 \\
15 & 14.5 & 15.5 & 856 & 1.337 & 0.090 & 0.029 & 0.119 \\
16 & 15.5 & 16.5 & 492 & 1.414 & 0.089 & 0.029 & 0.118 \\
17 & 16.5 & 17.5 & 320 & 1.454 & 0.086 & 0.025 & 0.111 \\
18 & 17.5 & 18.5 & 162 & 1.544 & 0.086 & 0.025 & 0.111 \\
19 & 18.5 & 19.5 & 103 & 1.637 & 0.087 & 0.021 & 0.108 \\
20 & 19.5 & 20.5 & 83 & 1.719 & 0.086 & 0.018 & 0.104 \\
21 & 20.5 & 21.5 & 73 & 1.852 & 0.088 & 0.017 & 0.106 \\
22 & 21.5 & 22.5 & 77 & 1.922 & 0.088 & 0.014 & 0.102 \\
23 & 22.5 & 23.5 & 51 & 1.906 & 0.083 & 0.013 & 0.096 \\
24 & 23.5 & 24.5 & 28 & 1.957 & 0.082 & 0.016 & 0.098 \\
25 & 24.5 & 25.5 & 8 & 2.112 & 0.085 & 0.018 & 0.104 \\
26 & 25.5 & 26.5 & 2 & 2.550 & 0.100 & 0.014 & 0.114
\end{tabular}




\section{Air Temperature and Density}

Over the reporting period, Clark's Point had an average temperature of $3.7^{\circ} \mathrm{C}$. The minimum recorded temperature during the measurement period was $-29.1^{\circ} \mathrm{C}$ and the maximum temperature was $28.0^{\circ} \mathrm{C}$, indicating a wide variability of the ambient temperature operating environment important to wind turbine operations. Consequent to Clark's Point's cool temperatures, the average air density of $1.271 \mathrm{~kg} / \mathrm{m}^{3}$ is approximately four percent higher than the standard air density of $1.225 \mathrm{~kg} / \mathrm{m}^{3}$ (at $15.01^{\circ} \mathrm{C}$ temperature and $101.29 \mathrm{kPa}$ pressure), indicating that Clark's Point, due to its cool annual temperature average, has denser air than the standard air density used to calculate turbine power curves.

\begin{tabular}{|c|c|c|c|c|c|c|c|}
\hline \multirow[b]{2}{*}{ Month } & \multicolumn{4}{|c|}{ Temperature } & \multicolumn{3}{|c|}{ Density } \\
\hline & $\begin{array}{c}\text { Mean } \\
\left({ }^{\circ} \mathrm{C}\right)\end{array}$ & $\begin{array}{l}\text { Min } \\
\left({ }^{\circ} \mathrm{C}\right)\end{array}$ & $\begin{array}{l}\operatorname{Max} \\
\left({ }^{\circ} \mathrm{C}\right)\end{array}$ & $\begin{array}{l}\text { Sta. } \\
\text { Dev. } \\
\left({ }^{\circ} \mathrm{C}\right)\end{array}$ & $\begin{array}{c}\text { Mean } \\
\left(\mathrm{kg} / \mathrm{m}^{3}\right)\end{array}$ & $\begin{array}{c}\text { Min } \\
\left(\mathrm{kg} / \mathrm{m}^{3}\right)\end{array}$ & $\begin{array}{c}\operatorname{Max} \\
\left(\mathrm{kg} / \mathrm{m}^{3}\right)\end{array}$ \\
\hline Jan & -12.7 & -29.1 & 1.2 & 8.00 & 1.350 & 1.280 & 1.439 \\
\hline Feb & -2.5 & -28.0 & 4.7 & 7.08 & 1.299 & 1.264 & 1.433 \\
\hline Mar & -4.5 & -18.4 & 4.0 & 4.65 & 1.308 & 1.267 & 1.379 \\
\hline Apr & 0.3 & -9.7 & 7.7 & 3.12 & 1.285 & 1.251 & 1.333 \\
\hline May & 8.6 & -1.4 & 28.0 & 6.03 & 1.247 & 1.166 & 1.292 \\
\hline Jun & 12.4 & 4.8 & 22.8 & 3.04 & 1.230 & 1.187 & 1.264 \\
\hline Jul & 16.1 & 8.1 & 24.2 & 2.93 & 1.214 & 1.181 & 1.249 \\
\hline Aug & 16.6 & 9.5 & 26.0 & 2.70 & 1.212 & 1.174 & 1.243 \\
\hline Sep & 11.9 & 3.2 & 17.8 & 2.10 & 1.232 & 1.207 & 1.271 \\
\hline Oct & 4.1 & -9.8 & 12.7 & 4.61 & 1.267 & 1.229 & 1.334 \\
\hline Nov & -7.8 & -24.9 & 4.8 & 5.61 & 1.324 & 1.264 & 1.415 \\
\hline $\mathrm{Dec}$ & -1.8 & -22.9 & 6.1 & 6.18 & 1.295 & 1.258 & 1.403 \\
\hline Annual & 3.7 & -29.1 & 28.0 & 10.62 & 1.271 & 1.166 & 1.439 \\
\hline
\end{tabular}

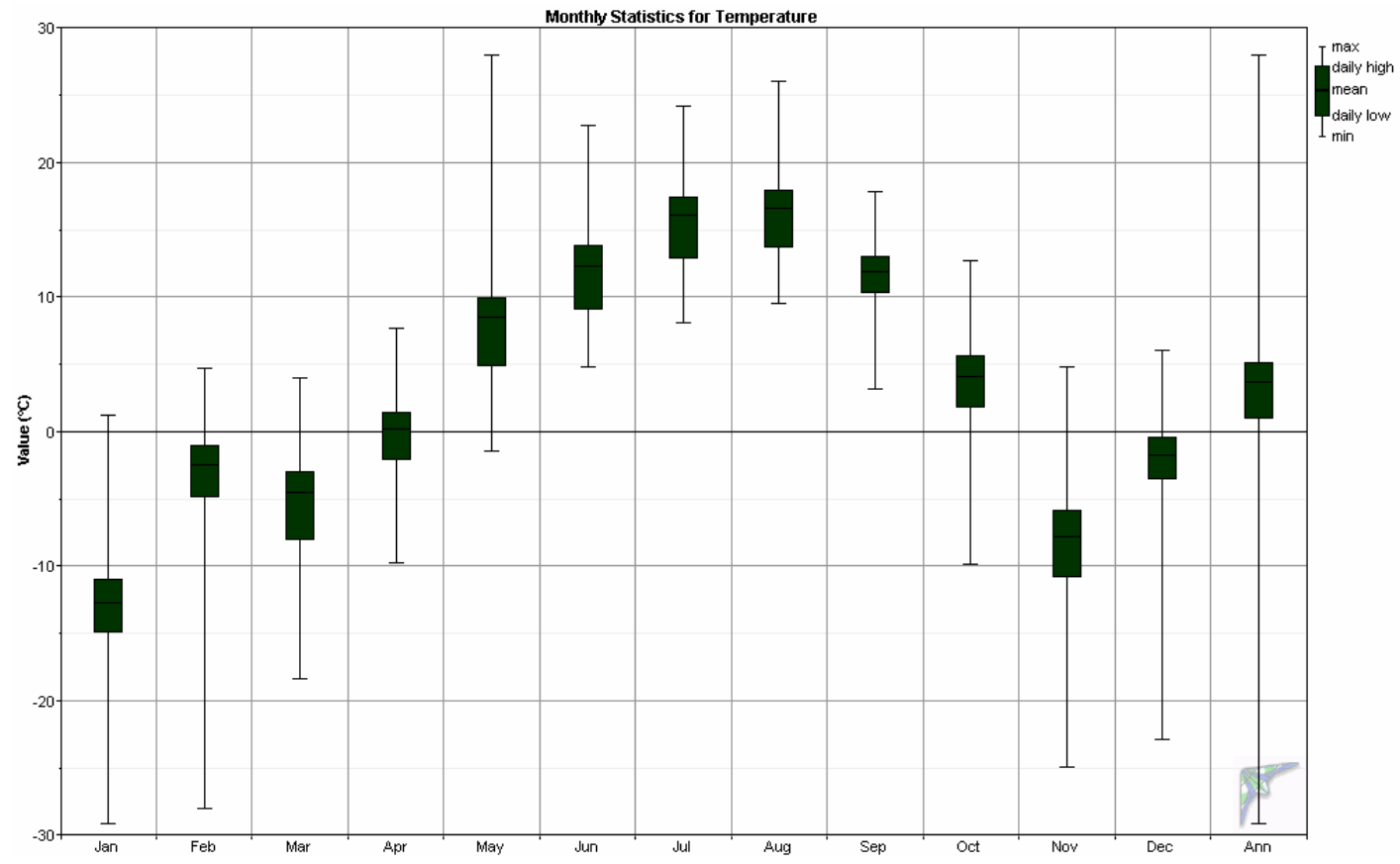




\section{Air Density DMap}

The DMap below is a visual indication of the daily and seasonal variations of air density (and hence temperature). Air densities higher than standard will yield higher turbine power than predicted by the turbine power curve, while densities lower than standard will yield lower turbine power than predicted. Density variance from standard is accounted for in the turbine performance predictions.

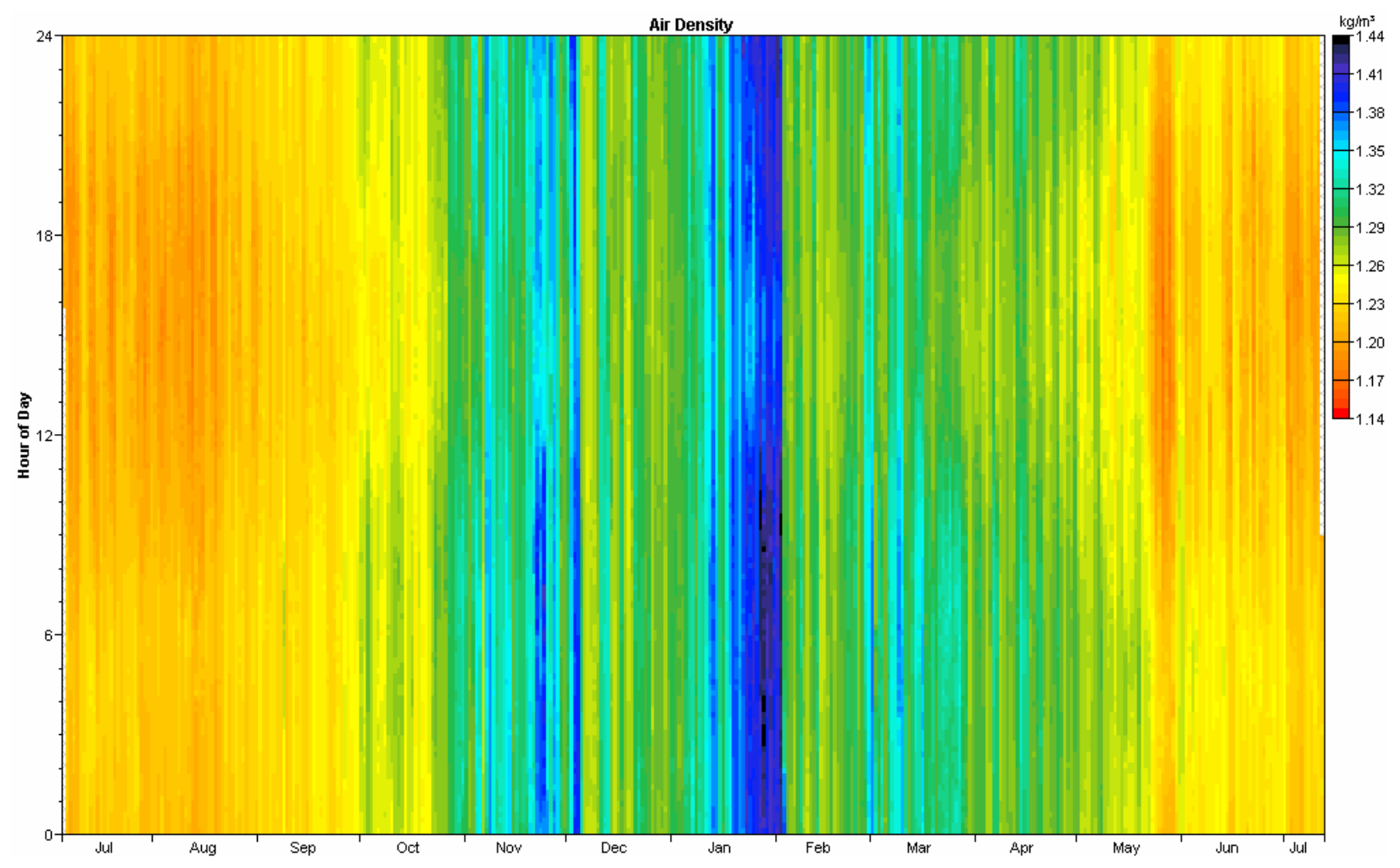




\section{Turbine Performance Predictions}

The turbine performance predictions noted below are based on 100 percent and 90 percent turbine availabilities. The 100 percent data is for use as a baseline of comparison, but it is realistic to expect ten percent or more of losses or downtime for wind turbines located in a small, remote community.

Note that these performance estimates were predicted with use of Windographer ${ }^{\circledR}$ wind analysis software; power curves provided by manufacturers are not independently verified and are assumed to be accurate. The power curves are presented for a standard air density of $1.225 \mathrm{~kg} / \mathrm{m}^{3}$ at sea level and at standard temperature and pressure. However, the predictions of power production are density compensated by multiplying the standard density power output by the ratio of the measured air density to standard air density, accounting for the site elevation.

A number of smaller village-scale grid-connected turbines are profiled in this report for comparison purposes. These turbines were selected because they have market availability and they are deemed to be within a suitable range for consideration of wind power development in a village the size of Clark's Point.

Southwest Skystream 3.7: $1.8 \mathrm{~kW}$ rated power output, 3.7 meter rotor diameter, stallcontrolled. Available tower heights: 10.7 and 33.5 meters. Additional information is available at www.skystreamenergy.com.

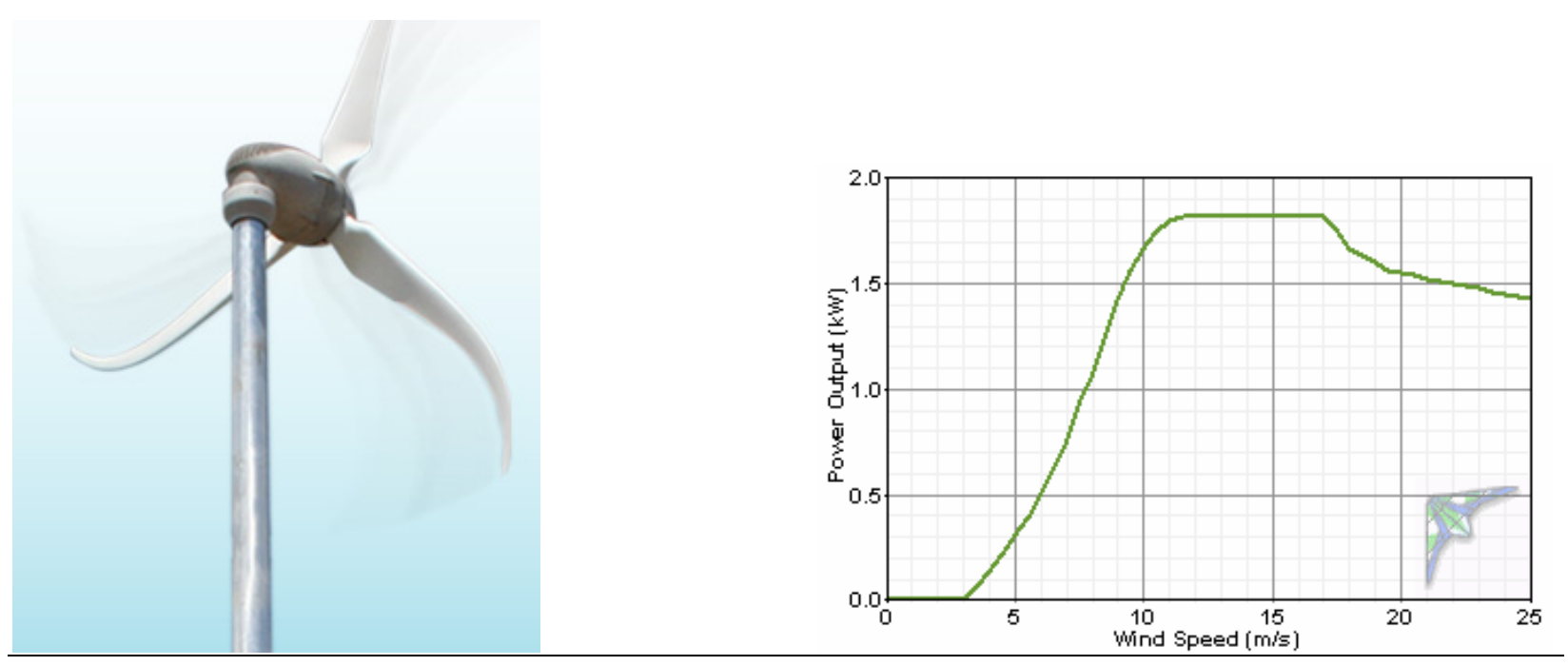

Bergey Excel-S: $10 \mathrm{~kW}$ rated power output, 6.7 meter rotor diameter, stall-controlled. Available tower heights: 18, 24, 30, 37 and 43 meters. Additional information is available at www.bergey.com. 

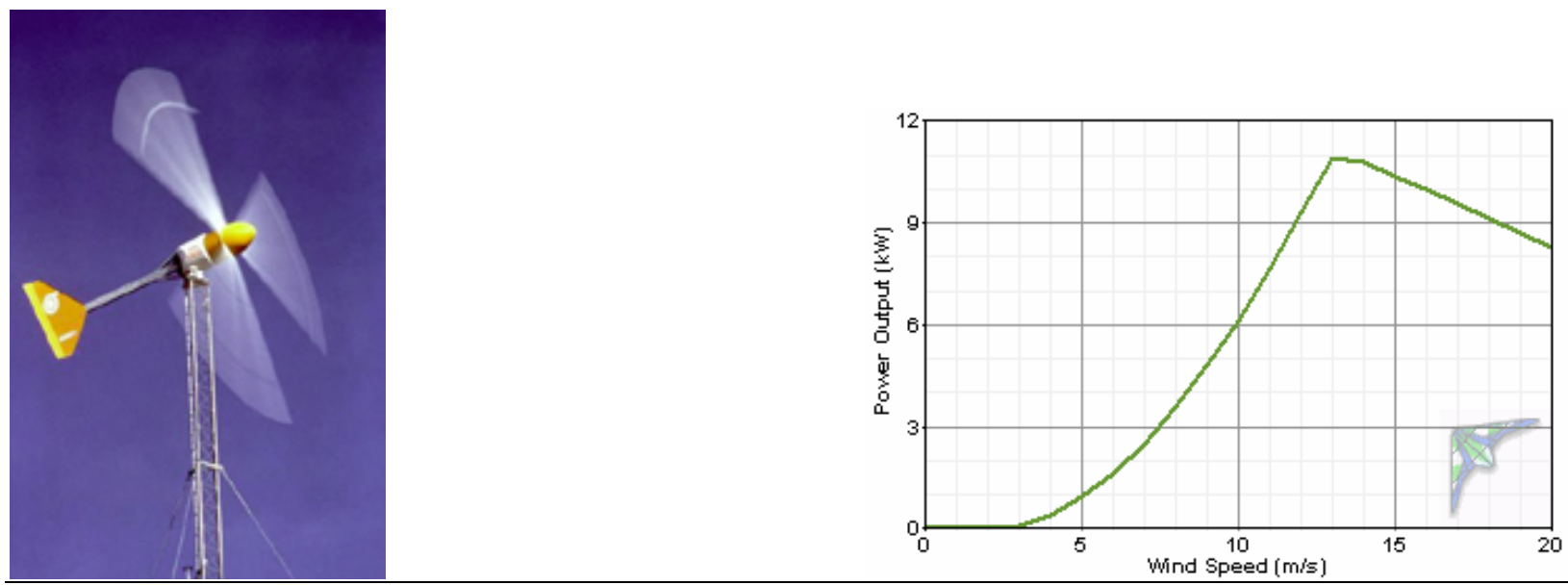

Fuhrländer FL30: $30 \mathrm{~kW}$ rated power output, 13 meter rotor, stall-controlled (power curve provided by Lorax Energy, LLC). Available tower heights: 26 and 30 meters. Additional information is available at http://www.fuhrlaender.de/ and http://www.lorax-energy.com/.
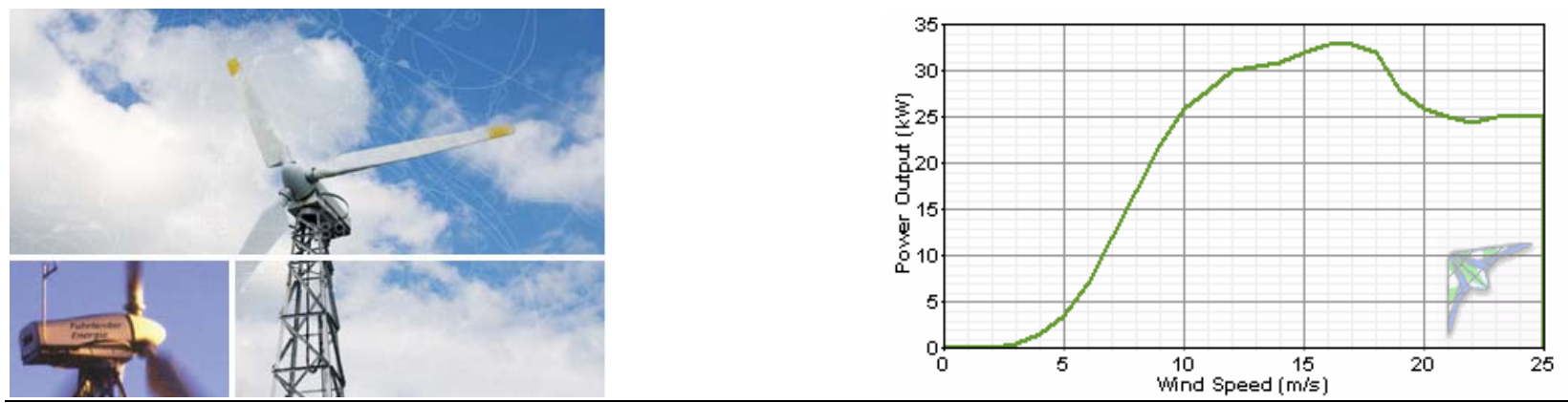

Entegrity eW-15: $65 \mathrm{~kW}$ rated power output, 15 meter rotor, stall-controlled (power curve provided by Entegrity Energy Systems). Available tower heights: 25 and 31 meters. Additional information is available at http://www.entegritywind.com/.
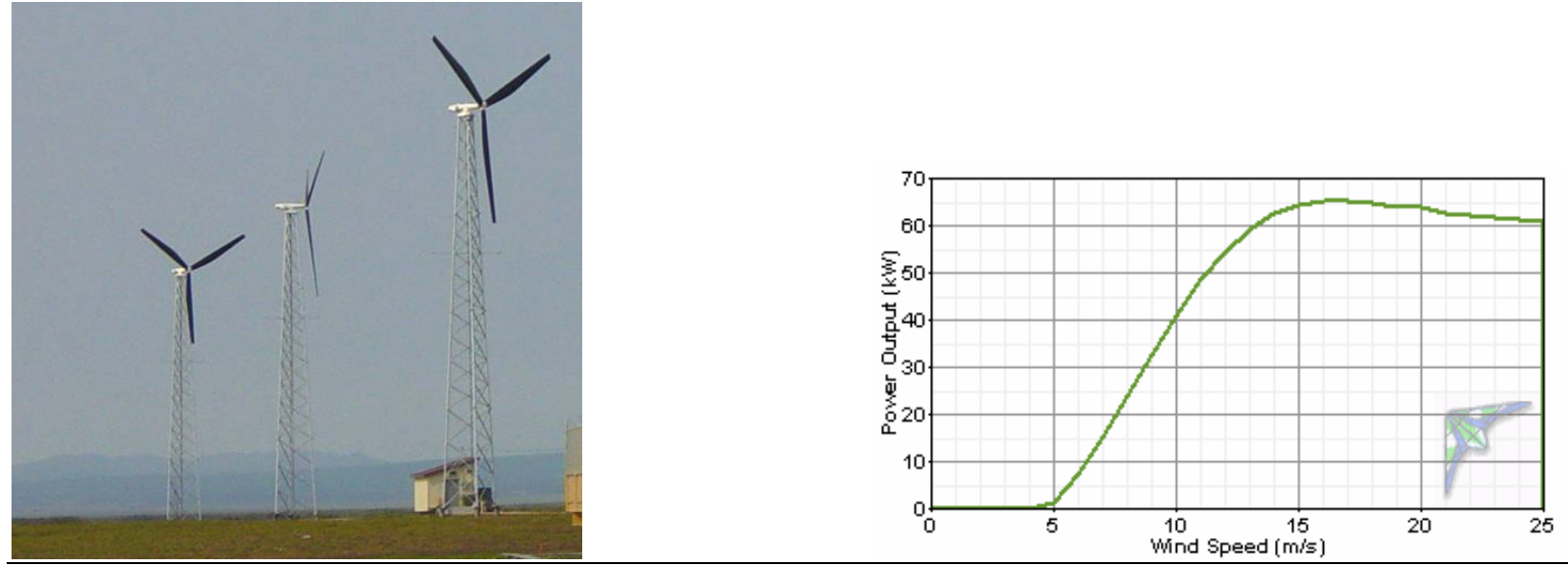
Vestas V15: $75 \mathrm{~kW}$ rated power output, 15 meter rotor, stall-controlled (power curve provided by Powercorp Alaska LLC). Available tower heights: 25, 31 and 34 meters. Additional information is available at http://www.pcorpalaska.com/.
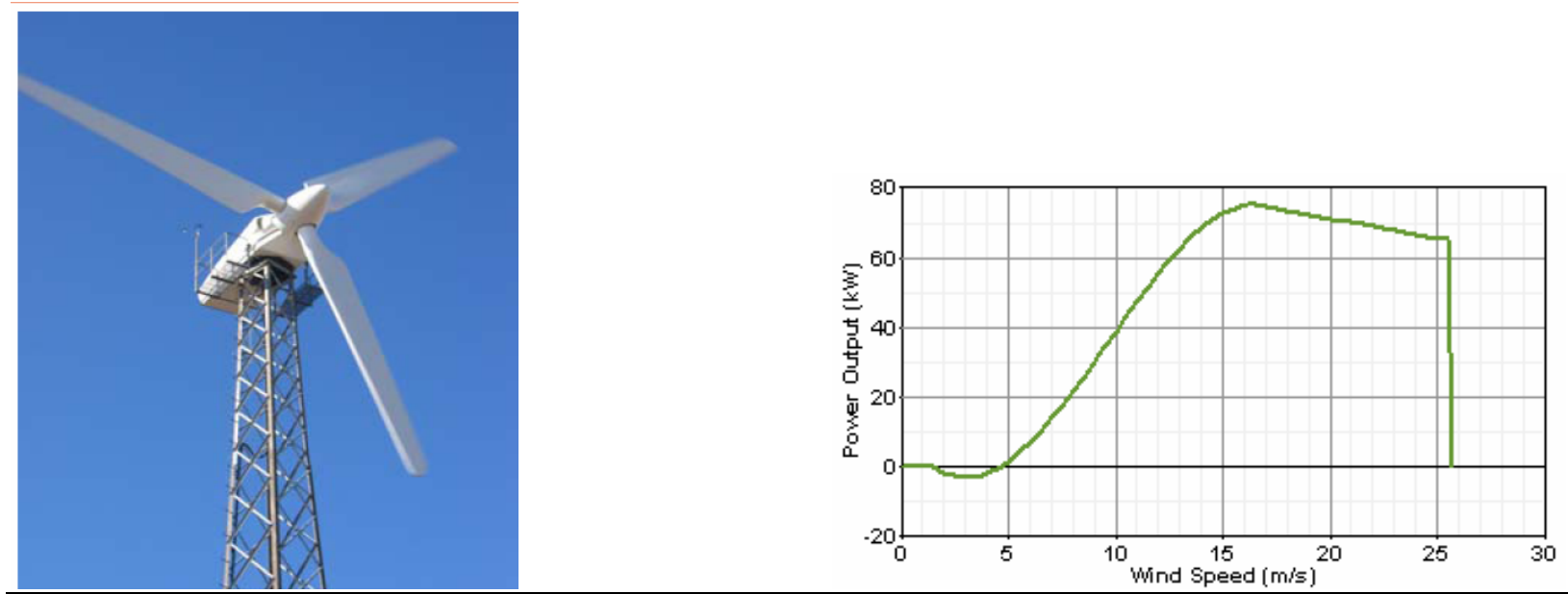

Northwind 100/20: $100 \mathrm{~kW}$ rated power output, 20 meter rotor (19 meter rotor blades with 0.6 meter blade root extensions added), stall-controlled (power curve provided by Northern Power Systems). Available tower heights: 25 and 32 meters. Additional information is available at http://www.northernpower.com/.
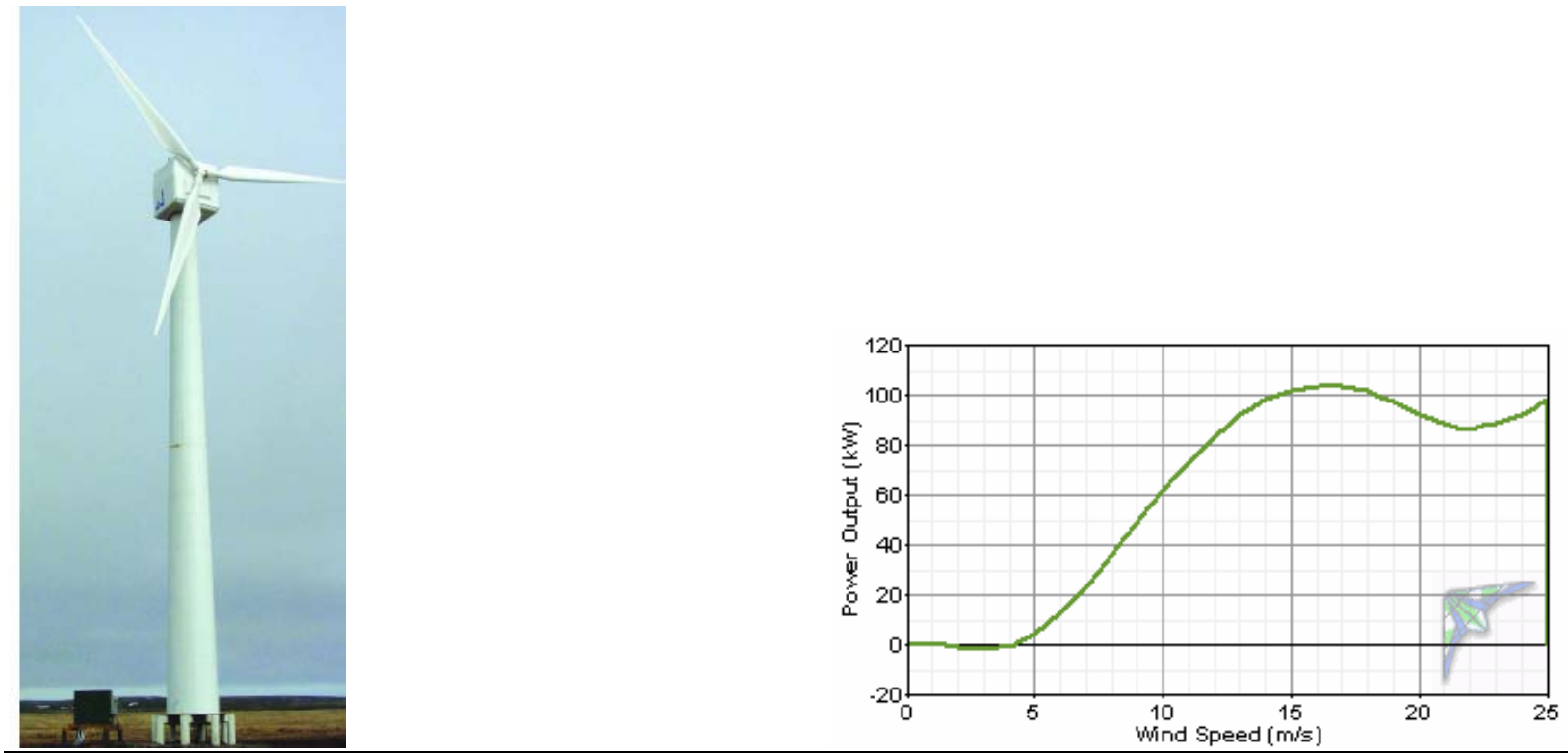
Clark’s Point, Alaska Wind Resource Report

Turbine Power Output Comparison (100\% turbine availability)

\begin{tabular}{|c|c|c|c|c|c|c|c|}
\hline Turbine & $\begin{array}{l}\text { Hub } \\
\text { Height } \\
\text { (m) }\end{array}$ & $\begin{array}{l}\text { Hub } \\
\text { Height } \\
\text { Wind } \\
\text { Speed } \\
(\mathrm{m} / \mathrm{s})\end{array}$ & $\begin{array}{l}\text { Time At } \\
\text { Zero } \\
\text { Output } \\
(\%)\end{array}$ & $\begin{array}{c}\text { Time At } \\
\text { Rated } \\
\text { Output } \\
(\%)\end{array}$ & $\begin{array}{c}\text { Average Net } \\
\text { Power } \\
\text { Output } \\
\text { (kW) }\end{array}$ & $\begin{array}{c}\text { Annual Net } \\
\text { Energy } \\
\text { Output } \\
\text { (kWh/yr) }\end{array}$ & $\begin{array}{c}\text { Average Net } \\
\text { Capacity } \\
\text { Factor } \\
(\%)\end{array}$ \\
\hline Southwest Skystream 3.7 & 10.7 & 6.04 & 16.9 & 9.5 & 0.63 & 5,481 & 34.8 \\
\hline Southwest Skystream 3.7 & 33.5 & 6.98 & 13.1 & 14.8 & 0.81 & 7,113 & 45.1 \\
\hline Bergey Excel-S & 24 & 6.69 & 6.1 & 6.1 & 2.96 & 25,938 & 29.6 \\
\hline Bergey Excel-S & 37 & 7.07 & 5.9 & 7.5 & 3.30 & 28,886 & 33.0 \\
\hline Fuhrländer FL30 & 26 & 6.75 & 5.8 & 2.6 & 12.0 & 104,977 & 36.3 \\
\hline Fuhrländer FL30 & 30 & 6.94 & 5.8 & 3.0 & 12.5 & 109,910 & 38.0 \\
\hline Entegrity eW-15 $60 \mathrm{~Hz}$ & 25 & 6.72 & 23.4 & 3.5 & 18.1 & 158,538 & 27.8 \\
\hline Entegrity eW-15 $60 \mathrm{~Hz}$ & 31 & 6.90 & 22.8 & 4.1 & 19.3 & 168,634 & 29.6 \\
\hline Vestas V15 & 25 & 6.72 & 29.6 & 1.9 & 17.2 & 150,482 & 22.9 \\
\hline Vestas V15 & 34 & 6.99 & 27.9 & 2.5 & 19.0 & 166,271 & 25.3 \\
\hline Northern Power NW 100/20 & 25 & 6.72 & 23.4 & 3.4 & 26.6 & 233,420 & 26.6 \\
\hline Northern Power NW 100/20 & 32 & 6.93 & 22.6 & 4.1 & 28.6 & 250,517 & 28.6 \\
\hline
\end{tabular}

Capacity Factor $<20 \%$

Capacity Factor $>20 \%,<30 \%$

Capacity Factor $>30 \%,<40 \%$

Capacity Factor $>40 \%,<50 \%$

Capacity Factor $>50 \%$

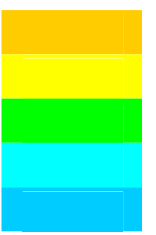

Assumed turbine losses for predictions of average power output, annual energy output, and average capacity factor:

Downtime (\%)

Array (\%)

Icing/soiling (\%)

Other (\%)

Total (\%)

0

0 
Clark’s Point, Alaska Wind Resource Report

Turbine Power Output Comparison (90\% availability)

\begin{tabular}{|c|c|c|c|c|c|c|c|}
\hline Turbine & $\begin{array}{l}\text { Hub } \\
\text { Height } \\
\text { (m) }\end{array}$ & $\begin{array}{l}\text { Hub } \\
\text { Height } \\
\text { Wind } \\
\text { Speed } \\
(\mathrm{m} / \mathrm{s})\end{array}$ & $\begin{array}{l}\text { Time At } \\
\text { Zero } \\
\text { Output } \\
(\%)\end{array}$ & $\begin{array}{l}\text { Time At } \\
\text { Rated } \\
\text { Output } \\
(\%)\end{array}$ & $\begin{array}{l}\text { Average Net } \\
\text { Power } \\
\text { Output } \\
\text { (kW) }\end{array}$ & $\begin{array}{c}\text { Annual Net } \\
\text { Energy } \\
\text { Output } \\
\text { (kWh/yr) }\end{array}$ & $\begin{array}{c}\text { Average Net } \\
\text { Capacity } \\
\text { Factor } \\
(\%)\end{array}$ \\
\hline Southwest Skystream 3.7 & 10.7 & 6.04 & 16.86 & 9.5 & 0.57 & 4,949 & 31.4 \\
\hline Southwest Skystream 3.7 & 33.5 & 6.98 & 13.13 & 14.8 & 0.73 & 6,424 & 40.7 \\
\hline Bergey Excel-S & 24 & 6.69 & 6.10 & 6.1 & 2.67 & 23,424 & 26.7 \\
\hline Bergey Excel-S & 37 & 7.07 & 5.88 & 7.5 & 2.98 & 26,086 & 29.8 \\
\hline Fuhrländer FL30 & 26 & 6.75 & 5.75 & 2.6 & 10.8 & 94,801 & 32.8 \\
\hline Fuhrländer FL30 & 30 & 6.94 & 5.83 & 3.0 & 11.3 & 99,257 & 34.3 \\
\hline Entegrity eW-15 $60 \mathrm{~Hz}$ & 25 & 6.72 & 23.43 & 3.5 & 16.3 & 143,171 & 25.1 \\
\hline Entegrity eW-15 $60 \mathrm{~Hz}$ & 31 & 6.90 & 22.77 & 4.1 & 17.4 & 152,288 & 26.7 \\
\hline Vestas V15 & 25 & 6.72 & 29.64 & 1.9 & 15.5 & 135,896 & 20.7 \\
\hline Vestas V15 & 34 & 6.99 & 27.94 & 2.5 & 17.1 & 150,155 & 22.9 \\
\hline Northern Power NW 100/20 & 25 & 6.72 & 23.43 & 3.4 & 24.1 & 210,794 & 24.1 \\
\hline Northern Power NW 100/20 & 32 & 6.93 & 22.62 & 4.1 & 25.8 & 226,234 & 25.8 \\
\hline
\end{tabular}

Capacity Factor $<20 \%$

Capacity Factor $>20 \%,<30 \%$

Capacity Factor $>30 \%,<40 \%$

Capacity Factor $>40 \%,<50 \%$

Capacity Factor $>50 \%$

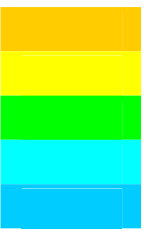

Assumed turbine losses for predictions of average power output, annual energy output, and average capacity factor:

Downtime (\%)

Array (\%)

Icing/soiling (\%)

Other (\%)

Total (\%)

$\begin{array}{cc}5 & \\ 0 & \\ 3 & \\ 2 & \\ 9.69 & \text { (factors are multiplicative) }\end{array}$


Annual Fuel Cost Avoided for Energy Generated by Wind Turbine vs. Diesel Generator

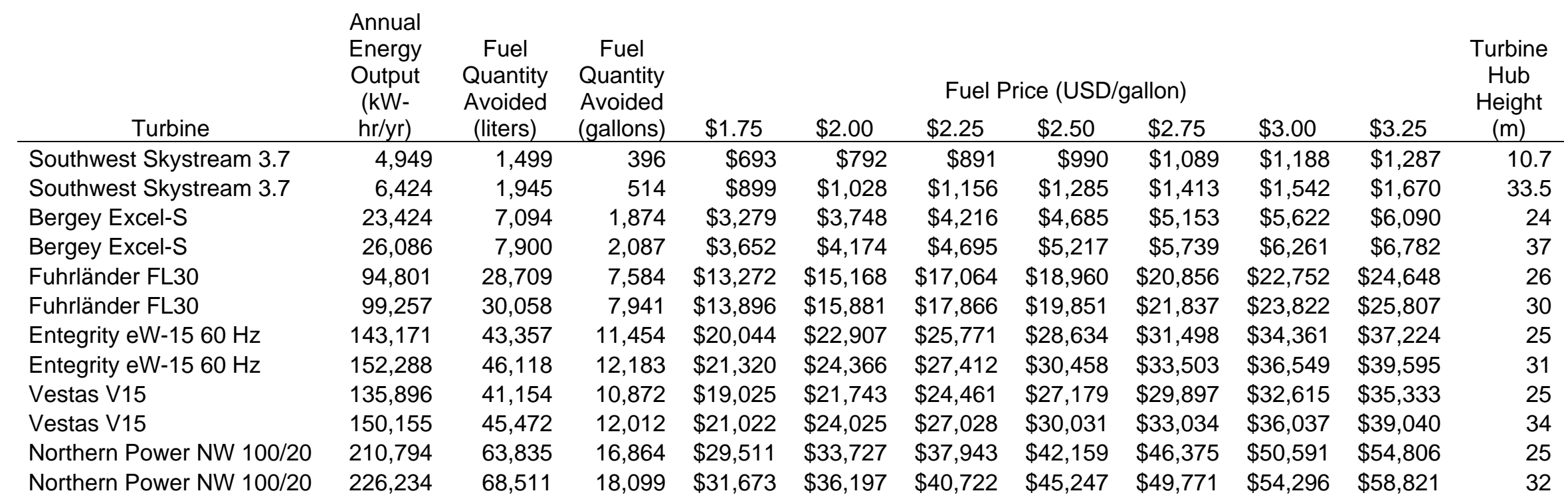

Notes:

1. Clark's Point electrical energy production efficiency assumed to be $12.5 \mathrm{~kW}$-hr/gal

2. Assumes $\mathbf{9 0} \%$ wind turbine availability with no diversion of power to a thermal or other dump load

3. Assumes linear diesel generator fuel efficiency (i.e., 1:1 tradeoff of wind turbine kW-hr to diesel genset kW-hr) 
Clark’s Point, Alaska Wind Resource Report

Temperature Conversion Chart ${ }^{\circ} \mathrm{C}$ to ${ }^{\circ} \mathrm{F}$

\begin{tabular}{|c|c|c|c|c|c|}
\hline${ }^{\circ} \mathbf{C}$ & ${ }^{\circ} \mathbf{F}$ & ${ }^{\circ} \mathbf{C}$ & ${ }^{\circ} \mathbf{F}$ & ${ }^{\circ} \mathbf{C}$ & ${ }^{\circ} \mathbf{F}$ \\
\hline-40 & -40 & -10 & 14 & 20 & 68 \\
\hline-39 & -38.2 & -9 & 15.8 & 21 & 69.8 \\
\hline-38 & -36.4 & -8 & 17.6 & 22 & 71.6 \\
\hline-37 & -34.6 & -7 & 19.4 & 23 & 73.4 \\
\hline-36 & -32.8 & -6 & 21.2 & 24 & 75.2 \\
\hline-35 & -31 & -5 & 23 & 25 & 77 \\
\hline-34 & 29.2 & -4 & 24.8 & 26 & 78.8 \\
\hline-33 & -27.4 & -3 & 26.6 & 27 & 80.6 \\
\hline-32 & -25.6 & -2 & 28.4 & 28 & 82.4 \\
\hline-31 & -23.8 & -1 & 30.2 & 29 & 84.2 \\
\hline-30 & -22 & 0 & 32 & 30 & 86 \\
\hline-29 & -20.2 & 1 & 33.8 & 31 & 87.8 \\
\hline-28 & -18.4 & 2 & 35.6 & 32 & 89.6 \\
\hline-27 & -16.6 & 3 & 37.4 & 33 & 91.4 \\
\hline-26 & -14.8 & 4 & 39.2 & 34 & 93.2 \\
\hline-25 & -13 & 5 & 41 & 35 & 95 \\
\hline-24 & -11.2 & 6 & 42.8 & 36 & 96.8 \\
\hline-23 & -9.4 & 7 & 44.6 & 37 & 98.6 \\
\hline-22 & -7.6 & 8 & 46.4 & 38 & 100.4 \\
\hline-21 & -5.8 & 9 & 48.2 & 39 & 102.2 \\
\hline-20 & -4 & 10 & 50 & 40 & 104 \\
\hline-19 & -2.2 & 11 & 51.8 & 41 & 105.8 \\
\hline-18 & -0.4 & 12 & 53.6 & 42 & 107.6 \\
\hline-17 & 1.4 & 13 & 55.4 & 43 & 109.4 \\
\hline-16 & 3.2 & 14 & 57.2 & 44 & 111.2 \\
\hline-15 & 5 & 15 & 59 & 45 & 113 \\
\hline-14 & 6.8 & 16 & 60.8 & 46 & 114.8 \\
\hline-13 & 8.6 & 17 & 62.6 & 47 & 116.6 \\
\hline-12 & 10.4 & 18 & 64.4 & 48 & 118.4 \\
\hline-11 & 12.2 & 19 & 66.2 & 49 & 120.2 \\
\hline & & & & & \\
\hline-21 & & & & \\
\hline
\end{tabular}


Wind Speed Conversion Chart $\mathrm{m} / \mathrm{s}$ to $\mathrm{mph}$

\begin{tabular}{|c|c|c|c|c|c|}
\hline $\mathbf{m} / \mathbf{s}$ & $\mathbf{m p h}$ & $\mathbf{m} / \mathbf{s}$ & $\mathbf{m p h}$ & $\mathbf{~ m / s}$ & $\mathbf{m p h}$ \\
\hline 0.5 & 1.1 & 10.5 & 23.5 & 20.5 & 45.9 \\
\hline 1.0 & 2.2 & 11.0 & 24.6 & 21.0 & 47.0 \\
\hline 1.5 & 3.4 & 11.5 & 25.7 & 21.5 & 48.1 \\
\hline 2.0 & 4.5 & 12.0 & 26.8 & 22.0 & 49.2 \\
\hline 2.5 & 5.6 & 12.5 & 28.0 & 22.5 & 50.3 \\
\hline 3.0 & 6.7 & 13.0 & 29.1 & 23.0 & 51.4 \\
\hline 3.5 & 7.8 & 13.5 & 30.2 & 23.5 & 52.6 \\
\hline 4.0 & 8.9 & 14.0 & 31.3 & 24.0 & 53.7 \\
\hline 4.5 & 10.1 & 14.5 & 32.4 & 24.5 & 54.8 \\
\hline 5.0 & 11.2 & 15.0 & 33.6 & 25.0 & 55.9 \\
\hline 5.5 & 12.3 & 15.5 & 34.7 & 25.5 & 57.0 \\
\hline 6.0 & 13.4 & 16.0 & 35.8 & 26.0 & 58.2 \\
\hline 6.5 & 14.5 & 16.5 & 36.9 & 26.5 & 59.3 \\
\hline 7.0 & 15.7 & 17.0 & 38.0 & 27.0 & 60.4 \\
\hline 7.5 & 16.8 & 17.5 & 39.1 & 27.5 & 61.5 \\
\hline 8.0 & 17.9 & 18.0 & 40.3 & 28.0 & 62.6 \\
\hline 8.5 & 19.0 & 18.5 & 41.4 & 28.5 & 63.8 \\
\hline 9.0 & 20.1 & 19.0 & 42.5 & 29.0 & 64.9 \\
\hline 9.5 & 21.3 & 19.5 & 43.6 & 29.5 & 66.0 \\
\hline 10.0 & 22.4 & 20.0 & 44.7 & 30.0 & 67.1 \\
\hline & & & & & \\
\hline
\end{tabular}

Distance Conversion $\mathrm{m}$ to $\mathrm{ft}$

\begin{tabular}{|c|c|c|c|}
\hline $\mathbf{m}$ & $\mathbf{f t}$ & $\mathbf{m}$ & $\mathbf{f t}$ \\
\hline 5 & 16 & 35 & 115 \\
\hline 10 & 33 & 40 & 131 \\
\hline 15 & 49 & 45 & 148 \\
\hline 20 & 66 & 50 & 164 \\
\hline 25 & 82 & 55 & 180 \\
\hline 30 & 98 & 60 & 197 \\
\hline
\end{tabular}


Selected definitions (courtesy of Windographer® software by Mistaya Engineering Inc.)

\section{$\underline{\text { Wind Power Class }}$}

The wind power class is a number indicating the average energy content of the wind resource. Wind power classes are based on the average wind power density at 50 meters above ground, according to the following table. Source: Wind Energy Resource Atlas of the United States (http://rredc.nrel.gov/wind/pubs/atlas/tables/A-8T.html)

\begin{tabular}{|c|l|c|}
\hline \multicolumn{2}{|c|}{} & \multicolumn{2}{|c|}{} \\
\hline Wind Power Class & Description & Power Density at 50m $\mathbf{( W / \mathbf { m } ^ { 2 }}$ \\
\hline 1 & Poor & $0-200$ \\
\hline 2 & Marginal & $200-300$ \\
\hline 3 & Fair & $300-400$ \\
\hline 4 & Good & $400-500$ \\
\hline 5 & Excellent & $500-600$ \\
\hline 6 & Outstanding & $600-800$ \\
\hline 7 & Superb & $800-2000$ \\
\hline
\end{tabular}

Windographer classifies any wind resource with an average wind power density above 2000 $\mathrm{W} / \mathrm{m}^{2}$ as class 8 .

Probability Distribution Function

The probability distribution function $\mathrm{f}(\mathrm{x})$ gives the probability that a variable will take on the value $\mathrm{x}$. It is often expressed using a frequency histogram, which gives the frequency with which the variable falls within certain ranges or bins.

\section{$\underline{\text { Wind Turbine Power Regulation }}$}

All wind turbines employ some method of limiting power output at high wind speeds to avoid damage to mechanical or electrical subsystems. Most wind turbines employ either stall control or pitch control to regulate power output.

A stall-controlled turbine typically has blades that are fixed in place, and are designed to experience aerodynamic stall at very high wind speeds. Aerodynamic stall dramatically reduces the torque produced by the blades, and therefore the power produced by the turbine.

On a pitch-controlled turbine, a controller adjusts the angle (pitch) of the blades to best match the wind speed. At very high wind speeds the controller increasingly feathers the blades out of the wind to limit the power output. 


\title{
Dillingham, Alaska Wind Resource Report Kanakanak Site
}

\author{
Report written by: Douglas Vaught, P.E., V3 Energy, LLC
}

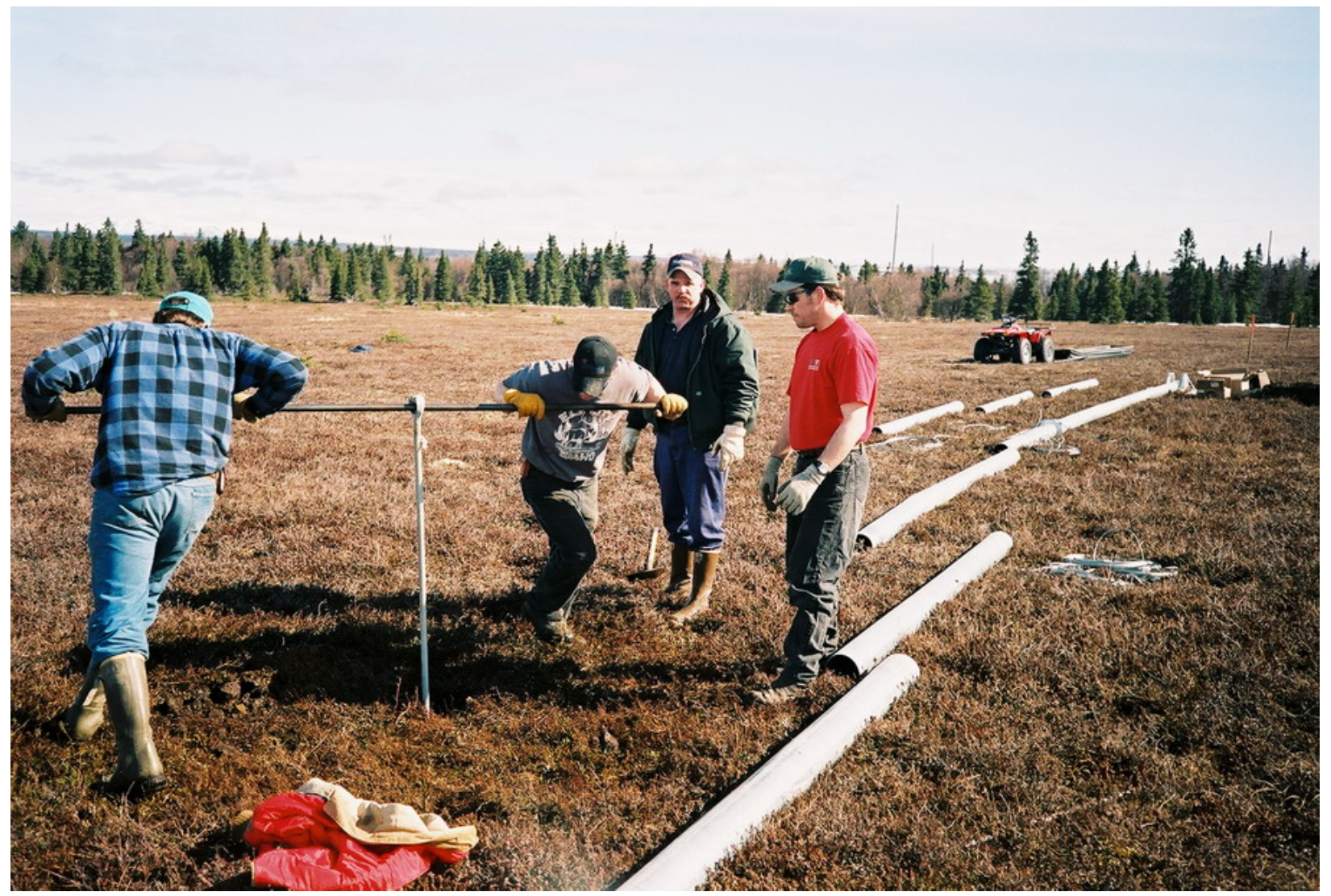

Photo ( Doug Vaught

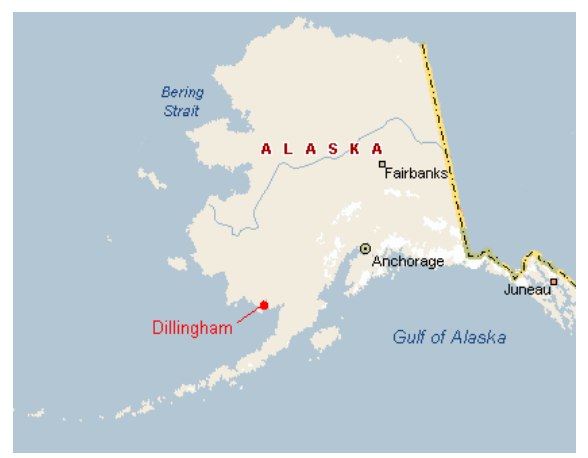

\section{Summary Information}

Winds measured in Dillingham were consistent with the State wind resource map and are sufficient for wind power development in the community. Because of the proximity of forest to the wind test site, the wind shear and turbulence were higher than seen in other Bristol Bay region 
communities. Because a successful wind power project has the potential to lower the electrical power generation costs in Dillingham, installation of a 50 meter meteorological tower and selection of a site further from the forest margin may yield better data.

\section{Meteorological Tower Data Synopsis}

Wind power class

Wind speed annual average (30 meters)

Maximum wind gust (2 sec. average)

Mean wind power density (50 meters)

Mean wind power density (30 meters)

Weibull distribution parameters

Roughness Class

Power law exponent

Turbulence Intensity

Data start date

End data date
Class 3 - Fair

$5.78 \mathrm{~m} / \mathrm{s}$

$30.9 \mathrm{~m} / \mathrm{s}$, April 2005

$374 \mathrm{~W} / \mathrm{m}^{2}$ (calculated)

$230 \mathrm{~W} / \mathrm{m}^{2}$ (measured)

$\mathrm{k}=2.01, \mathrm{c}=6.29 \mathrm{~m} / \mathrm{s}$

3.66 (forest)

0.286 (high wind shear)

0.124 (moderate)

April 23, 2004

October 5, 2005

\section{Community Profile}

Current Population: 2,370 (2005 State Demographer est.)

Pronunciation/Other Names: (DILL-eeng-ham); a.k.a. Curyung; Kanakanak

Incorporation Type: 1st Class City

Borough Located In: Unorganized

School District: Dillingham City Schools

Regional Native Corporation: Bristol Bay Native Corporation

\section{Location:}

Dillingham is located at the extreme northern end of Nushagak Bay in northern Bristol Bay, at the confluence of the Wood and Nushagak Rivers. It lies 327 miles southwest of Anchorage, and is a 6 hour flight from Seattle. It lies at approximately $59.039720^{\circ}$ North Latitude and $-158.457500^{\circ}$ West Longitude. (Sec. 21, T013S, R055W, Seward Meridian.) Dillingham is located in the Bristol Bay Recording District. The area encompasses 33.6 sq. miles of land and 2.1 sq. miles of water.

\section{History:}

The area around Dillingham was inhabited by both Eskimos and Athabascans and became a trade center when Russians erected the Alexandrovski Redoubt (Post) in 1818. Local Native groups and Natives from the Kuskokwim Region, the Alaska Peninsula and Cook Inlet mixed together as they came to visit or live at the post. The community was known as Nushagak by 1837, when a Russian Orthodox mission was established. In 1881 the U.S. Signal Corps established a meteorological station at Nushagak. In 1884 the first salmon cannery in the Bristol Bay region was constructed by Arctic Packing Co., east of the site of modern-day Dillingham. Ten more were established within the next seventeen years. The post office at Snag Point and town were named after U.S. Senator Paul Dillingham in 1904, who had toured Alaska extensively with his Senate subcommittee during 1903. The 1918-19 influenza epidemic struck the region, and left no more than 500 survivors. A hospital and orphanage were established in Kanakanak after the epidemic, 6 miles from the present-day City Center. The Dillingham townsite was first surveyed in 1947. The City was incorporated in 1963.

\section{Culture:}


Traditionally a Yup'ik Eskimo area, with Russian influences, Dillingham is now a highly mixed population of non-Natives and Natives. The outstanding commercial fishing opportunities in the Bristol Bay area are the focus of the local culture.

\section{Economy:}

Dillingham is the economic, transportation, and public service center for western Bristol Bay. Commercial fishing, fish processing, cold storage and support of the fishing industry are the primary activities. Icicle, Peter Pan, Trident and Unisea operate fish processing plants in Dillingham. Two hundred seventy-seven residents hold commercial fishing permits. During spring and summer, the population doubles. The city's role as the regional center for government and services helps to stabilize seasonal employment. Many residents depend on subsistence activities and trapping of beaver, otter, mink, lynx and fox provide cash income. Salmon, grayling, pike, moose, bear, caribou, and berries are harvested.

\section{Facilities:}

Around $90 \%$ of homes are fully plumbed. Dillingham's water is derived from three deep wells. Water is treated, stored in tanks (capacity is 1,250,000 gallons) and distributed. Approximately $40 \%$ of homes are served by the City's piped water system; $60 \%$ use individual wells. The core townsite is served by a piped sewage system; waste is treated in a sewage lagoon. However, the majority of residents (75\%) have septic systems. The City has requested funds to extend piped water to the old airstrip and Kenny Wren Road, and expand sewer service to the northeast. Dillingham Refuse Inc., a private firm, collects refuse three times a week. The Senior Center collects aluminum for recycling, and NAPA recycles used batteries. The Chamber of Commerce coordinates recycling of several materials, including fishing web. A new landfill site with a baling facility is currently being planned. Nushagak Electric owns and operates a diesel plant in Dillingham which also supplies power to Aleknagik.

\section{Transportation:}

Dillingham can be reached by air and sea. The State-owned airport provides a 6,404' long by 150' wide paved runway and Flight Service Station, and regular jet flights are available from Anchorage. A seaplane base is available 3 miles west at Shannon's Pond; it is owned by the U.S. Bureau of Land Management, Division of Lands. A heliport is available at Kanakanak Hospital. There is a City-operated small boat harbor with 320 slips, a dock, barge landing, boat launch, and boat haul-out facilities. It is a tidal harbor and only for seasonal use. Two barge lines make scheduled trips from Seattle. There is a 23-mile DOTmaintained gravel road to Aleknagik; it was first constructed in 1960.

\section{Climate:}

The primary climatic influence is maritime, however, the arctic climate of the Interior also affects the Bristol Bay coast. Average summer temperatures range from 37 to 66 degrees Fahrenheit. Average winter temperatures range from 4 to 30 degrees Fahrenheit. Annual precipitation is 26 inches, and annual snowfall is 65 inches. Heavy fog is common in July and August. Winds of up to 60-70 mph may occur between December and March. The Nushagak River is ice-free from June through November.

(Above information from State of Alaska Department of Commerce, Community, and Economic Development website, http://www.dced.state.ak.us/)

\section{Site Information and Location}

$\begin{array}{ll}\text { Site number } & 2259 \\ \text { Site Description } & \text { Dillingham } \\ \text { Latitude/longitude } & \text { N } 59^{\circ} 00.065^{\prime} \text { W } 158^{\circ} 32.756^{\prime} \\ \text { Site elevation } & 32 \text { meters } \\ \text { Datalogger type } & \text { NRG Symphonie } \\ \text { Tower type } & \text { NRG 30-meter tall tower, } 152 \text { mm (6 in) diameter }\end{array}$




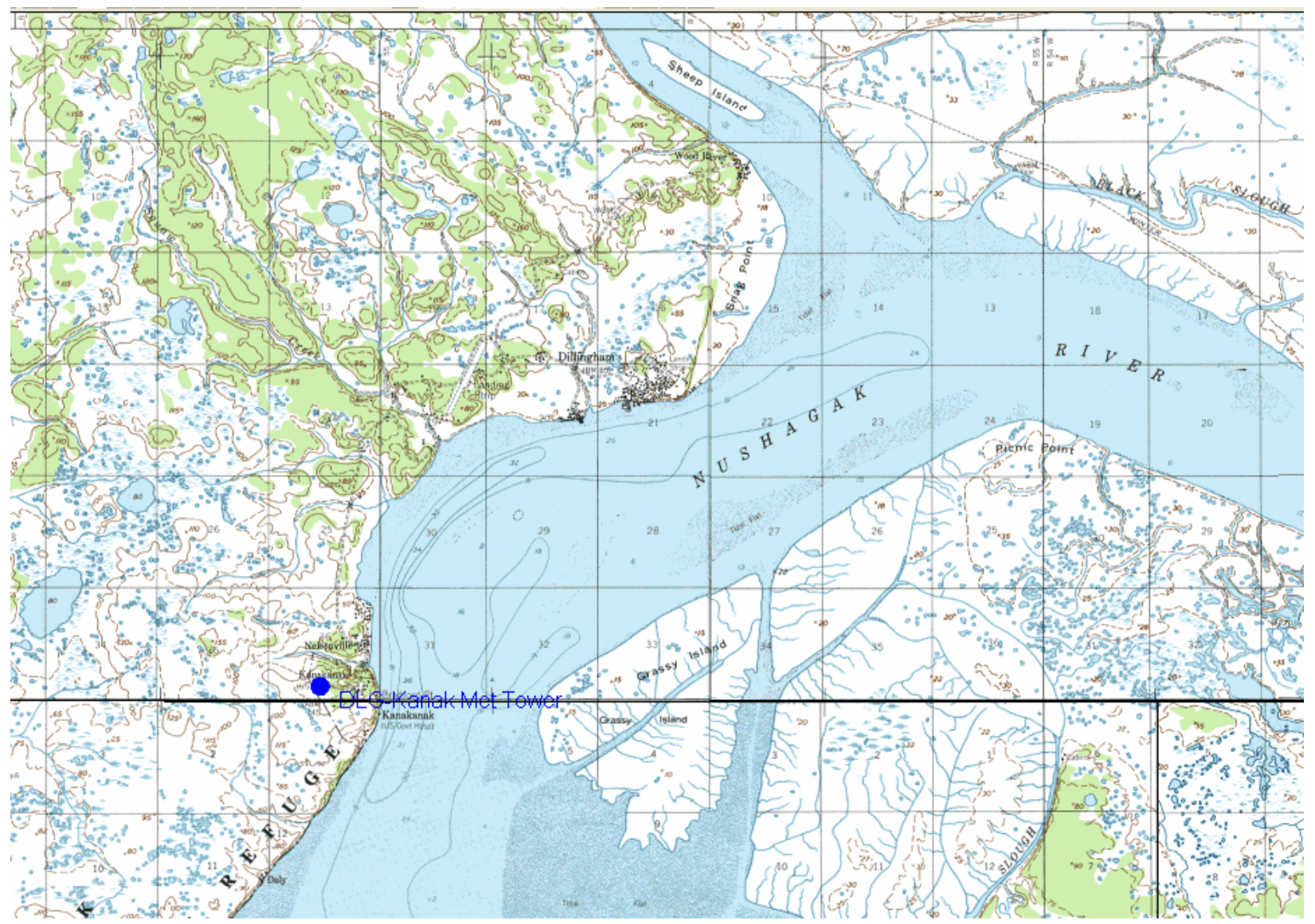

\section{Tower Sensor Information}

\begin{tabular}{clrrrc} 
Channel & Sensor type & Height & Multiplier & Offset & Orientation \\
\hline 1 & NRG \#40 anemometer & $30 \mathrm{~m}$ & 0.765 & 0.35 & South $\left(170^{\circ} \mathrm{T}\right)$ \\
2 & NRG \#40 anemometer & $20 \mathrm{~m}$ & 0.765 & 0.35 & NNE $\left(020^{\circ} \mathrm{T}\right)$ \\
7 & NRG \#200P wind vane & $30 \mathrm{~m}$ & 0.351 & 166 & NNW \\
9 & NRG \#110S Temp C & $2 \mathrm{~m}$ & 0.136 & -86.383 & N/A
\end{tabular}




\section{Data Quality Control}

Data was filtered to remove presumed icing events that yield false zero wind speed data. Data that met the following criteria were filtered: wind speed $<1 \mathrm{~m} / \mathrm{s}$, wind speed standard deviation $=0$, and temperature $<3{ }^{\circ} \mathrm{C}$. Note that data recovery during the months of May through October was $100 \%$, but during the months of November through April some data was filtered, with December being the most ice prone as far as data loss is concerned. Temperature data recovery was 100 percent, indicating full functioning of the temperature sensor. For this file, data was synthesized to replace data lost to icing events.

\begin{tabular}{|c|c|c|c|c|c|c|c|c|c|}
\hline \multirow[b]{2}{*}{ Year } & \multirow[b]{2}{*}{ Month } & \multicolumn{2}{|c|}{ Ch 1 anemometer } & \multicolumn{2}{|c|}{ Ch 2 anemometer } & \multicolumn{2}{|c|}{ Ch 7 vane } & \multicolumn{2}{|c|}{ Ch 9 temperature } \\
\hline & & Records & $\begin{array}{l}\text { Recovery } \\
\text { Rate (\%) }\end{array}$ & Records & $\begin{array}{l}\text { Recovery } \\
\text { Rate (\%) }\end{array}$ & Records & $\begin{array}{l}\text { Recovery } \\
\text { Rate (\%) }\end{array}$ & Records & $\begin{array}{l}\text { Recovery } \\
\text { Rate (\%) }\end{array}$ \\
\hline 2004 & Apr & 986 & 84.1 & 921 & 78.6 & 923 & 78.8 & 1,057 & 100 \\
\hline 2004 & May & 4,464 & 100 & 4,464 & 100 & 4,464 & 100 & 4,464 & 100 \\
\hline 2004 & Jun & 4,320 & 100 & 4,320 & 100 & 4,320 & 100 & 4,320 & 100 \\
\hline 2004 & Jul & 4,464 & 100 & 4,464 & 100 & 4,464 & 100 & 4,464 & 100 \\
\hline 2004 & Aug & 4,464 & 100 & 4,464 & 100 & 4,464 & 100 & 4,464 & 100 \\
\hline 2004 & Sep & 4,320 & 100 & 4,320 & 100 & 4,320 & 100 & 4,320 & 100 \\
\hline 2004 & Oct & 4,464 & 100 & 4,464 & 100 & 4,464 & 100 & 4,464 & 100 \\
\hline 2004 & Nov & 4,041 & 93.5 & 4,156 & 96.2 & 4,013 & 92.9 & 4,320 & 100 \\
\hline 2004 & Dec & 3,895 & 87.3 & 4,278 & 95.8 & 2,934 & 65.7 & 4,464 & 100 \\
\hline 2005 & Jan & 4,260 & 95.4 & 4,365 & 97.8 & 4,162 & 93.2 & 4,464 & 100 \\
\hline 2005 & Feb & 4,032 & 100 & 3,989 & 98.9 & 3,827 & 94.9 & 4,032 & 100 \\
\hline 2005 & Mar & 4,389 & 98.3 & 4,464 & 100 & 4,389 & 98.3 & 4,464 & 100 \\
\hline 2005 & Apr & 4,320 & 100 & 4,258 & 98.6 & 4,320 & 100 & 4,320 & 100 \\
\hline 2005 & May & 4,464 & 100 & 4,464 & 100 & 4,464 & 100 & 4,464 & 100 \\
\hline 2005 & Jun & 4,320 & 100 & 4,320 & 100 & 4,320 & 100 & 4,320 & 100 \\
\hline 2005 & Jul & 4,464 & 100 & 4,464 & 100 & 4,464 & 100 & 4,464 & 100 \\
\hline 2005 & Aug & 4,464 & 100 & 4,464 & 100 & 4,464 & 100 & 4,464 & 100 \\
\hline 2005 & Sep & 4,320 & 100 & 4,320 & 100 & 4,320 & 100 & 4,320 & 100 \\
\hline 2005 & Oct & 648 & 100 & 648 & 100 & 648 & 100 & 648 & 100 \\
\hline $\begin{array}{c}\text { All } \\
\text { data }\end{array}$ & & 75,099 & 98.3 & 75,607 & 98.9 & 73,744 & 96.5 & 76,297 & 100 \\
\hline
\end{tabular}




\section{Measured Wind Speeds}

The Channel 1 (30-meter) anemometer average annual wind speed for the reporting period is $5.78 \mathrm{~m} / \mathrm{s}$ and the Channel 2 (20-meter) anemometer wind speed average is $5.14 \mathrm{~m} / \mathrm{s}$. Note that these data are from a data file that includes data synthesized to remove ice event and other unacceptable original data.

\begin{tabular}{|c|c|c|c|c|c|c|c|}
\hline \multirow[b]{3}{*}{ Month } & \multirow[b]{3}{*}{$\begin{array}{l}\text { Mean } \\
(\mathrm{m} / \mathrm{s})\end{array}$} & \multicolumn{3}{|c|}{ Ch 1 speed (30 m) } & \multirow{3}{*}{$\begin{array}{c}\text { Weibull } \\
\text { c } \\
(\mathrm{m} / \mathrm{s})\end{array}$} & \multicolumn{2}{|c|}{ Ch 2 speed $(20 \mathrm{~m})$} \\
\hline & & & Std. & Weibull & & & \\
\hline & & $\begin{array}{l}\operatorname{Max} \\
(\mathrm{m} / \mathrm{s})\end{array}$ & $\begin{array}{l}\text { Dev. } \\
(\mathrm{m} / \mathrm{s})\end{array}$ & k & & $\begin{array}{l}\text { Mean } \\
(\mathrm{m} / \mathrm{s})\end{array}$ & $\begin{array}{l}\operatorname{Max} \\
(\mathrm{m} / \mathrm{s})\end{array}$ \\
\hline Jan & 6.80 & 15.9 & 2.71 & 2.67 & 7.60 & 5.97 & 14.3 \\
\hline Feb & 6.03 & 23.4 & 3.11 & 2.05 & 6.82 & 5.23 & 22.4 \\
\hline Mar & 6.58 & 17.2 & 3.12 & 2.19 & 7.40 & 5.77 & 15.1 \\
\hline Apr & 5.44 & 22.3 & 2.95 & 1.93 & 6.14 & 4.83 & 19.5 \\
\hline May & 4.85 & 16.8 & 2.53 & 1.98 & 5.46 & 4.28 & 14.1 \\
\hline Jun & 4.90 & 14.9 & 2.58 & 1.99 & 5.52 & 4.37 & 13.1 \\
\hline Jul & 4.81 & 12.7 & 2.23 & 2.26 & 5.42 & 4.33 & 11.8 \\
\hline Aug & 5.10 & 21.1 & 2.64 & 2.01 & 5.75 & 4.58 & 18.9 \\
\hline Sep & 5.92 & 16.2 & 2.82 & 2.21 & 6.67 & 5.32 & 15.0 \\
\hline Oct & 6.53 & 18.1 & 3.13 & 2.17 & 7.36 & 5.89 & 17.1 \\
\hline Nov & 6.36 & 17.0 & 3.26 & 1.96 & 7.12 & 5.66 & 14.8 \\
\hline Dec & 6.03 & 15.9 & 3.10 & 2.00 & 6.78 & 5.40 & 14.2 \\
\hline Annual & 5.78 & 23.4 & 2.87 & 2.01 & 6.29 & 5.14 & 22.4 \\
\hline
\end{tabular}

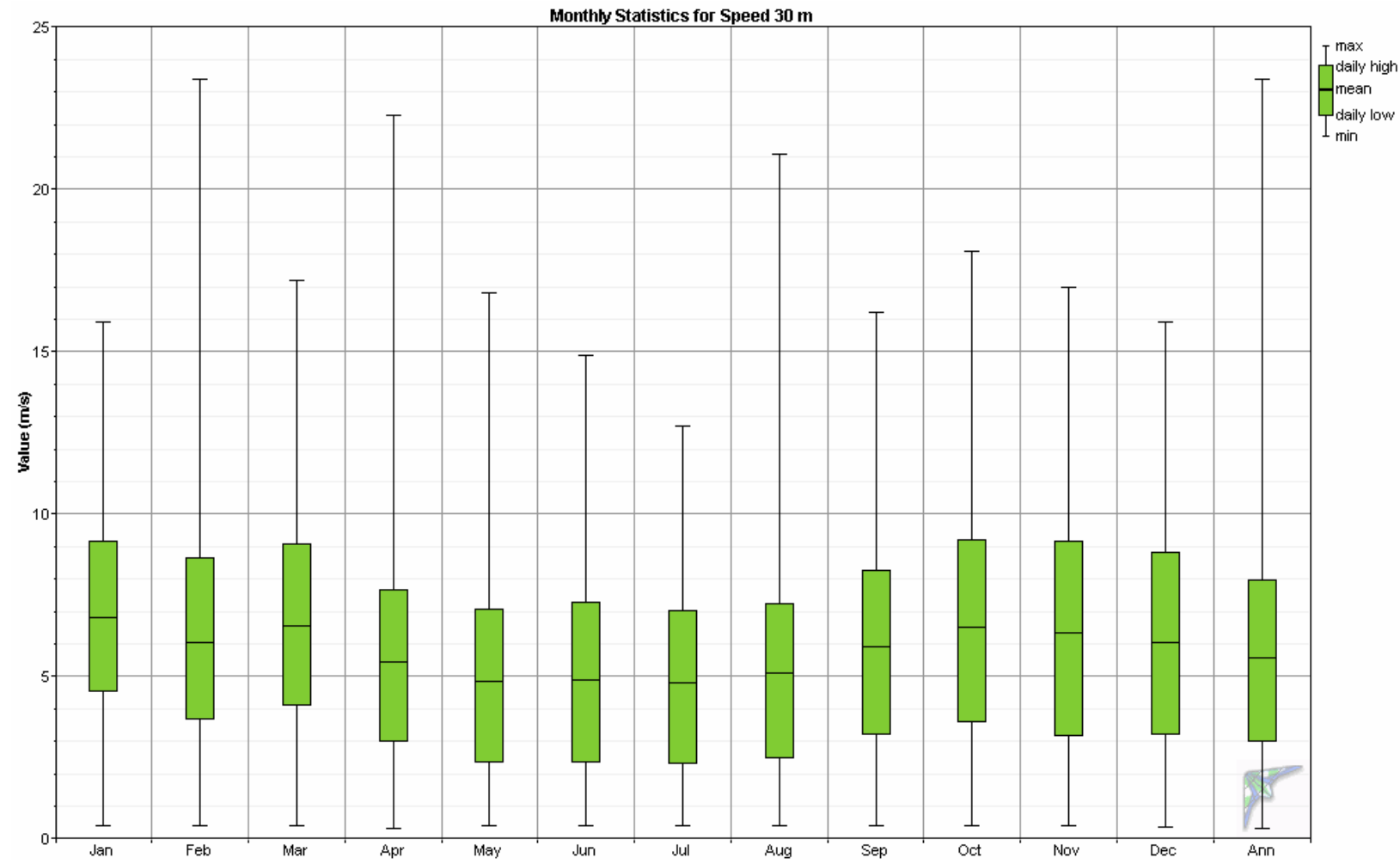


Dillingham, Alaska Kanakanak Wind Resource Report

\section{Daily Wind Profile}

The daily wind profile indicates that the lowest wind speeds of the day occur in the morning hours of 6 to 8 a.m. and the highest wind speeds of the day occur during the afternoon and evening hours of 3 to 5 p.m.
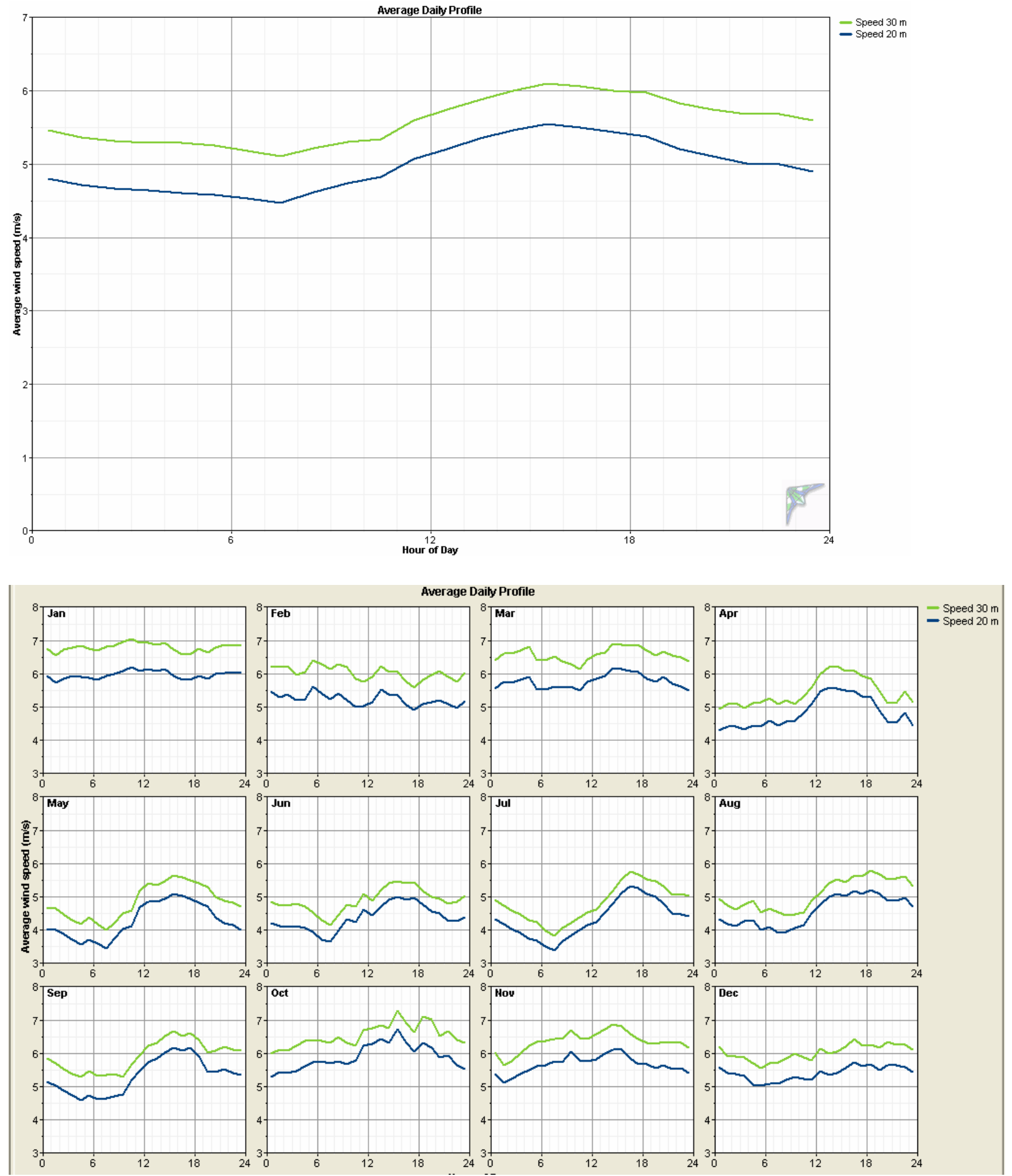
Dillingham, Alaska Kanakanak Wind Resource Report

Time Series of Wind Speed Averages

As expected, the highest winds in Dillingham occur during the fall through spring months with relatively light winds during the summer months of May through August.
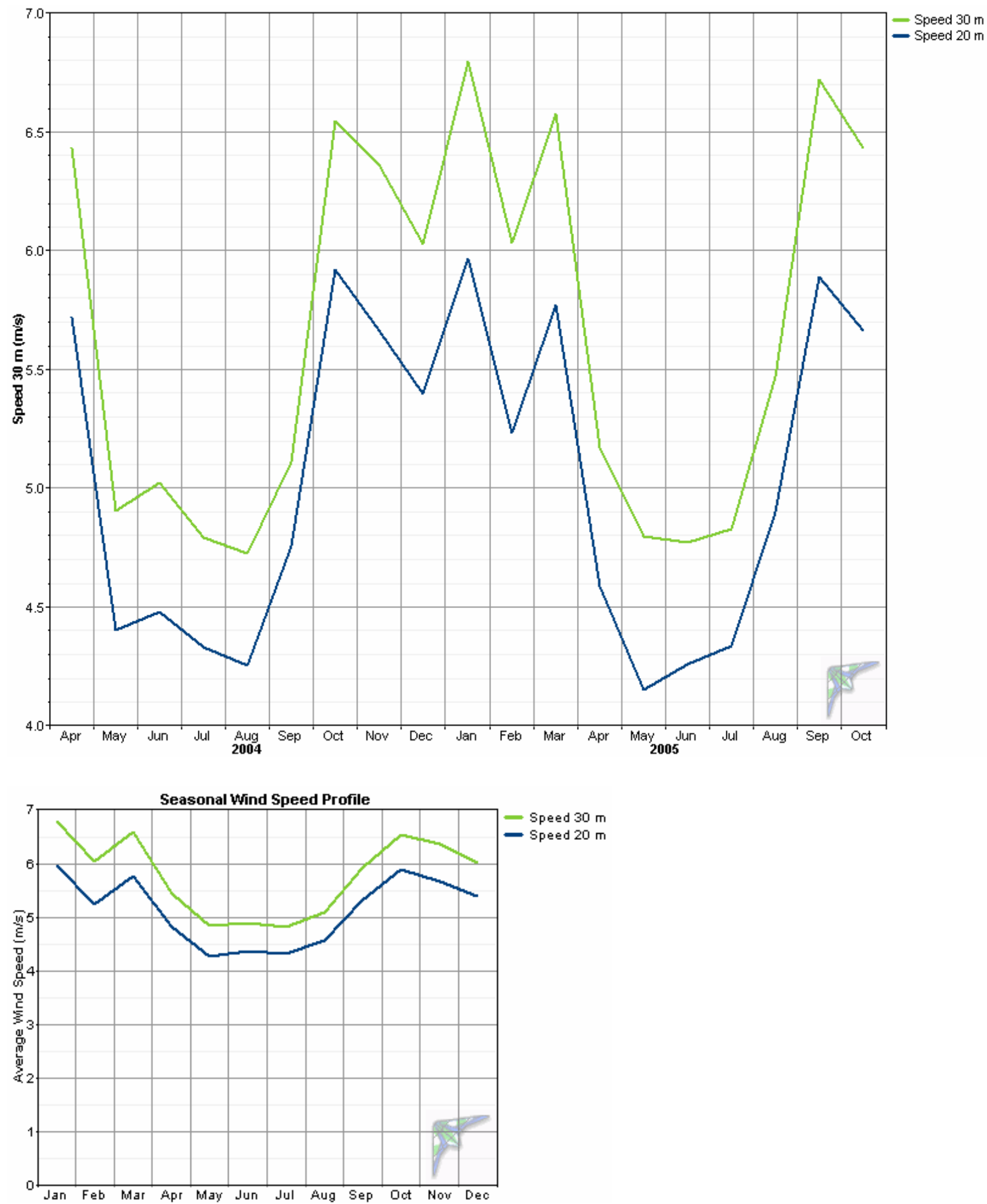


\section{Long-term Data Comparison}

The graph below of average annual wind speed for the nearby Dillingham airport indicates that 2004 and 2005 experienced possibly low average annual wind speeds when compared to data over the past thirty-two years, although in comparison to the past ten years, the 2004/05 wind speeds recorded at the airport were about average. The discrepancy between earlier data and the past ten years can be attributable to an FAA equipment upgrade approximately ten years ago.

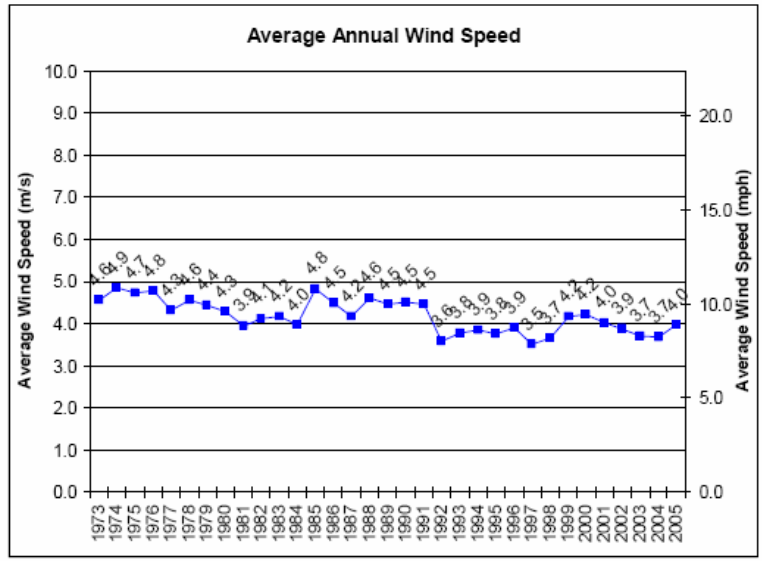




\section{Wind Shear Profile}

The power law exponent was calculated at 0.286, indicating relatively high wind shear at the Dillingham test site. Wind shear however likely was affected by the near presence of trees to the east and south of the test site and other structures further to the west. A higher met tower with instrumentation at 40 meters or higher would likely indicate less wind shear than indicated by this data. The practical application of relatively high wind shear is that a higher turbine tower height is desirable as there will be an appreciable marginal gain in wind speed/power recovery with additional height. A tower height/power recovery/construction cost tradeoff study is advisable. One caution is that wind speed and performance predictions with this data set may overestimate the wind resource at heights greater than 30 meters.
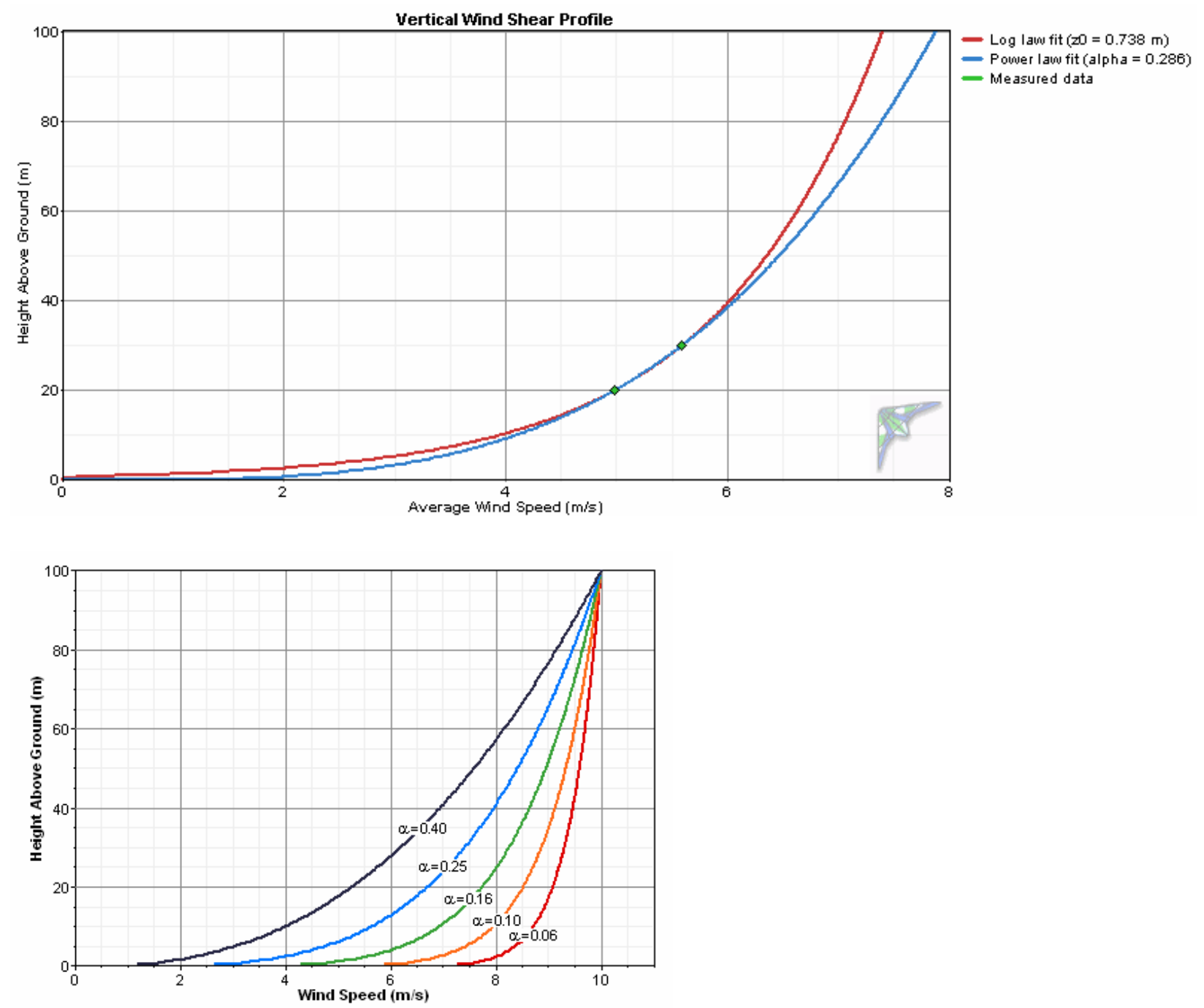
Dillingham, Alaska Kanakanak Wind Resource Report
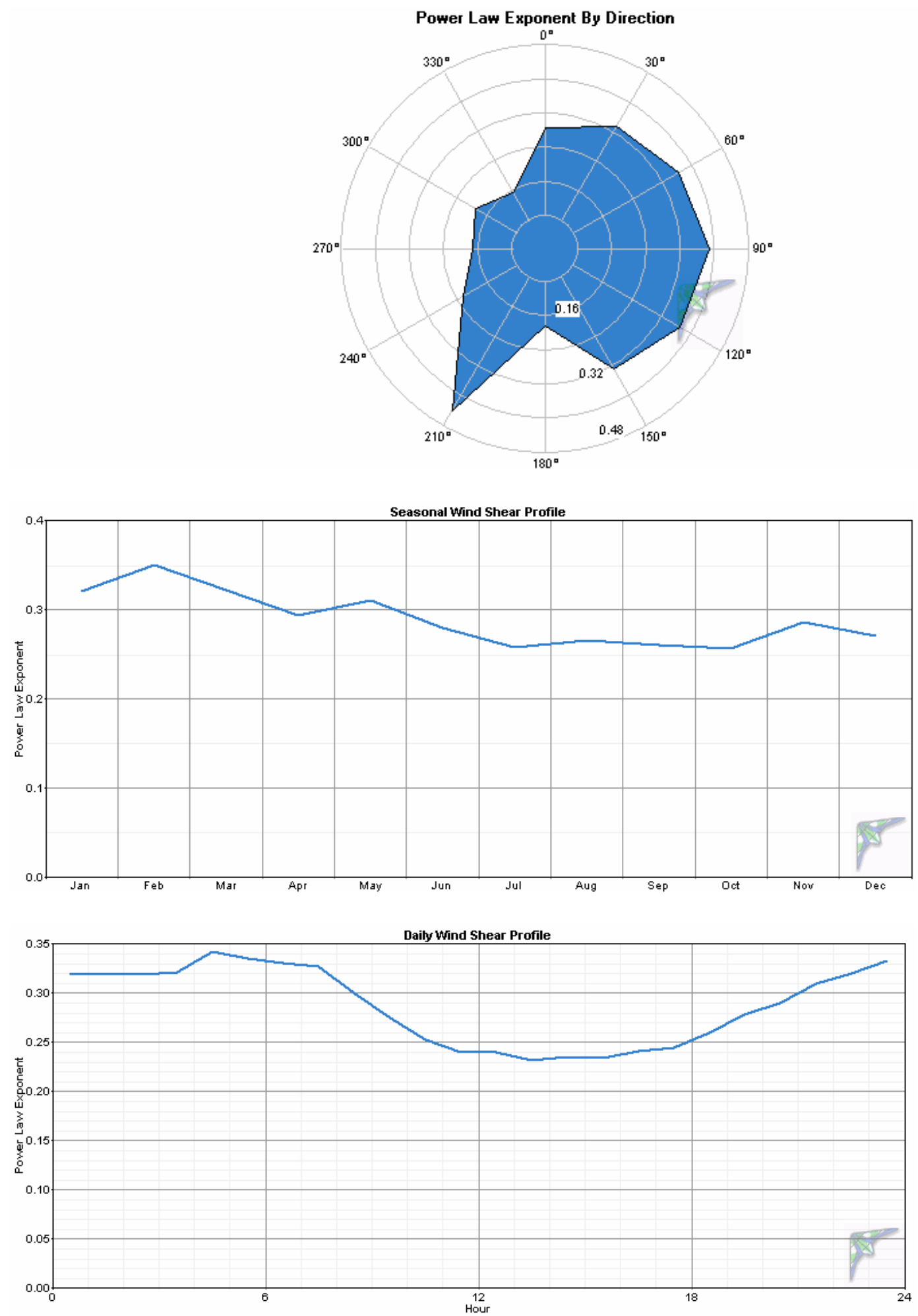


\section{Probability Distribution Function}

The probability distribution function provides a visual indication of measured wind speeds in one meter per second "bins". Note that most wind turbines do not begin to generate power until the wind speed at hub height reaches $4 \mathrm{~m} / \mathrm{s}$. The black line in the graph is a best fit Weibull distribution. At the 30 meter level, Weibull parameters are $\mathrm{k}=2.01$ (indicates a relatively low distribution of wind speeds) and $\mathrm{c}=6.29 \mathrm{~m} / \mathrm{s}$ (scale factor for the Weibull distribution) for the eighteen month data collection period. The PDF information is shown visually in another manner in the second graph, the Cumulative Distribution Function.
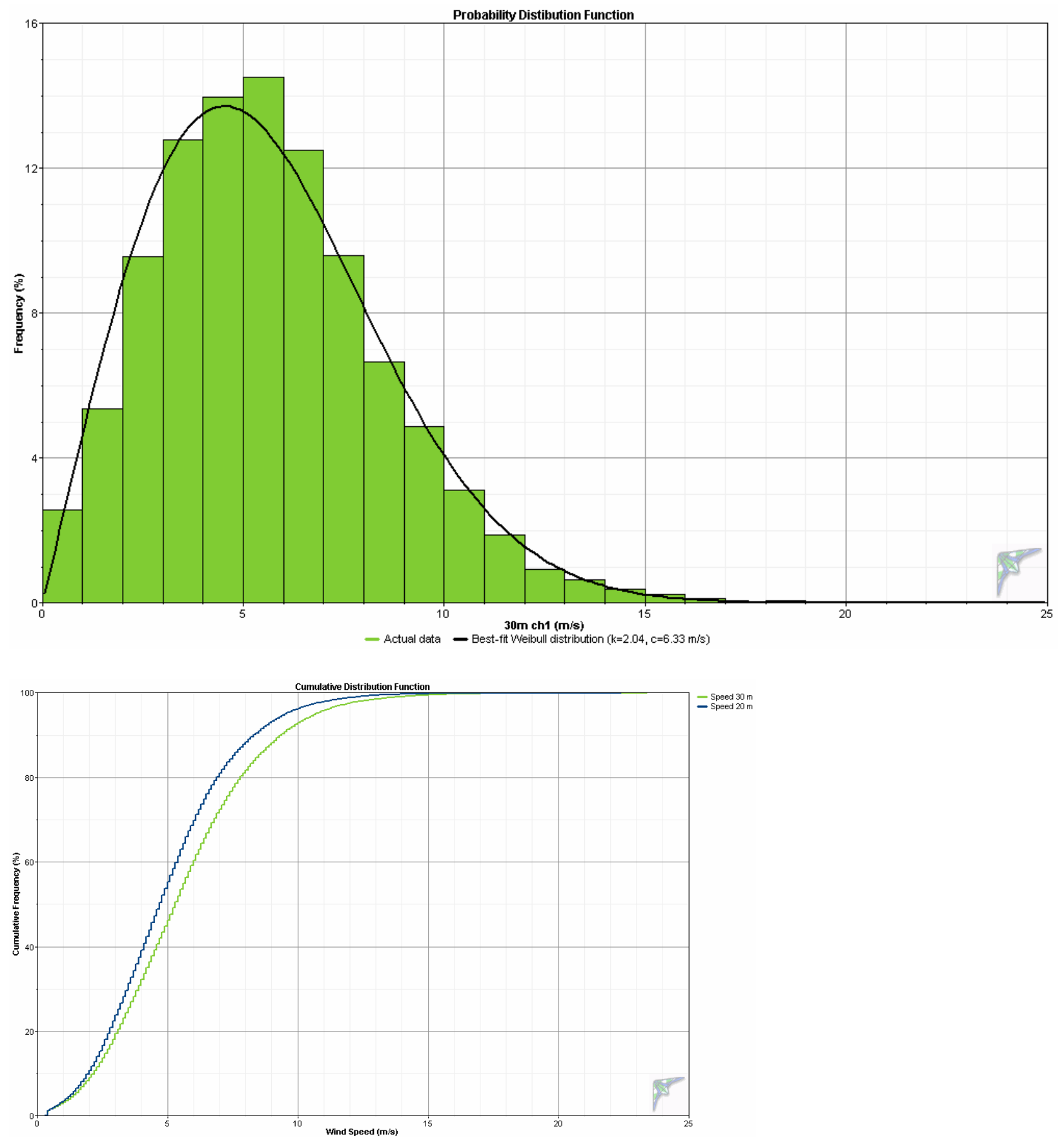


\section{Wind Roses}

Dillingham winds are not especially directional; the wind frequency rose indicates northeast, south and southwest components of wind. This observation is reinforced with reference to the power density rose below which indicates power producing winds from the same directions. The practical application of this information is that a site should be selected with adequate freedom from ground interference to the northeast, south and southwest, and if more than one turbine is installed, the turbines should be adequately spaced apart to prevent downwind (from the power producing winds) interference problems between the turbines. The indication below of 32 percent calm winds is calculated with a $4 \mathrm{~m} / \mathrm{s}$ wind speed threshold, the typical cut-in speed of wind turbines.

Wind Frequency Rose (30 meters)

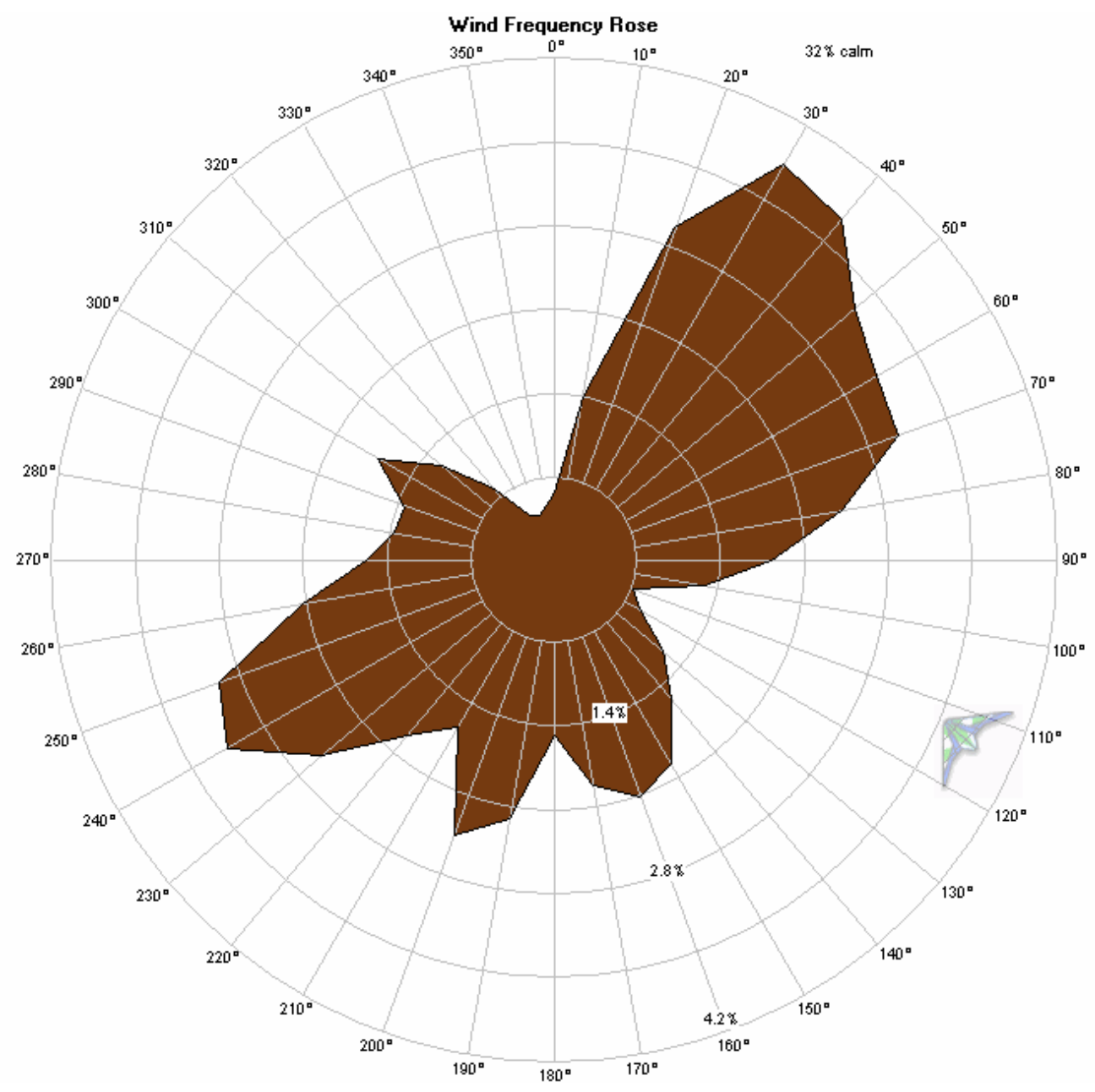


Dillingham, Alaska Kanakanak Wind Resource Report

Wind Power Density Rose (30 meters)

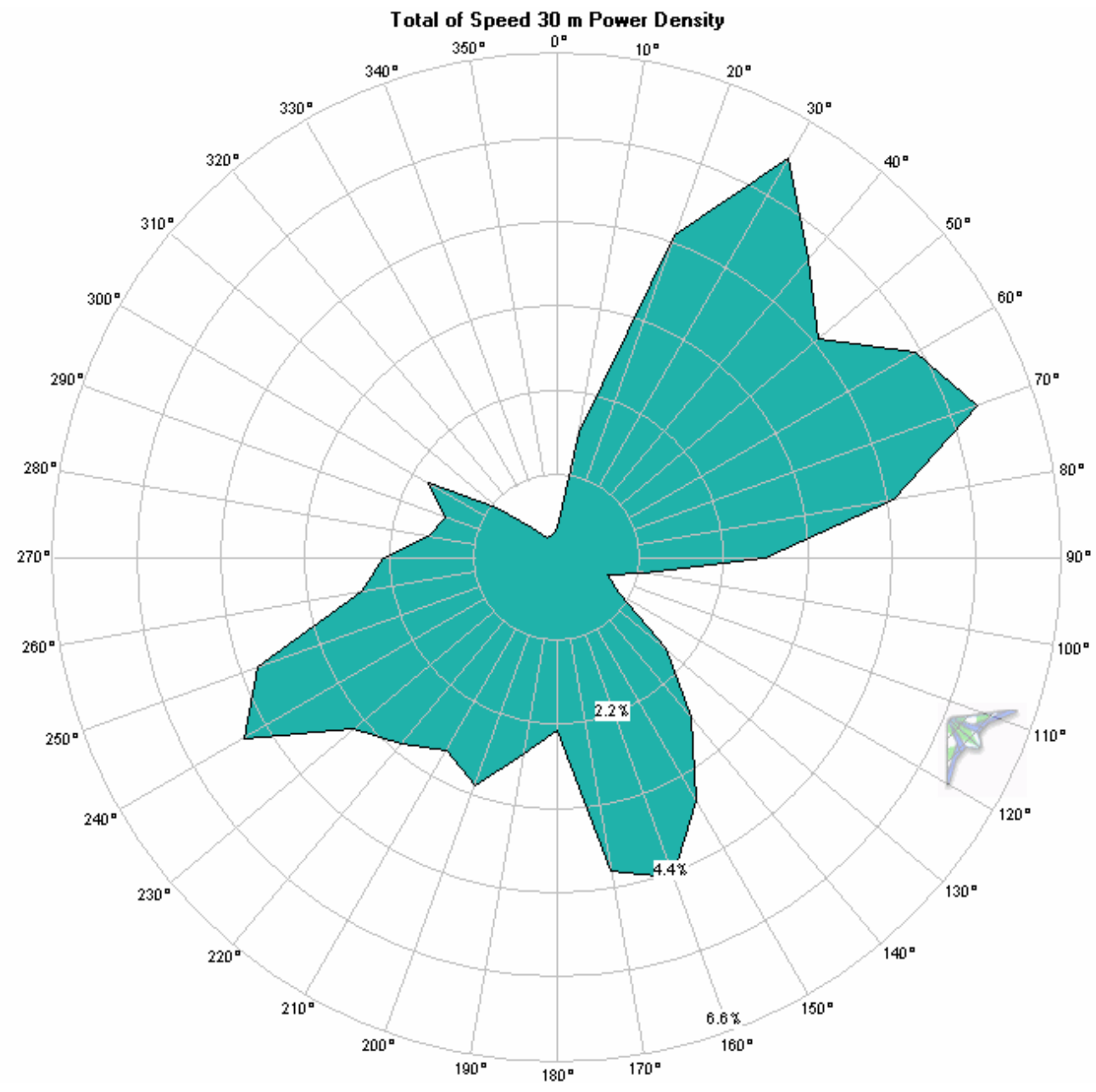

Wind Power Density Rose by Month (30 meters)

Note: for easier visualization of monthly wind direction variation, the scale is not common

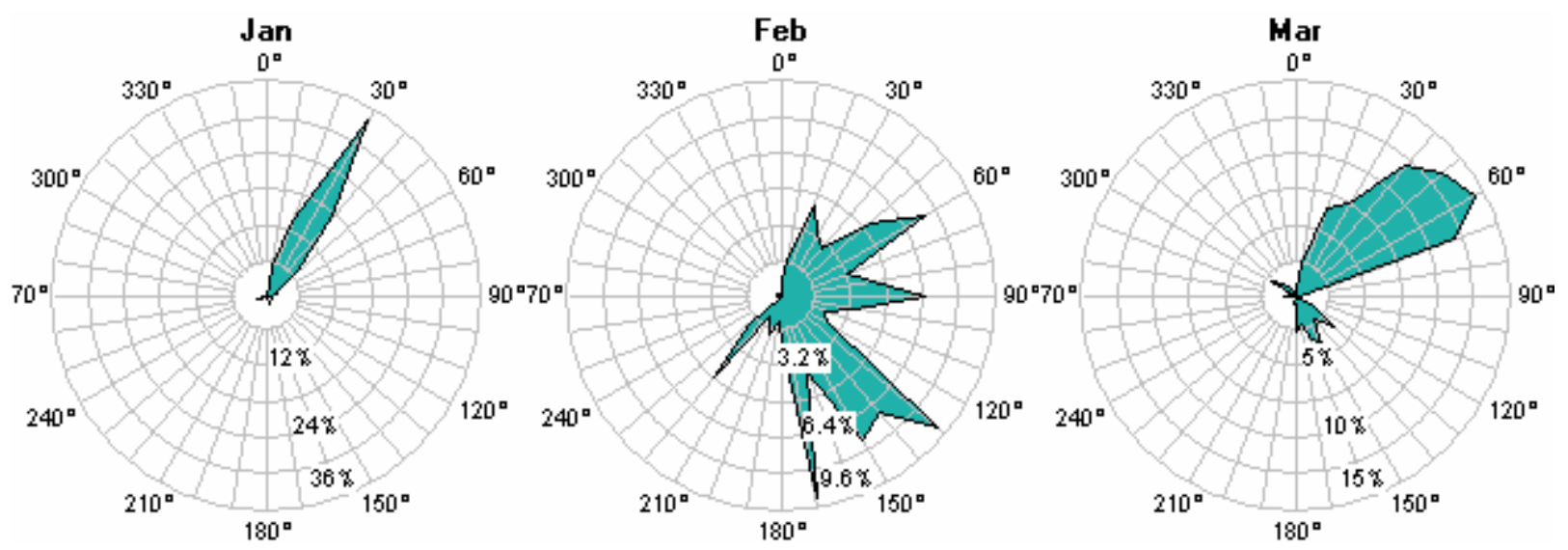


Dillingham, Alaska Kanakanak Wind Resource Report

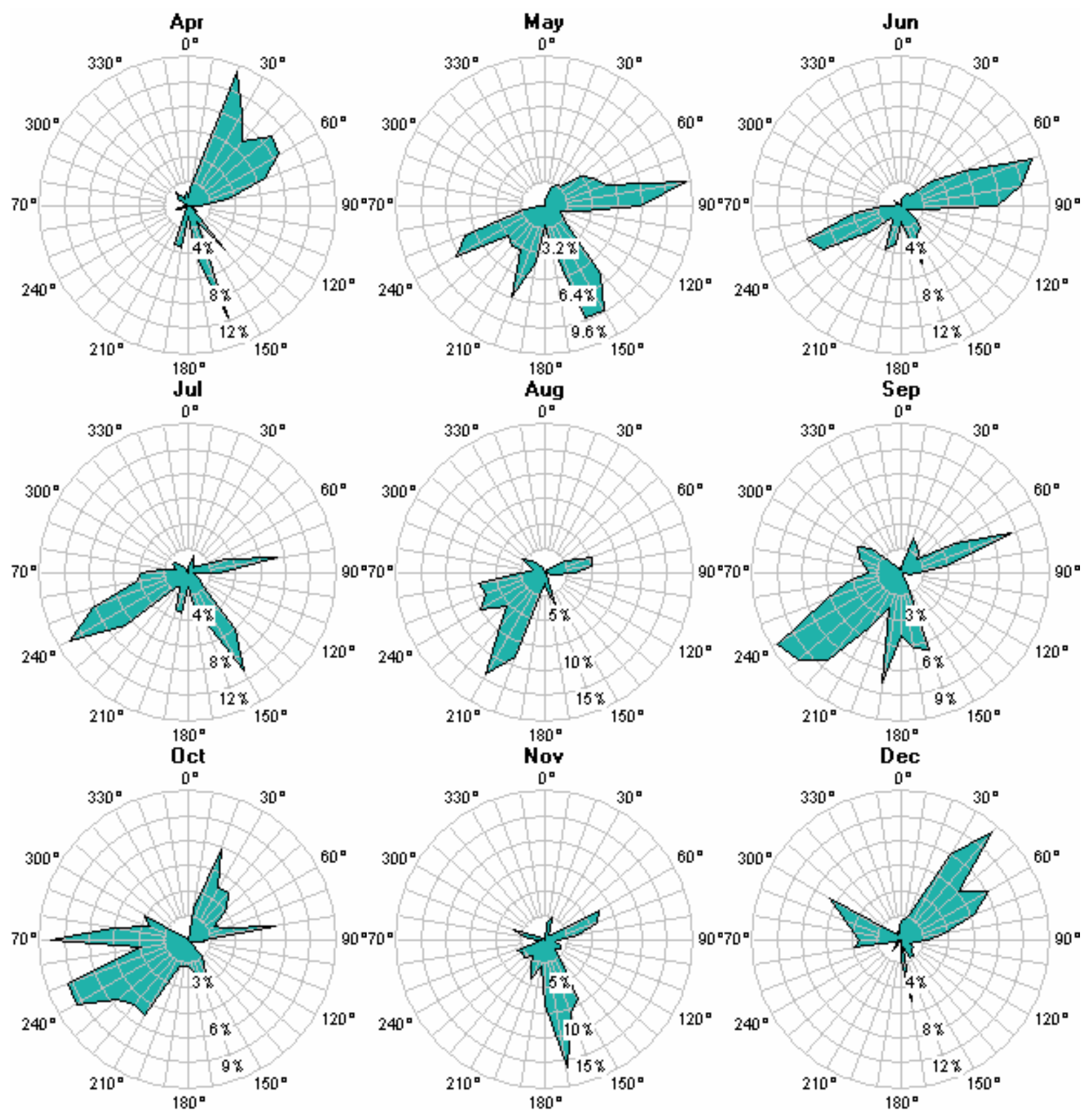




\section{Turbulence Intensity}

The turbulence intensity (TI) is acceptable for all wind directions, with a mean turbulence intensity of 0.125 (Channel 1) and 0.149 (Channel 2) for the eighteen month data collection period, indicating moderately smooth air. The higher turbulence intensity to the NE to SE directions may be attributable to the presence of nearby forest in this direction. Possibly, turbulence would be less in these directions if measured at a higher elevation above ground level. These TIs are calculated with a threshold wind speed of $4 \mathrm{~m} / \mathrm{s}$.

Turbulence Intensity Rose, 30 meters vane, 30 meter anemometer

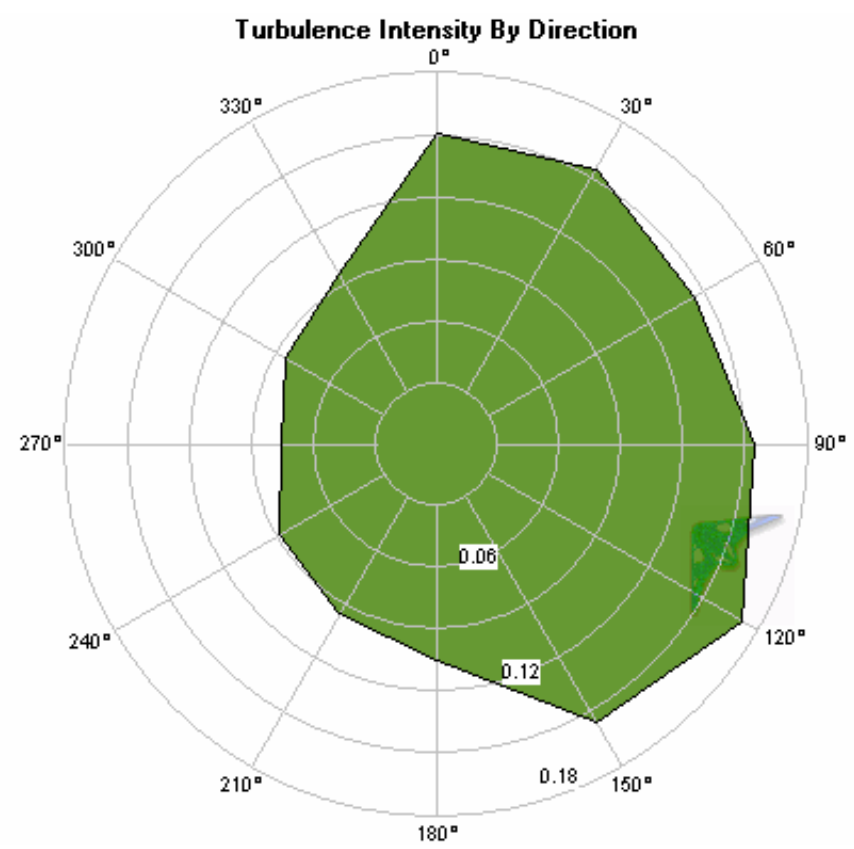

\section{IEC Turbulence Intensity Standards}

Turbulence at the Dillingham-Kanakanak met tower test site is within International Electrotechnical Commission (IEC) standards at all measured wind speeds and from all four quadrants of the wind rose (except for IEC Category B at higher wind speeds in $315^{\circ}$ to $45^{\circ}$ sector (this sector experiences infrequent winds, hence this is a minimal concern). 
Dillingham, Alaska Kanakanak Wind Resource Report

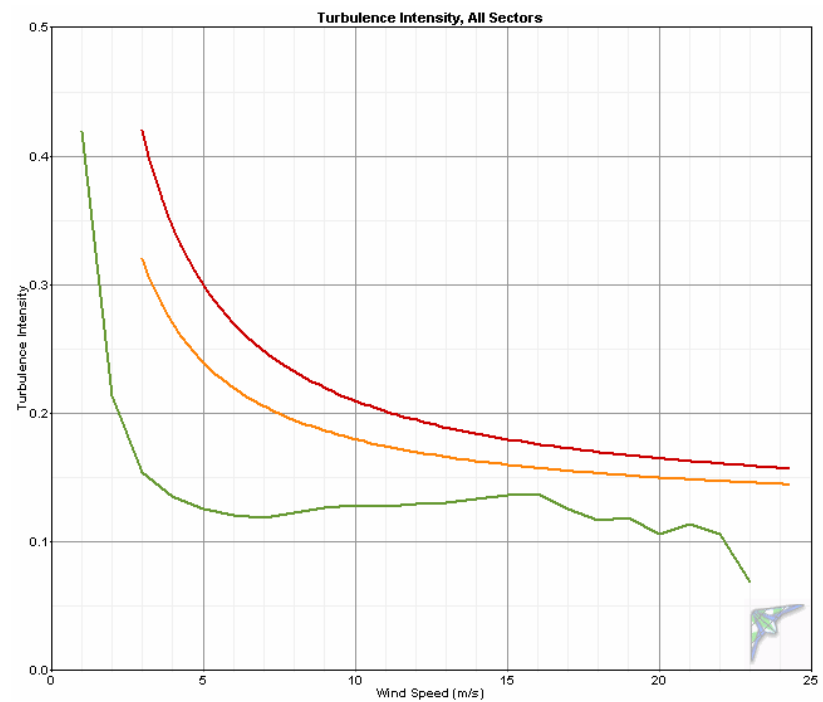

二 Mean Turbulence Intensity

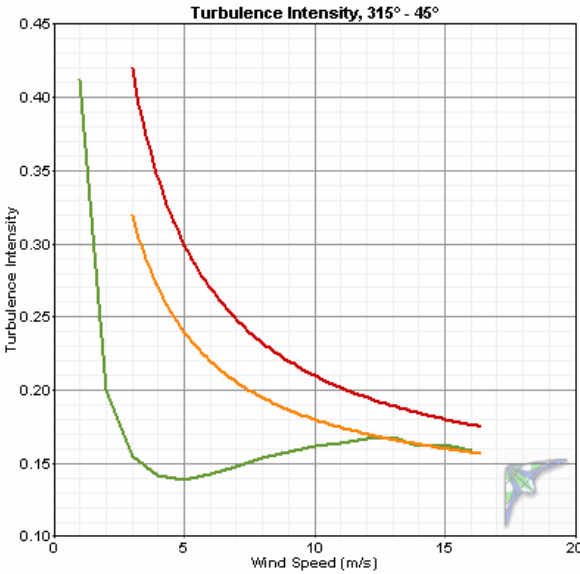

- Mean Turbulence Intensity - IEC Categony A

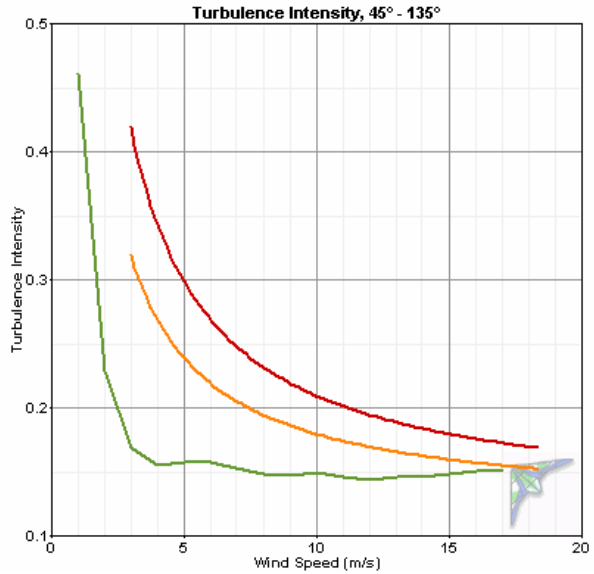
- IEA Categony A
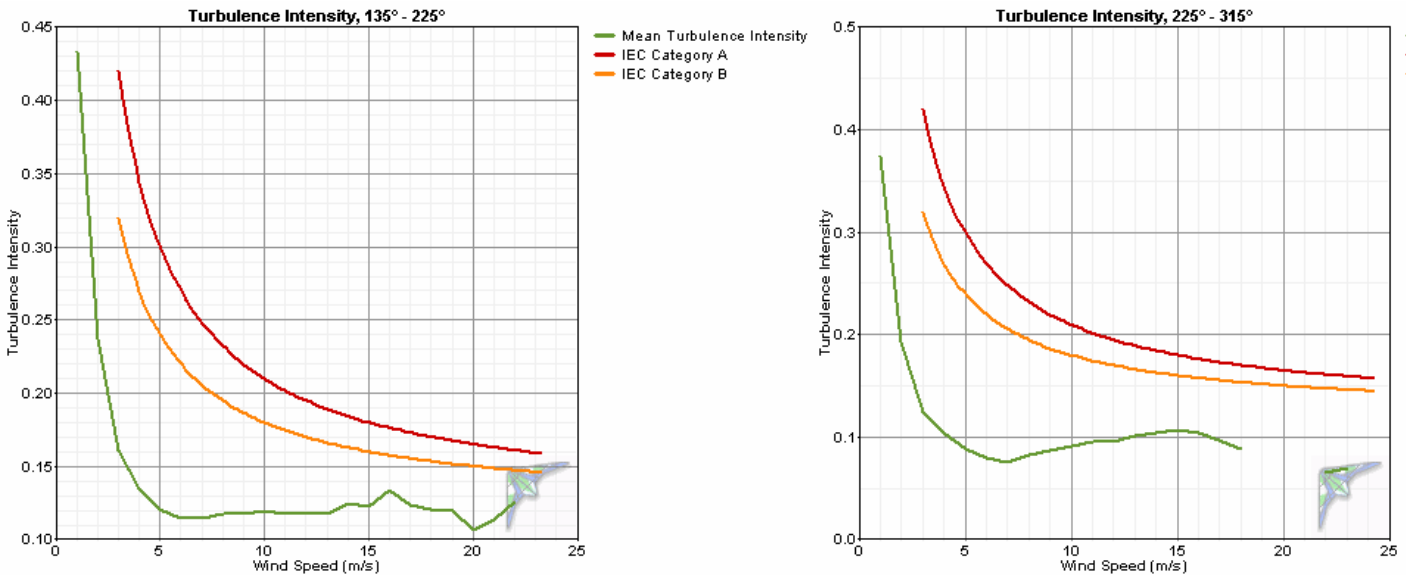

- Mean Turbulence Intensity - IEC Categony A
- IEC Categony B - IEC Categony A
- IEC Categony B 
Dillingham, Alaska Kanakanak Wind Resource Report

Turbulence Table

\begin{tabular}{|c|c|c|c|c|c|c|c|}
\hline \multirow{2}{*}{$\begin{array}{l}\text { Bin } \\
\text { Midpoint } \\
(\mathrm{m} / \mathrm{s})\end{array}$} & \multicolumn{2}{|c|}{ Bin Endpoints } & \multirow{2}{*}{$\begin{array}{c}\text { Records } \\
\text { In } \\
\text { Bin }\end{array}$} & \multirow{2}{*}{$\begin{array}{c}\text { Standard Devia- } \\
\text { tion } \\
\text { of Wind Speed } \\
(\mathrm{m} / \mathrm{s})\end{array}$} & \multirow{2}{*}{$\begin{array}{c}\text { Mean } \\
\text { Turbulence } \\
\text { Intensity }\end{array}$} & \multirow{2}{*}{$\begin{array}{l}\text { Standard Devia- } \\
\text { tion } \\
\text { of Turbulence } \\
\text { Intensity }\end{array}$} & \multirow{2}{*}{$\begin{array}{c}\text { Characteristic } \\
\text { Turbulence } \\
\text { Intensity }\end{array}$} \\
\hline & $\begin{array}{c}\text { Lower } \\
(\mathrm{m} / \mathrm{s})\end{array}$ & $\begin{array}{l}\text { Upper } \\
(\mathrm{m} / \mathrm{s})\end{array}$ & & & & & \\
\hline 1 & 0.5 & 1.5 & 2,845 & 0.406 & 0.419 & 0.189 & 0.608 \\
\hline 2 & 1.5 & 2.5 & 5,801 & 0.417 & 0.213 & 0.112 & 0.326 \\
\hline 3 & 2.5 & 3.5 & 9,040 & 0.458 & 0.155 & 0.073 & 0.228 \\
\hline 4 & 3.5 & 4.5 & 10,225 & 0.537 & 0.136 & 0.059 & 0.195 \\
\hline 5 & 4.5 & 5.5 & 10,897 & 0.623 & 0.126 & 0.054 & 0.180 \\
\hline 6 & 5.5 & 6.5 & 10,457 & 0.716 & 0.121 & 0.052 & 0.172 \\
\hline 7 & 6.5 & 7.5 & 8,362 & 0.824 & 0.119 & 0.050 & 0.168 \\
\hline 8 & 7.5 & 8.5 & 6,071 & 0.977 & 0.123 & 0.046 & 0.169 \\
\hline 9 & 8.5 & 9.5 & 4,325 & 1.129 & 0.126 & 0.043 & 0.170 \\
\hline 10 & 9.5 & 10.5 & 2,936 & 1.279 & 0.129 & 0.041 & 0.170 \\
\hline 11 & 10.5 & 11.5 & 1,891 & 1.395 & 0.128 & 0.039 & 0.167 \\
\hline 12 & 11.5 & 12.5 & 1,036 & 1.537 & 0.129 & 0.037 & 0.166 \\
\hline 13 & 12.5 & 13.5 & 574 & 1.698 & 0.131 & 0.037 & 0.169 \\
\hline 14 & 13.5 & 14.5 & 375 & 1.861 & 0.134 & 0.033 & 0.166 \\
\hline 15 & 14.5 & 15.5 & 234 & 2.029 & 0.136 & 0.030 & 0.166 \\
\hline 16 & 15.5 & 16.5 & 120 & 2.177 & 0.137 & 0.028 & 0.165 \\
\hline 17 & 16.5 & 17.5 & 73 & 2.111 & 0.125 & 0.031 & 0.156 \\
\hline 18 & 17.5 & 18.5 & 42 & 2.100 & 0.117 & 0.019 & 0.136 \\
\hline 19 & 18.5 & 19.5 & 31 & 2.245 & 0.119 & 0.024 & 0.143 \\
\hline 20 & 19.5 & 20.5 & 18 & 2.139 & 0.107 & 0.017 & 0.124 \\
\hline 21 & 20.5 & 21.5 & 15 & 2.360 & 0.114 & 0.030 & 0.144 \\
\hline 22 & 21.5 & 22.5 & 3 & 2.333 & 0.106 & 0.041 & 0.147 \\
\hline 23 & 22.5 & 23.5 & 2 & 1.600 & 0.069 & 0.005 & 0.074 \\
\hline 24 & 23.5 & 24.5 & 0 & 1.600 & 0.069 & 0.005 & 0.074 \\
\hline
\end{tabular}




\section{Air Temperature and Density}

Over the reporting period, Dillingham had an average temperature of $5.6^{\circ} \mathrm{C}$. The minimum recorded temperature during the measurement period was $-26.9^{\circ} \mathrm{C}$ and the maximum temperature was $27.6^{\circ} \mathrm{C}$, indicating a wide variability of an ambient temperature operating environment important to wind turbine operations. Consequent to Dillingham's cool temperatures, the average air density of $1.272 \mathrm{~kg} / \mathrm{m}^{3}$ is approximately four percent higher than the standard air density of $1.220 \mathrm{~kg} / \mathrm{m}^{3}$ (at $14.7^{\circ} \mathrm{C}$ temperature and $100.8 \mathrm{kPa}$ pressure at $40 \mathrm{~m}$ elevation), indicating that Dillingham, due to its cool annual temperature average and low elevation, has denser air than the standard air density used to calculate turbine power curves. This density variance from standard is accounted for in turbine performance predictions in this report.

\begin{tabular}{crrrrrrr}
\multicolumn{3}{c}{ Temperature } & \multicolumn{3}{c}{ Air Density } \\
Month & $\begin{array}{c}\text { Mean } \\
\left({ }^{\circ} \mathrm{C}\right)\end{array}$ & \multicolumn{1}{c}{$\begin{array}{c}\text { Min } \\
\left({ }^{\circ} \mathrm{C}\right)\end{array}$} & $\begin{array}{c}\text { Max } \\
\left({ }^{\circ} \mathrm{C}\right)\end{array}$ & $\begin{array}{c}\text { Std. } \\
\text { Dev. } \\
\left({ }^{\circ} \mathrm{C}\right)\end{array}$ & $\begin{array}{c}\text { Mean } \\
\left(\mathrm{kg} / \mathrm{m}^{3}\right)\end{array}$ & $\begin{array}{c}\text { Min } \\
\left(\mathrm{kg} / \mathrm{m}^{3}\right)\end{array}$ & $\begin{array}{c}\text { Max } \\
\left(\mathrm{kg} / \mathrm{m}^{3}\right)\end{array}$ \\
\hline Jan & -5.7 & -18.1 & 2.9 & 5.03 & 1.314 & 1.272 & 1.377 \\
Feb & -5.8 & -26.9 & 4.5 & 8.36 & 1.315 & 1.265 & 1.426 \\
Mar & -3.2 & -24.1 & 7.0 & 5.91 & 1.302 & 1.254 & 1.410 \\
Apr & 0.4 & -18.9 & 18.1 & 6.52 & 1.285 & 1.206 & 1.381 \\
May & 7.9 & -0.1 & 19.1 & 3.31 & 1.250 & 1.202 & 1.286 \\
Jun & 12.1 & 2.6 & 27.6 & 4.02 & 1.232 & 1.168 & 1.274 \\
Jul & 14.5 & 6.3 & 26.8 & 3.52 & 1.221 & 1.171 & 1.257 \\
Aug & 14.3 & 4.8 & 26.8 & 3.54 & 1.222 & 1.171 & 1.264 \\
Sep & 8.1 & -2.5 & 18.6 & 3.46 & 1.249 & 1.204 & 1.298 \\
Oct & 3.7 & -9.8 & 12.0 & 3.46 & 1.269 & 1.232 & 1.334 \\
Nov & -1.8 & -16.5 & 4.1 & 4.49 & 1.295 & 1.267 & 1.368 \\
Dec & -5.5 & -23.5 & 3.9 & 5.67 & 1.313 & 1.268 & 1.407 \\
\hline Annual & $\mathbf{3 . 2}$ & -26.9 & 27.6 & 8.78 & $\mathbf{1 . 2 7 2}$ & 1.168 & 1.426
\end{tabular}

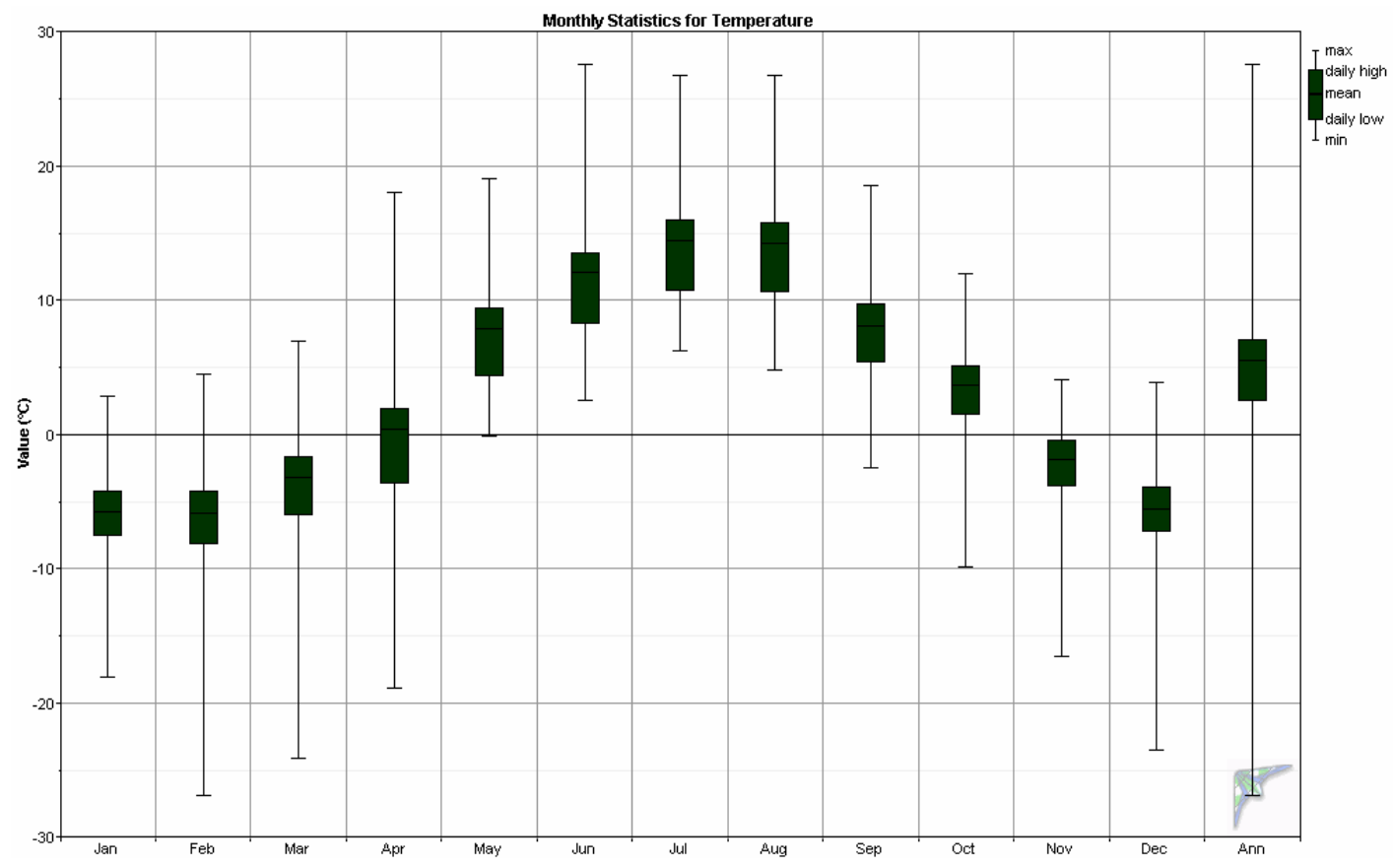




\section{Air Density DMap}

The DMap below is a visual indication of the daily and seasonal variations of air density (and hence temperature). Air densities higher than standard will yield higher turbine power than predicted by the turbine power curve, while densities lower than standard will yield lower turbine power than predicted. Density variance from standard is accounted for in the turbine performance predictions.

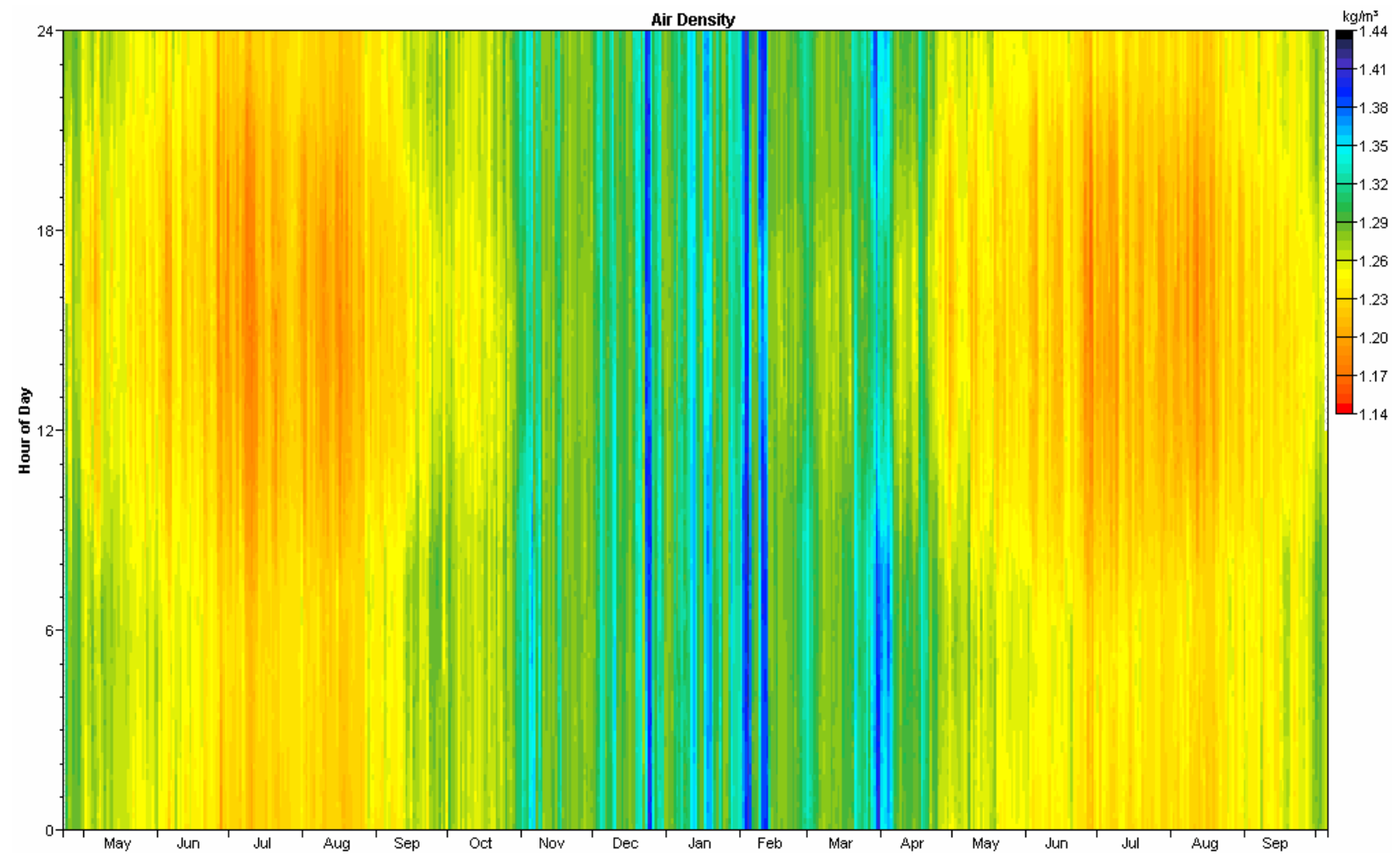




\section{Turbine Performance Predictions}

The turbine performance predictions noted below are based on 100 percent and 90 percent turbine availabilities. The 100 percent data is for use as a baseline of comparison, but it is realistic to expect ten percent losses or downtime for wind turbines, at least during the first year of operation.

Note that these performance estimates were predicted with use of Windographer ${ }^{\circledR}$ wind analysis software; power curves provided by manufacturers are not independently verified and are assumed to be accurate. The power curves are presented for a standard air density of $1.225 \mathrm{~kg} / \mathrm{m}^{3}$ at sea level and $15^{\circ} \mathrm{C}$. However, the predictions of power production are density compensated by multiplying the standard density power output by the ratio of the measured air density to standard air density, accounting for the site elevation.

A number of small to medium turbines are profiled in this report for comparison purposes. These turbines were selected because they have market availability and they are deemed to be within a suitable range for consideration of wind power development in a community the size of Naknek.

Bergey Excel-S: $10 \mathrm{~kW}$ rated power output, 6.7 meter rotor diameter, stall-controlled. Available tower heights: 18, 24, 30, 37 and 43 meters. Additional information is available at www.bergey.com.
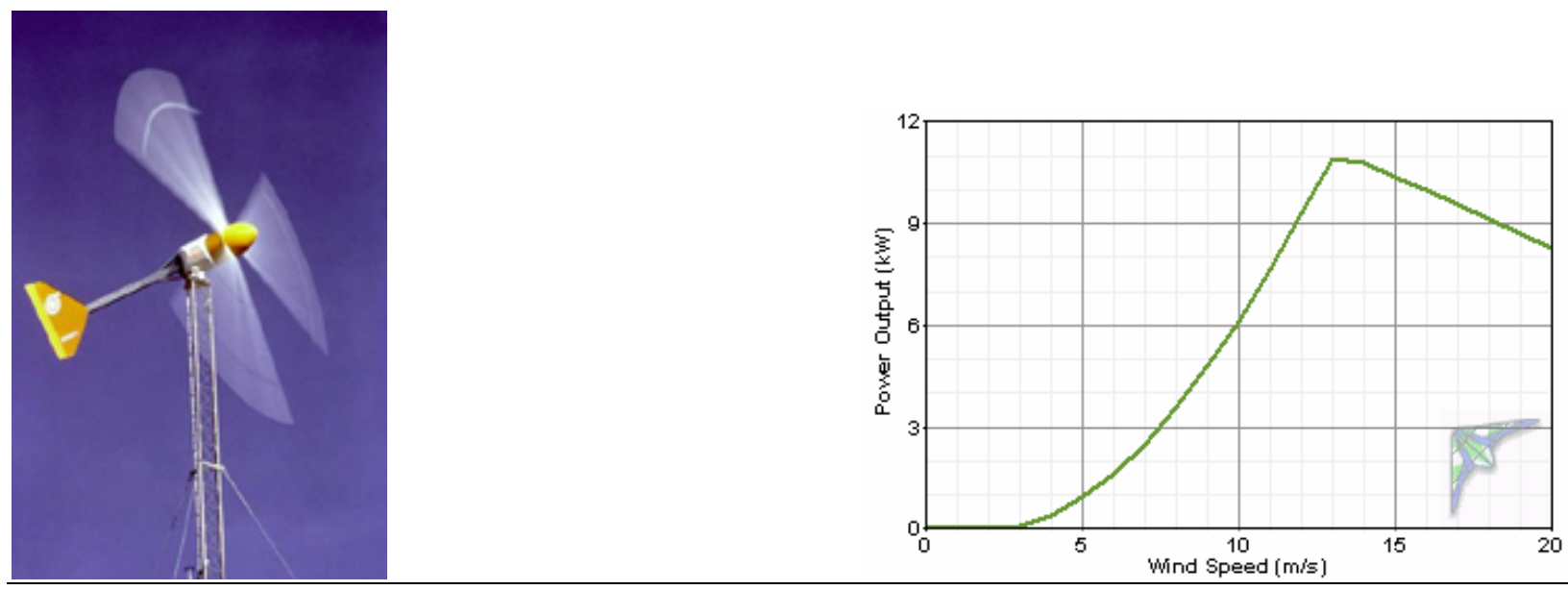

Entegrity eW-15: $65 \mathrm{~kW}$ rated power output, 15 meter rotor, stall-controlled (power curve provided by Entegrity Energy Systems). Available tower heights: 25 and 31 meters. Additional information is available at http://www.entegritywind.com/. 

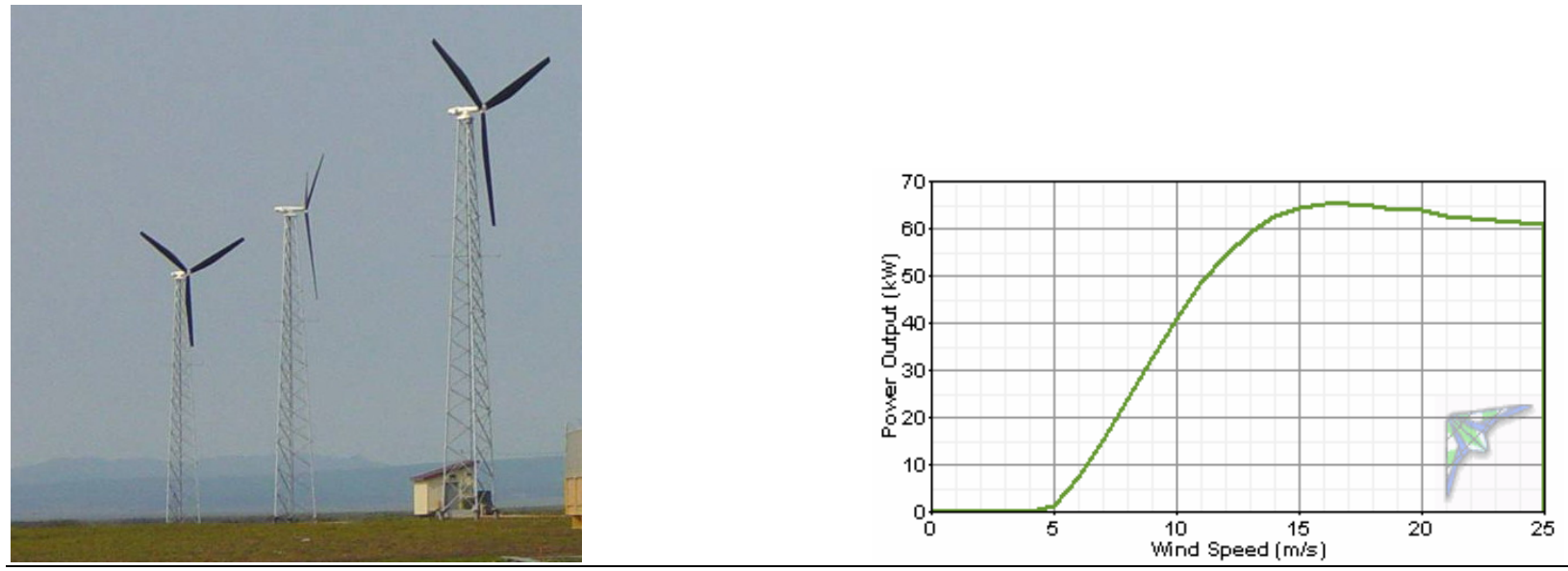

Vestas V15: $75 \mathrm{~kW}$ rated power output, 15 meter rotor, stall-controlled (power curve provided by Powercorp Alaska LLC). Available tower heights: 25, 31 and 34 meters. Additional information is available at http://www.pcorpalaska.com/.
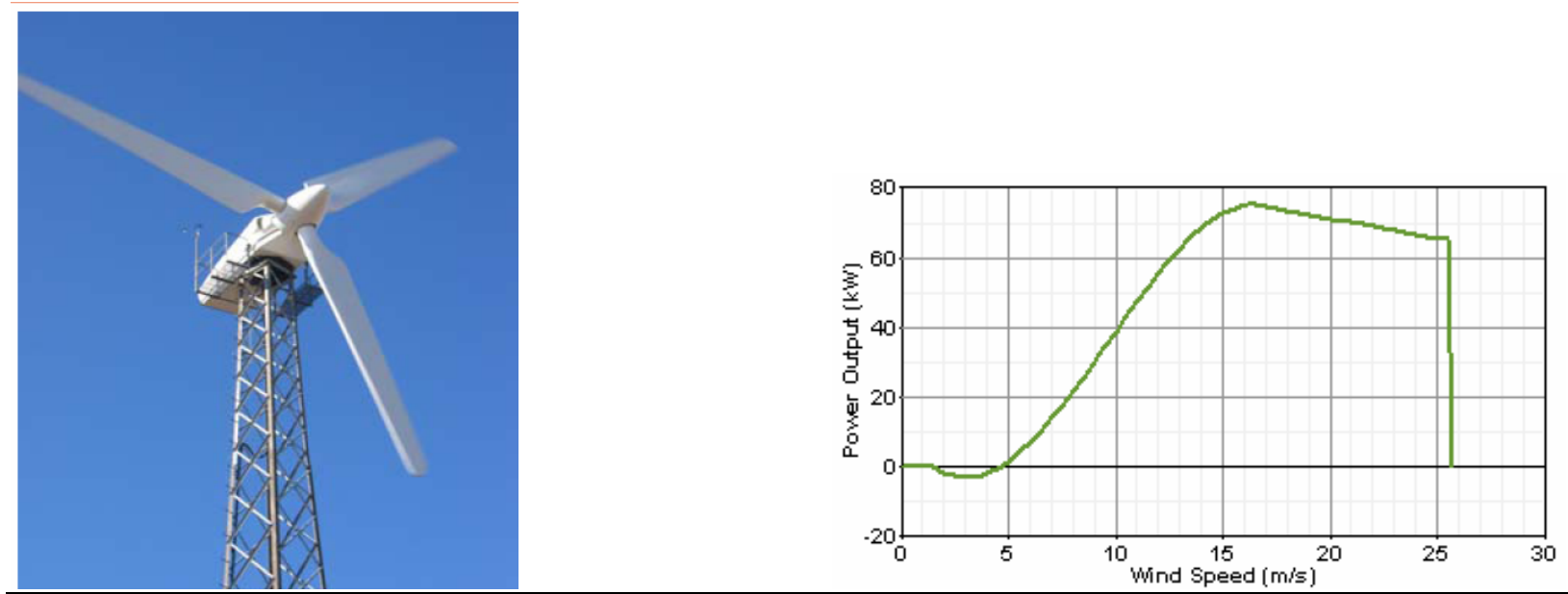

Northwind 100/20: $100 \mathrm{~kW}$ rated power output, 20 meter rotor (19 meter rotor blades with 0.6 meter blade root extensions added), stall-controlled (power curve provided by Northern Power Systems). Available tower heights: 25 and 32 meters. Additional information is available at http://www.northernpower.com/. 

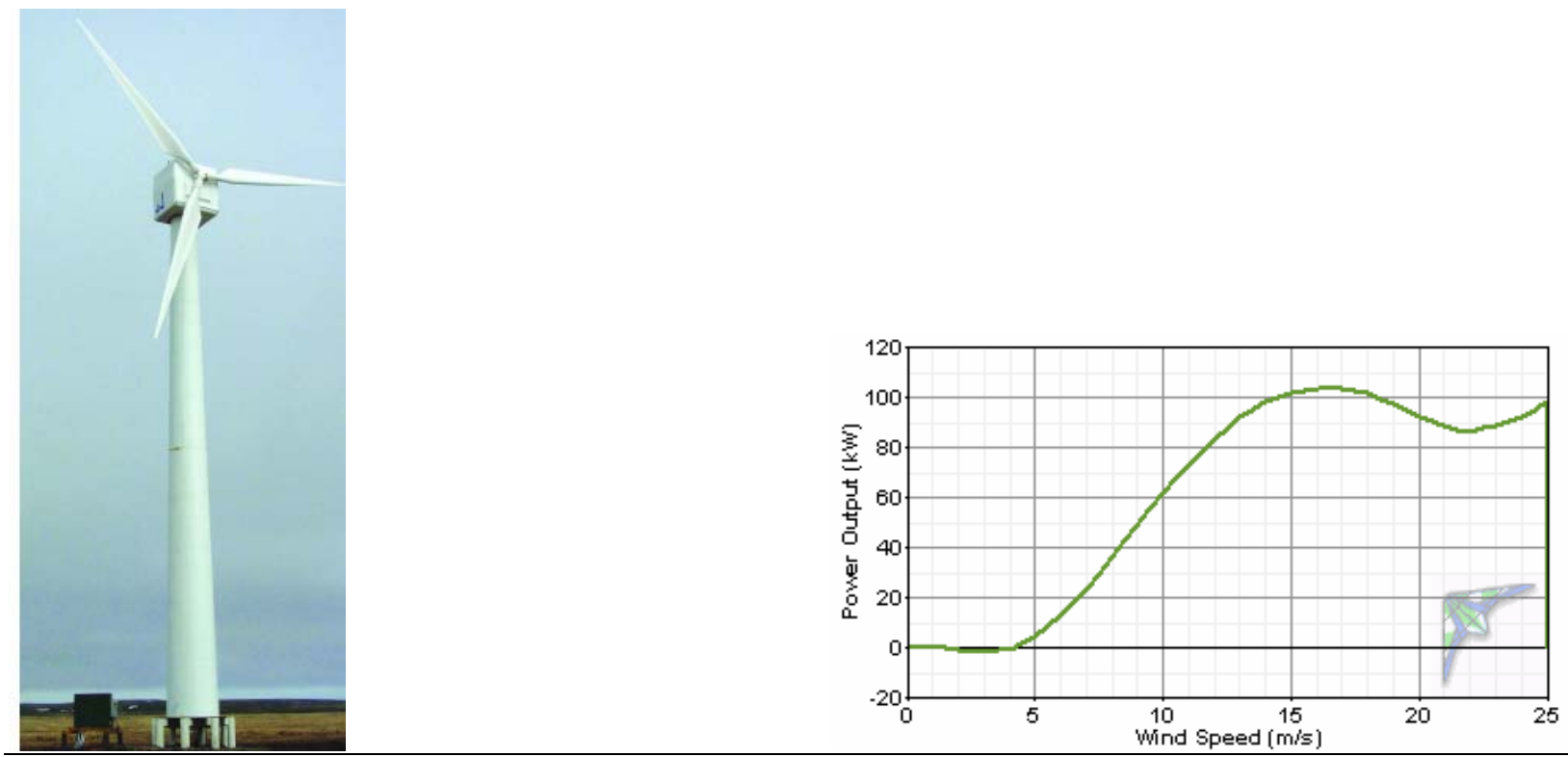

Vestas V27: $225 \mathrm{~kW}$ output, 27 meter rotor, pitch-controlled (power curve provided by Alaska Energy Authority).
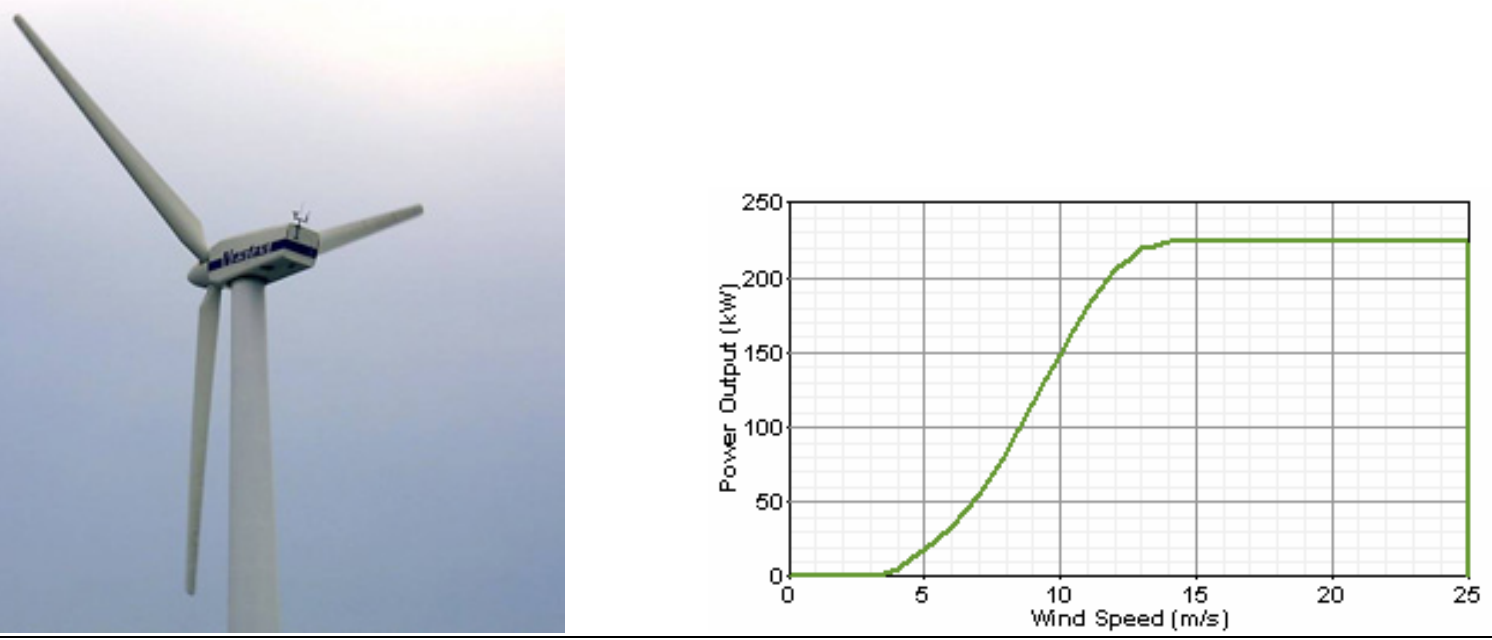

Fuhrländer FL250: 250 kW output, 29.5 meter rotor, stall-controlled (power curve provided by Lorax Energy Systems). Available tower heights: 42 and 50 meters. Additional information is available at www.lorax-energy.com. 

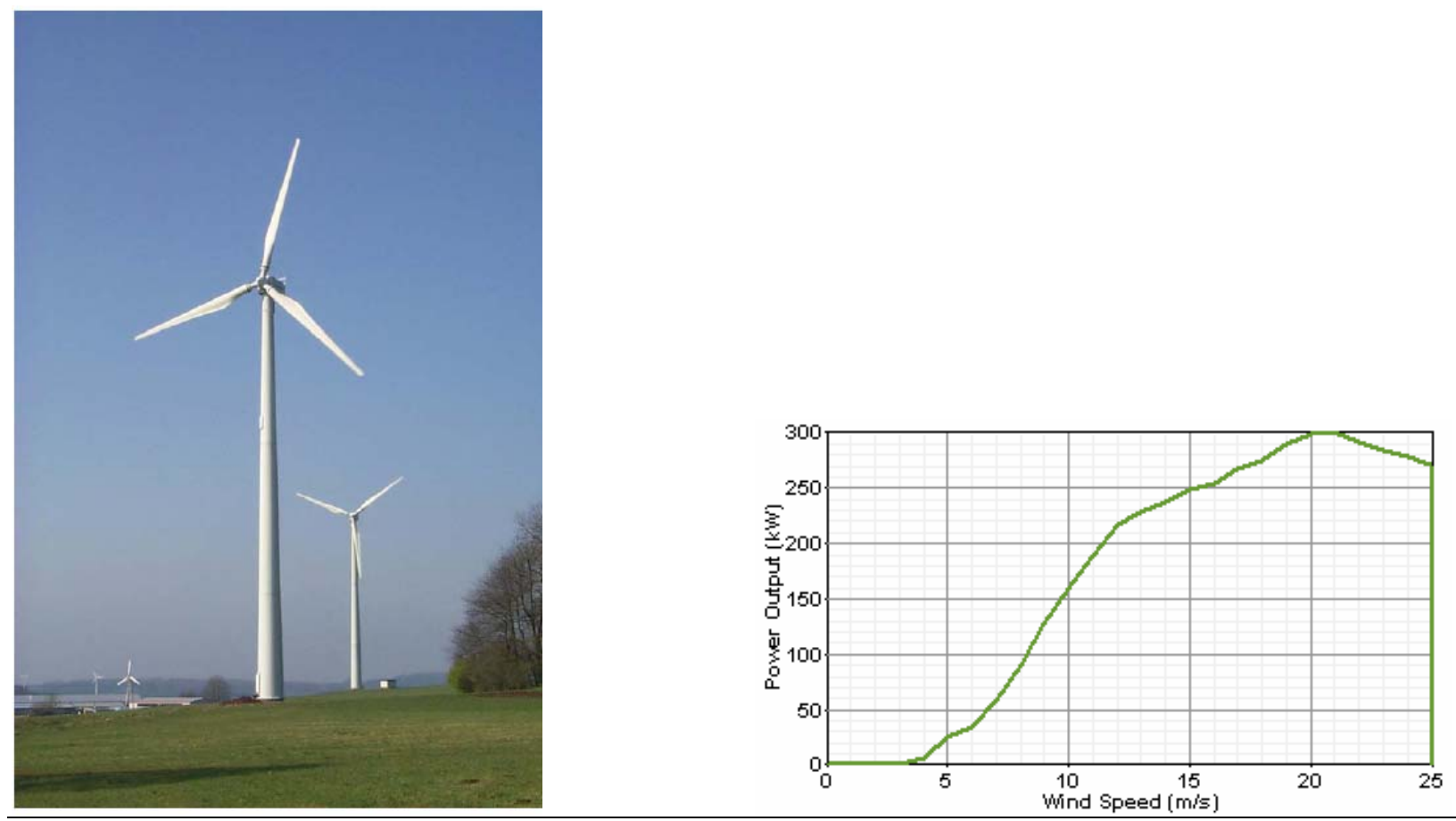

Vestas RRB 47/600: 600 kW output, 47 meter rotor, pitch-controlled (power curve provided by Vestas RRB, India). Available tower heights: 50 and 60 meters. Additional information is available at www.vestasrrb.com.
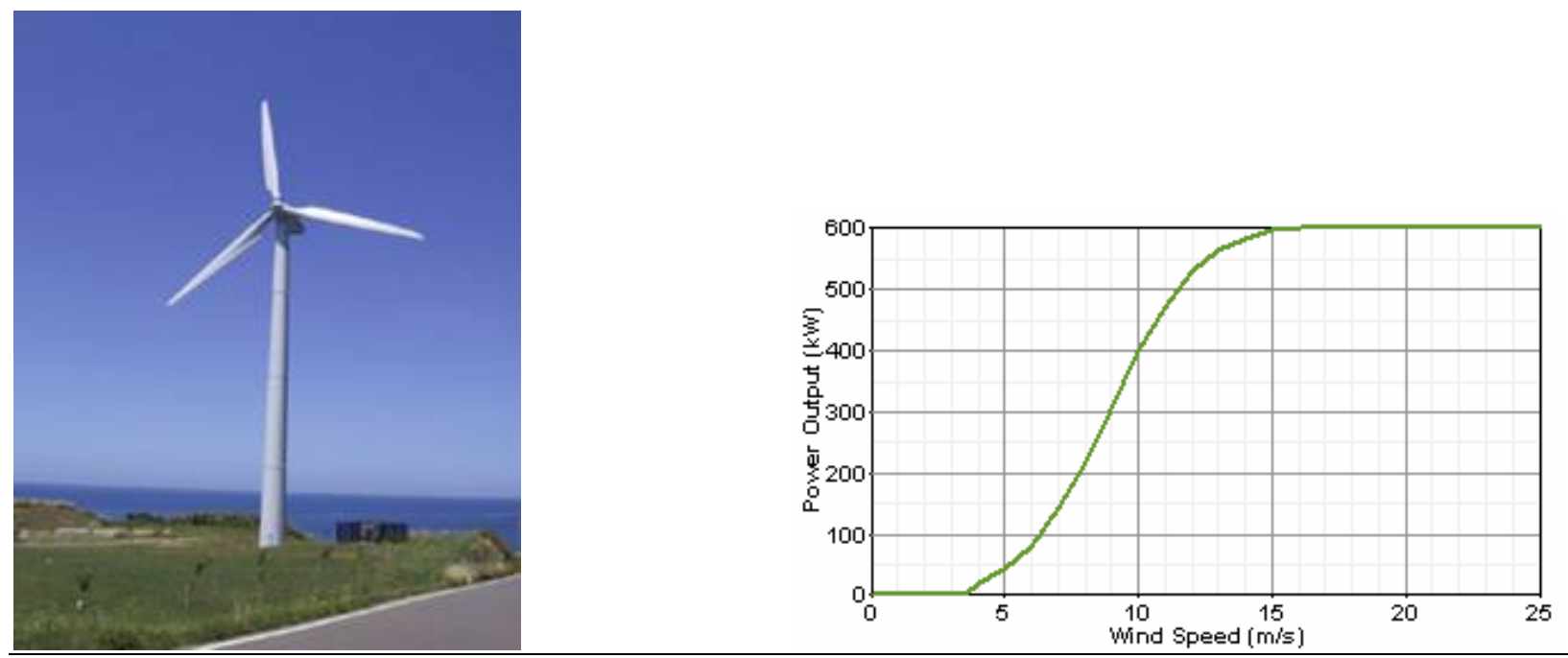
General Electric 1.5s: 1,500 kW output, 70.5 meter rotor, pitch controlled (power curve provided by GE). Available tower heights: 54.7 and 64.7 meters. Additional information is available at www.gewindenergy.com.
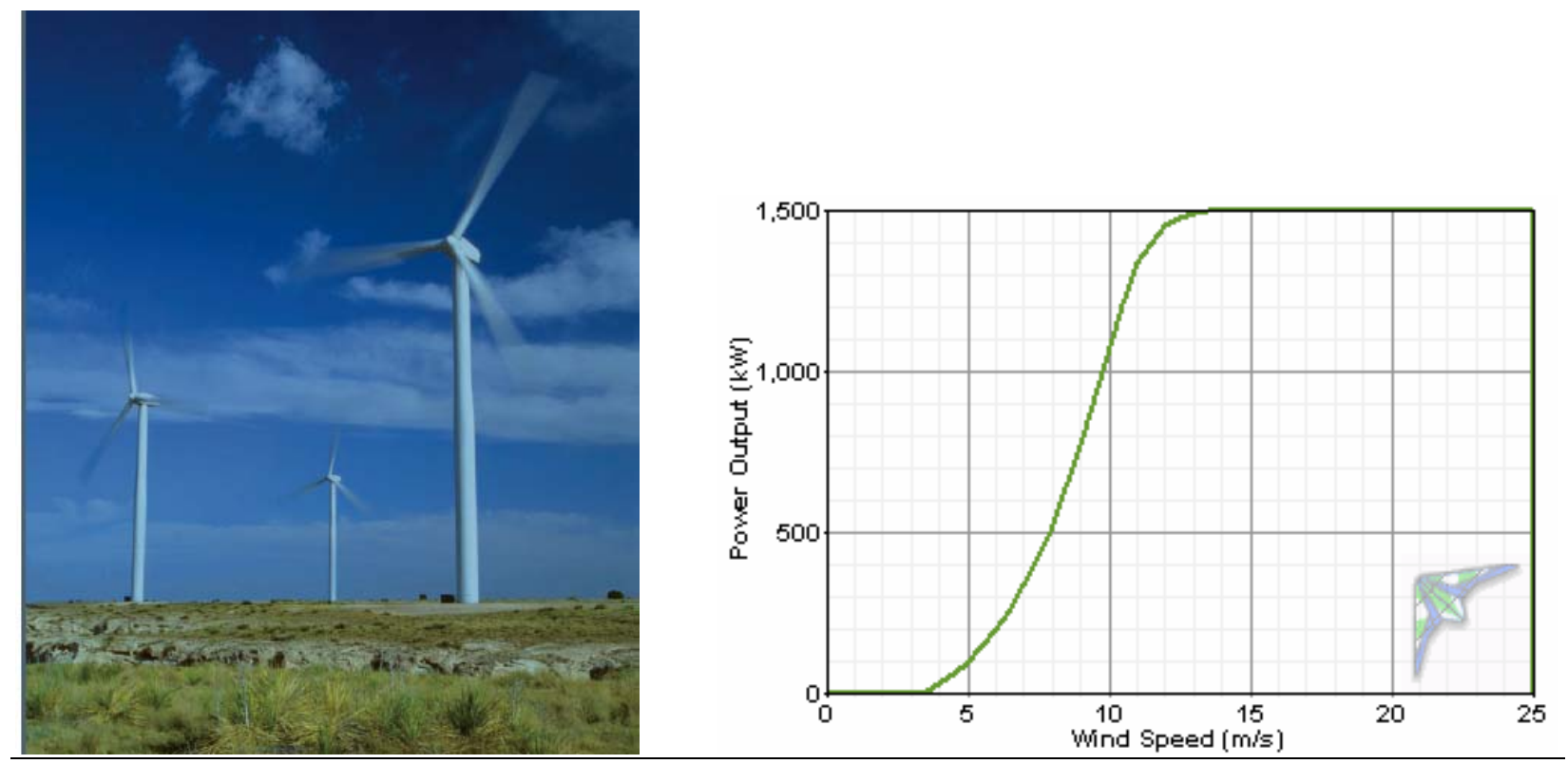
Dillingham, Alaska Kanakanak Wind Resource Report

Turbine Power Output Comparison (100\% availability)

\begin{tabular}{|c|c|c|c|c|c|c|c|}
\hline Turbine & $\begin{array}{l}\text { Hub } \\
\text { Height } \\
\text { (m) }\end{array}$ & $\begin{array}{c}\text { Hub Height } \\
\text { Wind Speed } \\
(\mathrm{m} / \mathrm{s})\end{array}$ & $\begin{array}{c}\text { Time At } \\
\text { Zero Output } \\
(\%)\end{array}$ & $\begin{array}{c}\text { Time At } \\
\text { Rated Output } \\
(\%)\end{array}$ & $\begin{array}{c}\text { Average Net } \\
\text { Power Output } \\
(\mathrm{kW})\end{array}$ & $\begin{array}{c}\text { Annual Net } \\
\text { Energy } \\
\text { Output } \\
\text { (kWh/yr) }\end{array}$ & $\begin{array}{c}\text { Average Net } \\
\text { Capacity } \\
\text { Factor } \\
(\%)\end{array}$ \\
\hline Bergey Excel-S & 43 & 6.44 & 7.4 & 3.9 & 2.8 & 24,771 & 28.3 \\
\hline Entegrity eW-15 $60 \mathrm{~Hz}$ & 31 & 5.83 & 29.4 & 1.2 & 13 & 116,432 & 20.5 \\
\hline Vestas V15 & 34 & 5.99 & 35.3 & 0.8 & 13 & 113,656 & 17.3 \\
\hline Northern Power NW 100/20 & 32 & 5.68 & 29.0 & 1.2 & 20 & 174,691 & 20.0 \\
\hline Vestas V27 & 50 & 6.74 & 10.2 & 2.2 & 70 & 611,977 & 31.1 \\
\hline Fuhrländer FL250 & 50 & 6.74 & 7.2 & 0.3 & 77 & 678,313 & 25.8 \\
\hline Vestas RRB 47/600 & 50 & 6.74 & 18.4 & 1.5 & 182 & $1,596,887$ & 30.4 \\
\hline General Electric 1.5s & 65 & 7.32 & 16.6 & 6.8 & 554 & $4,853,556$ & 37.0 \\
\hline \multicolumn{8}{|l|}{ Capacity Factor <20\% } \\
\hline \multicolumn{8}{|l|}{ Capacity Factor >20\%, <30\% } \\
\hline \multicolumn{8}{|l|}{ Capacity Factor $>30 \%,<40 \%$} \\
\hline \multicolumn{8}{|l|}{ Capacity Factor $>40 \%,<50 \%$} \\
\hline Capacity Factor $>50 \%$ & & & & & & & \\
\hline
\end{tabular}

Assumed turbine losses for predictions of average power output, annual energy output, and average capacity factor: Downtime (\%)

Array (\%)

Icing/soiling (\%)

Other (\%)

Total (\%) 
Dillingham, Alaska Kanakanak Wind Resource Report

Turbine Power Output Comparison (90\% availability)

\begin{tabular}{|c|c|c|c|c|c|c|c|}
\hline Turbine & $\begin{array}{l}\text { Hub } \\
\text { Height } \\
\text { (m) }\end{array}$ & $\begin{array}{c}\text { Hub Height } \\
\text { Wind Speed } \\
(\mathrm{m} / \mathrm{s})\end{array}$ & $\begin{array}{c}\text { Time At } \\
\text { Zero Output } \\
(\%)\end{array}$ & $\begin{array}{c}\text { Time At } \\
\text { Rated Output } \\
(\%)\end{array}$ & $\begin{array}{c}\text { Average Net } \\
\text { Power Output } \\
(\mathrm{kW})\end{array}$ & $\begin{array}{l}\text { Annual Net } \\
\text { Energy } \\
\text { Output } \\
\text { (kWh/yr) }\end{array}$ & $\begin{array}{l}\text { Average Net } \\
\text { Capacity } \\
\text { Factor } \\
(\%)\end{array}$ \\
\hline Bergey Excel-S & 43 & 6.21 & 7.9 & 3.3 & 2.4 & 22,381 & 25.6 \\
\hline Entegrity eW-15 $60 \mathrm{~Hz}$ & 31 & 5.63 & 31.2 & 0.9 & 11 & 105,196 & 18.5 \\
\hline Vestas V15 & 34 & 5.79 & 37.5 & 0.6 & 11 & 102,688 & 15.6 \\
\hline Northern Power NW 100/20 & 32 & 5.68 & 30.8 & 0.9 & 16 & 157,833 & 18.1 \\
\hline Vestas V27 & 50 & 6.50 & 10.9 & 1.8 & 58 & 552,921 & 28.1 \\
\hline Fuhrländer FL250 & 50 & 6.50 & 7.6 & 0.2 & 64 & 612,856 & 23.3 \\
\hline Vestas RRB 47/600 & 50 & 6.50 & 19.6 & 1.2 & 151 & $1,442,787$ & 27.5 \\
\hline General Electric 1.5s & 65 & 7.32 & 16.6 & 6.8 & 554 & $4,385,188$ & 33.4 \\
\hline \multicolumn{8}{|l|}{ Capacity Factor <20\% } \\
\hline \multicolumn{8}{|l|}{ Capacity Factor >20\%, <30\% } \\
\hline \multicolumn{8}{|l|}{ Capacity Factor $>30 \%,<40 \%$} \\
\hline \multicolumn{8}{|l|}{ Capacity Factor $>40 \%,<50 \%$} \\
\hline Capacity Factor $>50 \%$ & & & & & & & \\
\hline
\end{tabular}

Assumed turbine losses for predictions of average power output, annual energy output, and average capacity factor:

Downtime (\%)

Array (\%)

Icing/soiling (\%)

Other (\%)

4

Total (\%)

2

2

9.65 (factors are multiplicative) 
Dillingham, Alaska Kanakanak Wind Resource Report

Fuel Cost Avoided for Electricity Generation by Diesel Generator

\begin{tabular}{|c|c|c|c|c|c|c|c|c|c|c|}
\hline \multirow[b]{2}{*}{ Turbine } & \multirow{2}{*}{$\begin{array}{c}\text { Annual } \\
\text { Energy } \\
\text { Output } \\
\text { (kW-hr/yr) }\end{array}$} & \multirow{2}{*}{$\begin{array}{c}\text { Fuel } \\
\text { Quantity } \\
\text { Avoided } \\
\text { (gallons) }\end{array}$} & \multicolumn{7}{|c|}{ Fuel Price (USD/gallon) } & \multirow{2}{*}{$\begin{array}{c}\text { Turbine } \\
\text { Hub } \\
\text { Height } \\
(\mathrm{m})\end{array}$} \\
\hline & & & $\$ 1.75$ & $\$ 2.00$ & $\$ 2.25$ & $\$ 2.50$ & $\$ 2.75$ & $\$ 3.00$ & $\$ 3.25$ & \\
\hline Bergey Excel-S & 22,381 & 1,463 & $\$ 2,560$ & $\$ 2,926$ & $\$ 3,291$ & $\$ 3,657$ & $\$ 4,023$ & $\$ 4,388$ & $\$ 4,754$ & 43 \\
\hline Entegrity eW-15 $60 \mathrm{~Hz}$ & 105,196 & 6,876 & $\$ 12,032$ & $\$ 13,751$ & $\$ 15,470$ & $\$ 17,189$ & $\$ 18,908$ & $\$ 20,627$ & $\$ 22,346$ & 31 \\
\hline Vestas V15 & 102,688 & 6,712 & $\$ 11,745$ & $\$ 13,423$ & $\$ 15,101$ & $\$ 16,779$ & $\$ 18,457$ & $\$ 20,135$ & $\$ 21,813$ & 34 \\
\hline Northern Power NW 100/20 & 157,833 & 10,316 & $\$ 18,053$ & $\$ 20,632$ & $\$ 23,211$ & $\$ 25,790$ & $\$ 28,369$ & $\$ 30,948$ & $\$ 33,527$ & 32 \\
\hline Vestas V27 & 552,921 & 36,139 & $\$ 63,243$ & $\$ 72,277$ & $\$ 81,312$ & $\$ 90,347$ & $\$ 99,381$ & $\$ 108,416$ & $\$ 117,451$ & 50 \\
\hline Fuhrländer FL250 & 612,856 & 40,056 & $\$ 70,098$ & $\$ 80,112$ & $\$ 90,126$ & $\$ 100,140$ & $\$ 110,154$ & $\$ 120,168$ & $\$ 130,182$ & 50 \\
\hline Vestas RRB 47/600 & $1,442,787$ & 94,300 & $\$ 165,025$ & $\$ 188,600$ & $\$ 212,175$ & $\$ 235,750$ & $\$ 259,325$ & $\$ 282,899$ & $\$ 306,474$ & 50 \\
\hline General Electric 1.5s & $4,385,188$ & 286,614 & $\$ 501,574$ & $\$ 573,227$ & $\$ 644,881$ & $\$ 716,534$ & $\$ 788,187$ & $\$ 859,841$ & $\$ 931,494$ & 65 \\
\hline
\end{tabular}

Notes:

1. Dillingham electrical energy production efficiency is $15.3 \mathrm{~kW}$-hr/gal (source: Nushagak Electric Coop)

2. Assumes $90 \%$ wind turbine availability with no diversion of power to a thermal or other dump load

3. Assumes linear diesel generator fuel efficiency (i.e., 1:1 tradeoff of wind turbine kW-hr to diesel genset kW-hr) 
Dillingham, Alaska Kanakanak Wind Resource Report

Temperature Conversion Chart ${ }^{\circ} \mathrm{C}$ to ${ }^{\circ} \mathrm{F}$

\begin{tabular}{|c|c|c|c|c|c|}
\hline${ }^{\circ} \mathbf{C}$ & ${ }^{\circ} \mathbf{F}$ & ${ }^{\circ} \mathbf{C}$ & ${ }^{\circ} \mathbf{F}$ & ${ }^{\circ} \mathbf{C}$ & ${ }^{\circ} \mathbf{F}$ \\
\hline-40 & -40 & -10 & 14 & 20 & 68 \\
\hline-39 & -38.2 & -9 & 15.8 & 21 & 69.8 \\
\hline-38 & -36.4 & -8 & 17.6 & 22 & 71.6 \\
\hline-37 & -34.6 & -7 & 19.4 & 23 & 73.4 \\
\hline-36 & -32.8 & -6 & 21.2 & 24 & 75.2 \\
\hline-35 & -31 & -5 & 23 & 25 & 77 \\
\hline-34 & 29.2 & -4 & 24.8 & 26 & 78.8 \\
\hline-33 & -27.4 & -3 & 26.6 & 27 & 80.6 \\
\hline-32 & -25.6 & -2 & 28.4 & 28 & 82.4 \\
\hline-31 & -23.8 & -1 & 30.2 & 29 & 84.2 \\
\hline-30 & -22 & 0 & 32 & 30 & 86 \\
\hline-29 & -20.2 & 1 & 33.8 & 31 & 87.8 \\
\hline-28 & -18.4 & 2 & 35.6 & 32 & 89.6 \\
\hline-27 & -16.6 & 3 & 37.4 & 33 & 91.4 \\
\hline-26 & -14.8 & 4 & 39.2 & 34 & 93.2 \\
\hline-25 & -13 & 5 & 41 & 35 & 95 \\
\hline-24 & -11.2 & 6 & 42.8 & 36 & 96.8 \\
\hline-23 & -9.4 & 7 & 44.6 & 37 & 98.6 \\
\hline-22 & -7.6 & 8 & 46.4 & 38 & 100.4 \\
\hline-21 & -5.8 & 9 & 48.2 & 39 & 102.2 \\
\hline-20 & -4 & 10 & 50 & 40 & 104 \\
\hline-19 & -2.2 & 11 & 51.8 & 41 & 105.8 \\
\hline-18 & -0.4 & 12 & 53.6 & 42 & 107.6 \\
\hline-17 & 1.4 & 13 & 55.4 & 43 & 109.4 \\
\hline-16 & 3.2 & 14 & 57.2 & 44 & 111.2 \\
\hline-15 & 5 & 15 & 59 & 45 & 113 \\
\hline-14 & 6.8 & 16 & 60.8 & 46 & 114.8 \\
\hline-13 & 8.6 & 17 & 62.6 & 47 & 116.6 \\
\hline-12 & 10.4 & 18 & 64.4 & 48 & 118.4 \\
\hline-11 & 12.2 & 19 & 66.2 & 49 & 120.2 \\
\hline & & & & & \\
\hline-21 & & & & \\
\hline
\end{tabular}


Dillingham, Alaska Kanakanak Wind Resource Report

Wind Speed Conversion Chart $\mathrm{m} / \mathrm{s}$ to $\mathrm{mph}$

\begin{tabular}{|c|c|c|c|c|c|}
\hline $\mathbf{m} / \mathbf{s}$ & $\mathbf{m p h}$ & $\mathbf{m} / \mathbf{s}$ & $\mathbf{m p h}$ & $\mathbf{~ m / s}$ & $\mathbf{m p h}$ \\
\hline 0.5 & 1.1 & 10.5 & 23.5 & 20.5 & 45.9 \\
\hline 1.0 & 2.2 & 11.0 & 24.6 & 21.0 & 47.0 \\
\hline 1.5 & 3.4 & 11.5 & 25.7 & 21.5 & 48.1 \\
\hline 2.0 & 4.5 & 12.0 & 26.8 & 22.0 & 49.2 \\
\hline 2.5 & 5.6 & 12.5 & 28.0 & 22.5 & 50.3 \\
\hline 3.0 & 6.7 & 13.0 & 29.1 & 23.0 & 51.4 \\
\hline 3.5 & 7.8 & 13.5 & 30.2 & 23.5 & 52.6 \\
\hline 4.0 & 8.9 & 14.0 & 31.3 & 24.0 & 53.7 \\
\hline 4.5 & 10.1 & 14.5 & 32.4 & 24.5 & 54.8 \\
\hline 5.0 & 11.2 & 15.0 & 33.6 & 25.0 & 55.9 \\
\hline 5.5 & 12.3 & 15.5 & 34.7 & 25.5 & 57.0 \\
\hline 6.0 & 13.4 & 16.0 & 35.8 & 26.0 & 58.2 \\
\hline 6.5 & 14.5 & 16.5 & 36.9 & 26.5 & 59.3 \\
\hline 7.0 & 15.7 & 17.0 & 38.0 & 27.0 & 60.4 \\
\hline 7.5 & 16.8 & 17.5 & 39.1 & 27.5 & 61.5 \\
\hline 8.0 & 17.9 & 18.0 & 40.3 & 28.0 & 62.6 \\
\hline 8.5 & 19.0 & 18.5 & 41.4 & 28.5 & 63.8 \\
\hline 9.0 & 20.1 & 19.0 & 42.5 & 29.0 & 64.9 \\
\hline 9.5 & 21.3 & 19.5 & 43.6 & 29.5 & 66.0 \\
\hline 10.0 & 22.4 & 20.0 & 44.7 & 30.0 & 67.1 \\
\hline
\end{tabular}

Distance Conversion $\mathrm{m}$ to $\mathrm{ft}$

\begin{tabular}{|c|c|c|c|}
\hline $\mathbf{m}$ & $\mathbf{f t}$ & $\mathbf{m}$ & $\mathbf{f t}$ \\
\hline 5 & 16 & 35 & 115 \\
\hline 10 & 33 & 40 & 131 \\
\hline 15 & 49 & 45 & 148 \\
\hline 20 & 66 & 50 & 164 \\
\hline 25 & 82 & 55 & 180 \\
\hline 30 & 98 & 60 & 197 \\
\hline
\end{tabular}


Selected definitions (courtesy of Windographer® software by Mistaya Engineering Inc.)

\section{$\underline{\text { Wind Power Class }}$}

The wind power class is a number indicating the average energy content of the wind resource. Wind power classes are based on the average wind power density at 50 meters above ground, according to the following table. Source: Wind Energy Resource Atlas of the United States (http://rredc.nrel.gov/wind/pubs/atlas/tables/A-8T.html)

\begin{tabular}{|c|l|c|}
\hline \multicolumn{2}{|c|}{} & \multicolumn{2}{|c|}{} \\
\hline Wind Power Class & Description & Power Density at 50m $\mathbf{( W / \mathbf { m } ^ { 2 }}$ \\
\hline 1 & Poor & $0-200$ \\
\hline 2 & Marginal & $200-300$ \\
\hline 3 & Fair & $300-400$ \\
\hline 4 & Good & $400-500$ \\
\hline 5 & Excellent & $500-600$ \\
\hline 6 & Outstanding & $600-800$ \\
\hline 7 & Superb & $800-2000$ \\
\hline
\end{tabular}

Windographer classifies any wind resource with an average wind power density above 2000 $\mathrm{W} / \mathrm{m}^{2}$ as class 8 .

Probability Distribution Function

The probability distribution function $\mathrm{f}(\mathrm{x})$ gives the probability that a variable will take on the value $\mathrm{x}$. It is often expressed using a frequency histogram, which gives the frequency with which the variable falls within certain ranges or bins.

\section{$\underline{\text { Wind Turbine Power Regulation }}$}

All wind turbines employ some method of limiting power output at high wind speeds to avoid damage to mechanical or electrical subsystems. Most wind turbines employ either stall control or pitch control to regulate power output.

A stall-controlled turbine typically has blades that are fixed in place, and are designed to experience aerodynamic stall at very high wind speeds. Aerodynamic stall dramatically reduces the torque produced by the blades, and therefore the power produced by the turbine.

On a pitch-controlled turbine, a controller adjusts the angle (pitch) of the blades to best match the wind speed. At very high wind speeds the controller increasingly feathers the blades out of the wind to limit the power output. 


\section{Dillingham, Alaska Wind Resource Report Woodriver Road Site}

Report written by: Douglas Vaught, P.E., V3 Energy, LLC
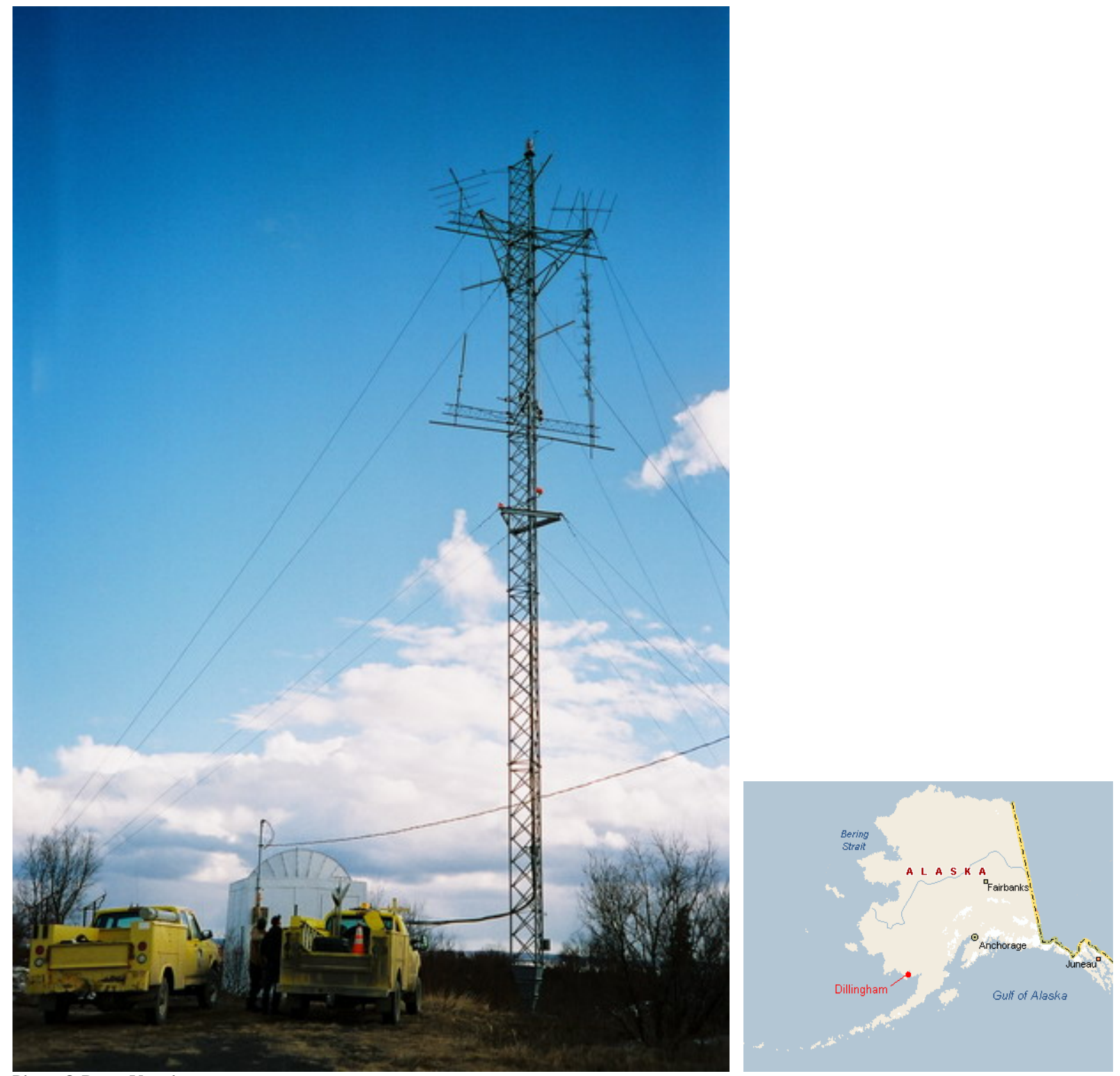

Photo (C) Doug Vaught

\section{Summary Information}

Winds measured in Dillingham were consistent with the State wind resource map and are acceptable for wind power development in the community. Because of the structural mass and complexity of the State EMS tower used as the test platform, the wind shear and turbulence were higher than is likely true. Because a successful wind power project has the potential to lower the 
electrical power generation costs in Dillingham, installation of a 40 or 50 meter meteorological tower nearby may yield better data.

\section{Meteorological Tower Data Synopsis}

Wind power class

Average annual wind speed (33 meters)

Maximum wind gust (2 sec. average)

Mean wind power density (50 meters)

Mean wind power density (33 meters)

Weibull distribution parameters

Roughness Class

Power law exponent

Turbulence Intensity

Data start date

End data date
Class 3 - Fair

$5.99 \mathrm{~m} / \mathrm{s}$

$31.3 \mathrm{~m} / \mathrm{s}, 4 / 21 / 05$

$375 \mathrm{~W} / \mathrm{m}^{2}$ (calculated)

$289 \mathrm{~W} / \mathrm{m}^{2}$ (measured)

$\mathrm{k}=1.85, \mathrm{c}=6.64 \mathrm{~m} / \mathrm{s}$

3.06 (forest)

0.235 (high wind shear)

0.110 (moderate)

April 22, 2004

July 13, 2006

Community Profile

Current Population: 2,370 (2005 State Demographer est.)

Pronunciation/Other Names: (DILL-eeng-ham); a.k.a. Curyung; Kanakanak

Incorporation Type: 1st Class City

Borough Located In: Unorganized

School District: Dillingham City Schools

Regional Native Corporation: Bristol Bay Native Corporation

\section{Location:}

Dillingham is located at the extreme northern end of Nushagak Bay in northern Bristol Bay, at the confluence of the Wood and Nushagak Rivers. It lies 327 miles southwest of Anchorage, and is a 6 hour flight from Seattle. It lies at approximately $59.039720^{\circ}$ North Latitude and $-158.457500^{\circ}$ West Longitude. (Sec. 21, T013S, R055W, Seward Meridian.) Dillingham is located in the Bristol Bay Recording District. The area encompasses 33.6 sq. miles of land and 2.1 sq. miles of water.

\section{History:}

The area around Dillingham was inhabited by both Eskimos and Athabascans and became a trade center when Russians erected the Alexandrovski Redoubt (Post) in 1818. Local Native groups and Natives from the Kuskokwim Region, the Alaska Peninsula and Cook Inlet mixed together as they came to visit or live at the post. The community was known as Nushagak by 1837, when a Russian Orthodox mission was established. In 1881 the U.S. Signal Corps established a meteorological station at Nushagak. In 1884 the first salmon cannery in the Bristol Bay region was constructed by Arctic Packing Co., east of the site of modern-day Dillingham. Ten more were established within the next seventeen years. The post office at Snag Point and town were named after U.S. Senator Paul Dillingham in 1904, who had toured Alaska extensively with his Senate subcommittee during 1903. The 1918-19 influenza epidemic struck the region, and left no more than 500 survivors. A hospital and orphanage were established in Kanakanak after the epidemic, 6 miles from the present-day City Center. The Dillingham townsite was first surveyed in 1947. The City was incorporated in 1963.

\section{Culture:}

Traditionally a Yup'ik Eskimo area, with Russian influences, Dillingham is now a highly mixed population 
of non-Natives and Natives. The outstanding commercial fishing opportunities in the Bristol Bay area are the focus of the local culture.

\section{Economy:}

Dillingham is the economic, transportation, and public service center for western Bristol Bay. Commercial fishing, fish processing, cold storage and support of the fishing industry are the primary activities. Icicle, Peter Pan, Trident and Unisea operate fish processing plants in Dillingham. Two hundred seventy-seven residents hold commercial fishing permits. During spring and summer, the population doubles. The city's role as the regional center for government and services helps to stabilize seasonal employment. Many residents depend on subsistence activities and trapping of beaver, otter, mink, lynx and fox provide cash income. Salmon, grayling, pike, moose, bear, caribou, and berries are harvested.

\section{Facilities:}

Around $90 \%$ of homes are fully plumbed. Dillingham's water is derived from three deep wells. Water is treated, stored in tanks (capacity is 1,250,000 gallons) and distributed. Approximately $40 \%$ of homes are served by the City's piped water system; $60 \%$ use individual wells. The core townsite is served by a piped sewage system; waste is treated in a sewage lagoon. However, the majority of residents (75\%) have septic systems. The City has requested funds to extend piped water to the old airstrip and Kenny Wren Road, and expand sewer service to the northeast. Dillingham Refuse Inc., a private firm, collects refuse three times a week. The Senior Center collects aluminum for recycling, and NAPA recycles used batteries. The Chamber of Commerce coordinates recycling of several materials, including fishing web. A new landfill site with a baling facility is currently being planned. Nushagak Electric owns and operates a diesel plant in Dillingham which also supplies power to Aleknagik.

\section{Transportation:}

Dillingham can be reached by air and sea. The State-owned airport provides a 6,404' long by 150' wide paved runway and Flight Service Station, and regular jet flights are available from Anchorage. A seaplane base is available 3 miles west at Shannon's Pond; it is owned by the U.S. Bureau of Land Management, Division of Lands. A heliport is available at Kanakanak Hospital. There is a City-operated small boat harbor with 320 slips, a dock, barge landing, boat launch, and boat haul-out facilities. It is a tidal harbor and only for seasonal use. Two barge lines make scheduled trips from Seattle. There is a 23-mile DOTmaintained gravel road to Aleknagik; it was first constructed in 1960.

\section{Climate:}

The primary climatic influence is maritime, however, the arctic climate of the Interior also affects the Bristol Bay coast. Average summer temperatures range from 37 to 66 degrees Fahrenheit. Average winter temperatures range from 4 to 30 degrees Fahrenheit. Annual precipitation is 26 inches, and annual snowfall is 65 inches. Heavy fog is common in July and August. Winds of up to 60-70 mph may occur between December and March. The Nushagak River is ice-free from June through November.

(Above information from State of Alaska Department of Commerce, Community, and Economic Development website, http://www.dced.state.ak.us/)

\section{Site Information and Location}

Site number

Site Description

Latitude/longitude

Site elevation

Datalogger type

Tower type
2255

Dillingham Woodriver Road, on State EMS tower

N 5903.700’ W $158^{\circ} 28.350^{\prime}$

38 meters

NRG Symphonie

State EMS communications tower 


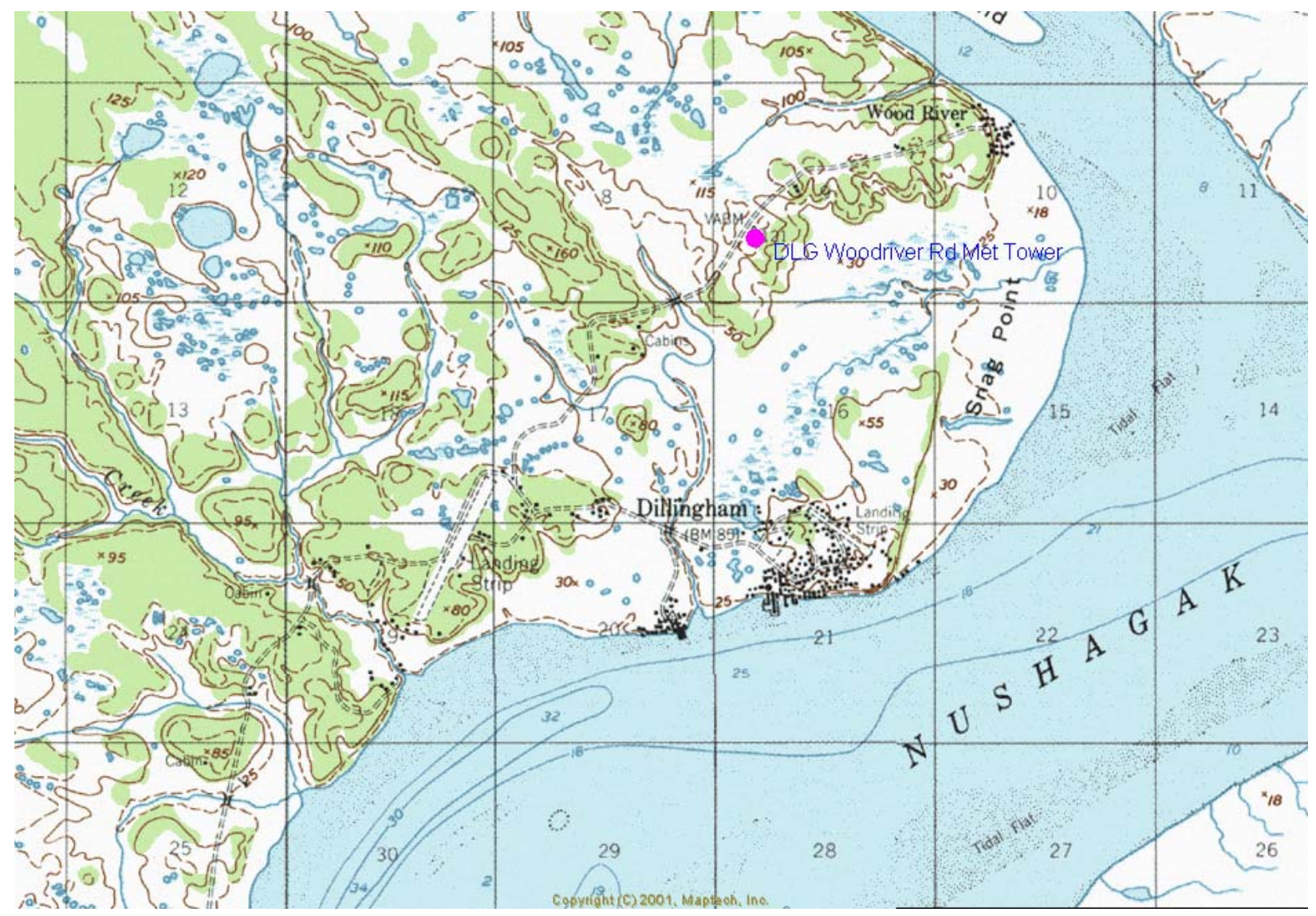

\section{Tower Sensor Information}

\begin{tabular}{clrrrc} 
Channel & Sensor type & Height & Multiplier & Offset & Orientation \\
\hline 1 & NRG \#40 anemometer & $33 \mathrm{~m}$ & 0.765 & 0.35 & East \\
2 & NRG \#40 anemometer & $19 \mathrm{~m}$ & 0.765 & 0.35 & Northwest \\
7 & NRG \#200P wind vane & $33 \mathrm{~m}$ & 0.351 & 172 & North \\
9 & NRG \#110S Temp C & $2 \mathrm{~m}$ & 0.136 & -86.383 & N/A
\end{tabular}




\section{Data Quality Control}

Data was filtered to remove presumed icing events that yield false zero wind speed data. Data that met the following criteria were filtered: wind speed $<1 \mathrm{~m} / \mathrm{s}$, wind speed standard deviation $=0$, and temperature $<3{ }^{\circ} \mathrm{C}$. Note that data recovery during the months of May through October was nearly $100 \%$, but during the months of November through April some data was filtered, with November being the most ice prone as far as data loss is concerned. Temperature data recovery was 100 percent, indicating full functioning of the temperature sensor. For this file, data was synthesized to replace data lost to icing events; all other analyses in this report are from the synthesized data set.

\begin{tabular}{|c|c|c|c|c|c|c|c|c|c|}
\hline \multirow[b]{2}{*}{ Year } & \multirow[b]{2}{*}{ Month } & \multicolumn{2}{|c|}{$33 \mathrm{~m}$ anemometer } & \multicolumn{2}{|c|}{$19 \mathrm{~m}$ anemometer } & \multicolumn{2}{|c|}{ Wind vane } & \multicolumn{2}{|c|}{ Temperature } \\
\hline & & Records & $\begin{array}{l}\text { Recovery } \\
\text { Rate (\%) }\end{array}$ & Records & $\begin{array}{l}\text { Recovery } \\
\text { Rate (\%) }\end{array}$ & Records & $\begin{array}{l}\text { Recovery } \\
\text { Rate (\%) }\end{array}$ & Records & $\begin{array}{l}\text { Recovery } \\
\text { Rate (\%) }\end{array}$ \\
\hline 2004 & Apr & 1,140 & 93.7 & 1,140 & 93.7 & 1,081 & 88.8 & 1,217 & 100 \\
\hline 2004 & May & 4,464 & 100 & 4,464 & 100 & 4,464 & 100 & 4,464 & 100 \\
\hline 2004 & Jun & 4,320 & 100 & 4,320 & 100 & 4,320 & 100 & 4,320 & 100 \\
\hline 2004 & Jul & 4,464 & 100 & 4,464 & 100 & 4,464 & 100 & 4,464 & 100 \\
\hline 2004 & Aug & 4,464 & 100 & 4,464 & 100 & 4,464 & 100 & 4,464 & 100 \\
\hline 2004 & Sep & 4,320 & 100 & 4,320 & 100 & 4,320 & 100 & 4,320 & 100 \\
\hline 2004 & Oct & 4,443 & 99.5 & 4,443 & 99.5 & 4,464 & 100 & 4,464 & 100 \\
\hline 2004 & Nov & 4,152 & 96.1 & 4,050 & 93.8 & 3,759 & 87.0 & 4,320 & 100 \\
\hline 2004 & Dec & 3,650 & 81.8 & 3,497 & 78.3 & 2,294 & 51.4 & 4,464 & 100 \\
\hline 2005 & Jan & 4,359 & 97.6 & 4,225 & 94.6 & 3,822 & 85.6 & 4,464 & 100 \\
\hline 2005 & Feb & 4,032 & 100 & 4,014 & 99.6 & 3,742 & 92.8 & 4,032 & 100 \\
\hline 2005 & Mar & 4,385 & 98.2 & 4,345 & 97.3 & 4,395 & 98.5 & 4,464 & 100 \\
\hline 2005 & Apr & 4,258 & 98.6 & 4,258 & 98.6 & 4,217 & 97.6 & 4,320 & 100 \\
\hline 2005 & May & 4,464 & 100 & 4,464 & 100 & 4,464 & 100 & 4,464 & 100 \\
\hline 2005 & Jun & 4,320 & 100 & 4,320 & 100 & 4,320 & 100 & 4,320 & 100 \\
\hline 2005 & Jul & 4,464 & 100 & 4,464 & 100 & 4,464 & 100 & 4,464 & 100 \\
\hline 2005 & Aug & 4,464 & 100 & 4,464 & 100 & 4,464 & 100 & 4,464 & 100 \\
\hline 2005 & Sep & 4,320 & 100 & 4,320 & 100 & 4,320 & 100 & 4,320 & 100 \\
\hline 2005 & Oct & 4,464 & 100 & 4,464 & 100 & 4,415 & 98.9 & 4,464 & 100 \\
\hline 2005 & Nov & 2,200 & 50.9 & 2,159 & 50.0 & 2,115 & 49.0 & 4,320 & 100 \\
\hline 2005 & Dec & 4,233 & 94.8 & 3,002 & 67.2 & 3,650 & 81.8 & 4,464 & 100 \\
\hline 2006 & Jan & 4,244 & 95.1 & 4,151 & 93.0 & 4,464 & 100 & 4,464 & 100 \\
\hline 2006 & Feb & 3,946 & 97.9 & 3,912 & 97.0 & 3,978 & 98.7 & 4,032 & 100 \\
\hline 2006 & Mar & 4,464 & 100 & 4,464 & 100 & 4,407 & 98.7 & 4,464 & 100 \\
\hline 2006 & Apr & 4,320 & 100 & 4,320 & 100 & 4,320 & 100 & 4,320 & 100 \\
\hline 2006 & May & 4,464 & 100 & 4,464 & 100 & 4,464 & 100 & 4,464 & 100 \\
\hline 2006 & Jun & 4,320 & 100 & 4,320 & 100 & 4,320 & 100 & 4,320 & 100 \\
\hline 2006 & Jul & 1,782 & 100 & 1,782 & 100 & 1,782 & 100 & 1,782 & 100 \\
\hline All data & & 112,920 & 96.6 & 111,074 & 95.0 & 109,753 & 93.9 & 116,903 & 100 \\
\hline
\end{tabular}


Dillingham, Alaska Woodriver Road Wind Resource Report

\section{Measured Wind Speeds}

The 33 meter (Channel 1) anemometer annual wind speed average for the reporting period is $5.90 \mathrm{~m} / \mathrm{s}$ and the 20 meter (Channel 2) anemometer wind speed average is $5.18 \mathrm{~m} / \mathrm{s}$.

\begin{tabular}{cccccccccc} 
& \multicolumn{9}{c}{$33 \mathrm{~m}$ speed } \\
Month & $\begin{array}{c}\text { Mean } \\
(\mathrm{m} / \mathrm{s})\end{array}$ & $\begin{array}{c}\text { Max } \\
(\mathrm{m} / \mathrm{s})\end{array}$ & $\begin{array}{c}\text { Std. } \\
\text { Dev. } \\
(\mathrm{m} / \mathrm{s})\end{array}$ & $\begin{array}{c}\text { Weibull } \\
\mathrm{k}\end{array}$ & $\begin{array}{c}\text { Weibull } \\
\mathrm{c} \\
(\mathrm{m} / \mathrm{s})\end{array}$ & $\begin{array}{c}\text { Mean } \\
(\mathrm{m} / \mathrm{s})\end{array}$ & $\begin{array}{c}\text { Max } \\
(\mathrm{m} / \mathrm{s})\end{array}$ & $\begin{array}{c}\text { Weibull } \\
\mathrm{k}\end{array}$ & $\begin{array}{c}\text { Weibull } \\
\mathrm{c} \\
(\mathrm{m} / \mathrm{s})\end{array}$ \\
\hline Jan & 7.23 & 19.5 & 3.916 & 1.869 & 8.107 & 6.29 & 17.6 & 1.682 & 6.995 \\
Feb & 7.25 & 24.8 & 4.023 & 1.886 & 8.174 & 6.17 & 22.8 & 1.891 & 6.950 \\
Mar & 6.44 & 18.2 & 3.411 & 1.947 & 7.249 & 5.54 & 16.3 & 1.925 & 6.223 \\
Apr & 5.71 & 25.1 & 3.103 & 1.919 & 6.435 & 5.06 & 19.7 & 1.918 & 5.690 \\
May & 5.22 & 17.5 & 2.698 & 1.993 & 5.874 & 4.59 & 15.9 & 1.990 & 5.166 \\
Jun & 5.21 & 19.3 & 2.699 & 2.015 & 5.879 & 4.56 & 16.1 & 1.995 & 5.132 \\
Jul & 4.88 & 13.5 & 2.242 & 2.287 & 5.492 & 4.33 & 12.2 & 2.321 & 4.866 \\
Aug & 4.82 & 21.7 & 2.577 & 1.944 & 5.431 & 4.33 & 20.3 & 1.929 & 4.881 \\
Sep & 5.58 & 16.1 & 2.908 & 1.999 & 6.290 & 5.03 & 14.7 & 2.065 & 5.665 \\
Oct & 5.84 & 18.4 & 3.199 & 1.874 & 6.559 & 5.27 & 17.3 & 1.935 & 5.943 \\
Nov & 6.78 & 24.9 & 3.961 & 1.709 & 7.559 & 5.89 & 21.6 & 1.742 & 6.597 \\
Dec & 6.92 & 19.3 & 3.511 & 2.007 & 7.763 & 6.03 & 16.6 & 1.962 & 6.754 \\
\hline Annual & $\mathbf{5 . 9 9}$ & 25.1 & 3.290 & 1.850 & 6.636 & $\mathbf{5 . 2 6}$ & 22.8 & 1.857 & 5.830
\end{tabular}

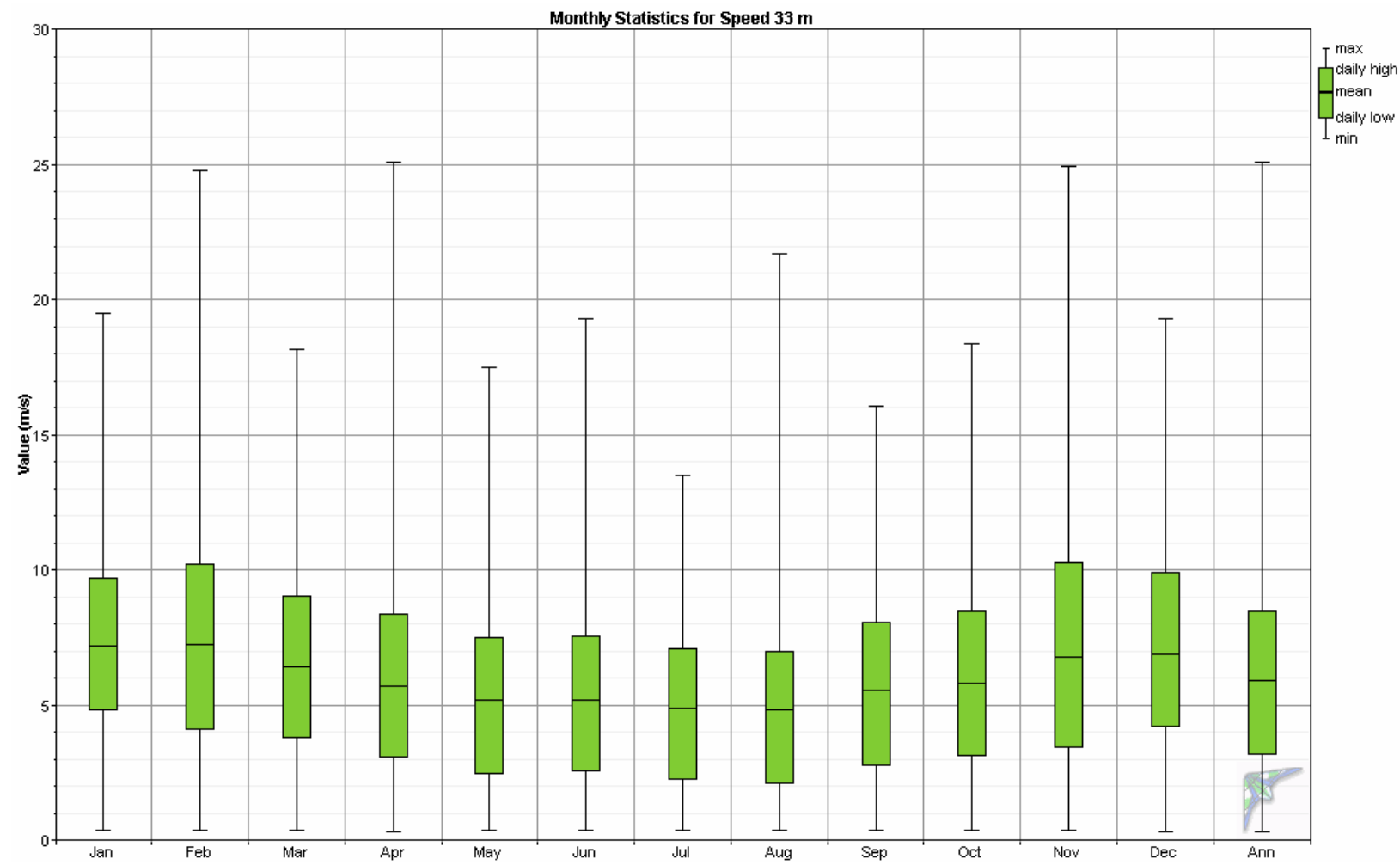

Daily Wind Profile 
The daily wind profile indicates that the lowest wind speeds of the day occur in the morning hours of 5 to 9 a.m. and the highest wind speeds of the day occur during the afternoon and evening hours of 2 to 6 p.m. The daily variation of wind speed is minimal on an annual basis but is more pronounced on a monthly basis.
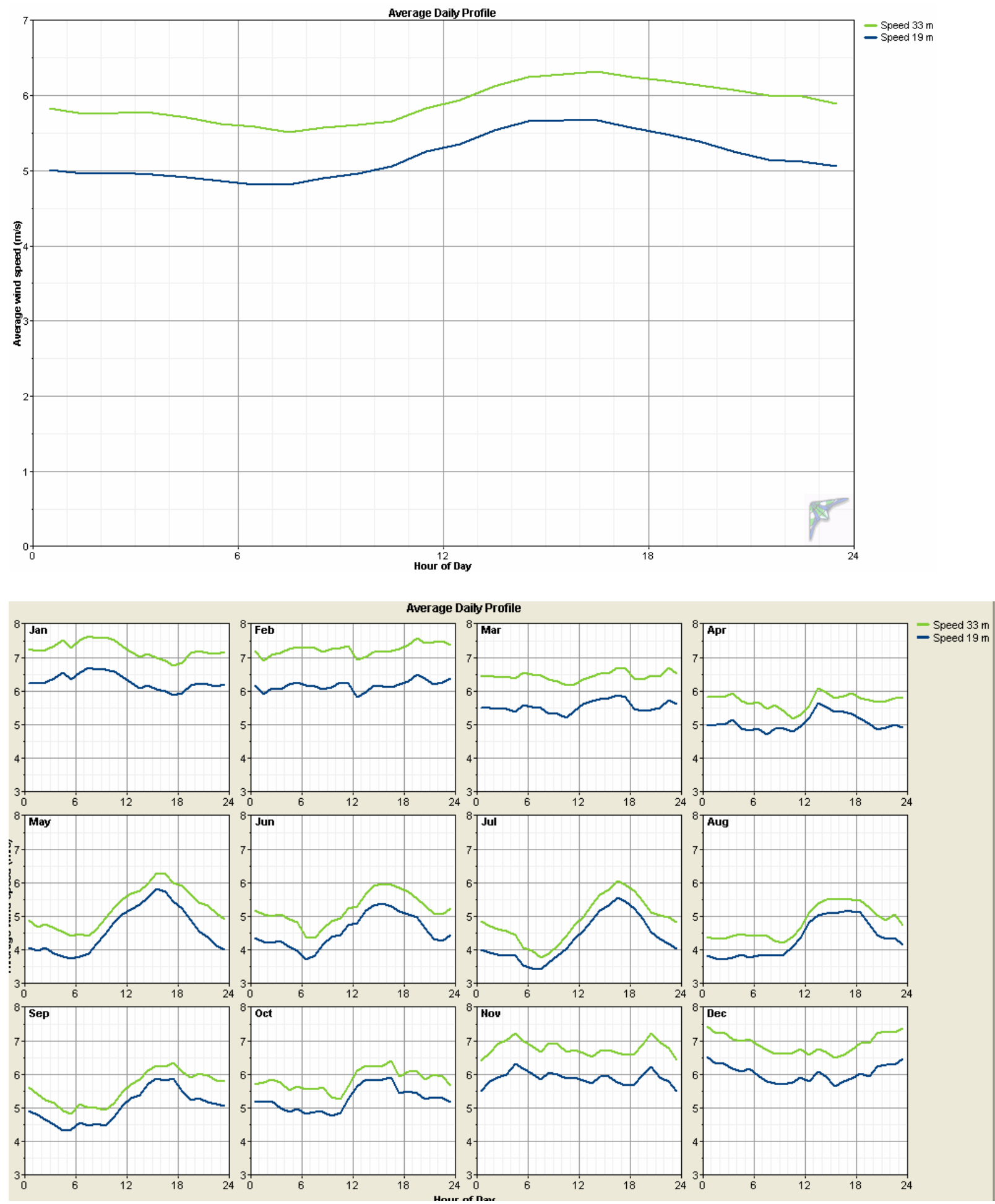


\section{Time Series of Wind Speed Averages}

As expected, the highest winds in Dillingham occur during the fall through spring months with relatively light winds during the summer months of May through August. The second graph indicates typical daily wind speed variation during winter months, while the third graph shows measured monthly wind speeds for the entire measurement period (data not combined).

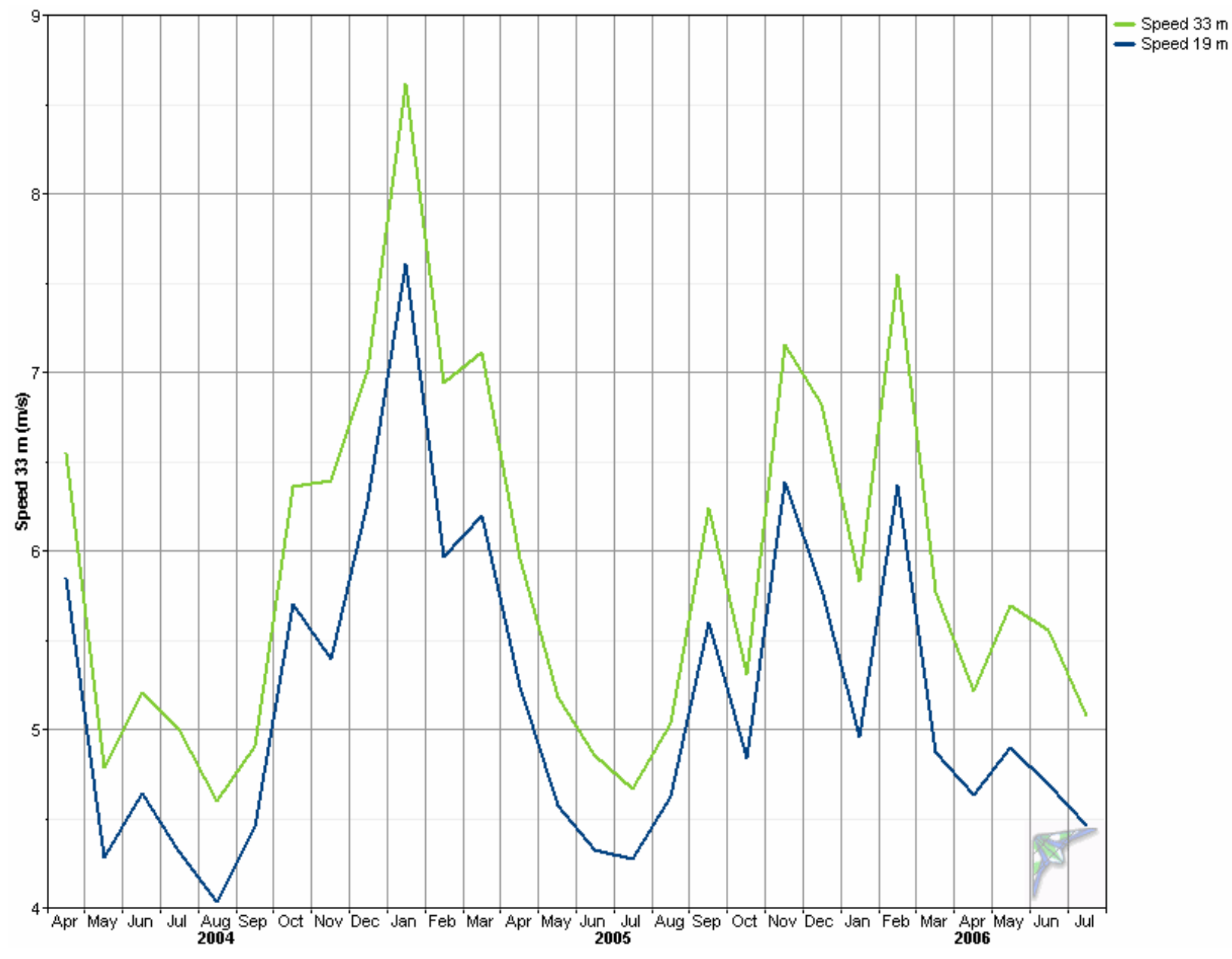




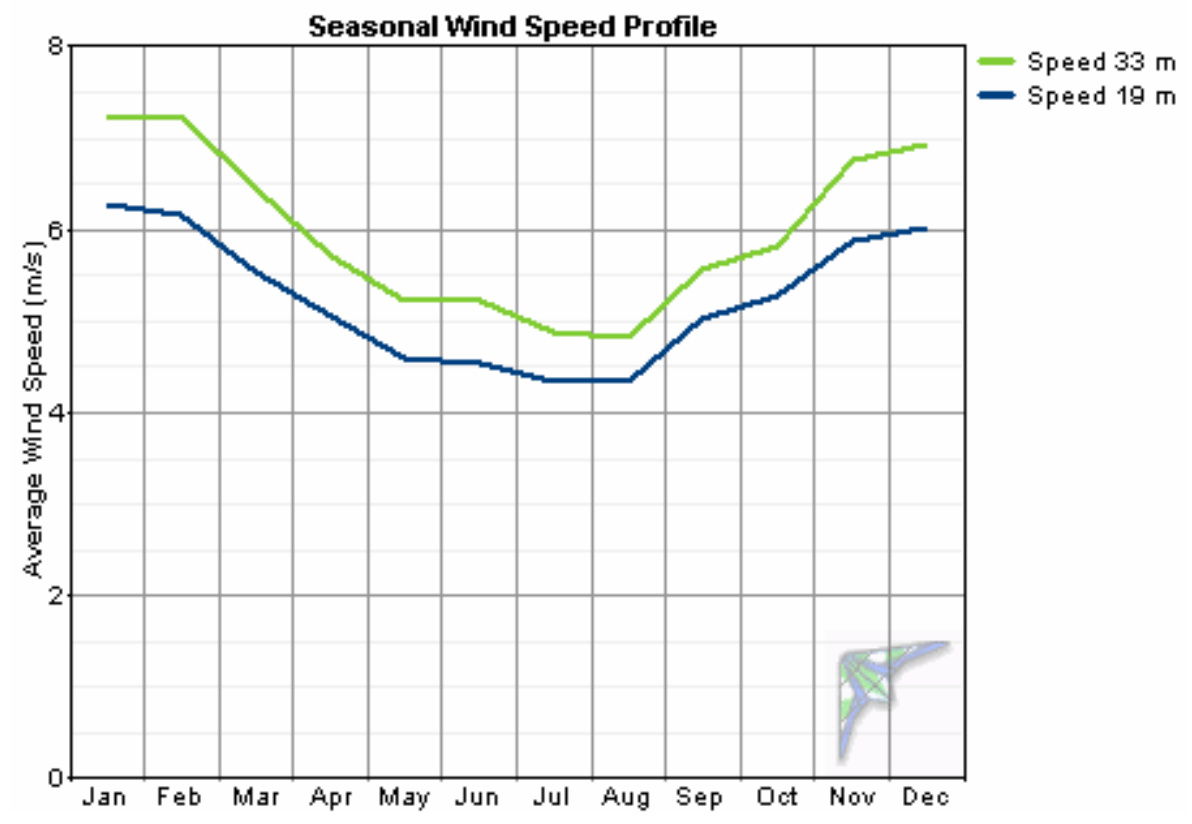

Long-term Data Comparison

The graph below of average annual wind speed for the nearby Dillingham airport indicates that 2004 and 2005 experienced possibly low average annual wind speeds when compared to data over the past thirty-two years, although in comparison to the past ten years, the 2004/05 wind speeds recorded at the airport were about average. The discrepancy between earlier data and the past ten years can be attributable to an ASOS equipment upgrade approximately ten years ago.

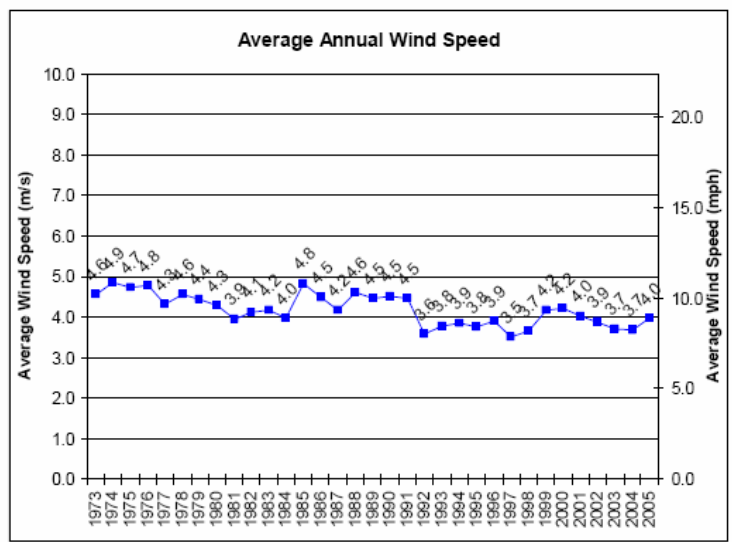




\section{Wind Shear Profile}

The power law exponent was calculated at 0.235 , indicating relatively high wind shear at the Dillingham test site. Wind shear however very likely negatively affected by the structure of the State EMS tower on which the sensors were placed. From certain wind directions, shading occurred which placed the 19 meter anemometer in a tower shadow compared to the higher anemometer. A meteorological tower, preferably 40 or more meters in height, would likely indicate less wind shear than indicated by this data. The practical application of relatively high wind shear is that a higher turbine tower height is desirable as there will be an appreciable marginal gain in wind speed/power recovery with additional height. A tower height/power recovery/construction cost tradeoff study is advisable. One caution is that wind speed and performance predictions with this particular data set may overestimate the wind resource at heights greater than 33 meters.
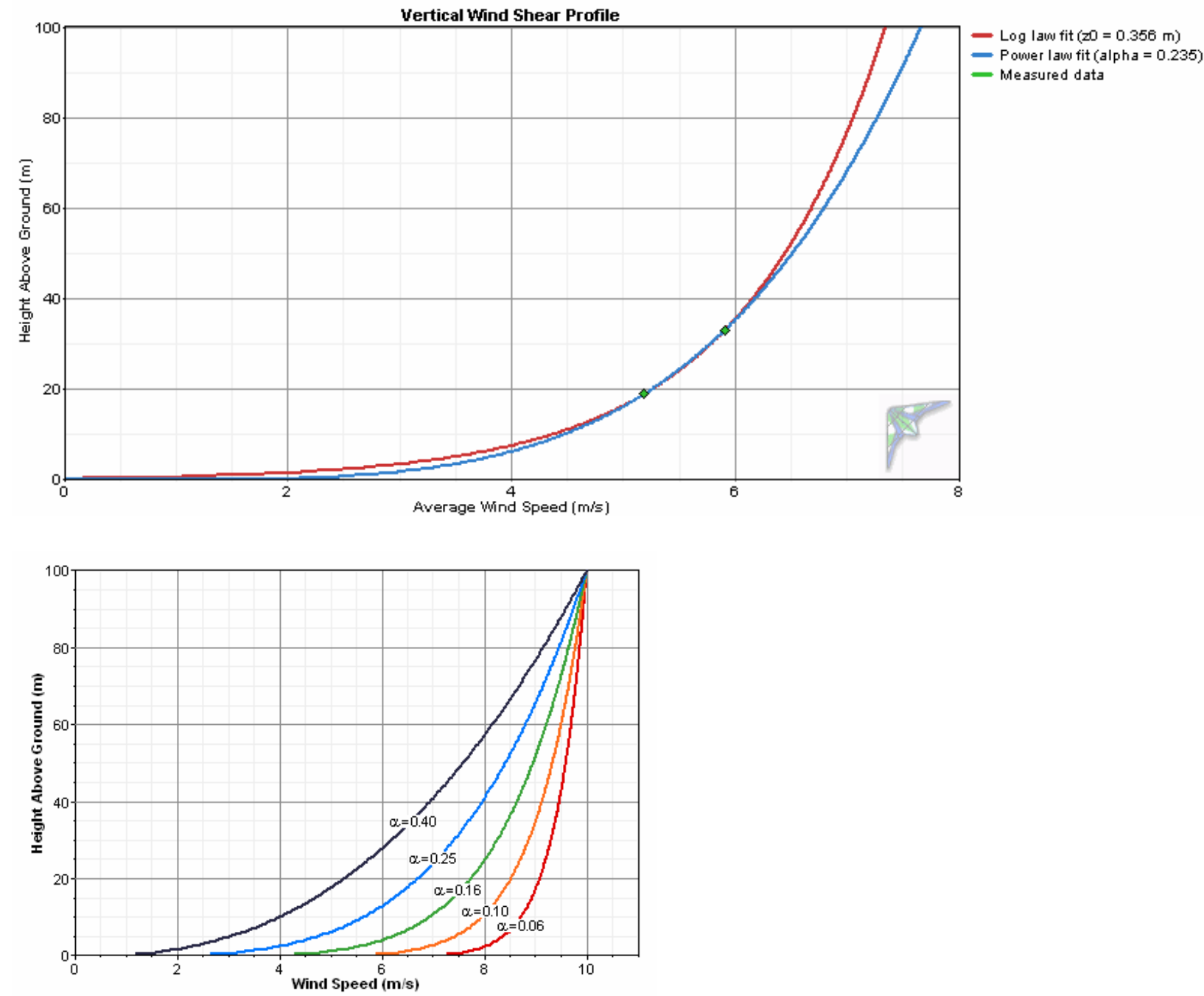
Dillingham, Alaska Woodriver Road Wind Resource Report
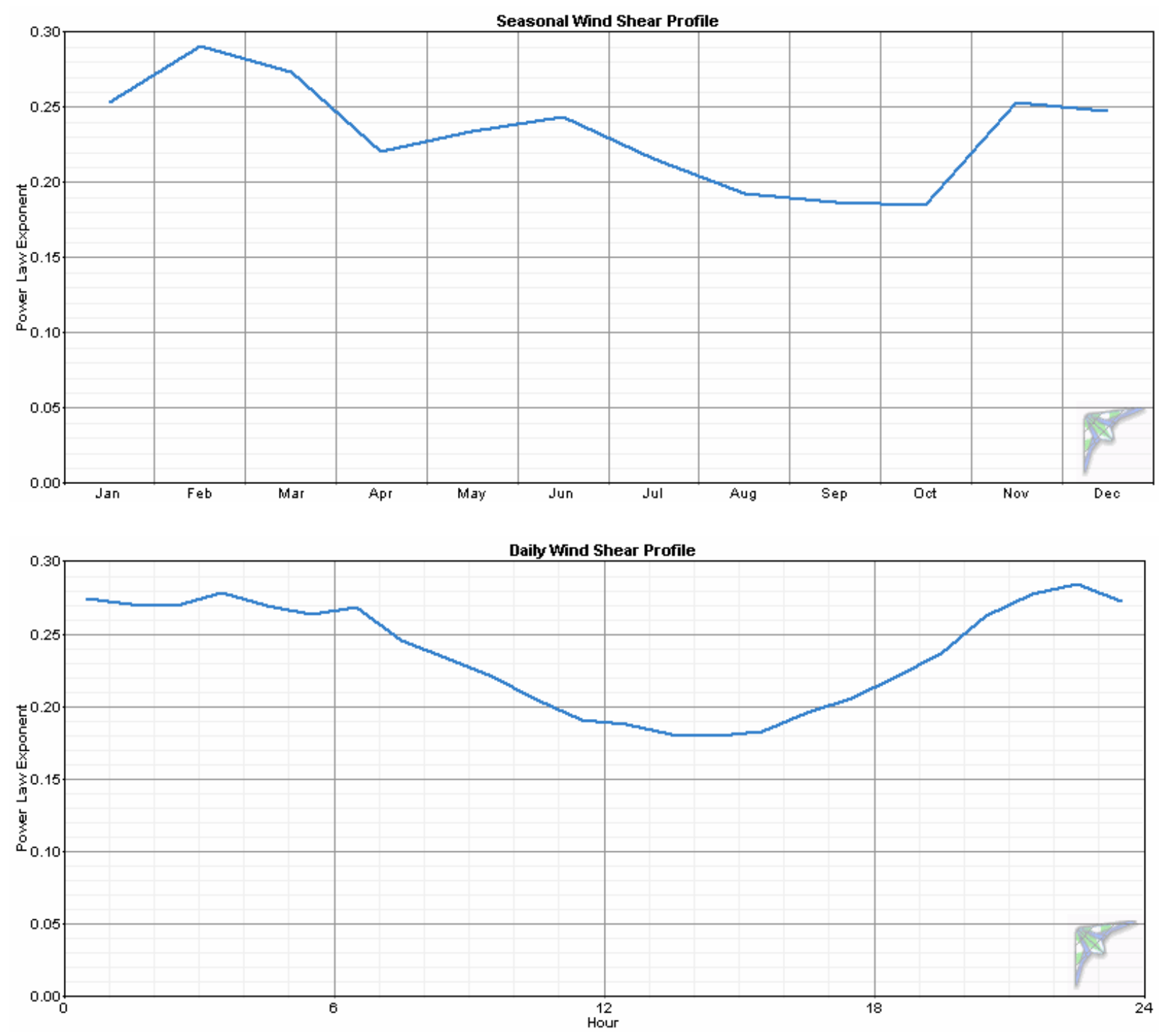


\section{Probability Distribution Function}

The probability distribution function provides a visual indication of measured wind speeds in one meter per second "bins". Note that most wind turbines do not begin to generate power until the wind speed at hub height reaches $4 \mathrm{~m} / \mathrm{s}$. The black line in the graph is a best fit Weibull distribution. At the 30 meter level, Weibull parameters are $\mathrm{k}=1.85$ (indicates a relatively low distribution of wind speeds) and $\mathrm{c}=6.64 \mathrm{~m} / \mathrm{s}$ (scale factor for the Weibull distribution). The PDF information is shown visually in another manner in the second graph, the Cumulative Distribution Function.
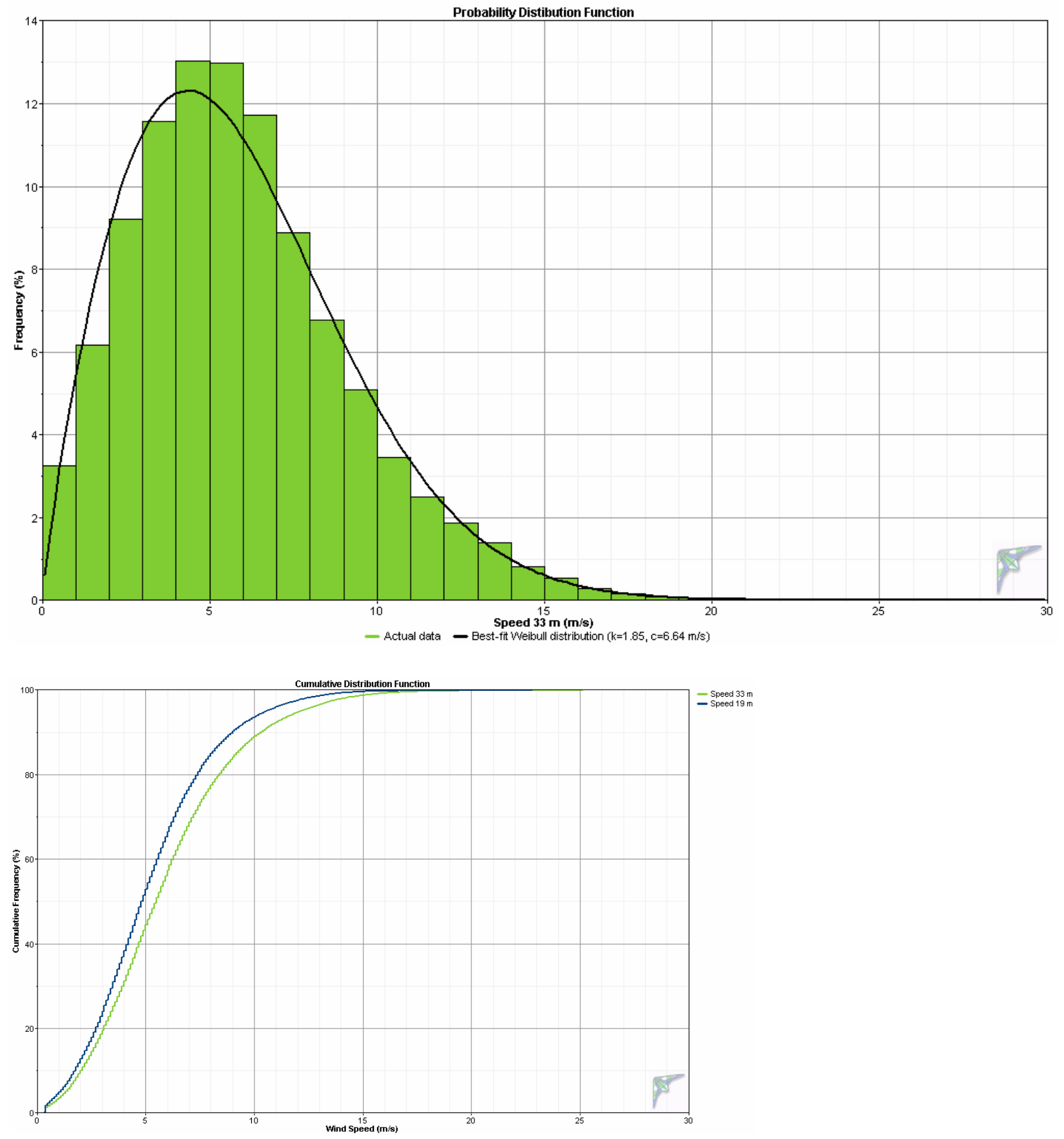


\section{Wind Roses}

Dillingham winds measured at Woodriver Road were directional, mostly from the north, but this may not be completely accurate as the wind vane faced north with a bulky tower structure behind it. The wind rose for at the Kanakanak test site several miles away indicated more variability in both the wind frequency and power density roses than observed at Woodriver Road. If a wind power project is planned at the Woodriver Road area in the future, it may be advisable to log wind direction again if multiple turbines are planned and site constraints require close placement; this will avoid excess tower shadow effects if there is more wind direction variability than these wind roses indicate. The indication below of 31 percent calm winds is calculated with a $4 \mathrm{~m} / \mathrm{s}$ wind speed threshold, the typical cut-in speed of wind turbines.

Wind Frequency Rose (33 meters)

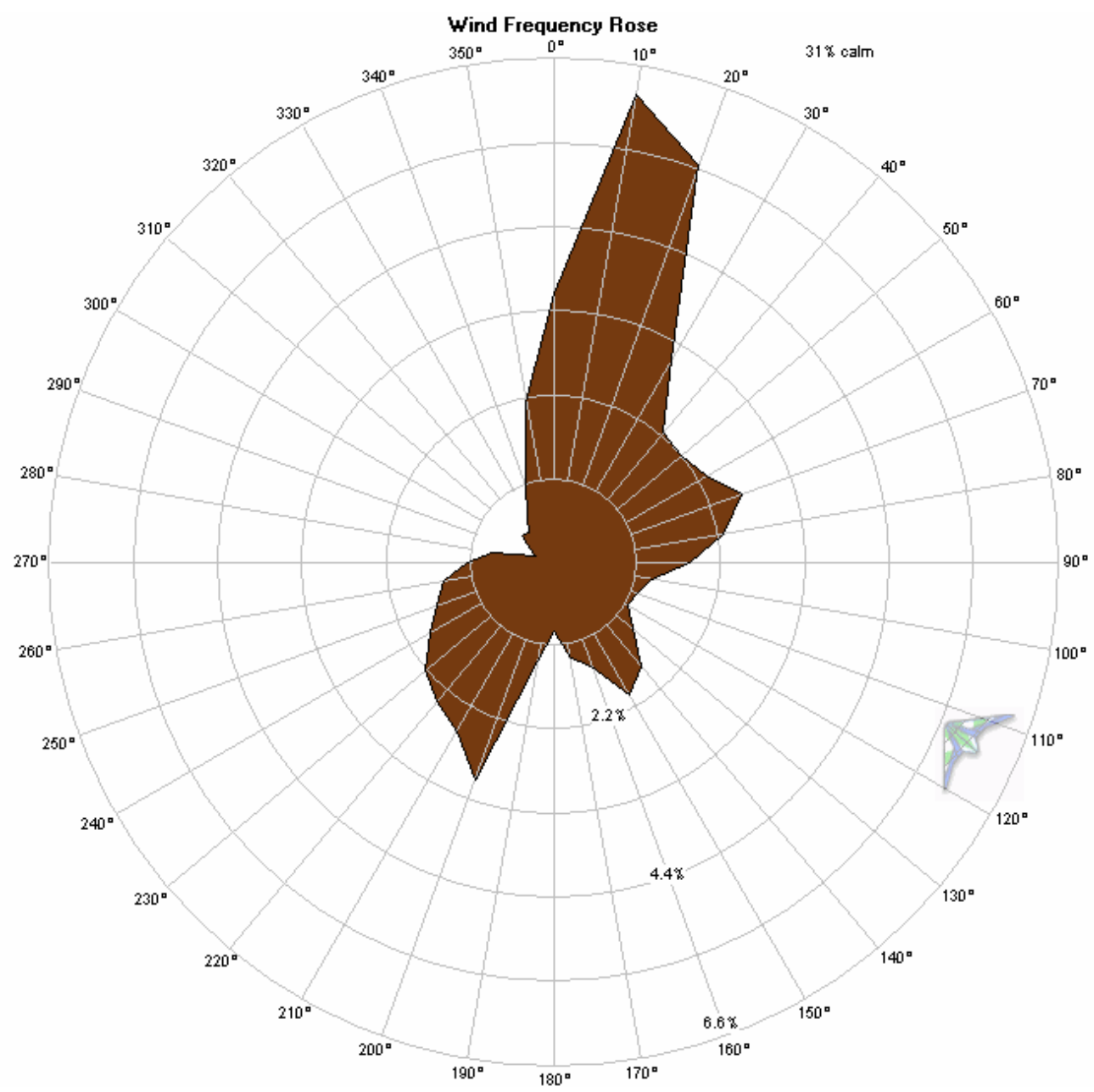


Dillingham, Alaska Woodriver Road Wind Resource Report

Wind Power Density Rose (33 meters)

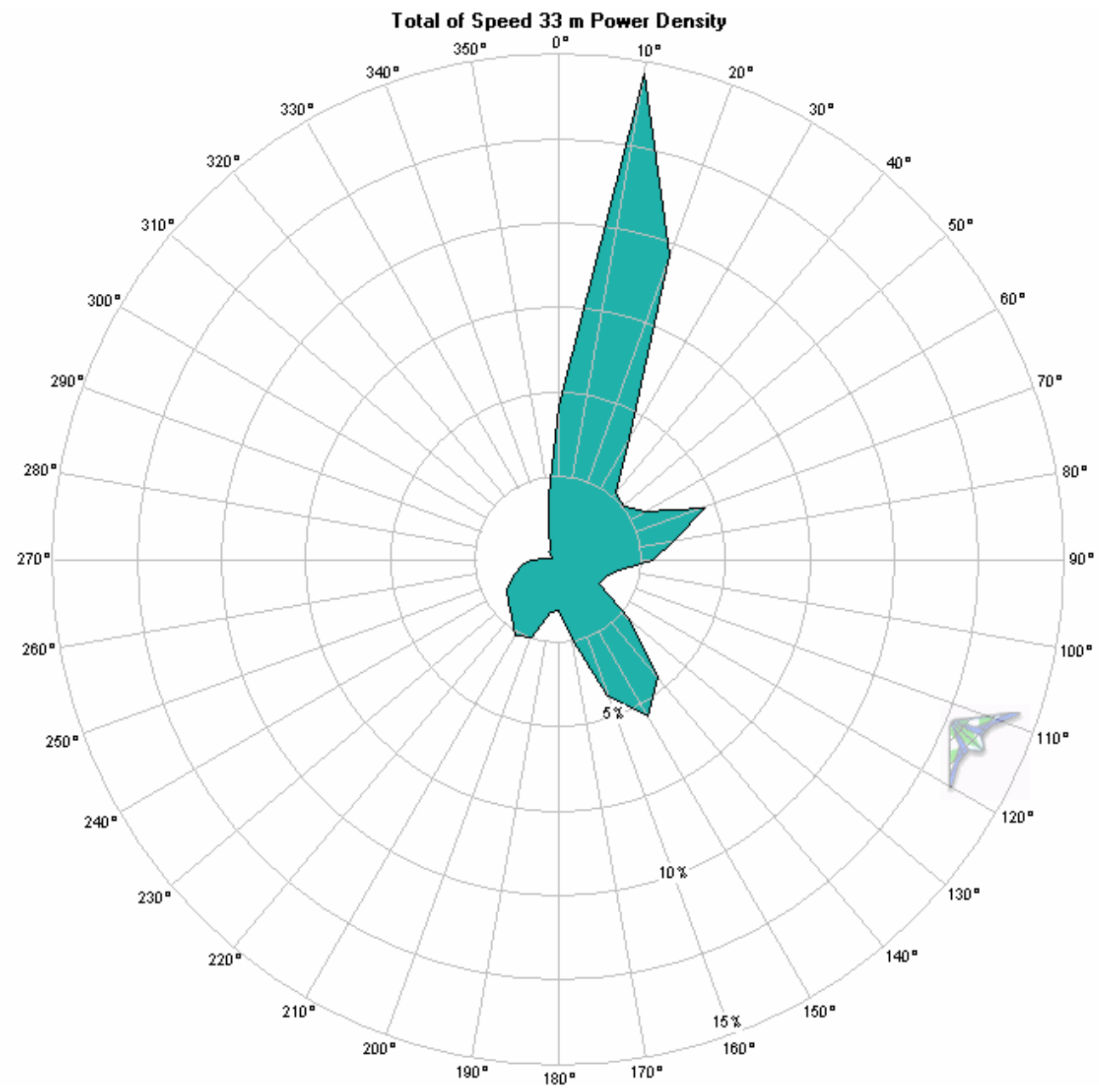

Wind Power Density Rose by Month (33 meters)

Note: scale is common

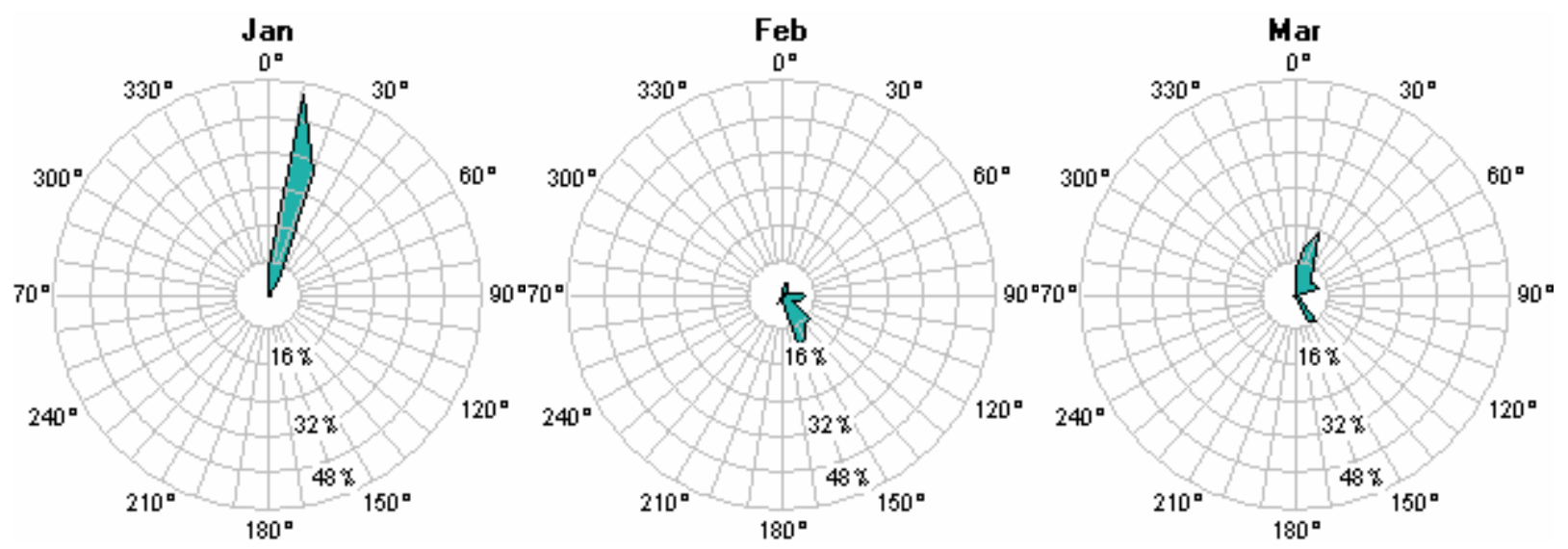


Dillingham, Alaska Woodriver Road Wind Resource Report

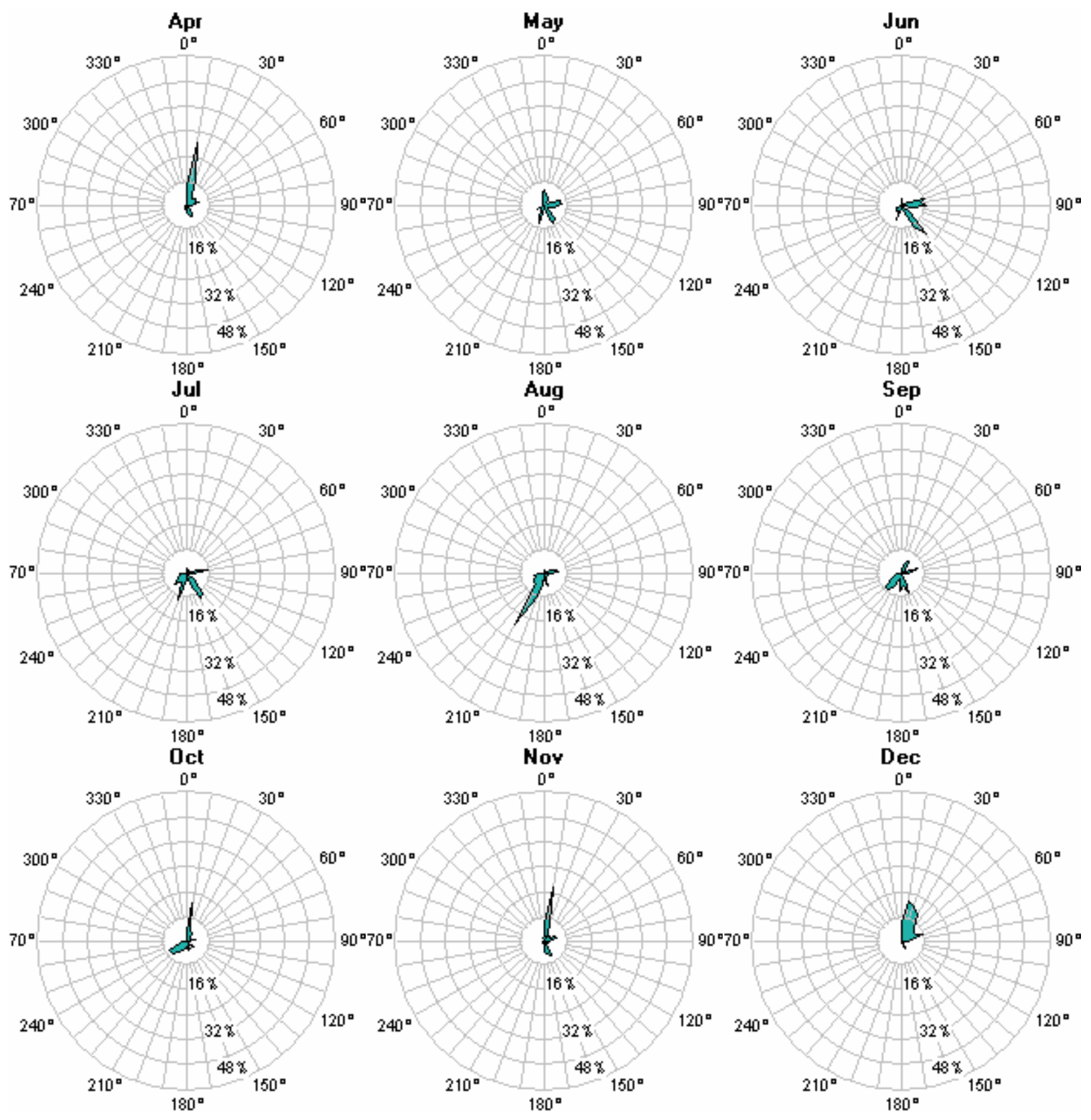




\section{Turbulence Intensity}

The turbulence intensity (TI) is acceptable for all wind direction, with a mean turbulence intensity at 33 meters of 0.110 (Channel 1) and at 19 meters of 0.128 (Channel 2), indicating moderately smooth air. The higher turbulence intensity to the southeast in the second TI rose below is because the 19 meter anemometer faced to the northwest. Southeast winds blew through the lattice structure of the tower, creating abnormally turbulent air. These TIs are calculated with a threshold wind speed of $4 \mathrm{~m} / \mathrm{s}$.

Turbulence Intensity Rose - 33 meters

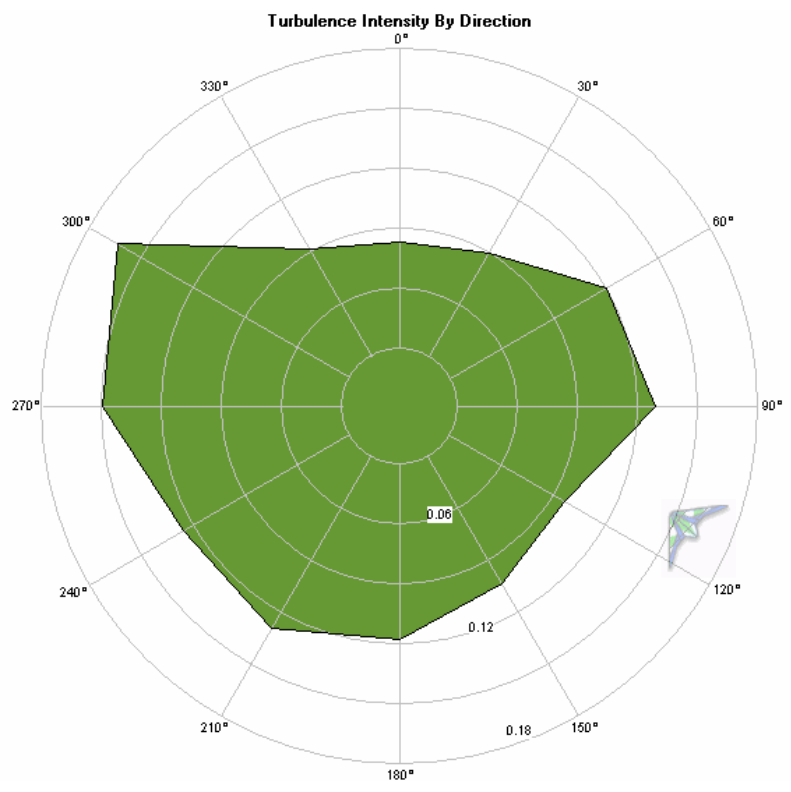

Turbulence Intensity Rose - 19 meters

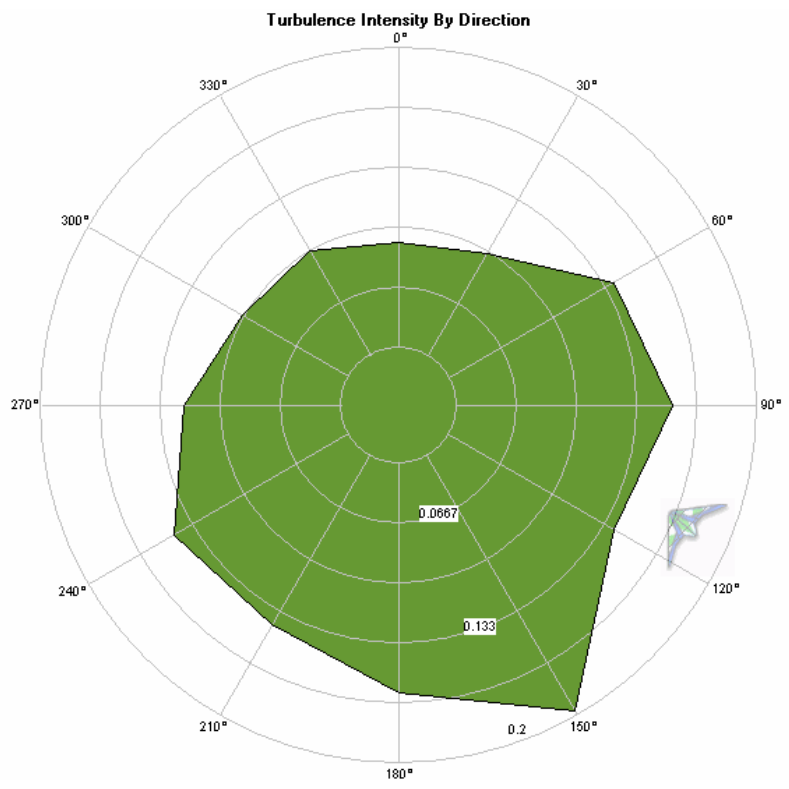




\section{IEC Turbulence Intensity Standards}

Turbulence at the Dillingham Woodriver met tower test site is within International Electrotechnical Commission (IEC) standards at all measured wind speeds and from all four quadrants of the wind rose (except for IEC Category B at higher wind speeds in $315^{\circ}$ to $45^{\circ}$ sector (this sector experiences infrequent winds, so this is a minimal concern).
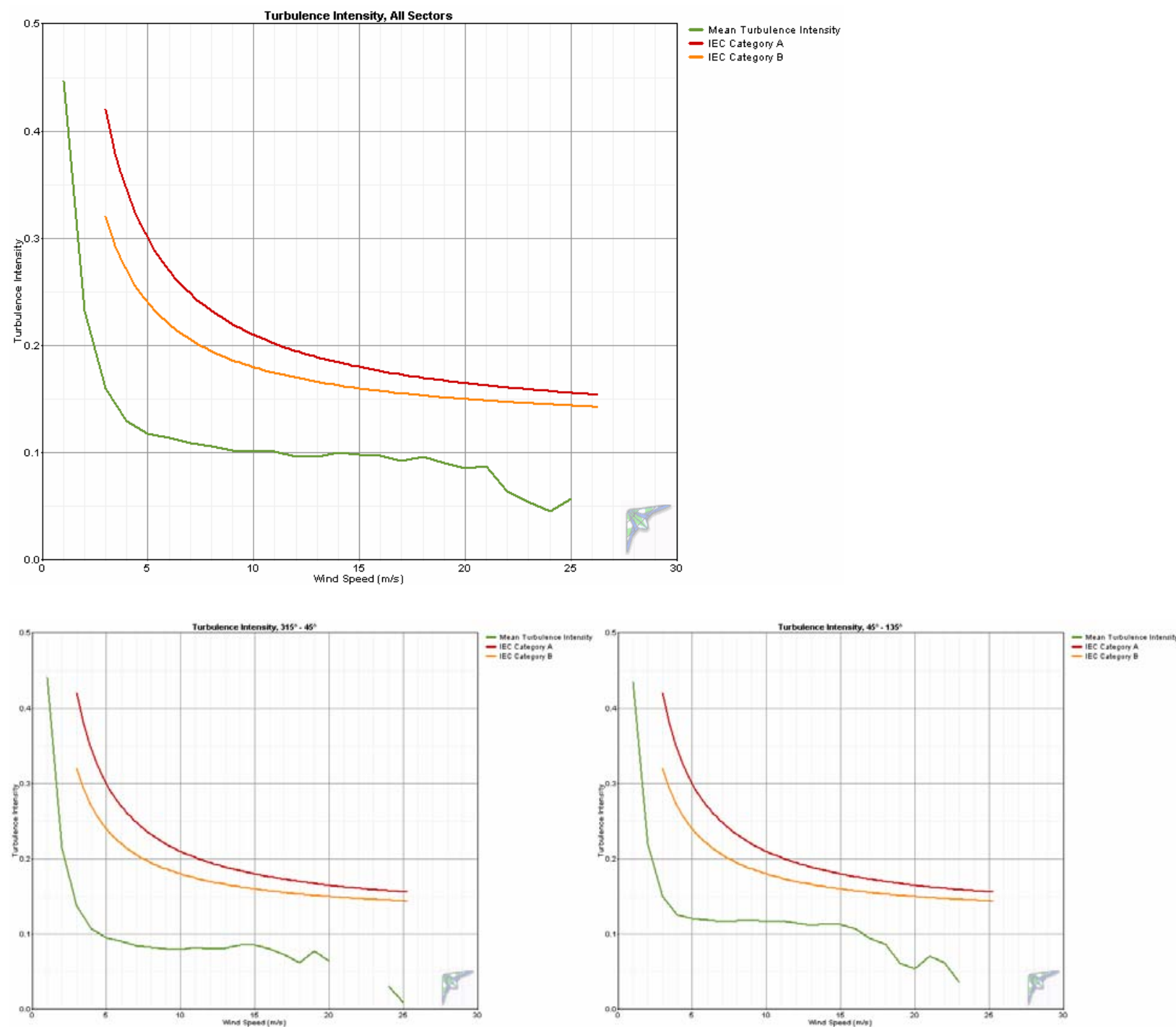
Dillingham, Alaska Woodriver Road Wind Resource Report
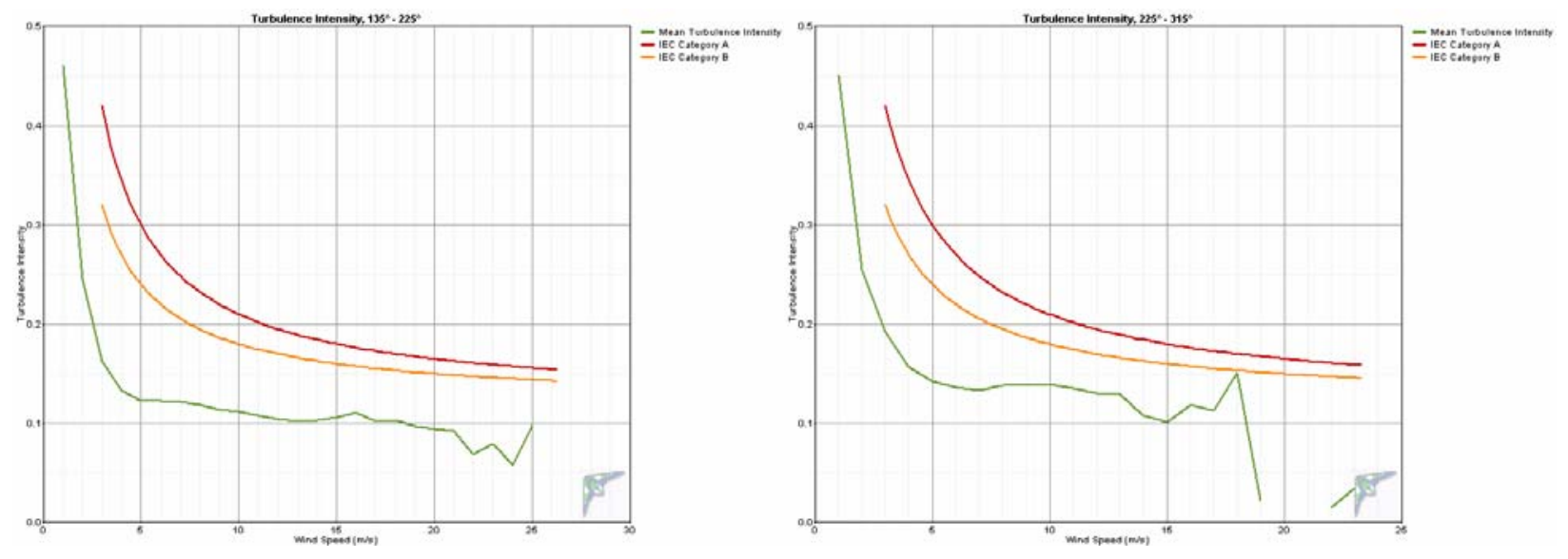

Turbulence Table

33 meter anemometer, 4/22/04 to 7/13/06, threshold $4 \mathrm{~m} / \mathrm{s}$

\begin{tabular}{|c|c|c|c|c|c|c|c|}
\hline $\begin{array}{c}\text { Bin } \\
\text { Midpoint } \\
(\mathrm{m} / \mathrm{s})\end{array}$ & $\begin{array}{l}\text { Bin En } \\
\text { Lower } \\
(\mathrm{m} / \mathrm{s})\end{array}$ & $\begin{array}{l}\text { points } \\
\text { Upper } \\
(\mathrm{m} / \mathrm{s})\end{array}$ & $\begin{array}{l}\text { Records } \\
\text { In } \\
\text { Bin }\end{array}$ & $\begin{array}{c}\text { Standard } \\
\text { Deviation } \\
\text { of Wind Speed } \\
(\mathrm{m} / \mathrm{s})\end{array}$ & $\begin{array}{c}\text { Mean } \\
\text { Turbulence } \\
\text { Intensity }\end{array}$ & $\begin{array}{l}\text { Standard } \\
\text { Deviation } \\
\text { of Turbulence } \\
\text { Intensity }\end{array}$ & $\begin{array}{c}\text { Characteristic } \\
\text { Turbulence } \\
\text { Intensity }\end{array}$ \\
\hline 1 & 0.5 & 1.5 & 5127 & 0.421 & 0.446 & 0.183 & 0.629 \\
\hline 2 & 1.5 & 2.5 & 9286 & 0.453 & 0.233 & 0.117 & 0.350 \\
\hline 3 & 2.5 & 3.5 & 12374 & 0.473 & 0.160 & 0.079 & 0.239 \\
\hline 4 & 3.5 & 4.5 & 14497 & 0.514 & 0.130 & 0.061 & 0.191 \\
\hline 5 & 4.5 & 5.5 & 15299 & 0.585 & 0.118 & 0.053 & 0.171 \\
\hline 6 & 5.5 & 6.5 & 14781 & 0.677 & 0.114 & 0.046 & 0.160 \\
\hline 7 & 6.5 & 7.5 & 12119 & 0.754 & 0.109 & 0.042 & 0.150 \\
\hline 8 & 7.5 & 8.5 & 8988 & 0.842 & 0.106 & 0.038 & 0.144 \\
\hline 9 & 8.5 & 9.5 & 6895 & 0.916 & 0.103 & 0.038 & 0.140 \\
\hline 10 & 9.5 & 10.5 & 4969 & 1.002 & 0.101 & 0.036 & 0.137 \\
\hline 11 & 10.5 & 11.5 & 3423 & 1.108 & 0.101 & 0.032 & 0.134 \\
\hline 12 & 11.5 & 12.5 & 2512 & 1.155 & 0.097 & 0.032 & 0.129 \\
\hline 13 & 12.5 & 13.5 & 1929 & 1.252 & 0.097 & 0.032 & 0.129 \\
\hline 14 & 13.5 & 14.5 & 1250 & 1.394 & 0.100 & 0.031 & 0.131 \\
\hline 15 & 14.5 & 15.5 & 767 & 1.474 & 0.099 & 0.030 & 0.129 \\
\hline 16 & 15.5 & 16.5 & 467 & 1.546 & 0.097 & 0.032 & 0.129 \\
\hline 17 & 16.5 & 17.5 & 278 & 1.565 & 0.092 & 0.031 & 0.123 \\
\hline 18 & 17.5 & 18.5 & 119 & 1.724 & 0.097 & 0.038 & 0.134 \\
\hline 19 & 18.5 & 19.5 & 92 & 1.712 & 0.090 & 0.035 & 0.125 \\
\hline 20 & 19.5 & 20.5 & 79 & 1.702 & 0.085 & 0.031 & 0.117 \\
\hline 21 & 20.5 & 21.5 & 57 & 1.839 & 0.088 & 0.034 & 0.122 \\
\hline 22 & 21.5 & 22.5 & 38 & 1.408 & 0.064 & 0.037 & 0.102 \\
\hline 23 & 22.5 & 23.5 & 14 & 1.240 & 0.054 & 0.035 & 0.090 \\
\hline 24 & 23.5 & 24.5 & 9 & 1.090 & 0.046 & 0.033 & 0.079 \\
\hline 25 & 24.5 & 25.5 & 4 & 1.430 & 0.057 & 0.048 & 0.105 \\
\hline 26 & 25.5 & 26.5 & 0 & 1.430 & 0.057 & 0.048 & 0.105 \\
\hline
\end{tabular}




\section{Air Temperature and Density}

Over the reporting period, Dillingham Woodriver had an average temperature of $2.1^{\circ} \mathrm{C}$. The minimum recorded temperature during the measurement period was $-33.2^{\circ} \mathrm{C}$ and the maximum temperature was $28.2^{\circ} \mathrm{C}$, indicating a wide variability of an ambient temperature operating environment important to wind turbine operations. Consequent to Dillingham's cool temperatures, the average air density of $1.278 \mathrm{~kg} / \mathrm{m}^{3}$ is approximately five percent higher than the standard air density of $1.221 \mathrm{~kg} / \mathrm{m}^{3}$ (at $14.7^{\circ} \mathrm{C}$ temperature and $100.84 \mathrm{kPa}$ pressure at 38 meters elevation), indicating that Dillingham, due to its cool annual temperature average, has denser air than standard. This density variance from standard is accounted for in turbine performance predictions in this report.

\begin{tabular}{crrrrrrr} 
& \multicolumn{3}{c}{ Temperature } & \multicolumn{3}{c}{ Air Density } \\
Month & $\begin{array}{c}\text { Mean } \\
\left({ }^{\circ} \mathrm{C}\right)\end{array}$ & \multicolumn{1}{c}{$\begin{array}{c}\text { Min } \\
\left({ }^{\circ} \mathrm{C}\right)\end{array}$} & $\begin{array}{c}\text { Max } \\
\left({ }^{\circ} \mathrm{C}\right)\end{array}$ & $\begin{array}{c}\text { Std. } \\
\text { Dev. } \\
\left({ }^{\circ} \mathrm{C}\right)\end{array}$ & $\begin{array}{c}\text { Mean } \\
\left(\mathrm{kg} / \mathrm{m}^{3}\right)\end{array}$ & $\begin{array}{c}\text { Min } \\
\left(\mathrm{kg} / \mathrm{m}^{3}\right)\end{array}$ & $\begin{array}{c}\text { Max } \\
\left(\mathrm{kg} / \mathrm{m}^{3}\right)\end{array}$ \\
\hline Jan & -11.1 & -33.2 & 3.1 & 8.43 & 1.342 & 1.272 & 1.464 \\
Feb & -5.9 & -33.2 & 4.8 & 8.54 & 1.316 & 1.264 & 1.464 \\
Mar & -5.4 & -26.9 & 7.0 & 5.98 & 1.313 & 1.254 & 1.427 \\
Apr & -0.5 & -20.0 & 18.1 & 5.89 & 1.289 & 1.206 & 1.388 \\
May & 7.8 & -3.7 & 26.1 & 4.93 & 1.251 & 1.174 & 1.304 \\
Jun & 11.9 & -0.4 & 28.2 & 4.47 & 1.233 & 1.166 & 1.288 \\
Jul & 14.8 & 5.3 & 27.3 & 4.02 & 1.220 & 1.169 & 1.262 \\
Aug & 14.5 & 3.9 & 26.8 & 3.98 & 1.222 & 1.171 & 1.268 \\
Sep & 8.2 & -1.7 & 18.5 & 3.62 & 1.249 & 1.205 & 1.294 \\
Oct & 2.5 & -12.1 & 12.7 & 4.38 & 1.275 & 1.229 & 1.346 \\
Nov & -6.7 & -27.8 & 4.2 & 7.22 & 1.319 & 1.267 & 1.432 \\
Dec & -5.1 & -27.3 & 3.7 & 6.47 & 1.312 & 1.269 & 1.429 \\
\hline Annual & $\mathbf{2 . 1}$ & -33.2 & 28.2 & 10.41 & $\mathbf{1 . 2 7 8}$ & 1.166 & 1.464
\end{tabular}

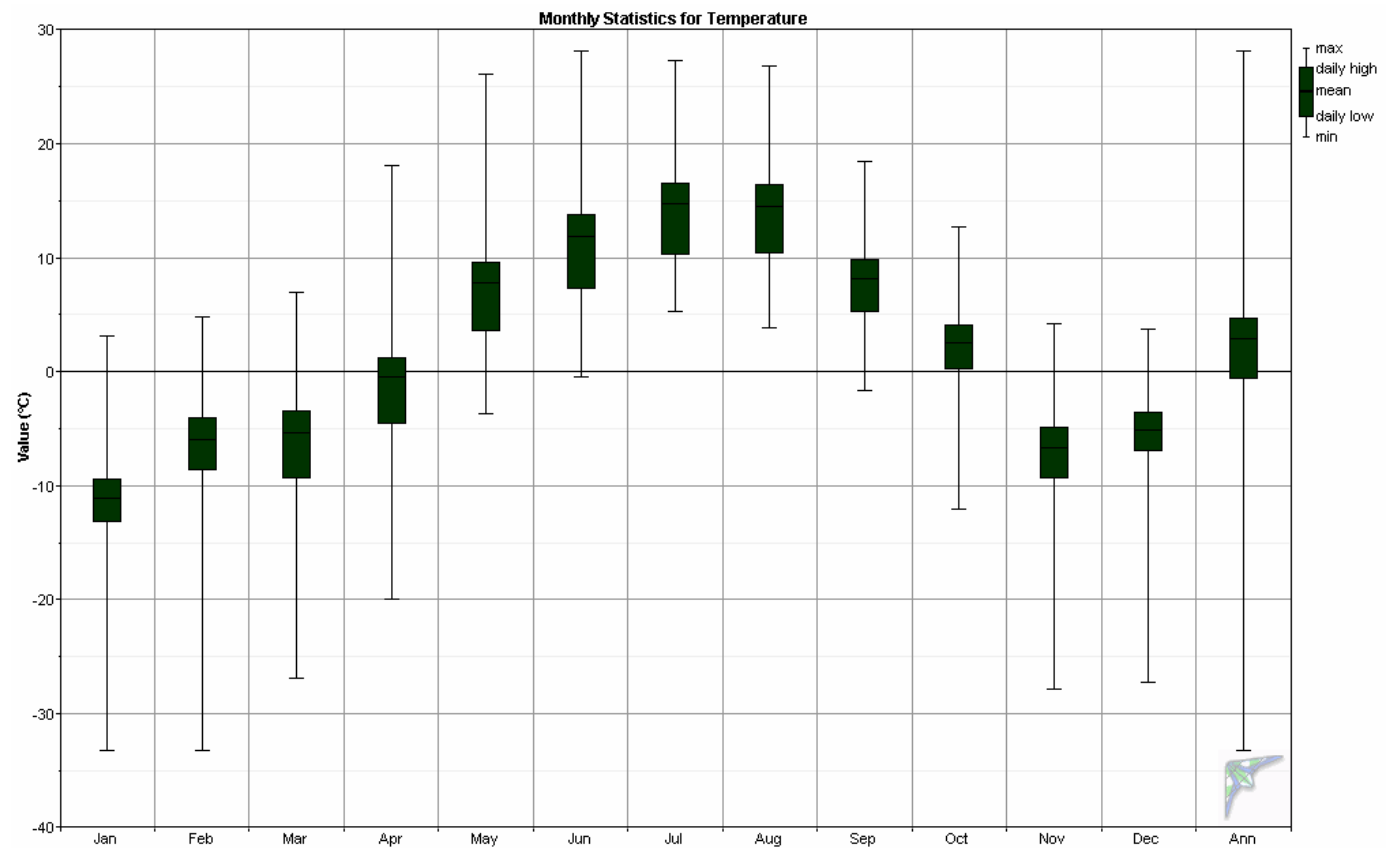




\section{Air Density DMap}

The DMap below is a visual indication of the daily and seasonal variations of air density (and hence temperature). Air densities higher than standard will yield higher turbine power than predicted by the turbine power curve, while densities lower than standard will yield lower turbine power than predicted. Density variance from standard is accounted for in the turbine performance predictions.

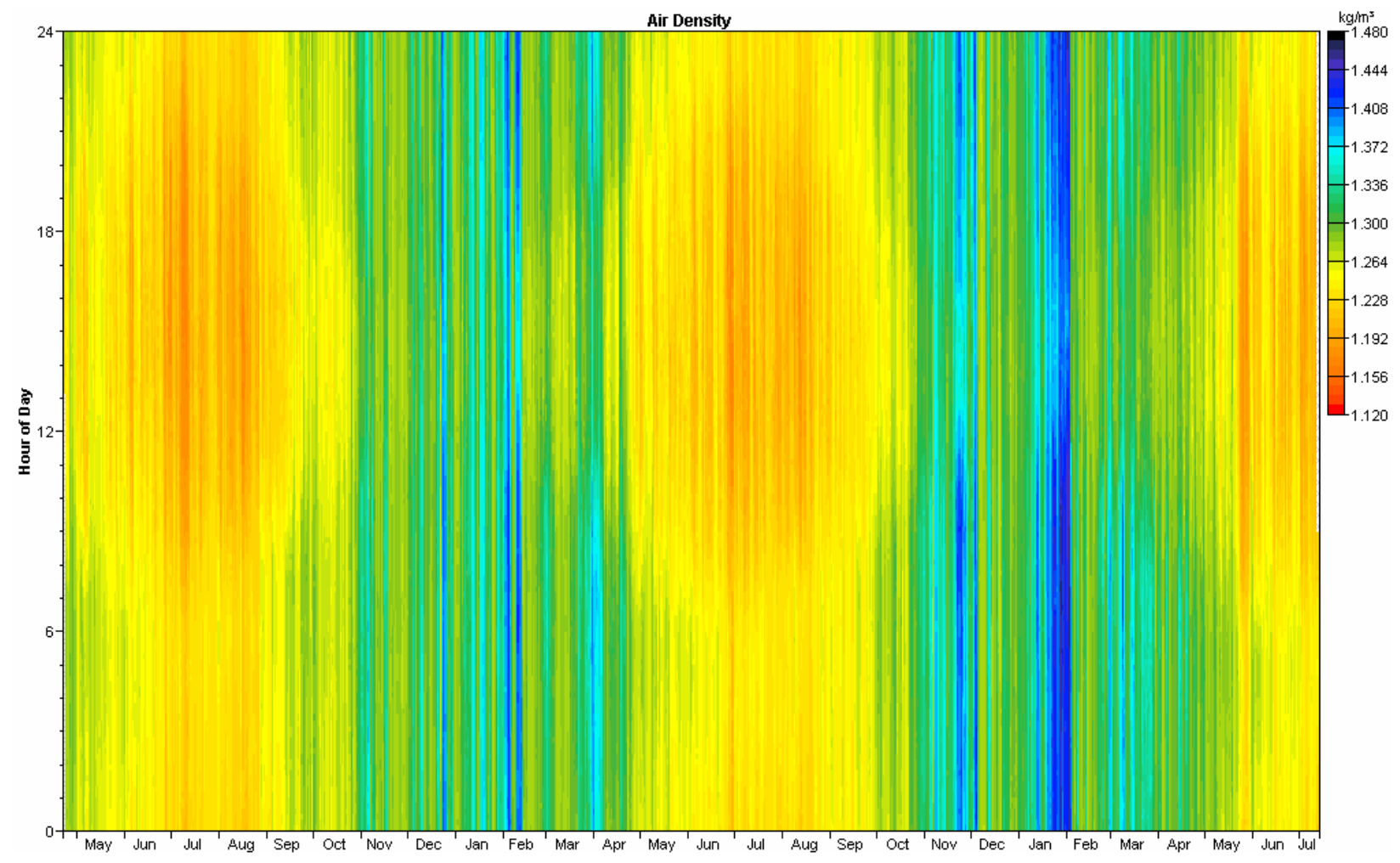




\section{Turbine Performance Predictions}

The turbine performance predictions noted below are based on 100 percent and 90 percent turbine availabilities. The 100 percent data is for use as a baseline of comparison, but it is realistic to expect ten percent losses or downtime for wind turbines, at least during the first year of operation.

Note that these performance estimates were predicted with use of Windographer ${ }^{\circledR}$ wind analysis software; power curves provided by manufacturers are not independently verified and are assumed to be accurate. The power curves are presented for a standard air density of $1.225 \mathrm{~kg} / \mathrm{m}^{3}$ at sea level and $15^{\circ} \mathrm{C}$. However, the predictions of power production are density compensated by multiplying the standard density power output by the ratio of the measured air density to standard air density, accounting for the site elevation.

A number of small to medium turbines are profiled in this report for comparison purposes. These turbines were selected because they have market availability and they are deemed to be within a suitable range for consideration of wind power development in a community the size of Naknek.

Bergey Excel-S: $10 \mathrm{~kW}$ rated power output, 6.7 meter rotor diameter, stall-controlled. Available tower heights: 18, 24, 30, 37 and 43 meters. Additional information is available at www.bergey.com.
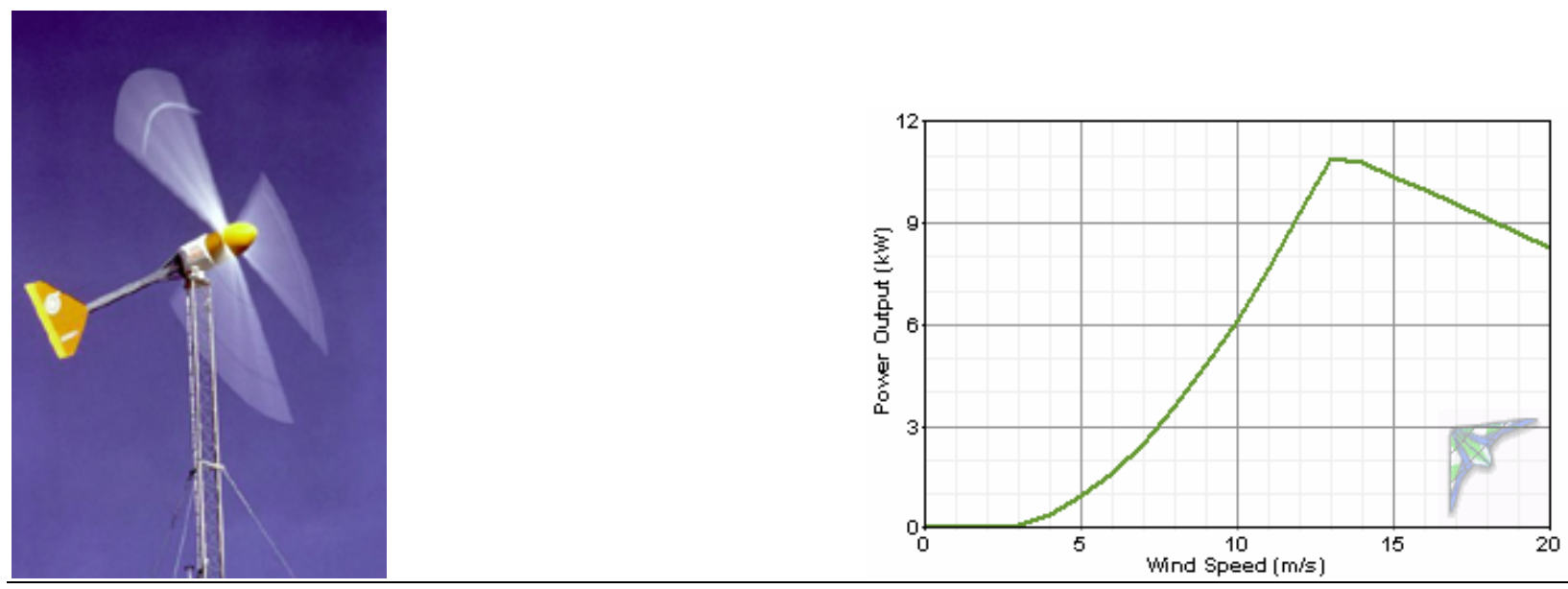

Entegrity eW-15: $65 \mathrm{~kW}$ rated power output, 15 meter rotor, stall-controlled (power curve provided by Entegrity Energy Systems). Available tower heights: 25 and 31 meters. Additional information is available at http://www.entegritywind.com/. 

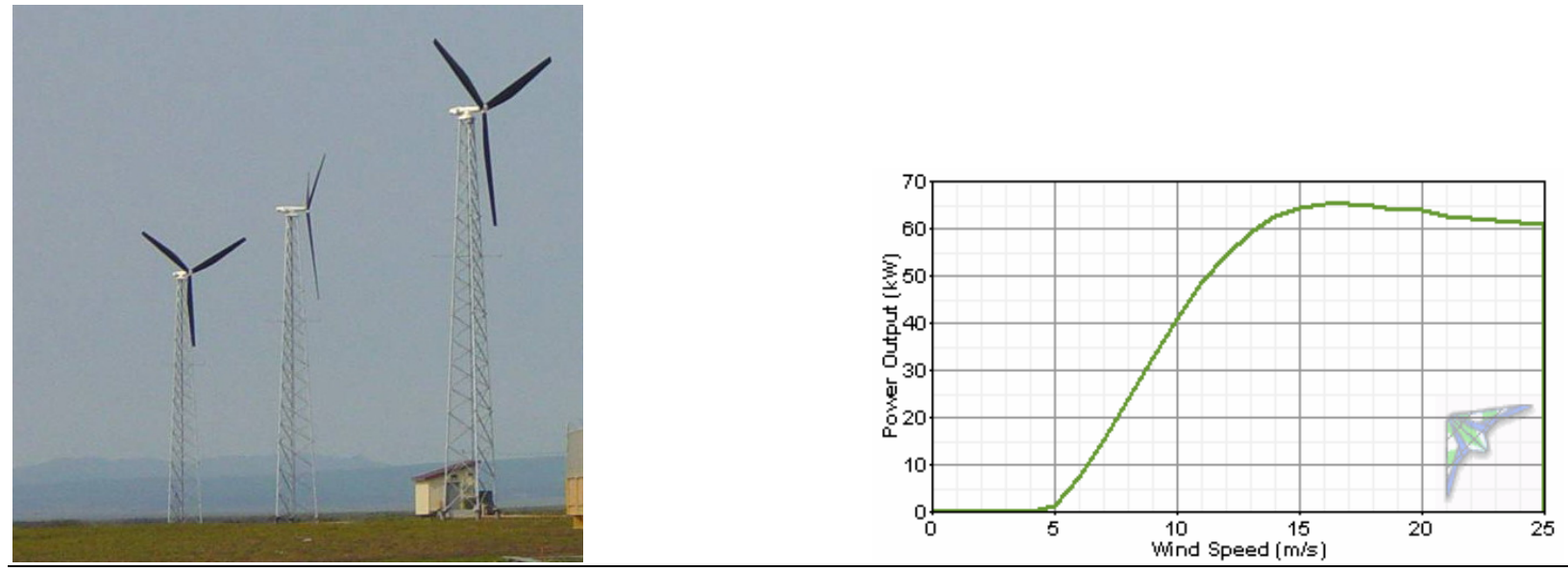

Vestas V15: $75 \mathrm{~kW}$ rated power output, 15 meter rotor, stall-controlled (power curve provided by Powercorp Alaska LLC). Available tower heights: 25, 31 and 34 meters. Additional information is available at http://www.pcorpalaska.com/.
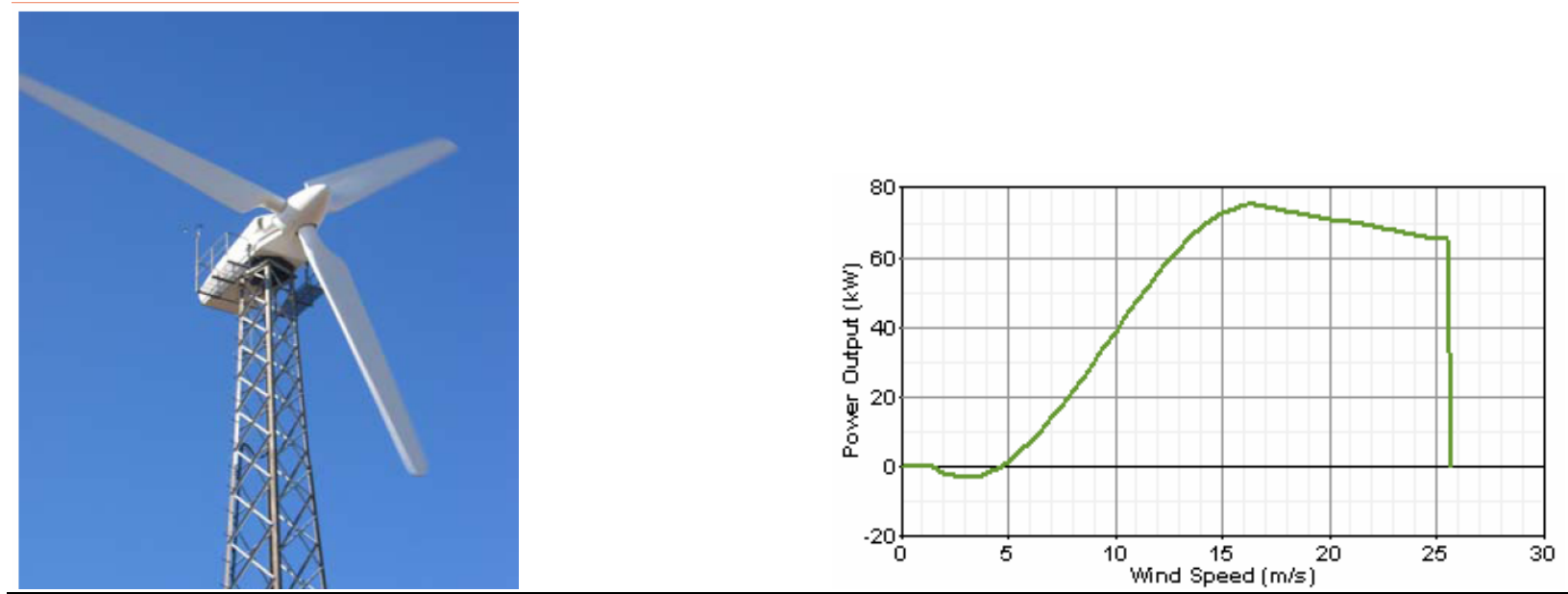

Northwind 100/20: $100 \mathrm{~kW}$ rated power output, 20 meter rotor (19 meter rotor blades with 0.6 meter blade root extensions added), stall-controlled (power curve provided by Northern Power Systems). Available tower heights: 25 and 32 meters. Additional information is available at http://www.northernpower.com/. 
Dillingham, Alaska Woodriver Road Wind Resource Report
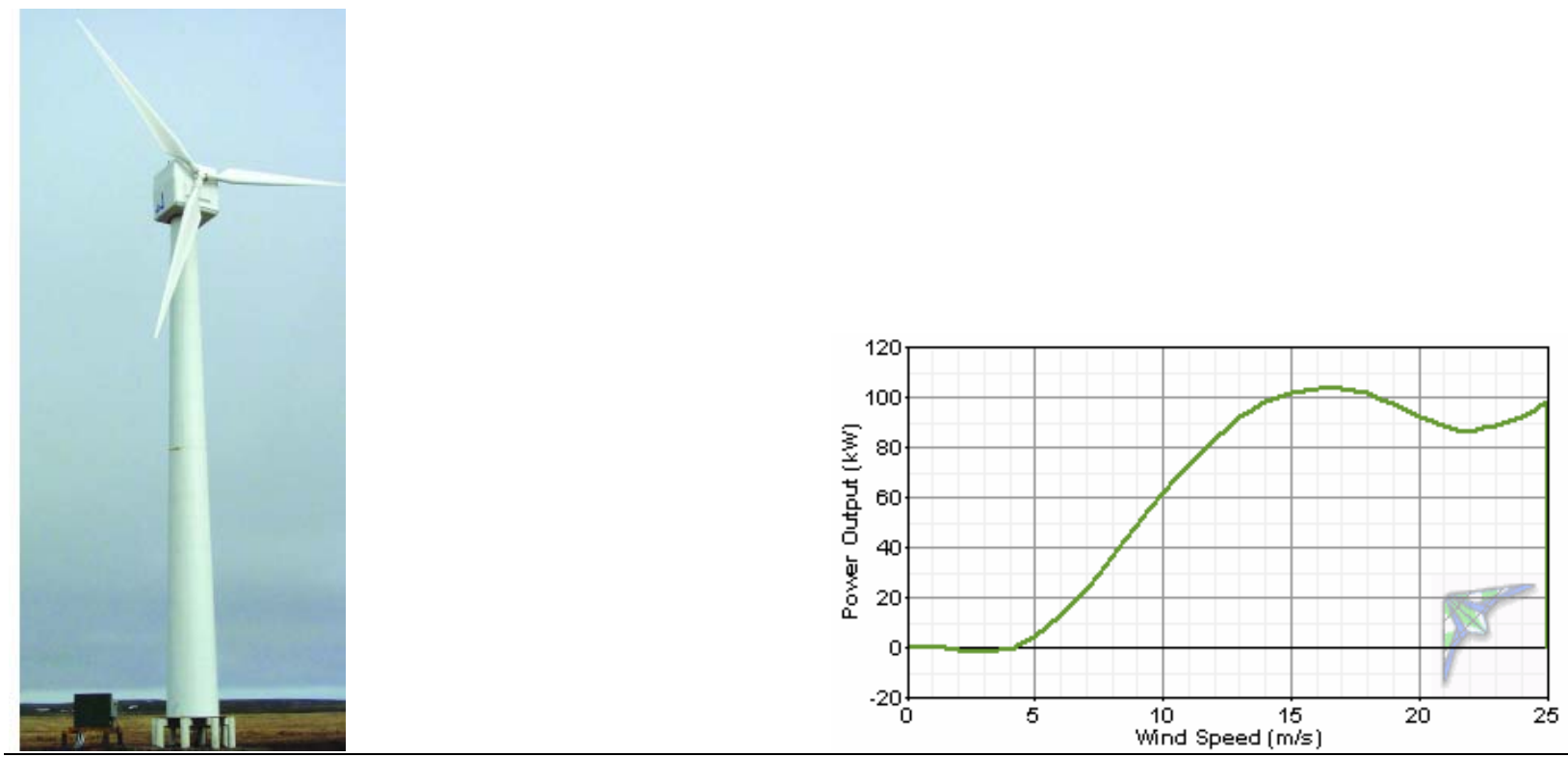

Vestas V27: $225 \mathrm{~kW}$ output, 27 meter rotor, pitch-controlled (power curve provided by Alaska Energy Authority).
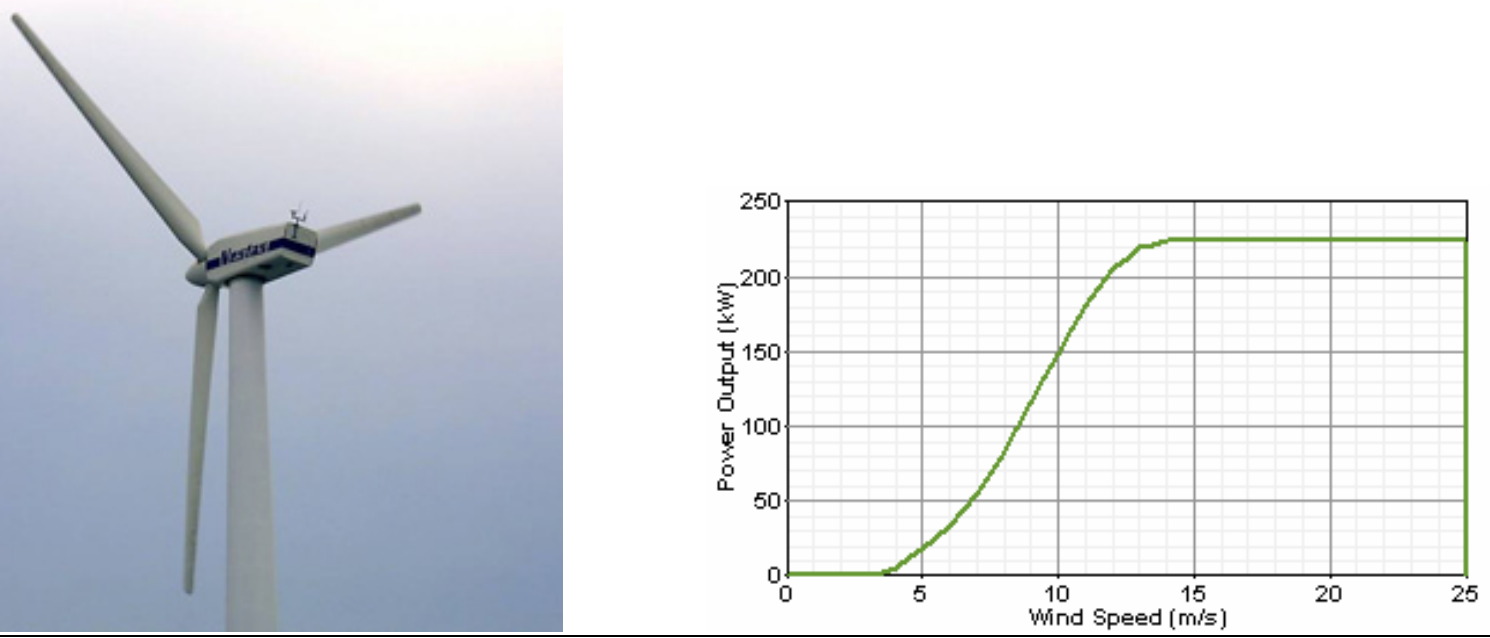

Fuhrländer FL250: 250 kW output, 29.5 meter rotor, stall-controlled (power curve provided by Lorax Energy Systems). Available tower heights: 42 and 50 meters. Additional information is available at www.lorax-energy.com. 
Dillingham, Alaska Woodriver Road Wind Resource Report
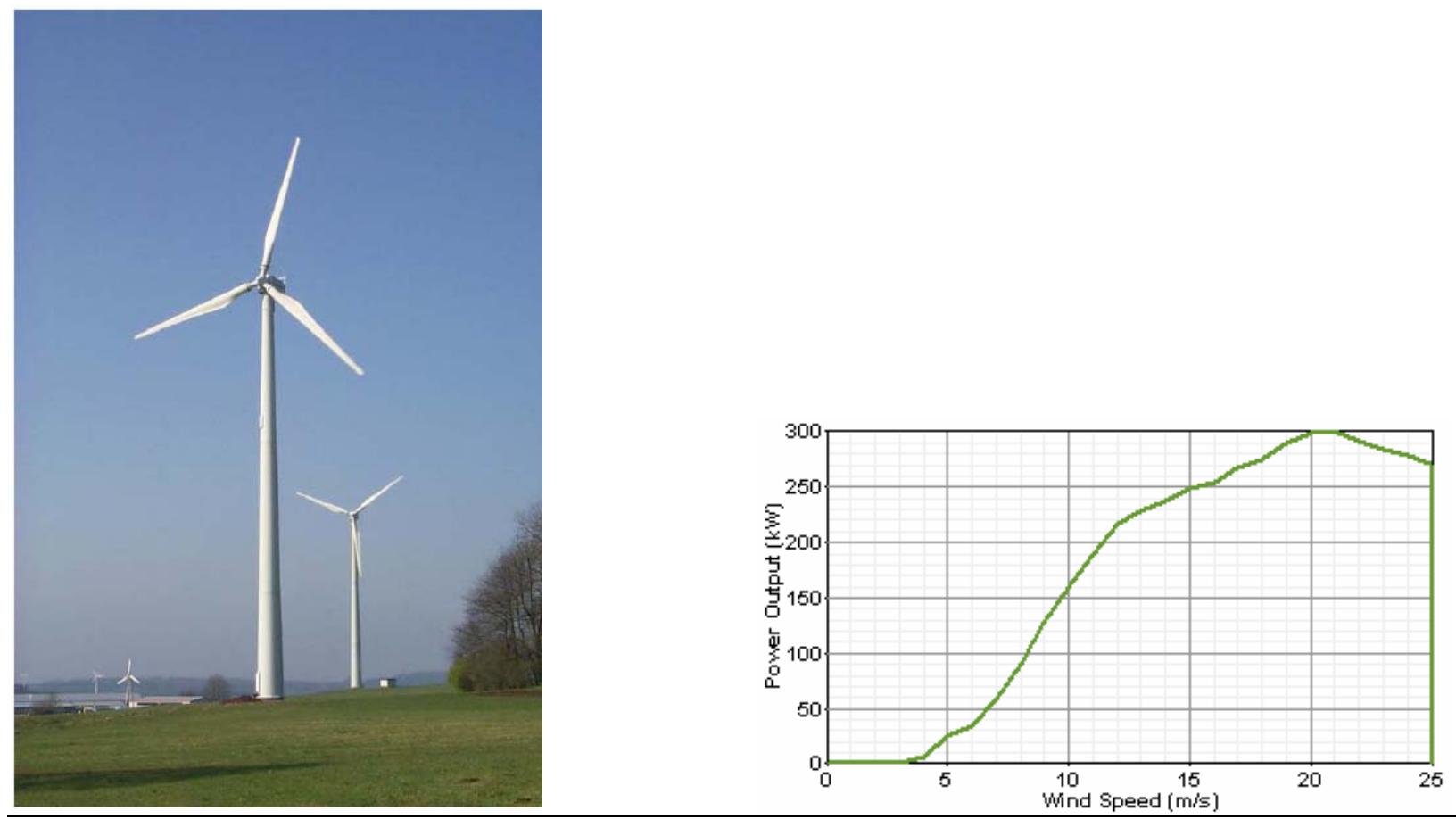

Vestas RRB 47/600: $600 \mathrm{~kW}$ output, 47 meter rotor, pitch-controlled (power curve provided by Vestas RRB, India). Available tower heights: 50 and 60 meters. Additional information is available at www.vestasrrb.com.
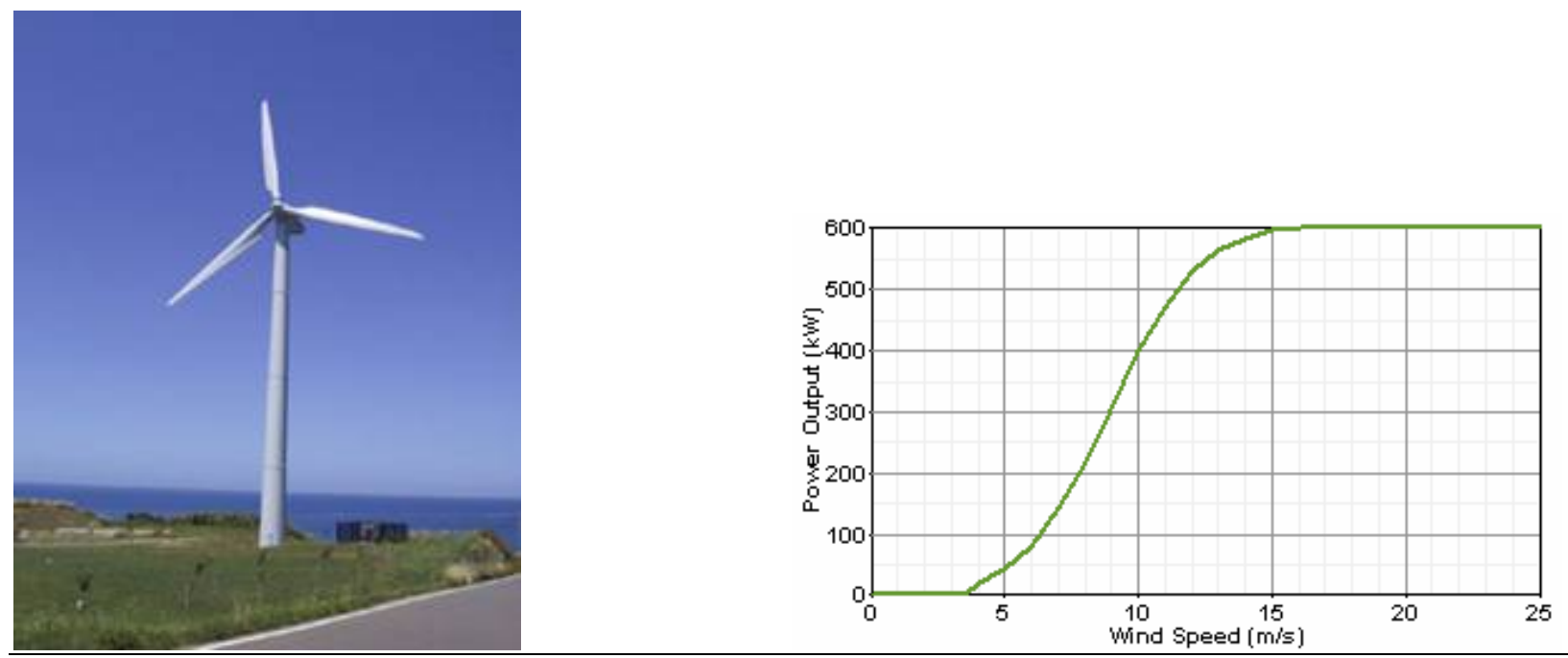
General Electric 1.5s: 1,500 kW output, 70.5 meter rotor, pitch controlled (power curve provided by GE). Available tower heights: 54.7 and 64.7 meters. Additional information is available at www.gewindenergy.com.
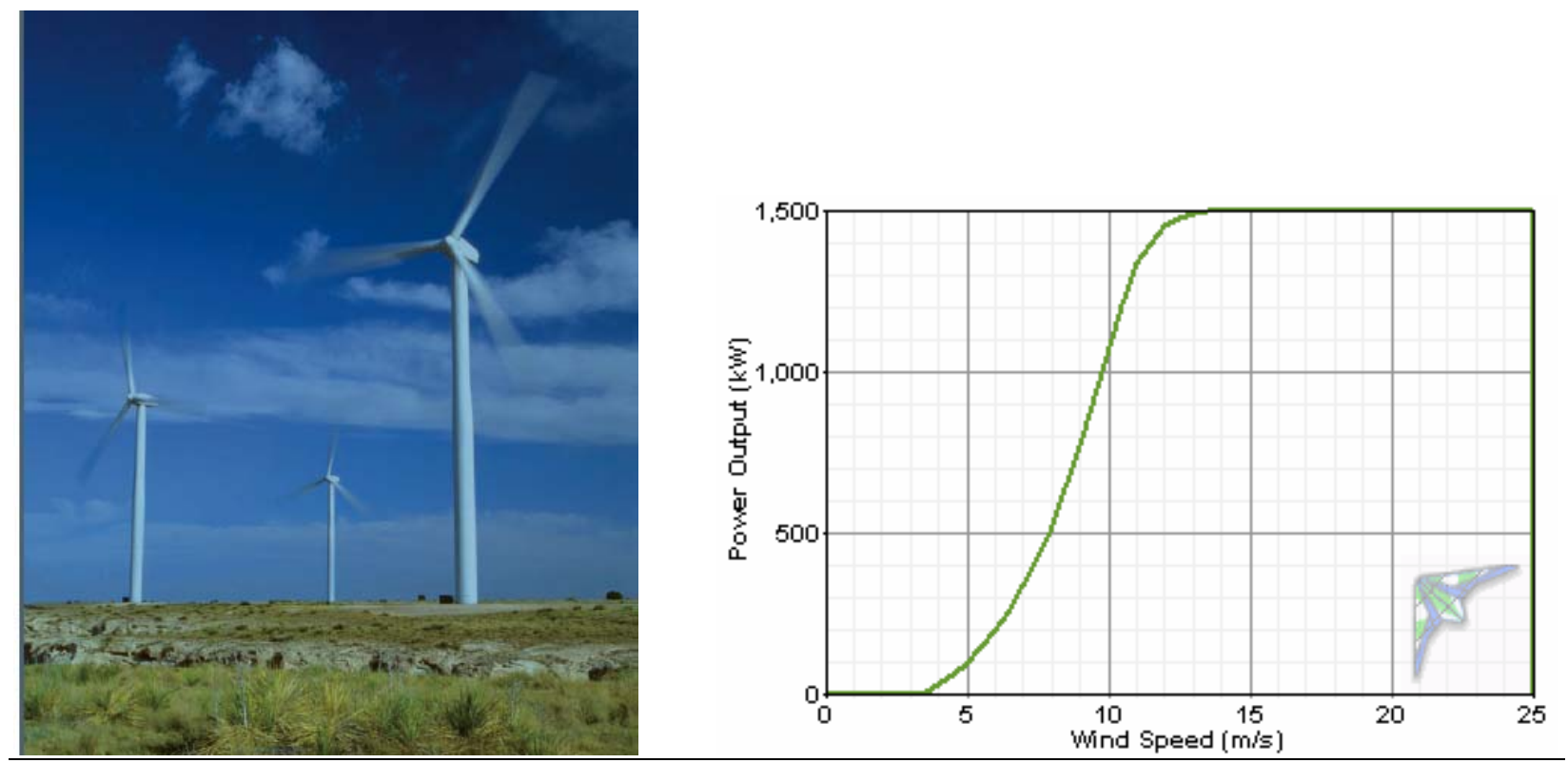
Dillingham, Alaska Woodriver Road Wind Resource Report

Turbine Power Output Comparison (100\% availability)

\begin{tabular}{|c|c|c|c|c|c|c|c|}
\hline Turbine & $\begin{array}{l}\text { Hub } \\
\text { Height } \\
\text { (m) }\end{array}$ & $\begin{array}{c}\text { Hub Height } \\
\text { Wind Speed } \\
(\mathrm{m} / \mathrm{s})\end{array}$ & $\begin{array}{c}\text { Time At } \\
\text { Zero Output } \\
(\%)\end{array}$ & $\begin{array}{c}\text { Time At } \\
\text { Rated Output } \\
(\%)\end{array}$ & $\begin{array}{c}\text { Average Net } \\
\text { Power Output } \\
(\mathrm{kW})\end{array}$ & $\begin{array}{c}\text { Annual Net } \\
\text { Energy } \\
\text { Output } \\
\text { (kWh/yr) }\end{array}$ & $\begin{array}{c}\text { Average Net } \\
\text { Capacity } \\
\text { Factor } \\
(\%)\end{array}$ \\
\hline Bergey Excel-S & 43 & 6.30 & 9.4 & 5.2 & 2.7 & 23,961 & 27.4 \\
\hline Entegrity eW-15 $60 \mathrm{~Hz}$ & 31 & 5.85 & 31.4 & 2.3 & 14 & 122,137 & 21.5 \\
\hline Vestas V15 & 34 & 5.97 & 37.7 & 1.5 & 14 & 118,038 & 18.0 \\
\hline Northern Power NW 100/20 & 32 & 5.89 & 31.1 & 2.1 & 21 & 182,435 & 20.9 \\
\hline Vestas V27 & 50 & 6.53 & 12.6 & 2.7 & 66 & 572,781 & 29.1 \\
\hline Fuhrländer FL250 & 50 & 6.53 & 9.1 & 0.3 & 73 & 640,500 & 24.4 \\
\hline Vestas RRB 47/600 & 50 & 6.53 & 21.1 & 1.8 & 171 & $1,493,985$ & 28.5 \\
\hline General Electric 1.5s & 65 & 6.94 & 19.5 & 6.8 & 496 & $4,331,722$ & 33.0 \\
\hline \multicolumn{8}{|l|}{ Capacity Factor <20\% } \\
\hline \multicolumn{8}{|l|}{ Capacity Factor >20\%, <30\% } \\
\hline \multicolumn{8}{|l|}{ Capacity Factor $>30 \%,<40 \%$} \\
\hline \multicolumn{8}{|l|}{ Capacity Factor $>40 \%,<50 \%$} \\
\hline Capacity Factor $>50 \%$ & & & & & & & \\
\hline
\end{tabular}

Assumed turbine losses for predictions of average power output, annual energy output, and average capacity factor: Downtime (\%)

Array (\%)

Icing/soiling (\%)

Other (\%)

Total (\%) 
Dillingham, Alaska Woodriver Road Wind Resource Report

Turbine Power Output Comparison (90\% availability)

\begin{tabular}{|c|c|c|c|c|c|c|c|}
\hline Turbine & $\begin{array}{l}\text { Hub } \\
\text { Height } \\
\text { (m) }\end{array}$ & $\begin{array}{c}\text { Hub Height } \\
\text { Wind Speed } \\
(\mathrm{m} / \mathrm{s})\end{array}$ & $\begin{array}{c}\text { Time At } \\
\text { Zero Output } \\
(\%)\end{array}$ & $\begin{array}{c}\text { Time At } \\
\text { Rated Output } \\
(\%)\end{array}$ & $\begin{array}{c}\text { Average Net } \\
\text { Power Output } \\
(\mathrm{kW})\end{array}$ & $\begin{array}{c}\text { Annual Net } \\
\text { Energy } \\
\text { Output } \\
\text { (kWh/yr) }\end{array}$ & $\begin{array}{c}\text { Average Net } \\
\text { Capacity } \\
\text { Factor } \\
(\%)\end{array}$ \\
\hline Bergey Excel-S & 43 & 6.21 & 9.5 & 4.8 & 2.4 & 21,649 & 24.8 \\
\hline Entegrity eW-15 $60 \mathrm{~Hz}$ & 31 & 5.77 & 31.9 & 2.1 & 12.1 & 110,351 & 19.4 \\
\hline Vestas V15 & 34 & 5.88 & 38.3 & 1.3 & 11.7 & 106,647 & 16.3 \\
\hline Northern Power NW 100/20 & 32 & 5.80 & 31.6 & 1.9 & 18.1 & 164,830 & 18.9 \\
\hline Vestas V27 & 50 & 6.43 & 12.8 & 2.6 & 57.2 & 517,508 & 26.3 \\
\hline Fuhrländer FL250 & 50 & 6.43 & 9.3 & 0.3 & 63.9 & 578,692 & 22.1 \\
\hline Vestas RRB 47/600 & 50 & 6.43 & 21.4 & 1.6 & 149 & $1,349,815$ & 25.7 \\
\hline General Electric 1.5s & 65 & 6.94 & 19.5 & 6.8 & 496 & $3,913,711$ & 29.9 \\
\hline \multicolumn{8}{|l|}{ Capacity Factor <20\% } \\
\hline \multicolumn{8}{|l|}{ Capacity Factor >20\%, <30\% } \\
\hline \multicolumn{8}{|l|}{ Capacity Factor $>30 \%,<40 \%$} \\
\hline \multicolumn{8}{|l|}{ Capacity Factor $>40 \%,<50 \%$} \\
\hline Capacity Factor $>50 \%$ & & & & & & & \\
\hline
\end{tabular}

Assumed turbine losses for predictions of average power output, annual energy output, and average capacity factor:

Downtime (\%)

Array (\%)

Icing/soiling (\%)

Other (\%)

4

Total (\%)

2

2

9.65 (factors are multiplicative) 
Dillingham, Alaska Woodriver Road Wind Resource Report

Fuel Cost Avoided for Electricity Generation by Diesel Generator

\begin{tabular}{|c|c|c|c|c|c|c|c|c|c|c|}
\hline \multirow[b]{2}{*}{ Turbine } & \multirow{2}{*}{$\begin{array}{c}\text { Annual } \\
\text { Energy } \\
\text { Output } \\
\text { (kW-hr/yr) }\end{array}$} & \multirow{2}{*}{$\begin{array}{c}\text { Fuel } \\
\text { Quantity } \\
\text { Avoided } \\
\text { (qallons) }\end{array}$} & \multicolumn{7}{|c|}{ Fuel Price (USD/gallon) } & \multirow{2}{*}{$\begin{array}{c}\text { Turbine } \\
\text { Hub } \\
\text { Height } \\
\text { (m) }\end{array}$} \\
\hline & & & $\$ 1.75$ & $\$ 2.00$ & $\$ 2.25$ & $\$ 2.50$ & $\$ 2.75$ & $\$ 3.00$ & $\$ 3.25$ & \\
\hline Bergey Excel-S & 21,649 & 1,415 & $\$ 2,476$ & $\$ 2,830$ & $\$ 3,184$ & $\$ 3,537$ & $\$ 3,891$ & $\$ 4,245$ & $\$ 4,599$ & 43 \\
\hline Entegrity eW-15 $60 \mathrm{~Hz}$ & 110,351 & 7,212 & $\$ 12,622$ & $\$ 14,425$ & $\$ 16,228$ & $\$ 18,031$ & $\$ 19,834$ & $\$ 21,637$ & $\$ 23,441$ & 31 \\
\hline Vestas V15 & 106,647 & 6,970 & $\$ 12,198$ & $\$ 13,941$ & $\$ 15,683$ & $\$ 17,426$ & $\$ 19,169$ & $\$ 20,911$ & $\$ 22,654$ & 34 \\
\hline Northern Power NW 100/20 & 164,830 & 10,773 & $\$ 18,853$ & $\$ 21,546$ & $\$ 24,240$ & $\$ 26,933$ & $\$ 29,626$ & $\$ 32,320$ & $\$ 35,013$ & 32 \\
\hline Vestas V27 & 517,508 & 33,824 & $\$ 59,192$ & $\$ 67,648$ & $\$ 76,104$ & $\$ 84,560$ & $\$ 93,016$ & $\$ 101,472$ & $\$ 109,928$ & 50 \\
\hline Fuhrländer FL250 & 578,692 & 37,823 & $\$ 66,190$ & $\$ 75,646$ & $\$ 85,102$ & $\$ 94,557$ & $\$ 104,013$ & $\$ 113,469$ & $\$ 122,925$ & 50 \\
\hline Vestas RRB 47/600 & $1,349,815$ & 88,223 & $\$ 154,391$ & $\$ 176,446$ & $\$ 198,502$ & $\$ 220,558$ & $\$ 242,614$ & $\$ 264,670$ & $\$ 286,726$ & 50 \\
\hline General Electric 1.5s & $3,913,711$ & 255,798 & $\$ 447,647$ & $\$ 511,596$ & $\$ 575,546$ & $\$ 639,495$ & $\$ 703,445$ & $\$ 767,394$ & $\$ 831,344$ & 65 \\
\hline
\end{tabular}

Notes:

1. Dillingham electrical energy production efficiency is $15.3 \mathrm{~kW}$-hr/gal (source: Nushagak Electric Coop)

2. Assumes $90 \%$ wind turbine availability with no diversion of power to a thermal or other dump load

3. Assumes linear diesel generator fuel efficiency (i.e., 1:1 tradeoff of wind turbine kW-hr to diesel genset kW-hr) 
Dillingham, Alaska Woodriver Road Wind Resource Report

Temperature Conversion Chart ${ }^{\circ} \mathrm{C}$ to ${ }^{\circ} \mathrm{F}$

\begin{tabular}{|c|c|c|c|c|c|}
\hline${ }^{\circ} \mathbf{C}$ & ${ }^{\circ} \mathbf{F}$ & ${ }^{\circ} \mathbf{C}$ & ${ }^{\circ} \mathbf{F}$ & ${ }^{\circ} \mathbf{C}$ & ${ }^{\circ} \mathbf{F}$ \\
\hline-40 & -40 & -10 & 14 & 20 & 68 \\
\hline-39 & -38.2 & -9 & 15.8 & 21 & 69.8 \\
\hline-38 & -36.4 & -8 & 17.6 & 22 & 71.6 \\
\hline-37 & -34.6 & -7 & 19.4 & 23 & 73.4 \\
\hline-36 & -32.8 & -6 & 21.2 & 24 & 75.2 \\
\hline-35 & -31 & -5 & 23 & 25 & 77 \\
\hline-34 & 29.2 & -4 & 24.8 & 26 & 78.8 \\
\hline-33 & -27.4 & -3 & 26.6 & 27 & 80.6 \\
\hline-32 & -25.6 & -2 & 28.4 & 28 & 82.4 \\
\hline-31 & -23.8 & -1 & 30.2 & 29 & 84.2 \\
\hline-30 & -22 & 0 & 32 & 30 & 86 \\
\hline-29 & -20.2 & 1 & 33.8 & 31 & 87.8 \\
\hline-28 & -18.4 & 2 & 35.6 & 32 & 89.6 \\
\hline-27 & -16.6 & 3 & 37.4 & 33 & 91.4 \\
\hline-26 & -14.8 & 4 & 39.2 & 34 & 93.2 \\
\hline-25 & -13 & 5 & 41 & 35 & 95 \\
\hline-24 & -11.2 & 6 & 42.8 & 36 & 96.8 \\
\hline-23 & -9.4 & 7 & 44.6 & 37 & 98.6 \\
\hline-22 & -7.6 & 8 & 46.4 & 38 & 100.4 \\
\hline-21 & -5.8 & 9 & 48.2 & 39 & 102.2 \\
\hline-20 & -4 & 10 & 50 & 40 & 104 \\
\hline-19 & -2.2 & 11 & 51.8 & 41 & 105.8 \\
\hline-18 & -0.4 & 12 & 53.6 & 42 & 107.6 \\
\hline-17 & 1.4 & 13 & 55.4 & 43 & 109.4 \\
\hline-16 & 3.2 & 14 & 57.2 & 44 & 111.2 \\
\hline-15 & 5 & 15 & 59 & 45 & 113 \\
\hline-14 & 6.8 & 16 & 60.8 & 46 & 114.8 \\
\hline-13 & 8.6 & 17 & 62.6 & 47 & 116.6 \\
\hline-12 & 10.4 & 18 & 64.4 & 48 & 118.4 \\
\hline-11 & 12.2 & 19 & 66.2 & 49 & 120.2 \\
\hline & & & & & \\
\hline-21 & & & & \\
\hline
\end{tabular}


Dillingham, Alaska Woodriver Road Wind Resource Report

Wind Speed Conversion Chart $\mathrm{m} / \mathrm{s}$ to $\mathrm{mph}$

\begin{tabular}{|c|c|c|c|c|c|}
\hline $\mathbf{m} / \mathbf{s}$ & $\mathbf{m p h}$ & $\mathbf{m} / \mathbf{s}$ & $\mathbf{m p h}$ & $\mathbf{~ m / s}$ & $\mathbf{m p h}$ \\
\hline 0.5 & 1.1 & 10.5 & 23.5 & 20.5 & 45.9 \\
\hline 1.0 & 2.2 & 11.0 & 24.6 & 21.0 & 47.0 \\
\hline 1.5 & 3.4 & 11.5 & 25.7 & 21.5 & 48.1 \\
\hline 2.0 & 4.5 & 12.0 & 26.8 & 22.0 & 49.2 \\
\hline 2.5 & 5.6 & 12.5 & 28.0 & 22.5 & 50.3 \\
\hline 3.0 & 6.7 & 13.0 & 29.1 & 23.0 & 51.4 \\
\hline 3.5 & 7.8 & 13.5 & 30.2 & 23.5 & 52.6 \\
\hline 4.0 & 8.9 & 14.0 & 31.3 & 24.0 & 53.7 \\
\hline 4.5 & 10.1 & 14.5 & 32.4 & 24.5 & 54.8 \\
\hline 5.0 & 11.2 & 15.0 & 33.6 & 25.0 & 55.9 \\
\hline 5.5 & 12.3 & 15.5 & 34.7 & 25.5 & 57.0 \\
\hline 6.0 & 13.4 & 16.0 & 35.8 & 26.0 & 58.2 \\
\hline 6.5 & 14.5 & 16.5 & 36.9 & 26.5 & 59.3 \\
\hline 7.0 & 15.7 & 17.0 & 38.0 & 27.0 & 60.4 \\
\hline 7.5 & 16.8 & 17.5 & 39.1 & 27.5 & 61.5 \\
\hline 8.0 & 17.9 & 18.0 & 40.3 & 28.0 & 62.6 \\
\hline 8.5 & 19.0 & 18.5 & 41.4 & 28.5 & 63.8 \\
\hline 9.0 & 20.1 & 19.0 & 42.5 & 29.0 & 64.9 \\
\hline 9.5 & 21.3 & 19.5 & 43.6 & 29.5 & 66.0 \\
\hline 10.0 & 22.4 & 20.0 & 44.7 & 30.0 & 67.1 \\
\hline
\end{tabular}

Distance Conversion $\mathrm{m}$ to $\mathrm{ft}$

\begin{tabular}{|c|c|c|c|}
\hline $\mathbf{m}$ & $\mathbf{f t}$ & $\mathbf{m}$ & $\mathbf{f t}$ \\
\hline 5 & 16 & 35 & 115 \\
\hline 10 & 33 & 40 & 131 \\
\hline 15 & 49 & 45 & 148 \\
\hline 20 & 66 & 50 & 164 \\
\hline 25 & 82 & 55 & 180 \\
\hline 30 & 98 & 60 & 197 \\
\hline
\end{tabular}


Selected definitions (courtesy of Windographer® software by Mistaya Engineering Inc.)

\section{$\underline{\text { Wind Power Class }}$}

The wind power class is a number indicating the average energy content of the wind resource. Wind power classes are based on the average wind power density at 50 meters above ground, according to the following table. Source: Wind Energy Resource Atlas of the United States (http://rredc.nrel.gov/wind/pubs/atlas/tables/A-8T.html)

\begin{tabular}{|c|l|c|}
\hline \multicolumn{2}{|c|}{} & \multicolumn{2}{|c|}{} \\
\hline Wind Power Class & Description & Power Density at 50m $\mathbf{( W / \mathbf { m } ^ { 2 }}$ \\
\hline 1 & Poor & $0-200$ \\
\hline 2 & Marginal & $200-300$ \\
\hline 3 & Fair & $300-400$ \\
\hline 4 & Good & $400-500$ \\
\hline 5 & Excellent & $500-600$ \\
\hline 6 & Outstanding & $600-800$ \\
\hline 7 & Superb & $800-2000$ \\
\hline
\end{tabular}

Windographer classifies any wind resource with an average wind power density above 2000 $\mathrm{W} / \mathrm{m}^{2}$ as class 8 .

Probability Distribution Function

The probability distribution function $\mathrm{f}(\mathrm{x})$ gives the probability that a variable will take on the value $\mathrm{x}$. It is often expressed using a frequency histogram, which gives the frequency with which the variable falls within certain ranges or bins.

\section{$\underline{\text { Wind Turbine Power Regulation }}$}

All wind turbines employ some method of limiting power output at high wind speeds to avoid damage to mechanical or electrical subsystems. Most wind turbines employ either stall control or pitch control to regulate power output.

A stall-controlled turbine typically has blades that are fixed in place, and are designed to experience aerodynamic stall at very high wind speeds. Aerodynamic stall dramatically reduces the torque produced by the blades, and therefore the power produced by the turbine.

On a pitch-controlled turbine, a controller adjusts the angle (pitch) of the blades to best match the wind speed. At very high wind speeds the controller increasingly feathers the blades out of the wind to limit the power output. 


\title{
Kokhanok, Alaska Wind Resource Report
}

\author{
Report written by: Douglas Vaught, P.E., V3 Energy, LLC
}

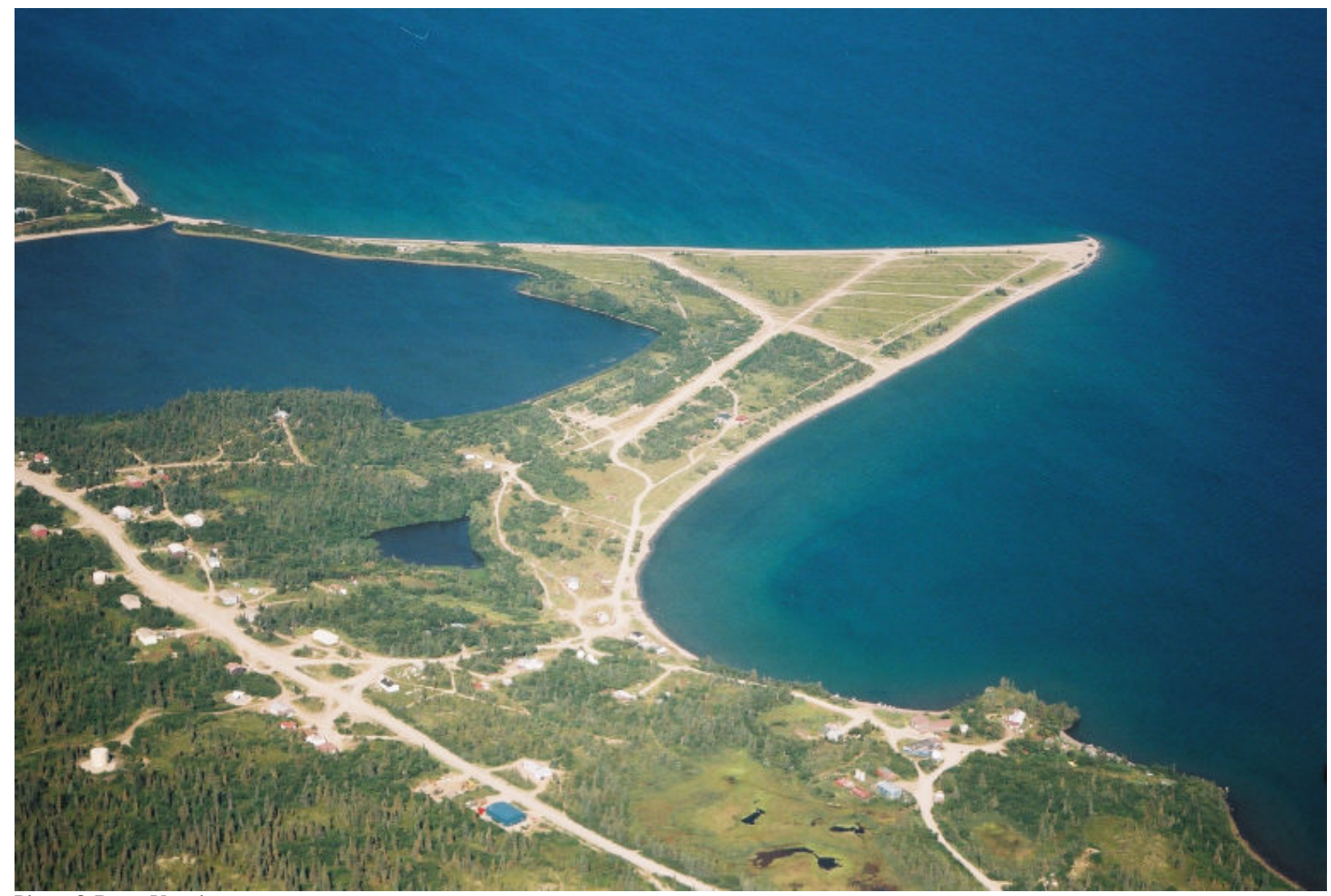

Photo (c) Doug Vaught

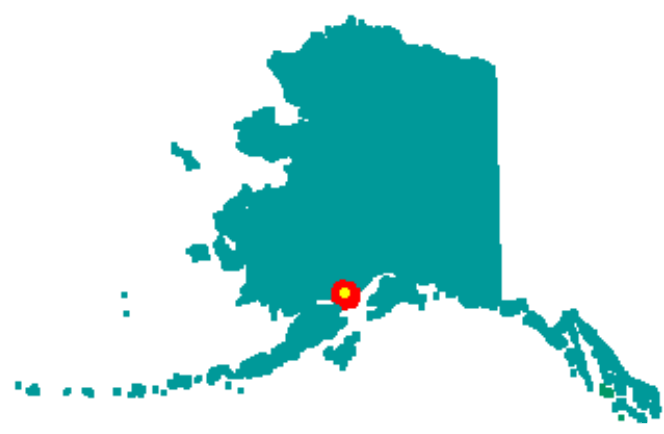

\section{Summary Information}

The wind resource in Kokhanok is superb by any measure - the winds are steady, smooth, low shear, highly directional and high power class. The selected wind site, near the tip of the spit of land jutting into Lake Iliamna (see photo above) is ideal for wind turbine installations as it is 
relatively far from the village but near an existing overhead power line, is comprised of stable rocky soil, and is in a location unlikely to be desired for other village uses (because of the wind).

\section{Meteorological Tower Data Synopsis}

Wind power class

Wind speed annual average (30 meters)

Maximum wind gust (2 sec. average)

Mean wind power density (50 meters)

Mean wind power density (30 meters)

Weibull distribution parameters

Turbulence intensity

Roughness class

Power law exponent

Data start date

Data end date
Class 6 - Outstanding

$7.84 \mathrm{~m} / \mathrm{s}$

$40.1 \mathrm{~m} / \mathrm{s}$ (Nov. 2004)

$763 \mathrm{~W} / \mathrm{m}^{2}$ (calculated)

$690 \mathrm{~W} / \mathrm{m}^{2}$ (measured)

$\mathrm{k}=1.64, \mathrm{c}=8.77 \mathrm{~m} / \mathrm{s}$

0.0985 (low)

0.00 (smooth)

0.0725 (very low wind shear)

August 12, 2004

June 14, 2006

Community Profile

Current Population: 179 (2005 State Demographer est.)

Pronunciation/Other Names: (KOCK-hone-ack); alt. Kakhonak

Incorporation Type: Unincorporated

Borough Located In: Lake \& Peninsula Borough

School District: Lake \& Peninsula Schools

Regional Native Corporation: Bristol Bay Native Corporation

\section{Location:}

Kokhanok is located on the south shore of Iliamna Lake, 22 miles south of Iliamna and 88 miles northeast of King Salmon. It lies at approximately $59.441600^{\circ}$ North Latitude and $-154.755140^{\circ}$ West Longitude.

(Sec. 32, T008S, R032W, Seward Meridian.) Kokhanok is located in the lliamna Recording District. The area encompasses 21.3 sq. miles of land and 0.1 sq. miles of water.

\section{History:}

This fishing village was first listed in the U.S. Census in 1890 by A.B. Schanz. The community was relocated to higher ground a few years ago when the rising level of Iliamna Lake threatened several community buildings.

\section{Culture:}

The village has a mixed Native population, primarily Alutiiq and Yup'ik. Subsistence activities are the focal point of the culture and lifestyle. The sale or importation of alcohol is banned in the village.

\section{Economy:}

The school is the largest employer in Kokhanok. Commercial fishing has declined since several limited entry permits were sold. Some residents travel to the Bristol Bay area each summer to fish; eight persons currently hold commercial fishing permits. People heavily rely on subsistence activities; many families have a summer fish camp near the Gibraltar River. Salmon, trout, grayling, moose, bear, rabbit, porcupine and seal are utilized. 


\section{Facilities:}

Bedrock has made the development of water and sewer facilities difficult. The Village operates a piped water and sewer system that serves 35 households. The water treatment plant is currently being upgraded. The school operates its own well and water treatment facility. Kokhanok generates power only during the summer months; in winter, electricity is purchased from the School District.

\section{Transportation:}

Kokhanok is accessible by air and water. A State-owned 2,920' long by 60' wide gravel airstrip and a seaplane base serve scheduled and charter air services from Anchorage, Iliamna, and King Salmon. Supplies delivered by barge via the Kvichak River must be lightered to shore. There are no docking facilities. The community wants to develop a boat harbor and launch ramp. Skiffs, ATVs and trucks are common forms of local transportation.

\section{Climate:}

Kokhanok lies in the transitional climatic zone. Average summer temperatures range from 40 to $64 \mathrm{~F}$; winter temperatures average 3 to $30 \mathrm{~F}$. The record high is $84 \mathrm{~F}$; the record low, $-47 \mathrm{~F}$. Precipitation averages 32 inches annually, including 89 inches of snowfall. Wind storms and ice fog are common during winter.

(Above information from State of Alaska Department of Commerce, Community, and Economic Development website, www.dced.state.ak.us)

Tower Sensor Information

\begin{tabular}{clcrcc} 
Channel & Sensor type & Height & Multiplier & Offset & Orientation \\
\hline 1 & NRG \#40 anemometer & $30 \mathrm{~m}$ & 0.765 & 0.35 & north \\
2 & NRG \#40 anemometer & $21 \mathrm{~m}$ & 0.765 & 0.35 & north \\
7 & NRG \#200P wind vane & $29 \mathrm{~m}$ & 0.351 & 350 & south \\
9 & NRG \#110S Temp C & $2 \mathrm{~m}$ & 0.136 & -86.383 & N/A
\end{tabular}

Site Information and Location

Site number

Site Description

Latitude/longitude

Site elevation

Datalogger type

Tower type
2257

Near tip of spit jutting north into Lake Iliamna

N 59 26.907' W $154^{\circ} 45.835^{\prime}$

23 meters

NRG Symphonie

NRG 30-meter tall tower, 152 mm (6 in) diameter 
Kokhanok, Alaska Wind Resource Report

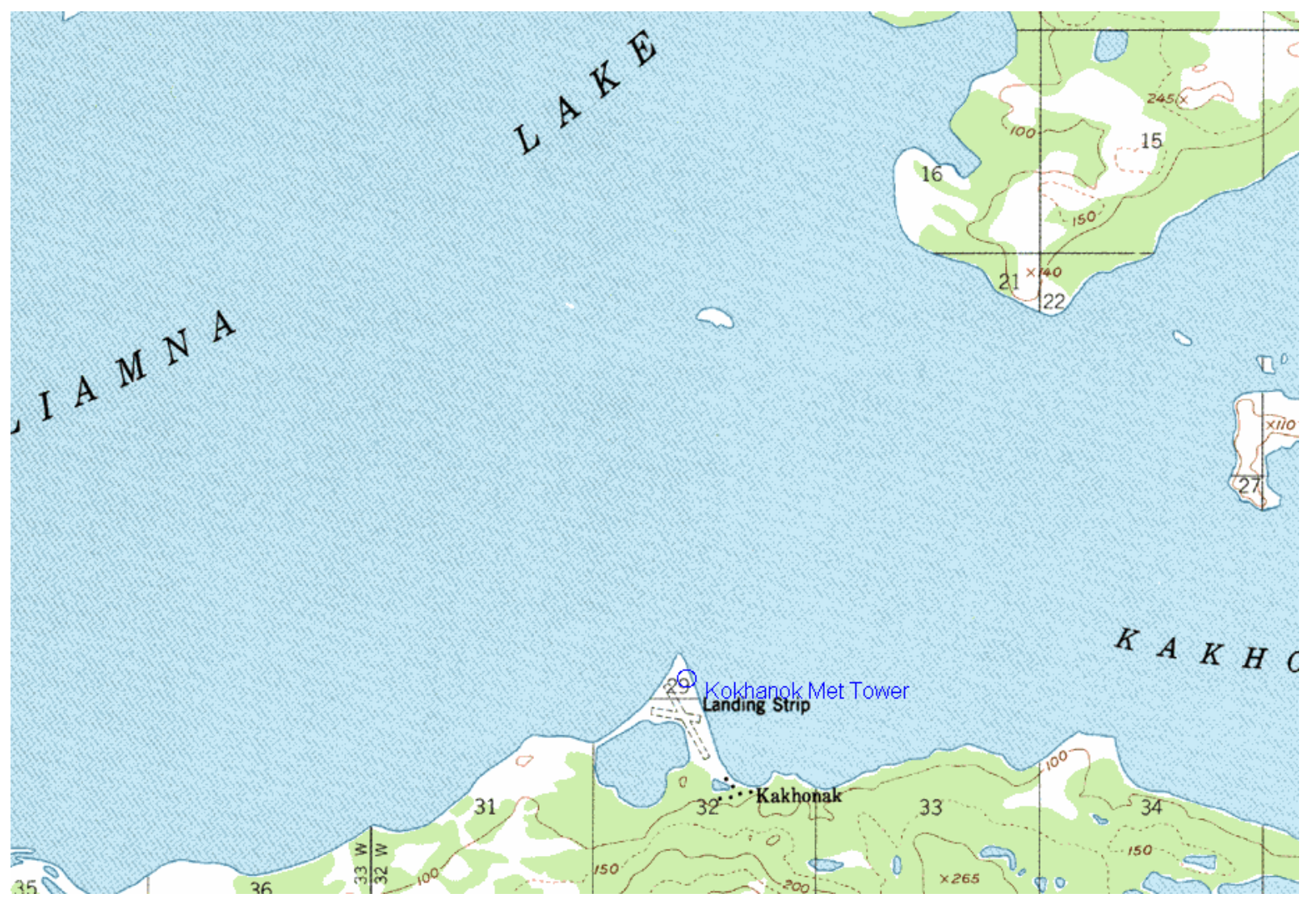


Kokhanok, Alaska Wind Resource Report

\section{Data Quality Control}

Data was filtered to remove presumed icing events that yield false zero wind speed data. Data that met the following criteria were filtered: wind speed $<1 \mathrm{~m} / \mathrm{s}$, wind speed standard deviation $=0$, and temperature $<3^{\circ} \mathrm{C}$. Note that data recovery during the months of May through October was nearly $100 \%$, but during the months of November through April some data was filtered.

Temperature data recovery was 100 percent, indicating full functioning of the temperature sensor. Because data recovery was so good, data was not synthesized to replace data missing from icing events.

\begin{tabular}{rrrrrrrrrr}
\multicolumn{2}{c}{30 m anemometer } & 21 m anemometer & \multicolumn{2}{c}{ Wind vane } & \multicolumn{2}{c}{ Temperature } \\
Year & Month & Records & $\begin{array}{r}\text { Recovery } \\
\text { Rate (\%) }\end{array}$ & Records & $\begin{array}{r}\text { Recovery } \\
\text { Rate (\%) }\end{array}$ & Records & $\begin{array}{r}\text { Recovery } \\
\text { Rate }(\%)\end{array}$ & Records & $\begin{array}{c}\text { Recovery } \\
\text { Rate }(\%)\end{array}$ \\
\hline 2004 & Aug & 2,812 & 100.0 & 2,812 & 100.0 & 2,812 & 100.0 & 2,812 & 100.0 \\
2004 & Sep & 4,320 & 100.0 & 4,320 & 100.0 & 4,320 & 100.0 & 4,320 & 100.0 \\
2004 & Oct & 4,462 & 100.0 & 4,462 & 100.0 & 4,462 & 100.0 & 4,464 & 100.0 \\
2004 & Nov & 4,291 & 99.3 & 4,295 & 99.4 & 4,291 & 99.3 & 4,320 & 100.0 \\
2004 & Dec & 4,371 & 97.9 & 4,370 & 97.9 & 4,370 & 97.9 & 4,464 & 100.0 \\
2005 & Jan & 4,357 & 97.6 & 4,353 & 97.5 & 4,353 & 97.5 & 4,464 & 100.0 \\
2005 & Feb & 3,957 & 98.1 & 3,951 & 98.0 & 3,951 & 98.0 & 4,032 & 100.0 \\
2005 & Mar & 4,427 & 99.2 & 4,428 & 99.2 & 4,427 & 99.2 & 4,464 & 100.0 \\
2005 & Apr & 4,266 & 98.8 & 4,252 & 98.4 & 4,252 & 98.4 & 4,320 & 100.0 \\
2005 & May & 4,463 & 100.0 & 4,463 & 100.0 & 4,463 & 100.0 & 4,464 & 100.0 \\
2005 & Jun & 4,320 & 100.0 & 4,320 & 100.0 & 4,320 & 100.0 & 4,320 & 100.0 \\
2005 & Jul & 4,464 & 100.0 & 4,464 & 100.0 & 4,464 & 100.0 & 4,464 & 100.0 \\
2005 & Aug & 4,464 & 100.0 & 4,464 & 100.0 & 4,464 & 100.0 & 4,464 & 100.0 \\
2005 & Sep & 4,320 & 100.0 & 4,320 & 100.0 & 4,320 & 100.0 & 4,320 & 100.0 \\
2005 & Oct & 4,464 & 100.0 & 4,464 & 100.0 & 4,464 & 100.0 & 4,464 & 100.0 \\
2005 & Nov & 4,285 & 99.2 & 4,288 & 99.3 & 4,285 & 99.2 & 4,320 & 100.0 \\
2005 & Dec & 4,383 & 98.2 & 4,374 & 98.0 & 4,374 & 98.0 & 4,464 & 100.0 \\
2006 & Jan & 4,275 & 95.8 & 4,237 & 94.9 & 4,232 & 94.8 & 4,464 & 100.0 \\
2006 & Feb & 3,878 & 96.2 & 3,892 & 96.5 & 3,878 & 96.2 & 4,032 & 100.0 \\
2006 & Mar & 4,213 & 94.4 & 4,179 & 93.6 & 4,166 & 93.3 & 4,464 & 100.0 \\
2006 & Apr & 4,234 & 98.0 & 4,230 & 97.9 & 4,219 & 97.7 & 4,320 & 100.0 \\
2006 & May & 4,453 & 99.8 & 4,458 & 99.9 & 4,453 & 99.8 & 4,464 & 100.0 \\
2006 & Jun & 1,938 & 100.0 & 1,938 & 100.0 & 1,938 & 100.0 & 1,938 & 100.0 \\
\hline All data & 95,417 & 98.8 & 95,334 & 98.7 & 95,278 & 98.6 & 96,622 & 100.0
\end{tabular}


Kokhanok, Alaska Wind Resource Report

\section{Measured Wind Speeds}

The Channel 1 (30-meter) anemometer annual wind speed average for the reporting period is $7.84 \mathrm{~m} / \mathrm{s}$ and the Channel 2 (20-meter) anemometer wind speed average is $7.66 \mathrm{~m} / \mathrm{s}$.

\begin{tabular}{crrrrrrr} 
& \multicolumn{9}{c}{$30 \mathrm{~m}$ anemometer } \\
Month & $\begin{array}{c}\text { Mean } \\
(\mathrm{m} / \mathrm{s})\end{array}$ & $\begin{array}{c}\text { Max } \\
(\mathrm{m} / \mathrm{s})\end{array}$ & $\begin{array}{c}\text { Sev. } \\
\text { Dev } \\
(\mathrm{m} / \mathrm{s})\end{array}$ & $\begin{array}{c}\text { Weibull } \\
\mathrm{k}\end{array}$ & $\begin{array}{c}\text { Weibull } \\
\mathrm{C}\end{array}$ & $\begin{array}{c}\text { Mean } \\
(\mathrm{m} / \mathrm{s})\end{array}$ & $\begin{array}{c}\text { Max } \\
(\mathrm{m} / \mathrm{s})\end{array}$ \\
\hline Jan & 7.73 & 21.9 & 4.51 & 1.72 & 8.64 & 7.53 & 21.7 \\
Feb & 10.01 & 27.2 & 6.08 & 1.61 & 11.11 & 9.81 & 26.8 \\
Mar & 8.53 & 27.4 & 4.86 & 1.77 & 9.55 & 8.35 & 26.9 \\
Apr & 7.22 & 27.3 & 4.46 & 1.64 & 8.05 & 7.00 & 26.7 \\
May & 7.09 & 24.1 & 4.81 & 1.41 & 7.74 & 6.97 & 23.6 \\
Jun & 7.84 & 25.3 & 5.01 & 1.49 & 8.60 & 7.60 & 24.7 \\
Jul & 7.03 & 19.1 & 3.49 & 2.04 & 7.87 & 6.79 & 18.6 \\
Aug & 6.68 & 20.7 & 3.60 & 1.86 & 7.48 & 6.53 & 20.2 \\
Sep & 7.33 & 26.8 & 3.85 & 1.93 & 8.22 & 7.23 & 26.1 \\
Oct & 6.86 & 25.6 & 4.22 & 1.63 & 7.63 & 6.77 & 25.0 \\
Nov & 8.46 & 28.4 & 4.63 & 1.87 & 9.51 & 8.27 & 27.4 \\
Dec & 9.32 & 27.2 & 5.62 & 1.61 & 10.34 & 9.08 & 26.5 \\
\hline Annual & 7.84 & 28.4 & 4.79 & 1.64 & 8.77 & 7.66 & 27.4
\end{tabular}

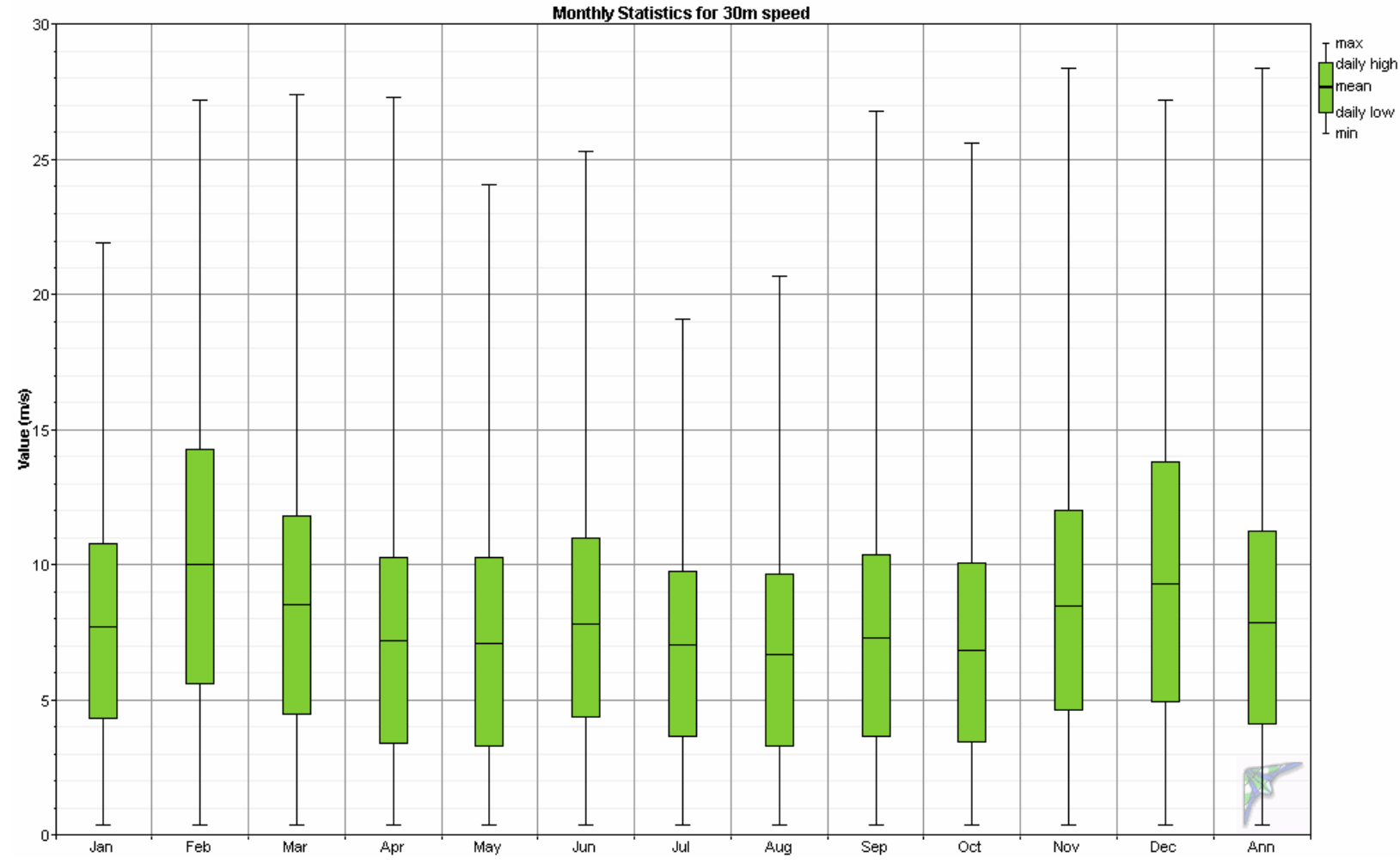


Kokhanok, Alaska Wind Resource Report

\section{Daily wind profile}

The daily wind profile indicates that the lowest wind speeds of the day occur in the morning hours of 5 a.m. to 7 a.m. and the highest wind speeds of the day occur during the afternoon hours of 1 p.m. to 4 p.m. The daily variation of wind speed is minimal on an annual basis but more pronounced on a monthly basis.
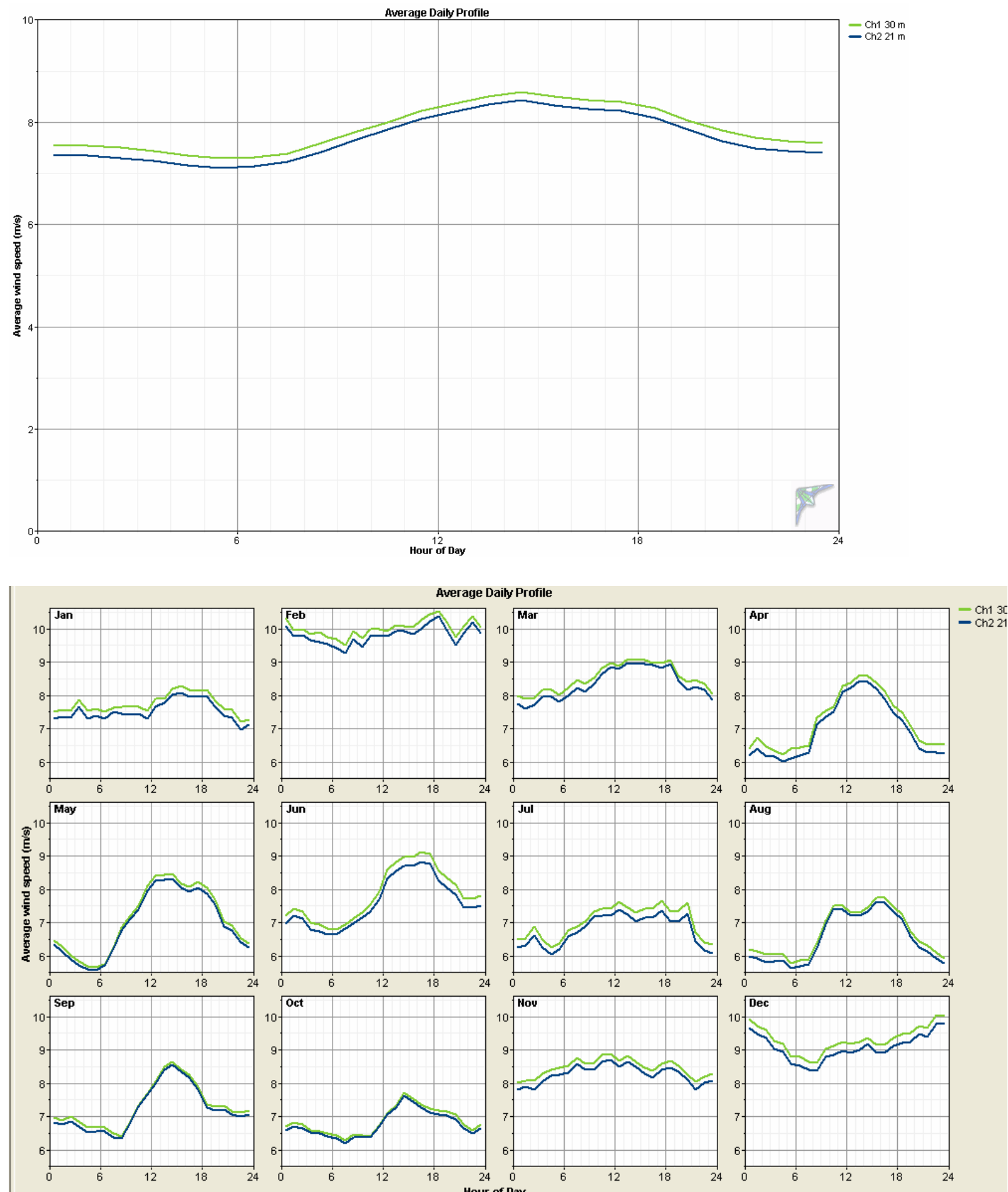


\section{Time Series of Wind Speed Averages}

As expected, the highest winds occur during the winter months and the lowest winds during spring, summer and early autumn, but in the case of Kokhanok, this is relative as the monthly average wind speeds are very good all year round. The unusually low winds measured in January 2006 were due to a persistent high pressure system over Alaska that month that yielded calm winds and extremely cold weather Statewide.
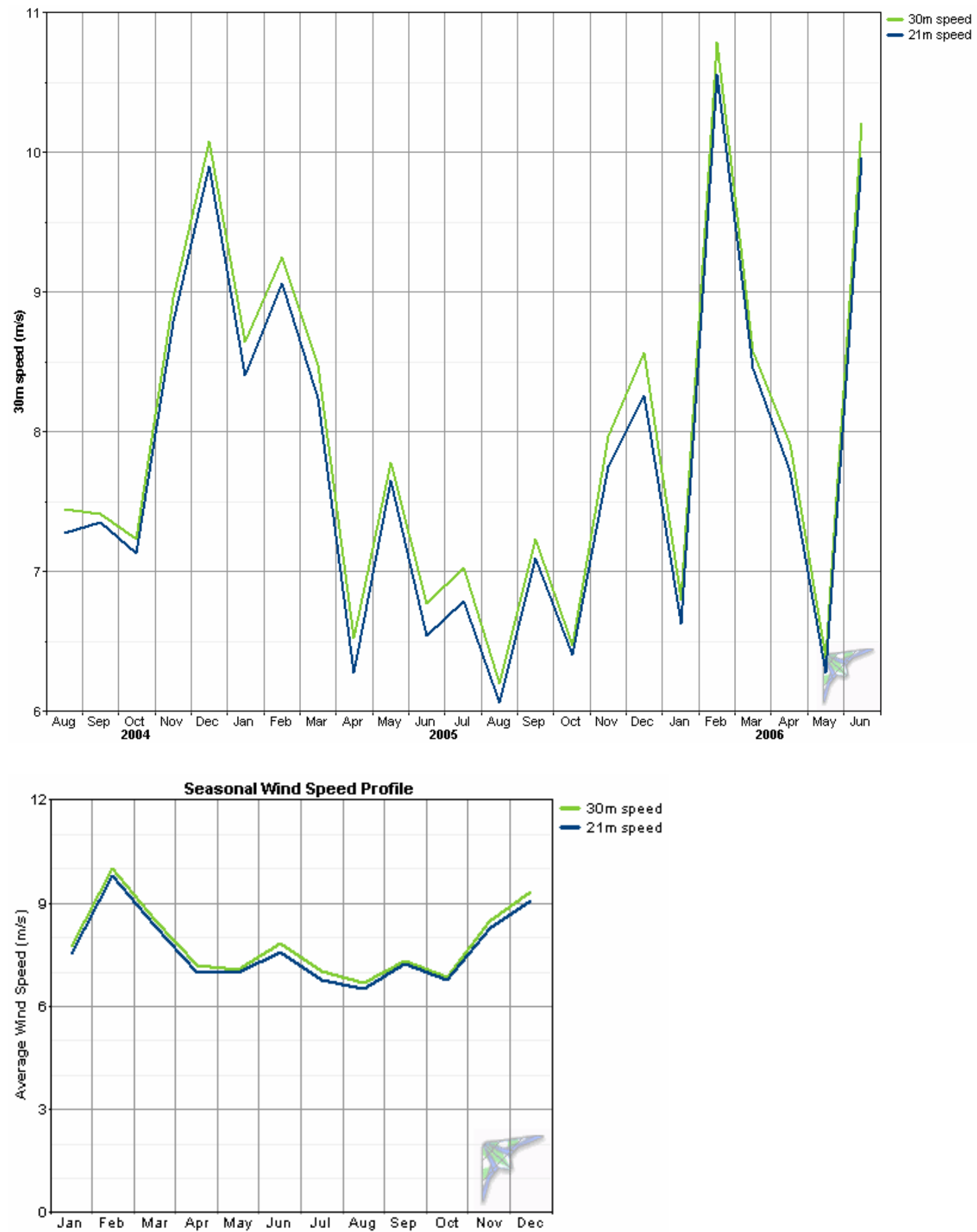


\section{Wind Shear Profile}

The power law exponent was calculated at 0.0656 indicating very low wind shear at the Kokhanok test site. The seasonal wind shear profile graph indicates that higher wind shear occurs in the summer months and lower wind shear in the winter months and that shear is lowest to the east and slightly higher to the southwest, although in all directions the wind shear is very low. The practical application of this data is that a low turbine tower height is possible as there will be only a marginal gain in wind speed/power recovery with additional height. A tower height/power recovery/construction cost tradeoff study is advisable.
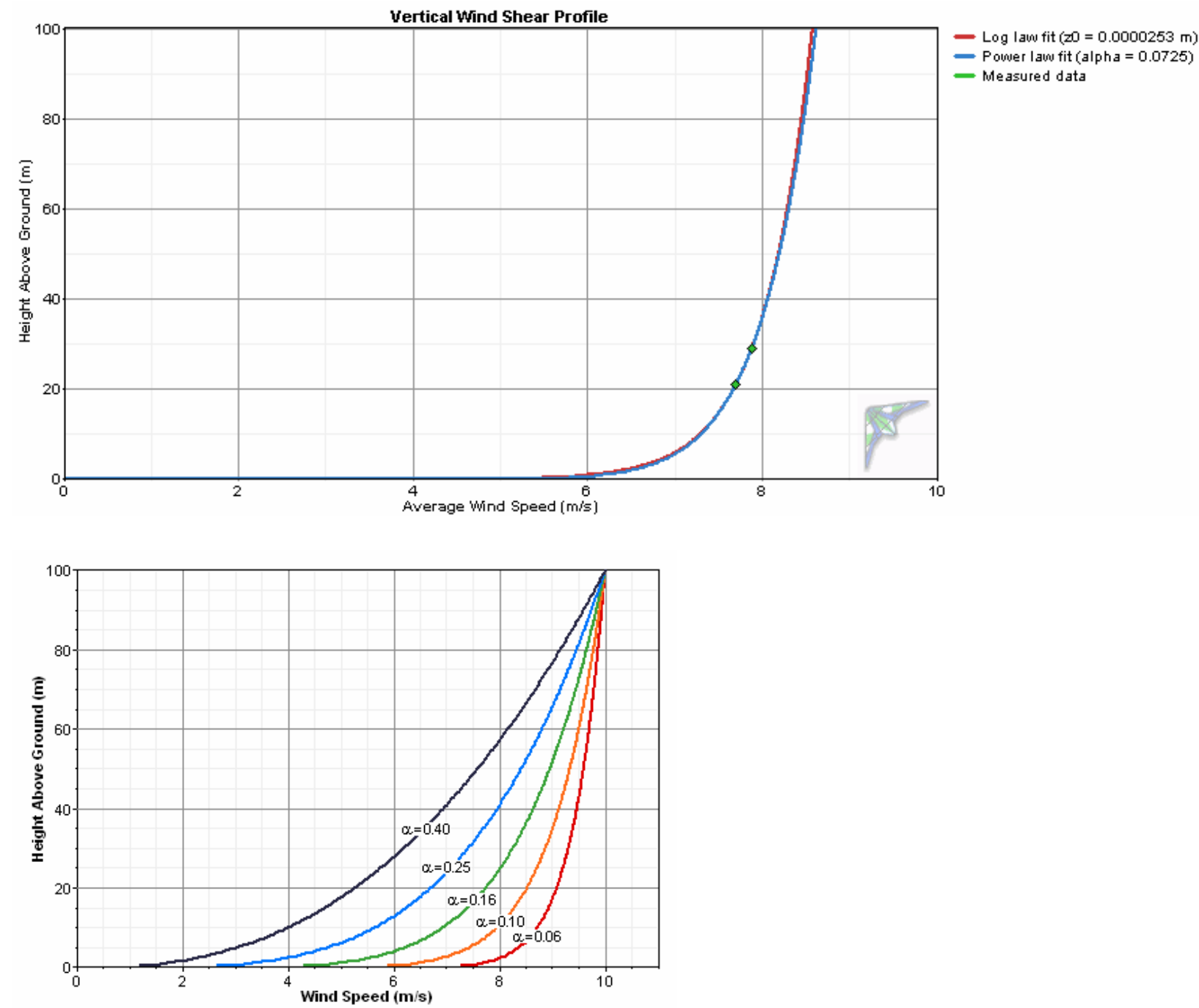
Kokhanok, Alaska Wind Resource Report
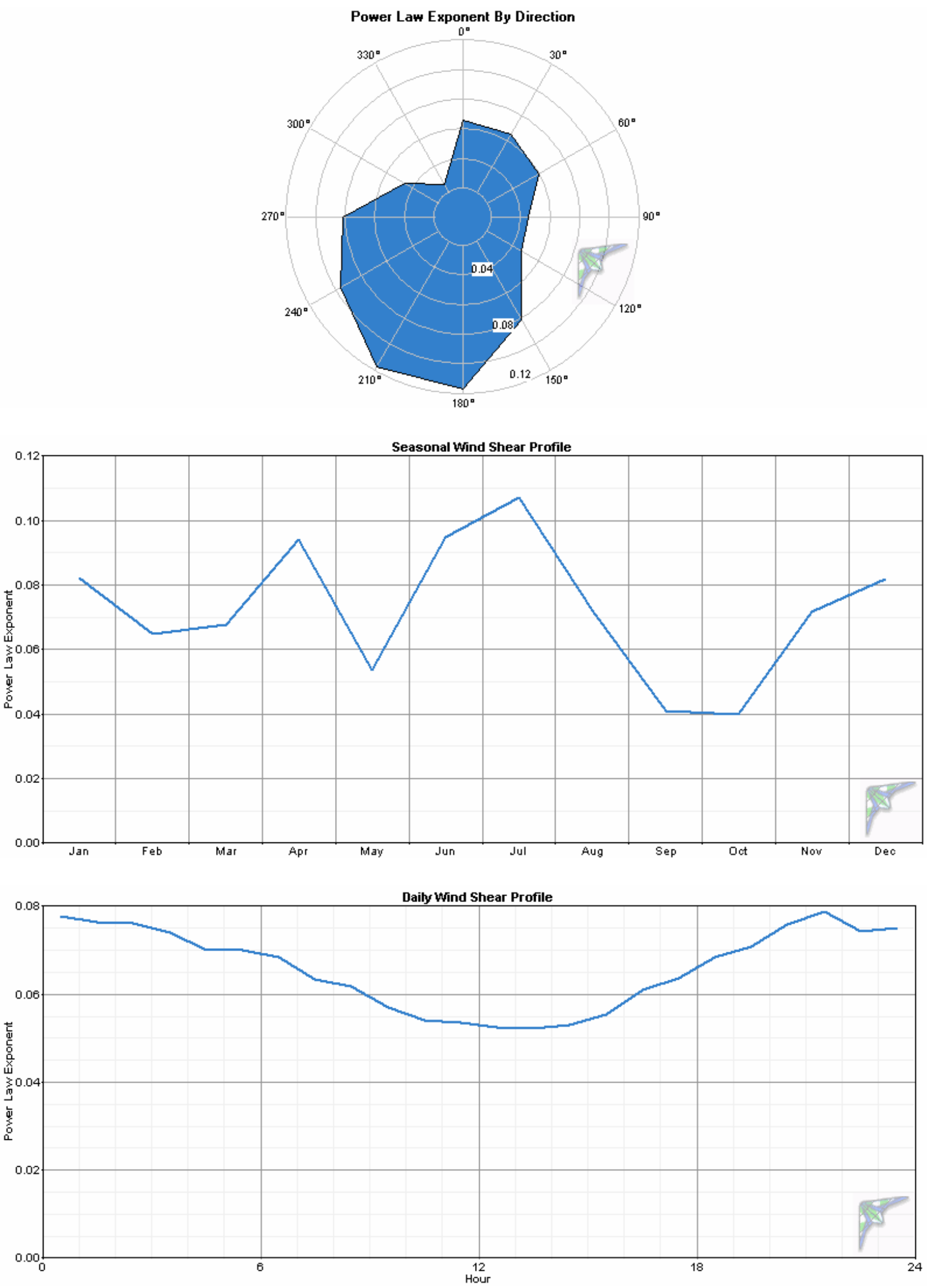


\section{Probability Distribution Function}

The probability distribution function provides a visual indication of measured wind speeds in one meter per second "bins". Note that most wind turbines do not begin to generate power until the wind speed at hub height reaches $4 \mathrm{~m} / \mathrm{s}$. The black line in the graph is a best fit Weibull distribution. Weibull parameters are $\mathrm{k}=1.64, \mathrm{c}=8.77 \mathrm{~m} / \mathrm{s}$. The PDF information is shown visually in another manner in the second graph, the Cumulative Distribution Function.
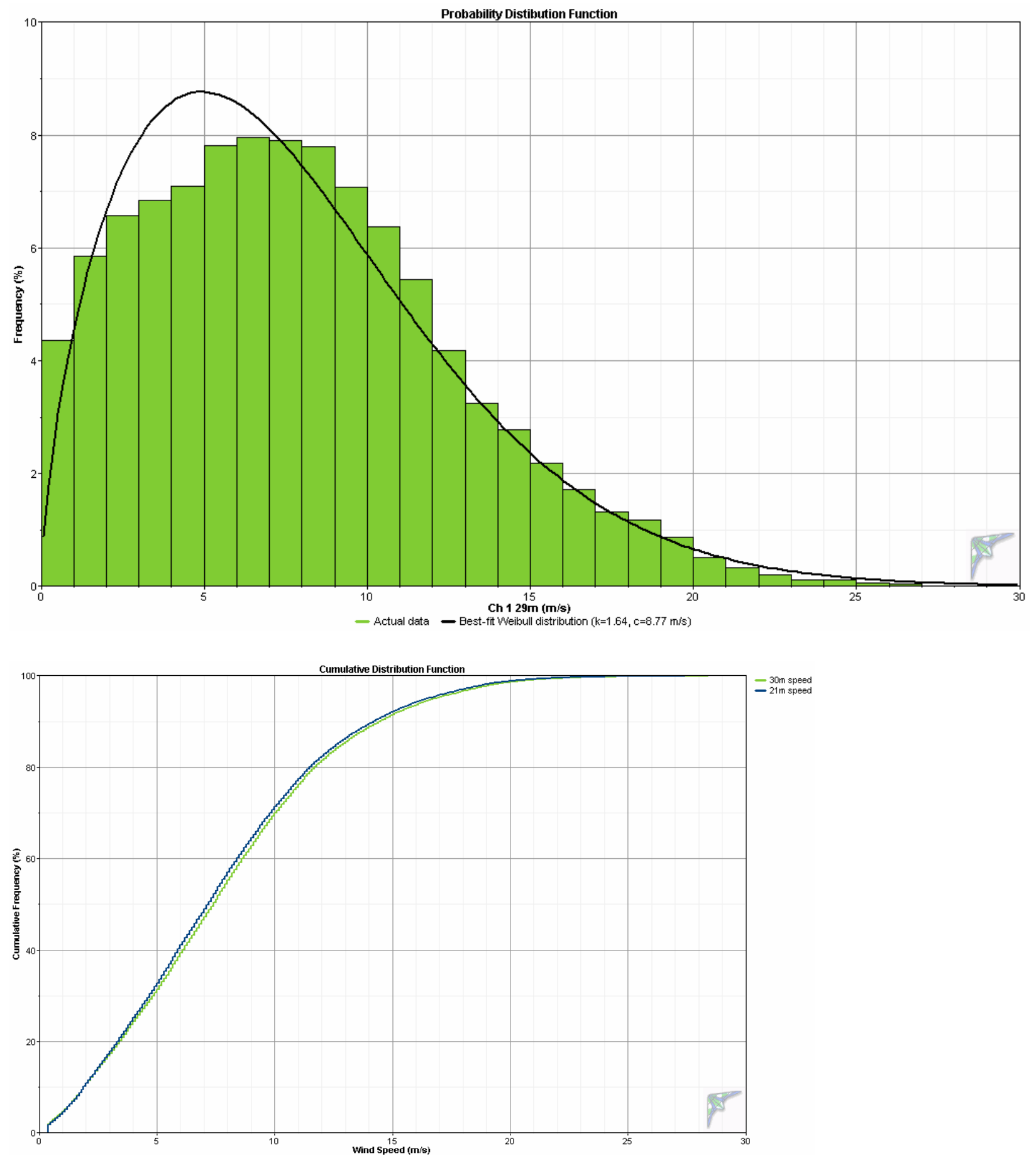


\section{Wind Roses}

Kokhanok winds are highly directional; the wind frequency rose indicates exclusively easterly and southwesterly winds. This observation is strongly reinforced with reference to the power density rose below. Power producing winds are almost entirely easterly. The practical application of this information is that the test site on the spit (the location of the Kokhanok's old airport) is ideal in that easterly winds travel a long fetch of water before traversing the site. If more than one turbine were to be placed in Kokhanok, they should be oriented north-south with a minimum 1.5 rotor diameter placement hub-to-hub. The indication below of 24 percent calm winds is calculated with a $4 \mathrm{~m} / \mathrm{s}$ wind speed threshold, the typical cut-in speed of wind turbines.

Wind Frequency Rose (30 meters)

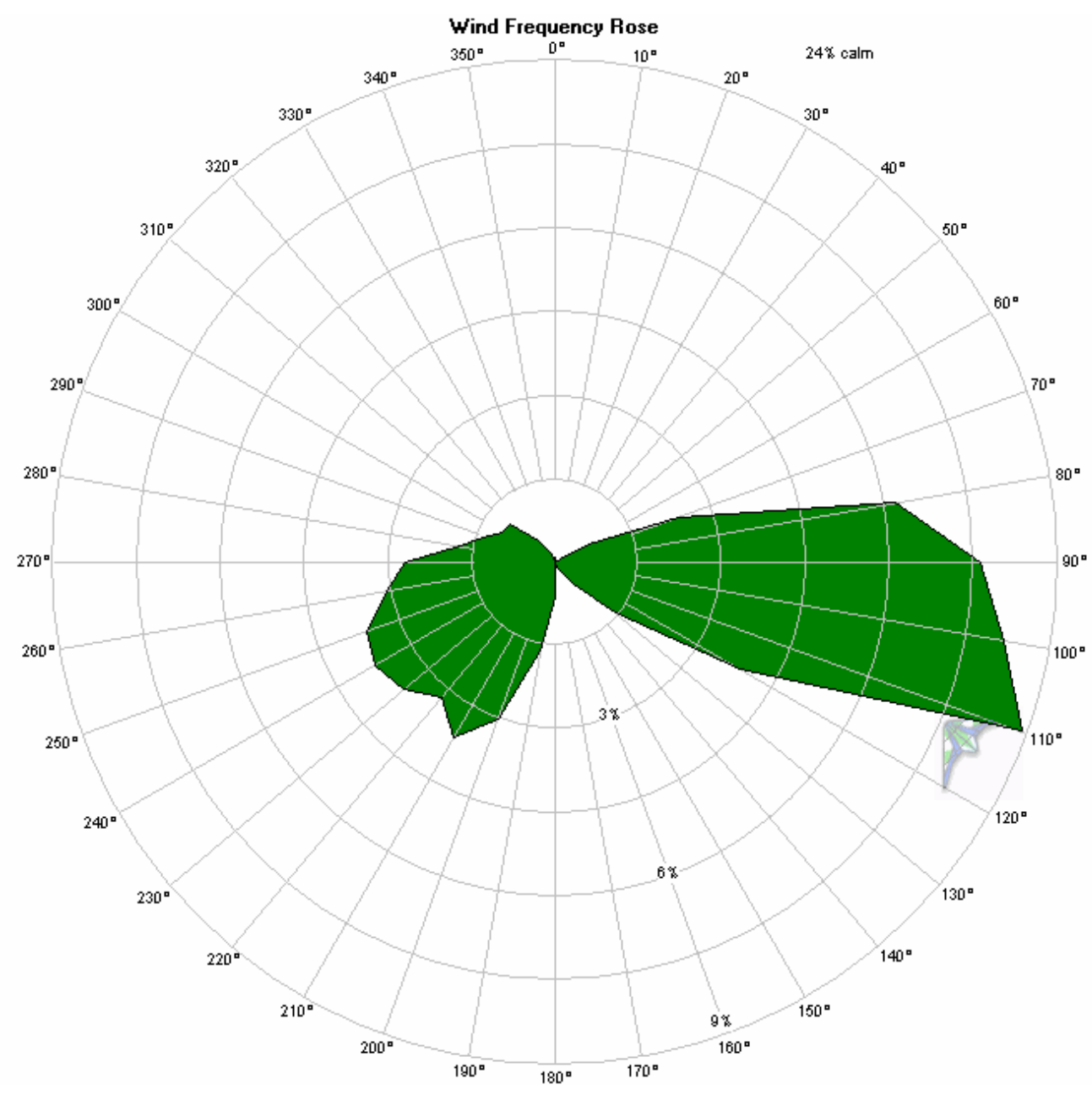


Kokhanok, Alaska Wind Resource Report

Wind Power Density Rose (30 meters)

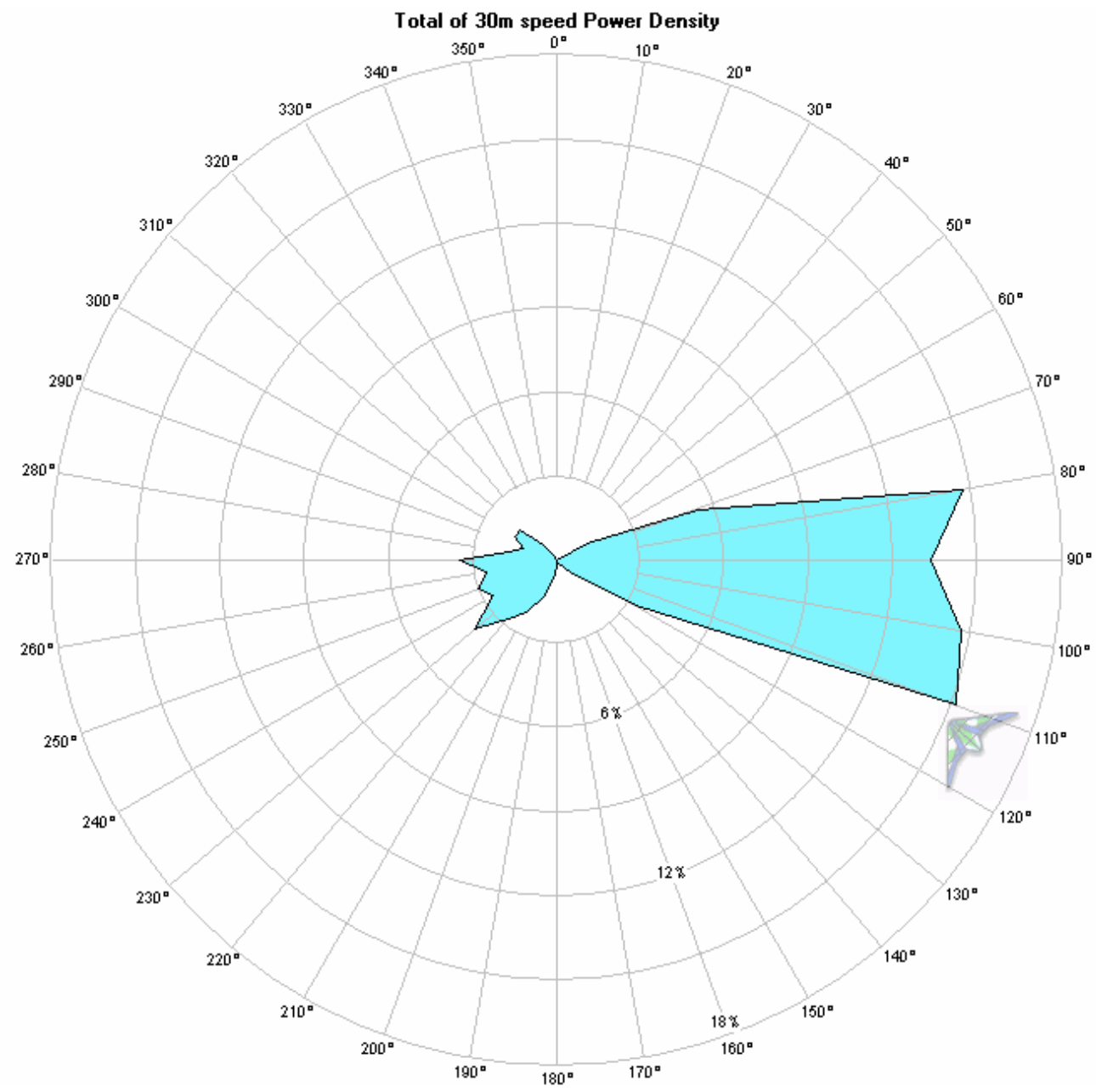

Wind Power Density Rose by Month (30 meters)

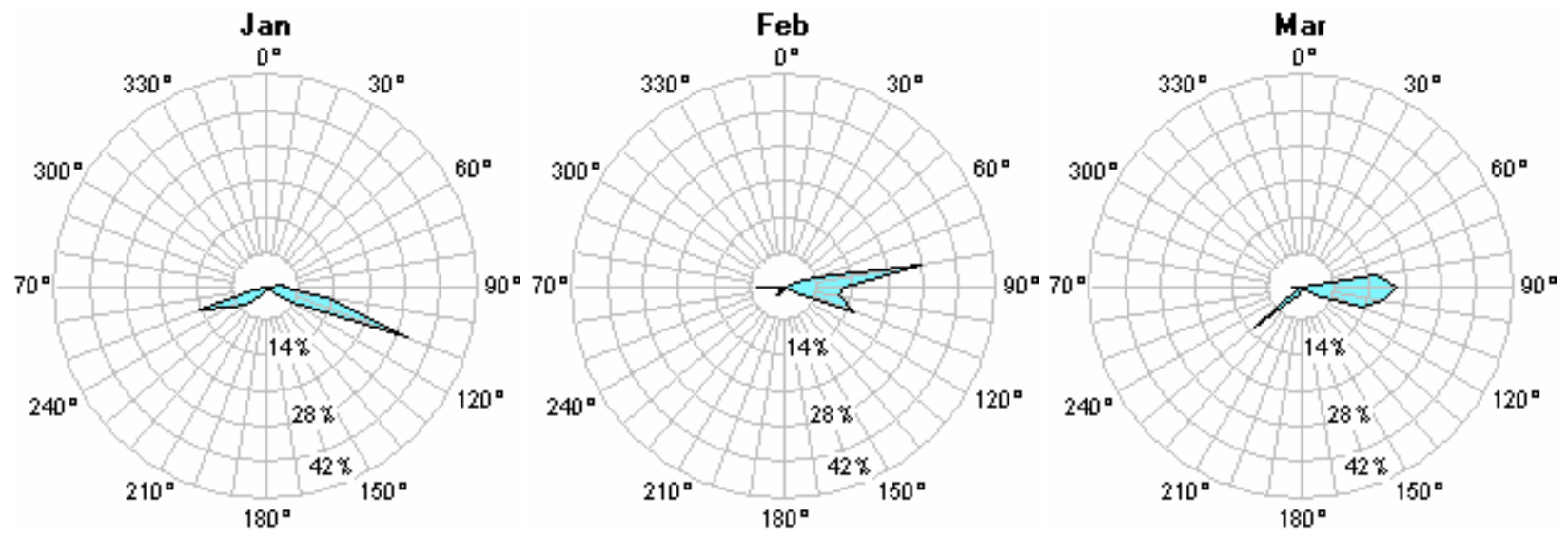


Kokhanok, Alaska Wind Resource Report
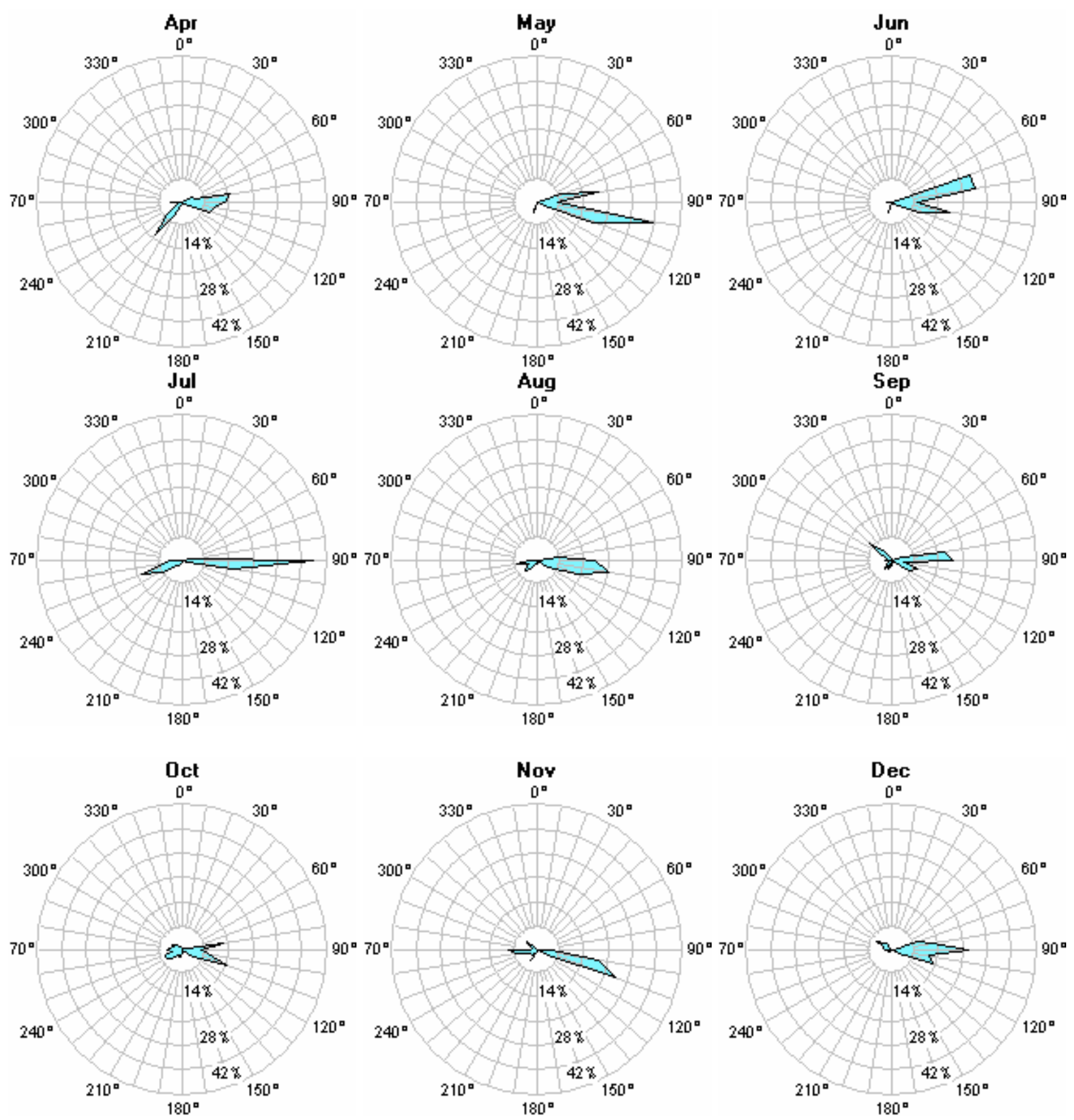


\section{Turbulence Intensity}

The turbulence intensity (TI) is quite acceptable for all wind direction, with a mean turbulence intensity of 0.0985 (30 meters) and 0.100 (20 meters), indicating very smooth air. These TIs are calculated with a threshold wind speed of $4 \mathrm{~m} / \mathrm{s}$. The spike of relatively high turbulence to the south and southeast in both graphs is due to the infrequent winds from these sectors. The most important TI is for winds from the east.

\section{0-meter Turbulence Intensity}

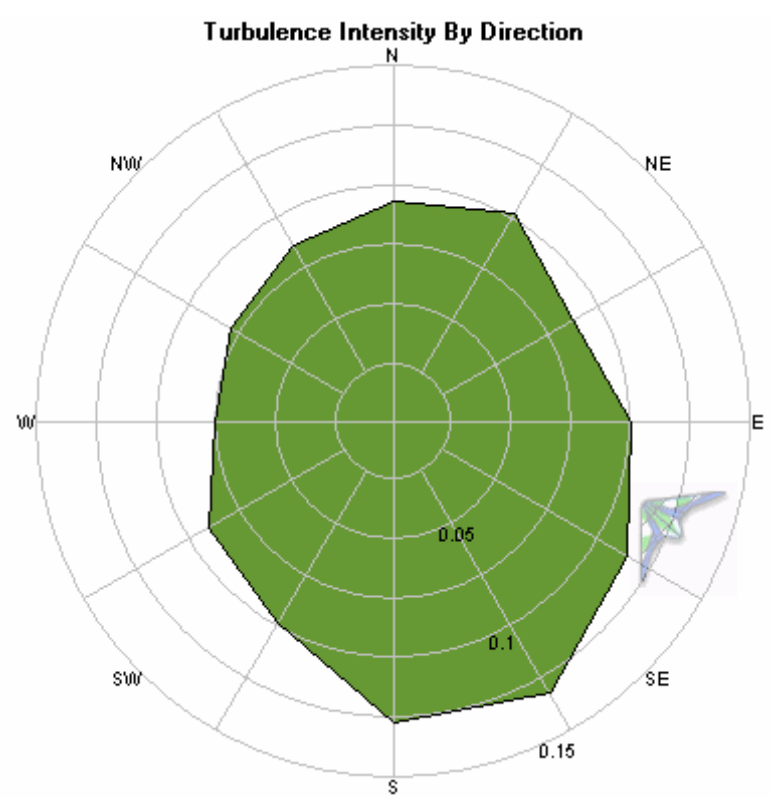

21-meter Turbulence Intensity

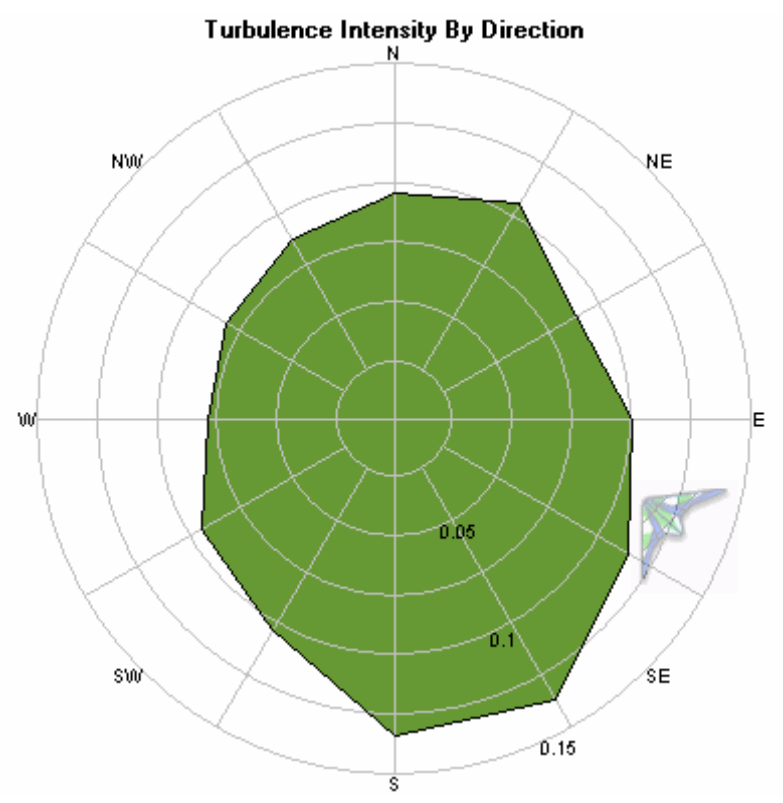


Kokhanok, Alaska Wind Resource Report

\section{IEC Turbulence Intensity Standards}

Turbulence at the Kokhanok project test site is well within International Electrotechnical Commission (IEC) standards at all measured wind speeds and from all four quadrants of the wind rose.
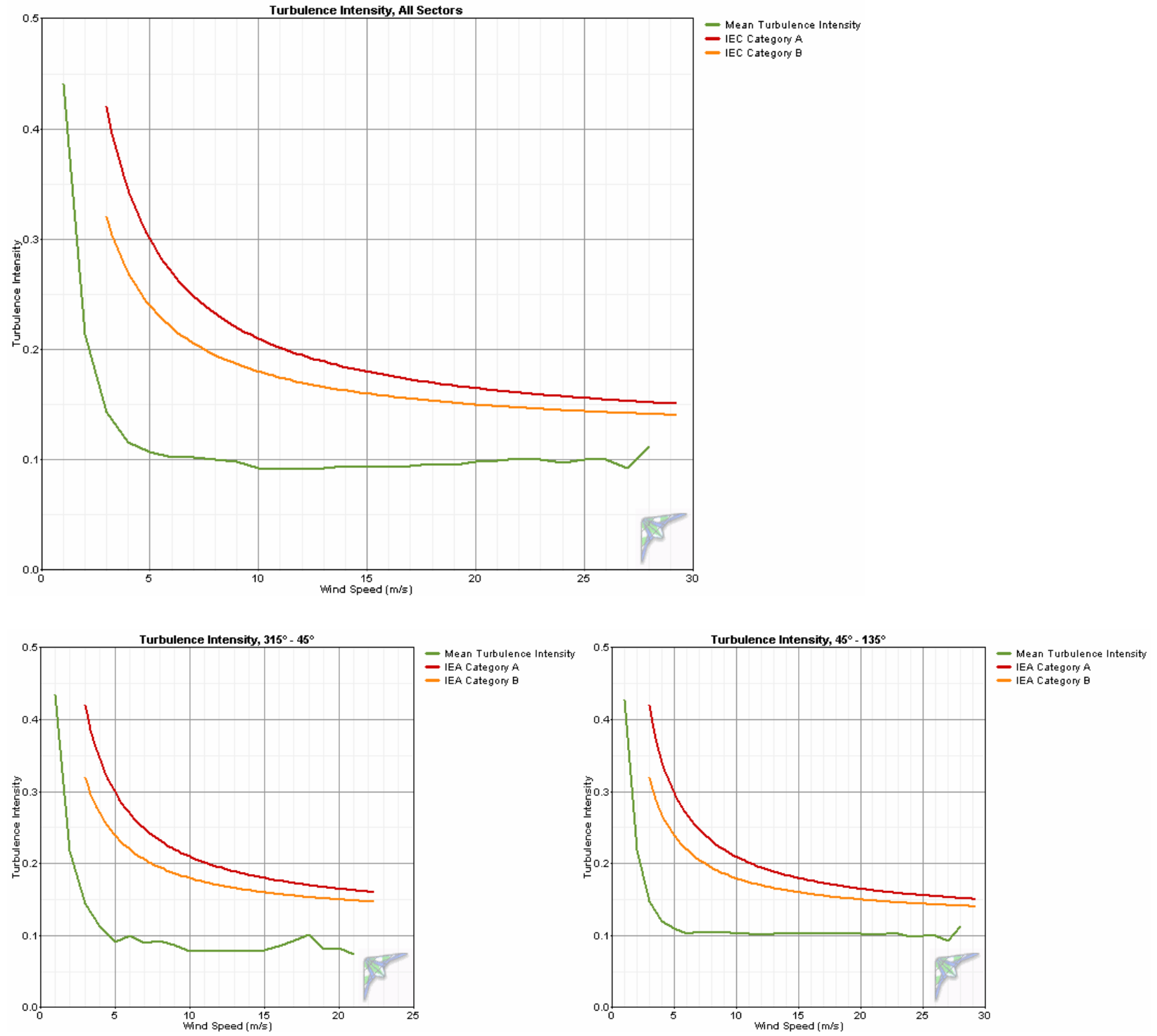
Kokhanok, Alaska Wind Resource Report
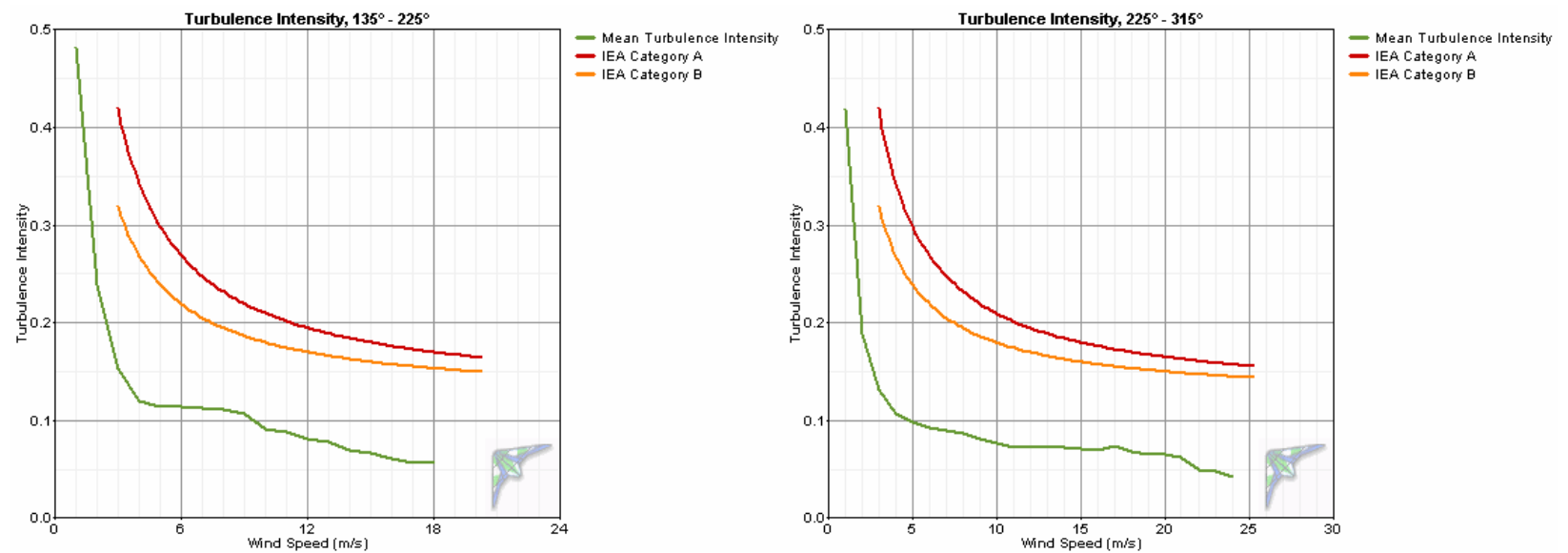

Turbulence Table

\begin{tabular}{|c|c|c|c|c|c|c|c|}
\hline \multirow{2}{*}{$\begin{array}{l}\text { Bin } \\
\text { Midpoint } \\
(\mathrm{m} / \mathrm{s})\end{array}$} & \multicolumn{2}{|c|}{ Bin Endpoints } & \multirow{2}{*}{$\begin{array}{l}\text { Records } \\
\text { In } \\
\text { Bin }\end{array}$} & \multirow{2}{*}{$\begin{array}{c}\text { Standard } \\
\text { Deviation } \\
\text { of Wind Speed } \\
(\mathrm{m} / \mathrm{s})\end{array}$} & \multirow{2}{*}{$\begin{array}{c}\text { Mean } \\
\text { Turbulence } \\
\text { Intensity } \\
\end{array}$} & \multirow{2}{*}{$\begin{array}{c}\text { Standard } \\
\text { Deviation } \\
\text { of Turbulence } \\
\text { Intensity }\end{array}$} & \multirow{2}{*}{$\begin{array}{c}\text { Characteristic } \\
\text { Turbulence } \\
\text { Intensity }\end{array}$} \\
\hline & $\begin{array}{c}\text { Lower } \\
(\mathrm{m} / \mathrm{s})\end{array}$ & $\begin{array}{c}\text { Upper } \\
(\mathrm{m} / \mathrm{s})\end{array}$ & & & & & \\
\hline 1 & 0.5 & 1.5 & 4729 & 0.400 & 0.441 & 0.180 & 0.620 \\
\hline 2 & 1.5 & 2.5 & 6175 & 0.409 & 0.214 & 0.121 & 0.335 \\
\hline 3 & 2.5 & 3.5 & 6396 & 0.421 & 0.144 & 0.079 & 0.222 \\
\hline 4 & 3.5 & 4.5 & 6665 & 0.456 & 0.116 & 0.059 & 0.174 \\
\hline 5 & 4.5 & 5.5 & 7029 & 0.529 & 0.107 & 0.047 & 0.154 \\
\hline 6 & 5.5 & 6.5 & 7605 & 0.607 & 0.102 & 0.041 & 0.144 \\
\hline 7 & 6.5 & 7.5 & 7526 & 0.707 & 0.102 & 0.038 & 0.140 \\
\hline 8 & 7.5 & 8.5 & 7705 & 0.798 & 0.100 & 0.035 & 0.136 \\
\hline 9 & 8.5 & 9.5 & 7016 & 0.875 & 0.098 & 0.035 & 0.133 \\
\hline 10 & 9.5 & 10.5 & 6397 & 0.922 & 0.093 & 0.035 & 0.127 \\
\hline 11 & 10.5 & 11.5 & 5770 & 1.005 & 0.092 & 0.031 & 0.123 \\
\hline 12 & 11.5 & 12.5 & 4517 & 1.096 & 0.092 & 0.030 & 0.121 \\
\hline 13 & 12.5 & 13.5 & 3511 & 1.200 & 0.093 & 0.028 & 0.121 \\
\hline 14 & 13.5 & 14.5 & 2814 & 1.317 & 0.094 & 0.026 & 0.120 \\
\hline 15 & 14.5 & 15.5 & 2410 & 1.394 & 0.093 & 0.026 & 0.119 \\
\hline 16 & 15.5 & 16.5 & 1882 & 1.489 & 0.093 & 0.025 & 0.119 \\
\hline 17 & 16.5 & 17.5 & 1380 & 1.604 & 0.095 & 0.025 & 0.120 \\
\hline 18 & 17.5 & 18.5 & 1231 & 1.726 & 0.096 & 0.025 & 0.121 \\
\hline 19 & 18.5 & 19.5 & 954 & 1.811 & 0.096 & 0.024 & 0.119 \\
\hline 20 & 19.5 & 20.5 & 638 & 1.945 & 0.098 & 0.023 & 0.121 \\
\hline 21 & 20.5 & 21.5 & 404 & 2.066 & 0.099 & 0.021 & 0.120 \\
\hline 22 & 21.5 & 22.5 & 261 & 2.212 & 0.101 & 0.023 & 0.124 \\
\hline 23 & 22.5 & 23.5 & 167 & 2.303 & 0.101 & 0.021 & 0.122 \\
\hline 24 & 23.5 & 24.5 & 90 & 2.326 & 0.097 & 0.020 & 0.117 \\
\hline 25 & 24.5 & 25.5 & 96 & 2.484 & 0.100 & 0.022 & 0.122 \\
\hline 26 & 25.5 & 26.5 & 55 & 2.598 & 0.100 & 0.022 & 0.122 \\
\hline 27 & 26.5 & 27.5 & 28 & 2.500 & 0.093 & 0.014 & 0.107 \\
\hline 28 & 27.5 & 28.5 & 2 & 3.150 & 0.112 & 0.020 & 0.133 \\
\hline 29 & 28.5 & 29.5 & 0 & 3.150 & 0.112 & 0.020 & 0.133 \\
\hline
\end{tabular}




\section{Air Temperature and Density}

Over the reporting period, Kokhanok had an average temperature of $4.5^{\circ} \mathrm{C}$. The minimum recorded temperature during the measurement period was $-23.9^{\circ} \mathrm{C}$ and the maximum temperature was $25.5^{\circ} \mathrm{C}$, indicating a wide variability of an ambient temperature operating environment important to wind turbine operations. Consequent to Kokhanok's cool temperatures, the average air density of $1.268 \mathrm{~kg} / \mathrm{m}^{3}$ is approximately four percent higher than the standard air density of $1.2223 \mathrm{~kg} / \mathrm{m}^{3}$ (14.8 ${ }^{\circ} \mathrm{C}$ and $101.02 \mathrm{kPa}$ at $23 \mathrm{~m}$ elevation), indicating that Kokhanok, due to its cool annual temperature average and low elevation, has denser air than the standard air density used to calculate turbine power curves. This density variance from standard is accounted for in turbine performance predictions in this report.

\begin{tabular}{ccrrrrrrr}
\multicolumn{7}{c}{ Temperature } \\
Month & \multicolumn{1}{c}{$\begin{array}{c}\text { Mean } \\
\left({ }^{\circ} \mathrm{C}\right)\end{array}$} & \multicolumn{1}{c}{$\begin{array}{c}\text { Min } \\
\left({ }^{\circ} \mathrm{C}\right)\end{array}$} & $\begin{array}{c}\text { Max } \\
\left({ }^{\circ} \mathrm{C}\right)\end{array}$ & $\begin{array}{l}\text { Sev. } \\
\left({ }^{\circ} \mathrm{C}\right)\end{array}$ & $\begin{array}{c}\text { Mean } \\
\left(\mathrm{kg} / \mathrm{m}^{3}\right)\end{array}$ & $\begin{array}{l}\text { Min } \\
\left(\mathrm{kg} / \mathrm{m}^{3}\right)\end{array}$ & $\begin{array}{l}\text { Max } \\
\left(\mathrm{kg} / \mathrm{m}^{3}\right)\end{array}$ & $\begin{array}{l}\text { Std. Dev. } \\
\left(\mathrm{kg} / \mathrm{m}^{3}\right)\end{array}$ \\
\hline Jan & -5.78 & -22.3 & 5.7 & 7.81 & 1.317 & 1.262 & 1.403 & 0.0393 \\
Feb & -3.47 & -23.9 & 10.2 & 7.33 & 1.306 & 1.242 & 1.412 & 0.0366 \\
Mar & -1.66 & -15.1 & 7.3 & 5.02 & 1.297 & 1.255 & 1.364 & 0.0243 \\
Apr & 1.89 & -15.8 & 16.6 & 4.93 & 1.280 & 1.215 & 1.367 & 0.0233 \\
May & 8.59 & 0.5 & 21.6 & 2.89 & 1.249 & 1.194 & 1.286 & 0.0127 \\
Jun & 12.34 & 3.9 & 24.6 & 2.76 & 1.233 & 1.182 & 1.270 & 0.0119 \\
Jul & 14.42 & 10.2 & 20.7 & 1.83 & 1.224 & 1.198 & 1.242 & 0.0078 \\
Aug & 14.67 & 7.2 & 25.5 & 2.58 & 1.223 & 1.178 & 1.255 & 0.0109 \\
Sep & 9.89 & 0.4 & 16.7 & 2.83 & 1.243 & 1.214 & 1.286 & 0.0125 \\
Oct & 6.10 & -6.9 & 12.3 & 3.45 & 1.260 & 1.233 & 1.322 & 0.0158 \\
Nov & -2.21 & -18.4 & 8.3 & 5.99 & 1.299 & 1.250 & 1.381 & 0.0291 \\
Dec & -0.68 & -19.4 & 7.9 & 5.50 & 1.292 & 1.252 & 1.387 & 0.0269 \\
\hline Annual & 4.51 & -23.9 & 25.5 & 8.38 & 1.268 & 1.178 & 1.412 & 0.0394
\end{tabular}

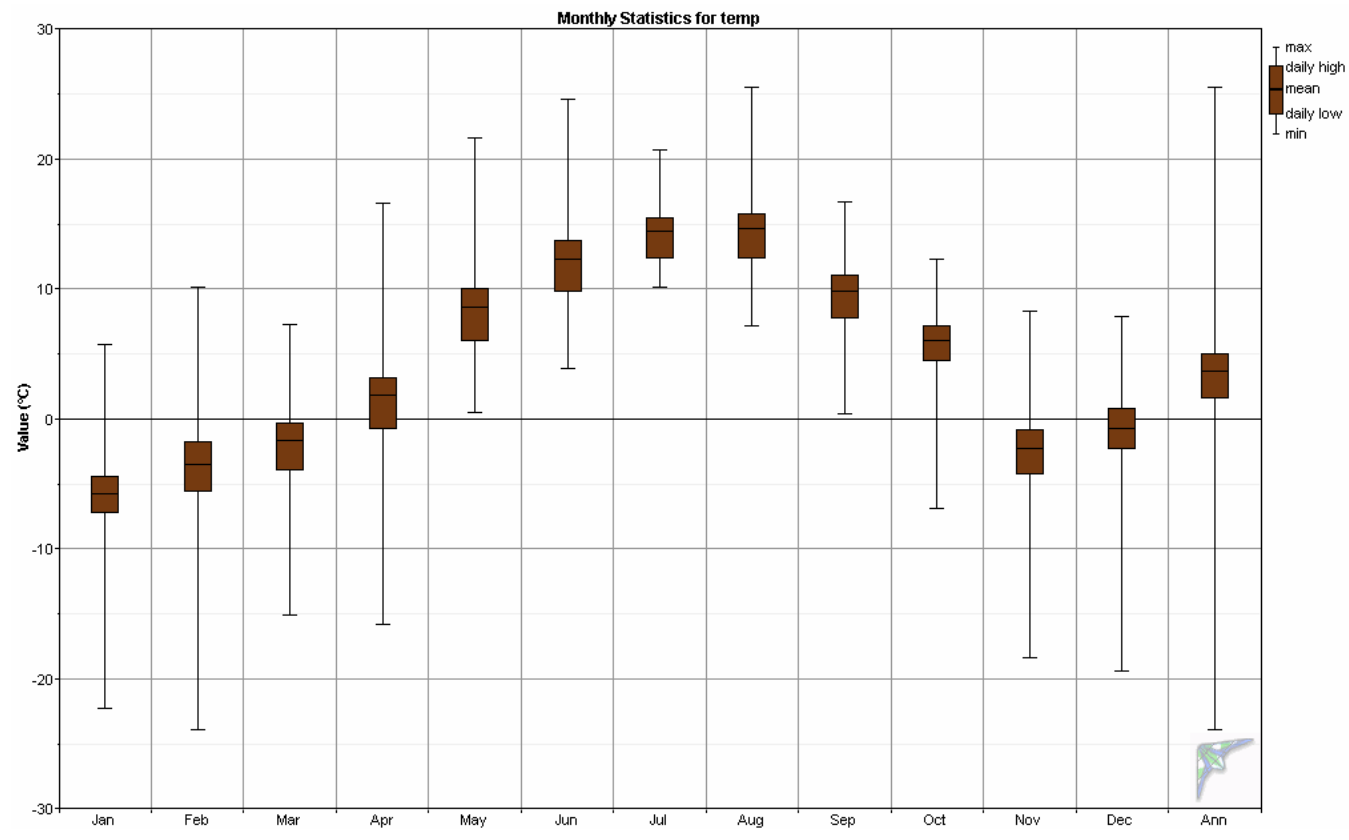




\section{Air Density DMap}

The DMap below is a visual indication of the daily and seasonal variations of air density (and hence temperature). Air densities higher than standard will yield higher turbine power than predicted by turbine power curves, while densities lower than standard will yield lower turbine power than predicted. Density variance from standard is accounted for in the turbine performance predictions.

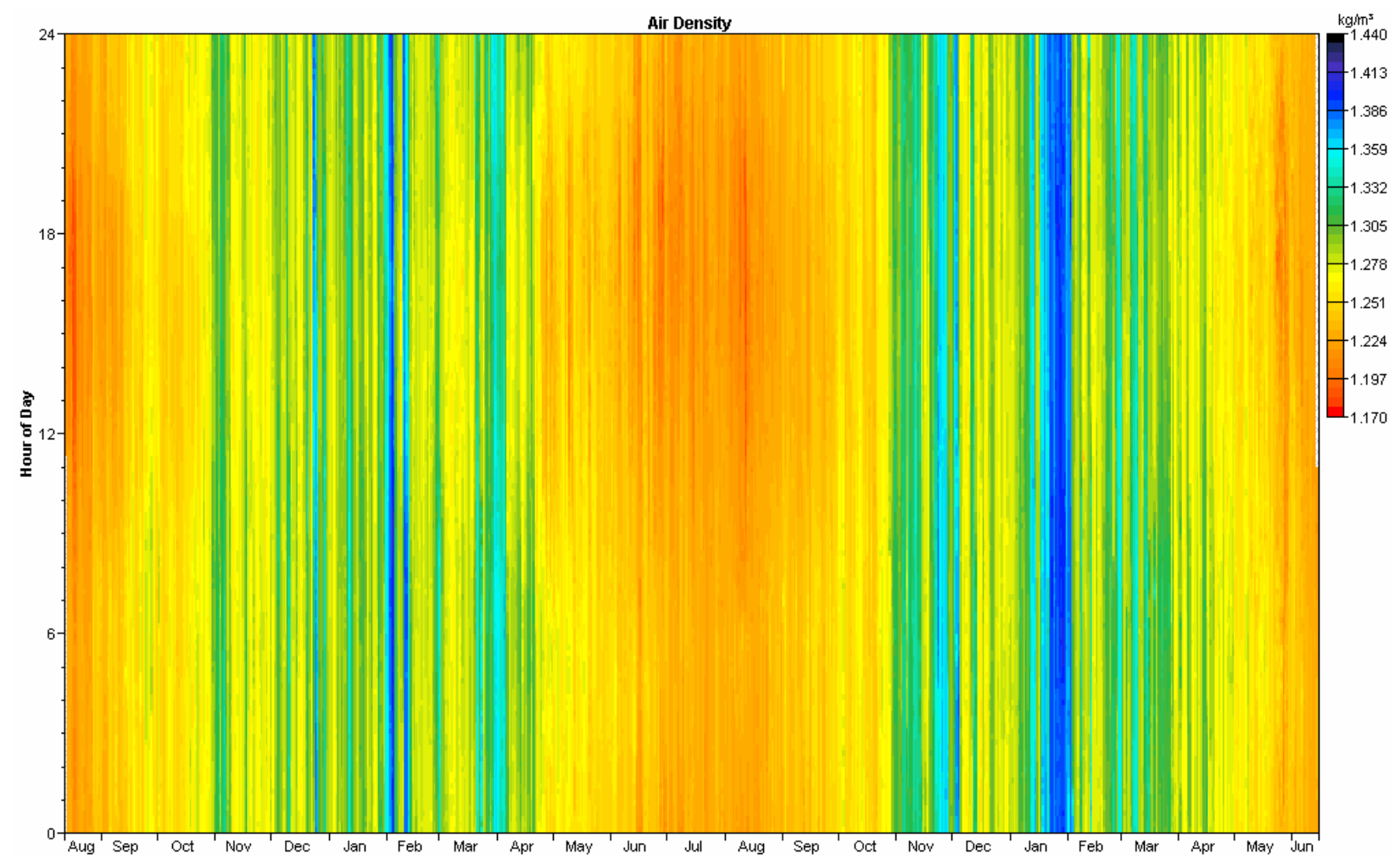




\section{Wind Turbine Performance}

The turbine performance predictions noted below are based on 100 percent and 90 percent turbine availabilities. The 100 percent data is for use as a baseline of comparison, but it is realistic to expect ten percent or more of losses or downtime for wind turbines located in a small, remote community.

Note that these performance estimates were predicted with use of Windographer ${ }^{\circledR}$ wind analysis software; power curves provided by manufacturers are not independently verified and are assumed to be accurate. The power curves are presented for a standard air density of $1.225 \mathrm{~kg} / \mathrm{m}^{3}$ at $15^{\circ} \mathrm{C}$ temperature and $101.3 \mathrm{kPa}$ pressure at sea level. However, the predictions of power production are density compensated by multiplying the standard density power output by the ratio of the measured air density to standard air density, accounting for the site elevation.

A number of smaller village-scale grid-connected turbines are profiled in this report for comparison purposes. These turbines were selected because they have market availability and they are deemed to be within a suitable range for consideration of wind power development in a village the size of Kokhanok.

Southwest Skystream 3.7: $1.8 \mathrm{~kW}$ rated power output, 3.7 meter rotor diameter, stallcontrolled. Available tower heights: 10.7 and 33.5 meters. Additional information is available at www.skystreamenergy.com.

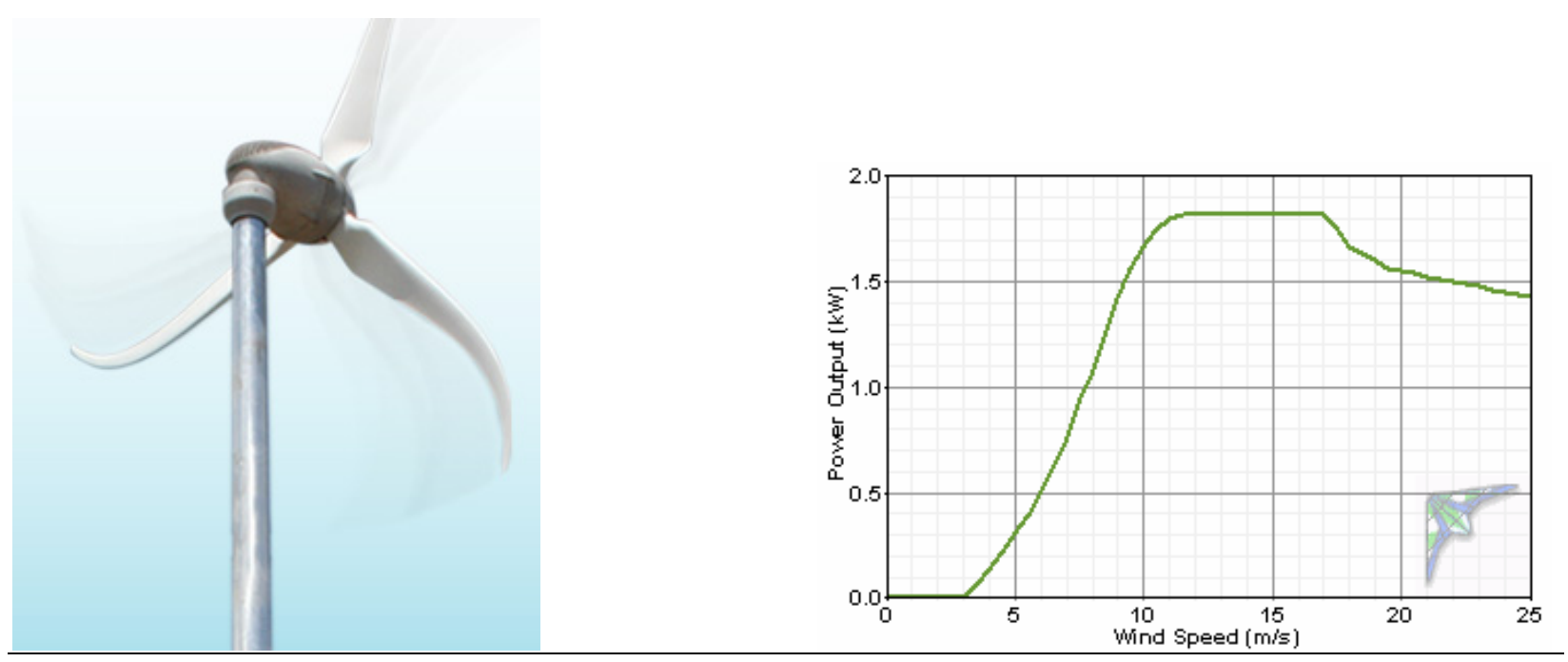

Bergey Excel-S: $10 \mathrm{~kW}$ rated power output, 6.7 meter rotor diameter, stall-controlled. Available tower heights: 18, 24, 30, 37 and 43 meters. Additional information is available at www.bergey.com. 

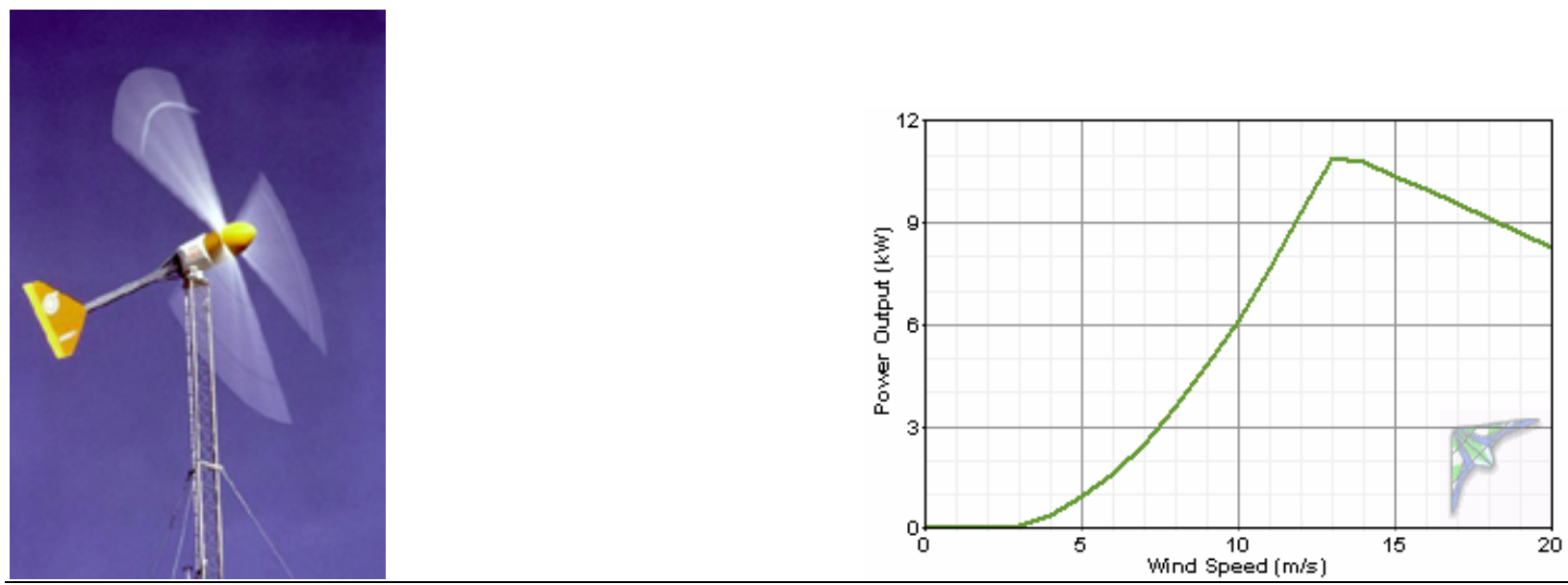

Fuhrländer FL30: $30 \mathrm{~kW}$ rated power output, 13 meter rotor, stall-controlled (power curve provided by Lorax Energy, LLC). Available tower heights: 26 and 30 meters. Additional information is available at http://www.fuhrlaender.de/ and http://www.lorax-energy.com/.
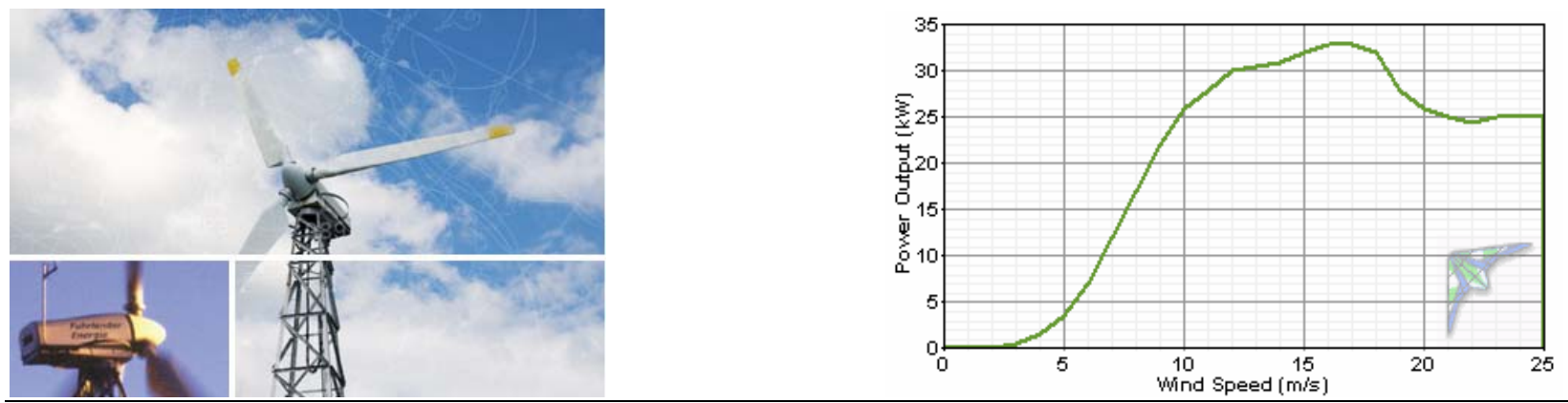

Entegrity eW-15: $65 \mathrm{~kW}$ rated power output, 15 meter rotor, stall-controlled (power curve provided by Entegrity Energy Systems). Available tower heights: 25 and 31 meters. Additional information is available at http://www.entegritywind.com/.
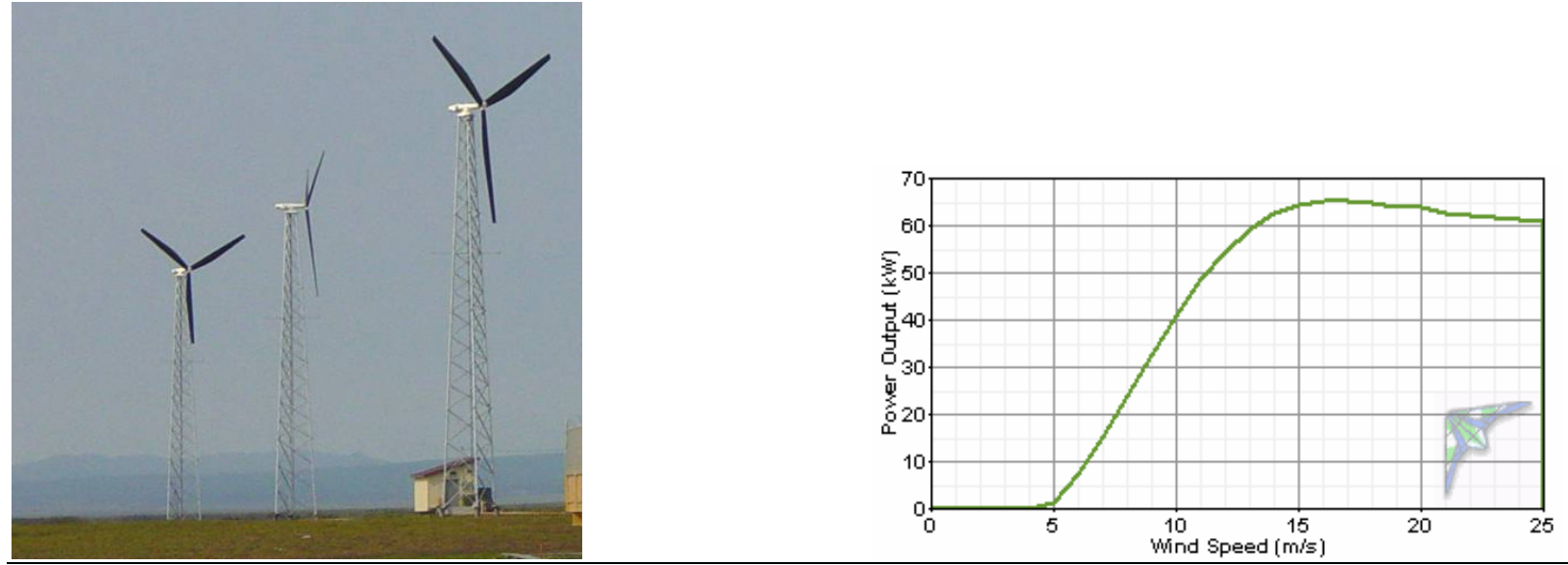
Vestas V15: $75 \mathrm{~kW}$ rated power output, 15 meter rotor, stall-controlled (power curve provided by Powercorp Alaska LLC). Available tower heights: 25, 31 and 34 meters. Additional information is available at http://www.pcorpalaska.com/.
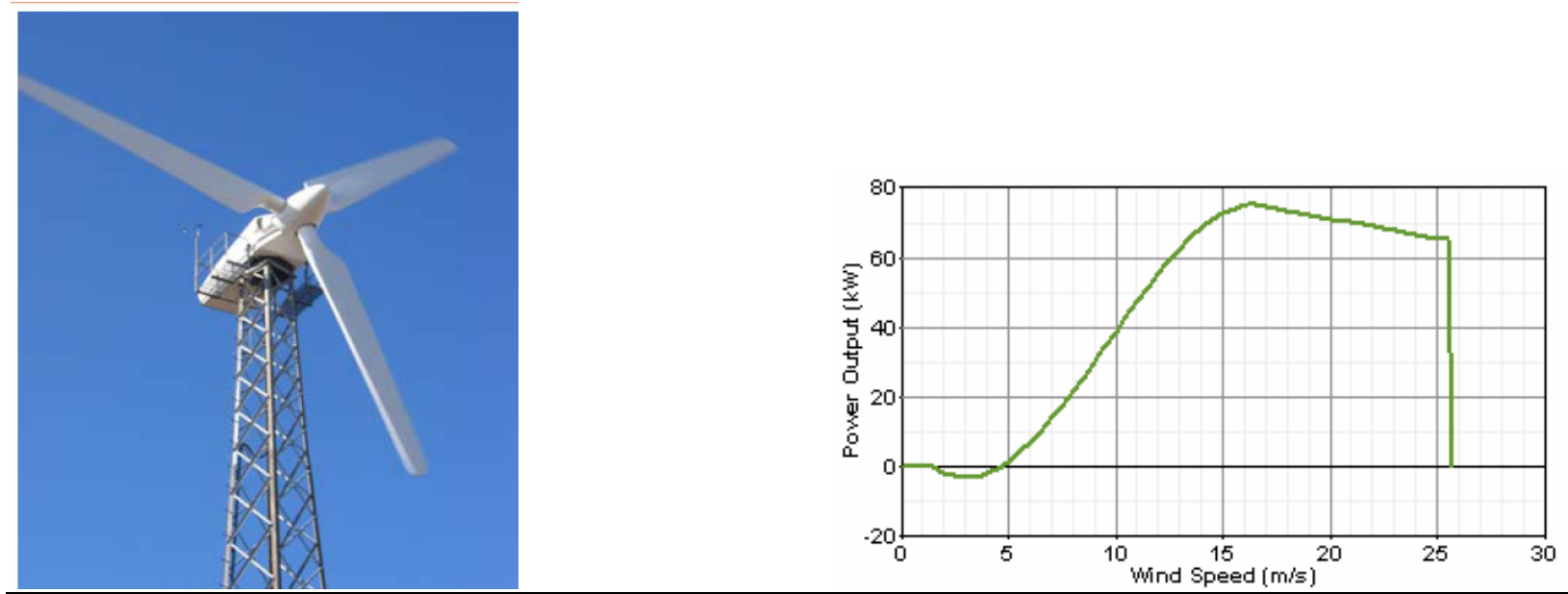

Northwind 100/20: $100 \mathrm{~kW}$ rated power output, 20 meter rotor (19 meter rotor blades with 0.6 meter blade root extensions added), stall-controlled (power curve provided by Northern Power Systems). Available tower heights: 25 and 32 meters. Additional information is available at http://www.northernpower.com/.
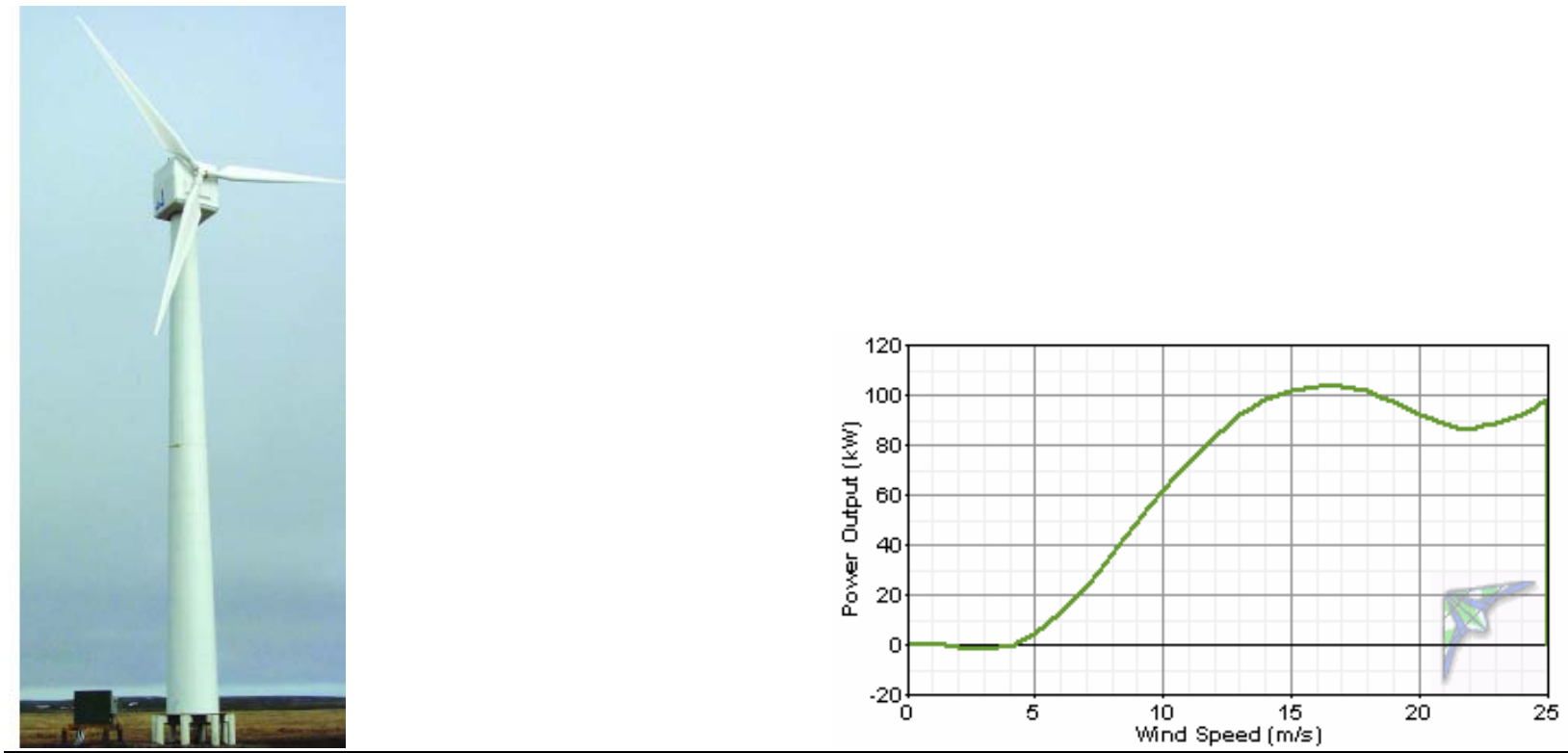
Kokhanok, Alaska Wind Resource Report

Turbine Power Output Comparison (100\% availability)

\begin{tabular}{|c|c|c|c|c|c|c|c|}
\hline Turbine & $\begin{array}{l}\text { Hub } \\
\text { Height } \\
(\mathrm{m})\end{array}$ & $\begin{array}{c}\text { Hub Height } \\
\text { Wind Speed } \\
(\mathrm{m} / \mathrm{s})\end{array}$ & $\begin{array}{c}\text { Time At } \\
\text { Zero Output } \\
(\%) \\
\end{array}$ & $\begin{array}{c}\text { Time At } \\
\text { Rated Output } \\
(\%)\end{array}$ & $\begin{array}{c}\text { Average Net } \\
\text { Power Output } \\
(\mathrm{kW})\end{array}$ & $\begin{array}{c}\text { Annual Net } \\
\text { Energy } \\
\text { Output } \\
\text { (kWh/yr) }\end{array}$ & $\begin{array}{l}\text { Average Net } \\
\text { Capacity } \\
\text { Factor } \\
(\%)\end{array}$ \\
\hline Southwest Skystream 3.7 & 10.7 & 7.37 & 18.8 & 20.9 & 0.88 & 7,711 & 48.9 \\
\hline Southwest Skystream 3.7 & 33.5 & 7.92 & 17.6 & 23.6 & 0.96 & 8,422 & 53.4 \\
\hline Bergey Excel-S & 18 & 7.63 & 11.5 & 10.1 & 3.81 & 33,376 & 38.1 \\
\hline Bergey Excel-S & 30 & 7.86 & 12.4 & 10.5 & 3.96 & 34,702 & 39.6 \\
\hline Fuhrländer FL30 & 26 & 7.80 & 10.9 & 6.8 & 15.1 & 132,559 & 45.9 \\
\hline Fuhrländer FL30 & 30 & 7.86 & 11.2 & 7.0 & 15.3 & 134,061 & 46.4 \\
\hline Entegrity eW-15 $60 \mathrm{~Hz}$ & 25 & 7.78 & 24.6 & 10.3 & 25.3 & 221,978 & 39.0 \\
\hline Entegrity eW-15 $60 \mathrm{~Hz}$ & 31 & 7.88 & 24.3 & 10.6 & 25.9 & 226,844 & 39.8 \\
\hline Vestas V15 & 25 & 7.78 & 28.7 & 6.8 & 25.3 & 221,585 & 33.7 \\
\hline Vestas V15 & 31 & 7.88 & 28.2 & 7.0 & 25.9 & 226,996 & 34.6 \\
\hline Northern Power NW 100/20 & 25 & 7.78 & 24.6 & 9.2 & 37.4 & 327,963 & 37.4 \\
\hline Northern Power NW 100/20 & 32 & 7.90 & 24.3 & 9.4 & 38.4 & 336,193 & 38.4 \\
\hline \multicolumn{8}{|l|}{ Capacity Factor $<20 \%$} \\
\hline \multicolumn{8}{|l|}{ Capacity Factor $>20 \%,<30 \%$} \\
\hline \multicolumn{8}{|l|}{ Capacity Factor $>30 \%,<40 \%$} \\
\hline \multicolumn{8}{|l|}{ Capacity Factor $>40 \%,<50 \%$} \\
\hline Capacity Factor $>50 \%$ & & & & & & & \\
\hline
\end{tabular}

Assumed turbine losses for predictions of average power output, annual energy output, and average capacity factor:

$\begin{array}{ll}\text { Downtime (\%) } & 0 \\ \text { Array (\%) } & 0 \\ \text { Icing/soiling (\%) } & 0 \\ \text { Other (\%) } & 0 \\ \text { Total (\%) } & 0\end{array}$

Note: Calculated for the data period 8/12/04 to 6/14/06 
Kokhanok, Alaska Wind Resource Report

Turbine Power Output Comparison (90\% availability)

\begin{tabular}{|c|c|c|c|c|c|c|c|}
\hline Turbine & $\begin{array}{l}\text { Hub } \\
\text { Height } \\
(\mathrm{m})\end{array}$ & $\begin{array}{c}\text { Hub Height } \\
\text { Wind Speed } \\
(\mathrm{m} / \mathrm{s})\end{array}$ & $\begin{array}{c}\text { Time At } \\
\text { Zero Output } \\
(\%)\end{array}$ & $\begin{array}{c}\text { Time At } \\
\text { Rated Output } \\
(\%)\end{array}$ & $\begin{array}{c}\text { Average Net } \\
\text { Power Output } \\
(\mathrm{kW})\end{array}$ & $\begin{array}{c}\text { Annual Net } \\
\text { Energy } \\
\text { Output } \\
\text { (kWh/yr) }\end{array}$ & $\begin{array}{l}\text { Average Net } \\
\text { Capacity } \\
\text { Factor } \\
(\%)\end{array}$ \\
\hline Southwest Skystream 3.7 & 10.7 & 7.37 & 18.8 & 20.9 & 0.80 & 6,963 & 44.2 \\
\hline Southwest Skystream 3.7 & 33.5 & 7.92 & 17.6 & 23.6 & 0.87 & 7,606 & 48.2 \\
\hline Bergey Excel-S & 18 & 7.63 & 11.5 & 10.1 & 3.44 & 30,141 & 34.4 \\
\hline Bergey Excel-S & 30 & 7.86 & 12.4 & 10.5 & 3.58 & 31,338 & 35.8 \\
\hline Fuhrländer FL30 & 26 & 7.80 & 10.9 & 6.8 & 13.7 & 119,710 & 41.4 \\
\hline Fuhrländer FL30 & 30 & 7.86 & 11.2 & 7.0 & 13.8 & 121,067 & 41.9 \\
\hline Entegrity eW-15 $60 \mathrm{~Hz}$ & 25 & 7.78 & 24.6 & 10.3 & 22.9 & 200,461 & 35.2 \\
\hline Entegrity eW-15 $60 \mathrm{~Hz}$ & 31 & 7.88 & 24.3 & 10.6 & 23.4 & 204,856 & 36.0 \\
\hline Vestas V15 & 25 & 7.78 & 28.7 & 6.8 & 22.8 & 200,107 & 30.5 \\
\hline Vestas V15 & 31 & 7.88 & 28.2 & 7.0 & 23.4 & 204,993 & 31.2 \\
\hline Northern Power NW 100/20 & 25 & 7.78 & 24.6 & 9.2 & 33.8 & 296,173 & 33.8 \\
\hline Northern Power NW 100/20 & 32 & 7.90 & 24.3 & 9.4 & 34.7 & 303,606 & 34.7 \\
\hline \multicolumn{8}{|l|}{ Capacity Factor $<20 \%$} \\
\hline \multicolumn{8}{|l|}{ Capacity Factor $>20 \%,<30 \%$} \\
\hline \multicolumn{8}{|l|}{ Capacity Factor $>30 \%,<40 \%$} \\
\hline \multicolumn{8}{|l|}{ Capacity Factor $>40 \%,<50 \%$} \\
\hline Capacity Factor $>50 \%$ & & & & & & & \\
\hline
\end{tabular}

Assumed turbine losses for predictions of average power output, annual energy output, and average capacity factor:

$\begin{array}{lcl}\text { Downtime (\%) } & 5 & \\ \text { Array (\%) } & 0 & \\ \text { Icing/soiling (\%) } & 3 & \\ \text { Other (\%) } & 2 & \\ \text { Total (\%) } & 9.69 \quad \text { (factors are multiplicative) }\end{array}$

Note: Calculated for the data period 8/12/04 to 6/14/06 
Kokhanok, Alaska Wind Resource Report

Annual Fuel Cost Avoided for Energy Generated by Wind Turbine vs. Diesel Generator

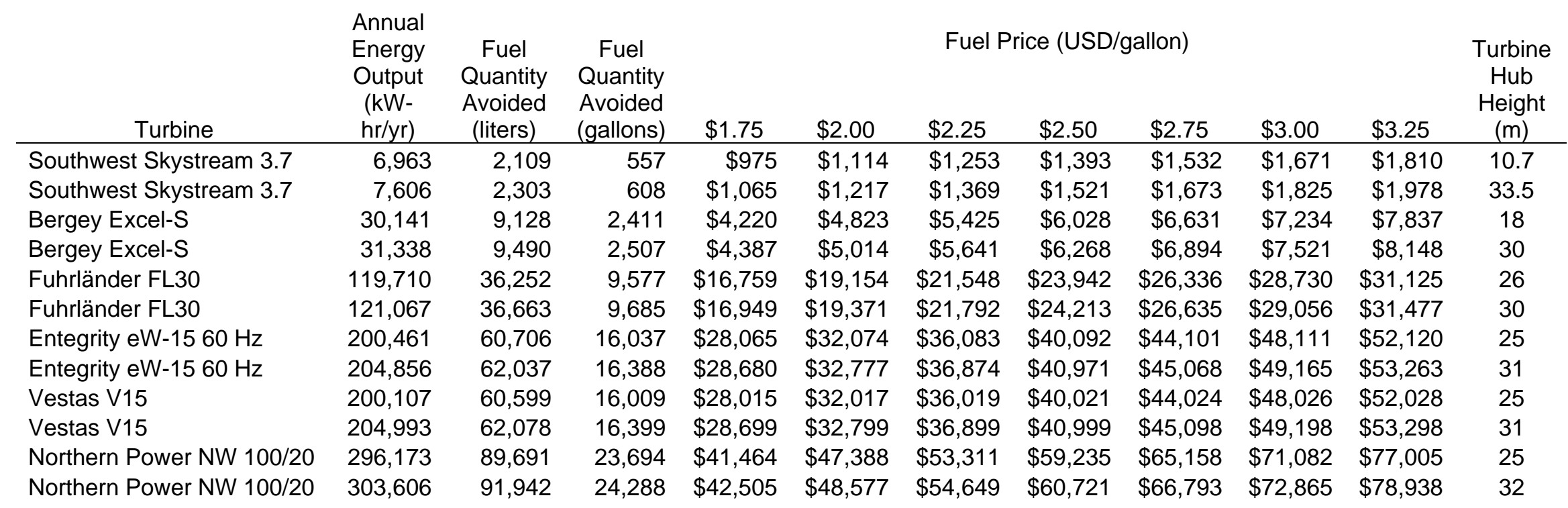

Notes:

1. Kokhanok electrical energy production efficiency assumed to be $12.5 \mathrm{~kW}$-hr/gal

2. Assumes $\underline{90 \%}$ wind turbine availability with no diversion of power to a thermal or other dump load

3. Assumes linear diesel generator fuel efficiency (i.e., 1:1 tradeoff of wind turbine kW-hr to diesel genset kW-hr)

4. Calculated for the data period $8 / 12 / 04$ to $6 / 14 / 06$ 
Kokhanok, Alaska Wind Resource Report

Temperature Conversion Chart ${ }^{\circ} \mathrm{C}$ to ${ }^{\circ} \mathrm{F}$

\begin{tabular}{|c|c|c|c|c|c|}
\hline${ }^{\circ} \mathbf{C}$ & ${ }^{\circ} \mathbf{F}$ & ${ }^{\circ} \mathbf{C}$ & ${ }^{\circ} \mathbf{F}$ & ${ }^{\circ} \mathbf{C}$ & ${ }^{\circ} \mathbf{F}$ \\
\hline-40 & -40 & -10 & 14 & 20 & 68 \\
\hline-39 & -38.2 & -9 & 15.8 & 21 & 69.8 \\
\hline-38 & -36.4 & -8 & 17.6 & 22 & 71.6 \\
\hline-37 & -34.6 & -7 & 19.4 & 23 & 73.4 \\
\hline-36 & -32.8 & -6 & 21.2 & 24 & 75.2 \\
\hline-35 & -31 & -5 & 23 & 25 & 77 \\
\hline-34 & 29.2 & -4 & 24.8 & 26 & 78.8 \\
\hline-33 & -27.4 & -3 & 26.6 & 27 & 80.6 \\
\hline-32 & -25.6 & -2 & 28.4 & 28 & 82.4 \\
\hline-31 & -23.8 & -1 & 30.2 & 29 & 84.2 \\
\hline-30 & -22 & 0 & 32 & 30 & 86 \\
\hline-29 & -20.2 & 1 & 33.8 & 31 & 87.8 \\
\hline-28 & -18.4 & 2 & 35.6 & 32 & 89.6 \\
\hline-27 & -16.6 & 3 & 37.4 & 33 & 91.4 \\
\hline-26 & -14.8 & 4 & 39.2 & 34 & 93.2 \\
\hline-25 & -13 & 5 & 41 & 35 & 95 \\
\hline-24 & -11.2 & 6 & 42.8 & 36 & 96.8 \\
\hline-23 & -9.4 & 7 & 44.6 & 37 & 98.6 \\
\hline-22 & -7.6 & 8 & 46.4 & 38 & 100.4 \\
\hline-21 & -5.8 & 9 & 48.2 & 39 & 102.2 \\
\hline-20 & -4 & 10 & 50 & 40 & 104 \\
\hline-19 & -2.2 & 11 & 51.8 & 41 & 105.8 \\
\hline-18 & -0.4 & 12 & 53.6 & 42 & 107.6 \\
\hline-17 & 1.4 & 13 & 55.4 & 43 & 109.4 \\
\hline-16 & 3.2 & 14 & 57.2 & 44 & 111.2 \\
\hline-15 & 5 & 15 & 59 & 45 & 113 \\
\hline-14 & 6.8 & 16 & 60.8 & 46 & 114.8 \\
\hline-13 & 8.6 & 17 & 62.6 & 47 & 116.6 \\
\hline-12 & 10.4 & 18 & 64.4 & 48 & 118.4 \\
\hline-11 & 12.2 & 19 & 66.2 & 49 & 120.2 \\
\hline & & & & & \\
\hline-21 & & & & \\
\hline
\end{tabular}


Kokhanok, Alaska Wind Resource Report

Wind Speed Conversion Chart, $\mathrm{m} / \mathrm{s}$ to $\mathrm{mph}$

\begin{tabular}{|c|c|c|c|c|c|c|c|c|c|}
\hline $\mathbf{m} / \mathbf{s}$ & $\mathbf{m p h}$ & $\mathbf{m} / \mathbf{s}$ & $\mathbf{m p h}$ & $\mathbf{m} / \mathbf{s}$ & $\mathbf{m p h}$ & $\mathbf{m} / \mathbf{s}$ & $\mathbf{~ m p h}$ & $\mathbf{m} / \mathbf{s}$ & $\mathbf{m p h}$ \\
\hline 0.5 & 1.1 & 10.5 & 23.5 & 20.5 & 45.9 & 30.5 & 68.2 & 40.5 & 90.6 \\
\hline 1.0 & 2.2 & 11.0 & 24.6 & 21.0 & 47.0 & 31.0 & 69.3 & 41.0 & 91.7 \\
\hline 1.5 & 3.4 & 11.5 & 25.7 & 21.5 & 48.1 & 31.5 & 70.5 & 41.5 & 92.8 \\
\hline 2.0 & 4.5 & 12.0 & 26.8 & 22.0 & 49.2 & 32.0 & 71.6 & 42.0 & 93.9 \\
\hline 2.5 & 5.6 & 12.5 & 28.0 & 22.5 & 50.3 & 32.5 & 72.7 & 42.5 & 95.1 \\
\hline 3.0 & 6.7 & 13.0 & 29.1 & 23.0 & 51.4 & 33.0 & 73.8 & 43.0 & 96.2 \\
\hline 3.5 & 7.8 & 13.5 & 30.2 & 23.5 & 52.6 & 33.5 & 74.9 & 43.5 & 97.3 \\
\hline 4.0 & 8.9 & 14.0 & 31.3 & 24.0 & 53.7 & 34.0 & 76.1 & 44.0 & 98.4 \\
\hline 4.5 & 10.1 & 14.5 & 32.4 & 24.5 & 54.8 & 34.5 & 77.2 & 44.5 & 99.5 \\
\hline 5.0 & 11.2 & 15.0 & 33.6 & 25.0 & 55.9 & 35.0 & 78.3 & 45.0 & 100.7 \\
\hline 5.5 & 12.3 & 15.5 & 34.7 & 25.5 & 57.0 & 35.5 & 79.4 & 45.5 & 101.8 \\
\hline 6.0 & 13.4 & 16.0 & 35.8 & 26.0 & 58.2 & 36.0 & 80.5 & 46.0 & 102.9 \\
\hline 6.5 & 14.5 & 16.5 & 36.9 & 26.5 & 59.3 & 36.5 & 81.6 & 46.5 & 104.0 \\
\hline 7.0 & 15.7 & 17.0 & 38.0 & 27.0 & 60.4 & 37.0 & 82.8 & 47.0 & 105.1 \\
\hline 7.5 & 16.8 & 17.5 & 39.1 & 27.5 & 61.5 & 37.5 & 83.9 & 47.5 & 106.3 \\
\hline 8.0 & 17.9 & 18.0 & 40.3 & 28.0 & 62.6 & 38.0 & 85.0 & 48.0 & 107.4 \\
\hline 8.5 & 19.0 & 18.5 & 41.4 & 28.5 & 63.8 & 38.5 & 86.1 & 48.5 & 108.5 \\
\hline 9.0 & 20.1 & 19.0 & 42.5 & 29.0 & 64.9 & 39.0 & 87.2 & 49.0 & 109.6 \\
\hline 9.5 & 21.3 & 19.5 & 43.6 & 29.5 & 66.0 & 39.5 & 88.4 & 49.5 & 110.7 \\
\hline 10.0 & 22.4 & 20.0 & 44.7 & 30.0 & 67.1 & 40.0 & 89.5 & 50.0 & 111.8 \\
\hline
\end{tabular}

Distance Conversion $\mathrm{m}$ to $\mathrm{ft}$

\begin{tabular}{|c|c|c|c|}
\hline $\mathbf{m}$ & $\mathbf{f t}$ & $\mathbf{m}$ & $\mathbf{f t}$ \\
\hline 5 & 16 & 35 & 115 \\
\hline 10 & 33 & 40 & 131 \\
\hline 15 & 49 & 45 & 148 \\
\hline 20 & 66 & 50 & 164 \\
\hline 25 & 82 & 55 & 180 \\
\hline 30 & 98 & 60 & 197 \\
\hline
\end{tabular}


Selected definitions (courtesy of Windographer® software by Mistaya Engineering Inc.)

\section{$\underline{\text { Wind Power Class }}$}

The wind power class is a number indicating the average energy content of the wind resource. Wind power classes are based on the average wind power density at 50 meters above ground, according to the following table. Source: Wind Energy Resource Atlas of the United States (http://rredc.nrel.gov/wind/pubs/atlas/tables/A-8T.html)

\begin{tabular}{|c|l|c|}
\hline \multicolumn{2}{|c|}{} & \multicolumn{2}{|c|}{} \\
\hline Wind Power Class & Description & Power Density at 50m $\mathbf{( W / \mathbf { m } ^ { 2 }}$ ) \\
\hline 1 & Poor & $0-200$ \\
\hline 2 & Marginal & $200-300$ \\
\hline 3 & Fair & $300-400$ \\
\hline 4 & Good & $400-500$ \\
\hline 5 & Excellent & $500-600$ \\
\hline 6 & Outstanding & $600-800$ \\
\hline 7 & Superb & $800-2000$ \\
\hline
\end{tabular}

Windographer classifies any wind resource with an average wind power density above 2000 $\mathrm{W} / \mathrm{m}^{2}$ as class 8 .

Probability Distribution Function

The probability distribution function $\mathrm{f}(\mathrm{x})$ gives the probability that a variable will take on the value $\mathrm{x}$. It is often expressed using a frequency histogram, which gives the frequency with which the variable falls within certain ranges or bins.

\section{$\underline{\text { Wind Turbine Power Regulation }}$}

All wind turbines employ some method of limiting power output at high wind speeds to avoid damage to mechanical or electrical subsystems. Most wind turbines employ either stall control or pitch control to regulate power output.

A stall-controlled turbine typically has blades that are fixed in place, and are designed to experience aerodynamic stall at very high wind speeds. Aerodynamic stall dramatically reduces the torque produced by the blades, and therefore the power produced by the turbine.

On a pitch-controlled turbine, a controller adjusts the angle (pitch) of the blades to best match the wind speed. At very high wind speeds the controller increasingly feathers the blades out of the wind to limit the power output. 


\section{Koliganek, Alaska Wind Resource Report}

Report written by: Douglas Vaught, P.E., V3 Energy, LLC

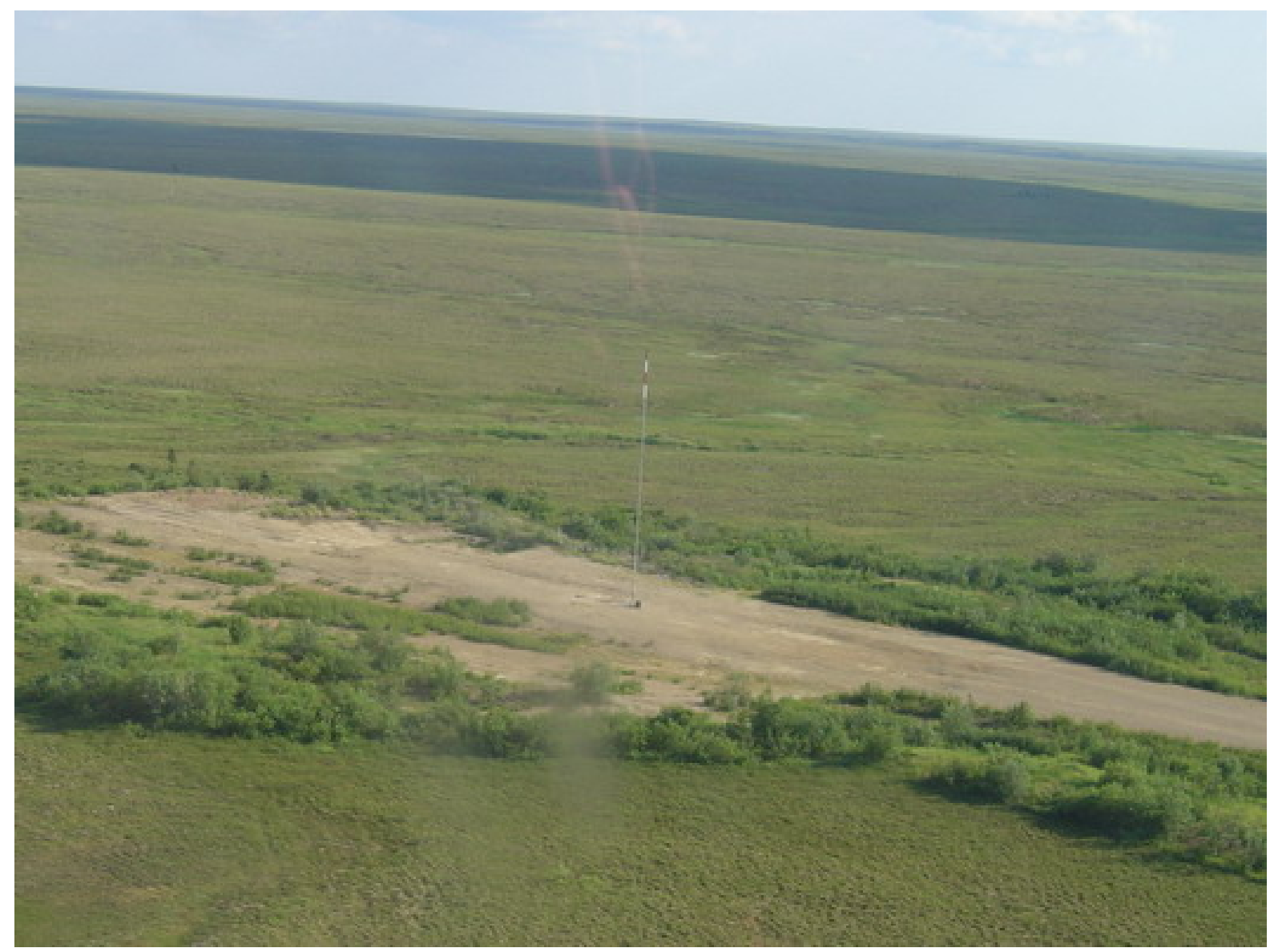

Photo by Hannah Willard

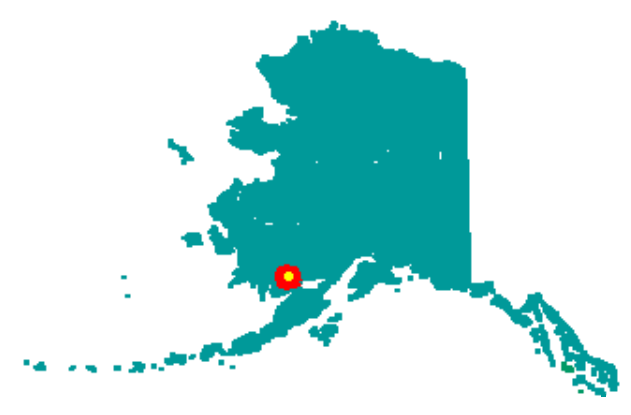

\section{Summary Information}

The wind resource study in Koliganek indicates very good potential for the development of wind power to augment the village's diesel power supply. One excellent advantage for the village is 
the old airstrip where the meteorological test tower was located. Because the village and surrounding area is comprised of permafrost soils, construction of wind turbines on the old airstrip would significantly reduce construction costs.

\section{Meteorological Tower Data Synopsis}

Wind power class

Wind speed annual average (30 meters)

Maximum wind gust (2 sec. average)

Mean wind power density (50 meters)

Mean wind power density (30 meters)

Weibull distribution parameters

Roughness class

Power law exponent

Turbulence intensity

Data start date

Data end date
Class 4 - Good

$5.72 \mathrm{~m} / \mathrm{s}$

$36.5 \mathrm{~m} / \mathrm{s}, 12 / 7 / 05$

$404 \mathrm{~W} / \mathrm{m}^{2}$ (calculated)

$320 \mathrm{~W} / \mathrm{m}^{2}$ (measured)

$\mathrm{k}=1.60, \mathrm{c}=6.40 \mathrm{~m} / \mathrm{s}$

2.92 (many trees)

0.227 (high wind shear)

0.115 (low)

July 8, 2005

July 13, 2006

\section{Community Profile}

Current Population: 167 (2005 State Demographer est.)

Pronunciation/Other Names: (koh-LIG-uh-neck)

Incorporation Type: Unincorporated

Borough Located In: Unorganized

School District: Southwest Region Schools

Regional Native Corporation: Bristol Bay Native Corporation

\section{Location:}

Koliganek is located on the left bank of the Nushagak River, and lies 65 miles northeast of Dillingham. The village hopes to get its own zip code. It currently shares one with Dillingham. It lies at approximately $59.728610^{\circ}$ North Latitude and $157.284440^{\circ}$ West Longitude. (Sec. 21, T005S, R047W, Seward Meridian.) Koliganek is located in the Bristol Bay Recording District. The area encompasses $12.5 \mathrm{sq}$. miles of land and 0.1 sq. miles of water.

\section{History:}

It is an Eskimo village first listed in the 1880 Census as "Kalignak." The name is local, recorded by the U.S. Geological Survey in 1930. Since that time, the village has moved four miles downstream from the original site.

\section{Culture:}

Koliganek is a Yup'ik Eskimo village with Russian Orthodox practices. Subsistence activities are an important part of the lifestyle.

\section{Economy:}

The school and village organization provide most year-round employment. Eighteen residents hold commercial fishing permits. Many residents trap, and subsistence activities are an important part of the economy. Residents are employed in sales and office work, management and professional, production and transportation, and service occupations. The town center contains the school, health clinic, two general stores, fuel storage, power generation building, and the village council building. A new health care clinic is 
scheduled to be constructed in 2006 and the existing facility will be remodeled for a family resource center. The IGAP program operates a recycling center.

\section{Facilities:}

Koliganek has operated a piped system for over 25 years. Water is derived from a well and is treated. Thirty-three homes and facilities are connected to the piped water and a community septic tank. Eight homes have individual wells and septic systems. Fifteen homes haul water and use honeybuckets. Koliganek purchases power from the School District, and also owns its own generator. The village has a "code red" fire suppression unit. The village has one village public safety officer. The community has completed a water and sewer feasibility study and is competing for funds to make improvements with the goal of connecting the entire community.

\section{Transportation:}

A new State-owned 3,000' long by $75^{\prime}$ wide runway is available. Boats and ATVs are used in the summer; snow machines in the winter. Locals travel to New Stuyahok frequently. There are no docking facilities; goods are lightered from Dillingham.

\section{Climate:}

The area is in a climatic transition zone. The primary influence is maritime, although a continental climate affects the weather. Average summer temperatures range from 37 to 66; winter temperatures range from 4 to 30 .

(Community profile information from State of Alaska Department of Commerce, Community, and Economic Development website, http://www.dced.state.ak.us/)

\section{Tower Sensor Information}

$\begin{array}{clcrcc}\text { Channel } & \text { Sensor type } & \text { Height } & \text { Multiplier } & \text { Offset } & \text { Orientation } \\ 1 & \text { NRG \#40 anemometer } & 30 \mathrm{~m} \mathrm{(A)} & 0.765 & 0.35 & \text { north } \\ 2 & \text { NRG \#40 anemometer } & 30 \mathrm{~m} \mathrm{(B)} & 0.765 & 0.35 & \text { south } \\ 3 & \text { NRG \#40 anemometer } & 20 \mathrm{~m} & 0.765 & 0.35 & \text { north } \\ 7 & \text { NRG \#200P wind vane } & 30 \mathrm{~m} & 0.351 & 310 & \text { southeast } \\ 9 & \text { NRG \#110S Temp C } & 2 \mathrm{~m} & 0.136 & -86.383 & \text { N/A }\end{array}$

\section{Site Information and Location}

Site number

Site Description

Latitude/longitude

Site elevation

Datalogger type

Tower type
3296

On south end of crosswind runway of previous airport

N 59 43.384' W $157^{\circ} 17.056^{\prime}$

95 meters

NRG Symphonie

NRG 30-meter tall tower, 152 mm (6 in) diameter 
Koliganek, Alaska Wind Resource Report

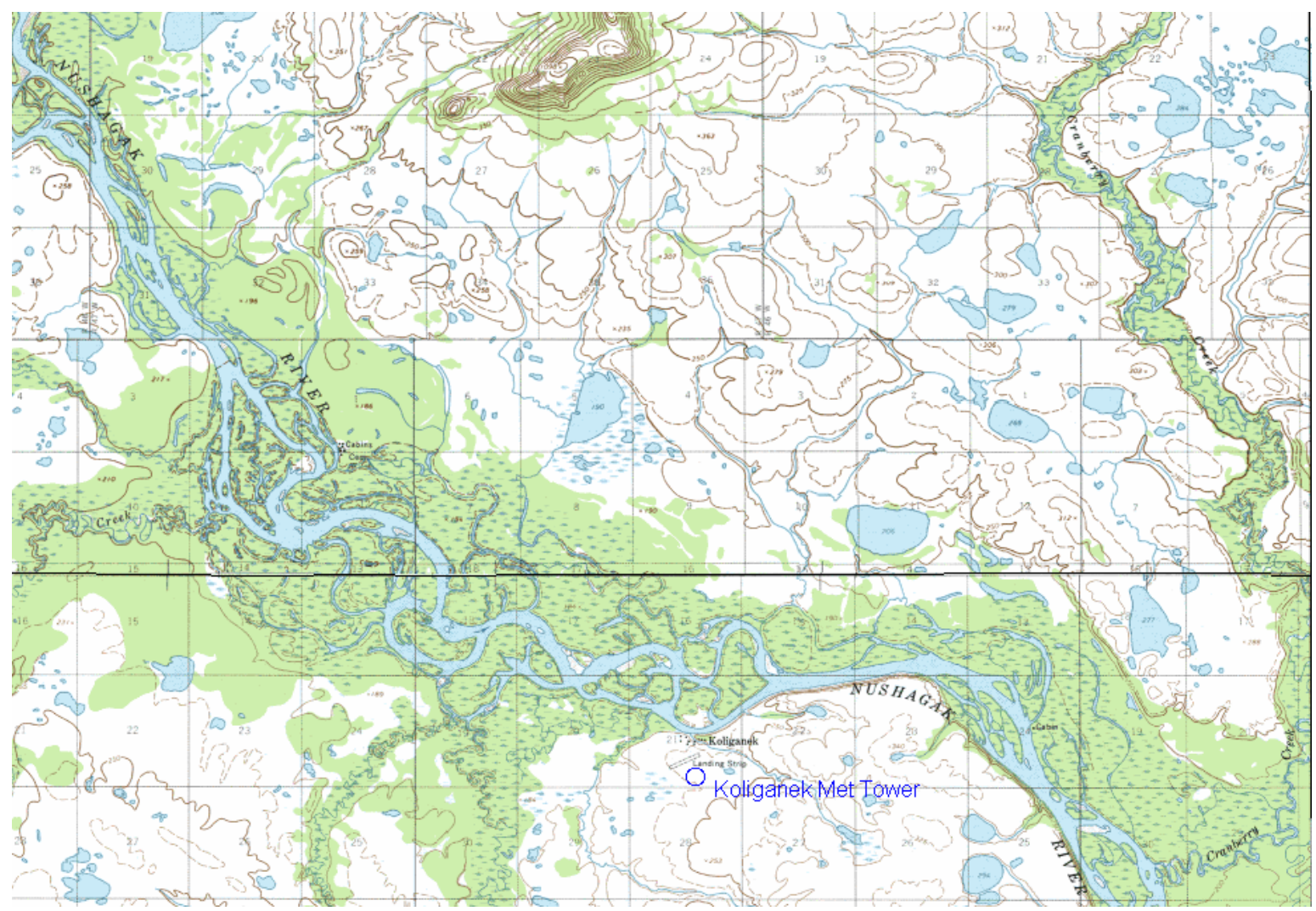




\section{Data Quality Control}

Data was filtered to remove presumed icing events that yield false zero wind speed data. Data that met the following criteria were filtered: wind speed $<1 \mathrm{~m} / \mathrm{s}$, wind speed standard deviation $=0$, and temperature $<3{ }^{\circ} \mathrm{C}$. Note that data recovery during the months of March through September was $100 \%$, but during the months of October through February some data was filtered, with November being quite ice prone with respect to data loss. Temperature data recovery was 100 percent, indicating full functioning of the temperature sensor. To make up for the lost icing data and to create a complete data set representative of all sensors fully functional, the removed icing data was synthesized with the data gap fill feature of the Windographer ${ }^{\circledR}$ wind analysis software.

\begin{tabular}{|c|c|c|c|c|c|c|c|}
\hline \multirow[b]{2}{*}{ Year } & \multirow[b]{2}{*}{ Month } & \multicolumn{2}{|c|}{$30 \mathrm{~m}(\mathrm{~A})$ anemometer } & \multicolumn{2}{|c|}{ 30m (B) anemometer } & \multicolumn{2}{|c|}{$20 \mathrm{~m}$ anemometer } \\
\hline & & Records & $\begin{array}{l}\text { Recovery } \\
\text { Rate (\%) }\end{array}$ & Records & $\begin{array}{l}\text { Recovery } \\
\text { Rate (\%) }\end{array}$ & Records & $\begin{array}{l}\text { Recovery } \\
\text { Rate (\%) }\end{array}$ \\
\hline 2005 & Jul & 3,352 & 100 & 3,352 & 100 & 3,352 & 100 \\
\hline 2005 & Aug & 4,464 & 100 & 4,464 & 100 & 4,464 & 100 \\
\hline 2005 & Sep & 4,320 & 100 & 4,320 & 100 & 4,320 & 100 \\
\hline 2005 & Oct & 4,388 & 98.3 & 4,464 & 100 & 4,372 & 97.9 \\
\hline 2005 & Nov & 2,427 & 56.2 & 2,427 & 56.2 & 2,861 & 66.2 \\
\hline 2005 & Dec & 4,464 & 100 & 4,036 & 90.4 & 4,040 & 90.5 \\
\hline 2006 & Jan & 4,464 & 100 & 4,464 & 100 & 4,464 & 100 \\
\hline 2006 & Feb & 4,032 & 100 & 3,844 & 95.3 & 4,032 & 100 \\
\hline 2006 & Mar & 4,464 & 100 & 4,464 & 100 & 4,464 & 100 \\
\hline 2006 & Apr & 4,320 & 100 & 4,320 & 100 & 4,320 & 100 \\
\hline 2006 & May & 4,464 & 100 & 4,464 & 100 & 4,464 & 100 \\
\hline 2006 & Jun & 4,320 & 100 & 4,320 & 100 & 4,320 & 100 \\
\hline 2006 & Jul & 1,812 & 100 & 1,812 & 100 & 1,812 & 100 \\
\hline \multirow[t]{3}{*}{ All data } & & 51,291 & 96.1 & 50,751 & 95.1 & 51,285 & 96.1 \\
\hline & & \multicolumn{2}{|c|}{ Wind direction } & \multicolumn{2}{|c|}{ Temperature } & & \\
\hline & & Records & $\begin{array}{c}\text { Recovery } \\
\text { Rate (\%) }\end{array}$ & Records & $\begin{array}{l}\text { Recovery } \\
\text { Rate (\%) }\end{array}$ & & \\
\hline 2005 & Jul & 3,352 & 100 & 3,353 & 100 & & \\
\hline 2005 & Aug & 4,464 & 100 & 4,464 & 100 & & \\
\hline 2005 & Sep & 4,320 & 100 & 4,320 & 100 & & \\
\hline 2005 & Oct & 4,390 & 98.3 & 4,464 & 100 & & \\
\hline 2005 & Nov & 2,392 & 55.4 & 4,320 & 100 & & \\
\hline 2005 & Dec & 3,270 & 73.3 & 4,464 & 100 & & \\
\hline 2006 & Jan & 4,269 & 95.6 & 4,464 & 100 & & \\
\hline 2006 & Feb & 4,032 & 100 & 4,032 & 100 & & \\
\hline 2006 & Mar & 4,464 & 100 & 4,464 & 100 & & \\
\hline 2006 & Apr & 4,320 & 100 & 4,320 & 100 & & \\
\hline 2006 & May & 4,464 & 100 & 4,464 & 100 & & \\
\hline 2006 & Jun & 4,320 & 100 & 4,320 & 100 & & \\
\hline 2006 & Jul & 1,812 & 100 & 1,812 & 100 & & \\
\hline All data & & 49,869 & 93.5 & 53,261 & 100 & & \\
\hline
\end{tabular}


Koliganek, Alaska Wind Resource Report

\section{Measured Wind Speeds}

The 30 meter (A) anemometer annual wind speed average for the reporting period is $5.72 \mathrm{~m} / \mathrm{s}$, the 30 meter (B) anemometer wind speed average is $5.59 \mathrm{~m} / \mathrm{s}$ and the 20 meter anemometer wind speed average is $5.16 \mathrm{~m} / \mathrm{s}$.

\begin{tabular}{|c|c|c|c|c|c|c|c|c|c|}
\hline \multirow[b]{2}{*}{ Month } & \multicolumn{5}{|c|}{$30 m(A)$ speed } & \multicolumn{2}{|c|}{ 30m (B) speed } & \multicolumn{2}{|c|}{$20 \mathrm{~m}$ speed } \\
\hline & $\begin{array}{l}\text { Mean } \\
(\mathrm{m} / \mathrm{s})\end{array}$ & $\begin{array}{l}\operatorname{Max} \\
(\mathrm{m} / \mathrm{s})\end{array}$ & $\begin{array}{l}\text { Std. } \\
\text { Dev. } \\
\text { (m/s) }\end{array}$ & $\begin{array}{c}\text { Weibull } \\
\text { k }\end{array}$ & $\begin{array}{c}\text { Weibull } \\
\mathrm{c} \\
(\mathrm{m} / \mathrm{s})\end{array}$ & $\begin{array}{l}\text { Mean } \\
(\mathrm{m} / \mathrm{s})\end{array}$ & $\begin{array}{l}\operatorname{Max} \\
(\mathrm{m} / \mathrm{s})\end{array}$ & $\begin{array}{l}\text { Mean } \\
(\mathrm{m} / \mathrm{s})\end{array}$ & $\begin{array}{l}\operatorname{Max} \\
(\mathrm{m} / \mathrm{s})\end{array}$ \\
\hline Jul & 4.79 & 14.80 & 2.69 & 1.849 & 5.393 & 4.75 & 14.60 & 4.26 & 14.10 \\
\hline Aug & 4.68 & 16.30 & 2.91 & 1.631 & 5.218 & 4.60 & 16.50 & 4.16 & 14.50 \\
\hline Sep & 5.79 & 18.00 & 3.06 & 1.951 & 6.515 & 5.72 & 18.00 & 5.00 & 16.70 \\
\hline Oct & 5.13 & 21.20 & 3.43 & 1.583 & 5.728 & 4.86 & 21.10 & 4.51 & 18.10 \\
\hline Nov & 5.94 & 15.00 & 2.87 & 2.099 & 6.648 & 5.42 & 14.90 & 4.96 & 13.80 \\
\hline Dec & 6.08 & 27.70 & 4.64 & 1.471 & 6.788 & 6.16 & 27.50 & 5.78 & 26.40 \\
\hline Jan & 4.60 & 13.00 & 2.29 & 2.117 & 5.200 & 4.28 & 12.60 & 4.06 & 11.50 \\
\hline Feb & 8.67 & 25.80 & 5.36 & 1.651 & 9.691 & 8.49 & 25.60 & 7.96 & 24.80 \\
\hline Mar & 6.35 & 20.60 & 4.20 & 1.585 & 7.105 & 6.23 & 20.40 & 5.86 & 19.70 \\
\hline Apr & 5.81 & 20.40 & 3.26 & 1.861 & 6.548 & 5.70 & 20.20 & 5.30 & 19.80 \\
\hline May & 5.95 & 16.20 & 2.81 & 2.242 & 6.722 & 5.90 & 16.10 & 5.45 & 15.30 \\
\hline Jun & 6.13 & 25.00 & 4.00 & 1.605 & 6.855 & 6.14 & 24.80 & 5.65 & 23.60 \\
\hline Jul & 4.68 & 20.80 & 3.59 & 1.439 & 5.191 & 4.74 & 20.70 & 4.36 & 19.60 \\
\hline Annual & 5.72 & 27.70 & 3.74 & 1.635 & 6.476 & 5.59 & 27.50 & 5.16 & 26.40 \\
\hline
\end{tabular}

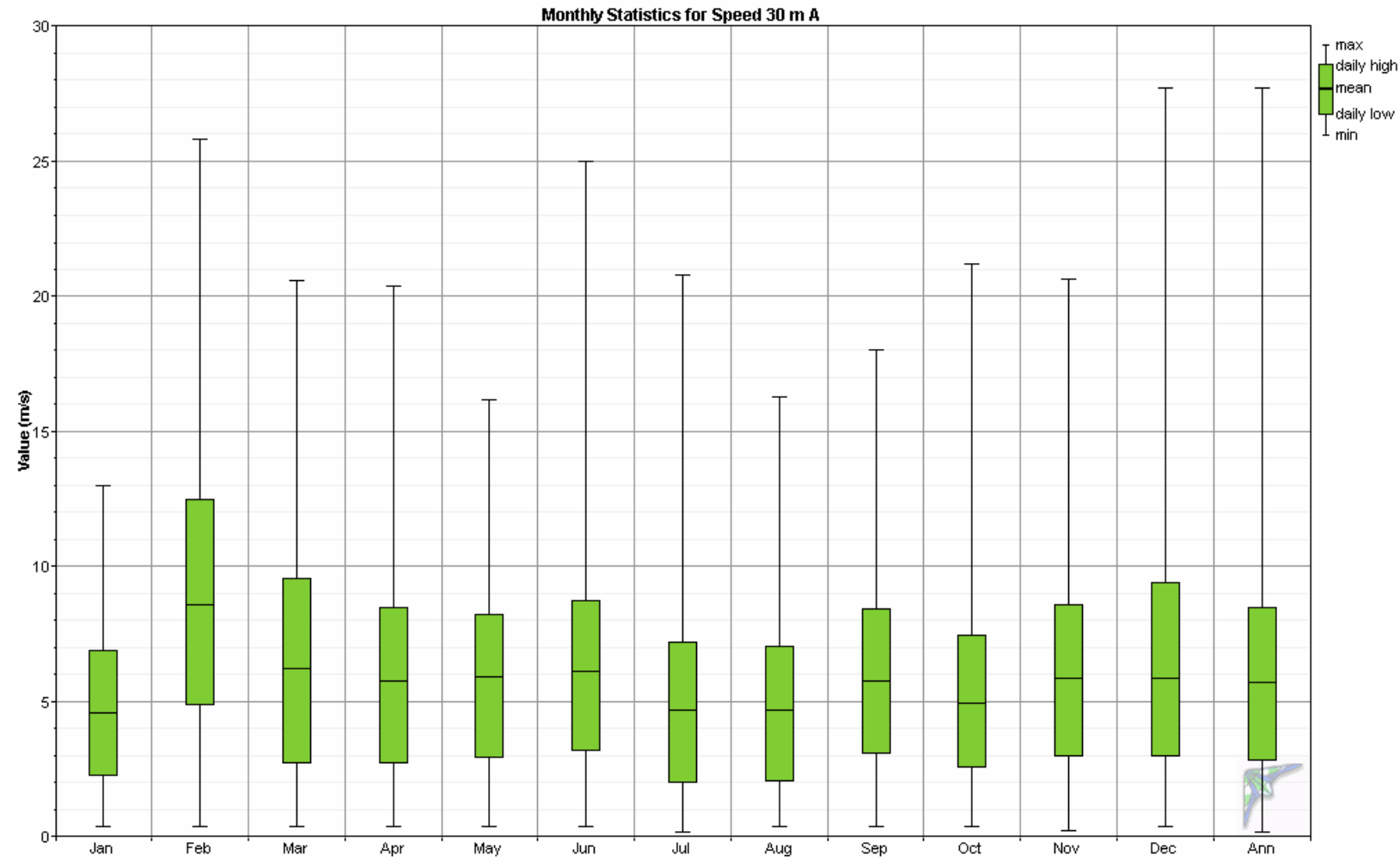

Daily wind profile 
The daily wind profile indicates that the lowest wind speeds of the day occur in the morning hours of 8 a.m. to 11 a.m. and the highest wind speeds of the day occur during the afternoon and evening hours of 5 p.m. to 9 p.m. The daily variation of wind speed is minimal on an annual basis but more pronounced on a monthly basis.
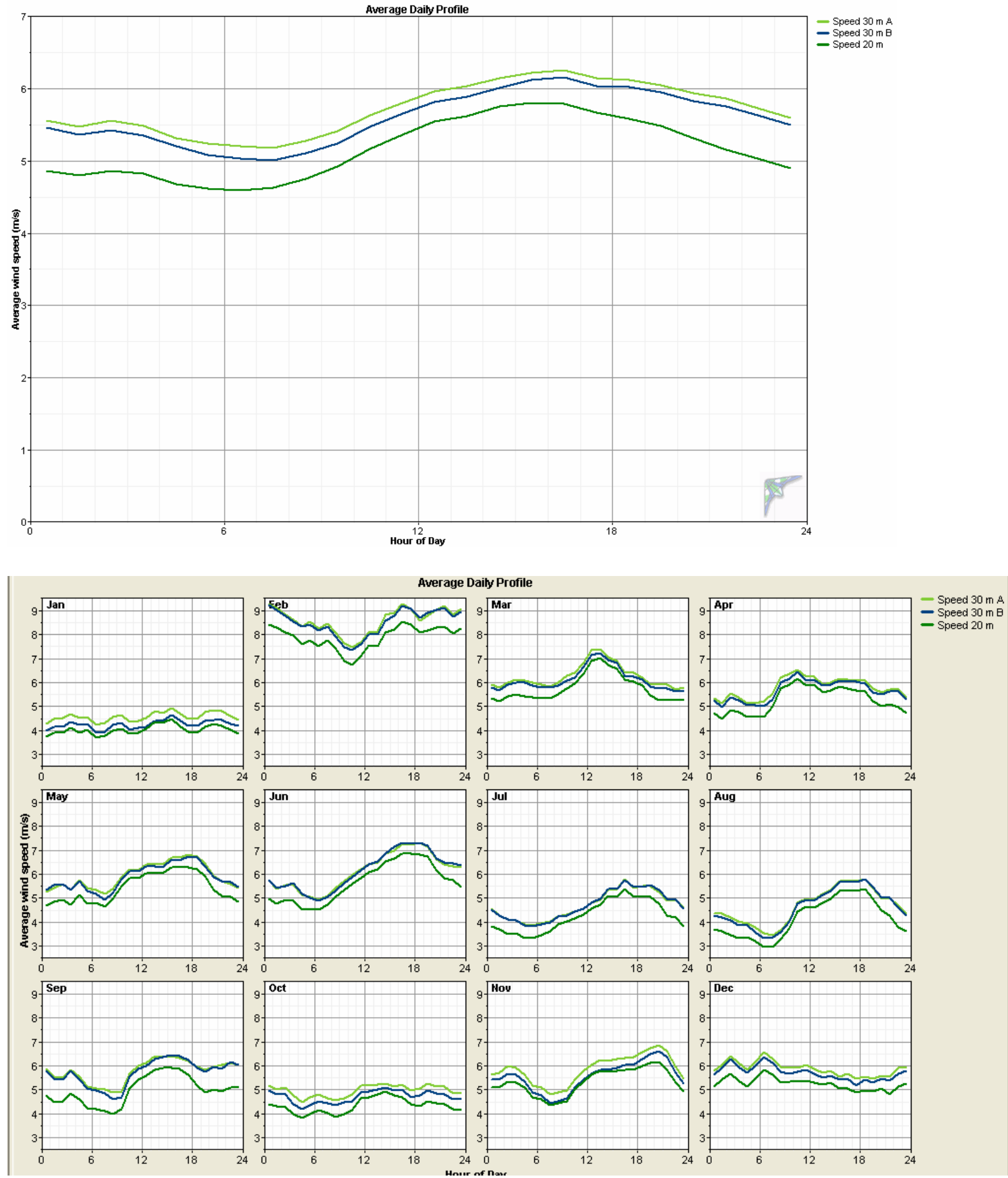


\section{Time Series of Wind Speed Monthly Averages}

Koliganek's highest winds occur during the fall, winter and spring months with the lowest winds during the summer. The unusually low winds measured in January 2006 were due to a persistent high pressure system over Alaska that month that yielded calm winds and extremely cold weather Statewide. Had the January winds been higher and more representative of a typical year, it is expected that the wind power average for this site would be higher, possibly in the mid-Class 4 range.
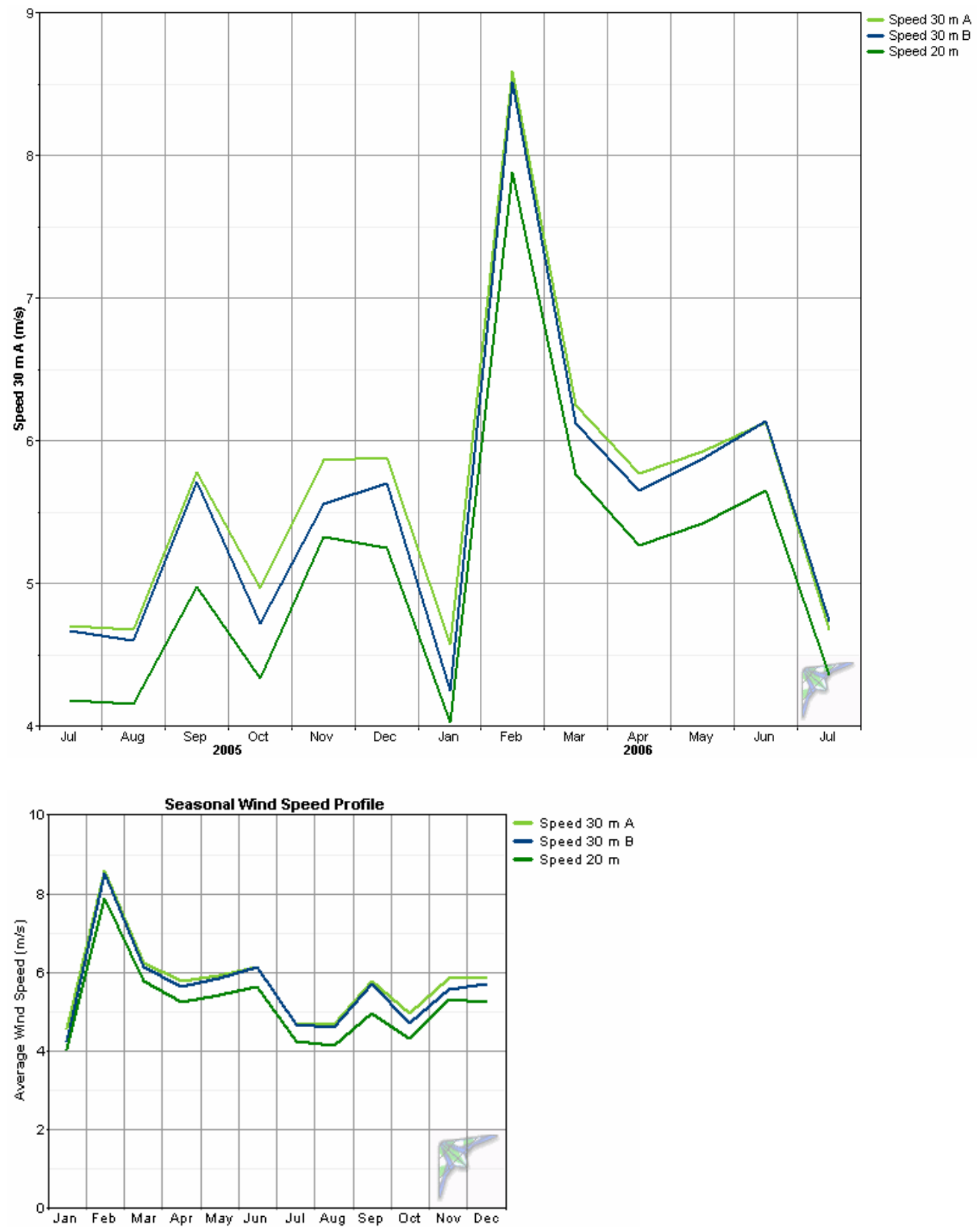


\section{Wind Shear Profile}

The power law exponent was calculated at 0.227 indicating relatively high wind shear at the Koliganek test site. The practical application of this data is that a higher turbine tower height is advantageous as there is an appreciable marginal gain in average wind speed and power recovery with additional height. However, a tower height/power recovery/construction cost tradeoff study would be advisable should a wind power project be initiated.
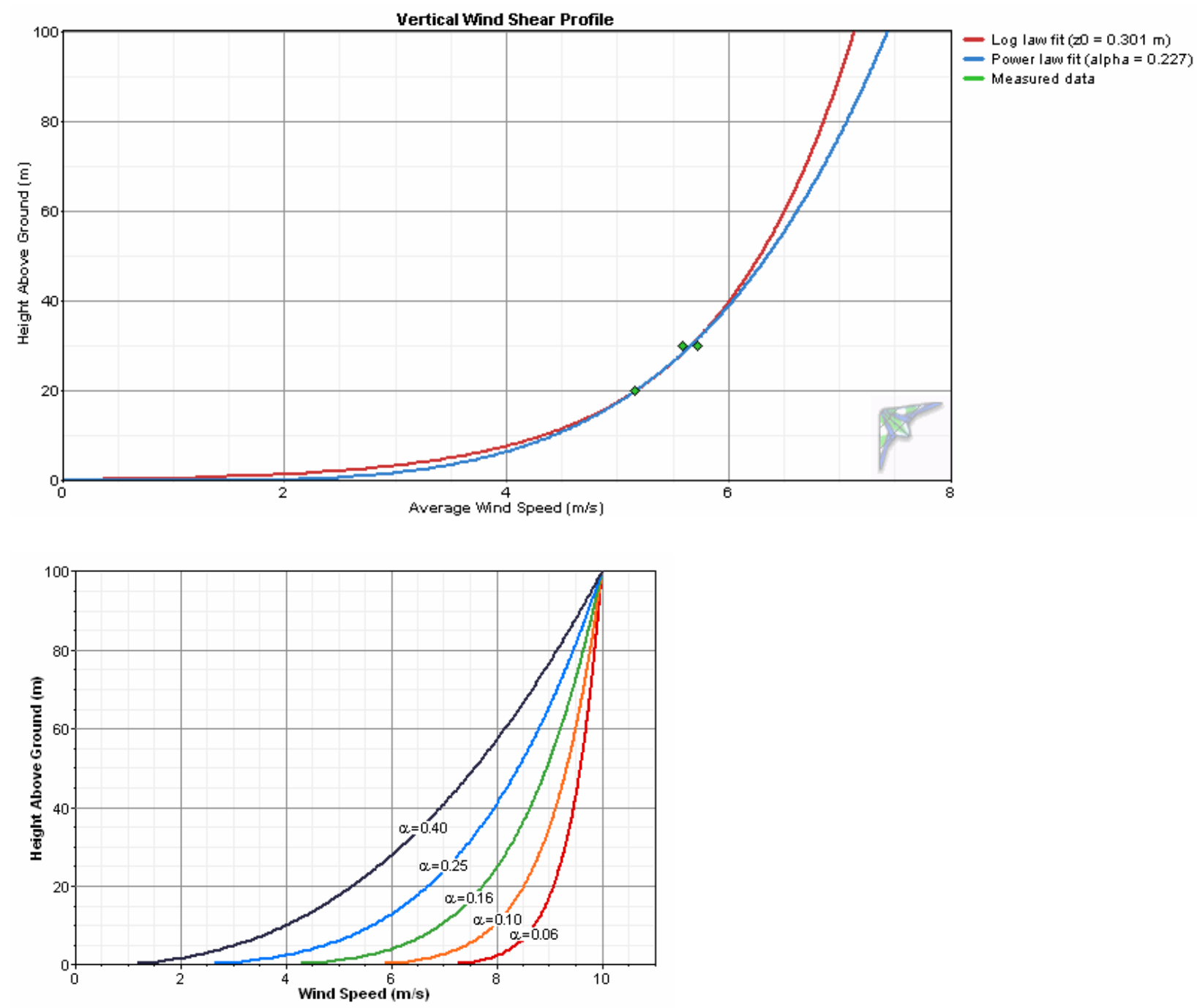
Koliganek, Alaska Wind Resource Report
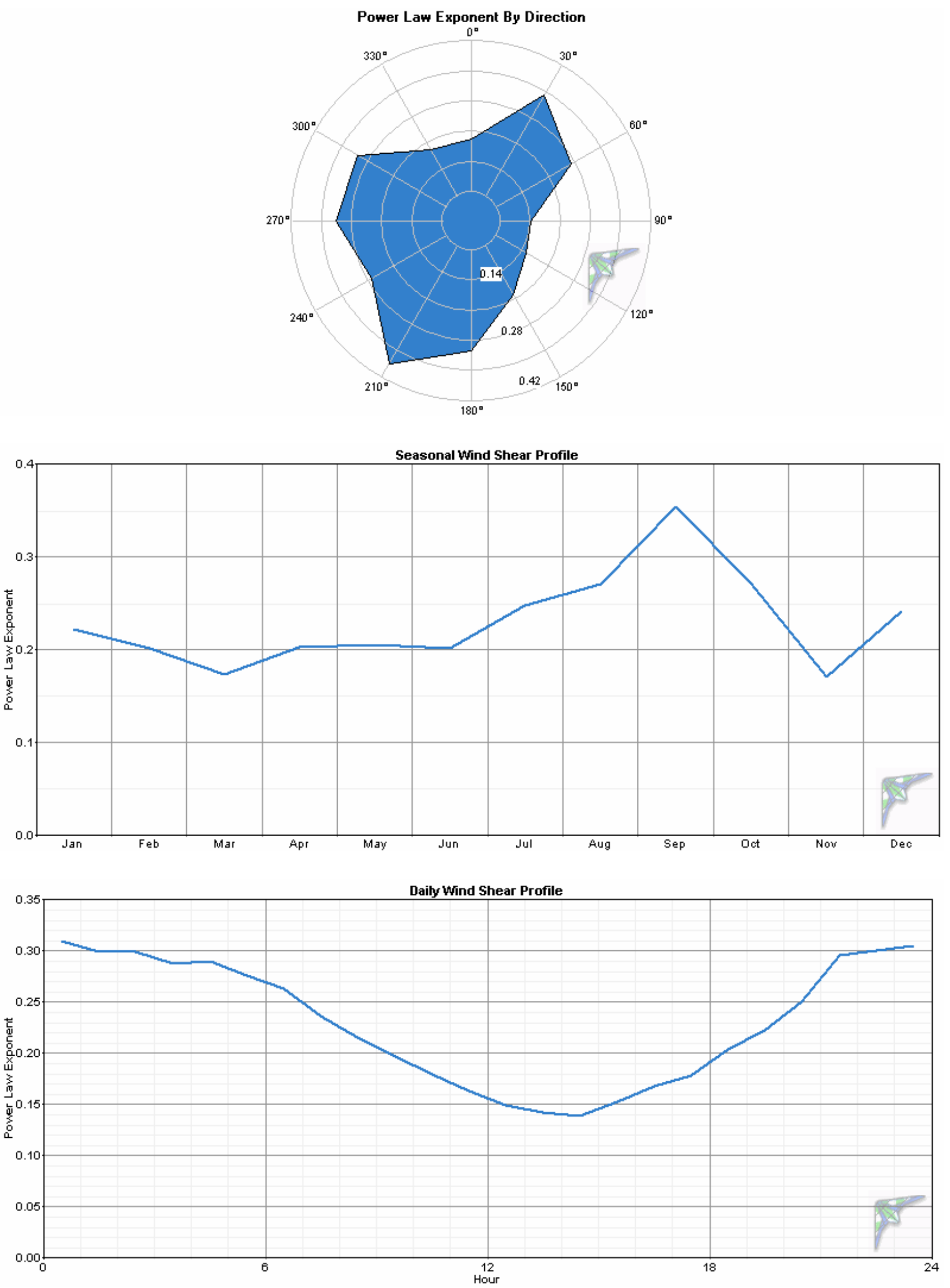


\section{Probability Distribution Function}

The probability distribution function (PDF) provides a visual indication of measured wind speeds in one meter per second "bins". Note that most wind turbines do not begin to generate power until the wind speed at hub height reaches $4 \mathrm{~m} / \mathrm{s}$, also known as the "cut-in" wind speed. The black line in the graph is a best fit Weibull distribution. At the 30 meter level, Weibull parameters are $\mathrm{k}=1.60$ (indicates a moderate distribution of wind speeds) and $\mathrm{c}=6.40 \mathrm{~m} / \mathrm{s}$ (a scale factor for the Weibull distribution). The PDF information is shown visually in another manner in the second graph, the cumulative distribution function.
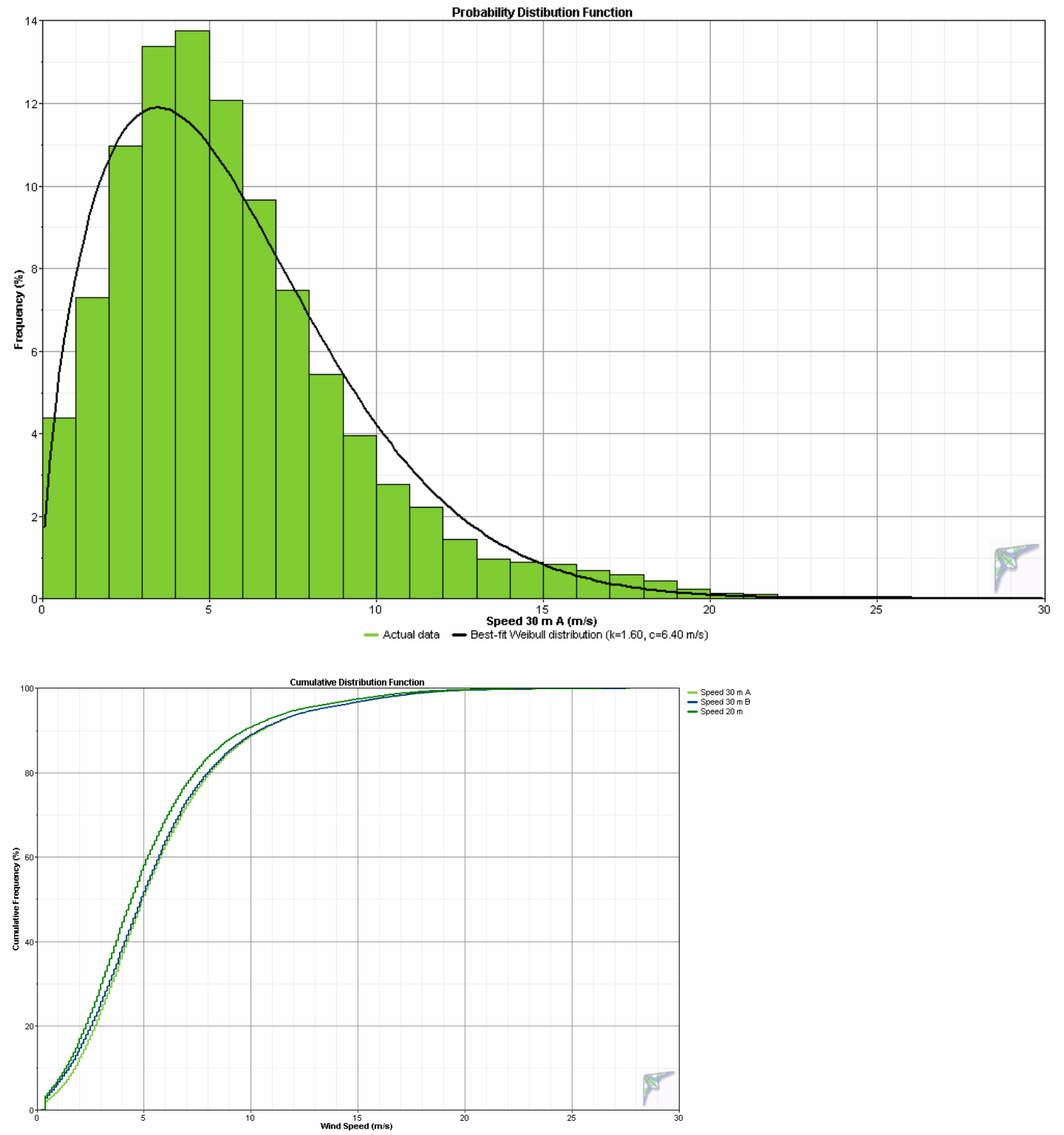


\section{Wind Roses}

Koliganek winds are rather directional; the wind frequency rose indicates northwest, eastsoutheast and south-southwest winds. Interestingly though, the power producing winds are strongly dominated by the east-southeast direction, with northwest and south-southwest to a much lesser extent. The practical application of this information is that a site should be selected with adequate freedom from ground interference toward these sectors and if more than one wind turbine is installed, the turbines should be adequately spaced apart to prevent downwind (from the power producing winds) interference problems between the turbines.

Note also that a wind threshold of $4 \mathrm{~m} / \mathrm{s}$ was selected for the definition of calm winds. This wind speed represents the cut-in wind speed of most wind turbines. By this definition, Koliganek experienced 37 percent calm conditions during the measurement period (see wind frequency rose below).

\section{Wind Frequency Rose (30 meters)}

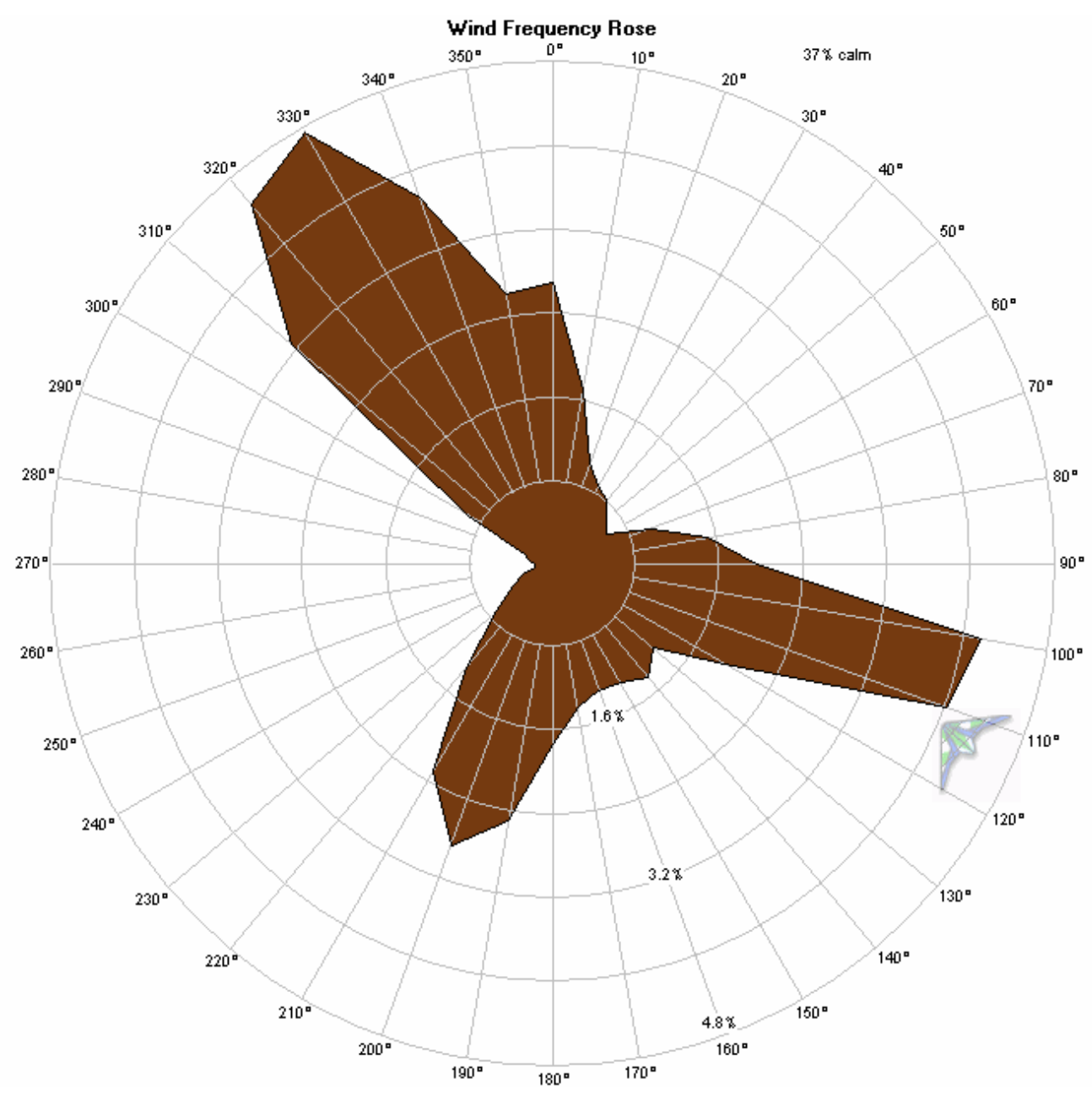


Koliganek, Alaska Wind Resource Report

Wind Power Density Rose (30 meters)

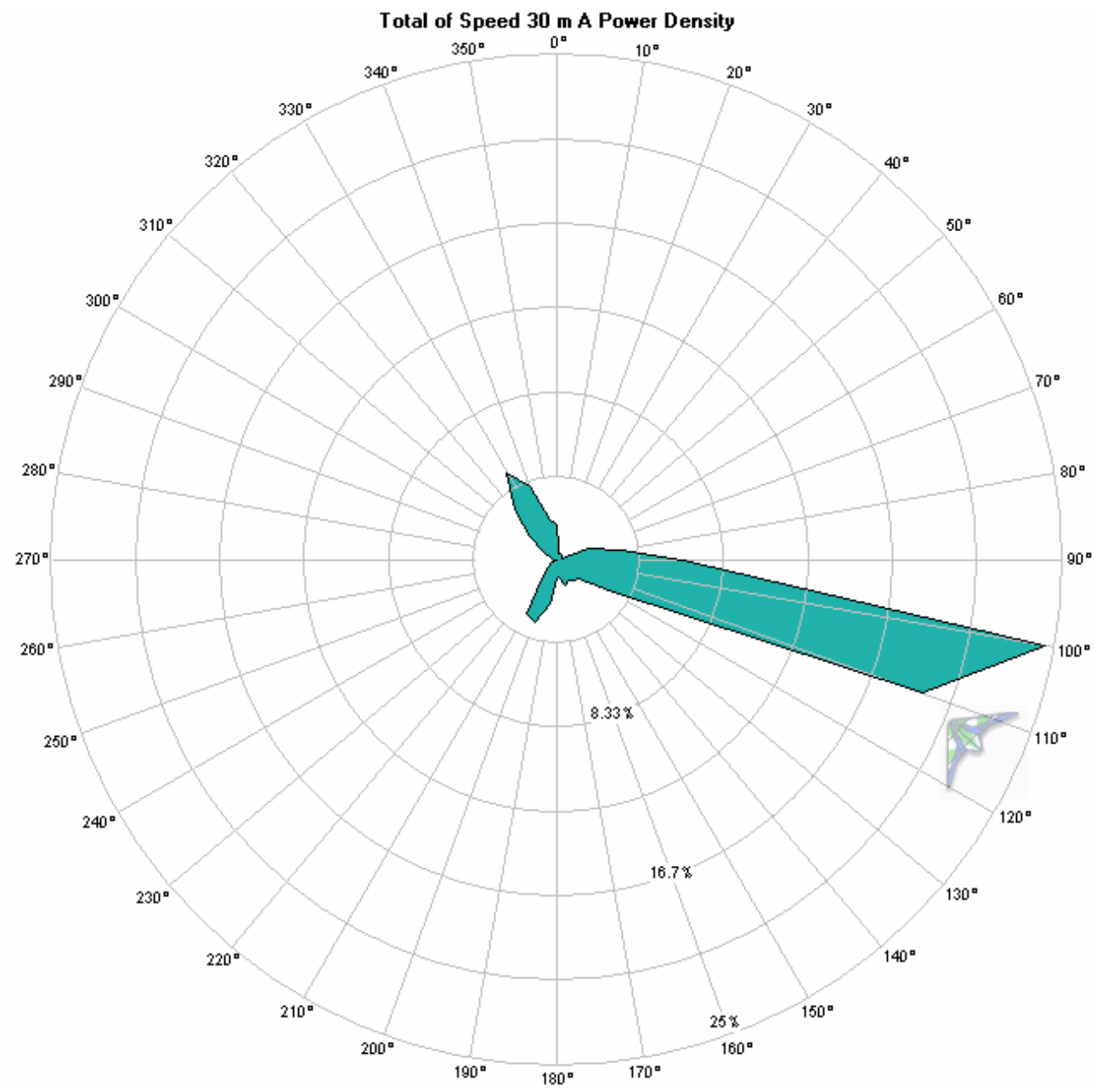

Wind Power Density Rose by Month (30 meters)

Note: for easier visualization of monthly wind power variation, the scale is not common
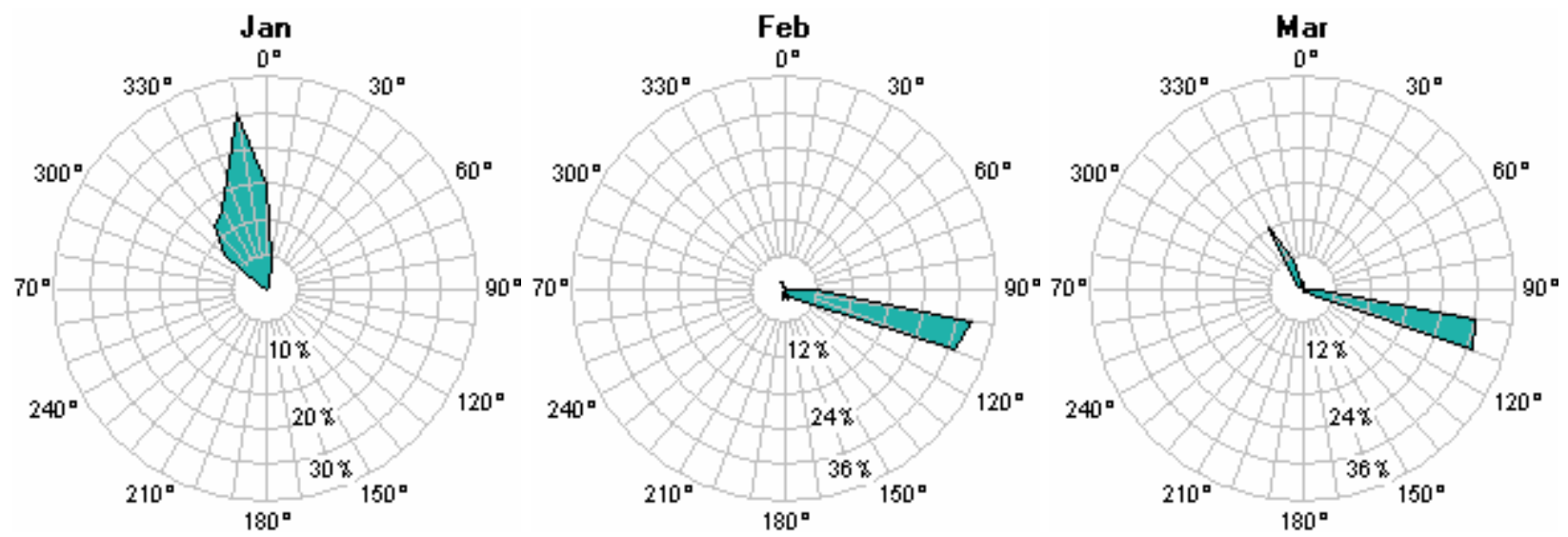
Koliganek, Alaska Wind Resource Report

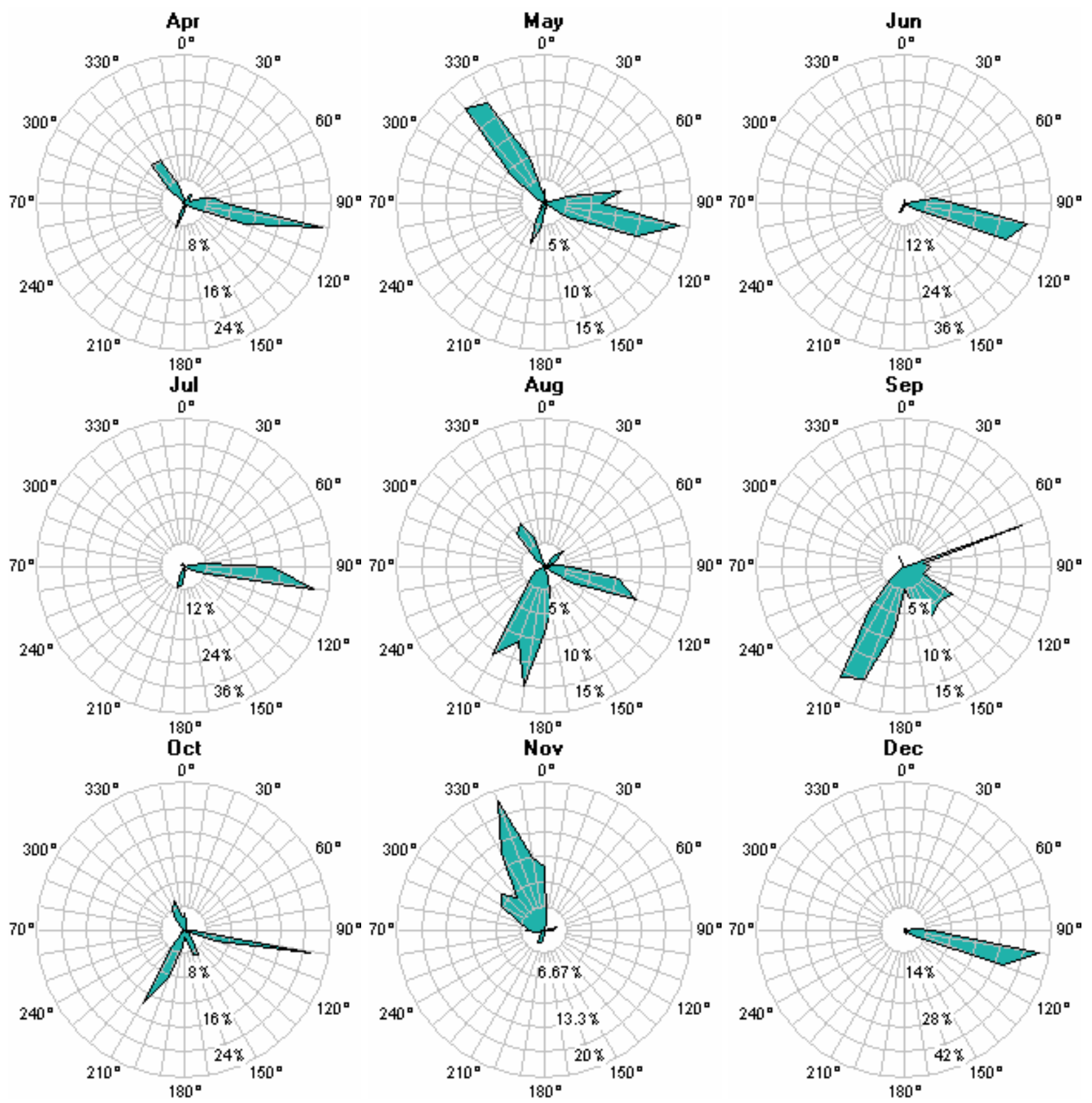




\section{Turbulence Intensity}

The turbulence intensity (TI) is quite acceptable for all wind direction, with a mean turbulence intensity of 0.115 (channel 1 - 30 meter A) and 0.117 (channel 2 - 30 meter B), indicating moderately smooth air. These TIs are calculated with a threshold wind speed of $4 \mathrm{~m} / \mathrm{s}$. The spike of relatively high turbulence to the north to northeast in both graphs is likely due to the presence of two old water tanks located several hundred meters north of the met tower test site and heavy brush and higher terrain both north and northeast of the met tower location.

30 meter (A) turbulence intensity

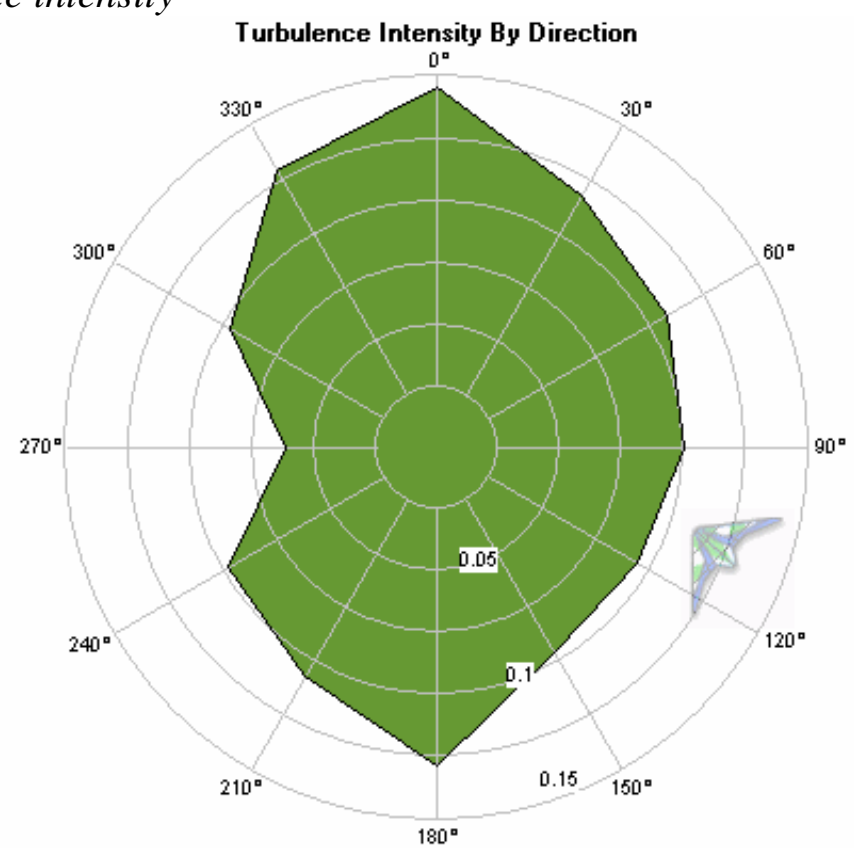

30 meter (B) turbulence intensity

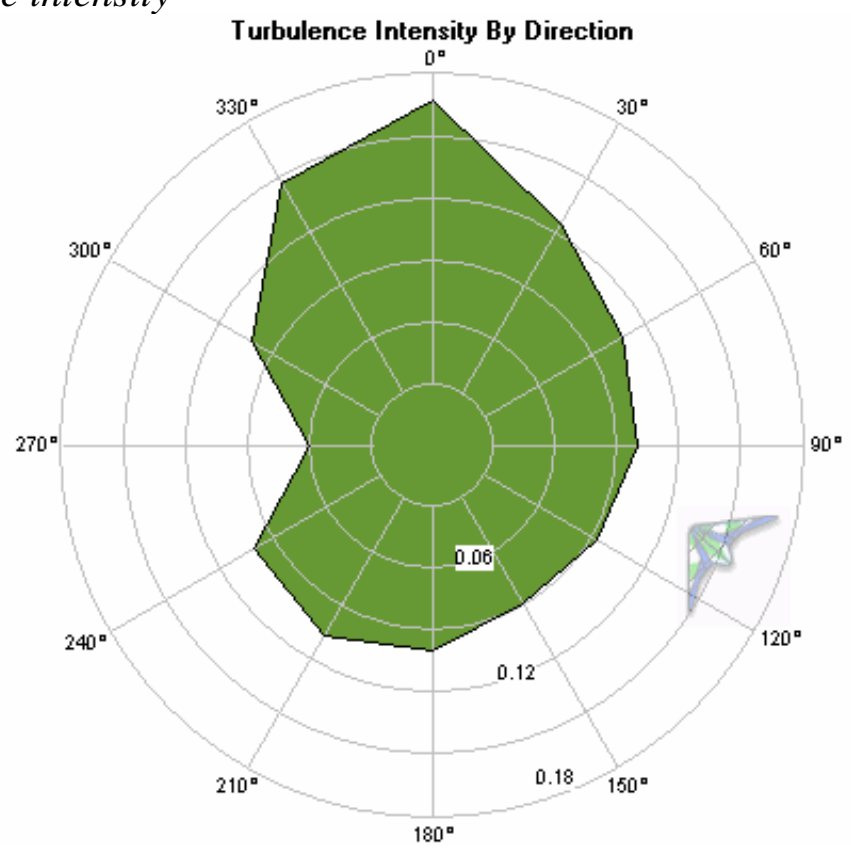


Koliganek, Alaska Wind Resource Report

\section{IEC Turbulence Intensity Standards}

As indicated in the graphs below, turbulence at the Koliganek project test site is well below International Electrotechnical (IEC) standards at all measured wind speeds and from all four quadrants of the wind rose.
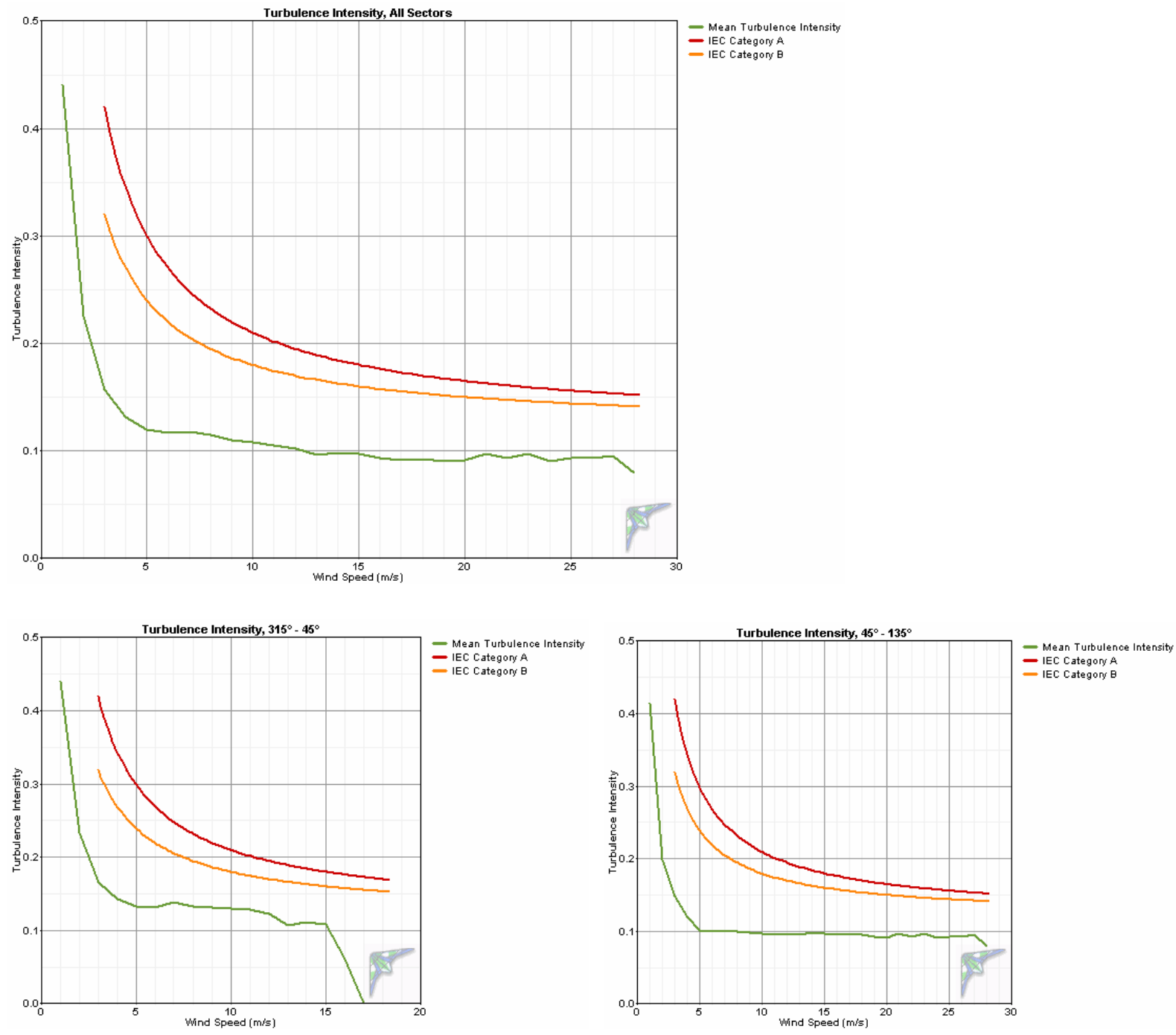

- Mean Turbulence Intensit/ - IEC Category A
- IEC Category $B$ 
Koliganek, Alaska Wind Resource Report
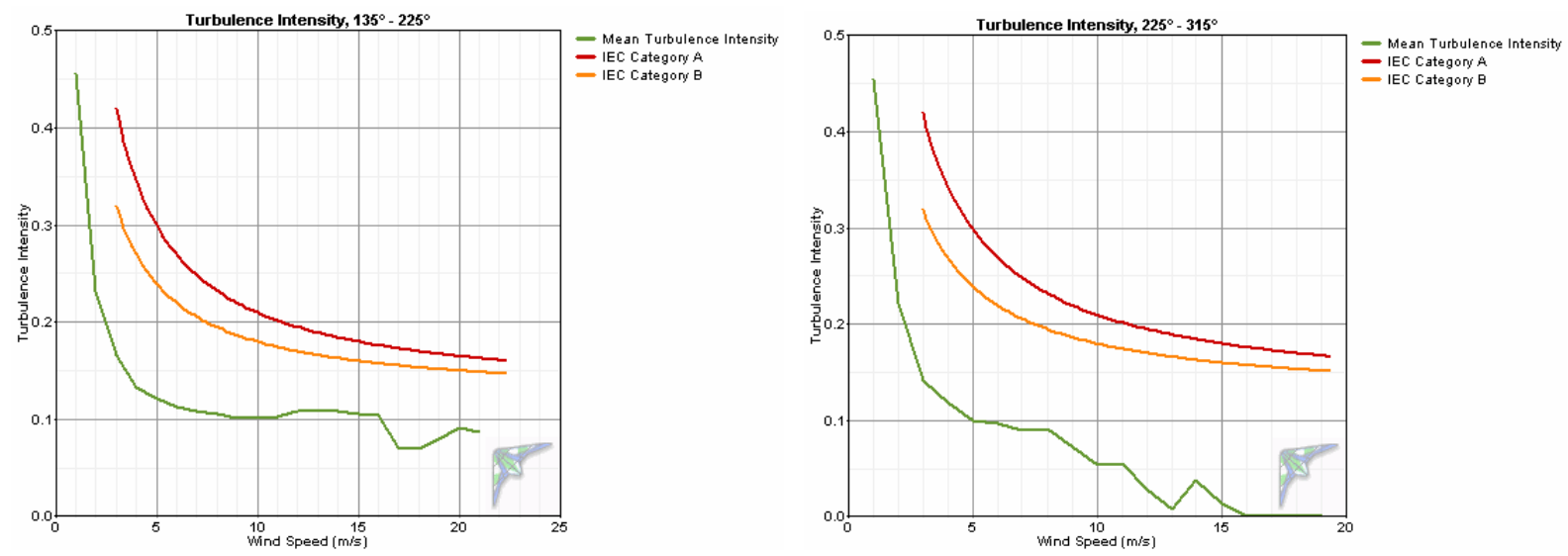

Turbulence Table

\begin{tabular}{|c|c|c|c|c|c|c|c|}
\hline $\begin{array}{c}\text { Bin } \\
\text { Midpoint } \\
(\mathrm{m} / \mathrm{s})\end{array}$ & $\begin{array}{l}\text { Bin En } \\
\text { Lower } \\
(\mathrm{m} / \mathrm{s})\end{array}$ & $\begin{array}{l}\text { Ipoints } \\
\text { Upper } \\
(\mathrm{m} / \mathrm{s}) \\
\end{array}$ & $\begin{array}{c}\text { Records } \\
\text { In } \\
\text { Bin }\end{array}$ & $\begin{array}{c}\text { Standard } \\
\text { Deviation } \\
\text { of WindSpeed } \\
(\mathrm{m} / \mathrm{s})\end{array}$ & $\begin{array}{c}\text { Mean } \\
\text { Turbulence } \\
\text { Intensity }\end{array}$ & $\begin{array}{c}\text { Standard } \\
\text { Deviation } \\
\text { of Turbulence } \\
\text { Intensity }\end{array}$ & $\begin{array}{c}\text { Characteristic } \\
\text { Turbulence } \\
\text { Intensity }\end{array}$ \\
\hline 1 & 0.5 & 1.5 & 2765 & 0.416 & 0.441 & 0.220 & 0.662 \\
\hline 2 & 1.5 & 2.5 & 5021 & 0.437 & 0.225 & 0.132 & 0.357 \\
\hline 3 & 2.5 & 3.5 & 6670 & 0.463 & 0.157 & 0.088 & 0.245 \\
\hline 4 & 3.5 & 4.5 & 7378 & 0.521 & 0.132 & 0.063 & 0.195 \\
\hline 5 & 4.5 & 5.5 & 7007 & 0.592 & 0.120 & 0.053 & 0.173 \\
\hline 6 & 5.5 & 6.5 & 5742 & 0.696 & 0.117 & 0.051 & 0.169 \\
\hline 7 & 6.5 & 7.5 & 4641 & 0.815 & 0.117 & 0.047 & 0.164 \\
\hline 8 & 7.5 & 8.5 & 3373 & 0.909 & 0.115 & 0.043 & 0.157 \\
\hline 9 & 8.5 & 9.5 & 2455 & 0.982 & 0.110 & 0.040 & 0.151 \\
\hline 10 & 9.5 & 10.5 & 1789 & 1.071 & 0.108 & 0.038 & 0.146 \\
\hline 11 & 10.5 & 11.5 & 1343 & 1.155 & 0.106 & 0.034 & 0.140 \\
\hline 12 & 11.5 & 12.5 & 945 & 1.217 & 0.102 & 0.032 & 0.134 \\
\hline 13 & 12.5 & 13.5 & 613 & 1.248 & 0.097 & 0.034 & 0.130 \\
\hline 14 & 13.5 & 14.5 & 456 & 1.376 & 0.099 & 0.033 & 0.132 \\
\hline 15 & 14.5 & 15.5 & 489 & 1.454 & 0.097 & 0.027 & 0.124 \\
\hline 16 & 15.5 & 16.5 & 398 & 1.483 & 0.093 & 0.029 & 0.122 \\
\hline 17 & 16.5 & 17.5 & 354 & 1.547 & 0.091 & 0.030 & 0.122 \\
\hline 18 & 17.5 & 18.5 & 267 & 1.660 & 0.093 & 0.029 & 0.122 \\
\hline 19 & 18.5 & 19.5 & 185 & 1.702 & 0.090 & 0.024 & 0.114 \\
\hline 20 & 19.5 & 20.5 & 100 & 1.820 & 0.092 & 0.018 & 0.110 \\
\hline 21 & 20.5 & 21.5 & 66 & 2.029 & 0.097 & 0.021 & 0.118 \\
\hline 22 & 21.5 & 22.5 & 52 & 2.038 & 0.093 & 0.015 & 0.108 \\
\hline 23 & 22.5 & 23.5 & 27 & 2.237 & 0.097 & 0.011 & 0.109 \\
\hline 24 & 23.5 & 24.5 & 25 & 2.184 & 0.091 & 0.013 & 0.104 \\
\hline 25 & 24.5 & 25.5 & 34 & 2.326 & 0.093 & 0.010 & 0.103 \\
\hline 26 & 25.5 & 26.5 & 20 & 2.415 & 0.093 & 0.012 & 0.105 \\
\hline 27 & 26.5 & 27.5 & 8 & 2.550 & 0.095 & 0.007 & 0.102 \\
\hline 28 & 27.5 & 28.5 & 1 & 2.200 & 0.079 & 0.000 & 0.079 \\
\hline
\end{tabular}




\section{Air Temperature and Density}

Over the reporting period, Koliganek had an average temperature of $1.3^{\circ} \mathrm{C}$. The minimum recorded temperature during the measurement period was $-40.4^{\circ} \mathrm{C}$ and the maximum temperature was $30.5^{\circ} \mathrm{C}$, indicating a wide variability of the ambient temperature operating environment important to wind turbine operations. Consequent to Koliganek's cool temperatures, the average air density of $1.274 \mathrm{~kg} / \mathrm{m}^{3}$ is five percent higher than the standard air density of $1.214 \mathrm{~kg} / \mathrm{m}^{3}$ (at $14.39^{\circ} \mathrm{C}$ temperature and $101.17 \mathrm{kPa}$ pressure at $95 \mathrm{~m}$ elevation), indicating that Koliganek, due to its cool annual temperature average, has denser air than the standard air density used to calculate turbine power curves.

\begin{tabular}{ccrrrrrrr} 
Year & \multicolumn{9}{c}{ Temperature } & \multicolumn{2}{c}{$\begin{array}{c}\text { Density } \\
\text { Month } \\
\end{array}$} & $\begin{array}{c}\text { Mean } \\
\left({ }^{\circ} \mathrm{C}\right)\end{array}$ & \multicolumn{1}{c}{$\begin{array}{c}\text { Min } \\
\left({ }^{\circ} \mathrm{C}\right)\end{array}$} & $\begin{array}{c}\text { Max } \\
\left({ }^{\circ} \mathrm{C}\right)\end{array}$ & $\begin{array}{c}\text { Dev. } \\
\left({ }^{\circ} \mathrm{C}\right)\end{array}$ & $\begin{array}{c}\text { Mean } \\
\left(\mathrm{kg} / \mathrm{m}^{3}\right)\end{array}$ & $\begin{array}{c}\text { Min } \\
\left(\mathrm{kg} / \mathrm{m}^{3}\right)\end{array}$ & $\begin{array}{c}\text { Max } \\
\left(\mathrm{kg} / \mathrm{m}^{3}\right)\end{array}$ \\
\hline 2005 & Jul & 15.8 & 7.6 & 29.0 & 3.9 & 1.208 & 1.155 & 1.243 \\
2005 & Aug & 14.8 & 3.1 & 29.3 & 4.7 & 1.212 & 1.154 & 1.263 \\
2005 & Sep & 9.7 & -1.8 & 18.2 & 3.6 & 1.234 & 1.198 & 1.286 \\
2005 & Oct & 1.4 & -11.0 & 12.5 & 4.8 & 1.271 & 1.222 & 1.331 \\
2005 & Nov & -13.9 & -32.2 & 0.8 & 6.3 & 1.347 & 1.274 & 1.448 \\
2005 & Dec & -4.1 & -28.8 & 5.9 & 7.6 & 1.298 & 1.251 & 1.428 \\
2006 & Jan & -18.0 & -37.0 & -1.7 & 7.5 & 1.369 & 1.286 & 1.478 \\
2006 & Feb & -5.4 & -40.4 & 3.8 & 9.2 & 1.305 & 1.260 & 1.499 \\
2006 & Mar & -7.5 & -22.6 & 3.8 & 5.8 & 1.314 & 1.260 & 1.393 \\
2006 & Apr & -1.1 & -15.7 & 9.3 & 4.3 & 1.283 & 1.235 & 1.355 \\
2006 & May & 8.2 & -5.8 & 27.3 & 6.8 & 1.241 & 1.161 & 1.305 \\
2006 & Jun & 12.2 & -0.2 & 24.4 & 4.5 & 1.223 & 1.173 & 1.278 \\
2006 & Jul & 16.3 & 5.6 & 30.5 & 5.5 & 1.206 & 1.149 & 1.252 \\
\hline Annual & & 1.3 & -40.4 & 30.5 & 12.4 & 1.274 & 1.149 & 1.499
\end{tabular}

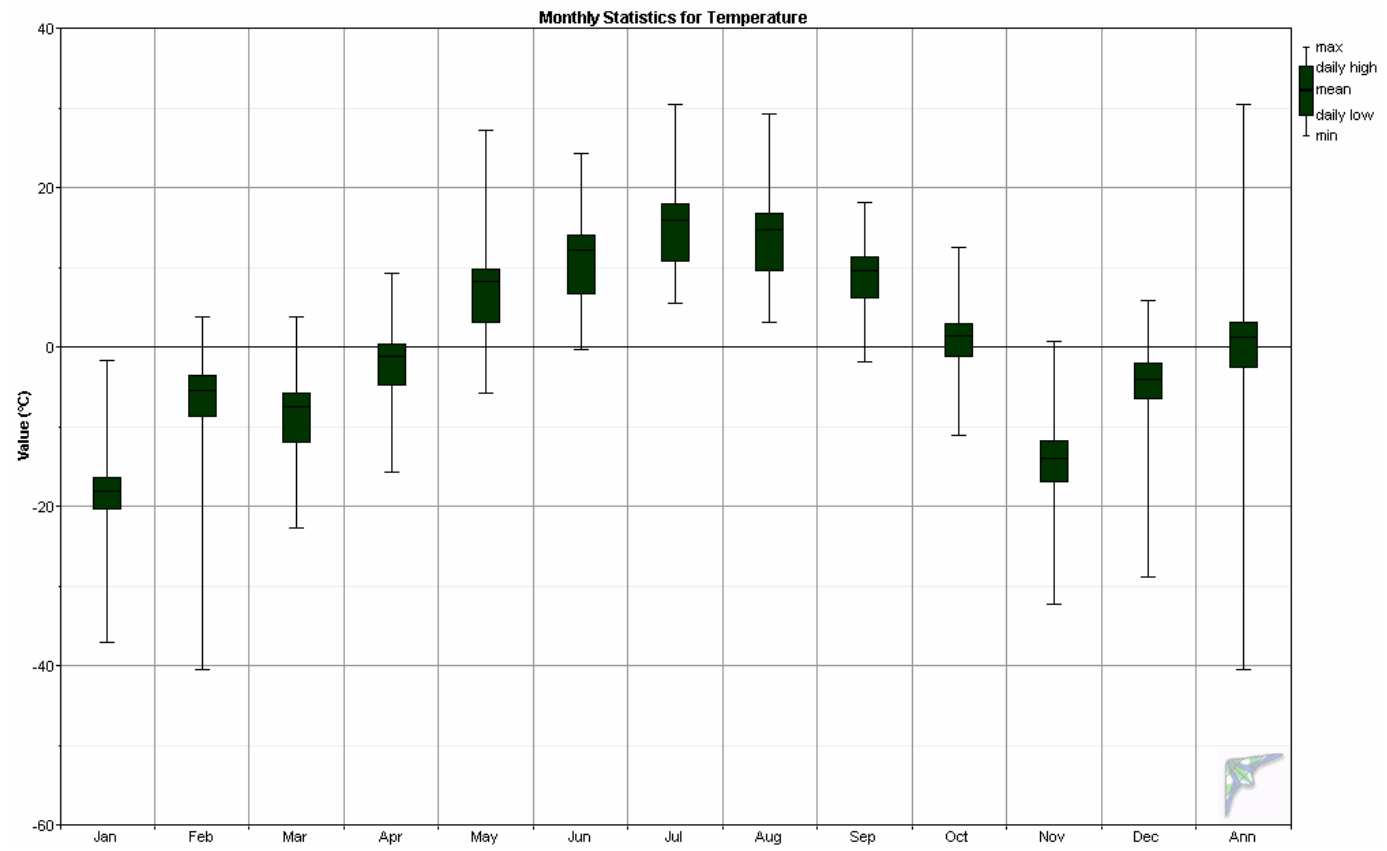




\section{Air Density DMap}

The DMap below is a visual indication of the daily and seasonal variations of air density (and hence temperature). Air densities higher than standard will yield higher turbine power than predicted by the turbine power curve, while densities lower than standard will yield lower turbine power than predicted. Density variance from standard is accounted for in the turbine performance predictions.

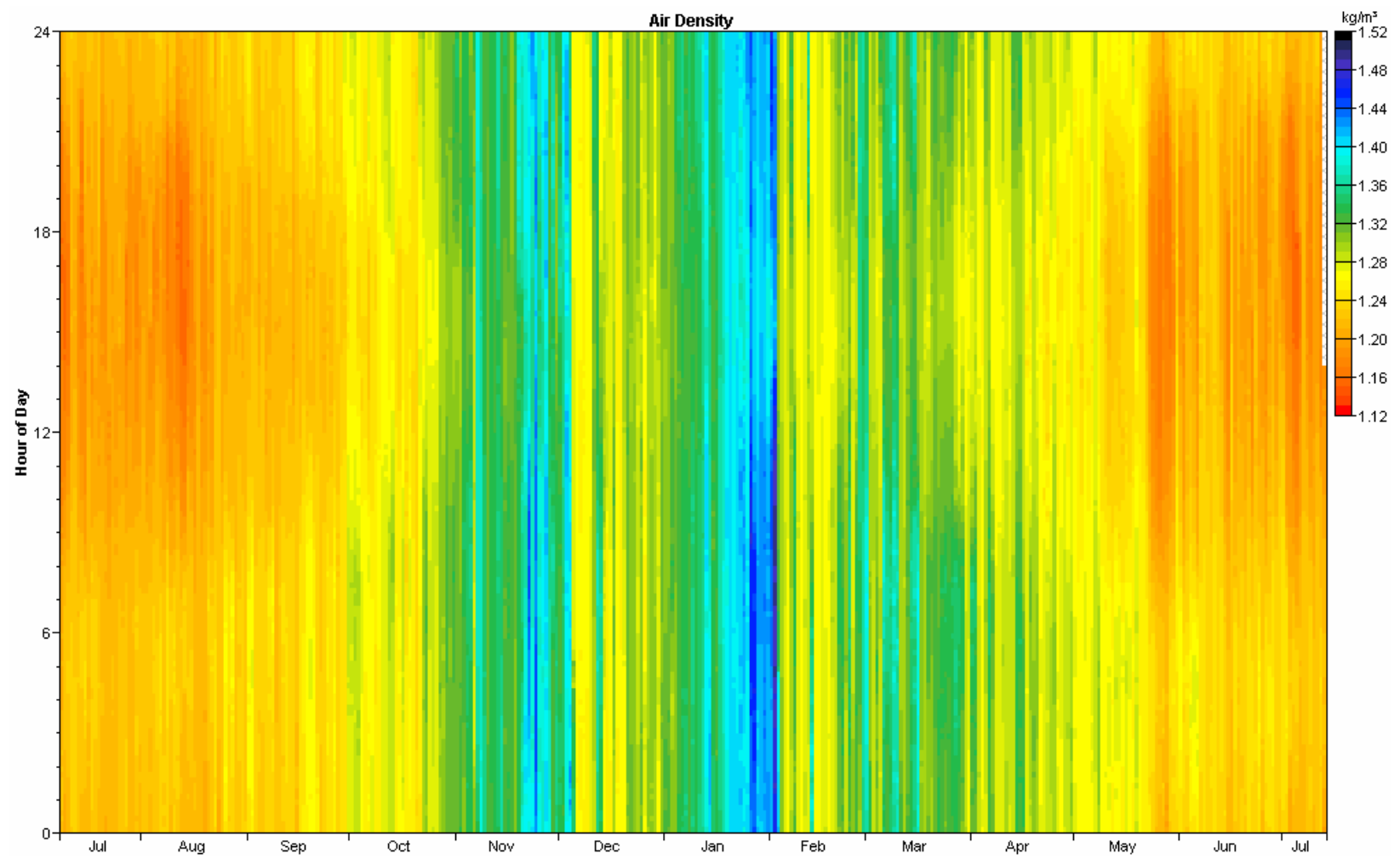




\section{Wind Turbine Performance}

The turbine performance predictions noted below are based on 100 percent and 89 percent turbine availabilities. The 100 percent data is for use as a baseline of comparison, but it is realistic to expect ten percent or more of losses or downtime for wind turbines located in a small, remote community.

Note that these performance estimates were predicted with use of Windographer ${ }^{\circledR}$ wind analysis software; power curves provided by manufacturers are not independently verified and are assumed to be accurate. The power curves are presented for a standard air density of $1.225 \mathrm{~kg} / \mathrm{m}^{3}$ at sea level and $15^{\circ} \mathrm{C}$. However, the predictions of power production are density compensated by multiplying the standard density power output by the ratio of the measured air density to standard air density, accounting for the site elevation.

A number of smaller village-scale grid-connected turbines are profiled in this report for comparison purposes. These turbines were selected because they have market availability and they are deemed to be within a suitable range for consideration of wind power development in a village the size of Koliganek.

Southwest Skystream 3.7: $1.8 \mathrm{~kW}$ rated power output, 3.7 meter rotor diameter, stallcontrolled. Available tower heights: 10.7 and 33.5 meters. Additional information is available at www.skystreamenergy.com.

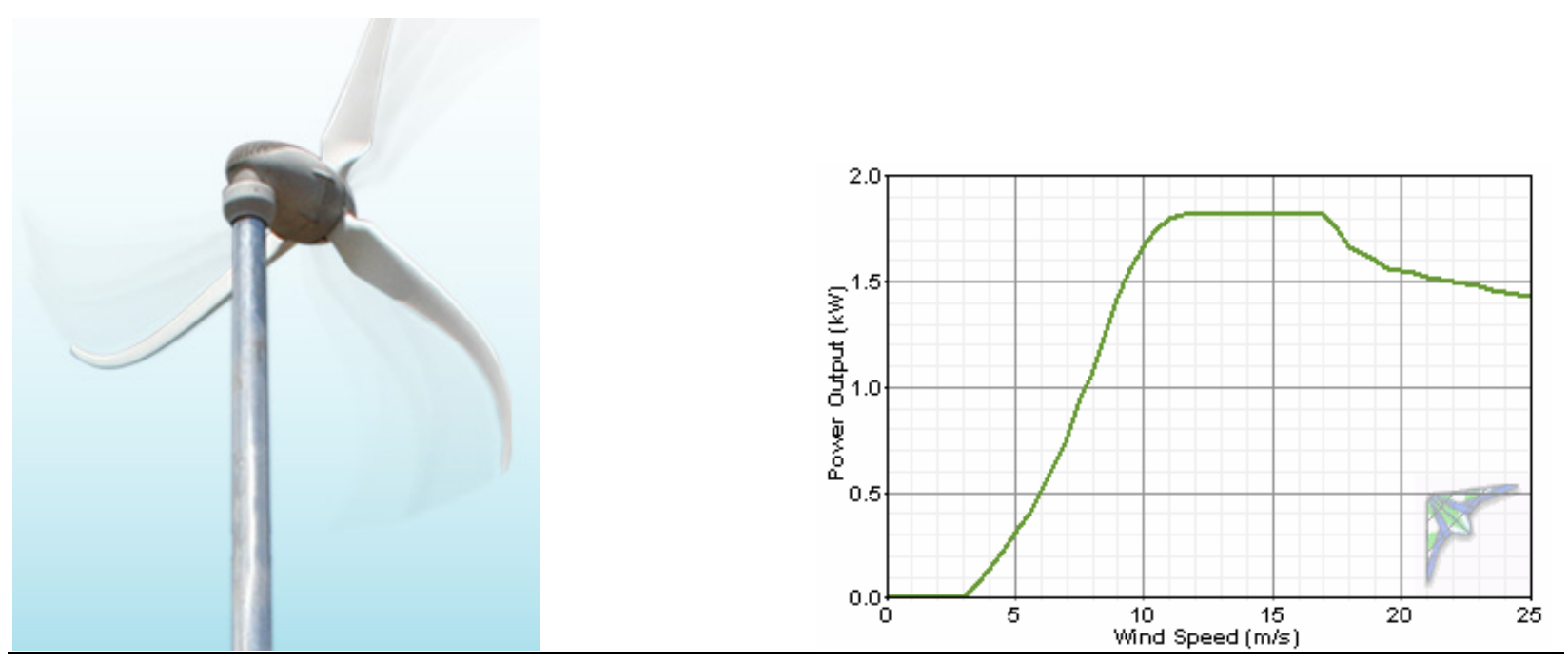

Bergey Excel-S: $10 \mathrm{~kW}$ rated power output, 6.7 meter rotor diameter, stall-controlled. Available tower heights: 18, 24, 30, 37 and 43 meters. Additional information is available at www.bergey.com. 

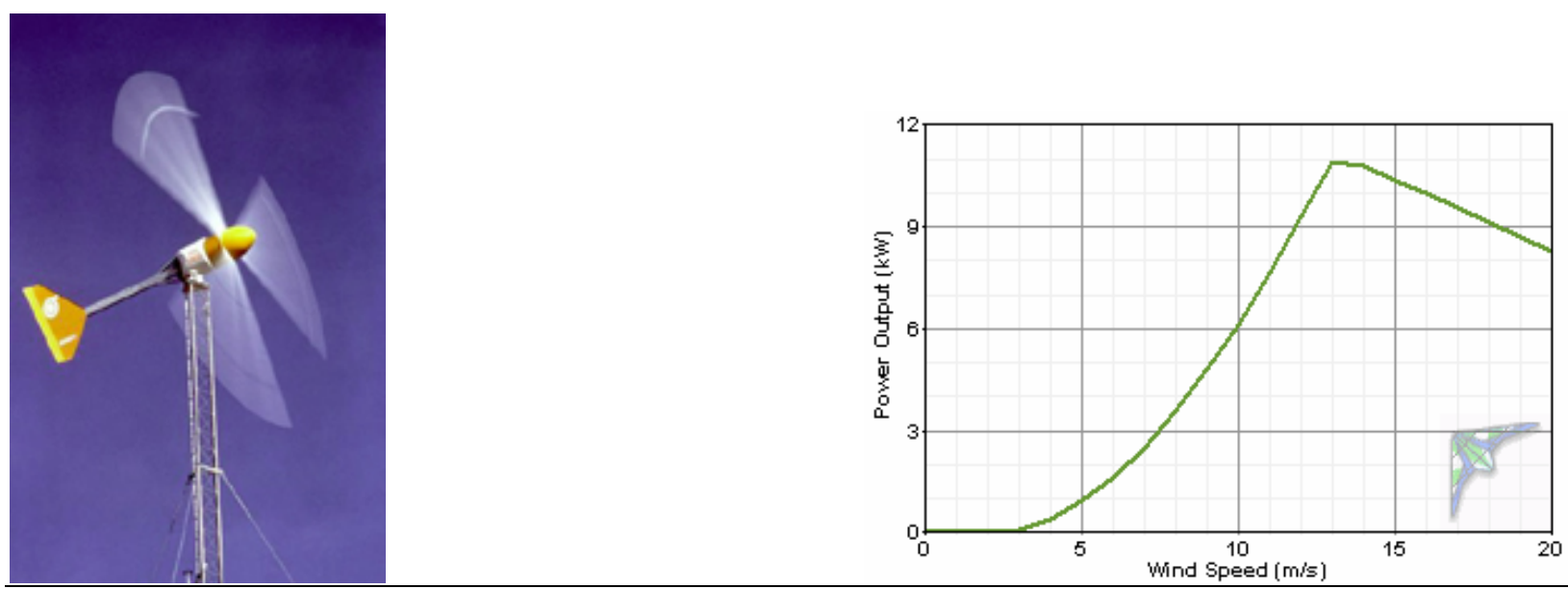

Fuhrländer FL30: $30 \mathrm{~kW}$ rated power output, 13 meter rotor, stall-controlled (power curve provided by Lorax Energy, LLC). Available tower heights: 26 and 30 meters. Additional information is available at http://www.fuhrlaender.de/ and http://www.lorax-energy.com/.
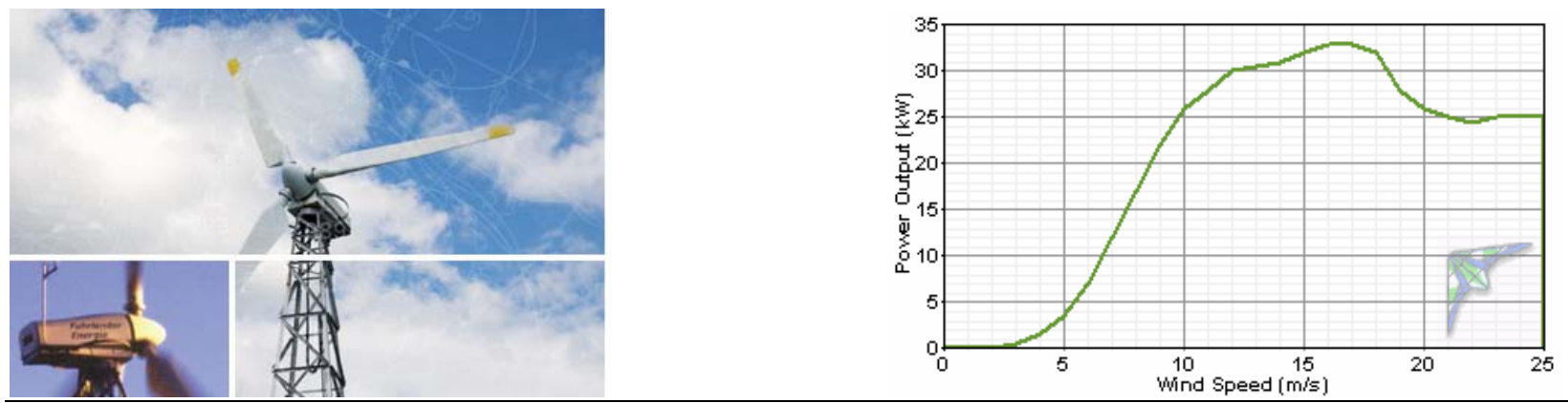

Entegrity eW-15: $65 \mathrm{~kW}$ rated power output, 15 meter rotor, stall-controlled (power curve provided by Entegrity Energy Systems). Available tower heights: 25 and 31 meters. Additional information is available at http://www.entegritywind.com/.
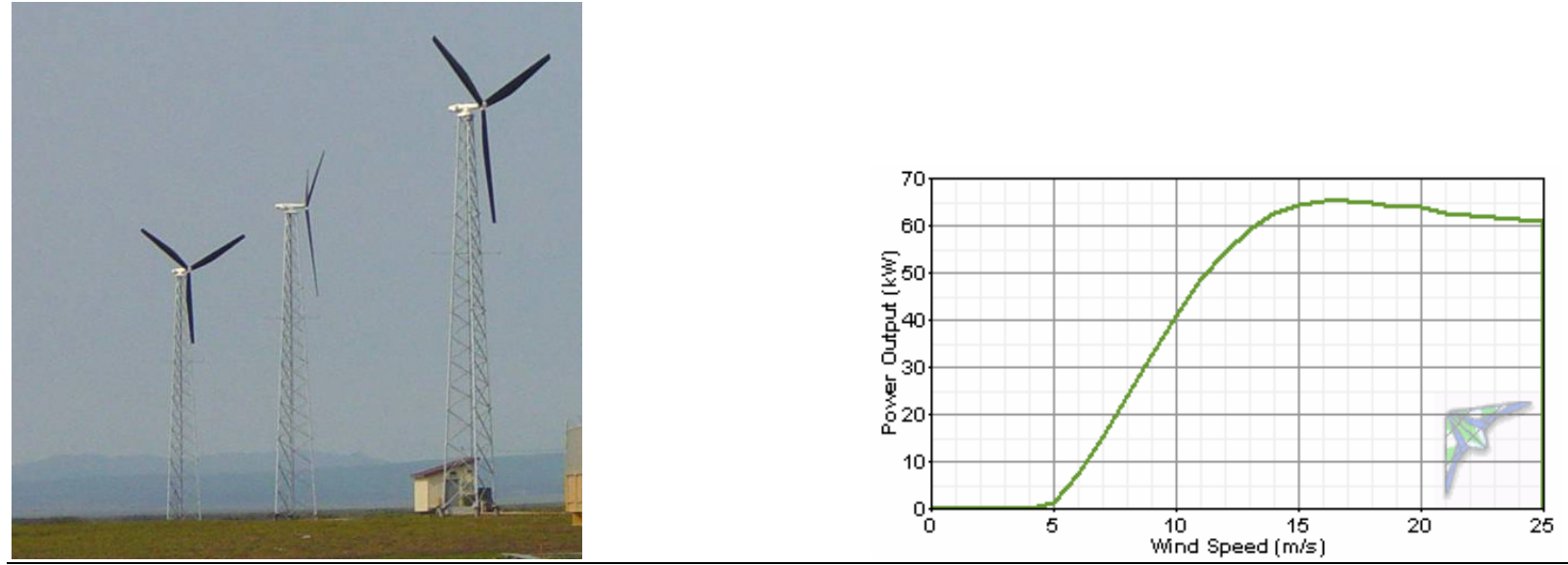
Vestas V15: $75 \mathrm{~kW}$ rated power output, 15 meter rotor, stall-controlled (power curve provided by Powercorp Alaska LLC). Available tower heights: 25, 31 and 34 meters. Additional information is available at http://www.pcorpalaska.com/.
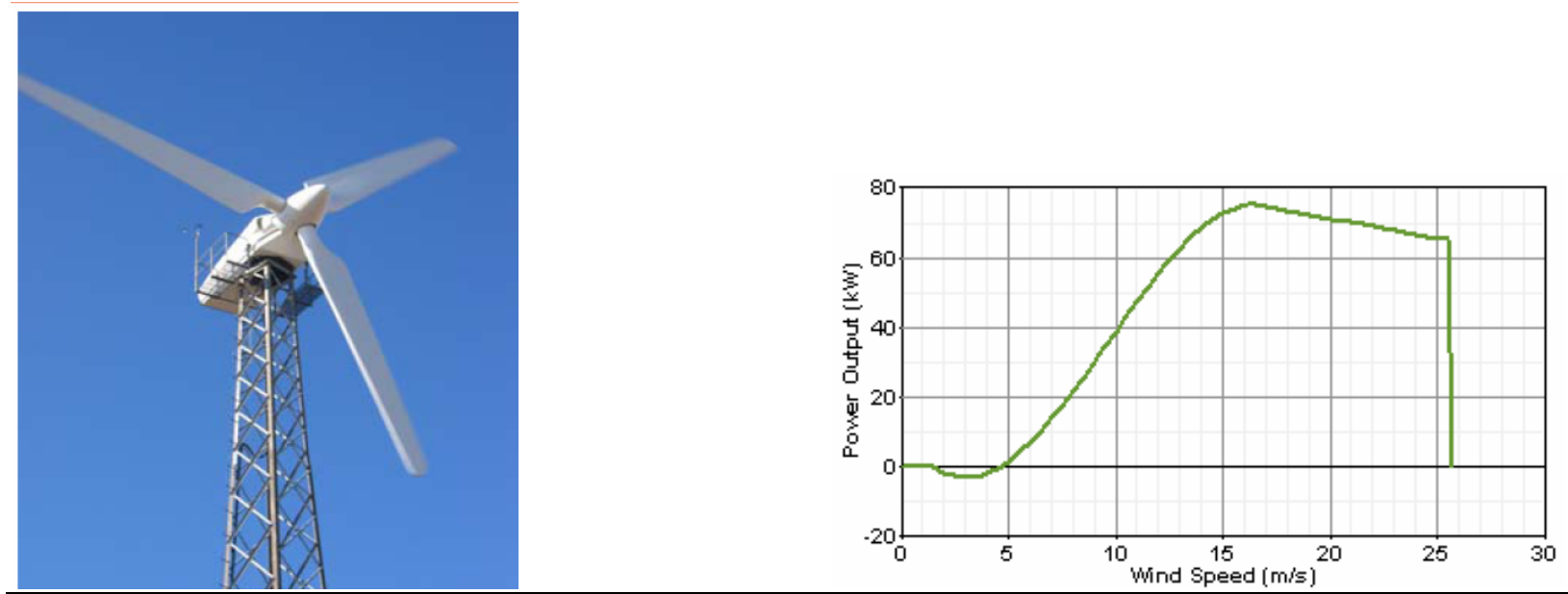

Northwind 100/20: $100 \mathrm{~kW}$ rated power output, 20 meter rotor (19 meter rotor blades with 0.6 meter blade root extensions added), stall-controlled (power curve provided by Northern Power Systems). Available tower heights: 25 and 32 meters. Additional information is available at http://www.northernpower.com/.
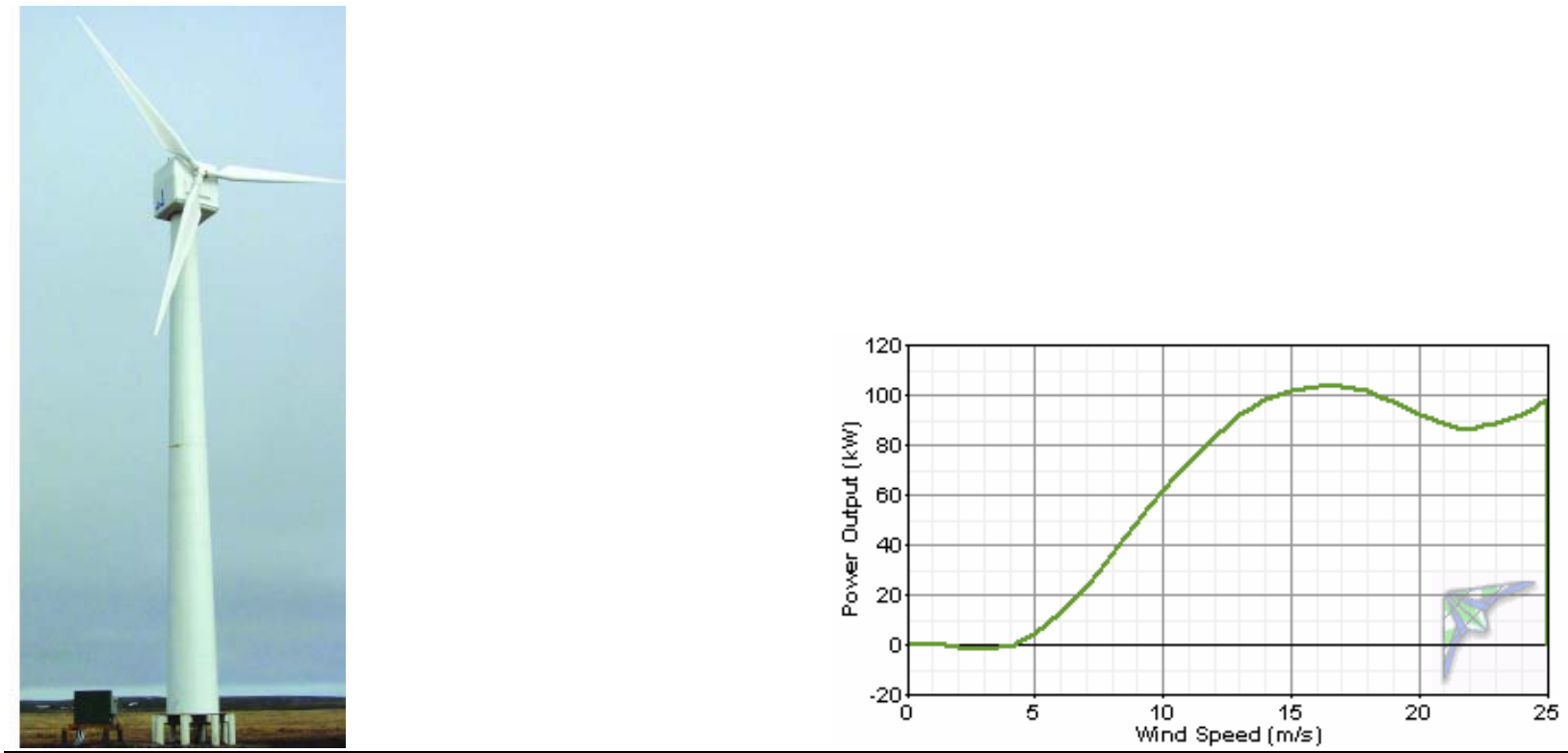
Koliganek, Alaska Wind Resource Report

Turbine Power Output Comparison (100\% availability)

\begin{tabular}{|c|c|c|c|c|c|c|c|}
\hline Turbine & $\begin{array}{l}\text { Hub } \\
\text { Height } \\
\text { (m) }\end{array}$ & $\begin{array}{l}\text { Hub } \\
\text { Height } \\
\text { Wind } \\
\text { Speed } \\
(\mathrm{m} / \mathrm{s})\end{array}$ & $\begin{array}{c}\text { Time At } \\
\text { Zero } \\
\text { Output } \\
(\%)\end{array}$ & $\begin{array}{c}\text { Time At } \\
\text { Rated } \\
\text { Output } \\
(\%)\end{array}$ & $\begin{array}{l}\text { Average } \\
\text { Power } \\
\text { Output } \\
\text { (kW) }\end{array}$ & $\begin{array}{c}\text { Annual } \\
\text { Energy } \\
\text { Output } \\
\text { (kWh/yr) }\end{array}$ & $\begin{array}{c}\text { Average } \\
\text { Capacity } \\
\text { Factor } \\
(\%)\end{array}$ \\
\hline Southwest Skystream 3.7 & 10.7 & 4.59 & 37.1 & 5.3 & 0.4 & 3,387 & 21.5 \\
\hline Southwest Skystream 3.7 & 33.5 & 5.74 & 24.0 & 8.6 & 0.6 & 5,029 & 31.9 \\
\hline Bergey Excel-S & 24 & 5.37 & 15.4 & 3.2 & 2.0 & 17,115 & 19.5 \\
\hline Bergey Excel-S & 37 & 5.87 & 13.5 & 3.8 & 2.3 & 20,079 & 22.9 \\
\hline Fuhrländer FL30 & 26 & 5.46 & 15.0 & 2.0 & 8.1 & 71,117 & 24.6 \\
\hline Fuhrländer FL30 & 30 & 5.72 & 12.5 & 2.1 & 8.8 & 76,617 & 26.5 \\
\hline Entegrity eW-15 $60 \mathrm{~Hz}$ & 25 & 5.42 & 40.5 & 3.1 & 11.7 & 102,612 & 18.0 \\
\hline Entegrity eW-15 $60 \mathrm{~Hz}$ & 31 & 5.65 & 37.4 & 3.4 & 12.8 & 111,880 & 19.6 \\
\hline Vestas V15 & 25 & 5.42 & 48.4 & 2.1 & 10.7 & 93,939 & 14.3 \\
\hline Vestas V15 & 34 & 5.76 & 43.8 & 2.4 & 12.4 & 108,608 & 16.5 \\
\hline Northern Power NW 100/20 & 25 & 5.42 & 40.5 & 2.9 & 17.4 & 152,548 & 17.4 \\
\hline Northern Power NW 100/20 & 32 & 5.69 & 37.0 & 3.2 & 19.2 & 168,281 & 19.2 \\
\hline \multicolumn{8}{|l|}{ Capacity Factor <20\% } \\
\hline \multicolumn{8}{|l|}{ Capacity Factor $>20 \%,<30 \%$} \\
\hline \multicolumn{8}{|l|}{ Capacity Factor >30\%, <40\% } \\
\hline \multicolumn{8}{|l|}{ Capacity Factor >40\%, <50\% } \\
\hline Capacity Factor >50\% & & & & & & & \\
\hline
\end{tabular}

Assumed turbine losses for predictions of average power output, annual energy output, and average capacity factor:

Downtime (\%)

Array (\%)

Icing/soiling (\%)

Other (\%)

Total (\%)

0

0

0 
Koliganek, Alaska Wind Resource Report

Turbine Power Output Comparison (89\% availability)

\begin{tabular}{|c|c|c|c|c|c|c|c|}
\hline Turbine & $\begin{array}{l}\text { Hub } \\
\text { Height } \\
\text { (m) }\end{array}$ & $\begin{array}{l}\text { Hub } \\
\text { Height } \\
\text { Wind } \\
\text { Speed } \\
(\mathrm{m} / \mathrm{s})\end{array}$ & $\begin{array}{l}\text { Time At } \\
\text { Zero } \\
\text { Output } \\
(\%)\end{array}$ & $\begin{array}{c}\text { Time At } \\
\text { Rated } \\
\text { Output } \\
(\%)\end{array}$ & $\begin{array}{c}\text { Average } \\
\text { Power } \\
\text { Output } \\
\text { (kW) }\end{array}$ & $\begin{array}{c}\text { Annual } \\
\text { Energy } \\
\text { Output } \\
\text { (kWh/yr) }\end{array}$ & $\begin{array}{c}\text { Average } \\
\text { Capacity } \\
\text { Factor } \\
(\%)\end{array}$ \\
\hline Southwest Skystream 3.7 & 10.7 & 4.59 & 37.1 & 5.3 & 0.3 & 3,028 & 19.2 \\
\hline Southwest Skystream 3.7 & 33.5 & 5.74 & 24.0 & 8.6 & 0.5 & 4,496 & 28.5 \\
\hline Bergey Excel-S & 24 & 5.37 & 15.4 & 3.2 & 1.8 & 15,302 & 17.5 \\
\hline Bergey Excel-S & 37 & 5.87 & 13.5 & 3.8 & 2.1 & 17,952 & 20.5 \\
\hline Fuhrländer FL30 & 26 & 5.46 & 15.0 & 2.0 & 7.3 & 63,582 & 22.0 \\
\hline Fuhrländer FL30 & 30 & 5.72 & 12.5 & 2.1 & 7.8 & 68,498 & 23.7 \\
\hline Entegrity eW-15 $60 \mathrm{~Hz}$ & 25 & 5.42 & 40.5 & 3.1 & 10.5 & 91,739 & 16.1 \\
\hline Entegrity eW-15 $60 \mathrm{~Hz}$ & 31 & 5.65 & 37.4 & 3.4 & 11.4 & 100,025 & 17.6 \\
\hline Vestas V15 & 25 & 5.42 & 48.4 & 2.1 & 9.6 & 83,985 & 12.8 \\
\hline Vestas V15 & 34 & 5.76 & 43.8 & 2.4 & 11.1 & 97,100 & 14.8 \\
\hline Northern Power NW 100/20 & 25 & 5.42 & 40.5 & 2.9 & 15.6 & 136,384 & 15.6 \\
\hline Northern Power NW 100/20 & 32 & 5.69 & 37.0 & 3.2 & 17.2 & 150,449 & 17.2 \\
\hline \multicolumn{8}{|l|}{ Capacity Factor <20\% } \\
\hline \multicolumn{8}{|l|}{ Capacity Factor >20\%, <30\% } \\
\hline \multicolumn{8}{|l|}{ Capacity Factor >30\%, <40\% } \\
\hline \multicolumn{8}{|l|}{ Capacity Factor $>40 \%,<50 \%$} \\
\hline Capacity Factor >50\% & & & & & & & \\
\hline
\end{tabular}

Assumed turbine losses for predictions of average power output, annual energy output, and average capacity factor:

Downtime (\%)

Array (\%)

Icing/soiling (\%)

Other (\%)

Total (\%)

$\begin{array}{cl}5 & \\ 1 & \\ 3 & \\ 2 & \\ 10.6 & \text { (factors are multiplicative) }\end{array}$


Koliganek, Alaska Wind Resource Report

Annual Fuel Cost Avoided for Energy Generated by Wind Turbine vs. Diesel Generator

\begin{tabular}{|c|c|c|c|c|c|c|c|c|c|c|c|}
\hline \multirow[b]{2}{*}{ Turbine } & \multirow{2}{*}{$\begin{array}{c}\text { Annual } \\
\text { Energy } \\
\text { Output } \\
\text { (kW-hr/yr) }\end{array}$} & \multirow{2}{*}{$\begin{array}{c}\text { Fuel } \\
\text { Quantity } \\
\text { Avoided } \\
\text { (liters) }\end{array}$} & \multirow[t]{2}{*}{$\begin{array}{c}\text { Fuel } \\
\text { Quantity } \\
\text { Avoided } \\
\text { (gallons) }\end{array}$} & \multicolumn{7}{|c|}{ Fuel Price (USD/gallon) } & \multirow[t]{2}{*}{$\begin{array}{c}\text { Turbine } \\
\text { Hub } \\
\text { Height } \\
\text { (m) }\end{array}$} \\
\hline & & & & $\$ 1.75$ & $\$ 2.00$ & $\$ 2.25$ & $\$ 2.50$ & $\$ 2.75$ & $\$ 3.00$ & $\$ 3.25$ & \\
\hline Southwest Skystream 3.7 & 3,028 & 917 & 242 & $\$ 424$ & $\$ 484$ & $\$ 545$ & $\$ 606$ & $\$ 666$ & $\$ 727$ & $\$ 787$ & 10.7 \\
\hline Bergey Excel-S & 15,302 & 4,634 & 1,224 & $\$ 2,142$ & $\$ 2,448$ & $\$ 2,754$ & $\$ 3,060$ & $\$ 3,366$ & $\$ 3,672$ & $\$ 3,979$ & 24 \\
\hline Bergey Excel-S & 17,952 & 5,436 & 1,436 & $\$ 2,513$ & $\$ 2,872$ & $\$ 3,231$ & $\$ 3,590$ & $\$ 3,949$ & $\$ 4,308$ & $\$ 4,668$ & 37 \\
\hline Fuhrländer FL30 & 63,582 & 19,255 & 5,087 & $\$ 8,901$ & $\$ 10,173$ & $\$ 11,445$ & $\$ 12,716$ & $\$ 13,988$ & $\$ 15,260$ & $\$ 16,531$ & 26 \\
\hline Entegrity eW-15 $60 \mathrm{~Hz}$ & 100,025 & 30,291 & 8,002 & $\$ 14,004$ & $\$ 16,004$ & $\$ 18,005$ & $\$ 20,005$ & $\$ 22,006$ & $\$ 24,006$ & $\$ 26,007$ & 31 \\
\hline Vestas V15 & 83,985 & 25,433 & 6,719 & $\$ 11,758$ & $\$ 13,438$ & $\$ 15,117$ & $\$ 16,797$ & $\$ 18,477$ & $\$ 20,156$ & $\$ 21,836$ & 25 \\
\hline Vestas V15 & 97,100 & 29,405 & 7,768 & $\$ 13,594$ & $\$ 15,536$ & $\$ 17,478$ & $\$ 19,420$ & $\$ 21,362$ & $\$ 23,304$ & $\$ 25,246$ & 34 \\
\hline Northern Power NW & 136,384 & & 10,911 & $\$ 19,094$ & $\$ 21,821$ & $\$ 24,549$ & $\$ 27,277$ & $\$ 30,004$ & $\$ 32,732$ & $\$ 35,460$ & 25 \\
\hline Northern Power NW 100/20 & 150,449 & 45,561 & 12,036 & $\$ 21,063$ & $\$ 24,072$ & $\$ 27,081$ & $\$ 30,090$ & $\$ 33,099$ & $\$ 36,108$ & $\$ 39,117$ & 32 \\
\hline
\end{tabular}

Notes:

1. Koliganek electrical energy production efficiency assumed to be $12.5 \mathrm{~kW}$-hr/gal

2. Assumes $89 \%$ wind turbine availability with no diversion of power to a thermal or other dump load

3. Assumes linear diesel generator fuel efficiency (i.e., 1:1 tradeoff of wind turbine kW-hr to diesel genset kW-hr) 
Koliganek, Alaska Wind Resource Report

Temperature Conversion Chart ${ }^{\circ} \mathrm{C}$ to ${ }^{\circ} \mathrm{F}$

\begin{tabular}{|c|c|c|c|c|c|}
\hline${ }^{\circ} \mathbf{C}$ & ${ }^{\circ} \mathbf{F}$ & ${ }^{\circ} \mathbf{C}$ & ${ }^{\circ} \mathbf{F}$ & ${ }^{\circ} \mathbf{C}$ & ${ }^{\circ} \mathbf{F}$ \\
\hline-40 & -40 & -10 & 14 & 20 & 68 \\
\hline-39 & -38.2 & -9 & 15.8 & 21 & 69.8 \\
\hline-38 & -36.4 & -8 & 17.6 & 22 & 71.6 \\
\hline-37 & -34.6 & -7 & 19.4 & 23 & 73.4 \\
\hline-36 & -32.8 & -6 & 21.2 & 24 & 75.2 \\
\hline-35 & -31 & -5 & 23 & 25 & 77 \\
\hline-34 & 29.2 & -4 & 24.8 & 26 & 78.8 \\
\hline-33 & -27.4 & -3 & 26.6 & 27 & 80.6 \\
\hline-32 & -25.6 & -2 & 28.4 & 28 & 82.4 \\
\hline-31 & -23.8 & -1 & 30.2 & 29 & 84.2 \\
\hline-30 & -22 & 0 & 32 & 30 & 86 \\
\hline-29 & -20.2 & 1 & 33.8 & 31 & 87.8 \\
\hline-28 & -18.4 & 2 & 35.6 & 32 & 89.6 \\
\hline-27 & -16.6 & 3 & 37.4 & 33 & 91.4 \\
\hline-26 & -14.8 & 4 & 39.2 & 34 & 93.2 \\
\hline-25 & -13 & 5 & 41 & 35 & 95 \\
\hline-24 & -11.2 & 6 & 42.8 & 36 & 96.8 \\
\hline-23 & -9.4 & 7 & 44.6 & 37 & 98.6 \\
\hline-22 & -7.6 & 8 & 46.4 & 38 & 100.4 \\
\hline-21 & -5.8 & 9 & 48.2 & 39 & 102.2 \\
\hline-20 & -4 & 10 & 50 & 40 & 104 \\
\hline-19 & -2.2 & 11 & 51.8 & 41 & 105.8 \\
\hline-18 & -0.4 & 12 & 53.6 & 42 & 107.6 \\
\hline-17 & 1.4 & 13 & 55.4 & 43 & 109.4 \\
\hline-16 & 3.2 & 14 & 57.2 & 44 & 111.2 \\
\hline-15 & 5 & 15 & 59 & 45 & 113 \\
\hline-14 & 6.8 & 16 & 60.8 & 46 & 114.8 \\
\hline-13 & 8.6 & 17 & 62.6 & 47 & 116.6 \\
\hline-12 & 10.4 & 18 & 64.4 & 48 & 118.4 \\
\hline-11 & 12.2 & 19 & 66.2 & 49 & 120.2 \\
\hline & & & & & \\
\hline-21 & & & & \\
\hline
\end{tabular}


Koliganek, Alaska Wind Resource Report

Wind Speed Conversion Chart $\mathrm{m} / \mathrm{s}$ to $\mathrm{mph}$

\begin{tabular}{|c|c|c|c|c|c|}
\hline $\mathbf{m} / \mathbf{s}$ & $\mathbf{m p h}$ & $\mathbf{m} / \mathbf{s}$ & $\mathbf{m p h}$ & $\mathbf{~} / \mathbf{s}$ & $\mathbf{m p h}$ \\
\hline 0.5 & 1.1 & 10.5 & 23.5 & 20.5 & 45.9 \\
\hline 1.0 & 2.2 & 11.0 & 24.6 & 21.0 & 47.0 \\
\hline 1.5 & 3.4 & 11.5 & 25.7 & 21.5 & 48.1 \\
\hline 2.0 & 4.5 & 12.0 & 26.8 & 22.0 & 49.2 \\
\hline 2.5 & 5.6 & 12.5 & 28.0 & 22.5 & 50.3 \\
\hline 3.0 & 6.7 & 13.0 & 29.1 & 23.0 & 51.4 \\
\hline 3.5 & 7.8 & 13.5 & 30.2 & 23.5 & 52.6 \\
\hline 4.0 & 8.9 & 14.0 & 31.3 & 24.0 & 53.7 \\
\hline 4.5 & 10.1 & 14.5 & 32.4 & 24.5 & 54.8 \\
\hline 5.0 & 11.2 & 15.0 & 33.6 & 25.0 & 55.9 \\
\hline 5.5 & 12.3 & 15.5 & 34.7 & 25.5 & 57.0 \\
\hline 6.0 & 13.4 & 16.0 & 35.8 & 26.0 & 58.2 \\
\hline 6.5 & 14.5 & 16.5 & 36.9 & 26.5 & 59.3 \\
\hline 7.0 & 15.7 & 17.0 & 38.0 & 27.0 & 60.4 \\
\hline 7.5 & 16.8 & 17.5 & 39.1 & 27.5 & 61.5 \\
\hline 8.0 & 17.9 & 18.0 & 40.3 & 28.0 & 62.6 \\
\hline 8.5 & 19.0 & 18.5 & 41.4 & 28.5 & 63.8 \\
\hline 9.0 & 20.1 & 19.0 & 42.5 & 29.0 & 64.9 \\
\hline 9.5 & 21.3 & 19.5 & 43.6 & 29.5 & 66.0 \\
\hline 10.0 & 22.4 & 20.0 & 44.7 & 30.0 & 67.1 \\
\hline
\end{tabular}

Distance Conversion $\mathrm{m}$ to $\mathrm{ft}$

\begin{tabular}{|c|c|c|c|}
\hline $\mathbf{m}$ & $\mathbf{f t}$ & $\mathbf{m}$ & $\mathbf{f t}$ \\
\hline 5 & 16 & 35 & 115 \\
\hline 10 & 33 & 40 & 131 \\
\hline 15 & 49 & 45 & 148 \\
\hline 20 & 66 & 50 & 164 \\
\hline 25 & 82 & 55 & 180 \\
\hline 30 & 98 & 60 & 197 \\
\hline
\end{tabular}


Selected definitions (courtesy of Windographer® software by Mistaya Engineering Inc.)

\section{$\underline{\text { Wind Power Class }}$}

The wind power class is a number indicating the average energy content of the wind resource. Wind power classes are based on the average wind power density at 50 meters above ground, according to the following table. Source: Wind Energy Resource Atlas of the United States (http://rredc.nrel.gov/wind/pubs/atlas/tables/A-8T.html)

\begin{tabular}{|c|l|c|}
\hline \multicolumn{2}{|c|}{} & \multicolumn{2}{|c|}{} \\
\hline Wind Power Class & Description & Power Density at 50m $\mathbf{( W / \mathbf { m } ^ { 2 }}$ \\
\hline 1 & Poor & $0-200$ \\
\hline 2 & Marginal & $200-300$ \\
\hline 3 & Fair & $300-400$ \\
\hline 4 & Good & $400-500$ \\
\hline 5 & Excellent & $500-600$ \\
\hline 6 & Outstanding & $600-800$ \\
\hline 7 & Superb & $800-2000$ \\
\hline
\end{tabular}

Windographer classifies any wind resource with an average wind power density above 2000 $\mathrm{W} / \mathrm{m}^{2}$ as class 8 .

Probability Distribution Function

The probability distribution function $\mathrm{f}(\mathrm{x})$ gives the probability that a variable will take on the value $\mathrm{x}$. It is often expressed using a frequency histogram, which gives the frequency with which the variable falls within certain ranges or bins.

\section{$\underline{\text { Wind Turbine Power Regulation }}$}

All wind turbines employ some method of limiting power output at high wind speeds to avoid damage to mechanical or electrical subsystems. Most wind turbines employ either stall control or pitch control to regulate power output.

A stall-controlled turbine typically has blades that are fixed in place, and are designed to experience aerodynamic stall at very high wind speeds. Aerodynamic stall dramatically reduces the torque produced by the blades, and therefore the power produced by the turbine.

On a pitch-controlled turbine, a controller adjusts the angle (pitch) of the blades to best match the wind speed. At very high wind speeds the controller increasingly feathers the blades out of the wind to limit the power output. 


\section{Naknek, Alaska Wind Resource Report}

Report written by: Douglas Vaught, P.E., V3 Energy, LLC

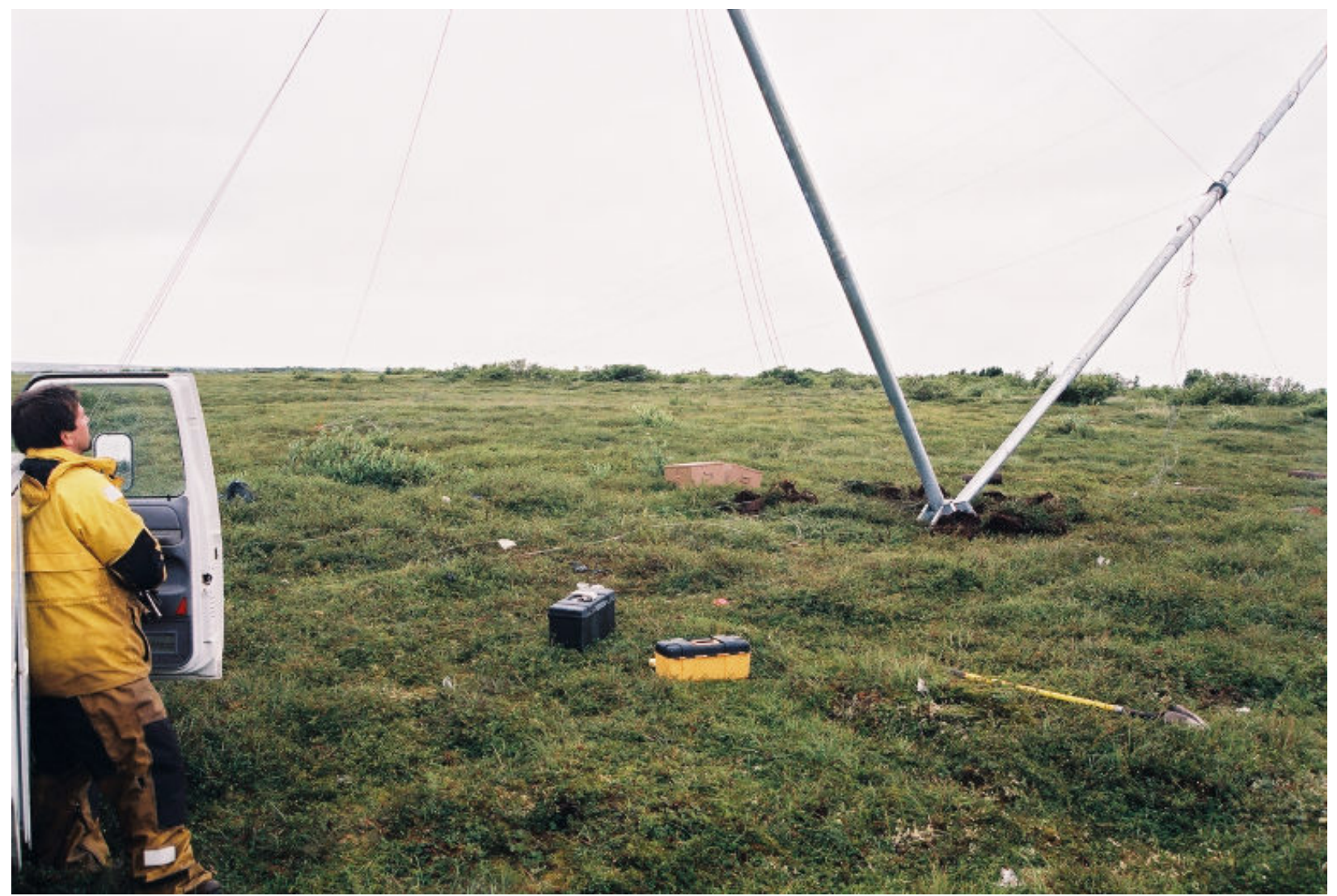

Photo (C) Doug Vaught

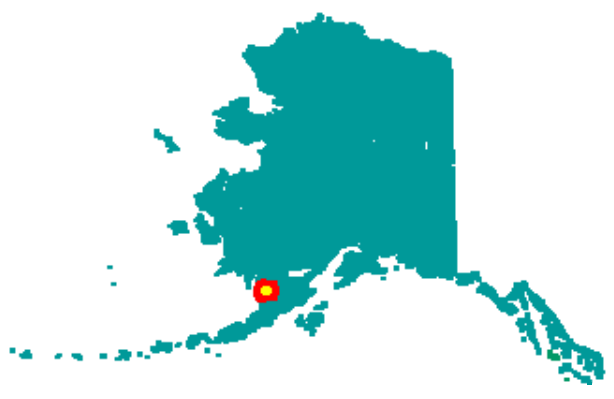

\section{Summary Information}

The measured wind resource in Naknek showed good potential for wind energy development as a mid-Class 3 wind power class and excellent turbulence behavior. The monitored site, near the borough landfill, does exhibit more wind shear than desirable, necessitating tall turbine towers, and in other respects may not be desirable to develop, but there is plenty of similar terrain nearby suitable for wind power development. In July 2006, the meteorological test tower was moved to 
a site closer to Naknek Bay which may prove superior to the landfill site because of its closer proximity to onshore winds; early data recovery from the new site suggests this will be the case.

\section{Meteorological Tower Data Synopsis}

Wind power class

Wind speed annual average (30 meters)

Maximum wind gust (2 sec. average)

Mean wind power density (50 meters)

Mean wind power density (50 meters)

Weibull distribution parameters

Roughness Class

Power law exponent

Turbulence Intensity (30 meters)

Data start date

Data end date
Class 3 - Fair

$6.22 \mathrm{~m} / \mathrm{s}$

$32.9 \mathrm{~m} / \mathrm{s}$, April, 2005

$368 \mathrm{~W} / \mathrm{m}^{2}$ (calculated)

$301 \mathrm{~W} / \mathrm{m}^{2}$ (measured)

$\mathrm{k}=1.99, \mathrm{c}=7.02 \mathrm{~m} / \mathrm{s}$

1.86 (few trees)

0.175 (moderate wind shear)

0.102 (excellent)

July 27, 2004

July 19, 2006

Community Profile

Current Population: 577 (2005 State Demographer est.)

Pronunciation/Other Names: (NACK-neck)

Incorporation Type: Unincorporated

Borough Located In: Bristol Bay Borough

School District: Bristol Bay Borough Schools

Regional Native Corporation: Bristol Bay Native Corporation

\section{Location:}

Naknek is located on the north bank of the Naknek River, at the northeastern end of Bristol Bay. It is 297 miles southwest of Anchorage. It lies at approximately $58.728330^{\circ}$ North Latitude and $-157.013890^{\circ}$ West Longitude. (Sec. 03, T017S, R047W, Seward Meridian.) Naknek is located in the Kvichak Recording District. The area encompasses 84.2 sq. miles of land and 0.7 sq. miles of water.

\section{History:}

This region was first settled over 6,000 years ago by Yup'ik Eskimos and Athabascan Indians. In 1821, the original Eskimo village of "Naugeik" was noted by Capt. Lt. Vasiliev. By 1880, the village was called Kinuyak. It was later spelled Naknek by the Russian Navy. The Russians built a fort near the village and fur trappers inhabited the area for some time prior to the U.S. purchase of Alaska. The first salmon cannery opened on the Naknek River in 1890. By 1900, there were approximately 12 canneries in Bristol Bay. The Homestead Act enabled canneries to acquire land for their plants, and also made land available to other institutions and individuals. The parcel owned by the Russian Orthodox Church on the north bank of the River was the first land recorded in Naknek. Squatters built shelters on the church property and were eventually sold lots in what became the center of Naknek. A post office was established in 1907. Naknek has developed over the years as a major fishery center.

\section{Culture:}

Naknek is a fishing community, with a mixed population of non-Natives, Yup'ik Eskimos, Alutiiq and Athabascans.

\section{Economy:}


The economy is based on government employment, salmon fishing and processing. Naknek has a seasonal economy as a service center for the huge red salmon fishery in Bristol Bay. One hundred fifteen residents hold commercial fishing permits, and several thousand people typically flood the area during the fishing season. Millions of pounds of salmon are trucked over Naknek-King Salmon road each summer, where jets transport the fish to the lower 48. Trident Seafoods, North Pacific Processors, Ocean Beauty and other fish processors operate facilities in Naknek. Naknek is also the seat of the Bristol Bay Borough.

\section{Facilities:}

The majority of households, the schools and HUD housing have individual wells. Almost all homes are fully plumbed. A piped sewage collection system operated by the Borough serves most residents; some have individual septic tanks. Funds have been requested to replace septic tanks in the Airplane Lake area with piped sewer. The landfill and bale fill are operated by the Borough, located at mile 5 between Naknek and King Salmon. Refuse collection is provided by a private firm.

\section{Transportation:}

Naknek is accessible by air and sea, and connects to King Salmon via a 15.5-mile road. The Tibbetts Airport has a lighted 1,700' long by 60' wide gravel runway. The State-owned Naknek Airport is located one mile north of Naknek. It has a 1,950' long by 50' wide lighted gravel runway and a 2,000' float plane landing area. Jet services are available at King Salmon. The Borough operates the cargo dock at Naknek, which is the Port of Bristol Bay. It has 800' of berthing space, a concrete surface and a couple of cranes. No commercial docking facilities are available at the canneries, although the development of a Fishermen's Dock, Freight dock and Industrial Park are regional priorities. Pickup trucks and cars are common, and taxis are available.

\section{Climate:}

The climate is mainly maritime, characterized by cool, humid, and windy weather. Average summer temperatures range from 42 to $63 \mathrm{~F}$; average winter temperatures range from 29 to $44 \mathrm{~F}$. Extremes from -46 $\mathrm{F}$ to $88 \mathrm{~F}$ have been recorded. Total precipitation is 20 inches annually, including 45 inches of snowfall. Fog is common during summer months.

(Above information from State of Alaska Department of Commerce, Community, and Economic Development website, www.dced.state.ak.us)

\section{Tower Sensor Information}

$\begin{array}{clrrrc}\text { Channel } & \text { Sensor type } & \text { Height } & \text { Multiplier } & \text { Offset } & \text { Orientation } \\ 1 & \text { NRG \#40 anemometer } & 30 \mathrm{~m} & 0.765 & 0.35 & \text { west } \\ 2 & \text { NRG \#40 anemometer } & 22 \mathrm{~m} & 0.765 & 0.35 & \text { southeast } \\ 7 & \text { NRG \#200P wind vane } & 30 \mathrm{~m} & 0.351 & 262 & \text { east } \\ 9 & \text { NRG \#110S Temp C } & 6 \mathrm{~m} & 0.136 & -86.383 & \text { N/A }\end{array}$

\section{General Site Information}

Site number

Site Description

Latitude/longitude

Site elevation

Datalogger type

Tower type
2398

Site is adjacent to the borough landfill between Naknek and King Salmon

N 58 44.551' W $156^{\circ} 52.739$ '

53 meters

NRG Symphonie

NRG 30-meter tall tower, 152 mm (6 in) diameter 
Naknek, Alaska Wind Resource Report

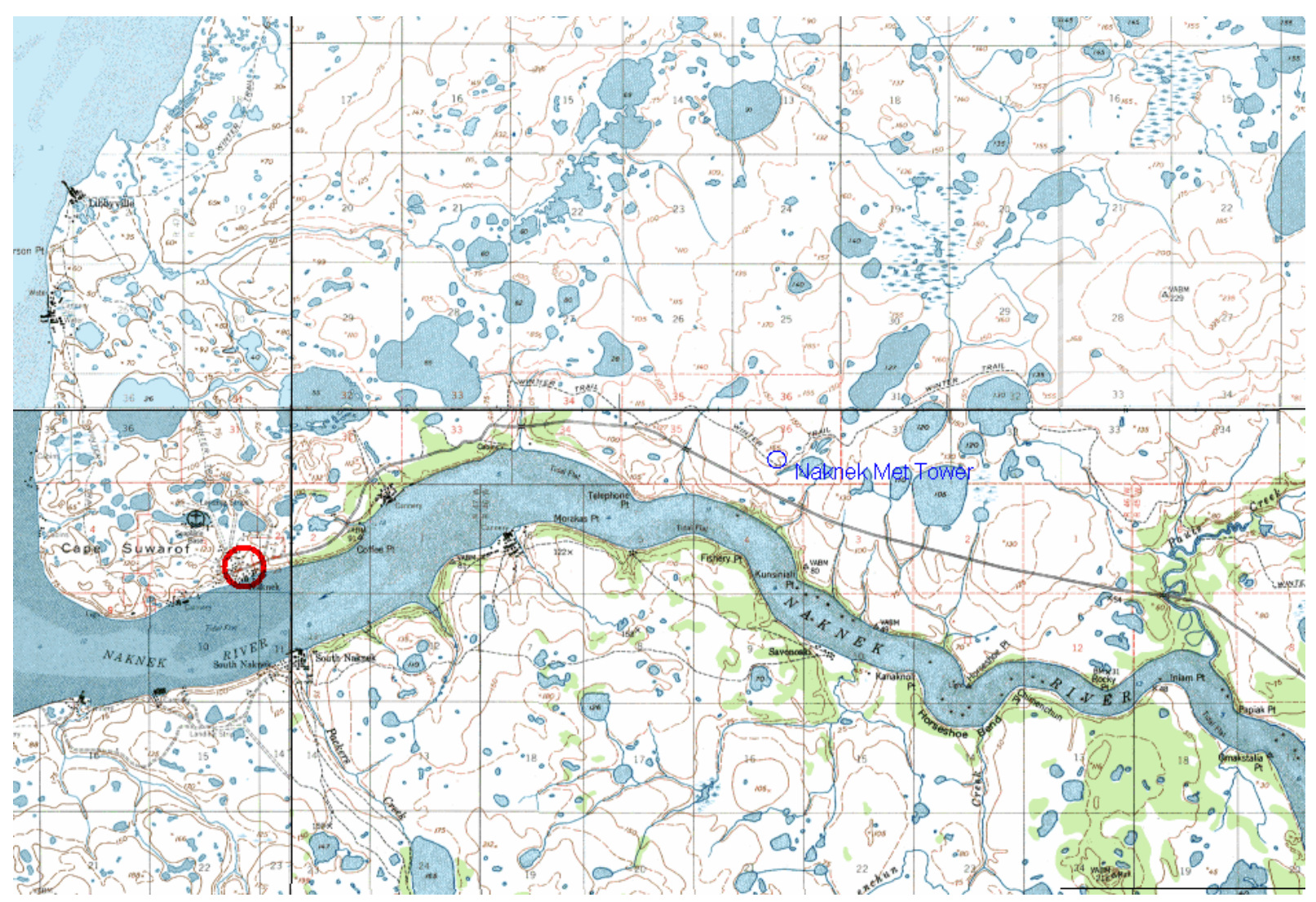


Naknek, Alaska Wind Resource Report

\section{Data Quality Control}

Data was filtered to remove presumed icing events that yield false zero wind speed data. Data that met the following criteria were filtered: wind speed $<1 \mathrm{~m} / \mathrm{s}$, wind speed standard deviation $=0$, and temperature $<3{ }^{\circ} \mathrm{C}$. Note that data recovery during the months of May through September was nearly 100\%, but during the months of October through April some data was filtered, with January being the most ice prone regarding data loss. Temperature data recovery was 100 percent, indicating full functioning of the temperature sensor. Data was synthesized to make up for data lost from icing events; the remainder of this report uses the synthesized data set.

\begin{tabular}{|c|c|c|c|c|c|c|c|c|c|}
\hline \multirow[b]{2}{*}{ Year } & \multirow[b]{2}{*}{ Month } & \multicolumn{2}{|c|}{$30 \mathrm{~m}$ anemometer } & \multicolumn{2}{|c|}{$20 \mathrm{~m}$ anemometer } & \multicolumn{2}{|c|}{ wind vane } & \multicolumn{2}{|c|}{ temperature } \\
\hline & & Records & $\begin{array}{l}\text { Recovery } \\
\text { Rate (\%) }\end{array}$ & Records & $\begin{array}{l}\text { Recovery } \\
\text { Rate (\%) }\end{array}$ & Records & $\begin{array}{l}\text { Recovery } \\
\text { Rate (\%) }\end{array}$ & Records & $\begin{array}{l}\text { Recovery } \\
\text { Rate (\%) }\end{array}$ \\
\hline 2004 & Jul & 606 & 100 & 606 & 100 & 606 & 100 & 606 & 100 \\
\hline 2004 & Aug & 4,464 & 100 & 4,464 & 100 & 4,464 & 100 & 4,464 & 100 \\
\hline 2004 & Sep & 4,320 & 100 & 4,320 & 100 & 4,320 & 100 & 4,320 & 100 \\
\hline 2004 & Oct & 4,462 & 100 & 4,453 & 99.8 & 4,453 & 99.8 & 4,464 & 100 \\
\hline 2004 & Nov & 4,116 & 95.3 & 4,113 & 95.2 & 3,711 & 85.9 & 4,320 & 100 \\
\hline 2004 & Dec & 3,995 & 89.5 & 3,995 & 89.5 & 2,686 & 60.2 & 4,464 & 100 \\
\hline 2005 & Jan & 3,793 & 85.0 & 3,783 & 84.7 & 3,752 & 84.1 & 4,464 & 100 \\
\hline 2005 & Feb & 3,977 & 98.6 & 3,981 & 98.7 & 3,753 & 93.1 & 4,032 & 100 \\
\hline 2005 & Mar & 3,957 & 88.6 & 4,231 & 94.8 & 4,005 & 89.7 & 4,464 & 100 \\
\hline 2005 & Apr & 4,227 & 97.8 & 4,244 & 98.2 & 4,224 & 97.8 & 4,320 & 100 \\
\hline 2005 & May & 4,464 & 100 & 4,464 & 100 & 4,464 & 100 & 4,464 & 100 \\
\hline 2005 & Jun & 4,320 & 100 & 4,320 & 100 & 4,320 & 100 & 4,320 & 100 \\
\hline 2005 & Jul & 4,464 & 100 & 4,464 & 100 & 4,464 & 100 & 4,464 & 100 \\
\hline 2005 & Aug & 4,464 & 100 & 4,464 & 100 & 4,464 & 100 & 4,464 & 100 \\
\hline 2005 & Sep & 4,320 & 100 & 4,320 & 100 & 4,320 & 100 & 4,320 & 100 \\
\hline 2005 & Oct & 4,436 & 99.4 & 4,391 & 98.4 & 4,391 & 98.4 & 4,464 & 100 \\
\hline 2005 & Nov & 4,070 & 94.2 & 4,006 & 92.7 & 3,584 & 83.0 & 4,320 & 100 \\
\hline 2005 & Dec & 4,274 & 95.7 & 4,282 & 95.9 & 3,297 & 73.9 & 4,464 & 100 \\
\hline 2006 & Jan & 3,953 & 88.6 & 3,876 & 86.8 & 3,973 & 89.0 & 4,464 & 100 \\
\hline 2006 & Feb & 3,980 & 98.7 & 3,992 & 99.0 & 3,973 & 98.5 & 4,032 & 100 \\
\hline 2006 & Mar & 4,411 & 98.8 & 4,307 & 96.5 & 4,096 & 91.8 & 4,464 & 100 \\
\hline 2006 & Apr & 4,316 & 99.9 & 4,249 & 98.4 & 4,220 & 97.7 & 4,320 & 100 \\
\hline 2006 & May & 4,442 & 99.5 & 4,455 & 99.8 & 4,440 & 99.5 & 4,464 & 100 \\
\hline 2006 & Jun & 4,320 & 100 & 4,320 & 100 & 4,320 & 100 & 4,320 & 100 \\
\hline 2006 & Jul & 2,676 & 100 & 2,676 & 100 & 2,676 & 100 & 2,676 & 100 \\
\hline All data & & 100,827 & 97.0 & 100,776 & 97.0 & 96,976 & 93.3 & 103,938 & 100 \\
\hline
\end{tabular}


Naknek, Alaska Wind Resource Report

Monthly Wind Speed Averages

The 30 meter anemometer annual wind speed average for the reporting period is $6.22 \mathrm{~m} / \mathrm{s}$ and the 20 meter anemometer wind speed average is $5.89 \mathrm{~m} / \mathrm{s}$.

\begin{tabular}{|c|c|c|c|c|c|c|c|}
\hline \multirow[b]{2}{*}{ Month } & \multicolumn{5}{|c|}{$30 \mathrm{~m}$ anemometer } & \multicolumn{2}{|c|}{$20 \mathrm{~m}$ anemometer } \\
\hline & $\begin{array}{l}\text { Mean } \\
(\mathrm{m} / \mathrm{s})\end{array}$ & $\begin{array}{l}\operatorname{Max} \\
(\mathrm{m} / \mathrm{s})\end{array}$ & $\begin{array}{l}\text { Dev. } \\
(\mathrm{m} / \mathrm{s})\end{array}$ & Weibull k & $\begin{array}{l}\text { Weibull c } \\
(\mathrm{m} / \mathrm{s})\end{array}$ & $\begin{array}{l}\text { Mean } \\
(\mathrm{m} / \mathrm{s})\end{array}$ & $\begin{array}{l}\text { Max } \\
(\mathrm{m} / \mathrm{s})\end{array}$ \\
\hline Jan & 6.96 & 17.8 & 3.31 & 2.21 & 7.85 & 6.67 & 16.9 \\
\hline Feb & 7.68 & 24.7 & 4.06 & 1.97 & 8.66 & 7.39 & 23.1 \\
\hline Mar & 6.66 & 19.2 & 3.42 & 2.05 & 7.53 & 6.31 & 21.7 \\
\hline Apr & 6.04 & 23.7 & 3.08 & 2.05 & 6.82 & 5.76 & 21.9 \\
\hline May & 5.77 & 17.9 & 2.71 & 2.25 & 6.51 & 5.53 & 17.5 \\
\hline Jun & 5.35 & 18.5 & 2.73 & 2.06 & 6.05 & 5.07 & 20.0 \\
\hline Jul & 5.02 & 17.0 & 2.38 & 2.20 & 5.66 & 4.73 & 16.4 \\
\hline Aug & 5.22 & 17.7 & 2.84 & 1.92 & 5.88 & 4.95 & 17.1 \\
\hline Sep & 5.88 & 19.4 & 2.96 & 2.09 & 6.64 & 5.46 & 20.9 \\
\hline Oct & 6.25 & 19.2 & 3.23 & 2.02 & 7.05 & 5.82 & 18.9 \\
\hline Nov & 6.56 & 22.3 & 3.34 & 2.03 & 7.38 & 6.10 & 21.5 \\
\hline Dec & 7.19 & 24.1 & 3.69 & 2.06 & 8.13 & 6.86 & 23.6 \\
\hline All data & 6.22 & 24.7 & 3.27 & 1.99 & 7.02 & 5.89 & 23.6 \\
\hline
\end{tabular}

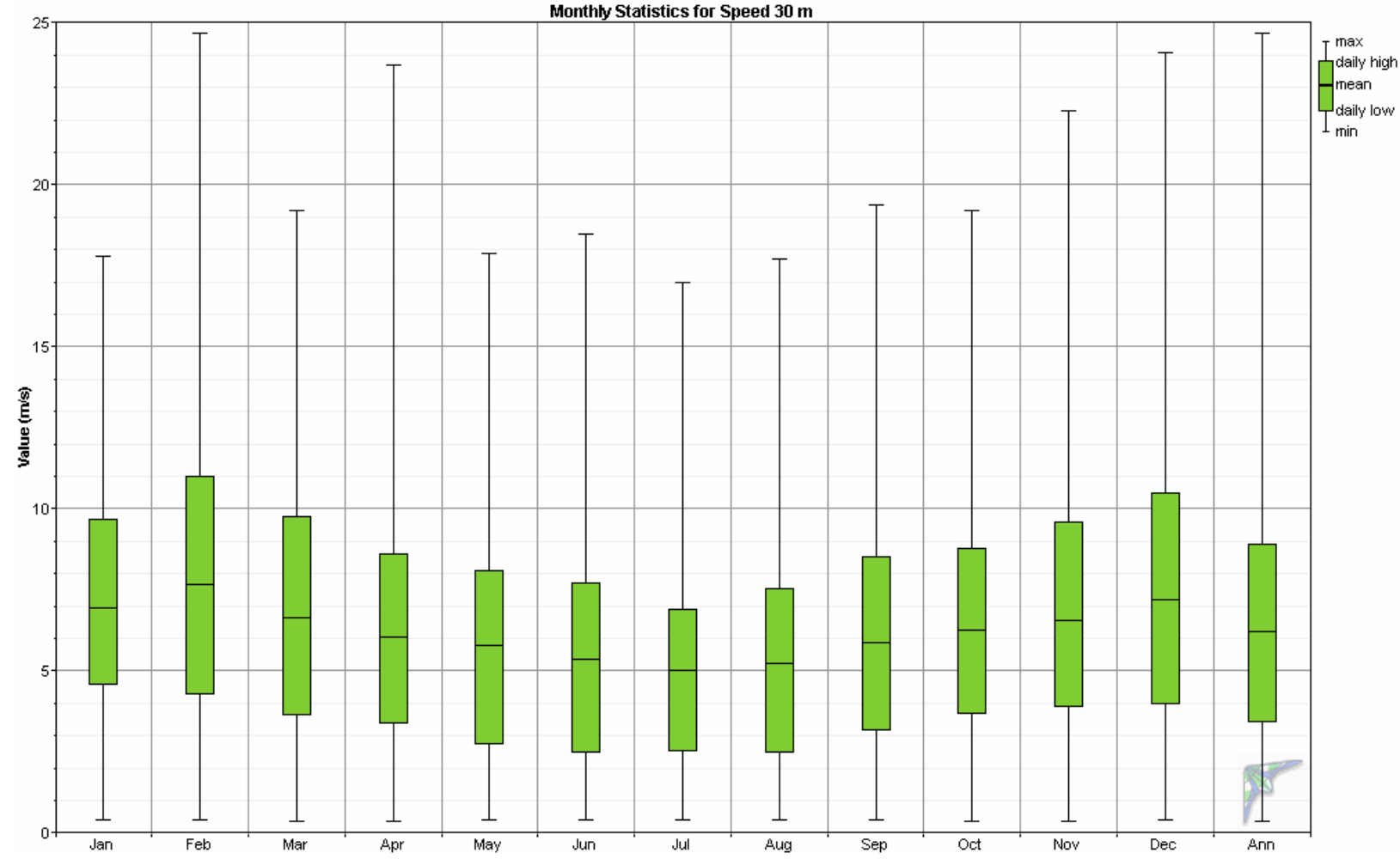

Daily wind profile 
The daily wind profile indicates that the lowest wind speeds of the day occur in the morning hours of 4 to 7 a.m. and the highest wind speeds of the day occur during the afternoon and evening hours of 3 to 6 p.m. The daily variation of wind speed is minimal on an annual basis but more pronounced on a monthly basis.
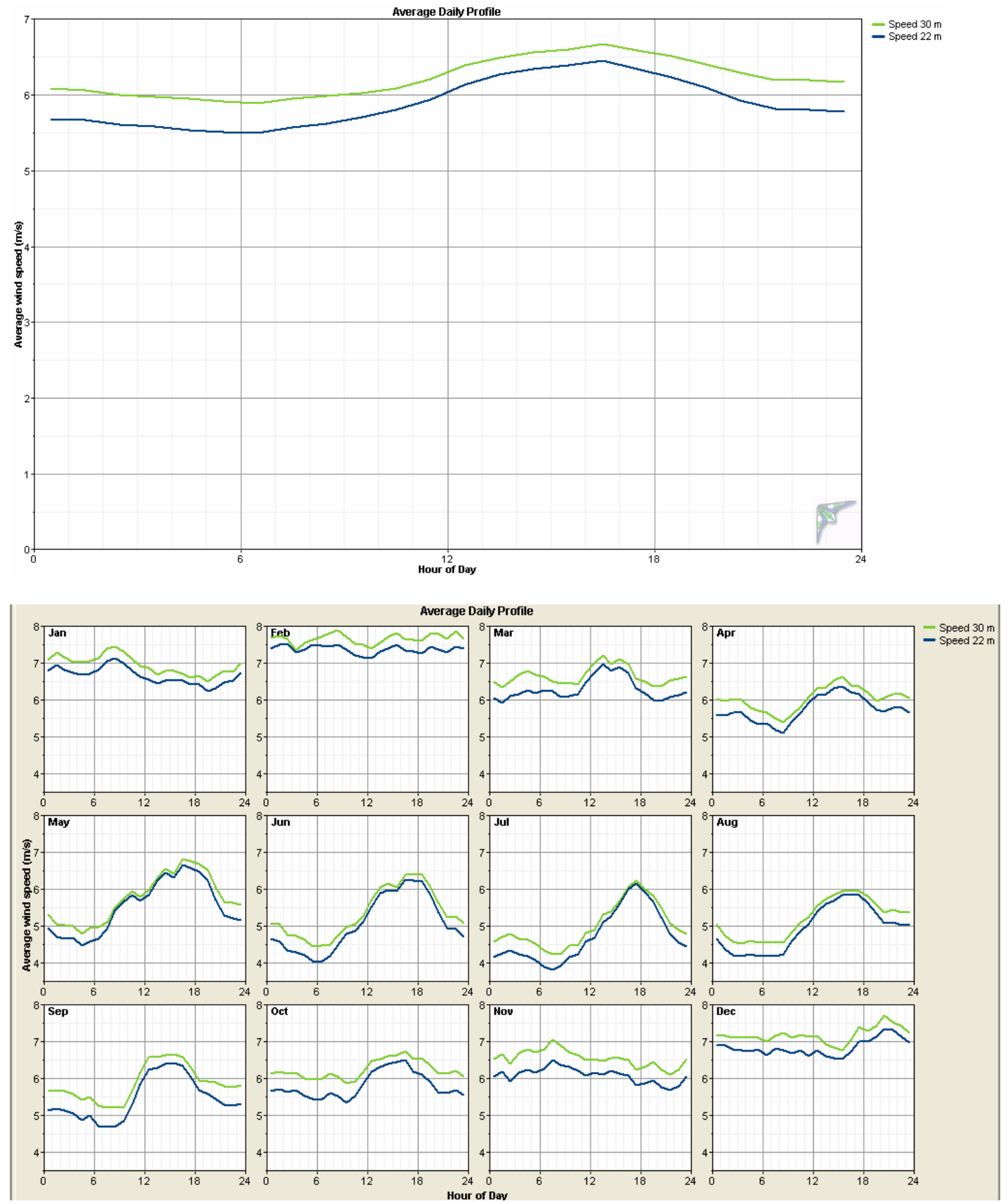


\section{Time Series of Wind Speed Monthly Averages}

As expected, Naknek's highest winds occur during the winter months of October through March with the lowest winds during the spring-summer-autumn months of April through September. The unusually low winds measured in January 2006 were due to a persistent high pressure system over Alaska that month that yielded calm winds and extremely cold weather Statewide.
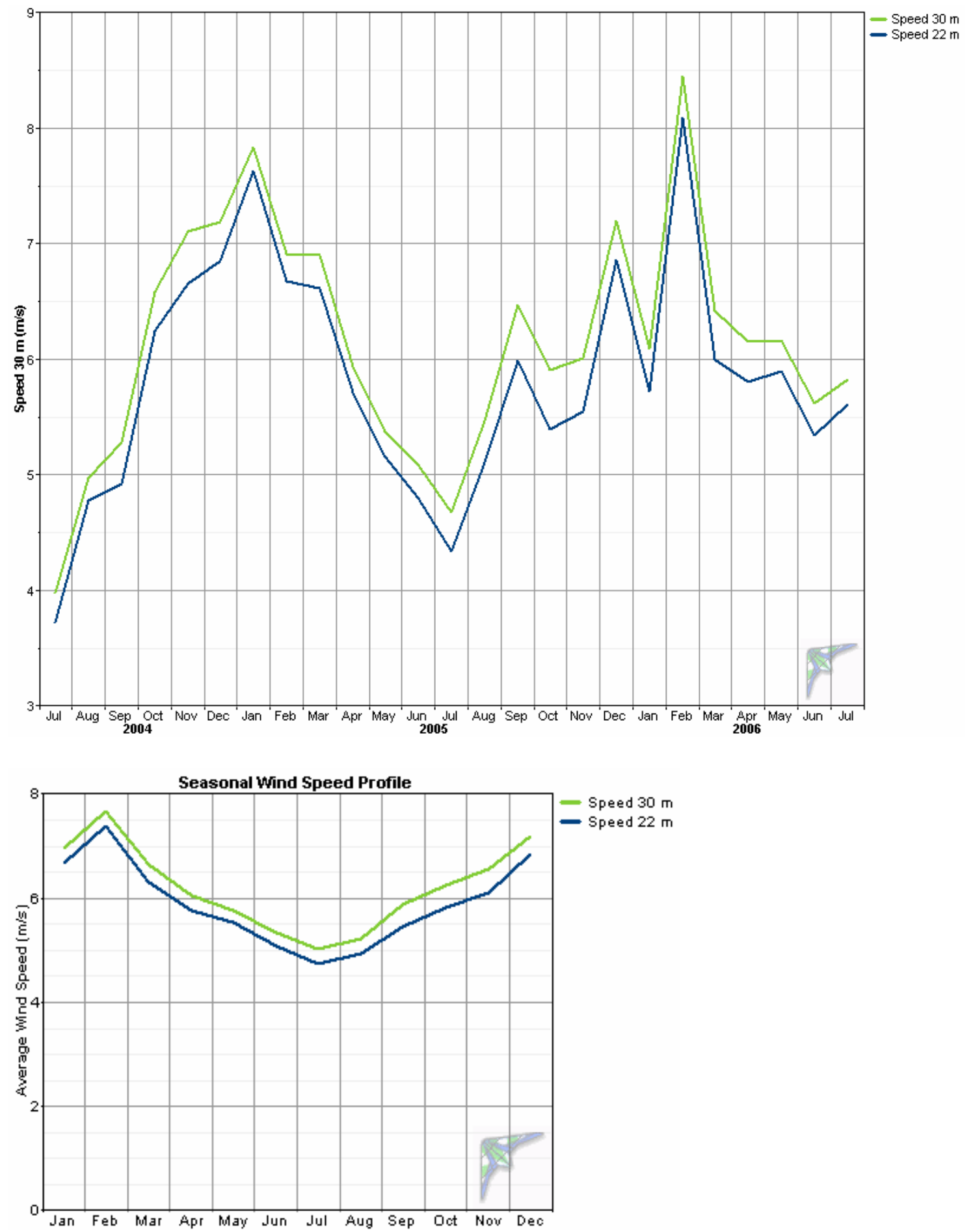


\section{Long-term Comparison}

The graph below of average annual wind speed for the nearby King Salmon airport indicates that 2004 and 2005 experienced possibly low average annual wind speeds when compared to data over the past thirty-two years, although in comparison to the past ten years, the 2004/05 wind speeds recorded at the airport were about average. The discrepancy between earlier data and the past ten years can be attributable to an ASOS equipment upgrade approximately ten years ago.

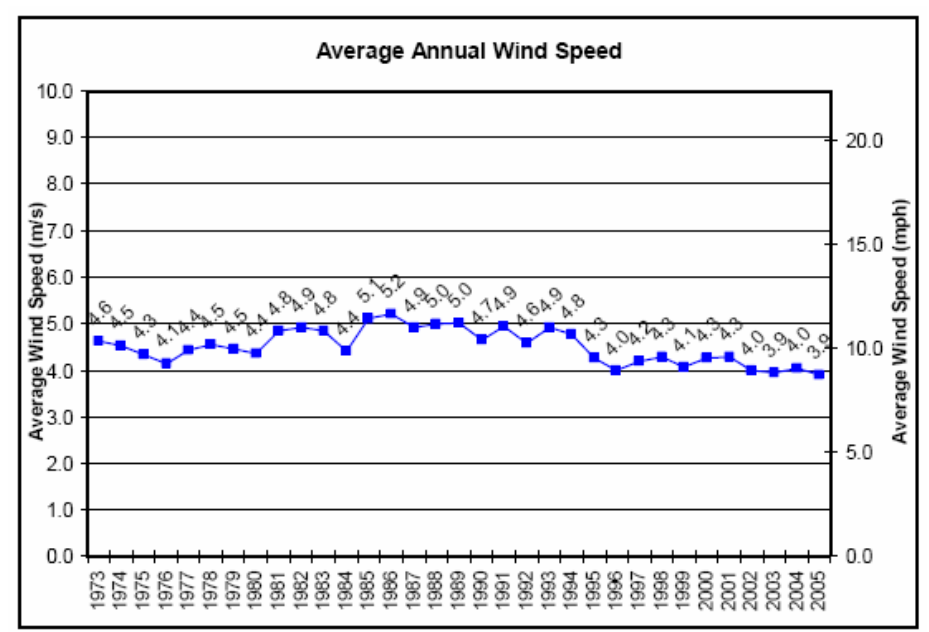




\section{Wind Shear Profile}

The power law exponent was calculated at 0.181 , indicating moderate wind shear at the Naknek test site. The practical application of this data is that a higher turbine tower height is desirable as there will be an appreciable marginal gain in wind speed/power recovery with additional height. A tower height/power recovery/construction cost tradeoff study is advisable.
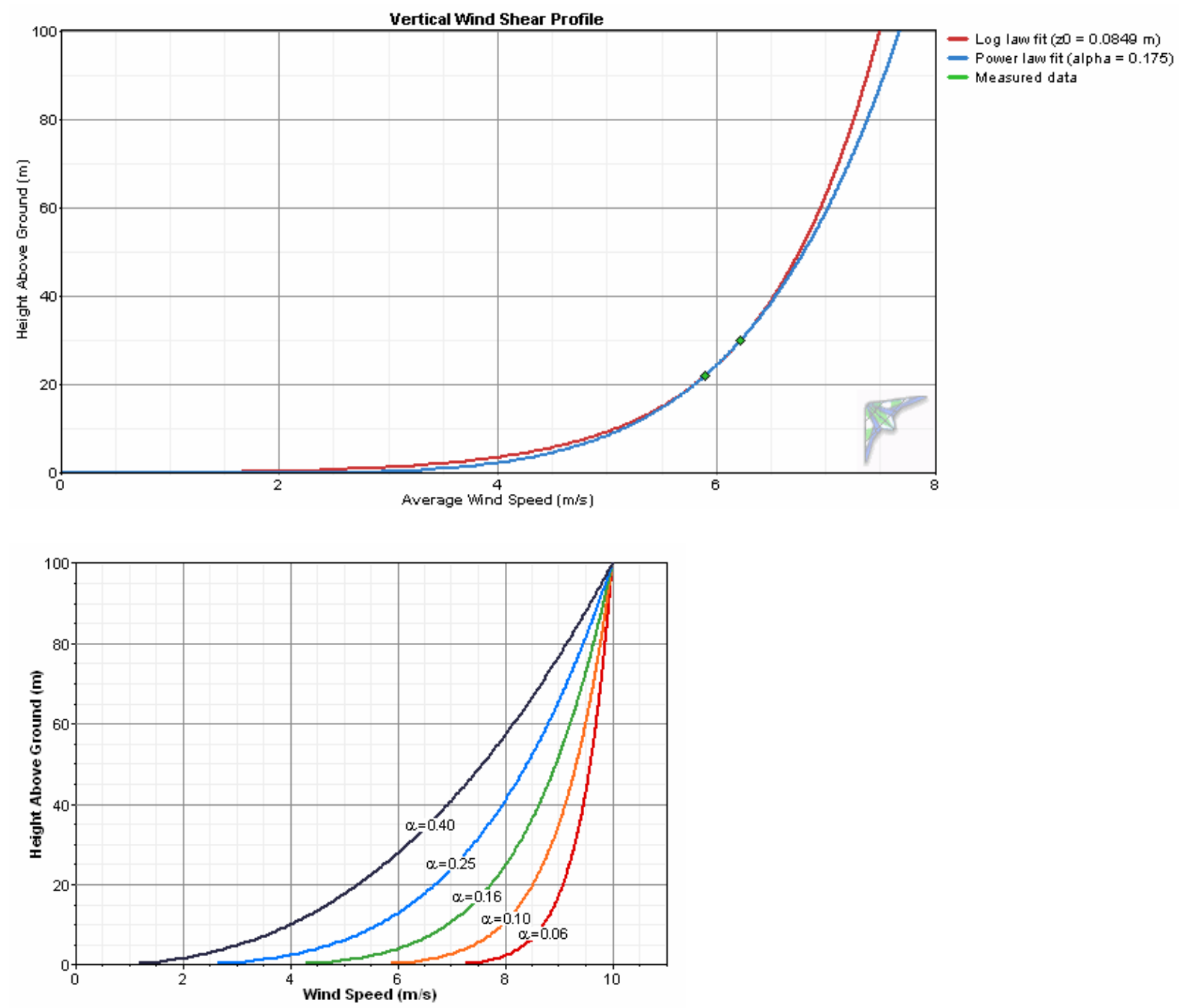
Naknek, Alaska Wind Resource Report
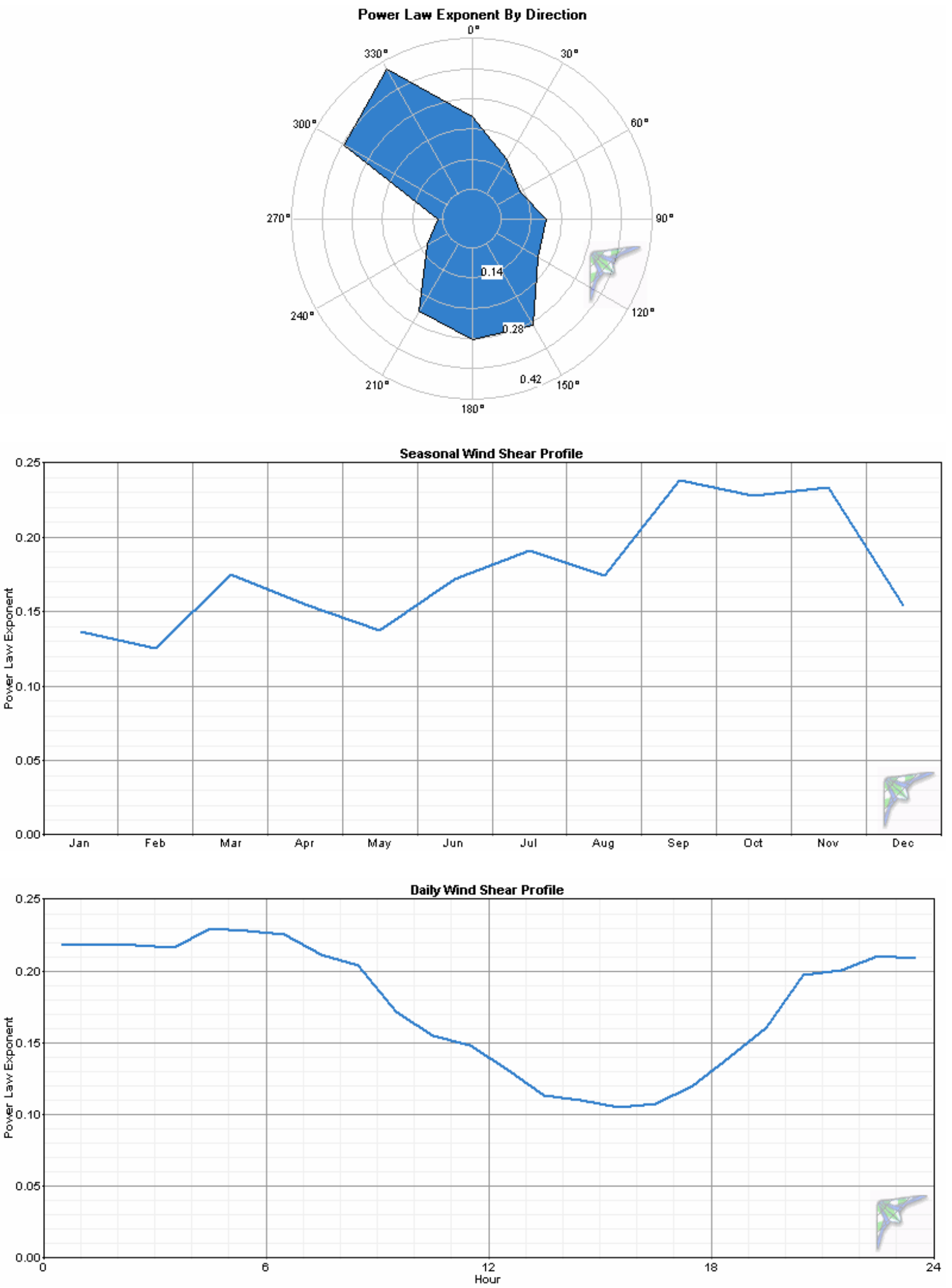


\section{Probability Distribution Function}

The probability distribution function provides a visual indication of measured wind speeds in one meter per second "bins". Note that most wind turbines do not begin to generate power until the wind speed at hub height reaches $4 \mathrm{~m} / \mathrm{s}$, known as the "cut-in" wind speed. The black line in the graph is a best fit Weibull distribution. At the 30 meter level, Weibull parameters are $\mathrm{k}=1.99$ and $\mathrm{c}=7.02 \mathrm{~m} / \mathrm{s}$ (scale factor). The PDF information is shown visually in another manner in the second graph, the Cumulative Distribution Function.
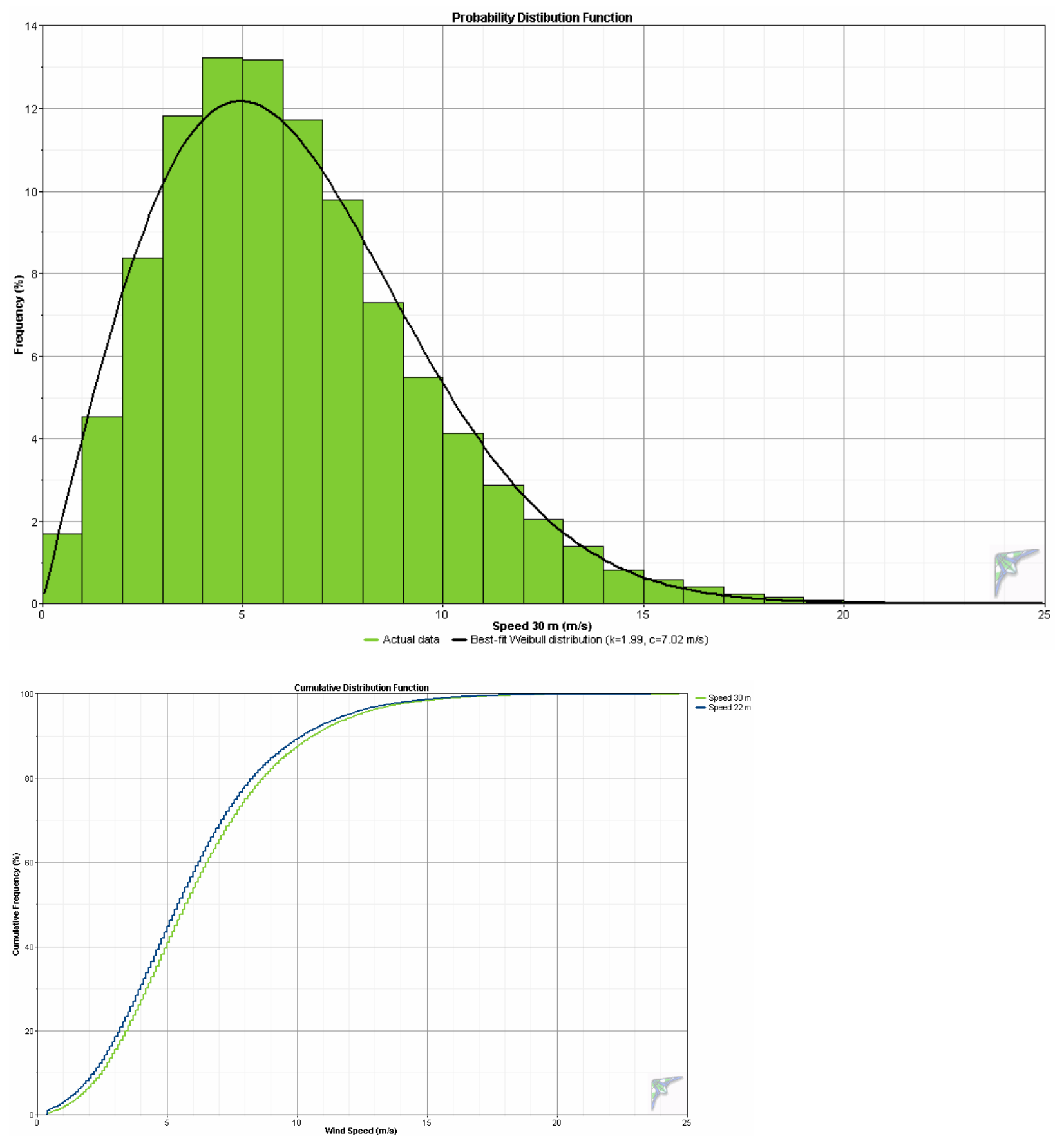


\section{Wind Roses}

Naknek winds are not especially directional; the wind frequency rose indicates north, west, east and south components of wind. This observation is reinforced with reference to the power density rose below. Power producing winds are chiefly north, south and east with lesser power winds from west and northeast. The practical application of this information is that a site should be selected with adequate freedom from ground interference in all directions and if more than one turbine is installed, the turbines should be adequately spaced apart to prevent downwind (from the power producing winds) interference problems between the turbines.

Note also that a wind threshold of $4 \mathrm{~m} / \mathrm{s}$ was selected for the definition of calm winds. This wind speed represents the cut-in wind speed of most wind turbines. By this definition, Naknek experienced 27 percent calm conditions during the measurement period (see wind frequency rose below).

\section{Wind Frequency Rose}

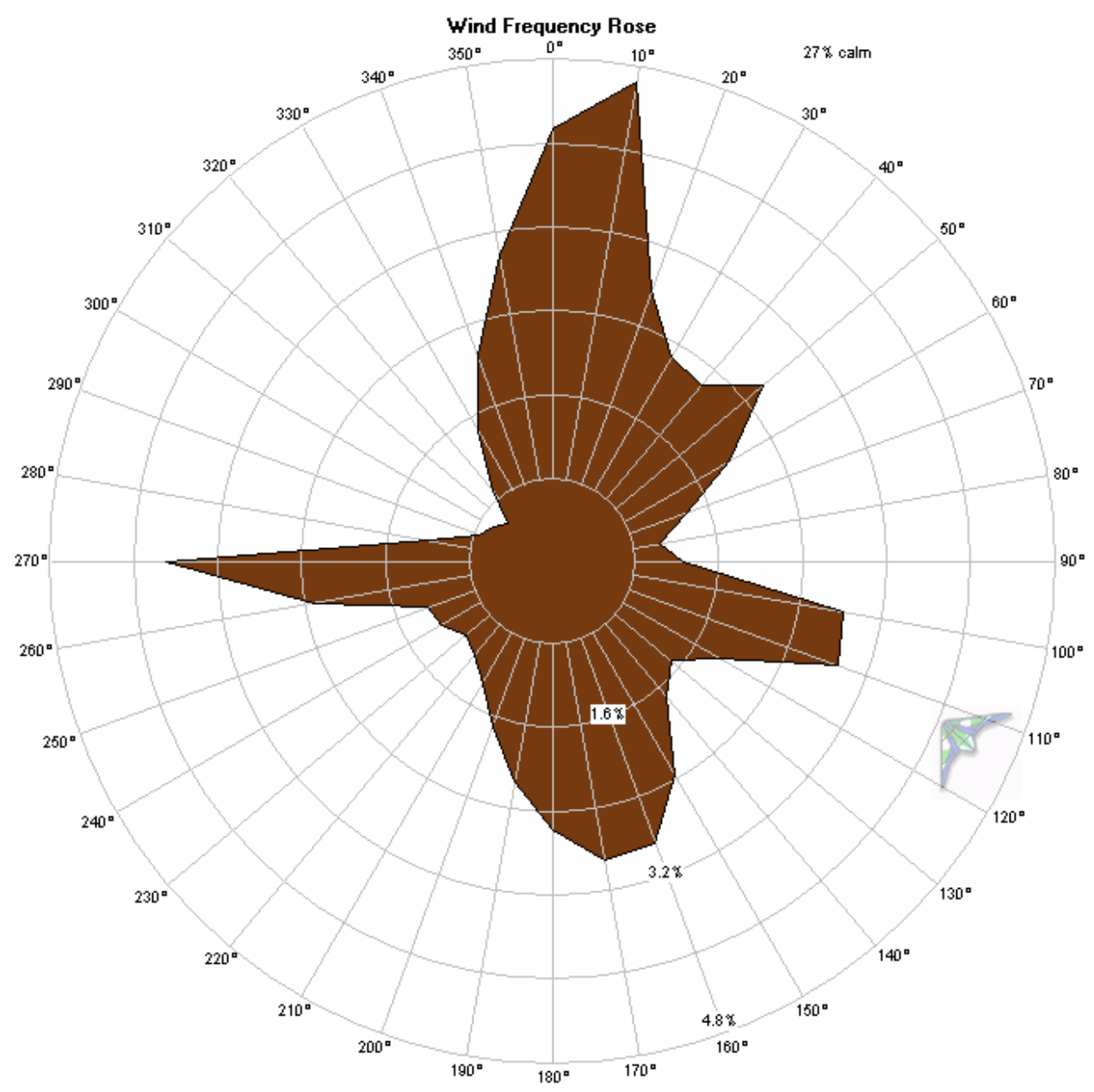


Naknek, Alaska Wind Resource Report

\section{Wind Power Density Rose}

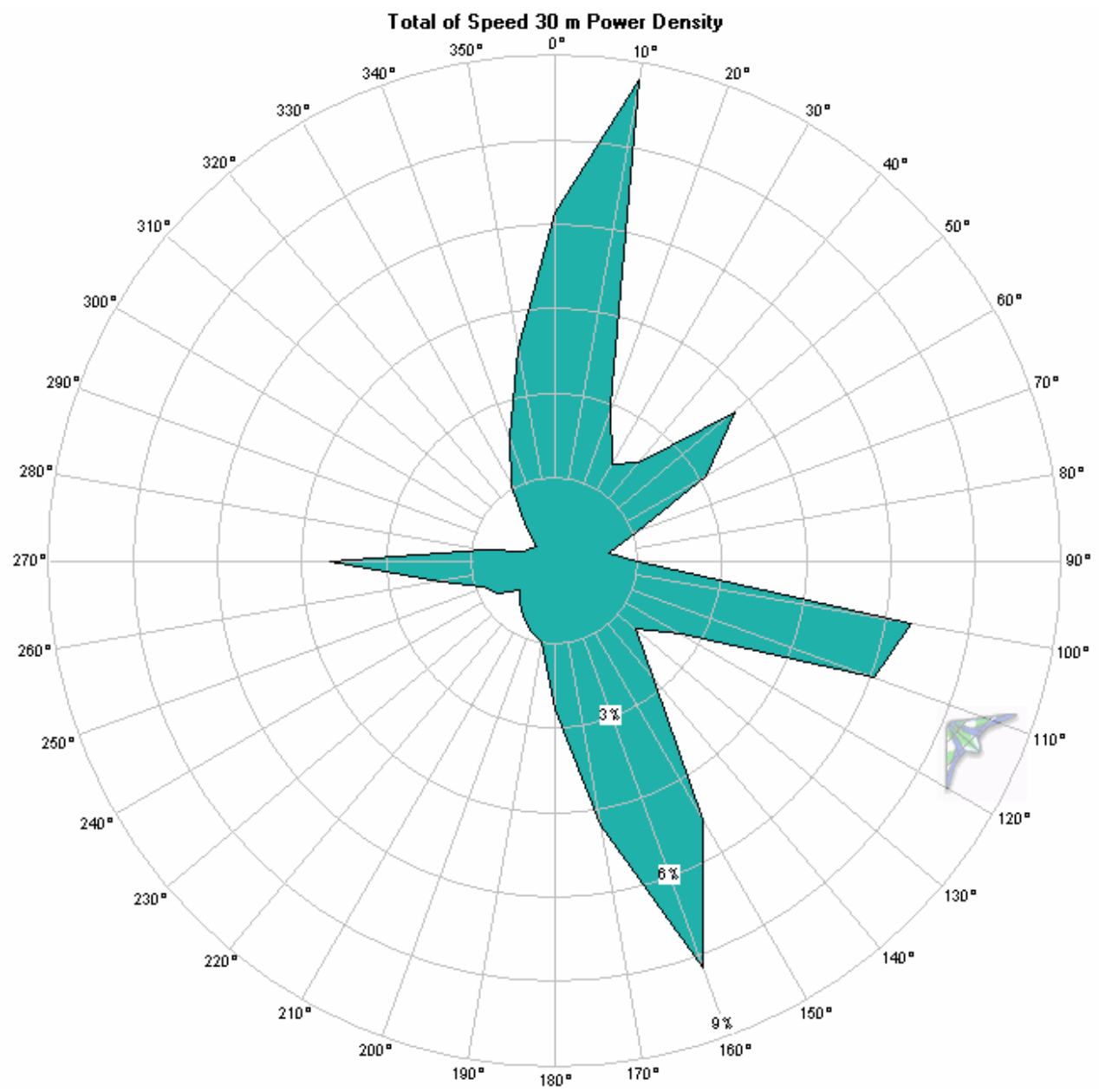

Wind Power Density Rose by Month (30 meters)

Note: for ease of visualization, the scale between months is not common.
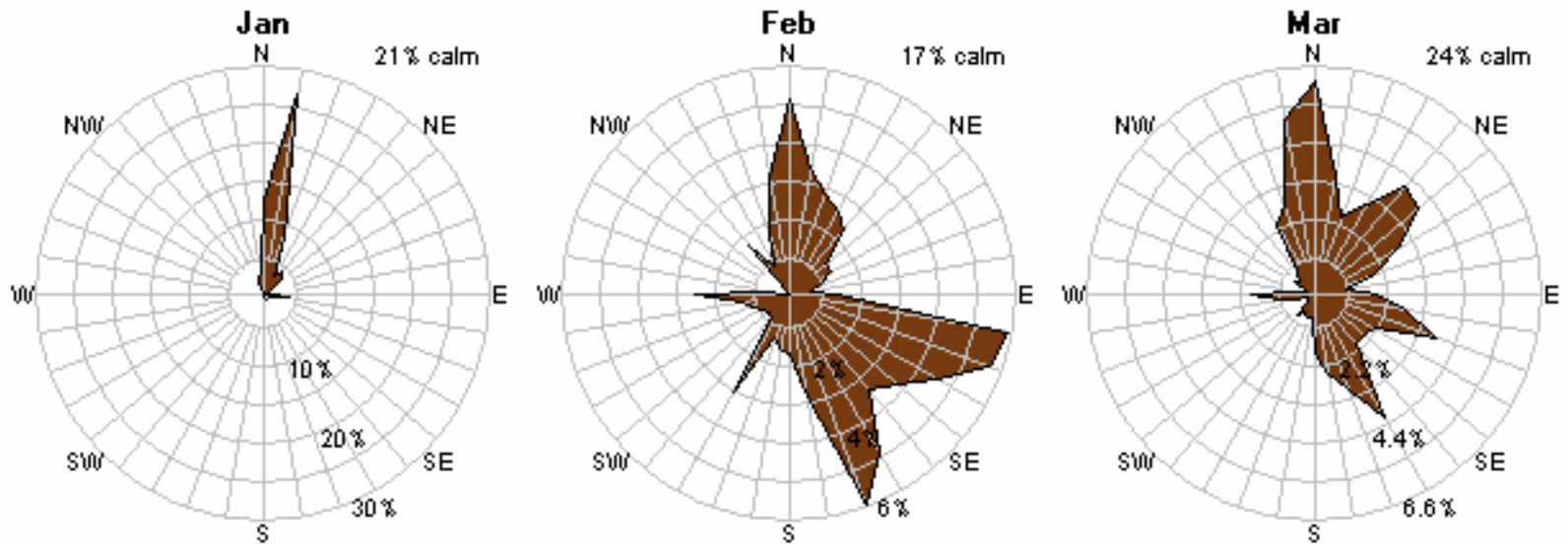
Naknek, Alaska Wind Resource Report
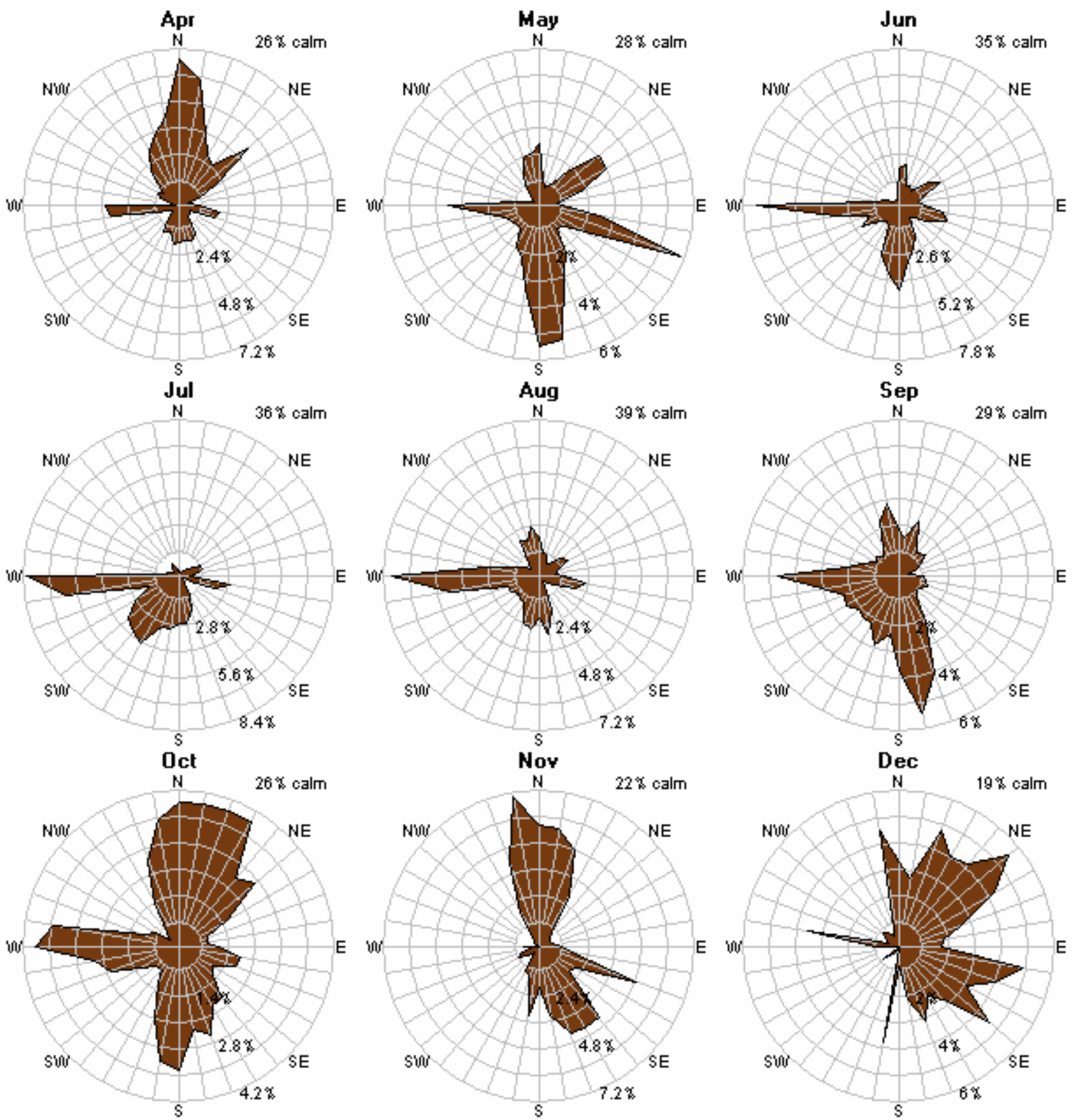


\section{Turbulence Intensity}

The turbulence intensity (TI) is quite acceptable for all wind direction, with a mean turbulence intensity of 0.102 (Channel 1) and 0.108 (Channel 2), indicating relatively smooth air. These TIs are calculated with a threshold wind speed of $4 \mathrm{~m} / \mathrm{s}$. The spike of relatively high turbulence to the east in the first graph is not observed in the second graph. This is due to placement of the 30 meter level anemometer in relation to the wind vane.

\section{0-meter Turbulence Intensity}

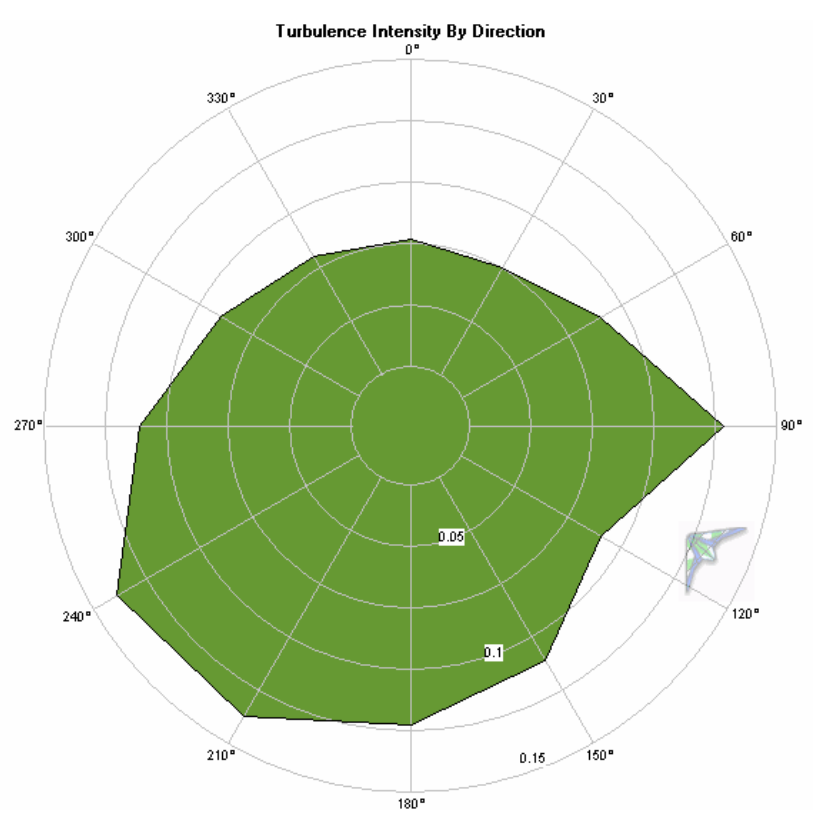

22-meter Turbulence Intensity

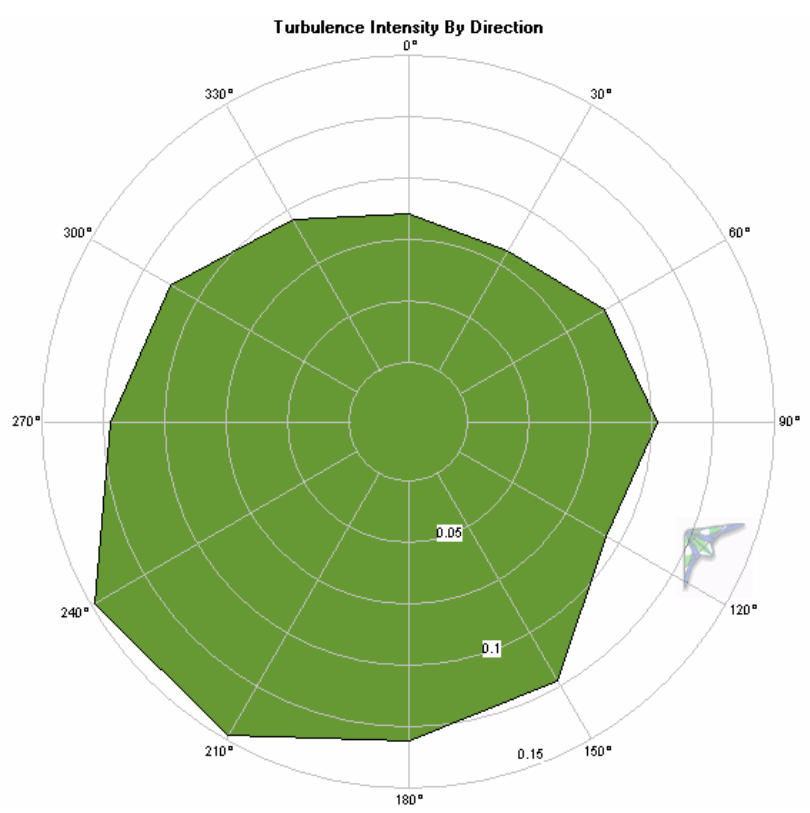


Naknek, Alaska Wind Resource Report

IEC Turbulence Intensity Standards

As indicated below, turbulence at the Naknek project test site is well within International Electrotechnical Commission (IEC) standards at all measured wind speeds and from all four quadrants of the wind rose.
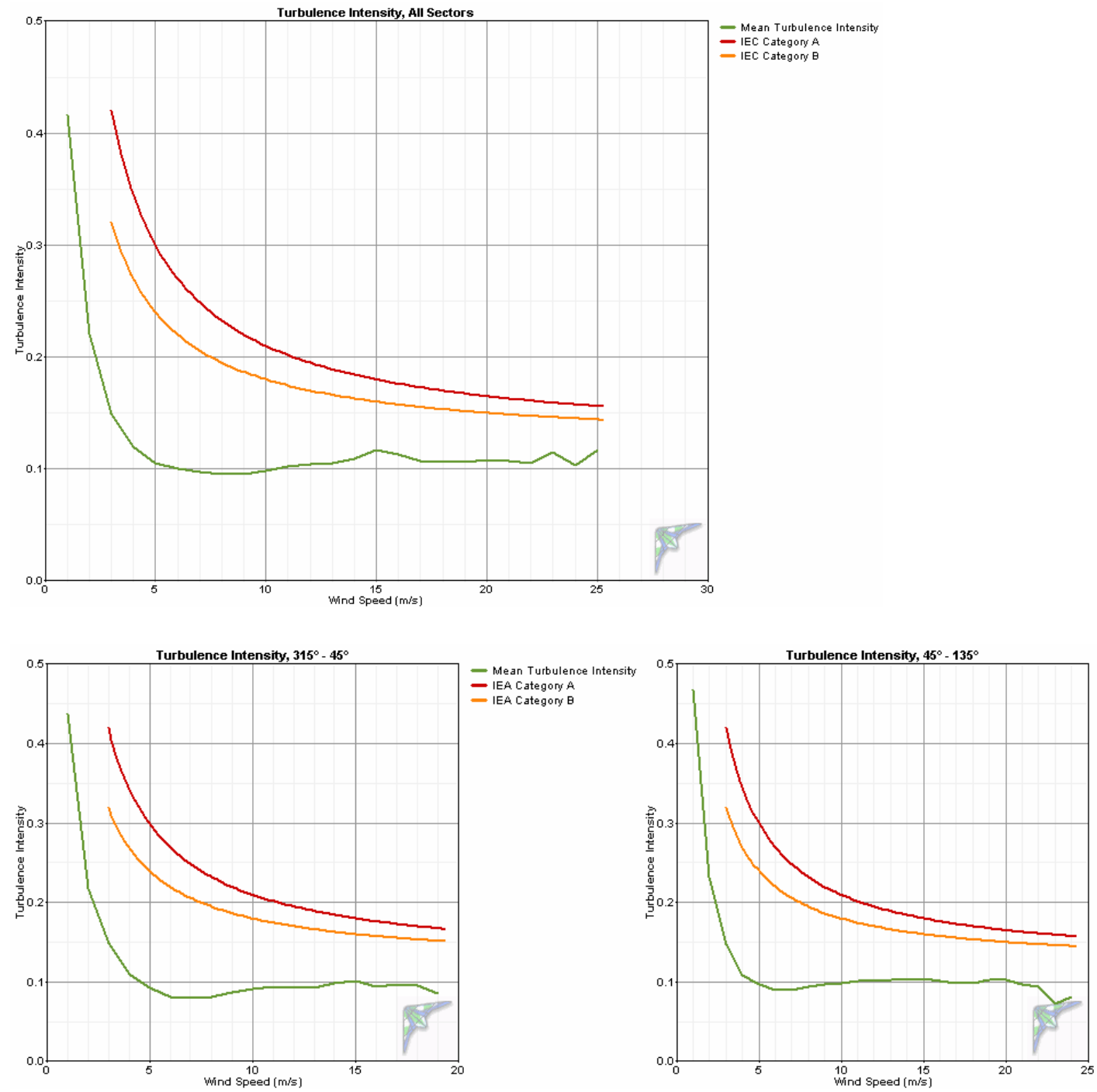

Z Mean Turbulence Intensity - IEA Categony A - IEA Category A 
Naknek, Alaska Wind Resource Report
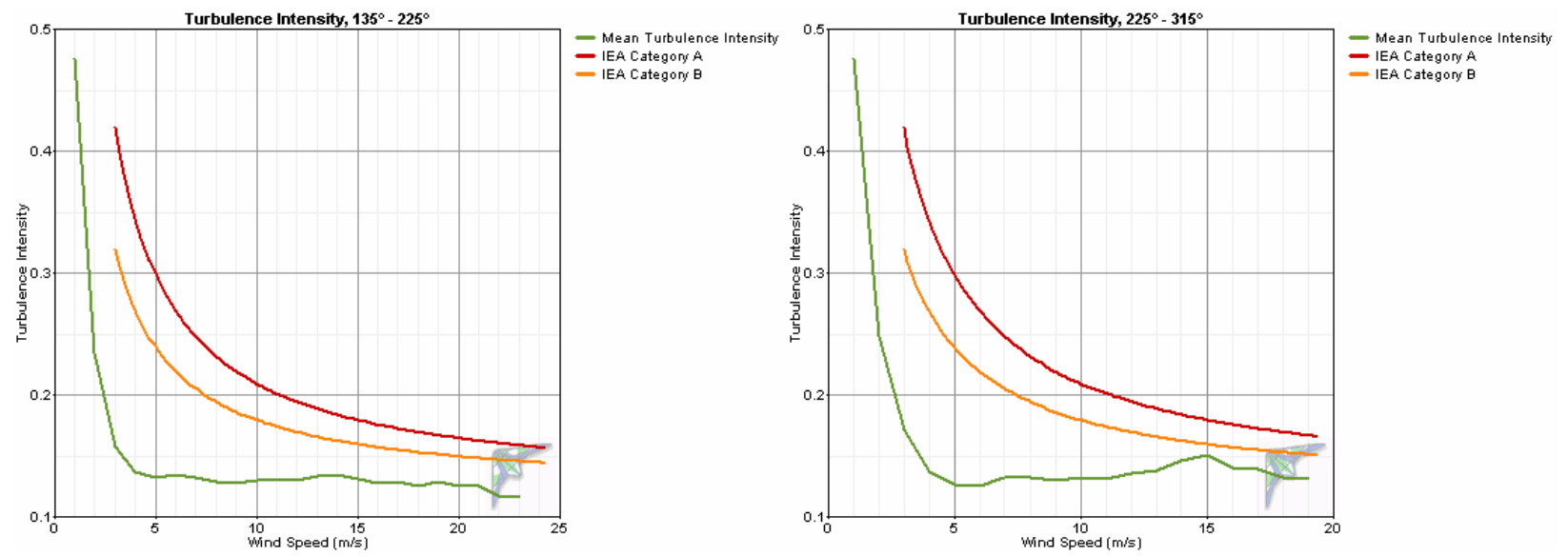

Turbulence Table

\begin{tabular}{cccccccc}
$\begin{array}{c}\text { Bin } \\
\begin{array}{c}\text { Midpoint } \\
(\mathrm{m} / \mathrm{s})\end{array}\end{array}$ & $\begin{array}{c}\text { Bin Endpoints } \\
\text { Lower } \\
(\mathrm{m} / \mathrm{s})\end{array}$ & $\begin{array}{c}\text { Upper } \\
(\mathrm{m} / \mathrm{s})\end{array}$ & $\begin{array}{c}\text { Records } \\
\text { In }\end{array}$ & $\begin{array}{c}\text { Sin } \\
\text { Bindard Devia- } \\
\text { tion } \\
\text { of Wind Speed } \\
(\mathrm{m} / \mathrm{s})\end{array}$ & $\begin{array}{c}\text { Mean } \\
\text { Turbulence } \\
\text { Intensity }\end{array}$ & $\begin{array}{c}\text { Standard Devia- } \\
\text { tion } \\
\text { of Turbulence } \\
\text { Intensity }\end{array}$ & $\begin{array}{c}\text { Characteristic } \\
\text { Turbulence } \\
\text { Intensity }\end{array}$ \\
\hline 1 & 0.5 & 1.5 & 901 & 0.401 & 0.424 & 0.199 & 0.624 \\
2 & 1.5 & 2.5 & 1728 & 0.424 & 0.216 & 0.118 & 0.334 \\
3 & 2.5 & 3.5 & 2757 & 0.443 & 0.150 & 0.088 & 0.238 \\
4 & 3.5 & 4.5 & 3502 & 0.440 & 0.112 & 0.061 & 0.173 \\
5 & 4.5 & 5.5 & 4149 & 0.454 & 0.092 & 0.045 & 0.136 \\
6 & 5.5 & 6.5 & 4432 & 0.482 & 0.081 & 0.040 & 0.121 \\
7 & 6.5 & 7.5 & 3997 & 0.552 & 0.080 & 0.032 & 0.112 \\
8 & 7.5 & 8.5 & 3141 & 0.639 & 0.080 & 0.031 & 0.112 \\
9 & 8.5 & 9.5 & 2260 & 0.762 & 0.085 & 0.030 & 0.116 \\
10 & 9.5 & 10.5 & 1375 & 0.885 & 0.089 & 0.028 & 0.117 \\
11 & 10.5 & 11.5 & 867 & 1.005 & 0.092 & 0.024 & 0.116 \\
12 & 11.5 & 12.5 & 694 & 1.112 & 0.093 & 0.021 & 0.114 \\
13 & 12.5 & 13.5 & 481 & 1.201 & 0.093 & 0.019 & 0.112 \\
14 & 13.5 & 14.5 & 156 & 1.359 & 0.098 & 0.019 & 0.117 \\
15 & 14.5 & 15.5 & 100 & 1.516 & 0.102 & 0.018 & 0.120 \\
16 & 15.5 & 16.5 & 76 & 1.500 & 0.095 & 0.019 & 0.114 \\
17 & 16.5 & 17.5 & 14 & 1.650 & 0.097 & 0.024 & 0.121 \\
18 & 17.5 & 18.5 & 3 & 1.700 & 0.096 & 0.009 & 0.105 \\
19 & 18.5 & 19.5 & 1 & 1.600 & 0.085 & 0.000 & 0.085 \\
20 & 19.5 & 20.5 & 0 & 1.600 & 0.085 & 0.000 & 0.085 \\
21 & 20.5 & 21.5 & 0 & 1.600 & 0.085 & 0.000 & 0.085 \\
22 & 21.5 & 22.5 & 1 & 1.800 & 0.083 & 0.000 & 0.083
\end{tabular}




\section{Air Temperature and Density}

Over the reporting period, Naknek had an average temperature of $3.0^{\circ} \mathrm{C}$. The minimum recorded temperature during the measurement period was $-36.6^{\circ} \mathrm{C}$ and the maximum temperature was $26.3^{\circ} \mathrm{C}$, indicating a wide variability of an ambient temperature operating environment important to wind turbine operations. Consequent to Naknek's cool temperatures, the average air density of $1.272 \mathrm{~kg} / \mathrm{m}^{3}$ is over four percent higher than the standard air density of $1.218 \mathrm{~kg} / \mathrm{m}^{3}$ $\left(14.6^{\circ} \mathrm{C}\right.$ and $100.6 \mathrm{kPa}$ standard temperature and pressure at $53 \mathrm{~m}$ elevation), indicating that Naknek has denser air than the standard air density used to calculate turbine power curves (power curves are calculate at a sea level standard of $15^{\circ} \mathrm{C}$ and $101.3 \mathrm{kPa}$ pressure). This density variance from standard is accounted for in turbine performance predictions in this report.

\begin{tabular}{|c|c|c|c|c|c|}
\hline \multirow[b]{2}{*}{ Month } & \multicolumn{3}{|c|}{ Temperature } & \multirow{2}{*}{\multicolumn{2}{|c|}{$\begin{array}{c}\text { Air Density } \\
\text { Mean } \\
\left(\mathrm{kg} / \mathrm{m}^{3}\right)\end{array}$}} \\
\hline & $\begin{array}{c}\text { Mean } \\
\left({ }^{\circ} \mathrm{C}\right)\end{array}$ & $\begin{array}{l}\text { Min } \\
\left({ }^{\circ} \mathrm{C}\right)\end{array}$ & $\begin{array}{l}\text { Max } \\
\left({ }^{\circ} \mathrm{C}\right)\end{array}$ & & \\
\hline Jan & -10.3 & -36.6 & 7.8 & 10.48 & 1.336 \\
\hline Feb & -4.1 & -33.7 & 8.4 & 8.93 & 1.305 \\
\hline Mar & -3.9 & -21.8 & 11.1 & 7.16 & 1.303 \\
\hline Apr & -0.2 & -20.7 & 22.1 & 6.38 & 1.285 \\
\hline May & 8.5 & -4.2 & 26.3 & 5.21 & 1.246 \\
\hline Jun & 12.0 & 1.0 & 24.7 & 4.04 & 1.230 \\
\hline Jul & 13.9 & 4.4 & 24.3 & 3.18 & 1.222 \\
\hline Aug & 15.8 & 5.7 & 26.3 & 3.59 & 1.214 \\
\hline Sep & 10.0 & -0.9 & 19.7 & 3.45 & 1.239 \\
\hline Oct & 4.0 & -10.4 & 14.8 & 4.74 & 1.266 \\
\hline Nov & -5.3 & -25.3 & 8.8 & 8.34 & 1.310 \\
\hline Dec & -3.0 & -26.8 & 8.0 & 6.70 & 1.299 \\
\hline Annual & 3.0 & -36.6 & 26.3 & 10.52 & 1.272 \\
\hline
\end{tabular}

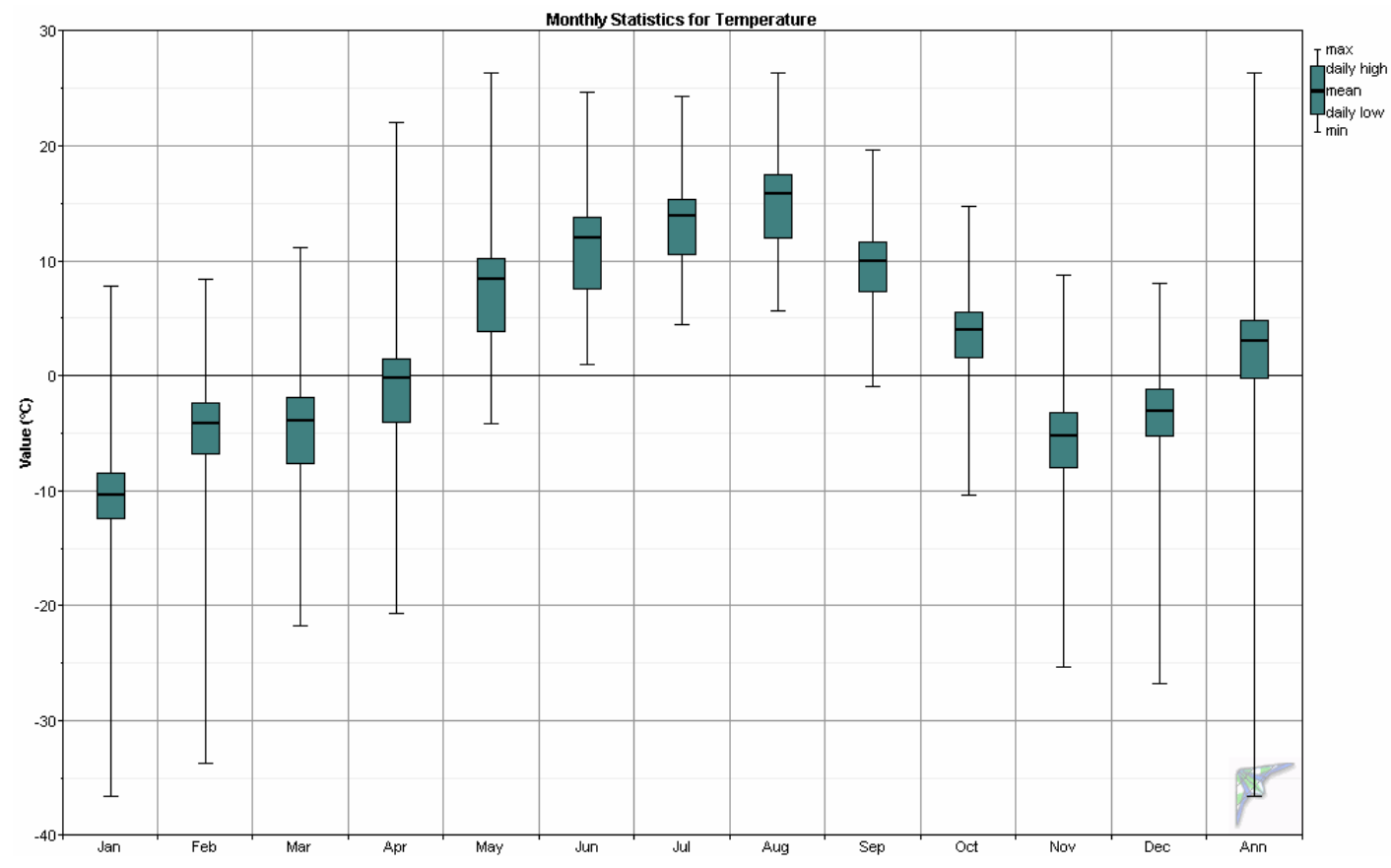




\section{Air Density DMap}

The DMap below is a visual indication of the daily and seasonal variations of air density (and hence temperature). Air densities higher than standard will yield higher turbine power than predicted by turbine power curves, while densities lower than standard will yield lower turbine power than predicted. Density variance from standard is accounted for in the turbine performance predictions.

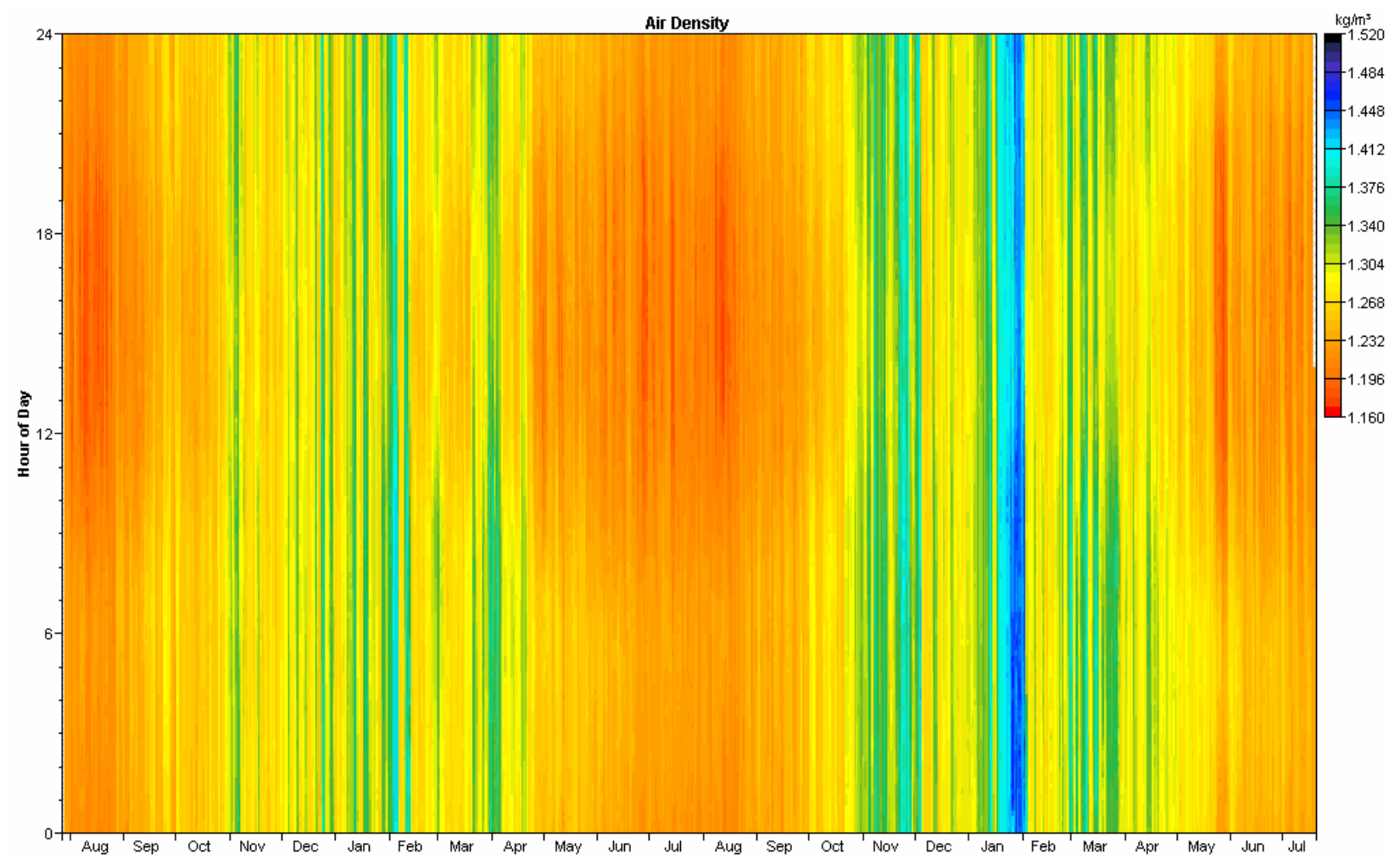




\section{Wind Turbine Performance}

The turbine performance predictions noted below are based on 100 percent and 90 percent turbine availabilities. The 100 percent data is for use as a baseline of comparison, but it is realistic to expect ten percent losses or downtime for wind turbines, at least during the first year of operation.

Note that these performance estimates were predicted with use of Windographer ${ }^{\circledR}$ wind analysis software; power curves provided by manufacturers are not independently verified and are assumed to be accurate. The power curves are presented for a standard air density of $1.225 \mathrm{~kg} / \mathrm{m}^{3}$ at sea level and $15^{\circ} \mathrm{C}$. However, the predictions of power production are density compensated by multiplying the standard density power output by the ratio of the measured air density to standard air density, accounting for the site elevation.

A number of small to medium turbines are profiled in this report for comparison purposes. These turbines were selected because they have market availability and they are deemed to be within a suitable range for consideration of wind power development in a community the size of Naknek.

Bergey Excel-S: $10 \mathrm{~kW}$ rated power output, 6.7 meter rotor diameter, stall-controlled. Available tower heights: 18, 24, 30, 37 and 43 meters. Additional information is available at www.bergey.com.
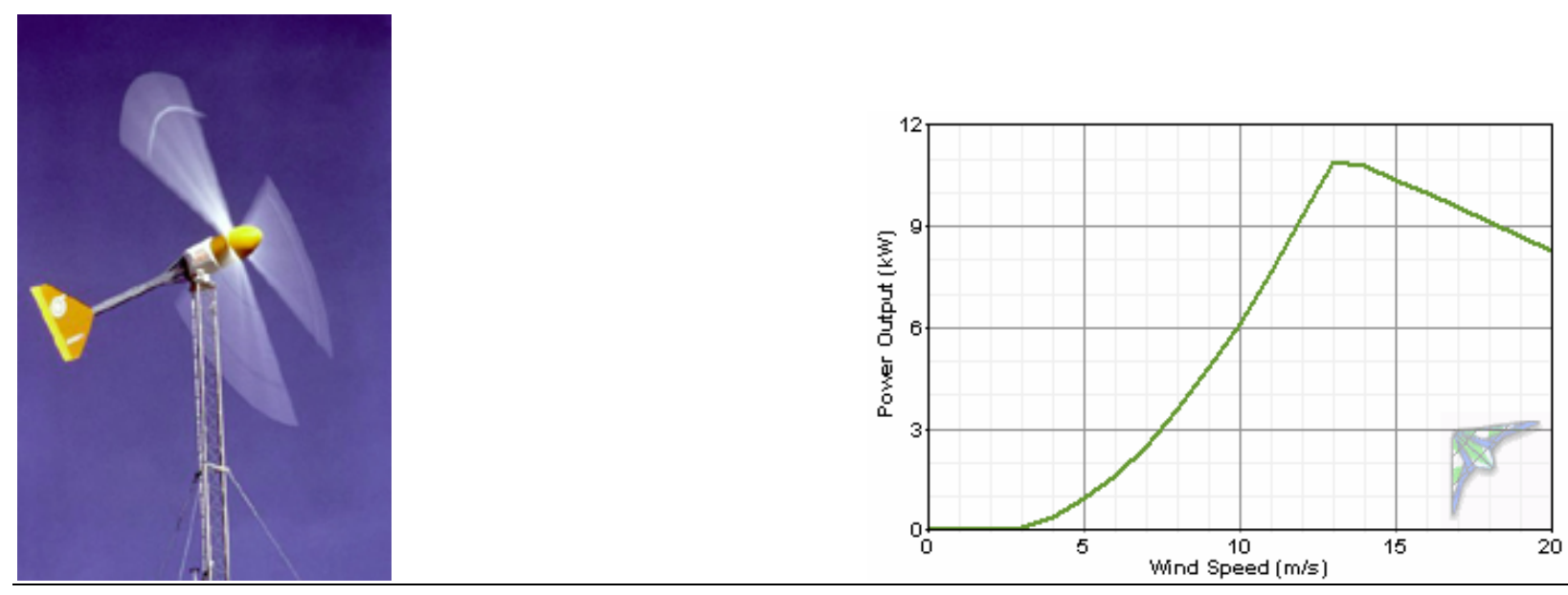

Entegrity eW-15: $65 \mathrm{~kW}$ rated power output, 15 meter rotor, stall-controlled (power curve provided by Entegrity Energy Systems). Available tower heights: 25 and 31 meters. Additional information is available at http://www.entegritywind.com/. 

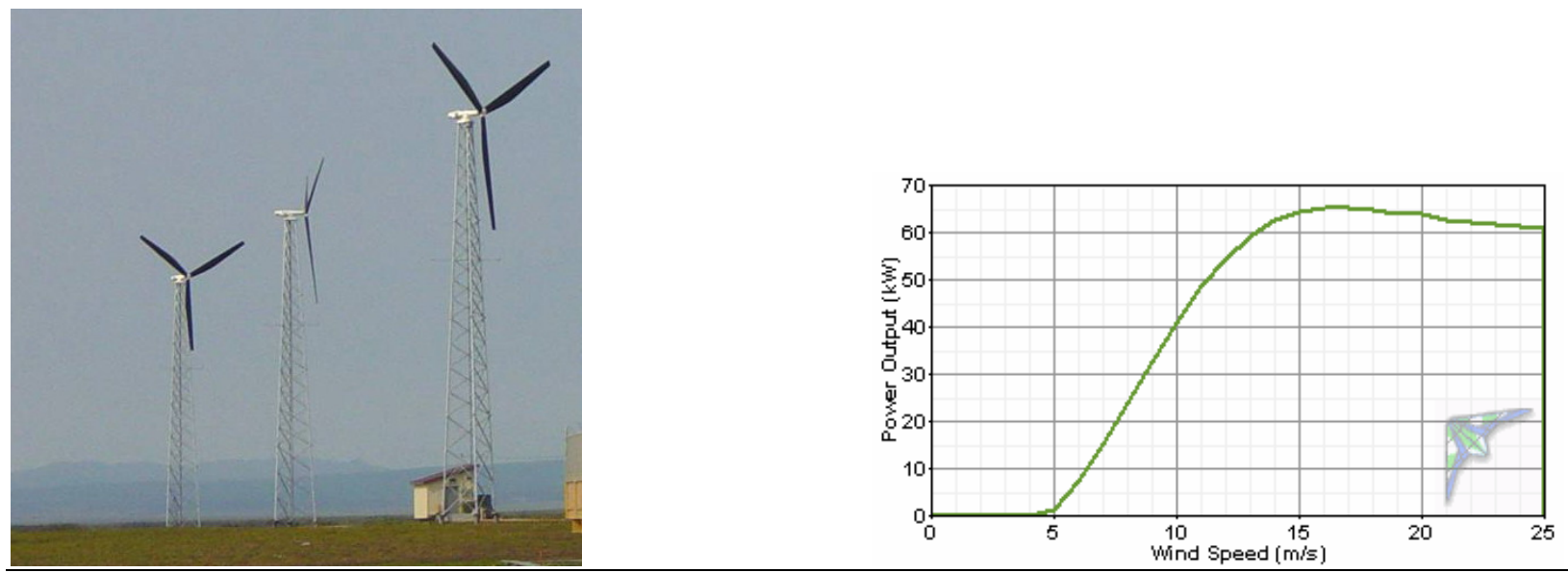

Vestas V15: $75 \mathrm{~kW}$ rated power output, 15 meter rotor, stall-controlled (power curve provided by Powercorp Alaska LLC). Available tower heights: 25, 31 and 34 meters. Additional information is available at http://www.pcorpalaska.com/.
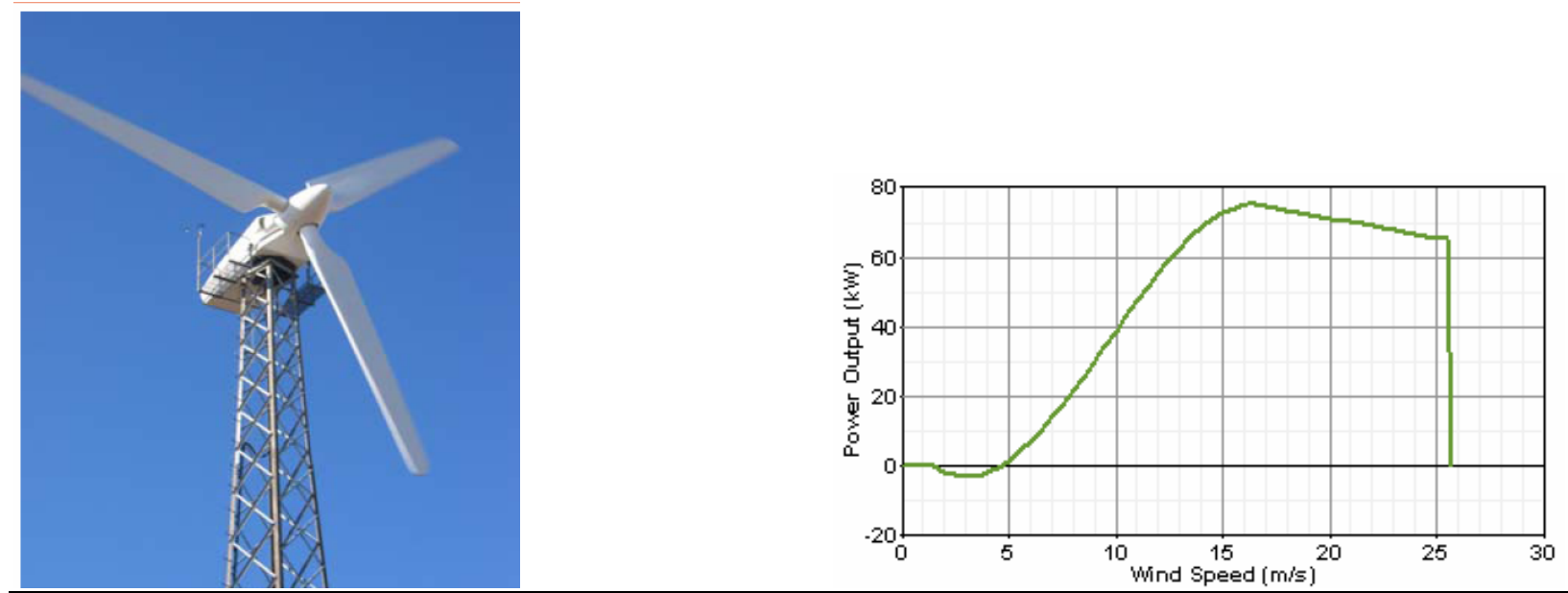

Northwind 100/20: $100 \mathrm{~kW}$ rated power output, 20 meter rotor (19 meter rotor blades with 0.6 meter blade root extensions added), stall-controlled (power curve provided by Northern Power Systems). Available tower heights: 25 and 32 meters. Additional information is available at http://www.northernpower.com/. 

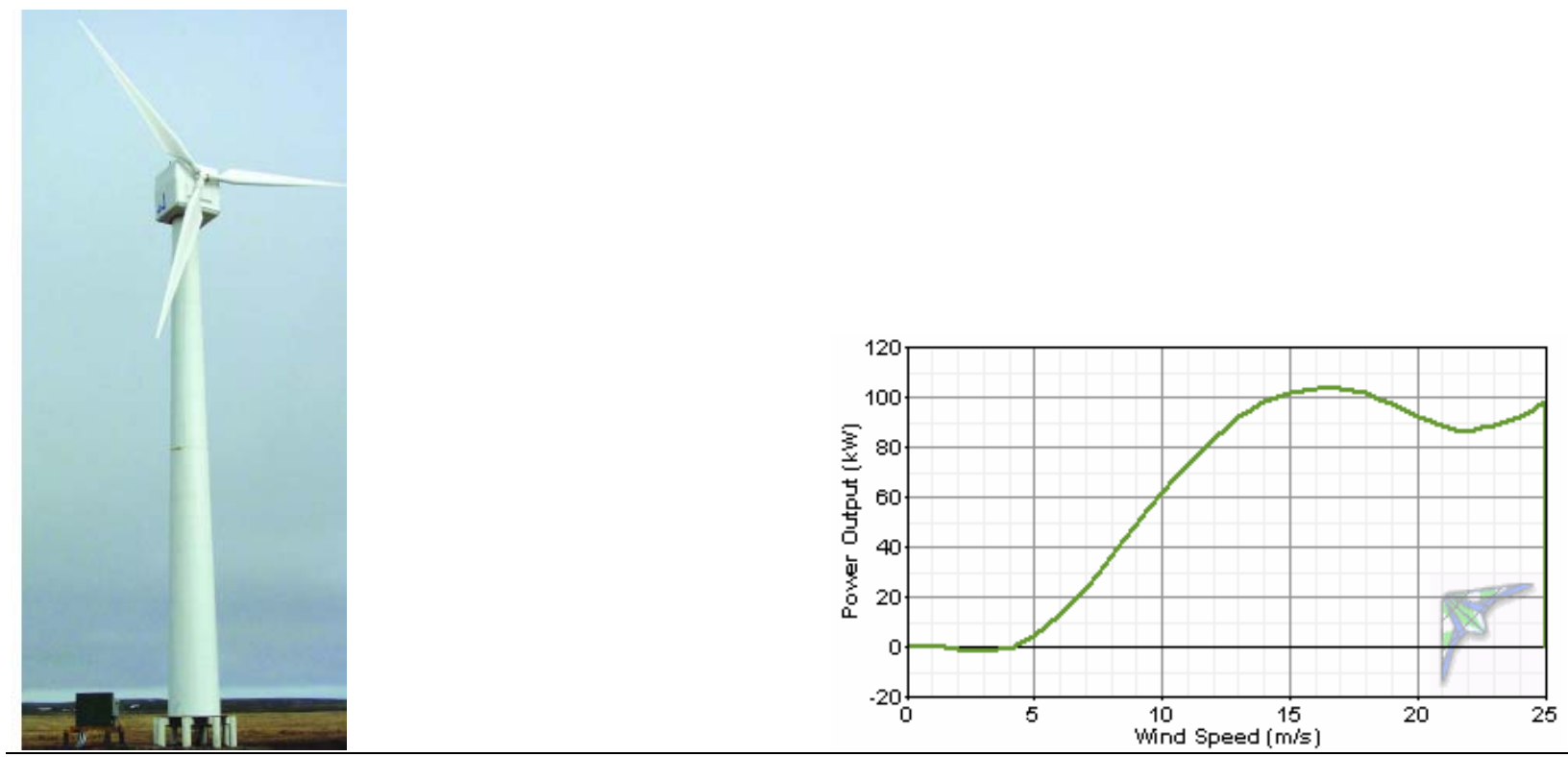

Vestas V27: $225 \mathrm{~kW}$ output, 27 meter rotor, pitch-controlled (power curve provided by Alaska Energy Authority).
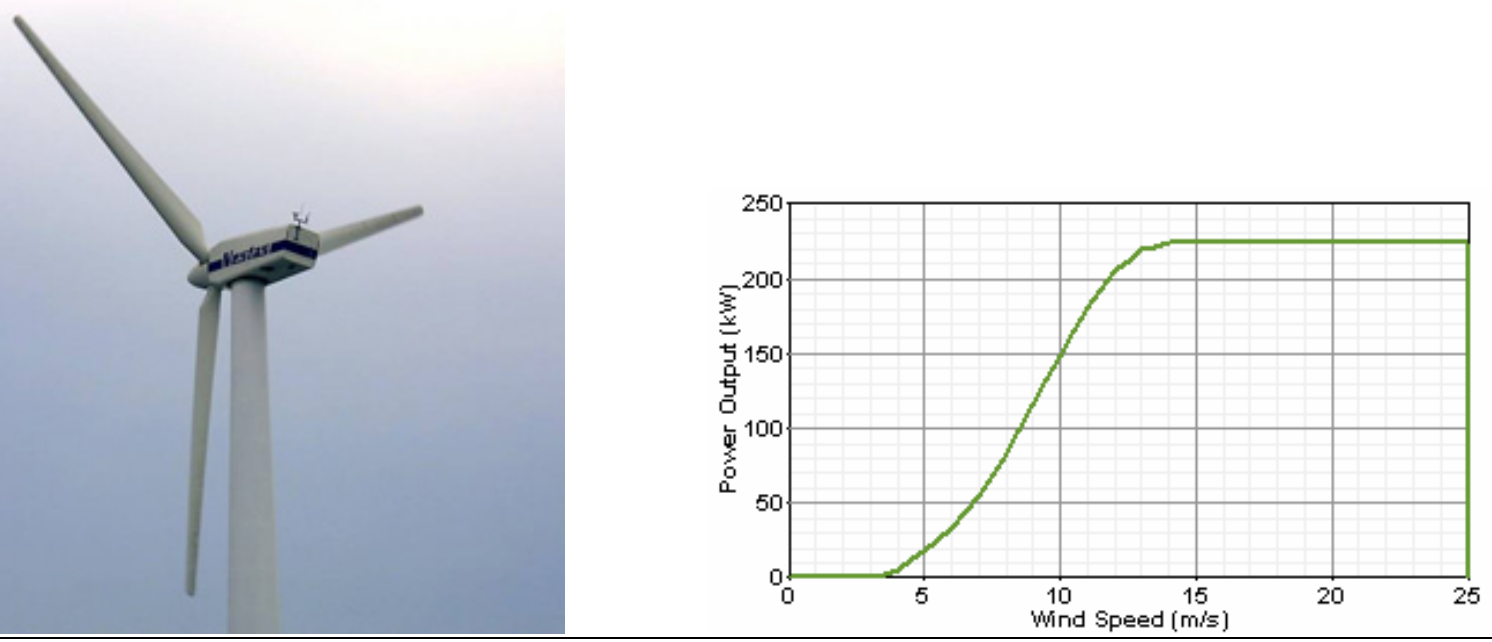

Fuhrländer FL250: 250 kW output, 29.5 meter rotor, stall-controlled (power curve provided by Lorax Energy Systems). Available tower heights: 42 and 50 meters. Additional information is available at www.lorax-energy.com. 

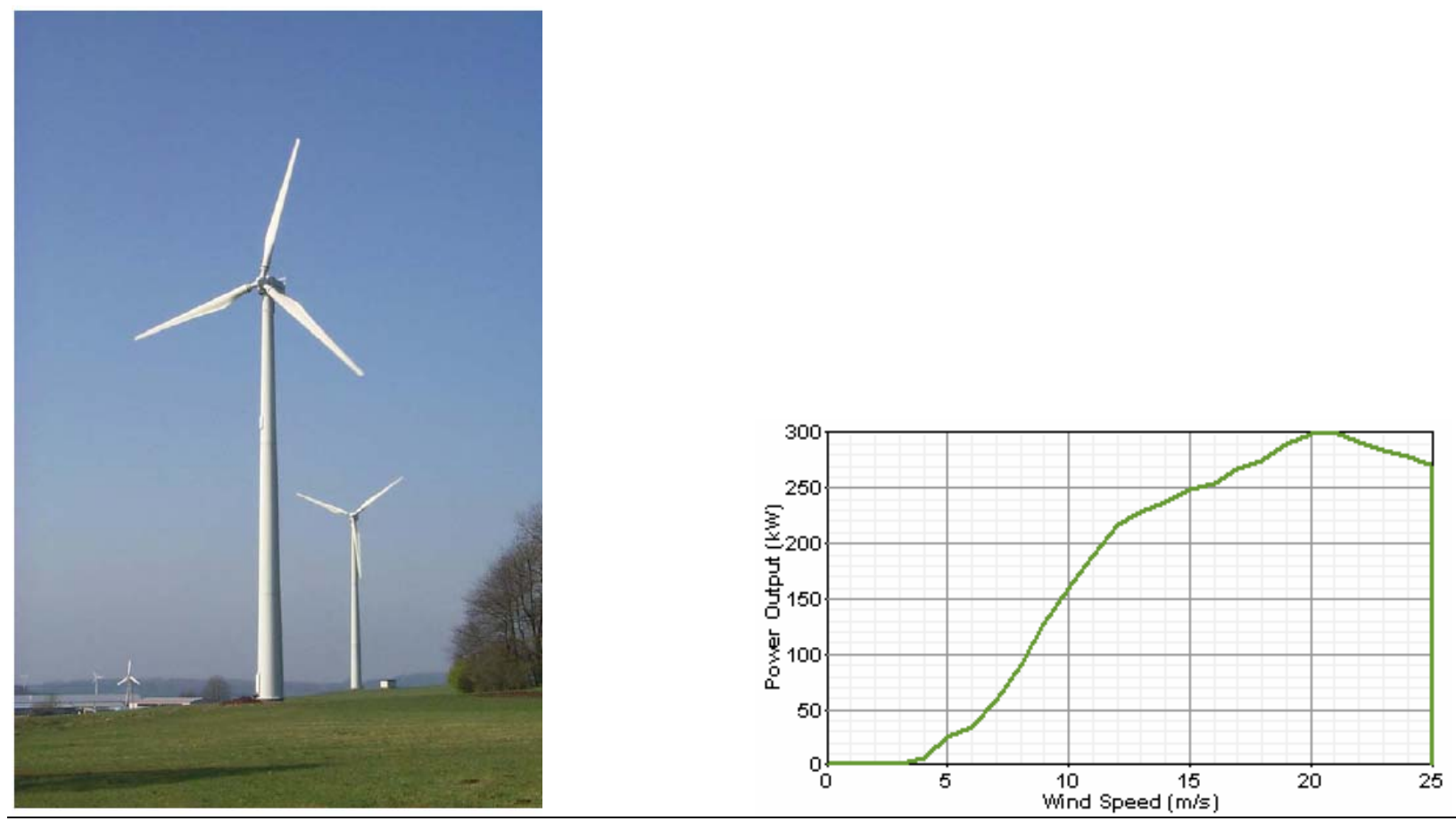

Vestas RRB 47/600: 600 kW output, 47 meter rotor, pitch-controlled (power curve provided by Vestas RRB, India). Available tower heights: 50 and 60 meters. Additional information is available at www.vestasrrb.com.
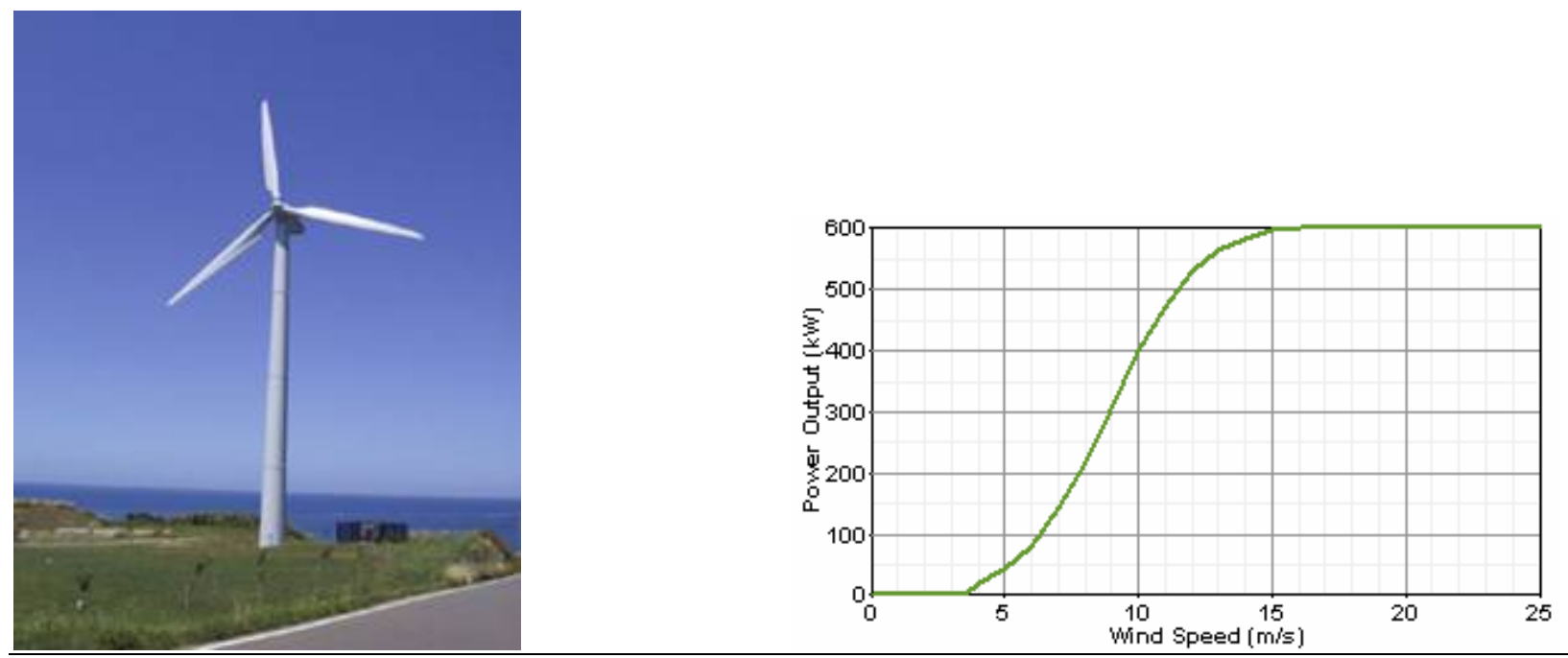
Naknek, Alaska Wind Resource Report

Turbine Power Output Comparison (100\% availability)

\begin{tabular}{|c|c|c|c|c|c|c|c|}
\hline Turbine & $\begin{array}{l}\text { Hub } \\
\text { Height } \\
(\mathrm{m})\end{array}$ & $\begin{array}{c}\text { Hub Height } \\
\text { Wind Speed } \\
(\mathrm{m} / \mathrm{s})\end{array}$ & $\begin{array}{c}\text { Time At } \\
\text { Zero Output } \\
(\%)\end{array}$ & $\begin{array}{c}\text { Time At } \\
\text { Rated Output } \\
(\%)\end{array}$ & $\begin{array}{c}\text { Average Net } \\
\text { Power Output } \\
(\mathrm{kW})\end{array}$ & $\begin{array}{l}\text { Annual Net } \\
\text { Energy } \\
\text { Output } \\
\text { (kWh/yr) } \\
\end{array}$ & $\begin{array}{c}\text { Average Net } \\
\text { Capacity } \\
\text { Factor } \\
(\%)\end{array}$ \\
\hline Bergey Excel-S & 43 & 6.60 & 6.5 & 5.3 & 2.9 & 25,631 & 29.3 \\
\hline Entegrity eW-15 $60 \mathrm{~Hz}$ & 31 & 6.22 & 27.0 & 2.5 & 15.5 & 135,670 & 23.8 \\
\hline Vestas V15 & 34 & 6.32 & 33.4 & 1.6 & 15.0 & 131,051 & 19.9 \\
\hline Northern Power NW 100/20 & 32 & 6.25 & 26.8 & 2.3 & 23.0 & 201,889 & 23.0 \\
\hline Vestas V27 & 50 & 6.79 & 9.0 & 2.8 & 69.1 & 605,677 & 30.7 \\
\hline Fuhrländer FL250 & 50 & 6.79 & 6.3 & 0.4 & 77.0 & 674,789 & 25.7 \\
\hline Vestas RRB 47/600 & 50 & 6.79 & 16.9 & 1.8 & 180.0 & $1,579,944$ & 30.1 \\
\hline \multicolumn{8}{|l|}{ Capacity Factor <20\% } \\
\hline \multicolumn{8}{|l|}{ Capacity Factor >20\%, <30\% } \\
\hline \multicolumn{8}{|l|}{ Capacity Factor $>30 \%,<40 \%$} \\
\hline \multicolumn{8}{|l|}{ Capacity Factor $>40 \%,<50 \%$} \\
\hline Capacity Factor $>50 \%$ & & & & & & & \\
\hline
\end{tabular}

Assumed turbine losses for predictions of average power output, annual energy output, and average capacity factor:

Downtime (\%)

Array (\%)

(\%)

Total (\%) 0 
Naknek, Alaska Wind Resource Report

Turbine Power Output Comparison (90\% availability)

\begin{tabular}{|c|c|c|c|c|c|c|c|}
\hline Turbine & $\begin{array}{l}\text { Hub } \\
\text { Height } \\
\text { (m) }\end{array}$ & $\begin{array}{c}\text { Hub Height } \\
\text { Wind Speed } \\
(\mathrm{m} / \mathrm{s})\end{array}$ & $\begin{array}{c}\text { Time At } \\
\text { Zero Output } \\
(\%)\end{array}$ & $\begin{array}{c}\text { Time At } \\
\text { Rated Output } \\
(\%)\end{array}$ & $\begin{array}{c}\text { Average Net } \\
\text { Power Output } \\
(\mathrm{kW})\end{array}$ & $\begin{array}{l}\text { Annual Net } \\
\text { Energy } \\
\text { Output } \\
\text { (kWh/yr) }\end{array}$ & $\begin{array}{l}\text { Average Net } \\
\text { Capacity } \\
\text { Factor } \\
(\%)\end{array}$ \\
\hline Bergey Excel-S & 43 & 6.60 & 6.5 & 5.3 & 2.6 & 23,159 & 26.4 \\
\hline Entegrity eW-15 $60 \mathrm{~Hz}$ & 31 & 6.22 & 27.0 & 2.5 & 14.0 & 122,584 & 21.5 \\
\hline Vestas V15 & 34 & 6.32 & 33.4 & 1.6 & 13.5 & 118,410 & 18.0 \\
\hline Northern Power NW 100/20 & 32 & 6.25 & 26.8 & 2.3 & 20.8 & 182,415 & 20.8 \\
\hline Vestas V27 & 50 & 6.79 & 9.0 & 2.8 & 62.5 & 547,256 & 27.8 \\
\hline Fuhrländer FL250 & 50 & 6.79 & 6.3 & 0.4 & 69.6 & 609,701 & 23.2 \\
\hline Vestas RRB 47/600 & 50 & 6.79 & 16.9 & 1.8 & 163.0 & $1,427,549$ & 27.2 \\
\hline \multicolumn{8}{|l|}{ Capacity Factor <20\% } \\
\hline \multicolumn{8}{|l|}{ Capacity Factor >20\%, <30\% } \\
\hline \multicolumn{8}{|l|}{ Capacity Factor $>30 \%,<40 \%$} \\
\hline \multicolumn{8}{|l|}{ Capacity Factor $>40 \%,<50 \%$} \\
\hline Capacity Factor >50\% & & & & & & & \\
\hline
\end{tabular}

Assumed turbine losses for predictions of average power output, annual energy output, and average capacity factor:

Downtime (\%)

Array (\%)

Icing/soiling (\%)

Other (\%)

Total (\%)
4

2

9.65 (factors are multiplicative) 
Naknek, Alaska Wind Resource Report

Fuel Cost Avoided for Electricity Generation by Diesel Generator

\begin{tabular}{|c|c|c|c|c|c|c|c|c|c|c|c|}
\hline \multirow[b]{2}{*}{ Turbine } & \multirow{2}{*}{$\begin{array}{c}\text { Annual } \\
\text { Energy } \\
\text { Output } \\
\text { (kW-hr/yr) }\end{array}$} & \multirow{2}{*}{$\begin{array}{c}\text { Fuel } \\
\text { Quantity } \\
\text { Avoided } \\
\text { (liters) }\end{array}$} & \multirow{2}{*}{$\begin{array}{c}\text { Fuel } \\
\text { Quantity } \\
\text { Avoided } \\
\text { (gallons) }\end{array}$} & \multicolumn{7}{|c|}{ Fuel Price (USD/gallon) } & \multirow{2}{*}{$\begin{array}{c}\text { Turbine } \\
\text { Hub } \\
\text { Height } \\
\text { (m) }\end{array}$} \\
\hline & & & & $\$ 1.75$ & $\$ 2.00$ & $\$ 2.25$ & $\$ 2.50$ & $\$ 2.75$ & $\$ 3.00$ & $\$ 3.25$ & \\
\hline Bergey Excel-S & 23,159 & 6,494 & 1,715 & $\$ 3,002$ & $\$ 3,431$ & $\$ 3,860$ & $\$ 4,289$ & $\$ 4,718$ & $\$ 5,146$ & $\$ 5,575$ & 43 \\
\hline Entegrity eW-15 $60 \mathrm{~Hz}$ & 122,584 & 34,373 & 9,080 & $\$ 15,891$ & $\$ 18,161$ & $\$ 20,431$ & $\$ 22,701$ & $\$ 24,971$ & $\$ 27,241$ & $\$ 29,511$ & 31 \\
\hline Vestas V15 & 118,410 & 33,202 & 8,771 & $\$ 15,349$ & $\$ 17,542$ & $\$ 19,735$ & $\$ 21,928$ & $\$ 24,121$ & $\$ 26,313$ & $\$ 28,506$ & 34 \\
\hline Northern Power NW 100/20 & 182,415 & 51,149 & 13,512 & $\$ 23,646$ & $\$ 27,024$ & $\$ 30,403$ & $\$ 33,781$ & $\$ 37,159$ & $\$ 40,537$ & $\$ 43,915$ & 32 \\
\hline Vestas V27 & 547,256 & 153,451 & 40,537 & $\$ 70,941$ & $\$ 81,075$ & $\$ 91,209$ & $\$ 101,344$ & $\$ 111,478$ & $\$ 121,612$ & $\$ 131,747$ & 50 \\
\hline Fuhrländer FL250 & 609,701 & 170,960 & 45,163 & $\$ 79,035$ & $\$ 90,326$ & $\$ 101,617$ & $\$ 112,908$ & $\$ 124,198$ & $\$ 135,489$ & $\$ 146,780$ & 50 \\
\hline Vestas RRB 47/600 & $1,427,549$ & 400,285 & 105,744 & $\$ 185,053$ & $\$ 211,489$ & $\$ 237,925$ & $\$ 264,361$ & $\$ 290,797$ & $\$ 317,233$ & $\$ 343,669$ & 50 \\
\hline
\end{tabular}

Notes:

1. Naknek electrical energy production efficiency assumed to be $13.5 \mathrm{~kW}$-hr/gal

2. Assumes $90 \%$ wind turbine availability with no diversion of power to a thermal or other dump load

3. Assumes linear diesel generator fuel efficiency (i.e., 1:1 tradeoff of wind turbine kW-hr to diesel genset kW-hr) 
Naknek, Alaska Wind Resource Report

Temperature Conversion Chart ${ }^{\circ} \mathrm{C}$ to ${ }^{\circ} \mathrm{F}$

\begin{tabular}{|c|c|c|c|c|c|}
\hline${ }^{\circ} \mathbf{C}$ & ${ }^{\circ} \mathbf{F}$ & ${ }^{\circ} \mathbf{C}$ & ${ }^{\circ} \mathbf{F}$ & ${ }^{\circ} \mathbf{C}$ & ${ }^{\circ} \mathbf{F}$ \\
\hline-40 & -40 & -10 & 14 & 20 & 68 \\
\hline-39 & -38.2 & -9 & 15.8 & 21 & 69.8 \\
\hline-38 & -36.4 & -8 & 17.6 & 22 & 71.6 \\
\hline-37 & -34.6 & -7 & 19.4 & 23 & 73.4 \\
\hline-36 & -32.8 & -6 & 21.2 & 24 & 75.2 \\
\hline-35 & -31 & -5 & 23 & 25 & 77 \\
\hline-34 & 29.2 & -4 & 24.8 & 26 & 78.8 \\
\hline-33 & -27.4 & -3 & 26.6 & 27 & 80.6 \\
\hline-32 & -25.6 & -2 & 28.4 & 28 & 82.4 \\
\hline-31 & -23.8 & -1 & 30.2 & 29 & 84.2 \\
\hline-30 & -22 & 0 & 32 & 30 & 86 \\
\hline-29 & -20.2 & 1 & 33.8 & 31 & 87.8 \\
\hline-28 & -18.4 & 2 & 35.6 & 32 & 89.6 \\
\hline-27 & -16.6 & 3 & 37.4 & 33 & 91.4 \\
\hline-26 & -14.8 & 4 & 39.2 & 34 & 93.2 \\
\hline-25 & -13 & 5 & 41 & 35 & 95 \\
\hline-24 & -11.2 & 6 & 42.8 & 36 & 96.8 \\
\hline-23 & -9.4 & 7 & 44.6 & 37 & 98.6 \\
\hline-22 & -7.6 & 8 & 46.4 & 38 & 100.4 \\
\hline-21 & -5.8 & 9 & 48.2 & 39 & 102.2 \\
\hline-20 & -4 & 10 & 50 & 40 & 104 \\
\hline-19 & -2.2 & 11 & 51.8 & 41 & 105.8 \\
\hline-18 & -0.4 & 12 & 53.6 & 42 & 107.6 \\
\hline-17 & 1.4 & 13 & 55.4 & 43 & 109.4 \\
\hline-16 & 3.2 & 14 & 57.2 & 44 & 111.2 \\
\hline-15 & 5 & 15 & 59 & 45 & 113 \\
\hline-14 & 6.8 & 16 & 60.8 & 46 & 114.8 \\
\hline-13 & 8.6 & 17 & 62.6 & 47 & 116.6 \\
\hline-12 & 10.4 & 18 & 64.4 & 48 & 118.4 \\
\hline-11 & 12.2 & 19 & 66.2 & 49 & 120.2 \\
\hline & & & & & \\
\hline-21 & & & & \\
\hline
\end{tabular}


Naknek, Alaska Wind Resource Report

Wind Speed Conversion Chart $\mathrm{m} / \mathrm{s}$ to $\mathrm{mph}$

\begin{tabular}{|c|c|c|c|c|c|}
\hline $\mathbf{m} / \mathbf{s}$ & $\mathbf{m p h}$ & $\mathbf{m} / \mathbf{s}$ & $\mathbf{m p h}$ & $\mathbf{~} / \mathbf{s}$ & $\mathbf{m p h}$ \\
\hline 0.5 & 1.1 & 10.5 & 23.5 & 20.5 & 45.9 \\
\hline 1.0 & 2.2 & 11.0 & 24.6 & 21.0 & 47.0 \\
\hline 1.5 & 3.4 & 11.5 & 25.7 & 21.5 & 48.1 \\
\hline 2.0 & 4.5 & 12.0 & 26.8 & 22.0 & 49.2 \\
\hline 2.5 & 5.6 & 12.5 & 28.0 & 22.5 & 50.3 \\
\hline 3.0 & 6.7 & 13.0 & 29.1 & 23.0 & 51.4 \\
\hline 3.5 & 7.8 & 13.5 & 30.2 & 23.5 & 52.6 \\
\hline 4.0 & 8.9 & 14.0 & 31.3 & 24.0 & 53.7 \\
\hline 4.5 & 10.1 & 14.5 & 32.4 & 24.5 & 54.8 \\
\hline 5.0 & 11.2 & 15.0 & 33.6 & 25.0 & 55.9 \\
\hline 5.5 & 12.3 & 15.5 & 34.7 & 25.5 & 57.0 \\
\hline 6.0 & 13.4 & 16.0 & 35.8 & 26.0 & 58.2 \\
\hline 6.5 & 14.5 & 16.5 & 36.9 & 26.5 & 59.3 \\
\hline 7.0 & 15.7 & 17.0 & 38.0 & 27.0 & 60.4 \\
\hline 7.5 & 16.8 & 17.5 & 39.1 & 27.5 & 61.5 \\
\hline 8.0 & 17.9 & 18.0 & 40.3 & 28.0 & 62.6 \\
\hline 8.5 & 19.0 & 18.5 & 41.4 & 28.5 & 63.8 \\
\hline 9.0 & 20.1 & 19.0 & 42.5 & 29.0 & 64.9 \\
\hline 9.5 & 21.3 & 19.5 & 43.6 & 29.5 & 66.0 \\
\hline 10.0 & 22.4 & 20.0 & 44.7 & 30.0 & 67.1 \\
\hline
\end{tabular}

Distance Conversion $\mathrm{m}$ to $\mathrm{ft}$

\begin{tabular}{|c|c|c|c|}
\hline $\mathbf{m}$ & $\mathbf{f t}$ & $\mathbf{m}$ & $\mathbf{f t}$ \\
\hline 5 & 16 & 35 & 115 \\
\hline 10 & 33 & 40 & 131 \\
\hline 15 & 49 & 45 & 148 \\
\hline 20 & 66 & 50 & 164 \\
\hline 25 & 82 & 55 & 180 \\
\hline 30 & 98 & 60 & 197 \\
\hline
\end{tabular}


Selected definitions (courtesy of Windographer® software by Mistaya Engineering Inc.)

\section{$\underline{\text { Wind Power Class }}$}

The wind power class is a number indicating the average energy content of the wind resource. Wind power classes are based on the average wind power density at 50 meters above ground, according to the following table. Source: Wind Energy Resource Atlas of the United States (http://rredc.nrel.gov/wind/pubs/atlas/tables/A-8T.html)

\begin{tabular}{|c|l|c|}
\hline \multicolumn{2}{|c|}{} & \multicolumn{2}{|c|}{} \\
\hline Wind Power Class & Description & Power Density at 50m $\mathbf{( W / \mathbf { m } ^ { 2 }}$ \\
\hline 1 & Poor & $0-200$ \\
\hline 2 & Marginal & $200-300$ \\
\hline 3 & Fair & $300-400$ \\
\hline 4 & Good & $400-500$ \\
\hline 5 & Excellent & $500-600$ \\
\hline 6 & Outstanding & $600-800$ \\
\hline 7 & Superb & $800-2000$ \\
\hline
\end{tabular}

Windographer classifies any wind resource with an average wind power density above 2000 $\mathrm{W} / \mathrm{m}^{2}$ as class 8 .

Probability Distribution Function

The probability distribution function $\mathrm{f}(\mathrm{x})$ gives the probability that a variable will take on the value $\mathrm{x}$. It is often expressed using a frequency histogram, which gives the frequency with which the variable falls within certain ranges or bins.

\section{$\underline{\text { Wind Turbine Power Regulation }}$}

All wind turbines employ some method of limiting power output at high wind speeds to avoid damage to mechanical or electrical subsystems. Most wind turbines employ either stall control or pitch control to regulate power output.

A stall-controlled turbine typically has blades that are fixed in place, and are designed to experience aerodynamic stall at very high wind speeds. Aerodynamic stall dramatically reduces the torque produced by the blades, and therefore the power produced by the turbine.

On a pitch-controlled turbine, a controller adjusts the angle (pitch) of the blades to best match the wind speed. At very high wind speeds the controller increasingly feathers the blades out of the wind to limit the power output. 


\section{New Stuyahok, Alaska Wind Resource Report}

Report written by: Douglas Vaught, P.E., V3 Energy, LLC, Eagle River, AK

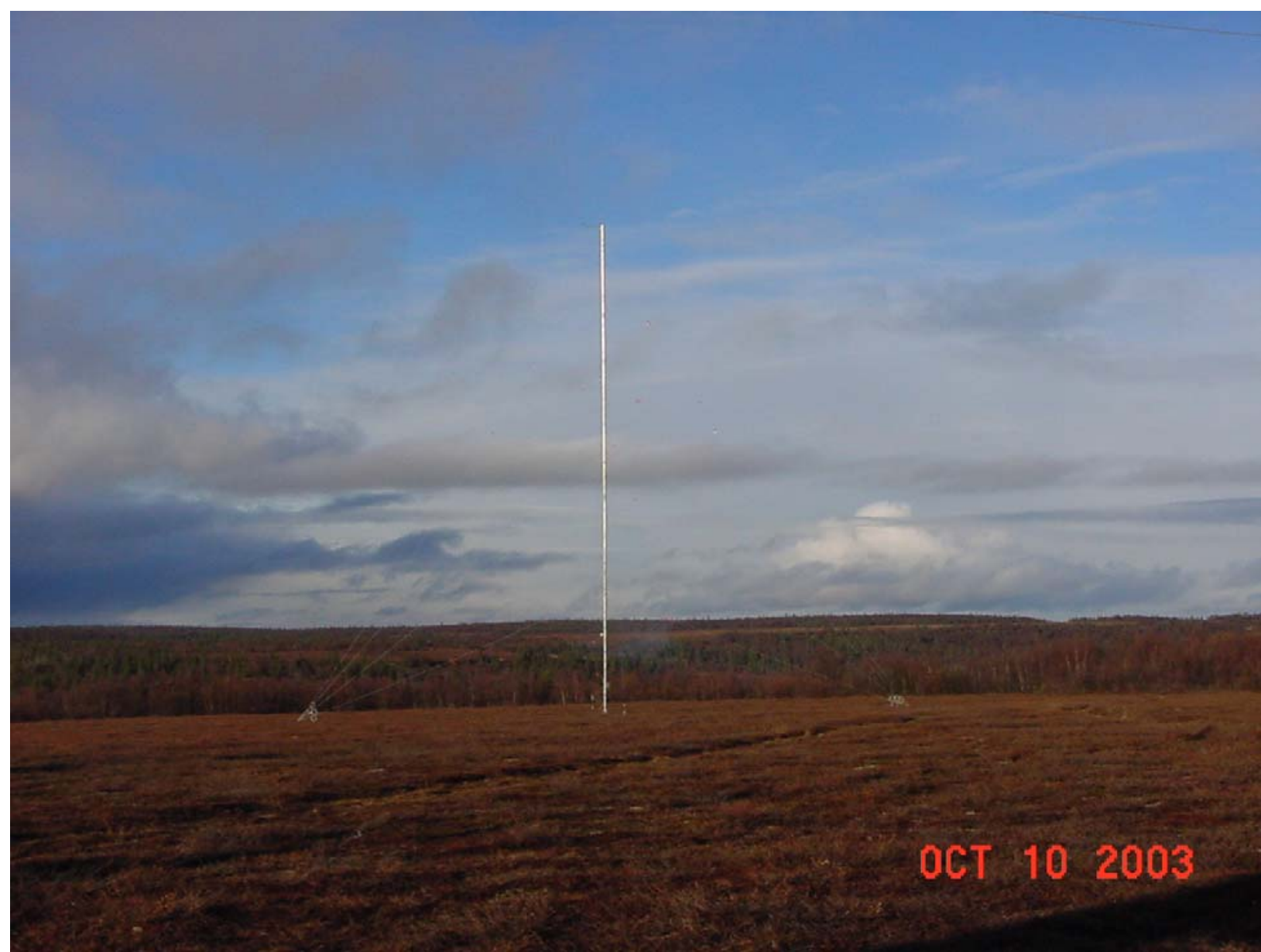

Photo (C) Doug Vaught

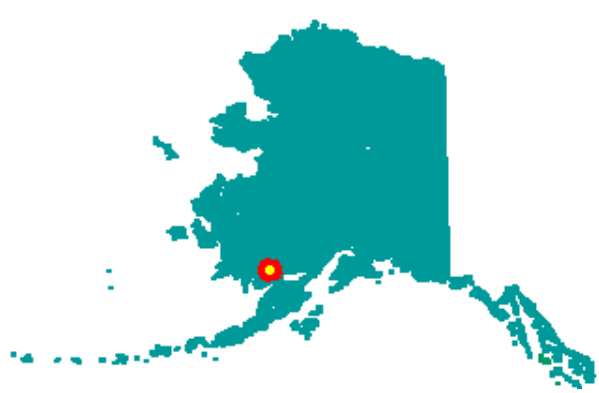

\section{Summary Information}

New Stuyahok has fair to good potential for wind power development, provided a slightly better location for wind turbines is found than the meteorological tower test site. The test site appeared 
to be adversely affected by the presence of trees nearby. When the new airfield opens and the old one abandoned, the old runway would be an ideal location for wind turbines: it is higher and more open than the met tower test site, and turbine foundations would be easier to construct.

\title{
Data Synopsis
}

Wind power class

Wind speed annual average (30 meters)

Maximum wind speed measured

Mean wind power density (50 meters)

Mean wind power density (30 meters)

Weibull distribution parameters

Roughness Class

Power law exponent

Turbulence Intensity

Data start date

Data end date

*Wind power density at 50 meters likely an overestimate due to high shear measured
Class 4 - Good

$5.46 \mathrm{~m} / \mathrm{s}$

$33.6 \mathrm{~m} / \mathrm{s}$, November 2004

$414 \mathrm{~W} / \mathrm{m}^{2}$ (calculated*)

$232 \mathrm{~W} / \mathrm{m}^{2}$ (measured)

$\mathrm{k}=1.76, \mathrm{c}=6.29 \mathrm{~m} / \mathrm{s}$

$4.39 \mathrm{~m}$ (suburban)

0.382 (high wind shear)

0.151 (moderate to high)

October 10, 2003

July 7, 2005

\section{Community Profile}

\author{
Current Population: 472 (2005 State Demographer est.) \\ Pronunciation/Other Names: (STEW-yuh-hawk) \\ Incorporation Type: 2nd Class City \\ Borough Located In: Unorganized \\ School District: Southwest Region Schools \\ Regional Native Corporation: Bristol Bay Native Corporation
}

\section{Location:}

New Stuyahok is located on the Nushagak River, about 12 miles upriver from Ekwok and 52 miles northeast of Dillingham. The village has been constructed at two elevations -- one 25 feet above river level, and one about 40 feet above river level. It lies at approximately $59.452780^{\circ}$ North Latitude and 157.311940 West Longitude. (Sec. 29, T008S, R047W, Seward Meridian.) New Stuyahok is located in the Bristol Bay Recording District. The area encompasses 32.6 sq. miles of land and 2.0 sq. miles of water.

\section{History:}

The present location is the third site that villagers can remember. The village moved downriver to the Mulchatna area from the "Old Village" in 1918. During the 1920s and 30s, the village was engaged in herding reindeer for the U.S. government. However, by 1942 the herd had dwindled to nothing; the village had been subjected to flooding; and the site was too far inland even to receive barge service. So in 1942, the village moved downriver again to its present location. Stuyahok appropriately means "going downriver place." The first school was built in 1961. A post office was also established during that year. An airstrip was built soon thereafter, and the 1960 s saw a $40 \%$ increase in the village population. The City was incorporated in 1972.

\section{Culture:}

New Stuyahok is a southern Yup'ik Eskimo village with Russian Orthodox influences. Residents practice a fishing and subsistence lifestyle. 


\section{Economy:}

The primary economic base in New Stuyahok is the salmon fishery; forty-three residents hold commercial fishing permits. Many trap as well. The entire community relies upon subsistence foods. Subsistence items are often traded between communities. Salmon, moose, caribou, rabbit, ptarmigan, duck and geese are the primary sources of meat.

\section{Facilities:}

Water is derived from a well and is treated. A new well is under development. The majority of the community (94 homes), facilities and the school are connected to a piped water and sewer system installed in 1971 and have complete plumbing. Some residents use individual wells and septic tanks; six homes are without complete plumbing. A Master Plan has been funded.

\section{Transportation:}

Air transport is most frequently used to reach the community. Regular and charter flights are available from Dillingham. The State-owned gravel airstrip is 1,800' long by $50^{\prime}$ wide and lighted. It is located on a hilltop; windy conditions often preclude landing. The community has requested funds for construction of a crosswind landing strip. There are no docking facilities. Goods are lightered on a regular basis during the summer. Skiffs, ATVs and snowmachines are prevalent forms of local transportation.

\section{Climate:}

New Stuyahok is located in a climatic transition zone. The primary influence is maritime, although a continental climate affects the weather. Average summer temperatures range from 37 to 66; winter temperatures average 4 to 30 . Annual precipitation ranges from 20 to 35 inches. Fog and low clouds are common during the summer; strong winds often preclude access during the winter. The River is ice-free from June through mid-November.

(Above information from State of Alaska Department of Commerce, Community and Economic Development website, www.dced.state.ak.us)

\section{Tower Sensor Information}

$\begin{array}{clrrrr}\text { Channel } & \text { Sensor type } & \text { Height } & \text { Multiplier } & \text { Offset } & \text { Orientation } \\ 1 & \text { NRG \#40 anemometer } & 30 \mathrm{~m} & 0.765 & 0.35 & \text { north } \\ 2 & \text { NRG \#40 anemometer } & 20 \mathrm{~m} & 0.765 & 0.35 & \text { north } \\ 7 & \text { NRG \#200P wind vane } & 30 \mathrm{~m} & 0.351 & 090 & \text { west } \\ 9 & \text { NRG \#110S Temp C } & 2 \mathrm{~m} & 0.136 & -86.383 & \text { N/A }\end{array}$

Site Information and Location

Site number

Site Description

Latitude/longitude

Site elevation

Datalogger type

Tower type
0064

New Stuyahok - AVEC

N 59 27.115'; W $157^{\circ} 19.427^{\prime}$

125 meters

NRG Symphonie

NRG 30-meter tall tower, 152 mm (6-in) diameter 
New Stuyahok, Alaska Wind Resource Report

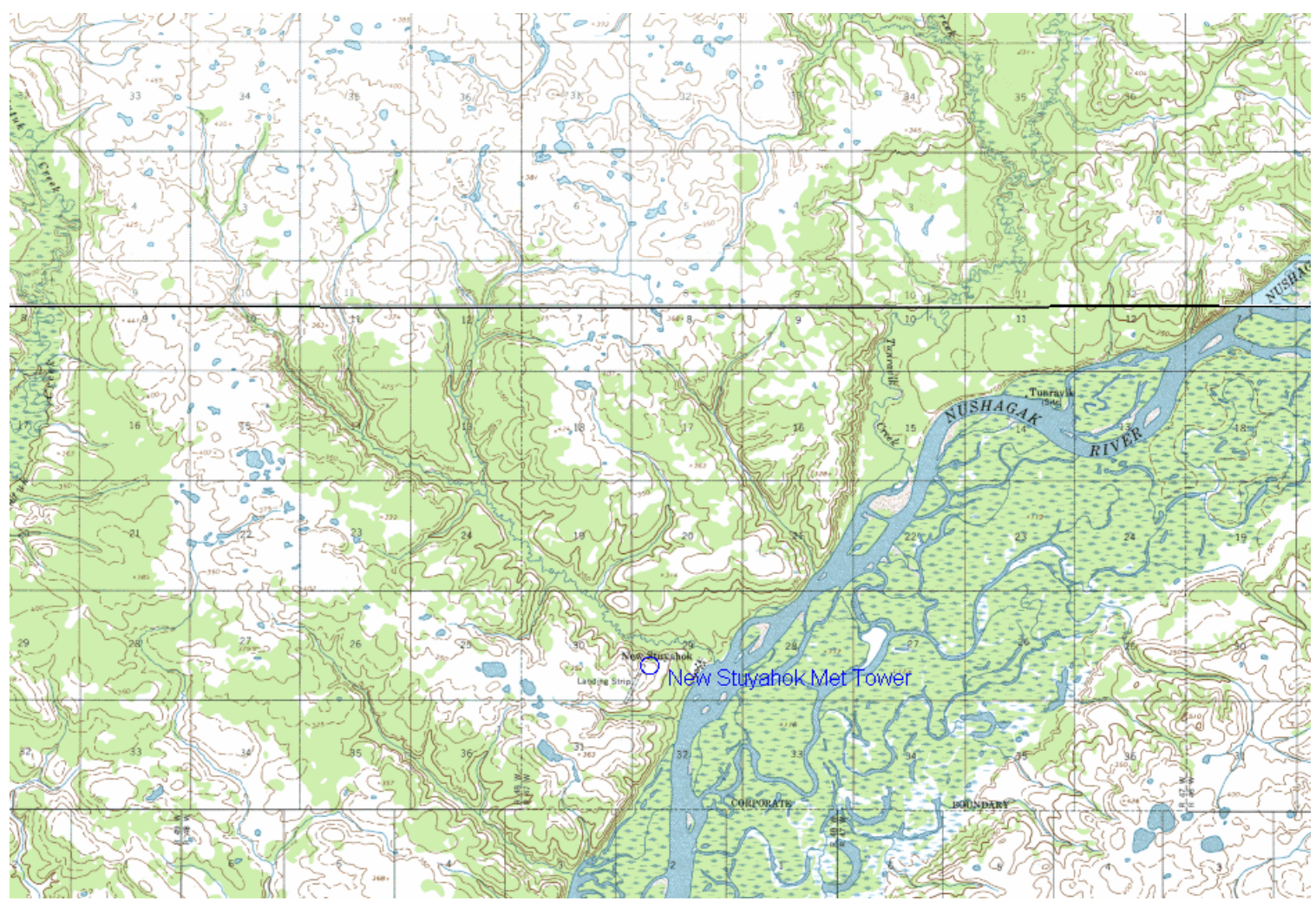


New Stuyahok, Alaska Wind Resource Report

\section{Data Quality Control}

Data was filtered to remove presumed icing events that yield false zero wind speed data. Data that met the following criteria were filtered: wind speed $<1 \mathrm{~m} / \mathrm{s}$, wind speed standard deviation $=0$, and temperature $<2{ }^{\circ} \mathrm{C}$. Note that wind speed data recovery during the months of June, July and August was 100\%, but during the winter months of November through March larger amounts data was filtered, with December being the most ice prone as far as data loss is concerned. Temperature data recovery was 100 percent, indicating full functioning of the temperature sensor. Data was synthesized to replace data removed due to icing events; the synthesized data set is used in this report.

\begin{tabular}{rrrrrrrrrr} 
& & \multicolumn{2}{c}{$30 \mathrm{~m}$ anemometer } \\
Year & Month & Records $\begin{array}{c}\text { Recovery } \\
\text { Rate }(\%)\end{array}$ & Records & $\begin{array}{c}\text { Recovery } \\
\text { Rate }(\%)\end{array}$ & \multicolumn{2}{c}{$\begin{array}{c}\text { Wind vane } \\
\text { Records }\end{array}$} & $\begin{array}{c}\text { Tecovery } \\
\text { Rate }(\%)\end{array}$ & $\begin{array}{r}\text { Records } \\
\text { Recovery } \\
\text { Rate }(\%)\end{array}$ \\
\hline 2003 & Oct & 3,021 & 99.9 & 3,020 & 99.9 & 2,761 & 91.3 & 3,024 & 100 \\
2003 & Nov & 4,274 & 98.9 & 4,202 & 97.3 & 3,871 & 89.6 & 4,320 & 100 \\
2003 & Dec & 4,383 & 98.2 & 4,331 & 97.0 & 4,088 & 91.6 & 4,464 & 100 \\
2004 & Jan & 4,190 & 93.9 & 4,189 & 93.8 & 4,456 & 99.8 & 4,464 & 100 \\
2004 & Feb & 3,825 & 91.6 & 4,040 & 96.7 & 3,609 & 86.4 & 4,176 & 100 \\
2004 & Mar & 4,338 & 97.2 & 4,330 & 97.0 & 4,303 & 96.4 & 4,464 & 100 \\
2004 & Apr & 4,280 & 99.1 & 4,278 & 99.0 & 4,272 & 98.9 & 4,320 & 100 \\
2004 & May & 4,458 & 99.9 & 4,457 & 99.8 & 4,456 & 99.8 & 4,464 & 100 \\
2004 & Jun & 4,320 & 100 & 4,320 & 100 & 4,320 & 100 & 4,320 & 100 \\
2004 & Jul & 4,464 & 100 & 4,464 & 100 & 4,464 & 100 & 4,464 & 100 \\
2004 & Aug & 4,464 & 100 & 4,464 & 100 & 4,464 & 100 & 4,464 & 100 \\
2004 & Sep & 4,286 & 99.2 & 4,275 & 99.0 & 4,274 & 98.9 & 4,320 & 100 \\
2004 & Oct & 4,346 & 97.4 & 4,347 & 97.4 & 4,343 & 97.3 & 4,464 & 100 \\
2004 & Nov & 3,868 & 89.5 & 3,906 & 90.4 & 3,111 & 72.0 & 4,320 & 100 \\
2004 & Dec & 3,478 & 77.9 & 3,630 & 81.3 & 2,797 & 62.7 & 4,464 & 100 \\
2005 & Jan & 4,102 & 91.9 & 4,081 & 91.4 & 4,201 & 94.1 & 4,464 & 100 \\
2005 & Feb & 3,894 & 96.6 & 3,913 & 97.0 & 3,894 & 96.6 & 4,032 & 100 \\
2005 & Mar & 4,205 & 94.2 & 4,226 & 94.7 & 4,200 & 94.1 & 4,464 & 100 \\
2005 & Apr & 4,195 & 97.1 & 4,256 & 98.5 & 4,196 & 97.1 & 4,320 & 100 \\
2005 & May & 4,464 & 100 & 4,464 & 100 & 4,464 & 100 & 4,464 & 100 \\
2005 & Jun & 4,320 & 100 & 4,320 & 100 & 4,320 & 100 & 4,320 & 100 \\
2005 & Jul & 912 & 100 & 912 & 100 & 912 & 100 & 912 & 100 \\
\hline All data & & 88,087 & 96.3 & 88,425 & 96.7 & 85,776 & 93.8 & 91,488 & 100
\end{tabular}


New Stuyahok, Alaska Wind Resource Report

\section{Measured Wind Speeds}

The 30 meter anemometer wind speed average for the reporting period is $5.46 \mathrm{~m} / \mathrm{s}$ and the 20 meter anemometer wind speed average is $4.67 \mathrm{~m} / \mathrm{s}$.

\begin{tabular}{ccccccccc} 
Month & $\begin{array}{c}\text { Mean } \\
(\mathrm{m} / \mathrm{s})\end{array}$ & $\begin{array}{c}\text { Max } \\
(\mathrm{m} / \mathrm{s})\end{array}$ & $\begin{array}{c}\text { SD } \\
(\mathrm{m} / \mathrm{s})\end{array}$ & Weibull k & $\begin{array}{c}\text { Weibull c } \\
(\mathrm{m} / \mathrm{s})\end{array}$ & $\begin{array}{c}\text { Mean } \\
(\mathrm{m} / \mathrm{s})\end{array}$ & $\begin{array}{c}\text { Max } \\
(\mathrm{m} / \mathrm{s})\end{array}$ & $\begin{array}{c}\text { Std. Dev. } \\
(\mathrm{m} / \mathrm{s})\end{array}$ \\
\hline Jan & 7.44 & 19.5 & 3.10 & 2.54 & 8.36 & 6.43 & 16.8 & 2.81 \\
Feb & 6.52 & 20.9 & 3.58 & 1.90 & 7.35 & 5.59 & 17.6 & 3.12 \\
Mar & 6.06 & 21.3 & 3.34 & 1.88 & 6.81 & 5.31 & 18.1 & 2.94 \\
Apr & 5.97 & 20.0 & 3.51 & 1.76 & 6.71 & 5.19 & 17.3 & 3.08 \\
May & 4.56 & 19.5 & 3.08 & 1.52 & 5.07 & 3.95 & 15.9 & 2.59 \\
Jun & 4.68 & 17.6 & 2.94 & 1.63 & 5.23 & 3.98 & 14.4 & 2.44 \\
Jul & 3.98 & 15.9 & 2.22 & 1.89 & 4.49 & 3.40 & 12.9 & 1.92 \\
Aug & 4.38 & 14.6 & 2.49 & 1.84 & 4.93 & 3.68 & 12.6 & 2.16 \\
Sep & 4.58 & 13.1 & 2.76 & 1.68 & 5.12 & 3.87 & 11.5 & 2.51 \\
Oct & 5.99 & 20.7 & 2.98 & 2.08 & 6.74 & 5.11 & 17.0 & 2.64 \\
Nov & 5.58 & 21.9 & 3.09 & 1.87 & 6.29 & 4.69 & 18.7 & 2.74 \\
Dec & 5.85 & 20.9 & 3.31 & 1.83 & 6.58 & 4.99 & 19.0 & 2.98 \\
\hline All data & 5.46 & 21.9 & 3.26 & 1.77 & 6.29 & 4.67 & 19.0 & 2.87
\end{tabular}

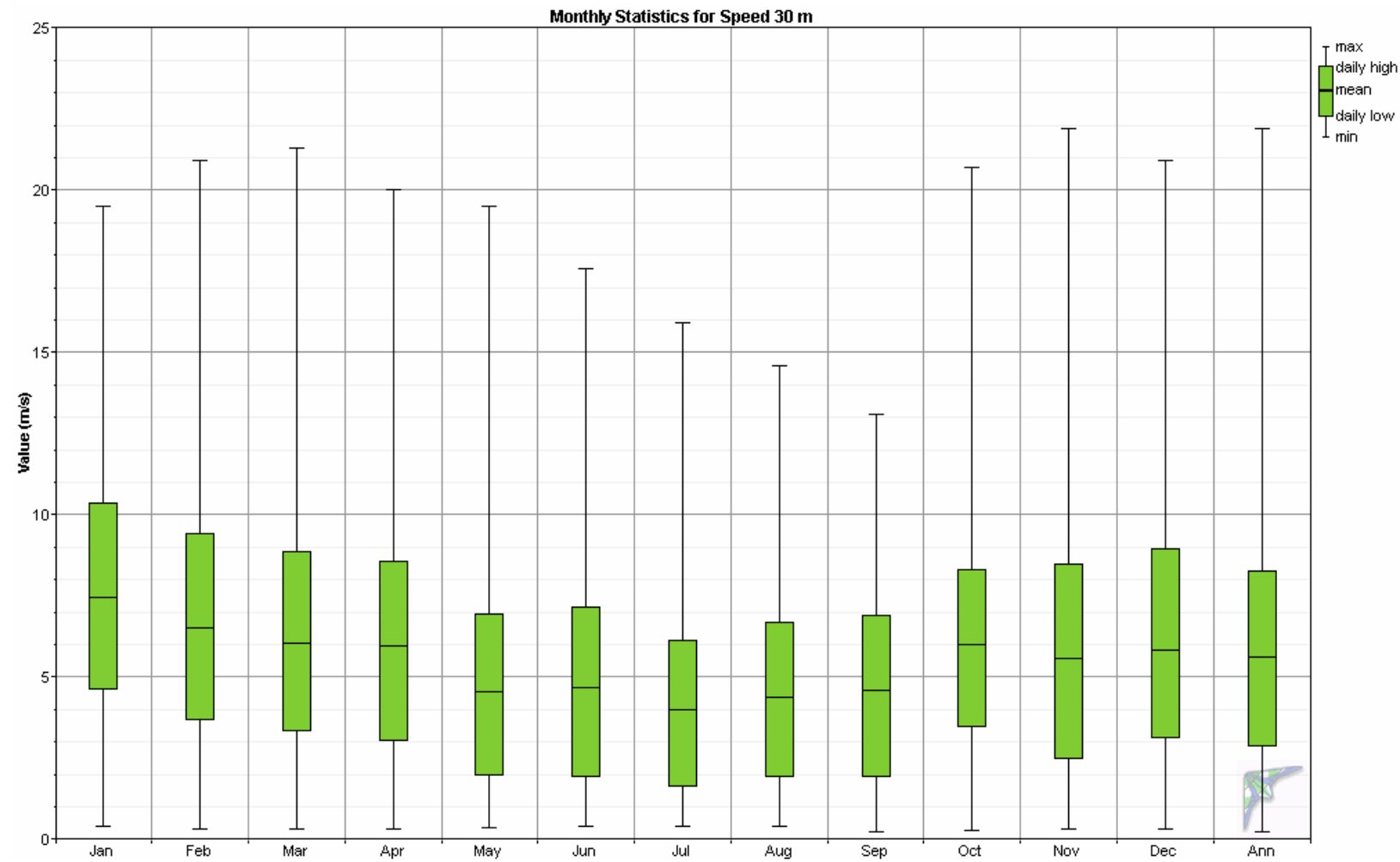

Daily Wind Profile

The daily wind profile indicates that the lowest wind speeds of the day occur in the morning hours of 3 to 6 a.m. and the highest wind speeds of the day occur during the afternoon and 
evening hours of 1 to 6 p.m. The daily variation of wind speed is minimal on an annual basis but more pronounced on a monthly basis.
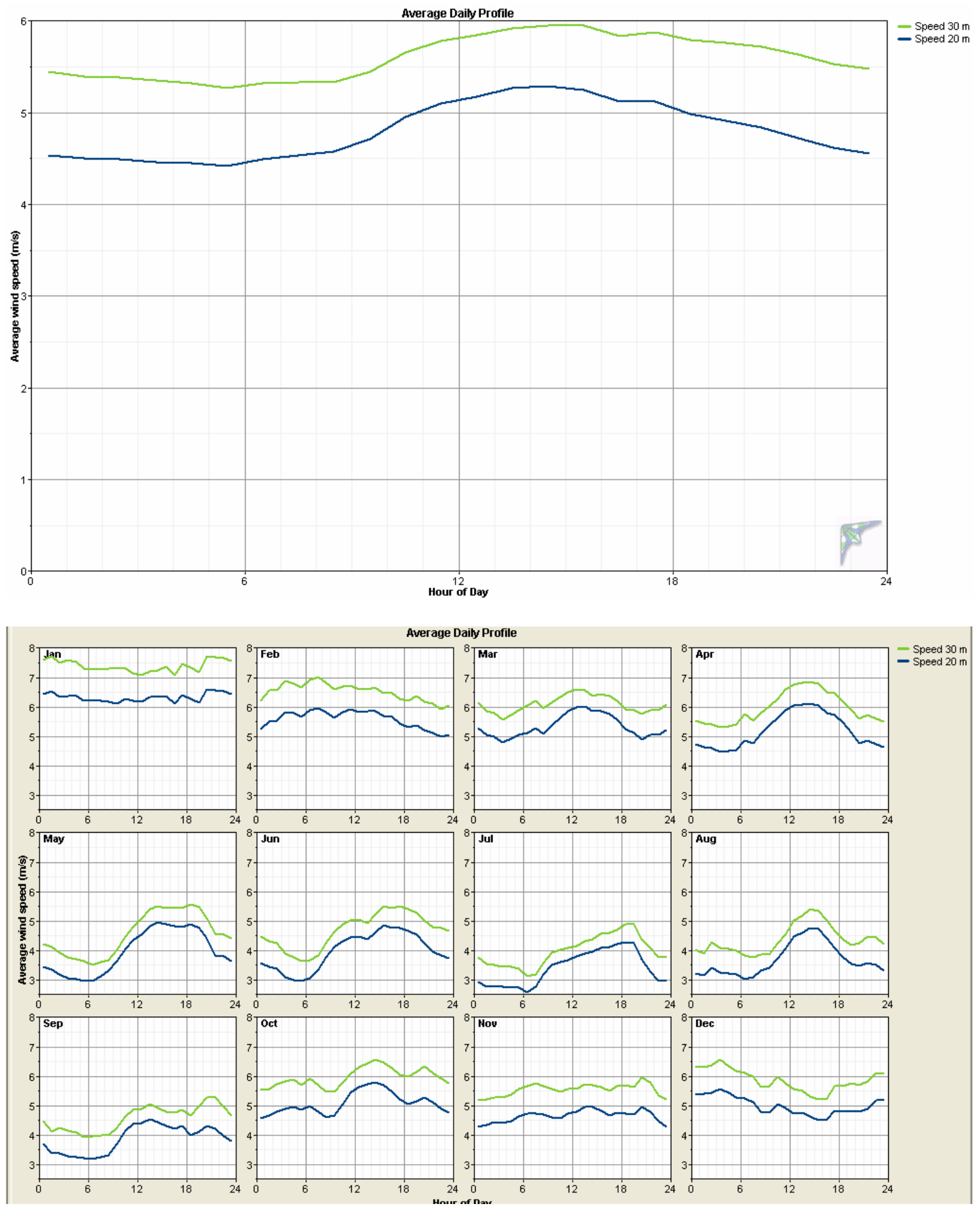
New Stuyahok, Alaska Wind Resource Report

\section{Time Series of Wind Speed Averages}

As expected, higher winds occur during the winter and spring months of October through April while lower winds occur during the summer and autumn months, although the seasonal differential in New Stuyahok is more pronounced than observed in coastal villages.
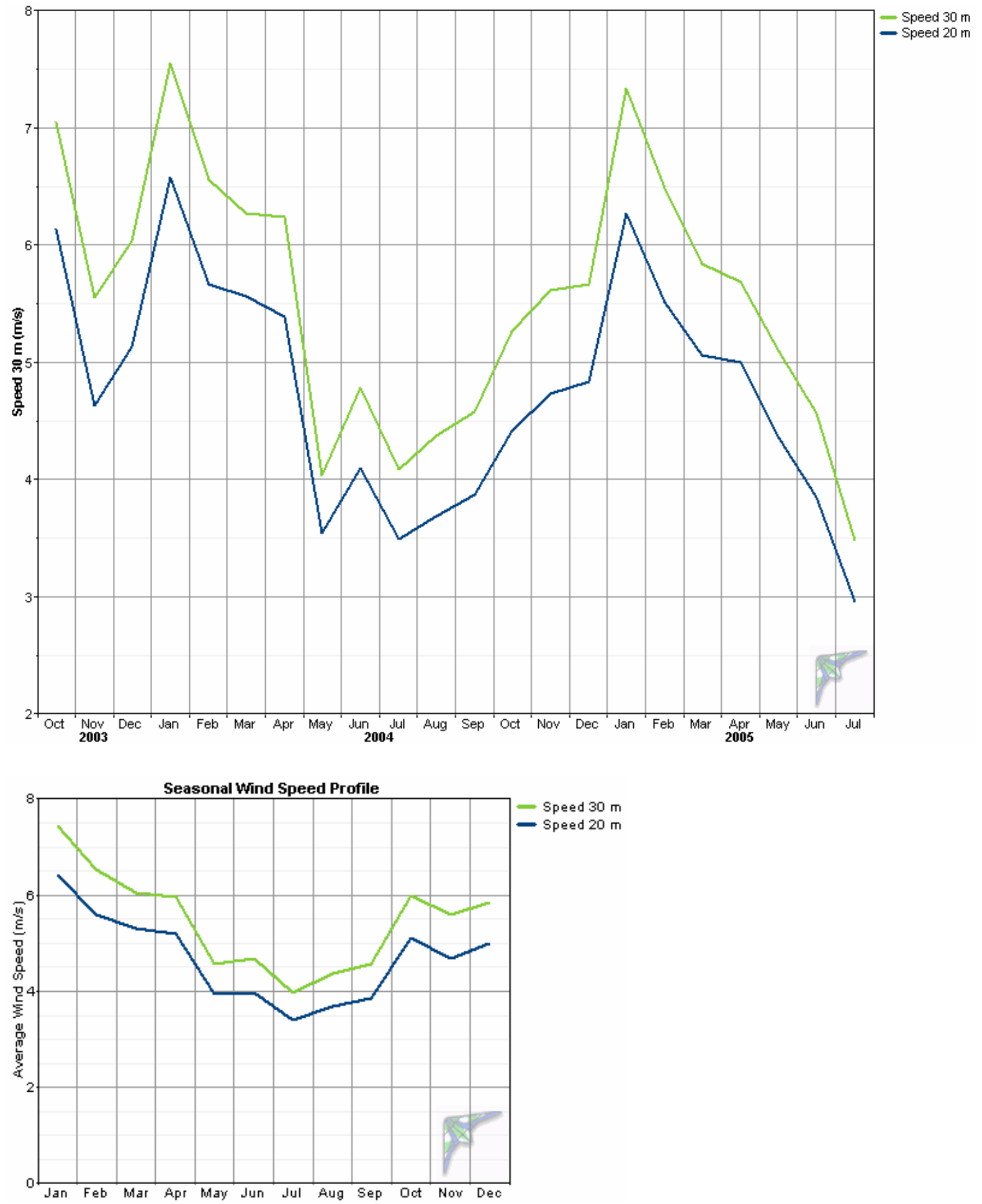


\section{Wind Shear Profile}

The power law exponent was calculated at 0.382, indicating high wind shear at the New Stuyahok test site, as noted in the second graph below. There is a possibility though that the presence of trees near the meteorological tower test site may have affected the 20 meter anemometer more significantly than the $30 \mathrm{~m}$ anemometer, resulting in a higher shear power law exponent than one might expect. In the village of Koliganek, upriver from New Stuyahok, a more open wind test site measured a wind shear of power law exponent of 0.227 , which although moderately high itself, is more likely representative of New Stuyahok than the measured exponent of 0.382. If in fact the real shear exponent in New Stuyahok is lower than measured, the 50 meter wind power density listed in the data synopsis on page one of this report will be biased high and a 50 meter wind power density of approximately 375 to $400 \mathrm{~W} / \mathrm{m}^{2}$ is likely more realistic.

The practical application of this data is that a higher turbine tower height is desirable as there will be a substantial gain in wind speed/power recovery with additional height. A tower height/power recovery/ construction cost tradeoff study is advisable.
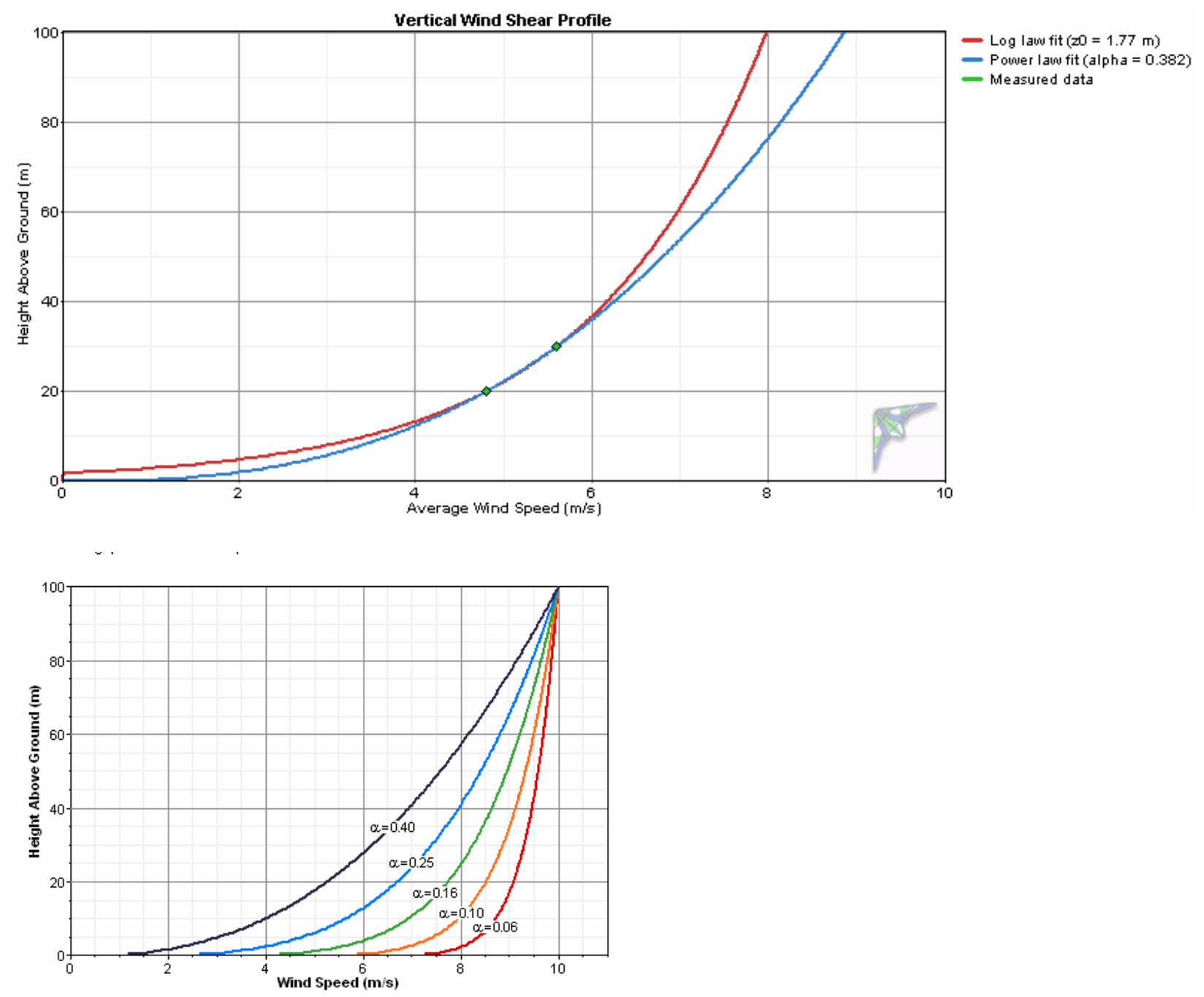
New Stuyahok, Alaska Wind Resource Report
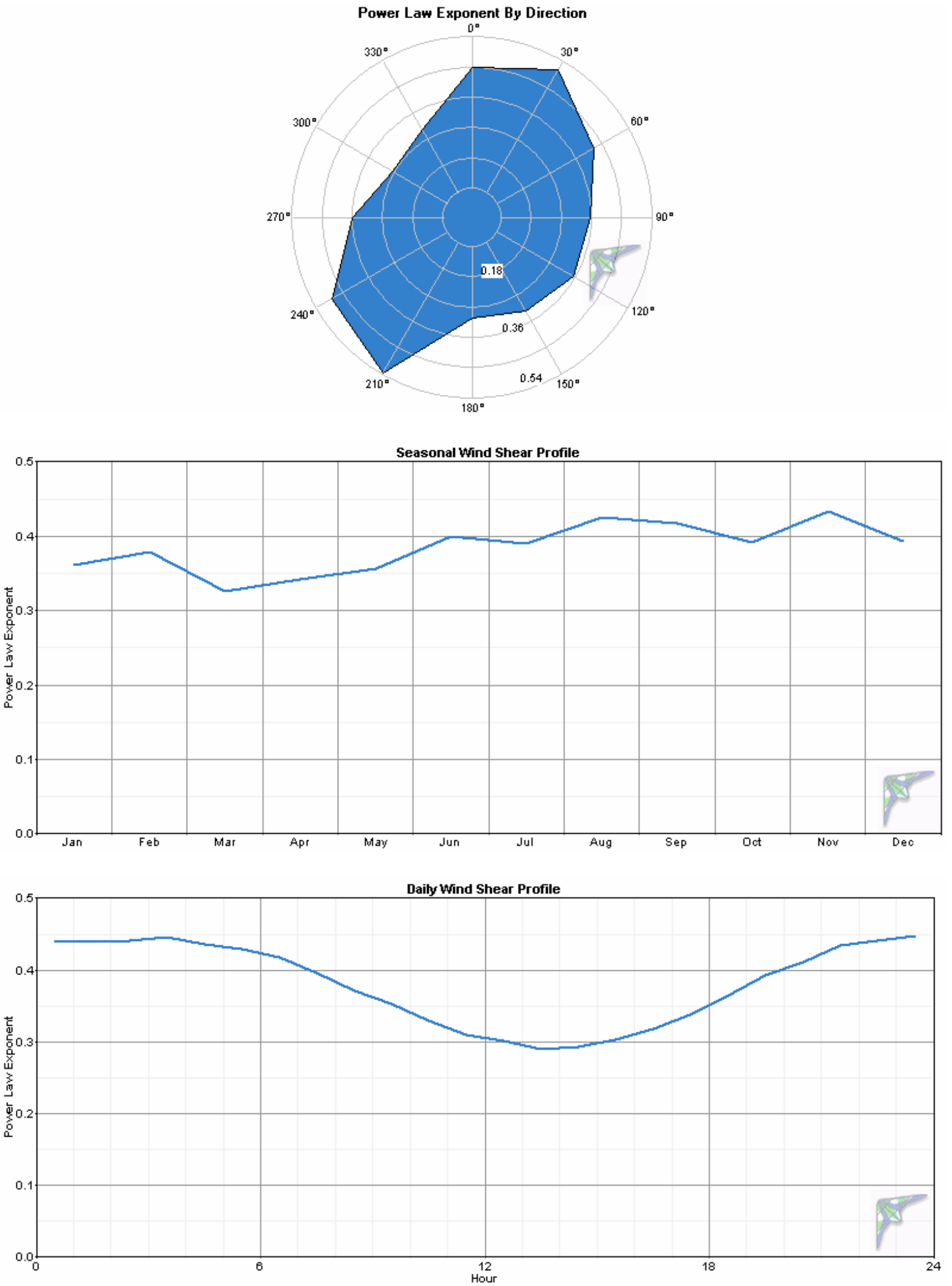


\section{Probability Distribution Function}

The probability distribution function provides a visual indication of measured wind speeds in one meter per second "bins". Note that most wind turbines do not begin to generate power until the wind speed at hub height reaches $4 \mathrm{~m} / \mathrm{s}$. The black line in the graph is a best fit Weibull distribution. At the 30 meter level, measured Weibull parameters are $\mathrm{k}=1.76$ (indicates a moderate distribution of wind speeds) and $\mathrm{c}=6.29$ (scale factor). The PDF information is shown visually in another manner in the second graph, the Cumulative Distribution Function.
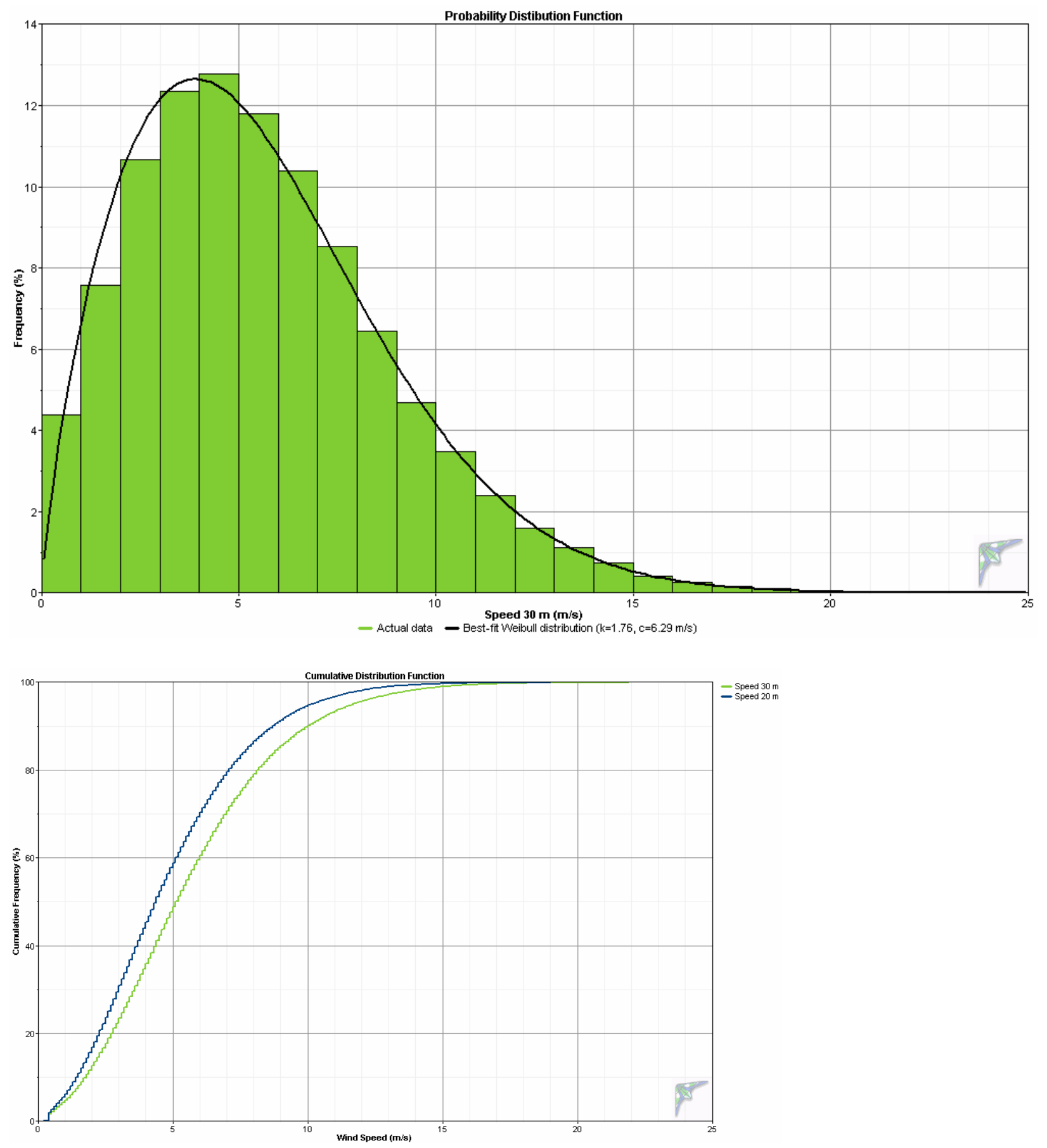


\section{Wind Roses}

New Stuyahok winds are highly directional with, as the wind frequency rose indicates, northnorthwest (NNW) and east-northeast (ENE) winds predominating. This observation is reinforced with reference to the power density rose below. The power producing winds in New Stuyahok are nearly exclusively NNW and ENE. The practical application of this information is that site(s) should be selected with relatively few obstructions from west to north to southeast to minimize wind turbulence at the turbines.

Note also that a wind threshold of $4 \mathrm{~m} / \mathrm{s}$ was selected for the definition of calm winds. This wind speed represents the cut-in wind speed of most wind turbines. By this definition, Naknek experienced 36 percent calm conditions during the measurement period (see wind frequency rose below).

Wind Frequency Rose (30 meters)

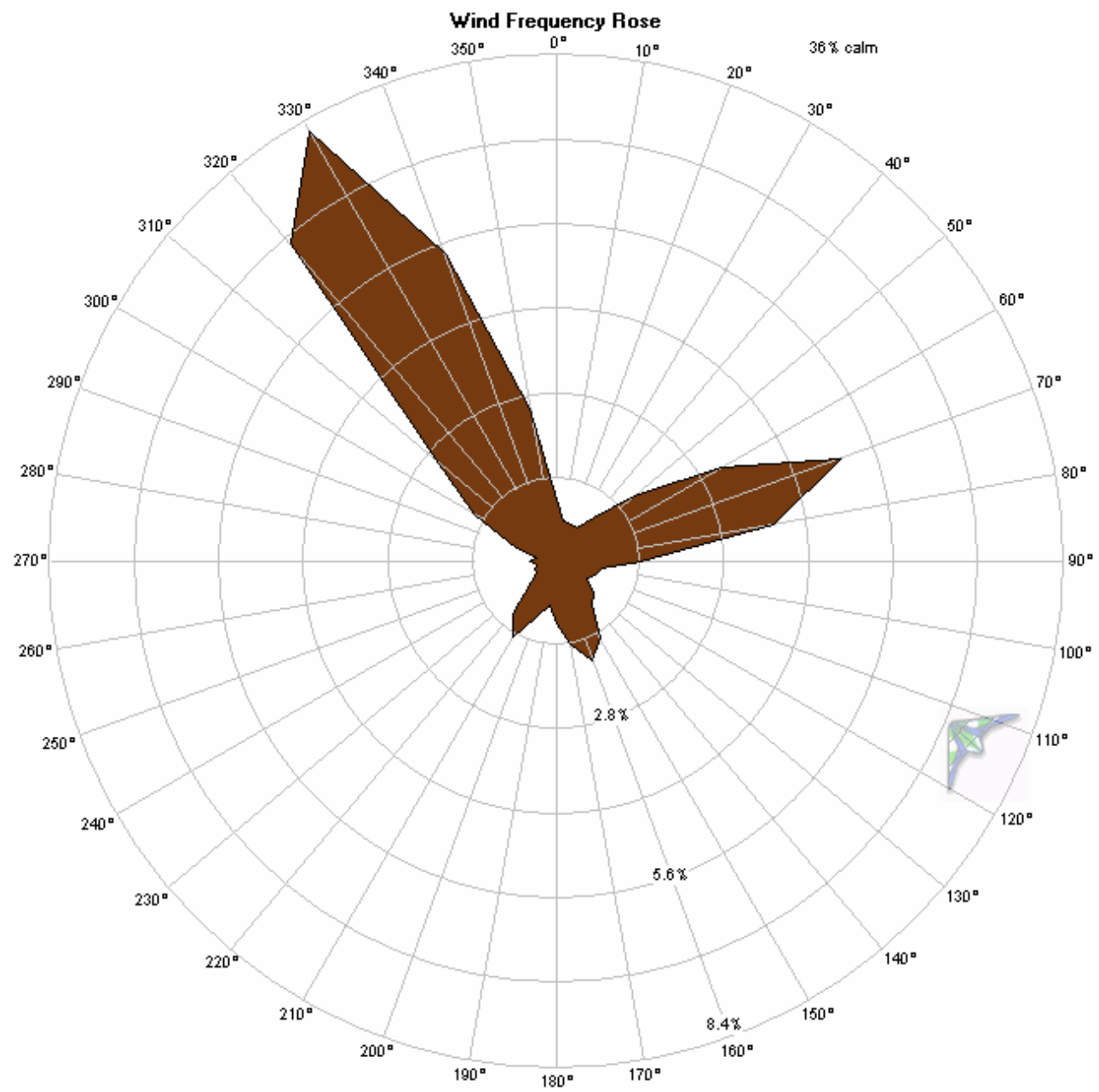


New Stuyahok, Alaska Wind Resource Report

\section{Wind Power Density Rose}

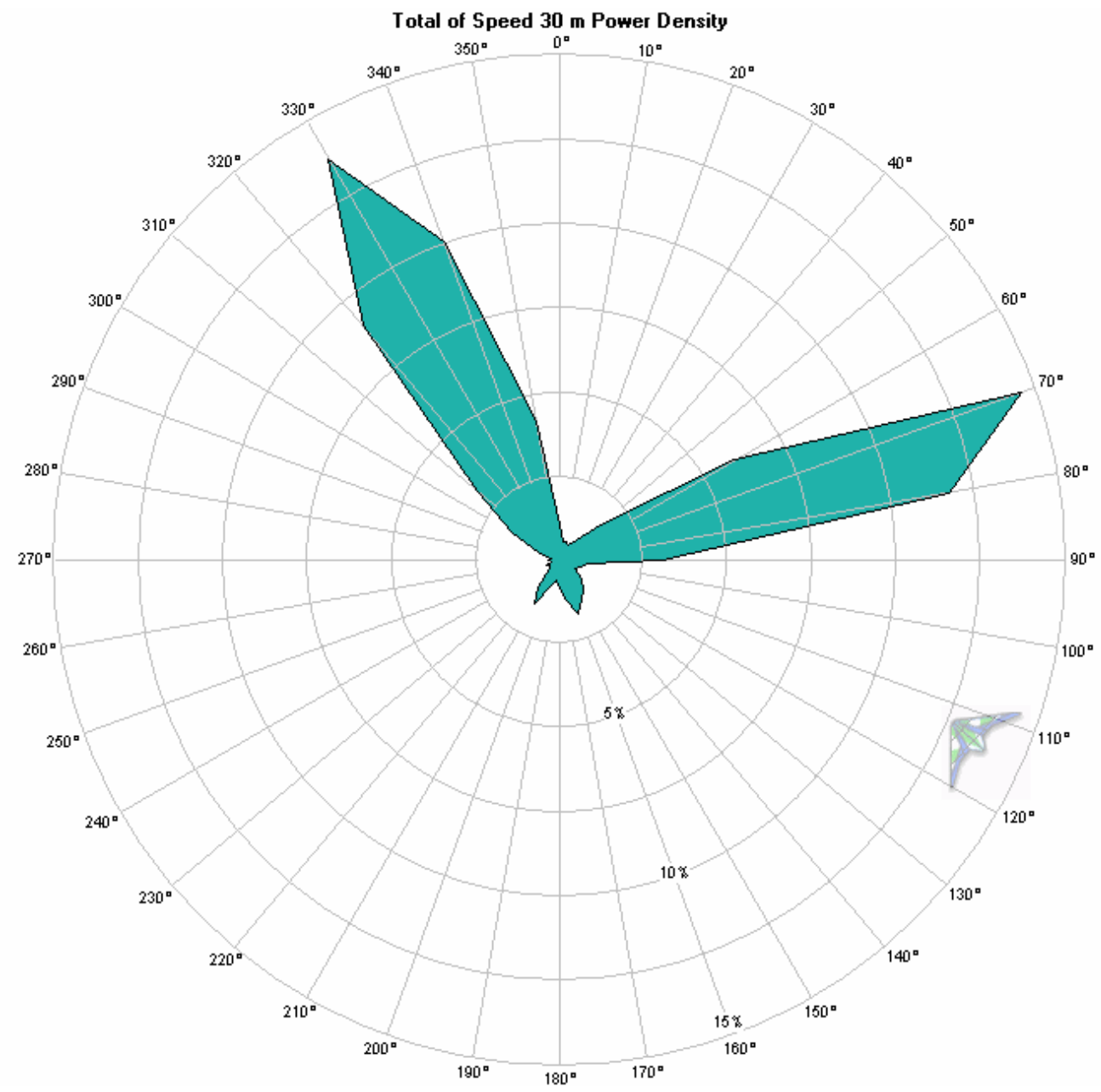

Wind Power Density Roses by Month

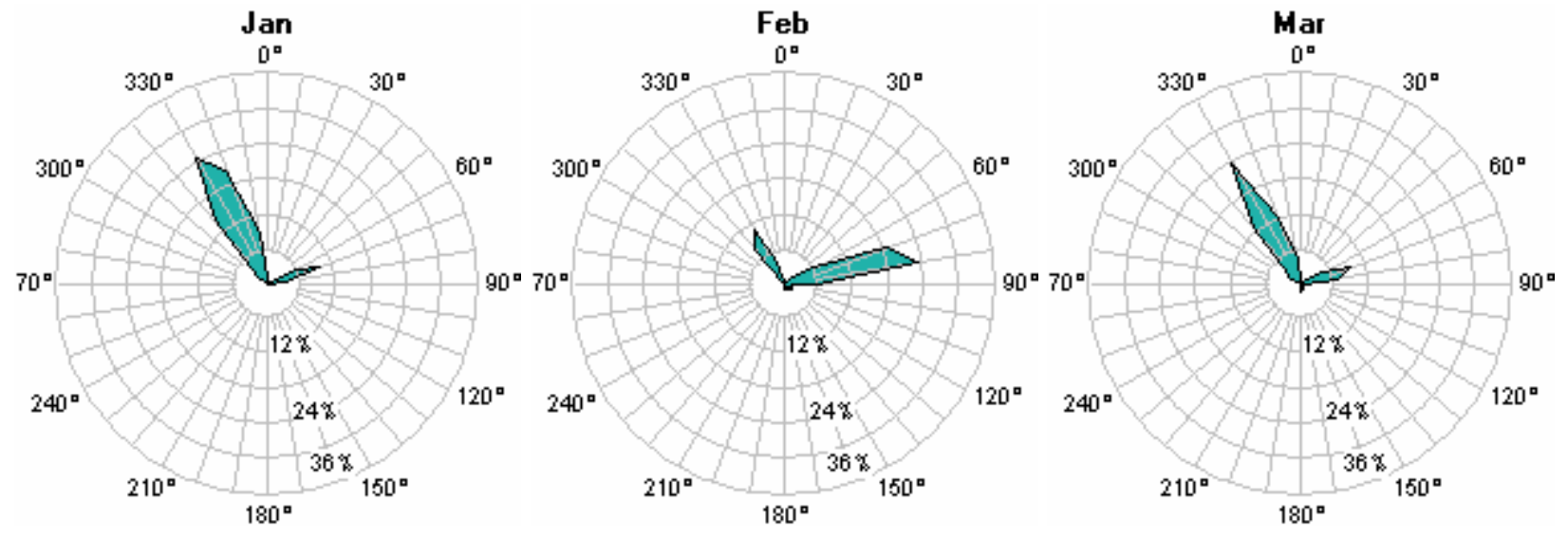


New Stuyahok, Alaska Wind Resource Report

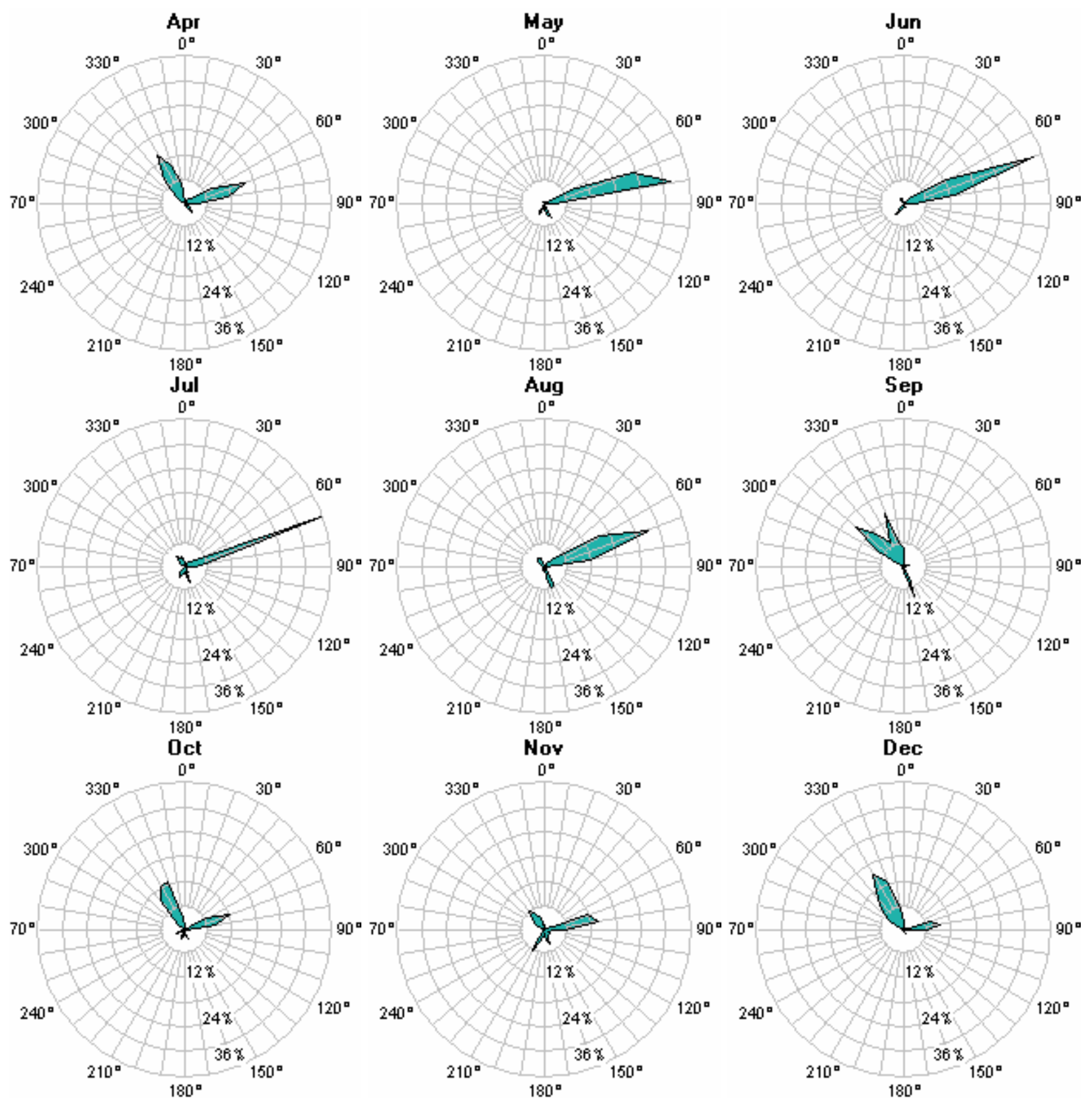




\section{Turbulence Intensity}

The turbulence intensity (TI) is minimally acceptable for all wind directions, with a mean turbulence intensity during the twenty-one month reporting period of 0.150 at 30 meters (threshold wind speed is $4 \mathrm{~m} / \mathrm{s}$ ).

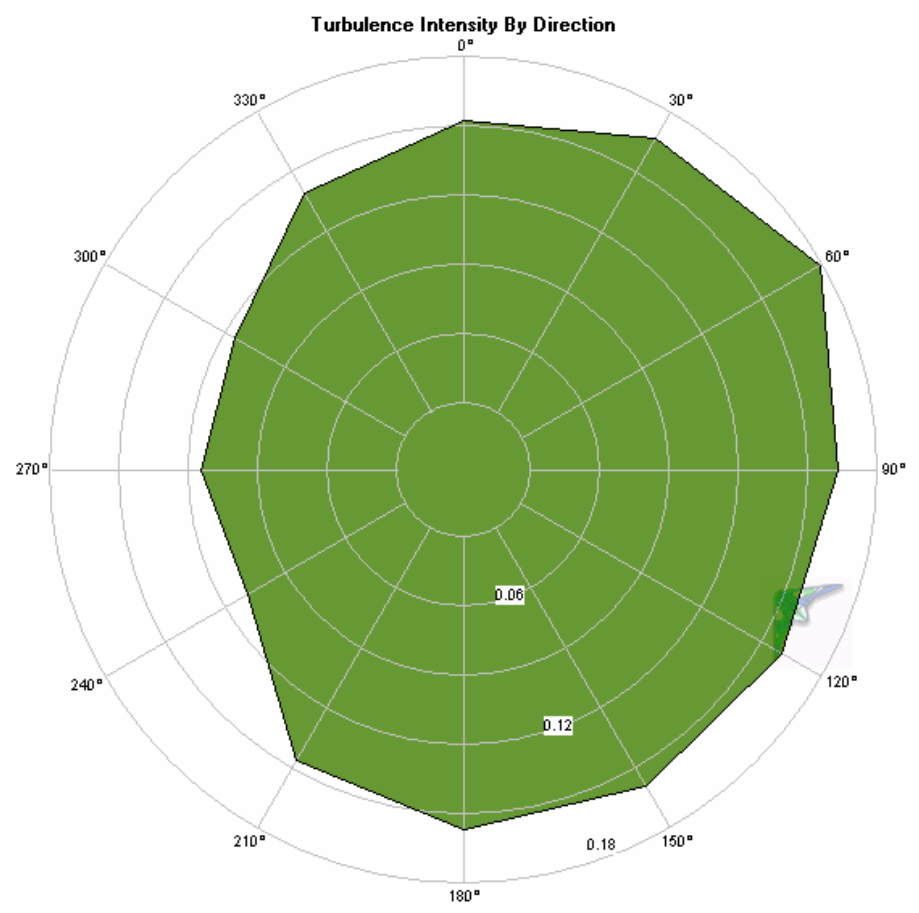

IEC Turbulence Intensity Standards

The turbulence intensities at 30 meters at the New Stuyahok project test site do not meet International Electrotechnical Commission (IEC) Category A standards in the northeast to southeast quadrant and IEC Category A in the southeast to southwest quadrant. This is less important in the SE to SW quadrant as the wind rarely blows from this direction, but is more so important in the NE to SE quadrant as significant power producing winds blow from the NE at this site. 
New Stuyahok, Alaska Wind Resource Report
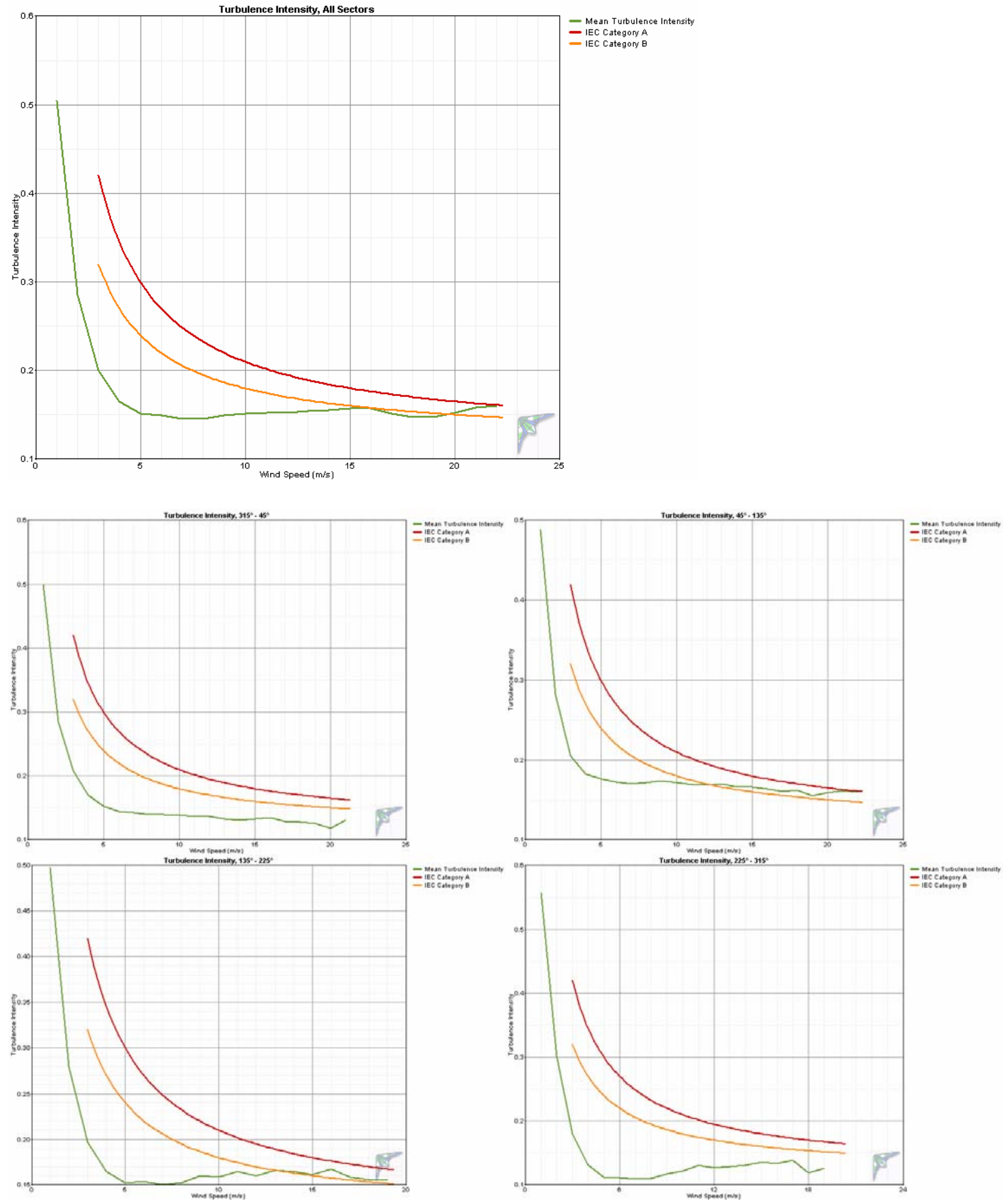
New Stuyahok, Alaska Wind Resource Report

Turbulence Table

\begin{tabular}{cccccccc}
$\begin{array}{c}\text { Bin } \\
\begin{array}{c}\text { Midpoint } \\
(\mathrm{m} / \mathrm{s})\end{array}\end{array}$ & $\begin{array}{c}\text { Bin Endpoints } \\
\text { Lower } \\
(\mathrm{m} / \mathrm{s})\end{array}$ & $\begin{array}{c}\text { Upper } \\
(\mathrm{m} / \mathrm{s})\end{array}$ & $\begin{array}{c}\text { Records } \\
\text { In }\end{array}$ & $\begin{array}{c}\text { Sin } \\
\text { Deviation } \\
\text { of Wind Speed } \\
(\mathrm{m} / \mathrm{s})\end{array}$ & $\begin{array}{c}\text { Mean } \\
\text { Turbulence } \\
\text { Intensity }\end{array}$ & $\begin{array}{c}\text { Standard } \\
\text { Deviation } \\
\text { of Turbulence } \\
\text { Intensity }\end{array}$ & $\begin{array}{c}\text { Characteristic } \\
\text { Turbulence } \\
\text { Intensity }\end{array}$ \\
\hline 1 & 0.5 & 1.5 & 5336 & 0.477 & 0.505 & 0.300 & 0.805 \\
2 & 1.5 & 2.5 & 8533 & 0.556 & 0.285 & 0.149 & 0.434 \\
3 & 2.5 & 3.5 & 10788 & 0.591 & 0.200 & 0.092 & 0.292 \\
4 & 3.5 & 4.5 & 11573 & 0.654 & 0.165 & 0.069 & 0.235 \\
5 & 4.5 & 5.5 & 11508 & 0.750 & 0.152 & 0.057 & 0.208 \\
6 & 5.5 & 6.5 & 10122 & 0.887 & 0.149 & 0.048 & 0.197 \\
7 & 6.5 & 7.5 & 8555 & 1.012 & 0.146 & 0.042 & 0.188 \\
8 & 7.5 & 8.5 & 6830 & 1.153 & 0.145 & 0.040 & 0.185 \\
9 & 8.5 & 9.5 & 5137 & 1.335 & 0.150 & 0.037 & 0.186 \\
10 & 9.5 & 10.5 & 3683 & 1.501 & 0.151 & 0.033 & 0.184 \\
11 & 10.5 & 11.5 & 2697 & 1.668 & 0.153 & 0.030 & 0.183 \\
12 & 11.5 & 12.5 & 1783 & 1.818 & 0.153 & 0.030 & 0.182 \\
13 & 12.5 & 13.5 & 1241 & 1.996 & 0.154 & 0.032 & 0.186 \\
14 & 13.5 & 14.5 & 835 & 2.159 & 0.155 & 0.028 & 0.183 \\
15 & 14.5 & 15.5 & 517 & 2.342 & 0.157 & 0.026 & 0.183 \\
16 & 15.5 & 16.5 & 285 & 2.500 & 0.157 & 0.022 & 0.179 \\
17 & 16.5 & 17.5 & 192 & 2.562 & 0.151 & 0.023 & 0.174 \\
18 & 17.5 & 18.5 & 129 & 2.652 & 0.148 & 0.024 & 0.172 \\
19 & 18.5 & 19.5 & 64 & 2.795 & 0.148 & 0.020 & 0.168 \\
20 & 19.5 & 20.5 & 35 & 3.014 & 0.152 & 0.019 & 0.171 \\
21 & 20.5 & 21.5 & 17 & 3.306 & 0.158 & 0.021 & 0.179 \\
22 & 21.5 & 22.5 & 6 & 3.483 & 0.160 & 0.016 & 0.177
\end{tabular}


New Stuyahok, Alaska Wind Resource Report

\section{Air Temperature and Density}

Over the reporting period, New Stuyahok had an average temperature of $1.7^{\circ} \mathrm{C}$. The minimum recording temperature during the measurement period was $-32.9^{\circ} \mathrm{C}$ and the maximum temperature was $28.5^{\circ} \mathrm{C}$. Consequent to New Stuyahok's cool temperatures, the average air density of $1.275 \mathrm{~kg} / \mathrm{m}^{3}$ is approximately five percent higher than the standard air density of 1.217 $\mathrm{kg} / \mathrm{m}^{3}$ (at $14.5^{\circ} \mathrm{C}$ temperature and $100.46 \mathrm{kPa}$ pressure at $70 \mathrm{~m}$ elevation).

\begin{tabular}{cccccccc} 
Month & $\begin{array}{c}\text { Mean } \\
\left({ }^{\circ} \mathrm{C}\right)\end{array}$ & $\begin{array}{c}\text { Min } \\
\left({ }^{\circ} \mathrm{C}\right)\end{array}$ & $\begin{array}{c}\text { Max } \\
\left({ }^{\circ} \mathrm{C}\right)\end{array}$ & $\begin{array}{c}\text { Std. Dev. } \\
\left({ }^{\circ} \mathrm{C}\right)\end{array}$ & $\begin{array}{c}\text { Mean } \\
\left(\mathrm{kg} / \mathrm{m}^{3}\right)\end{array}$ & $\begin{array}{c}\text { Air Density } \\
\left(\mathrm{kg} / \mathrm{m}^{3}\right)\end{array}$ & $\begin{array}{c}\text { Max } \\
\left(\mathrm{kg} / \mathrm{m}^{3}\right)\end{array}$ \\
\hline Jan & -12.0 & -31.1 & 2.7 & 7.37 & 1.341 & 1.269 & 1.446 \\
Feb & -6.5 & -32.9 & 5.5 & 9.02 & 1.314 & 1.256 & 1.457 \\
Mar & -6.3 & -29.9 & 6.6 & 7.72 & 1.313 & 1.251 & 1.439 \\
Apr & -0.1 & -24.1 & 16.0 & 6.93 & 1.283 & 1.210 & 1.405 \\
May & 8.5 & -2.6 & 20.2 & 3.86 & 1.243 & 1.193 & 1.294 \\
Jun & 12.6 & 0.9 & 27.2 & 4.70 & 1.225 & 1.165 & 1.277 \\
Jul & 15.1 & 4.8 & 28.5 & 4.26 & 1.214 & 1.160 & 1.259 \\
Aug & 14.8 & 2.8 & 27.3 & 4.50 & 1.216 & 1.165 & 1.268 \\
Sep & 6.3 & -4.9 & 17.2 & 4.57 & 1.253 & 1.205 & 1.305 \\
Oct & 1.8 & -11.5 & 11.3 & 4.43 & 1.273 & 1.230 & 1.338 \\
Nov & -3.3 & -23.5 & 8.4 & 7.24 & 1.298 & 1.243 & 1.402 \\
Dec & -10.0 & -31.5 & 3.9 & 8.32 & 1.331 & 1.263 & 1.448 \\
\hline All data & 1.7 & -32.9 & 28.5 & 11.11 & 1.275 & 1.160 & 1.457
\end{tabular}

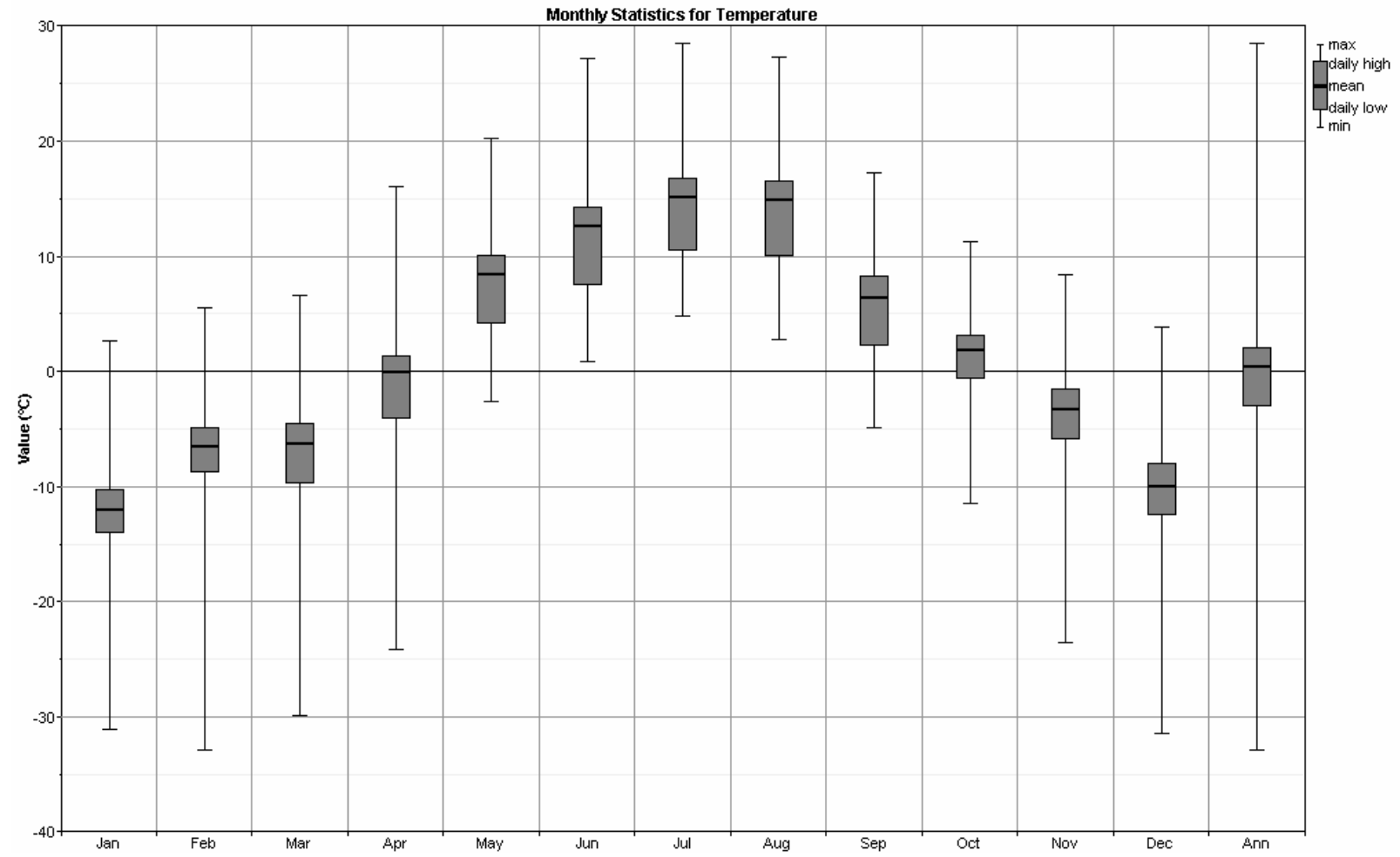




\section{Air Density DMap}

The DMap below is a visual indication of the daily and seasonal variations of air density (and temperature). Air densities higher than standard will yield higher turbine power than predicted by the turbine power curves, while densities lower than average will yield lower turbine power than predicted. Density variance from standard is accounted for in the turbine performance predictions.

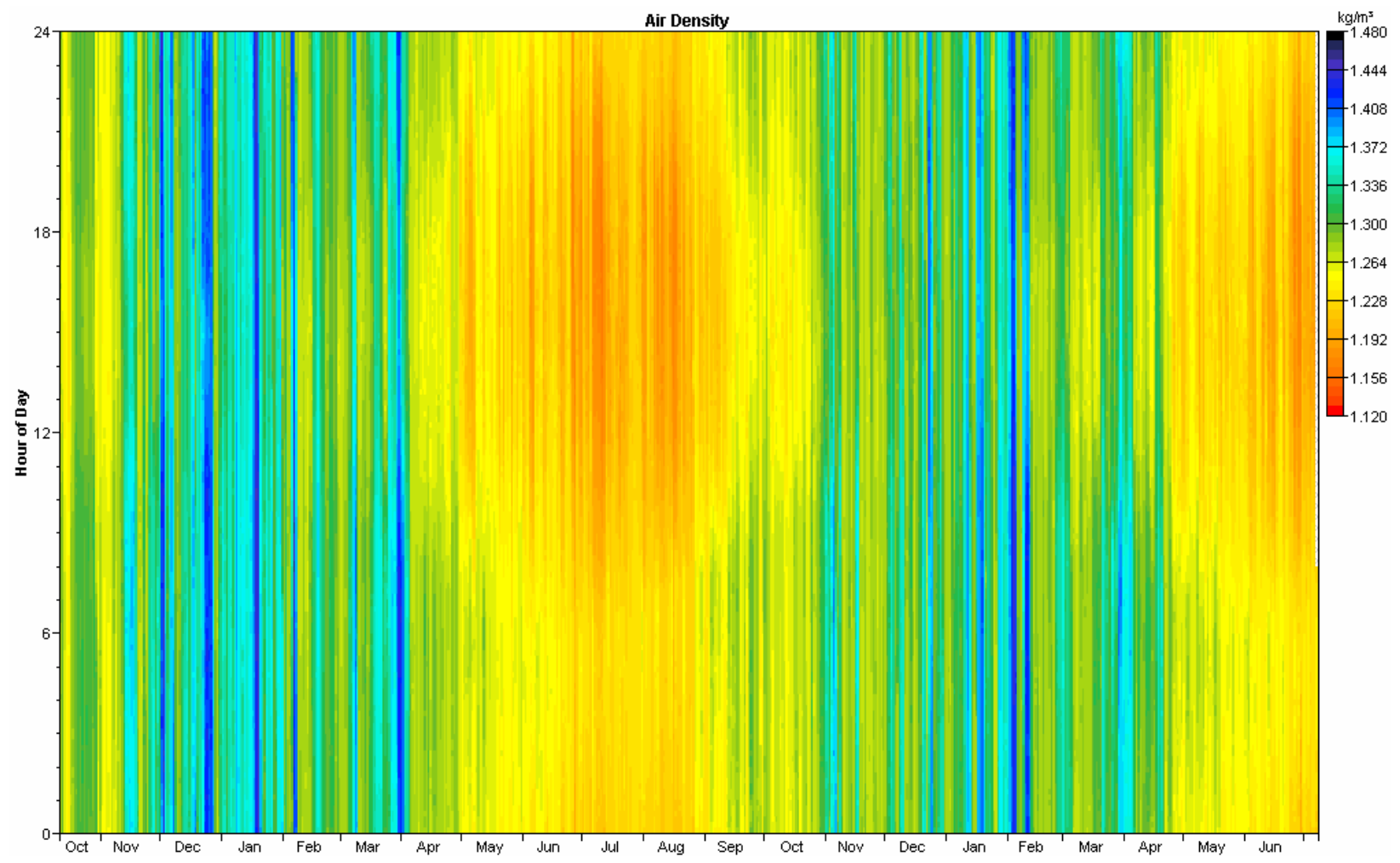




\section{Wind Turbine Performance}

The turbine performance predictions noted below are based on 100\% and 90\% turbine availabilities. It is realistic to expect five to ten percent downtime for maintenance, repairs and/or other outages should be expected.

Note that these performance estimates were predicted with use of Windographer ${ }^{\circledR}$ wind analysis software; power curves provided by manufacturers are not independently verified and are assumed to be accurate. The power curves are presented for a standard air density of $1.225 \mathrm{~kg} / \mathrm{m}^{3}$ at $15^{\circ} \mathrm{C}$ temperature and $101.3 \mathrm{kPa}$ at sea level; however the predictions of power production are density compensated by multiplying the standard density power output by the ratio of the measured air density to standard air density.

A number of smaller village-scale grid-connected turbines are profiled belong for comparison purposes. These turbines were selected because they have market availability and they are deemed to be within a suitable range for consideration of wind power development in a village the size of New Stuyahok.

Bergey Excel-S: $10 \mathrm{~kW}$ rated power output, 6.7 meter rotor diameter, stall-controlled (power curve provided by Bergey). Available tower heights: 18, 24, 30, 37 and 43 meters. Additional information is available at www.bergey.com.
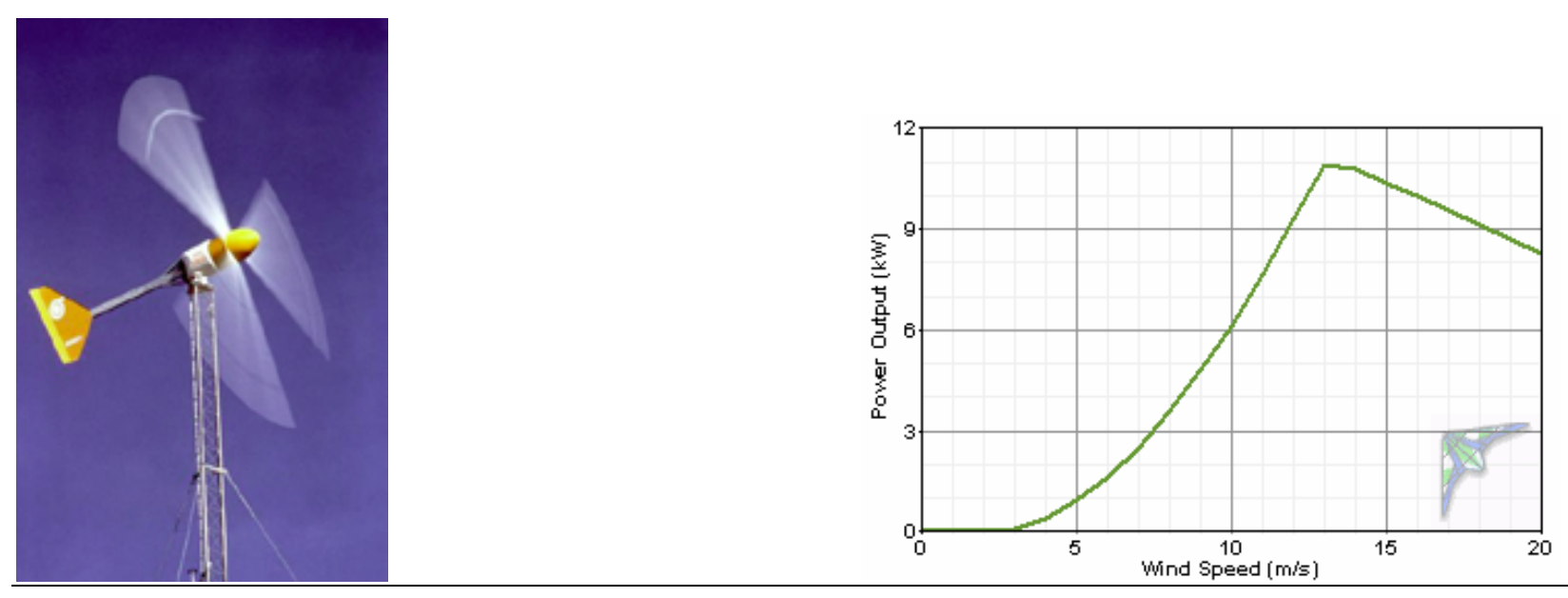

Entegrity eW-15: $65 \mathrm{~kW}$ rated power output, 15 meter rotor, stall-controlled (power curve provided by Entegrity Energy Systems). Available tower heights: 25 and 31 meters. Additional information is available at http://www.entegritywind.com/. 

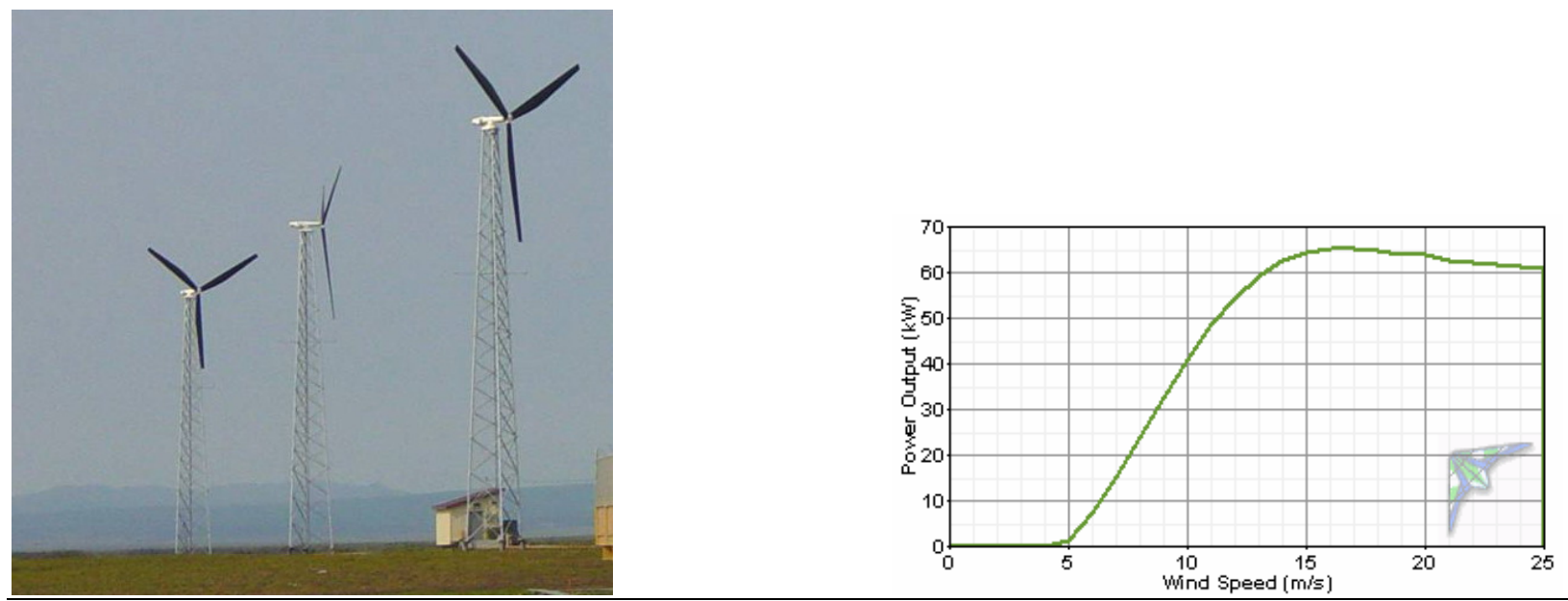

Vestas V15: $75 \mathrm{~kW}$ rated power output, 15 meter rotor, stall-controlled (power curve provided by Powercorp Alaska LLC). Available tower heights: 25, 31 and 34 meters. Additional information is available at http://www.pcorpalaska.com/.
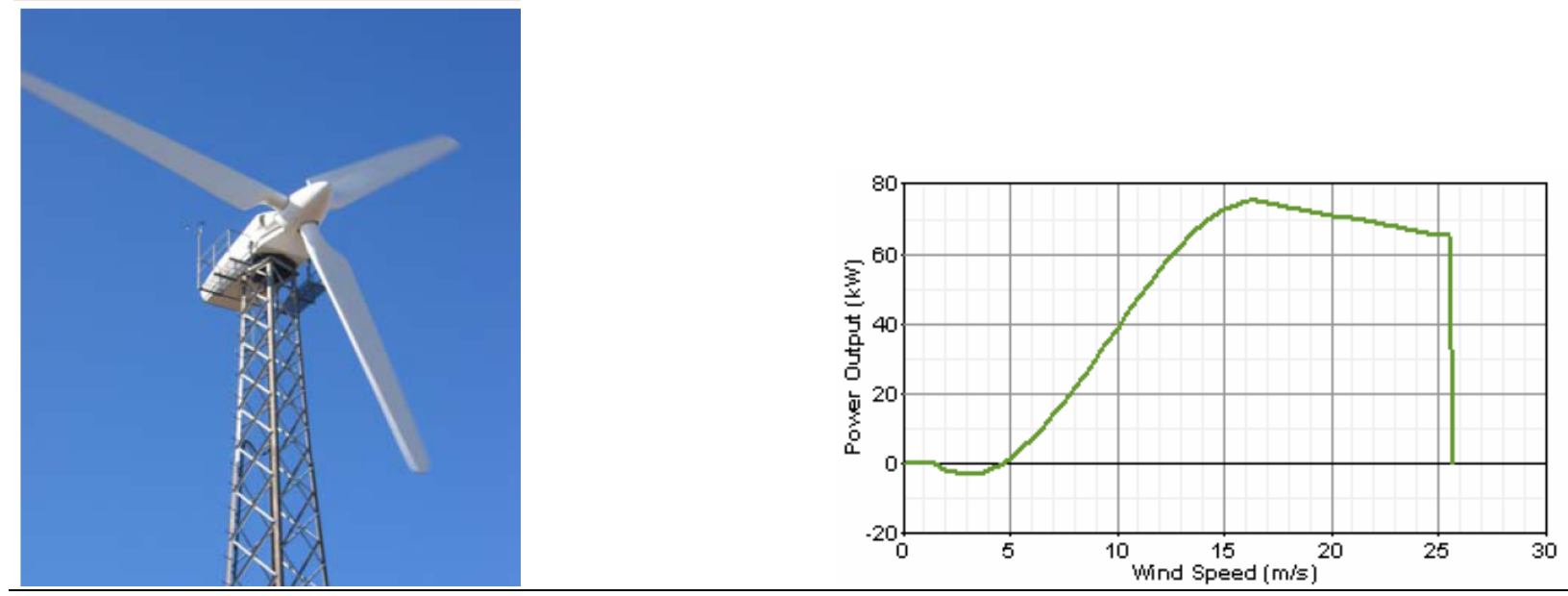

Northwind 100/19 and 100/20: $100 \mathrm{~kW}$ rated power output, 19 meter rotor and 20 meter rotor (19 meter rotor blades with 0.6 meter blade root extensions added) models, stall-controlled (power curve provided by Northern Power Systems). Available tower heights: 25 and 32 meters. Additional information is available at http://www.northernpower.com/. 

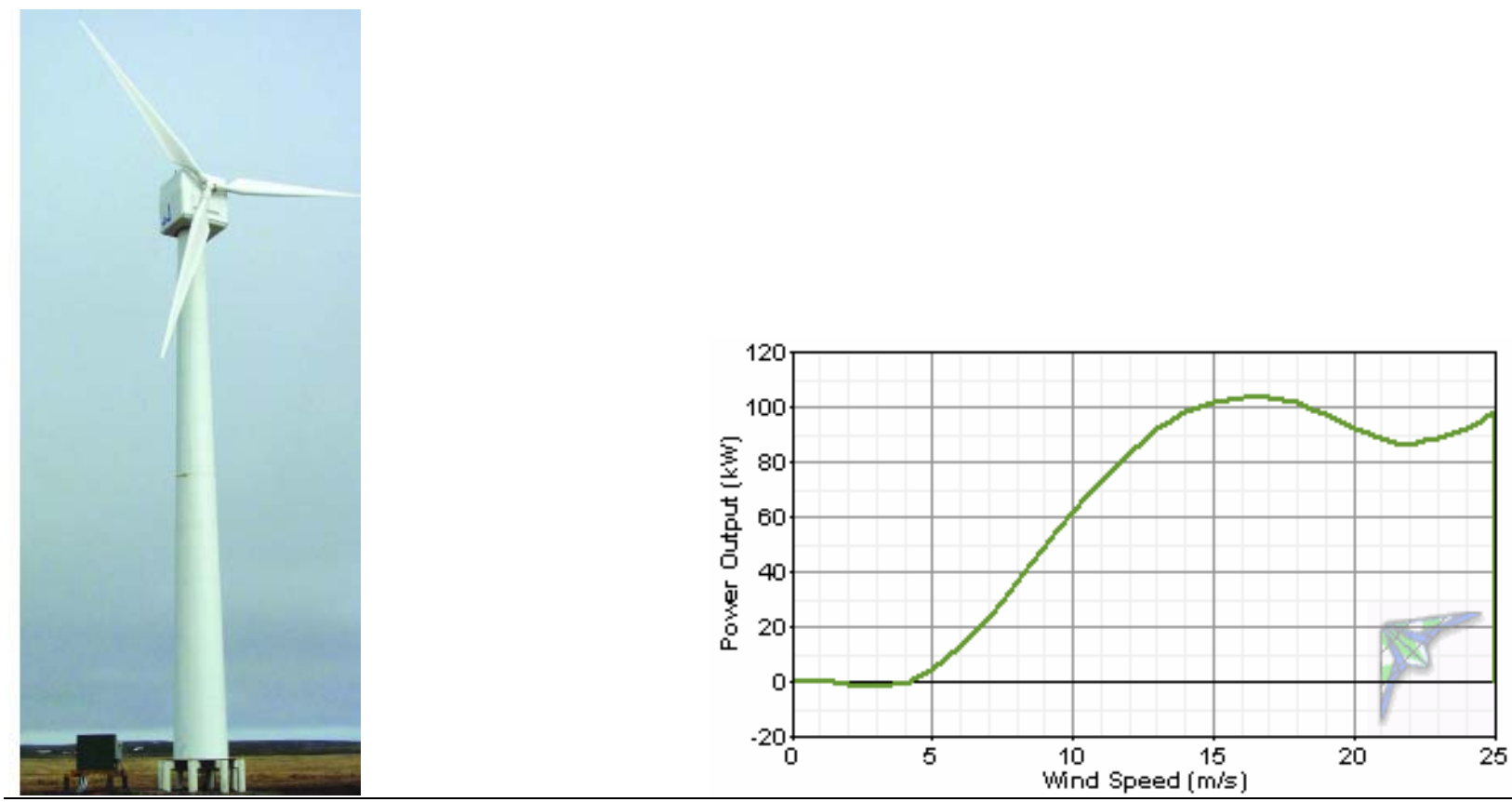

Fuhrländer FL100: 100 kW rated output (125 kW max output), 21 meter rotor, stall-controlled, 35 meter hub height (power curve provided by lorax-energy.com). Available tower height: 35 meters. Additional information is available at http://www.lorax-energy.com/.
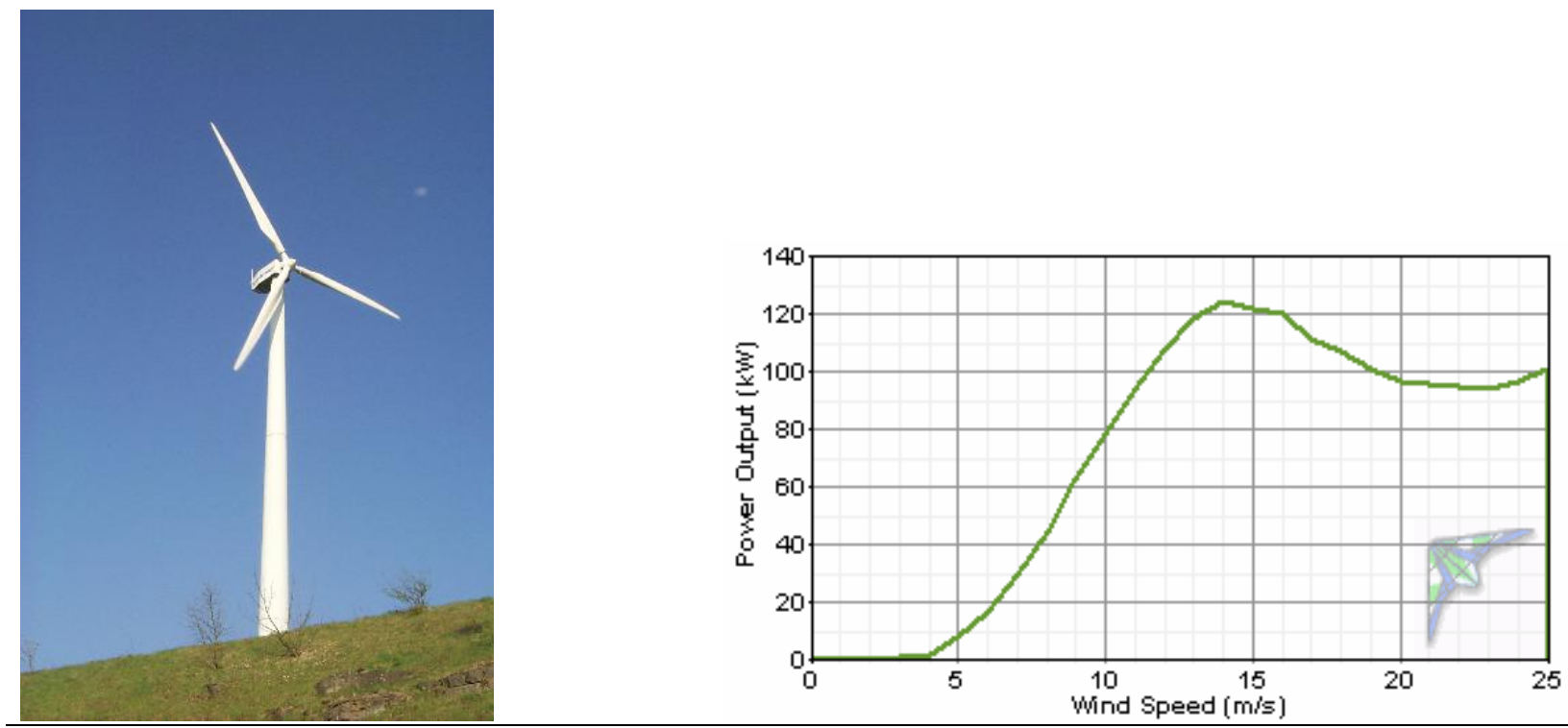

Vestas V27: $225 \mathrm{~kW}$ rated power output, 27 meter rotor, pitch-controlled (power curve provided by Alaska Energy Authority) 
New Stuyahok, Alaska Wind Resource Report
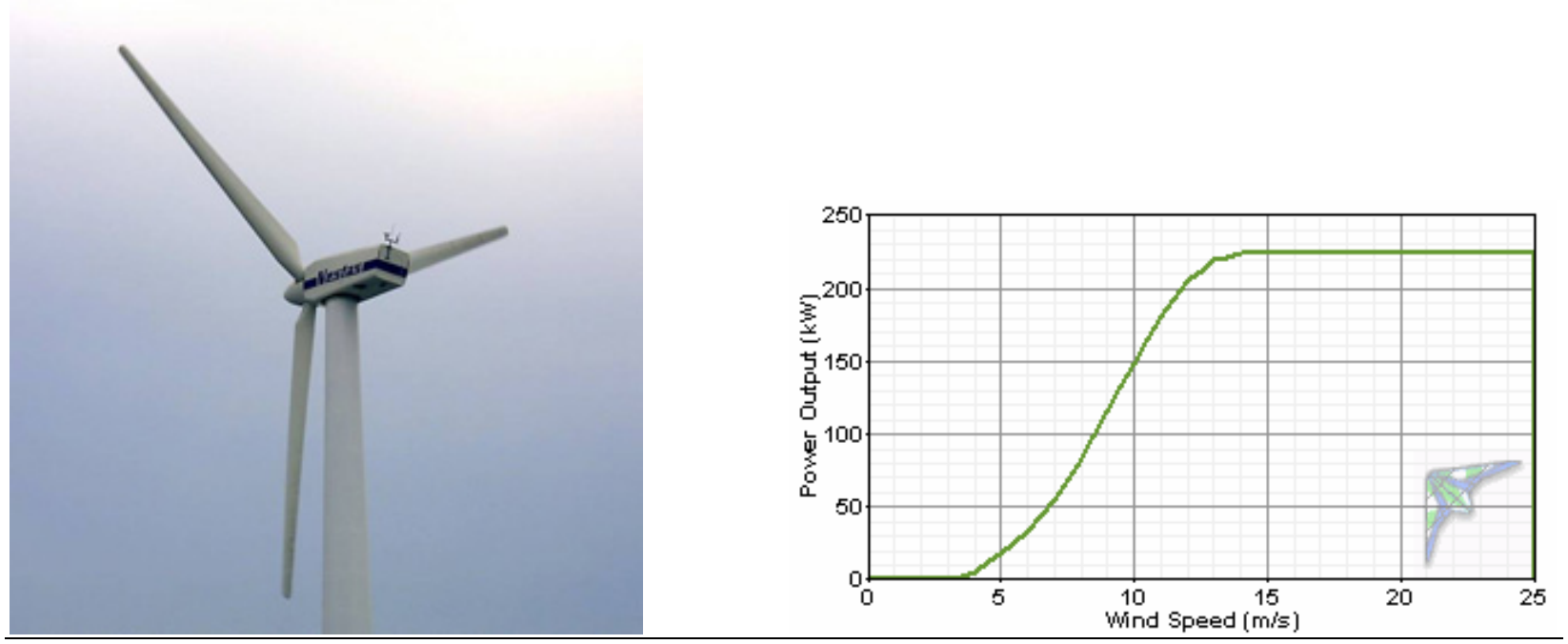
New Stuyahok, Alaska Wind Resource Report

Turbine Power Output Comparison (100\% availability)

\begin{tabular}{|c|c|c|c|c|c|c|c|}
\hline Turbine & $\begin{array}{l}\text { Hub } \\
\text { Height } \\
\text { (m) }\end{array}$ & $\begin{array}{c}\text { Hub Height } \\
\text { Wind Speed } \\
(\mathrm{m} / \mathrm{s})\end{array}$ & $\begin{array}{c}\text { Time At } \\
\text { Zero Output } \\
(\%)\end{array}$ & $\begin{array}{c}\text { Time At } \\
\text { Rated Output } \\
(\%)\end{array}$ & $\begin{array}{c}\text { Average Net } \\
\text { Power Output } \\
(\mathrm{kW})\end{array}$ & $\begin{array}{c}\text { Annual Net } \\
\text { Energy } \\
\text { Output } \\
\text { (kWh/yr) }\end{array}$ & $\begin{array}{c}\text { Average Net } \\
\text { Capacity } \\
\text { Factor } \\
(\%)\end{array}$ \\
\hline Bergey Excel-S & 37 & 5.90 & 12.08 & 4.22 & 2.47 & 21,566 & 24.7 \\
\hline Entegrity eW-15 $60 \mathrm{~Hz}$ & 31 & 5.51 & 36.74 & 1.98 & 12.65 & 110,550 & 19.5 \\
\hline Vestas V15 & 34 & 5.71 & 42.09 & 1.47 & 12.57 & 109,652 & 16.7 \\
\hline Northern Power NW 100/20 & 32 & 5.57 & 36.05 & 1.92 & 19.11 & 167,109 & 19.1 \\
\hline Fuhrländer FL100 & 35 & 5.77 & 12.55 & 2.42 & 28.29 & 247,355 & 22.6 \\
\hline Vestas V27 & 42 & 6.19 & 15.60 & 2.51 & 60.49 & 529,059 & 26.9 \\
\hline \multicolumn{8}{|l|}{ Capacity Factor $<20 \%$} \\
\hline \multicolumn{8}{|l|}{ Capacity Factor $>20 \%,<30 \%$} \\
\hline \multicolumn{8}{|l|}{ Capacity Factor $>30 \%,<40 \%$} \\
\hline \multicolumn{8}{|l|}{ Capacity Factor $>40 \%,<50 \%$} \\
\hline Capacity Factor $>50 \%$ & & & & & & & \\
\hline
\end{tabular}

Assumed turbine losses for predictions of average power output, annual energy output, and average capacity factor: Downtime (\%) 0

Array (\%) 0

Icing/soiling (\%) 0

Other (\%) 0

Total $(\%)$ 
New Stuyahok, Alaska Wind Resource Report

Turbine Power Output Comparison (90\% availability)

\begin{tabular}{|c|c|c|c|c|c|c|c|}
\hline Turbine & $\begin{array}{l}\text { Hub } \\
\text { Height } \\
\text { (m) }\end{array}$ & $\begin{array}{c}\text { Hub Height } \\
\text { Wind Speed } \\
(\mathrm{m} / \mathrm{s})\end{array}$ & $\begin{array}{c}\text { Time At } \\
\text { Zero Output } \\
(\%)\end{array}$ & $\begin{array}{c}\text { Time At } \\
\text { Rated Output } \\
(\%)\end{array}$ & $\begin{array}{c}\text { Average Net } \\
\text { Power Output } \\
(\mathrm{kW})\end{array}$ & $\begin{array}{l}\text { Annual Net } \\
\text { Energy } \\
\text { Output } \\
\text { (kWh/yr) }\end{array}$ & $\begin{array}{l}\text { Average Net } \\
\text { Capacity } \\
\text { Factor } \\
(\%)\end{array}$ \\
\hline Bergey Excel-S & 37 & 6.04 & 11.6 & 4.6 & 2.3 & 19,476 & 22.3 \\
\hline Entegrity eW-15 $60 \mathrm{~Hz}$ & 31 & 5.65 & 35.1 & 2.3 & 12.1 & 99,838 & 17.6 \\
\hline Vestas V15 & 34 & 5.85 & 40.3 & 1.7 & 12.1 & 99,027 & 15.1 \\
\hline Northern Power NW 100/20 & 32 & 5.72 & 34.5 & 2.2 & 18.3 & 150,916 & 17.3 \\
\hline Fuhrländer FL100 & 35 & 5.92 & 12.1 & 2.8 & 27.0 & 223,386 & 20.4 \\
\hline Vestas V27 & 42 & 6.35 & 14.9 & 2.8 & 57.5 & 477,793 & 24.3 \\
\hline \multicolumn{8}{|l|}{ Capacity Factor <20\% } \\
\hline \multicolumn{8}{|l|}{ Capacity Factor >20\%, <30\% } \\
\hline \multicolumn{8}{|l|}{ Capacity Factor >30\%, <40\% } \\
\hline \multicolumn{8}{|l|}{ Capacity Factor $>40 \%,<50 \%$} \\
\hline Capacity Factor >50\% & & & & & & & \\
\hline
\end{tabular}

Assumed turbine losses for predictions of average power output, annual energy output, and average capacity factor:

Downtime (\%)

Array (\%)

Icing/soiling (\%)

Other (\%)

Total (\%)
5

0

3

2

9.69 (factors are multiplicative) 
New Stuyahok, Alaska Wind Resource Report

Annual Fuel Cost Avoided for Energy Generated by Wind Turbine vs. Diesel Generator

\begin{tabular}{|c|c|c|c|c|c|c|c|c|c|c|}
\hline Turbine & $\begin{array}{c}\text { Annual } \\
\text { Energy } \\
\text { Output } \\
\text { (kW-hr/yr) }\end{array}$ & $\begin{array}{c}\text { Fuel } \\
\text { Quantity } \\
\text { Avoided } \\
\text { (gallons) }\end{array}$ & $\$ 1.75$ & $\$ 2.00$ & $\$ 2.25$ & Price (USL & /gallon) & $\$ 3.00$ & $\$ 3.25$ & $\begin{array}{c}\text { Turbine } \\
\text { Hub } \\
\text { Height } \\
\text { (m) }\end{array}$ \\
\hline Bergey Excel-S & 20,522 & 1,642 & $\$ 2,873$ & $\$ 3,284$ & $\$ 3,694$ & $\$ 4,104$ & $\$ 4,515$ & $\$ 4,925$ & $\$ 5,336$ & 37 \\
\hline Entegrity eW-15 $60 \mathrm{~Hz}$ & 106,345 & 8,508 & $\$ 14,888$ & $\$ 17,015$ & $\$ 19,142$ & $\$ 21,269$ & $\$ 23,396$ & $\$ 25,523$ & $\$ 27,650$ & 31 \\
\hline Vestas V15 & 106,145 & 8,492 & $\$ 14,860$ & $\$ 16,983$ & $\$ 19,106$ & $\$ 21,229$ & $\$ 23,352$ & $\$ 25,475$ & $\$ 27,598$ & 34 \\
\hline Northern Power NW 100/20 & 160,595 & 12,848 & $\$ 22,483$ & $\$ 25,695$ & $\$ 28,907$ & $\$ 32,119$ & $\$ 35,331$ & $\$ 38,543$ & $\$ 41,755$ & 32 \\
\hline Fuhrländer FL100 & 236,560 & 18,925 & $\$ 33,118$ & $\$ 37,850$ & $\$ 42,581$ & $\$ 47,312$ & $\$ 52,043$ & $\$ 56,774$ & $\$ 61,506$ & 35 \\
\hline Vestas V27 & 503,500 & 40,280 & $\$ 70,490$ & $\$ 80,560$ & $\$ 90,630$ & $\$ 100,700$ & $\$ 110,770$ & $\$ 120,840$ & $\$ 130,910$ & 42 \\
\hline
\end{tabular}

Notes:

1. New Stuyahok electrical energy production efficiency assumed to be $12.5 \mathrm{~kW}$-hr/gal

2. Assumes $90 \%$ wind turbine availability with no diversion of power to a thermal or other dump load

3. Assumes linear diesel generator fuel efficiency (i.e., 1:1 tradeoff of wind turbine kW-hr to diesel genset kW-hr) 
New Stuyahok, Alaska Wind Resource Report

Temperature Conversion Chart ${ }^{\circ} \mathrm{C}$ to ${ }^{\circ} \mathrm{F}$

\begin{tabular}{|c|c|c|c|c|c|}
\hline${ }^{\circ} \mathrm{C}$ & ${ }^{\circ} \mathrm{F}$ & ${ }^{\circ} \mathrm{C}$ & ${ }^{\circ} \mathrm{F}$ & ${ }^{\circ} \mathrm{C}$ & ${ }^{\circ} \mathrm{F}$ \\
\hline-40 & -40.0 & -10 & 14.0 & 20 & 68.0 \\
\hline-39 & -38.2 & -9 & 15.8 & 21 & 69.8 \\
\hline-38 & -36.4 & -8 & 17.6 & 22 & 71.6 \\
\hline-37 & -34.6 & -7 & 19.4 & 23 & 73.4 \\
\hline-36 & -32.8 & -6 & 21.2 & 24 & 75.2 \\
\hline-35 & -31.0 & -5 & 23.0 & 25 & 77.0 \\
\hline-34 & 29.2 & -4 & 24.8 & 26 & 78.8 \\
\hline-33 & -27.4 & -3 & 26.6 & 27 & 80.6 \\
\hline-32 & -25.6 & -2 & 28.4 & 28 & 82.4 \\
\hline-31 & -23.8 & -1 & 30.2 & 29 & 84.2 \\
\hline-30 & -22.0 & 0 & 32.0 & 30 & 86.0 \\
\hline-29 & -20.2 & 1 & 33.8 & 31 & 87.8 \\
\hline-28 & -18.4 & 2 & 35.6 & 32 & 89.6 \\
\hline-27 & -16.6 & 3 & 37.4 & 33 & 91.4 \\
\hline-26 & -14.8 & 4 & 39.2 & 34 & 93.2 \\
\hline-25 & -13.0 & 5 & 41.0 & 35 & 95.0 \\
\hline-24 & -11.2 & 6 & 42.8 & 36 & 96.8 \\
\hline-23 & -9.4 & 7 & 44.6 & 37 & 98.6 \\
\hline-22 & -7.6 & 8 & 46.4 & 38 & 100.4 \\
\hline-21 & -5.8 & 9 & 48.2 & 39 & 102.2 \\
\hline-20 & -4.0 & 10 & 50.0 & 40 & 104.0 \\
\hline-19 & -2.2 & 11 & 51.8 & 41 & 105.8 \\
\hline-18 & -0.4 & 12 & 53.6 & 42 & 107.6 \\
\hline-17 & 1.4 & 13 & 55.4 & 43 & 109.4 \\
\hline-16 & 3.2 & 14 & 57.2 & 44 & 111.2 \\
\hline-15 & 5.0 & 15 & 59.0 & 45 & 113.0 \\
\hline-14 & 6.8 & 16 & 60.8 & 46 & 114.8 \\
\hline-13 & 8.6 & 17 & 62.6 & 47 & 116.6 \\
\hline-12 & 10.4 & 18 & 64.4 & 48 & 118.4 \\
\hline-11 & 12.2 & 19 & 66.2 & 49 & 120.2 \\
\hline
\end{tabular}


New Stuyahok, Alaska Wind Resource Report

Wind Speed Conversion Chart, $\mathrm{m} / \mathrm{s}$ to $\mathrm{mph}$

\begin{tabular}{|c|c|c|c|c|c|c|c|c|c|}
\hline $\mathbf{m} / \mathbf{s}$ & $\mathbf{m p h}$ & $\mathbf{m} / \mathbf{s}$ & $\mathbf{m p h}$ & $\mathbf{~ m / s}$ & $\mathbf{m p h}$ & $\mathbf{~} / \mathbf{s}$ & $\mathbf{~ m p h}$ & $\mathbf{~} / \mathbf{s}$ & $\mathbf{m p h}$ \\
\hline 0.5 & 1.1 & 10.5 & 23.5 & 20.5 & 45.9 & 30.5 & 68.2 & 40.5 & 90.6 \\
\hline 1.0 & 2.2 & 11.0 & 24.6 & 21.0 & 47.0 & 31.0 & 69.3 & 41.0 & 91.7 \\
\hline 1.5 & 3.4 & 11.5 & 25.7 & 21.5 & 48.1 & 31.5 & 70.5 & 41.5 & 92.8 \\
\hline 2.0 & 4.5 & 12.0 & 26.8 & 22.0 & 49.2 & 32.0 & 71.6 & 42.0 & 93.9 \\
\hline 2.5 & 5.6 & 12.5 & 28.0 & 22.5 & 50.3 & 32.5 & 72.7 & 42.5 & 95.1 \\
\hline 3.0 & 6.7 & 13.0 & 29.1 & 23.0 & 51.4 & 33.0 & 73.8 & 43.0 & 96.2 \\
\hline 3.5 & 7.8 & 13.5 & 30.2 & 23.5 & 52.6 & 33.5 & 74.9 & 43.5 & 97.3 \\
\hline 4.0 & 8.9 & 14.0 & 31.3 & 24.0 & 53.7 & 34.0 & 76.1 & 44.0 & 98.4 \\
\hline 4.5 & 10.1 & 14.5 & 32.4 & 24.5 & 54.8 & 34.5 & 77.2 & 44.5 & 99.5 \\
\hline 5.0 & 11.2 & 15.0 & 33.6 & 25.0 & 55.9 & 35.0 & 78.3 & 45.0 & 100.7 \\
\hline 5.5 & 12.3 & 15.5 & 34.7 & 25.5 & 57.0 & 35.5 & 79.4 & 45.5 & 101.8 \\
\hline 6.0 & 13.4 & 16.0 & 35.8 & 26.0 & 58.2 & 36.0 & 80.5 & 46.0 & 102.9 \\
\hline 6.5 & 14.5 & 16.5 & 36.9 & 26.5 & 59.3 & 36.5 & 81.6 & 46.5 & 104.0 \\
\hline 7.0 & 15.7 & 17.0 & 38.0 & 27.0 & 60.4 & 37.0 & 82.8 & 47.0 & 105.1 \\
\hline 7.5 & 16.8 & 17.5 & 39.1 & 27.5 & 61.5 & 37.5 & 83.9 & 47.5 & 106.3 \\
\hline 8.0 & 17.9 & 18.0 & 40.3 & 28.0 & 62.6 & 38.0 & 85.0 & 48.0 & 107.4 \\
\hline 8.5 & 19.0 & 18.5 & 41.4 & 28.5 & 63.8 & 38.5 & 86.1 & 48.5 & 108.5 \\
\hline 9.0 & 20.1 & 19.0 & 42.5 & 29.0 & 64.9 & 39.0 & 87.2 & 49.0 & 109.6 \\
\hline 9.5 & 21.3 & 19.5 & 43.6 & 29.5 & 66.0 & 39.5 & 88.4 & 49.5 & 110.7 \\
\hline 10.0 & 22.4 & 20.0 & 44.7 & 30.0 & 67.1 & 40.0 & 89.5 & 50.0 & 111.8 \\
\hline
\end{tabular}

Distance Conversion $\mathrm{m}$ to $\mathrm{ft}$

\begin{tabular}{|c|c|c|c|}
\hline $\mathbf{m}$ & $\mathbf{f t}$ & $\mathbf{m}$ & $\mathbf{f t}$ \\
\hline 5 & 16 & 35 & 115 \\
\hline 10 & 33 & 40 & 131 \\
\hline 15 & 49 & 45 & 148 \\
\hline 20 & 66 & 50 & 164 \\
\hline 25 & 82 & 55 & 180 \\
\hline 30 & 98 & 60 & 197 \\
\hline
\end{tabular}


Selected definitions (courtesy of Windographer ${ }^{\circledR}$ software by Mistaya Engineering Inc.)

\section{$\underline{\text { Wind Power Class }}$}

The wind power class is a number indicating the average energy content of the wind resource. Wind power classes are based on the average wind power density at 50 meters above ground, according to the following table. Source: Wind Energy Resource Atlas of the United States (http://rredc.nrel.gov/wind/pubs/atlas/tables/A-8T.html)

\begin{tabular}{|c|l|c|}
\hline \multicolumn{2}{|c|}{} & \multicolumn{2}{|c|}{} \\
\hline Wind Power Class & Description & Power Density at 50m (W/. $\mathbf{2})$ \\
\hline 1 & Poor & $0-200$ \\
\hline 2 & Marginal & $200-300$ \\
\hline 3 & Fair & $300-400$ \\
\hline 4 & Good & $400-500$ \\
\hline 5 & Excellent & $500-600$ \\
\hline 6 & Outstanding & $600-800$ \\
\hline 7 & Superb & $800-2000$ \\
\hline
\end{tabular}

Windographer classifies any wind resource with an average wind power density above 2000 $\mathrm{W} / \mathrm{m}^{2}$ as class 8 .

\section{Probability Distribution Function}

The probability distribution function $\mathrm{f}(\mathrm{x})$ gives the probability that a variable will take on the value $\mathrm{x}$. It is often expressed using a frequency histogram, which gives the frequency with which the variable falls within certain ranges or bins.

\section{Wind Turbine Power Regulation}

All wind turbines employ some method of limiting power output at high wind speeds to avoid damage to mechanical or electrical subsystems. Most wind turbines employ either stall control or pitch control to regulate power output.

A stall-controlled turbine typically has blades that are fixed in place, and are designed to experience aerodynamic stall at very high wind speeds. Aerodynamic stall dramatically reduces the torque produced by the blades, and therefore the power produced by the turbine.

On a pitch-controlled turbine, a controller adjusts the angle (pitch) of the blades to best match the wind speed. At very high wind speeds the controller increasingly feathers the blades out of the wind to limit the power output. 


\section{Perryville, Alaska Wind Resource Update Report}

\section{Report written by: Douglas Vaught, P.E., V3 Energy, LLC}

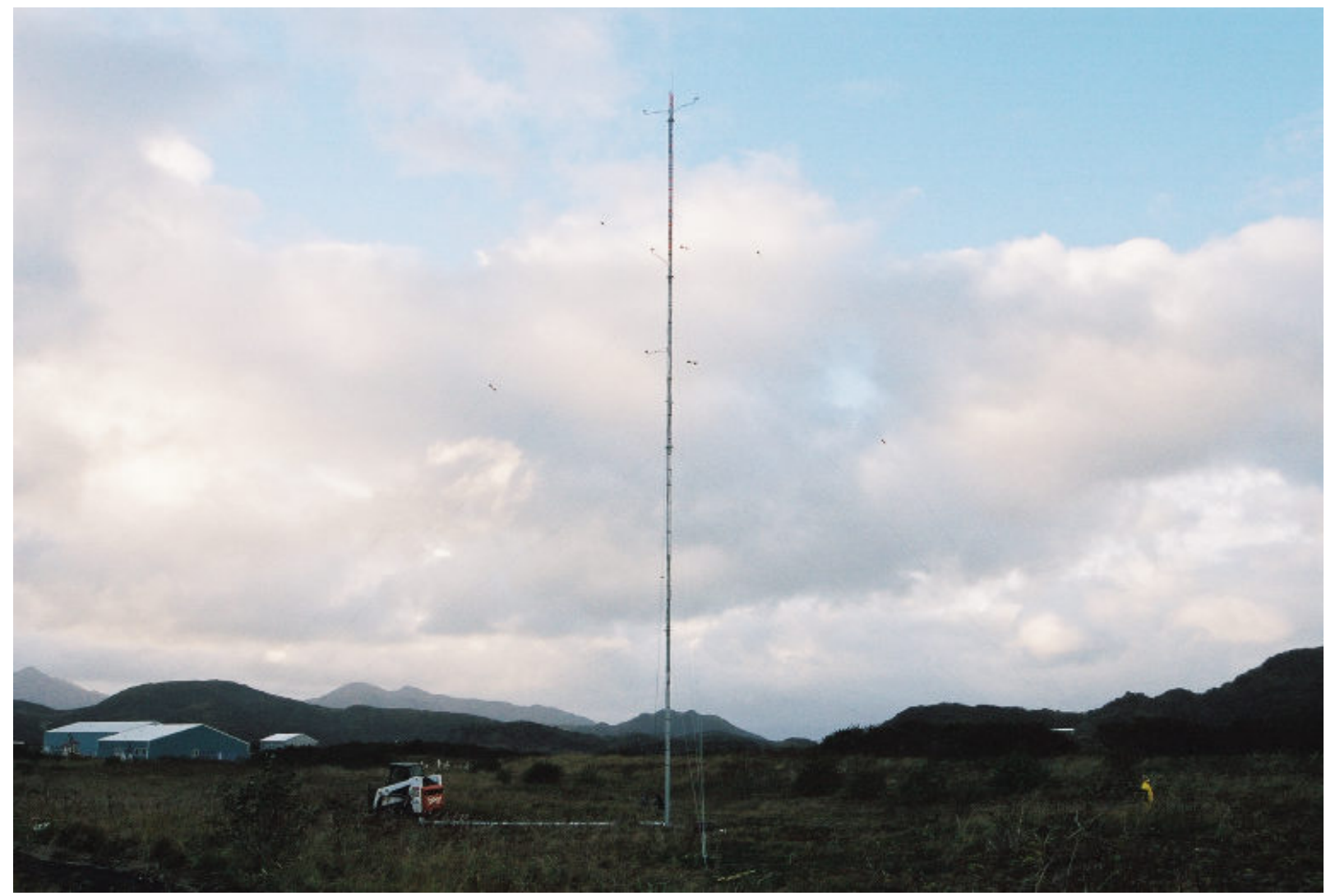

Photo by Doug Vaught, V3 Energy, LLC

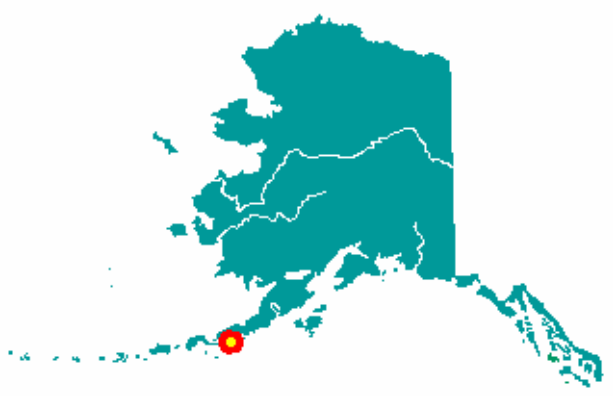

\section{Summary Information}

The wind resource study in Perryville defied expectations of measuring strong winds. It appears that local geographic features effectively shield the test site, and the nearby village, from the ferocious winds common to the southern Alaska Peninsula coast. With a measured wind power class of 2 (marginal), Perryville does not appear at this time to be a promising location for 
village-scale wind power development, although there is always the possibility of successful home-scale wind power development.

\section{Meteorological Tower Data Synopsis}

Wind power class

Class 2 - Marginal

Wind speed annual average (30 meters)

$4.60 \mathrm{~m} / \mathrm{s}$

Maximum wind gust (2 sec. average)

$24.4 \mathrm{~m} / \mathrm{s}$ (Nov 2004)

Mean wind power density (50 meters)

$240 \mathrm{~W} / \mathrm{m}^{2}$ (calculated)

Mean wind power density (30 meters)

$185 \mathrm{~W} / \mathrm{m}^{2}$ (measured)

Wiebull distribution parameters

Roughness class

$\mathrm{k}=1.36, \mathrm{c}=5.02 \mathrm{~m} / \mathrm{s}$

Power law exponent

1.93 (few trees)

Turbulence intensity

0.181 (moderate wind shear)

Data start date

0.158

Most recent data date

October 9, 2004

October 4, 2006

Community Profile

Current Population: 114 (2005 State Demographer est.)

Incorporation Type: Unincorporated

Borough Located In: Lake \& Peninsula Borough

School District: Lake \& Peninsula Schools

Regional Native Corporation: Bristol Bay Native Corporation

\section{Location:}

Perryville is located on the south coast of the Alaska Peninsula, 275 miles southwest of Kodiak and 500 miles southwest of Anchorage. It lies at approximately $55.912780^{\circ}$ North Latitude and $159.145560^{\circ}$ West Longitude. (Sec. 27, T049S, R064W, Seward Meridian.) Perryville is located in the Aleutian Islands Recording District. The area encompasses 9.2 sq. miles of land and 0.1 sq. miles of water.

\section{History:}

The community was founded in 1912 as a refuge for Alutiiq people driven away from their villages by the eruption of Mt. Katmai. Many villagers from Douglas and Katmai survived the eruption because they were out fishing at the time. Captain Perry of the ship "Manning" transported people from the Katmai area to Ivanof Bay, and later, to the new village site. The village was originally called "Perry," but the "ville" was added to conform to the post office name, established in 1930.

\section{Culture:}

The village maintains an Alutiiq culture and a subsistence lifestyle. Commercial fishing provides cash income.

\section{Economy:}

Eleven residents hold commercial fishing permits for the Chignik salmon fishery. During the summer, the majority of residents leave Perryville to fish in Chignik or Chignik Lagoon. Only a few year-round jobs are available. Some trap during the winter, and all rely heavily on subsistence food sources. Salmon, trout, marine fish, crab, clams, moose, caribou, bear, porcupine and seal are harvested. 


\section{Facilities:}

Water is supplied by a nearby stream and 60,000-gallon timber dam gravity system. It is treated, stored in a new 50,000-gallon tank, and distributed via water mains. Thirty homes and the school have piped water. Individual septic tanks are used by most residents and there is a septic system for community facilities. The landfill is recorded as inactive. A number of homes are used only seasonally.

\section{Transportation:}

Perryville is accessible by air and sea. There is a State-owned 2,467' long by 50' wide gravel runway and seaplane base and scheduled and charter flights are available from King Salmon. Cargo barges deliver fuel and supplies each spring. A small boat harbor is needed for the growing fishing community and the west side of Three Star Point has been selected for development. ATVs and skiffs are the primary means of local transportation.

\section{Climate:}

Perryville's maritime climate is characterized by cool summers, warm winters and rainy weather. Average summer temperatures range from $39^{\circ}$ to $60^{\circ} \mathrm{F}$; winter temperatures average $21^{\circ}$ to $50^{\circ} \mathrm{F}$. Low clouds, rain squalls, fog and snow showers frequently limit visibility. Average annual precipitation is 127 inches, including 58 inches of snow.

(Above information from State of Alaska Department of Commerce, Community, and Economic Development website, http://www.dced.state.ak.us/)

\section{Tower Sensor Information}

\begin{tabular}{clrrrc} 
Channel & Sensor type & Height & Multiplier & Offset & Orientation \\
\hline 1 & NRG \#40 anemometer & $30 \mathrm{~m}$ & 0.765 & 0.35 & west \\
2 & NRG \#40 anemometer & $23 \mathrm{~m}$ & 0.765 & 0.35 & south \\
3 & NRG \#40 anemometer & $19 \mathrm{~m}$ & 0.765 & 0.35 & west \\
7 & NRG \#200P wind vane & $30 \mathrm{~m}$ & 0.351 & 265 & east \\
9 & NRG \#110S Temp C & $2 \mathrm{~m}$ & 0.136 & -86.383 & N/A
\end{tabular}

Site Information and Location

Site number

Site Description

Latitude/longitude

Site elevation

Datalogger type

Tower type
2858

Coastal flat, behind beach dunes, east side of village

N 55 54.648'; W 1590 08.387'

2 meters

NRG Symphonie

NRG 30-meter tall tower, 152 mm (6-in) diameter 
Perryville, Alaska Wind Resource Report

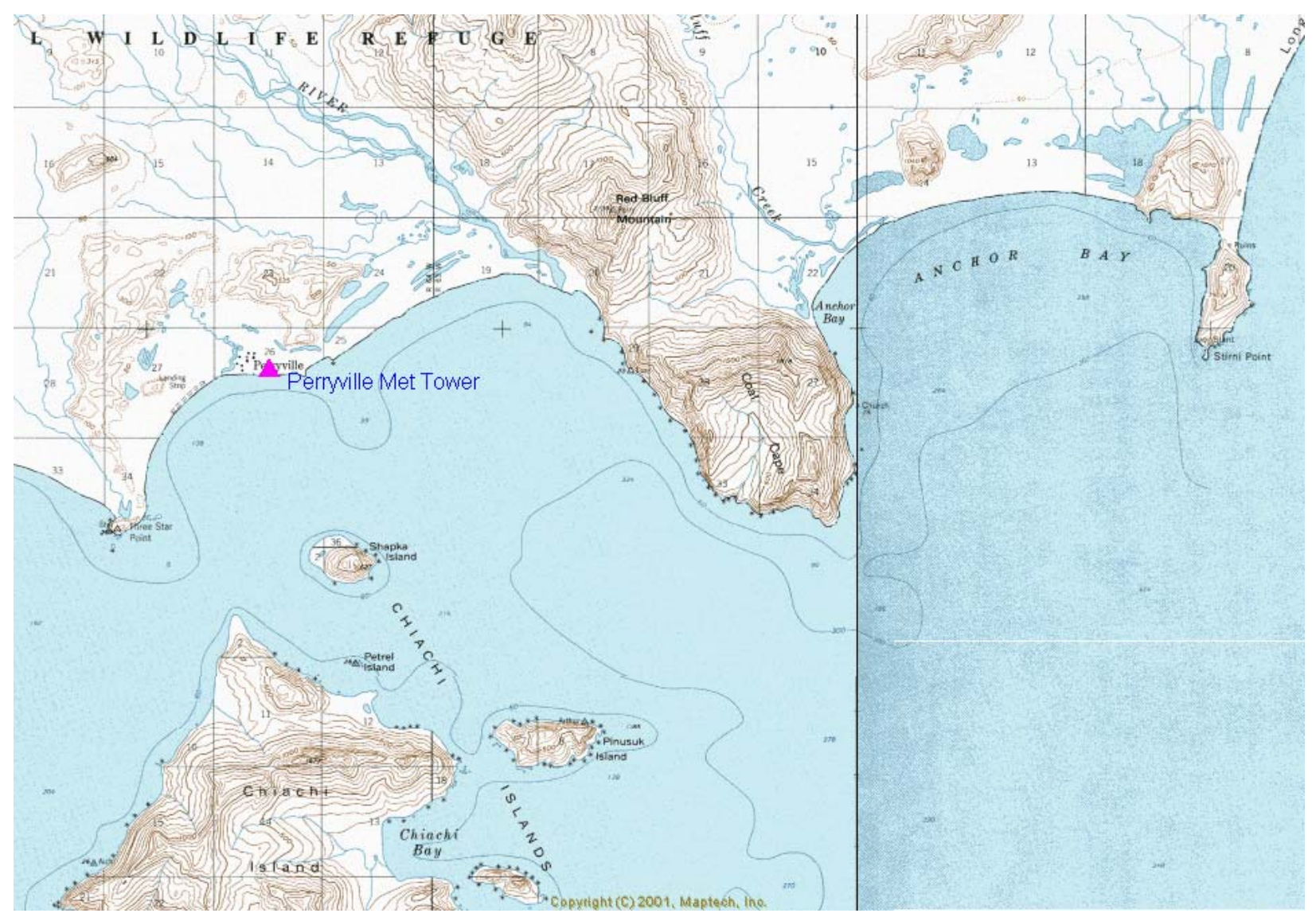


Perryville, Alaska Wind Resource Report

\section{Data Quality Control}

Data was filtered to remove presumed icing events that yield false zero wind speed data. Data that met the following criteria were filtered: wind speed $<1 \mathrm{~m} / \mathrm{s}$, wind speed standard deviation $=0$, and temperature $<2^{\circ} \mathrm{C}$. Note that data recovery for the Perryville met tower was excellent with very little data lost to icing events and no data lost to failed sensors. Because sensor icing was so minimal, filtered data was not synthesized and replaced.

\begin{tabular}{|c|c|c|c|c|c|c|c|}
\hline \multirow[b]{2}{*}{ Year } & \multirow[b]{2}{*}{ Month } & \multicolumn{2}{|c|}{ Ch 1 (speed 30 m) } & \multicolumn{2}{|c|}{ Ch 2 (speed 23 m) } & \multicolumn{2}{|c|}{ Ch 3 (speed 19 m) } \\
\hline & & Records & $\begin{array}{l}\text { Recovery } \\
\text { Rate (\%) }\end{array}$ & Records & $\begin{array}{l}\text { Recovery } \\
\text { Rate (\%) }\end{array}$ & Records & $\begin{array}{l}\text { Recovery } \\
\text { Rate (\%) }\end{array}$ \\
\hline 2004 & Oct & 3,198 & 99.2 & 3,198 & 99.2 & 3,198 & 99.2 \\
\hline 2004 & Nov & 4,198 & 97.2 & 4,178 & 96.7 & 4,237 & 98.1 \\
\hline 2004 & Dec & 4,464 & 100 & 4,464 & 100 & 4,464 & 100 \\
\hline 2005 & Jan & 4,464 & 100 & 4,464 & 100 & 4,464 & 100 \\
\hline 2005 & Feb & 4,032 & 100 & 4,032 & 100 & 4,032 & 100 \\
\hline 2005 & Mar & 4,357 & 97.6 & 4,357 & 97.6 & 4,357 & 97.6 \\
\hline 2005 & Apr & 4,320 & 100 & 4,320 & 100 & 4,320 & 100 \\
\hline 2005 & May & 4,464 & 100 & 4,464 & 100 & 4,464 & 100 \\
\hline 2005 & Jun & 4,320 & 100 & 4,320 & 100 & 4,320 & 100 \\
\hline 2005 & Jul & 4,464 & 100 & 4,464 & 100 & 4,464 & 100 \\
\hline 2005 & Aug & 4,464 & 100 & 4,464 & 100 & 4,464 & 100 \\
\hline 2005 & Sep & 4,320 & 100 & 4,320 & 100 & 4,320 & 100 \\
\hline 2005 & Oct & 4,464 & 100 & 4,464 & 100 & 4,464 & 100 \\
\hline 2005 & Nov & 4,320 & 100 & 4,320 & 100 & 4,320 & 100 \\
\hline 2005 & Dec & 4,464 & 100 & 4,464 & 100 & 4,464 & 100 \\
\hline 2006 & Jan & 4,464 & 100 & 4,464 & 100 & 4,464 & 100 \\
\hline 2006 & Feb & 4,032 & 100 & 4,032 & 100 & 4,032 & 100 \\
\hline 2006 & Mar & 4,464 & 100 & 4,415 & 98.9 & 4,464 & 100 \\
\hline 2006 & Apr & 4,281 & 99.1 & 4,320 & 100 & 4,320 & 100 \\
\hline 2006 & May & 4,464 & 100 & 4,464 & 100 & 4,464 & 100 \\
\hline 2006 & Jun & 4,320 & 100 & 4,320 & 100 & 4,320 & 100 \\
\hline 2006 & Jul & 4,464 & 100 & 4,464 & 100 & 4,464 & 100 \\
\hline 2006 & Aug & 4,464 & 100 & 4,464 & 100 & 4,464 & 100 \\
\hline 2006 & Sep & 4,320 & 100 & 4,320 & 100 & 4,320 & 100 \\
\hline 2006 & Oct & 486 & 100 & 486 & 100 & 486 & 100 \\
\hline \multicolumn{2}{|l|}{ All data } & 104,072 & 99.7 & 104,042 & 99.7 & 104,150 & 99.8 \\
\hline & & \multicolumn{2}{|c|}{ Ch 7 (wind vane) } & \multicolumn{2}{|c|}{ Ch 9 (temperature) } & & \\
\hline Year & Month & Records & $\begin{array}{l}\text { Recovery } \\
\text { Rate (\%) }\end{array}$ & Records & $\begin{array}{l}\text { Recovery } \\
\text { Rate (\%) }\end{array}$ & & \\
\hline 2004 & Oct & 3,223 & 100 & 3,223 & 100 & & \\
\hline 2004 & Nov & 4,320 & 100 & 4,320 & 100 & & \\
\hline 2004 & Dec & 4,464 & 100 & 4,464 & 100 & & \\
\hline 2005 & Jan & 4,464 & 100 & 4,464 & 100 & & \\
\hline 2005 & Feb & 4,032 & 100 & 4,032 & 100 & & \\
\hline 2005 & Mar & 4,464 & 100 & 4,464 & 100 & & \\
\hline 2005 & Apr & 4,320 & 100 & 4,320 & 100 & & \\
\hline 2005 & May & 4,464 & 100 & 4,464 & 100 & & \\
\hline 2005 & Jun & 4,320 & 100 & 4,320 & 100 & & \\
\hline
\end{tabular}


Perryville, Alaska Wind Resource Report

\begin{tabular}{rrrrrr}
2005 & Jul & 4,464 & 100 & 4,464 & 100 \\
2005 & Aug & 4,464 & 100 & 4,464 & 100 \\
2005 & Sep & 4,320 & 100 & 4,320 & 100 \\
2005 & Oct & 4,464 & 100 & 4,464 & 100 \\
2005 & Nov & 4,320 & 100 & 4,320 & 100 \\
2005 & Dec & 4,464 & 100 & 4,464 & 100 \\
2006 & Jan & 4,464 & 100 & 4,464 & 100 \\
2006 & Feb & 4,032 & 100 & 4,032 & 100 \\
2006 & Mar & 4,464 & 100 & 4,464 & 100 \\
2006 & Apr & 4,320 & 100 & 4,320 & 100 \\
2006 & May & 4,464 & 100 & 4,464 & 100 \\
2006 & Jun & 4,320 & 100 & 4,320 & 100 \\
2006 & Jul & 4,464 & 100 & 4,464 & 100 \\
2006 & Aug & 4,464 & 100 & 4,464 & 100 \\
2006 & Sep & 4,320 & 100 & 4,320 & 100 \\
2006 & Oct & 486 & 100 & 486 & 100 \\
\hline All data & & 104,365 & 100 & 104,365 & 100
\end{tabular}


Perryville, Alaska Wind Resource Report

\section{Measured Wind Speeds}

The Channel 1 (30-meter) anemometer annual wind speed average for the reporting period is $4.60 \mathrm{~m} / \mathrm{s}$, the Channel 2 (23-meter) anemometer wind speed average is $4.45 \mathrm{~m} / \mathrm{s}$, and the Channel 3 (19-meter) anemometer wind speed average is $4.22 \mathrm{~m} / \mathrm{s}$.

\begin{tabular}{|c|c|c|c|c|c|c|c|c|c|}
\hline \multirow[b]{3}{*}{ Month } & \multicolumn{5}{|c|}{30 m speed (Ch 1) } & \multicolumn{2}{|c|}{23 m speed (Ch 2) } & \multicolumn{2}{|c|}{19 m speed (Ch 3) } \\
\hline & & & Std. & Weibull & Weibull & & & & \\
\hline & $\begin{array}{c}\text { Mean } \\
(\mathrm{m} / \mathrm{s})\end{array}$ & $\begin{array}{l}\text { Max } \\
(\mathrm{m} / \mathrm{s})\end{array}$ & $\begin{array}{l}\text { Dev. } \\
(\mathrm{m} / \mathrm{s})\end{array}$ & $\mathrm{k}$ & $\begin{array}{c}\mathrm{C} \\
(\mathrm{m} / \mathrm{s})\end{array}$ & $\begin{array}{l}\text { Mean } \\
(\mathrm{m} / \mathrm{s})\end{array}$ & $\begin{array}{l}\text { Max } \\
(\mathrm{m} / \mathrm{s})\end{array}$ & $\begin{array}{c}\text { Mean } \\
(\mathrm{m} / \mathrm{s})\end{array}$ & $\begin{array}{c}\operatorname{Max} \\
(\mathrm{m} / \mathrm{s})\end{array}$ \\
\hline Jan & 4.48 & 17.0 & 3.08 & 1.42 & 4.91 & 4.35 & 16.5 & 4.07 & 15.8 \\
\hline Feb & 6.38 & 24.5 & 4.53 & 1.39 & 6.98 & 6.10 & 23.7 & 5.89 & 23.3 \\
\hline Mar & 5.13 & 21.9 & 3.46 & 1.44 & 5.63 & 4.99 & 20.4 & 4.77 & 19.6 \\
\hline Apr & 4.61 & 20.3 & 2.98 & 1.56 & 5.12 & 4.43 & 19.4 & 4.29 & 18.9 \\
\hline May & 4.29 & 18.7 & 2.78 & 1.54 & 4.75 & 4.20 & 18.0 & 4.00 & 17.4 \\
\hline Jun & 3.54 & 16.2 & 2.65 & 1.37 & 3.87 & 3.50 & 16.7 & 3.25 & 15.1 \\
\hline Jul & 3.56 & 16.3 & 2.66 & 1.33 & 3.87 & 3.53 & 16.2 & 3.27 & 14.3 \\
\hline Aug & 3.72 & 15.5 & 2.69 & 1.33 & 4.03 & 3.63 & 14.8 & 3.38 & 14.3 \\
\hline Sep & 4.35 & 18.3 & 3.05 & 1.36 & 4.73 & 4.23 & 18.4 & 3.93 & 16.6 \\
\hline Oct & 4.98 & 16.3 & 3.38 & 1.43 & 5.47 & 4.77 & 15.5 & 4.57 & 15.3 \\
\hline Nov & 5.47 & 23.2 & 3.71 & 1.50 & 6.06 & 5.19 & 22.4 & 5.01 & 21.9 \\
\hline Dec & 4.87 & 23.3 & 3.71 & 1.29 & 5.26 & 4.73 & 21.6 & 4.44 & 20.8 \\
\hline Annual & 4.60 & 24.5 & 3.35 & 1.36 & 5.02 & 4.46 & 23.7 & 4.22 & 23.3 \\
\hline
\end{tabular}

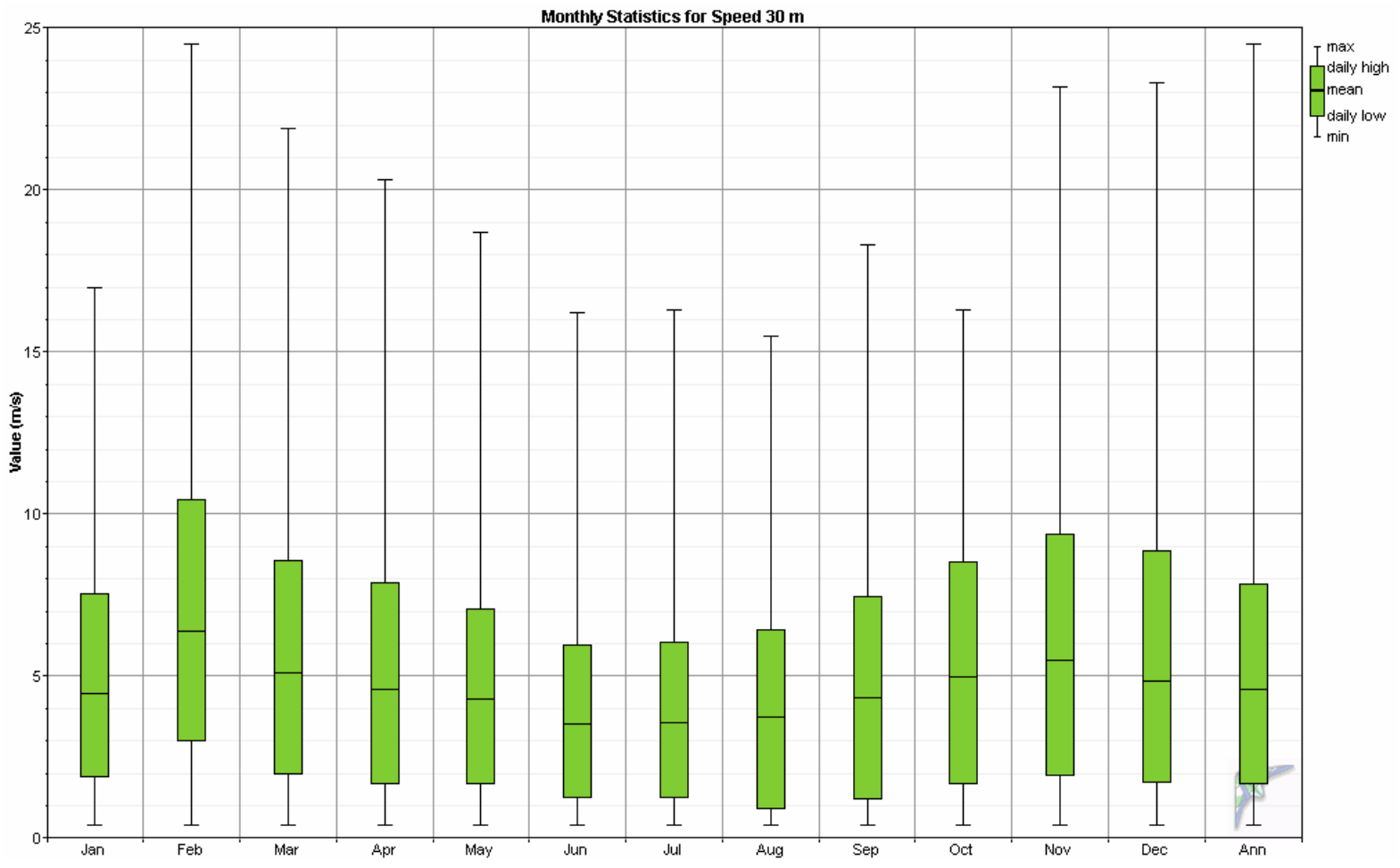


Perryville, Alaska Wind Resource Report

\section{Daily Wind Profile}

The daily wind profile indicates a strong daily variation of wind speeds with the lowest wind speeds occurring in the morning hours of 3 to 9 a.m. and the highest wind speeds of the day occur during the afternoon and early evening hours of 2 to 6 p.m. The daily variation of wind speed, which is relatively pronounced on an annual basis, is quite more pronounced on a monthly basis.
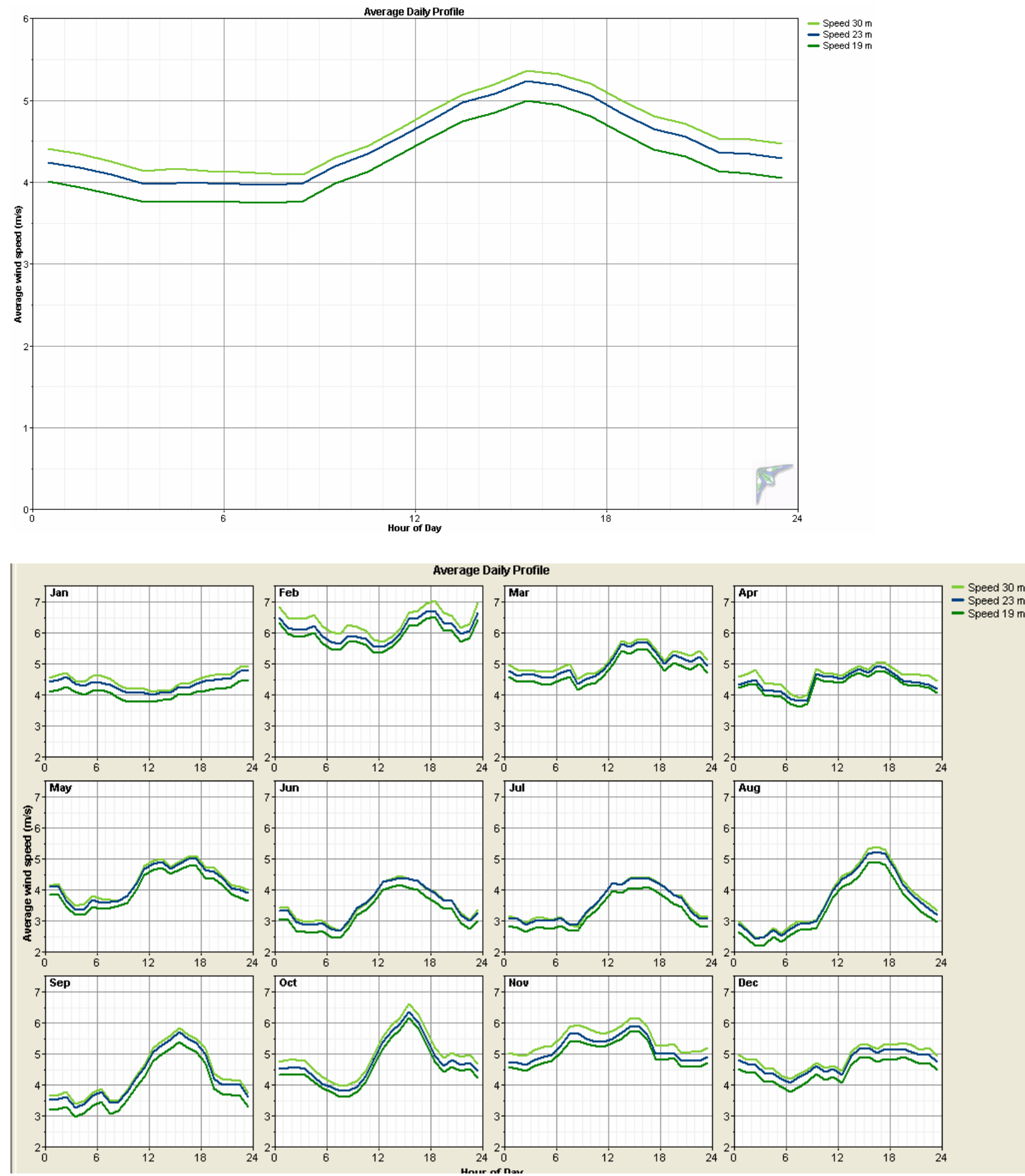


\section{Time Series of Wind Speed Averages}

As expected, the highest winds occurred during the fall through spring months with relatively light winds during the summer months of June through August. Interestingly, Perryville's winds are much lighter than had been expected given its geographic location on the Pacific coast of the Alaska Range. This may be due to the presence of significant mountainous terrain immediately west, north and east of the village as well as a large and high island just only a mile offshore that may act to block onshore winds. Perryville does experience strong winds sufficient for excellent wind energy recovery, but these winds tend to be quite short-lived, and then quickly drop off to very low speeds for long periods. A daily time series of the three wind vanes in late December, 2005 illustrates the typical dynamic of winds in Perryville and helps to explain the rather low average wind speed measured through the two year test period.
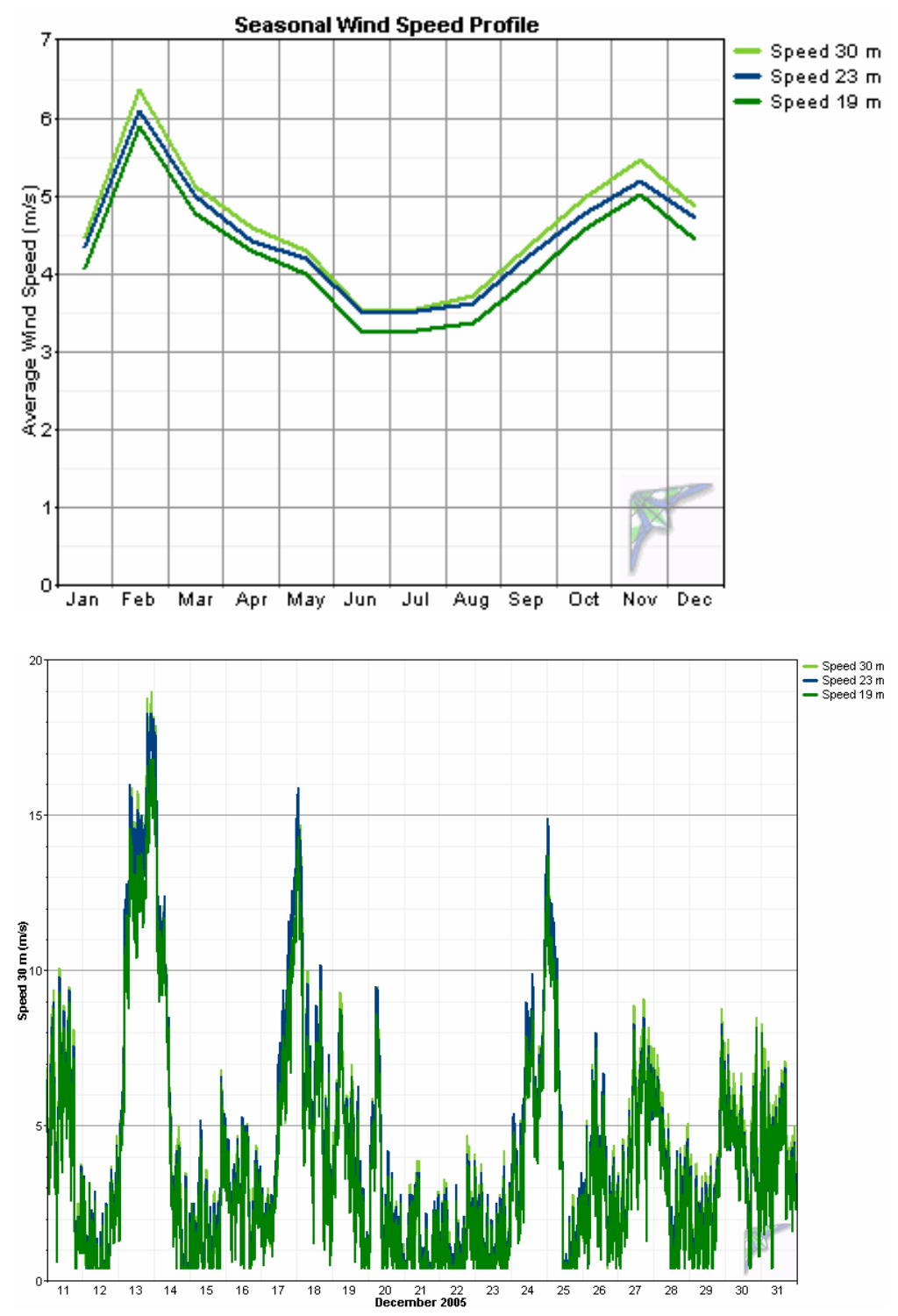
Perryville, Alaska Wind Resource Report

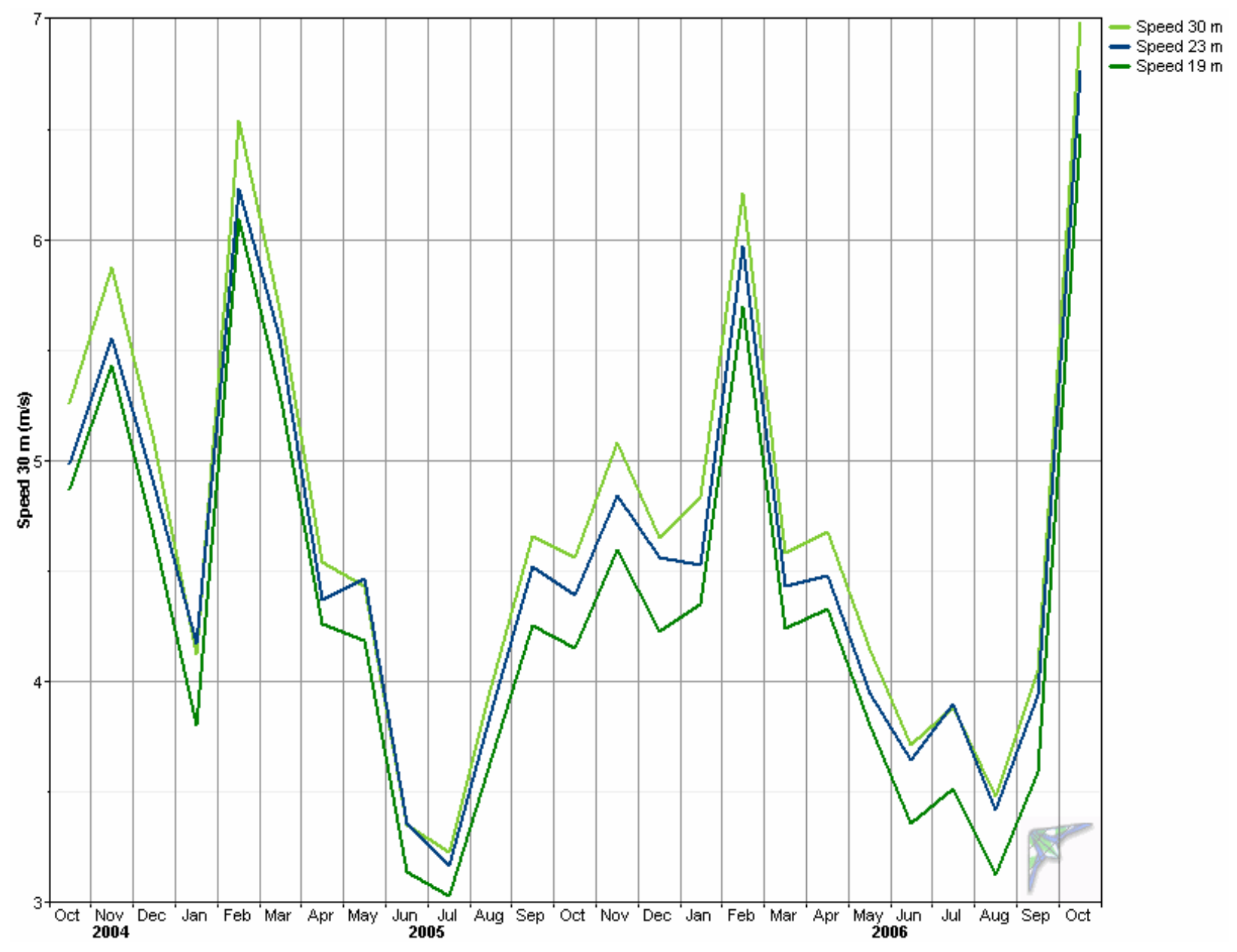




\section{Wind Shear Profile}

The average power law exponent was calculated at 0.181 , indicating moderate wind shear at the Perryville met tower test site. The practical application of this information is that a higher turbine tower height is advantageous as there is an appreciable marginal gain in average wind speed with height. However, a tower height/power recovery/construction cost tradeoff study would be advisable should a wind power project be initiated.
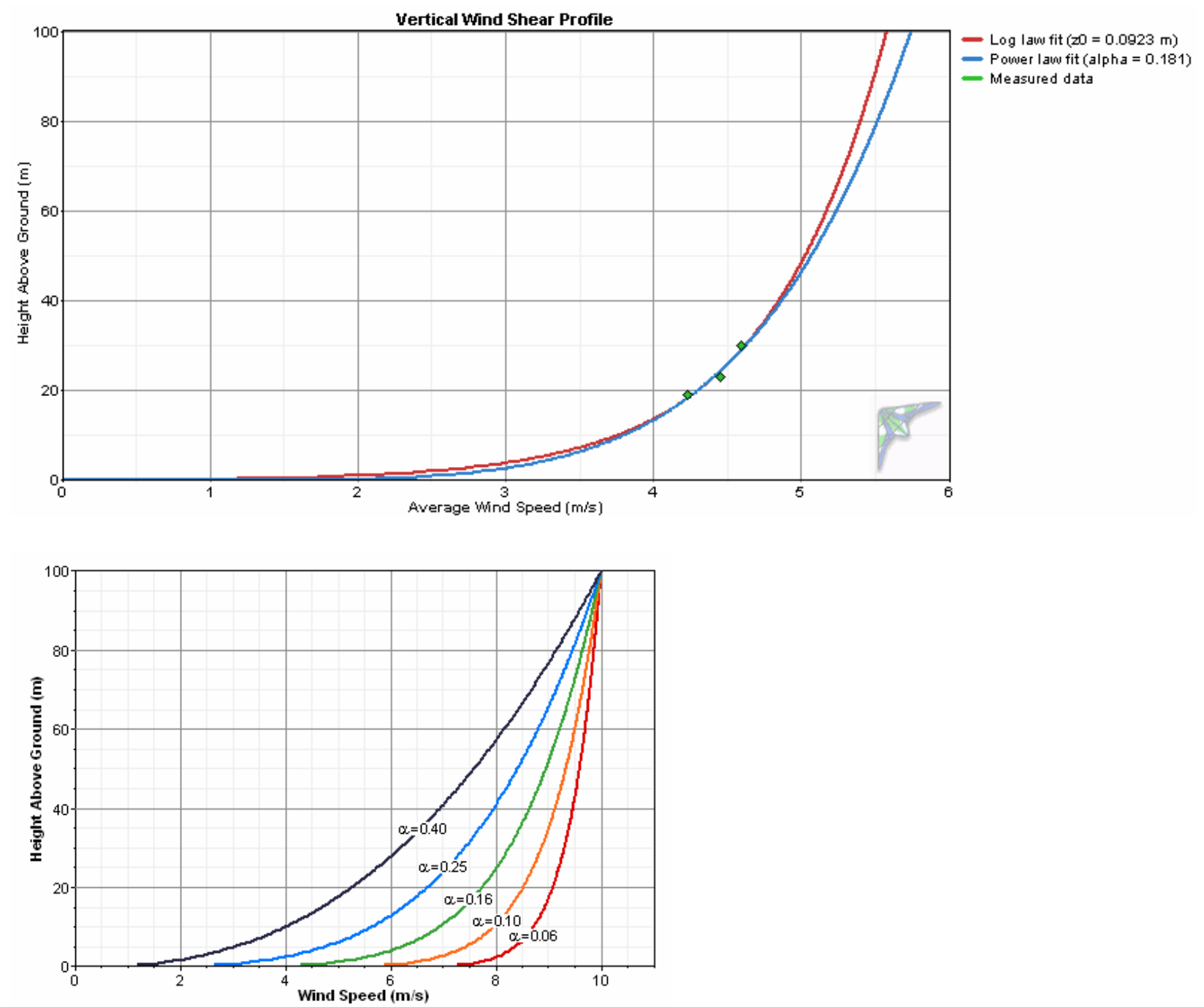
Perryville, Alaska Wind Resource Report
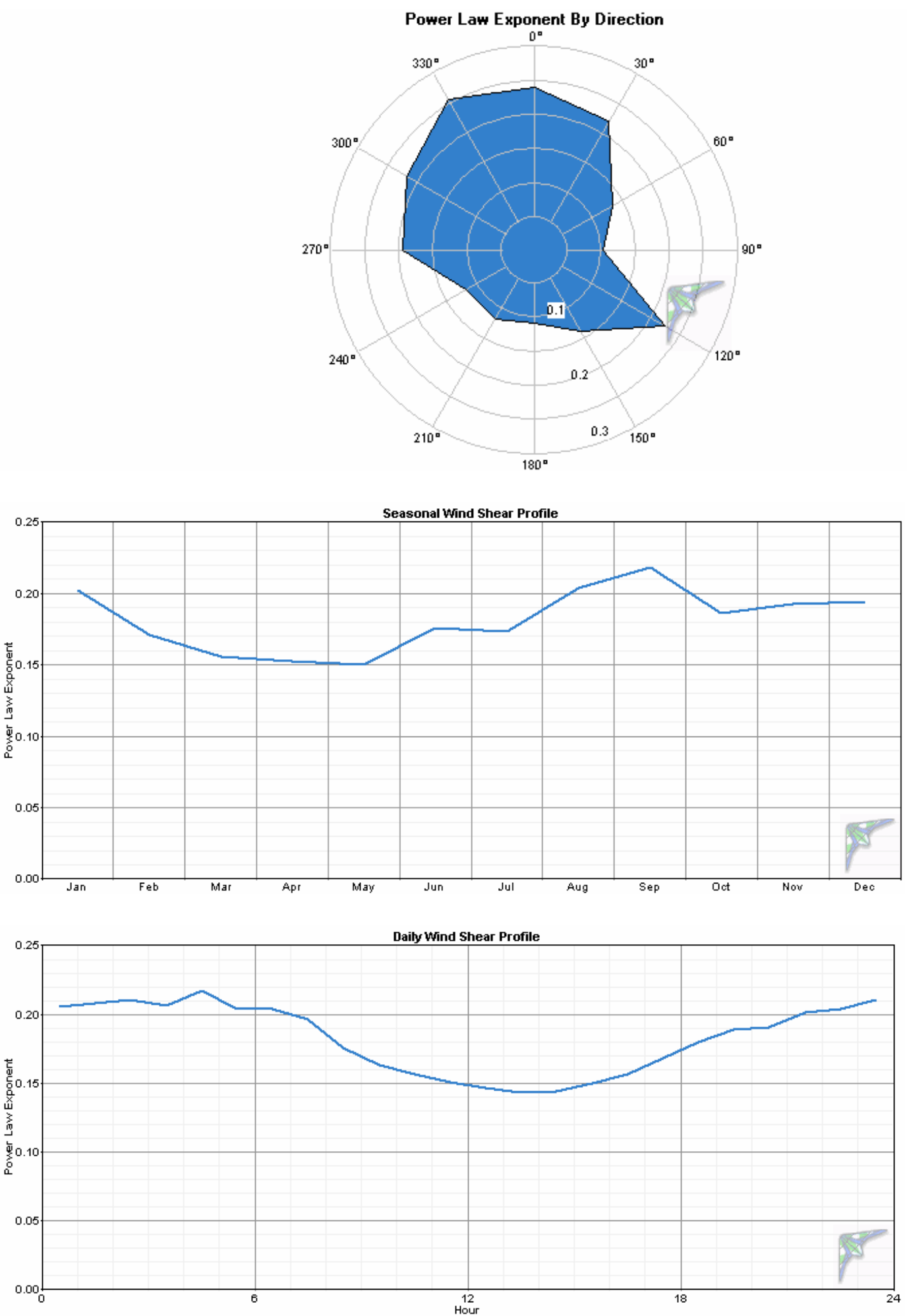


\section{Probability Distribution Function}

The probability distribution function (PDF) provides a visual indication of measured wind speeds in one meter per second "bins". Note that most wind turbines do not begin to generate power until the wind speed at hub height reaches $4 \mathrm{~m} / \mathrm{s}$, also known as the "cut-in" wind speed. The black line in the graph is a best fit Weibull distribution. At the 30 meter level, Weibull parameters are $\mathrm{k}=1.36$ (indicates a moderate distribution of wind speeds) and $\mathrm{c}=5.02 \mathrm{~m} / \mathrm{s}$ (scale factor for the Weibull distribution). The PDF information is shown visually in another manner in the second graph, the Cumulative Distribution Function.
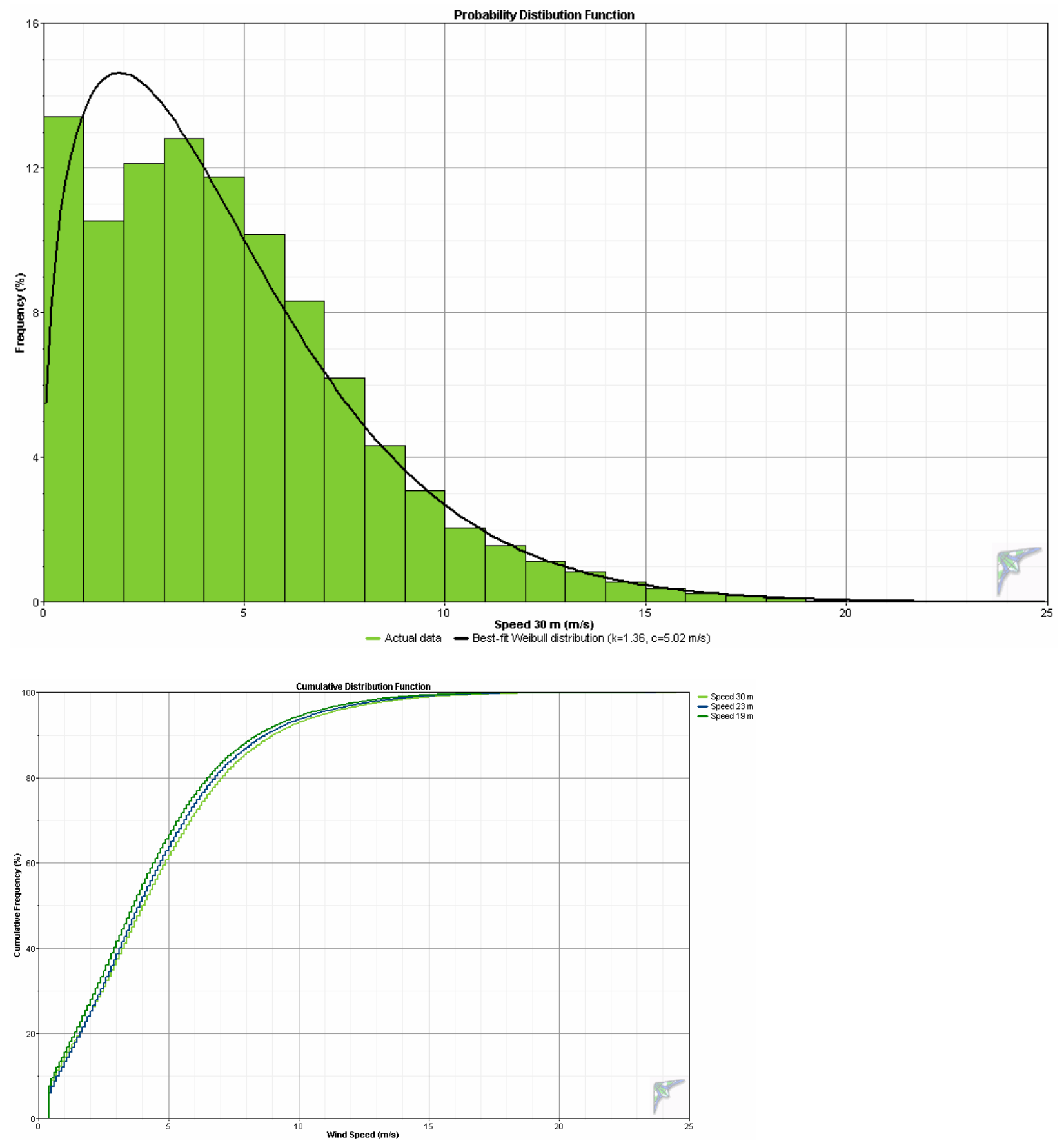


\section{Wind Roses}

Perryville's winds are not strongly directional; the wind frequency rose indicates predominately northwest winds with a lesser component of easterly and westerly winds. This data observation changes somewhat upon consideration of the power density rose (second wind rose). As one can see, the power producing winds are almost equally east, southeast, southwest, and northwest. The practical application of this information is that multiple turbines must be space rather far apart to prevent power loss to downwind machines.

Note also that a wind threshold of $4 \mathrm{~m} / \mathrm{s}$ was selected for the definition of calm winds. This wind speed represents the cut-in wind speed of most wind turbines. Remarkably, Perryville experiences fifty percent calm conditions by this definition (see wind frequency rose below), much higher than most other Alaska coastal locations.

Wind frequency rose (30 meters)

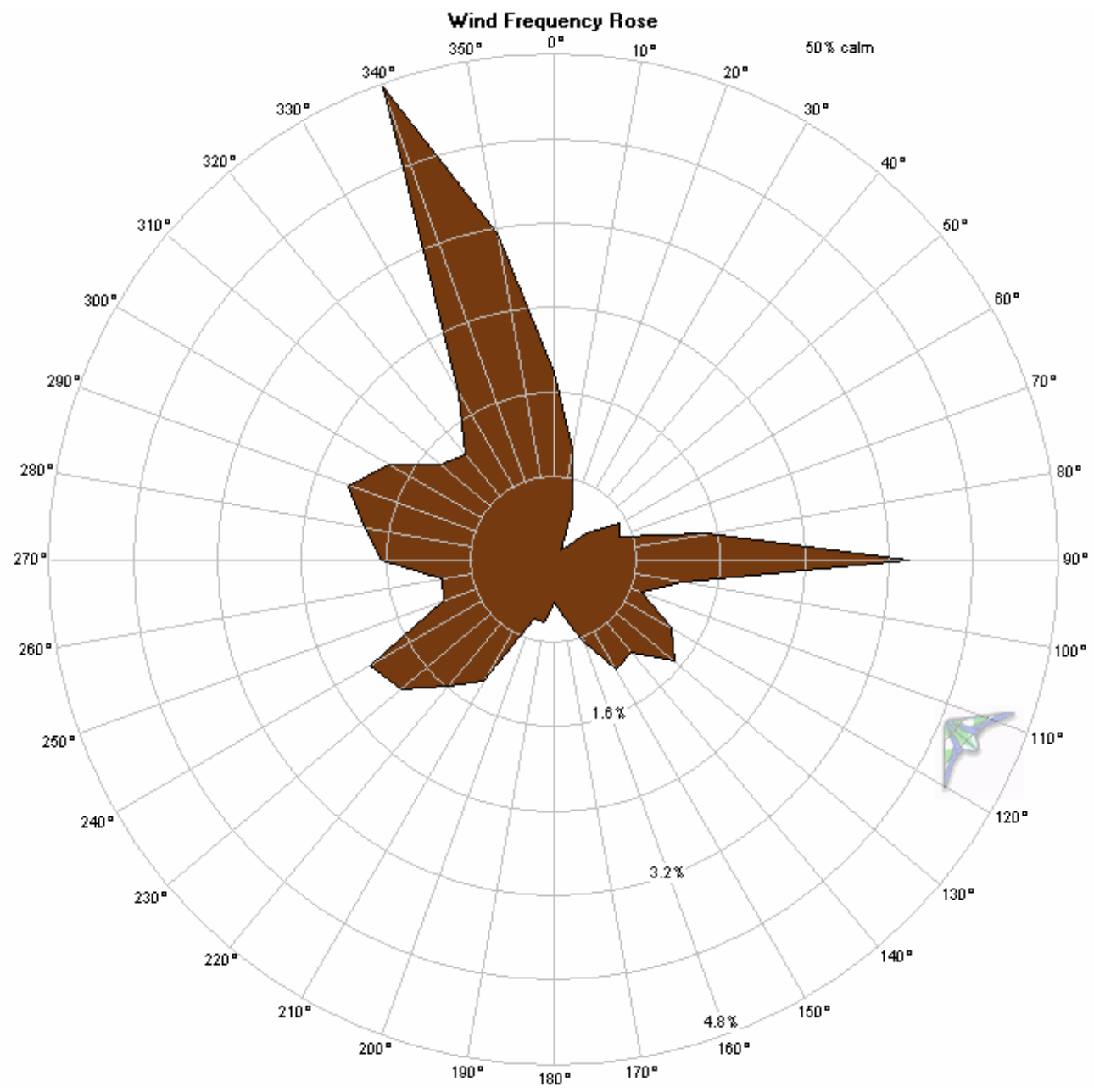


Perryville, Alaska Wind Resource Report

Wind Power Density Rose (30 meters)

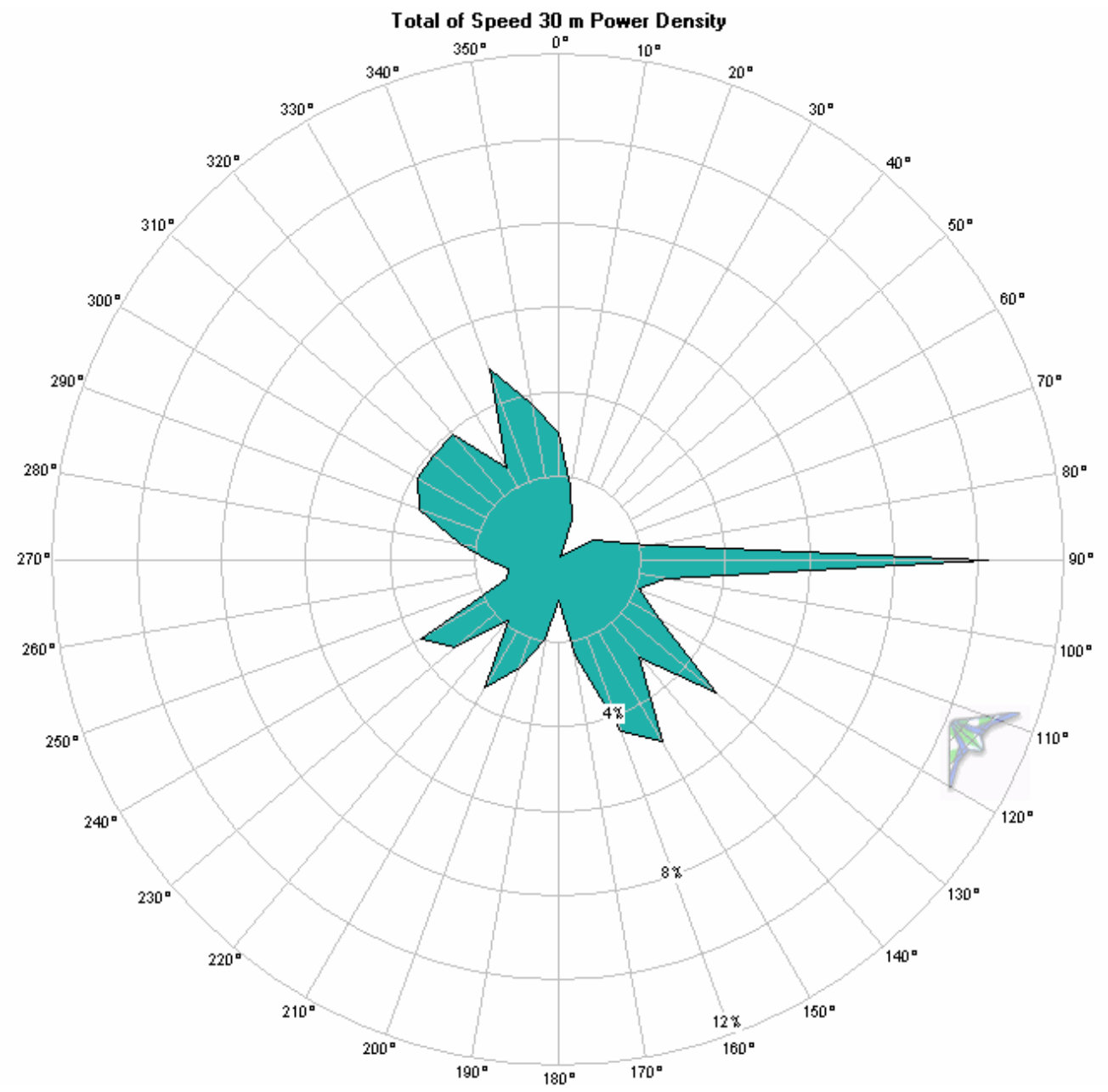

Wind Power Density Rose by Month (30 meters)

Note: for easier visualization of monthly wind power variation, the scale is not common
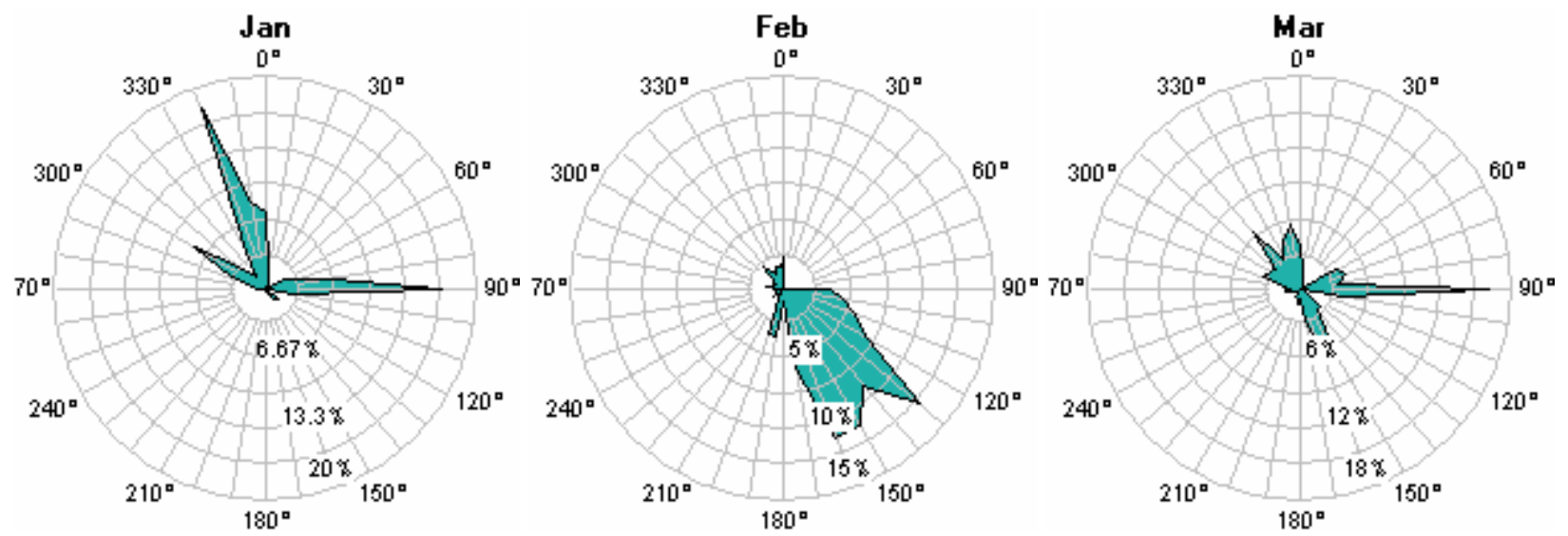
Perryville, Alaska Wind Resource Report

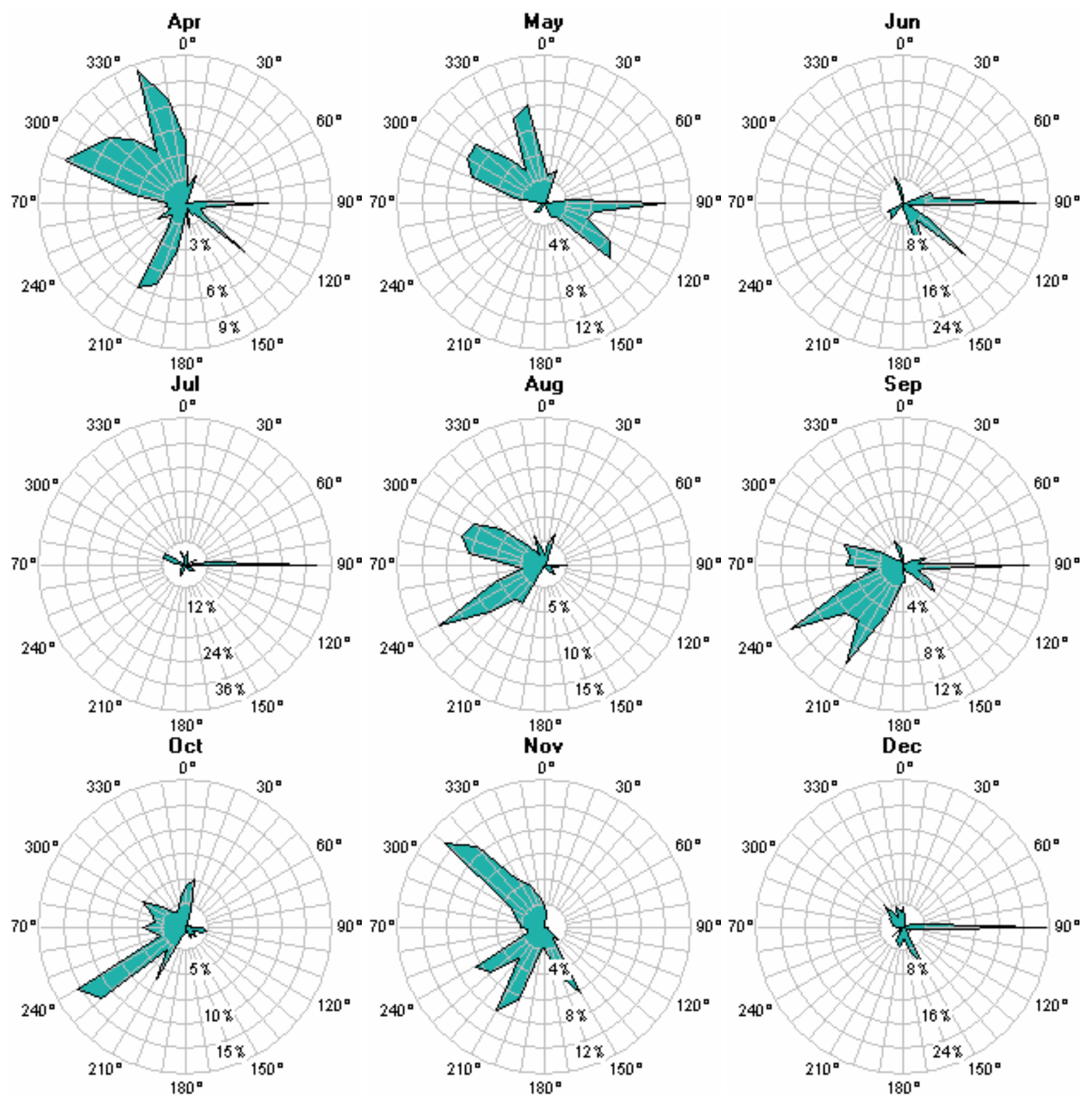




\section{Turbulence Intensity}

The turbulence intensity is marginally acceptable to unacceptable for the most frequent wind directions, with mean turbulence intensity at 30 meters of 0.158 (threshold wind speed is $4 \mathrm{~m} / \mathrm{s}$ ), indicating somewhat turbulent air for wind power development. The high turbulence intensities to the northeast and south are insignificant as winds rarely blow from these sectors, but the relatively high turbulence intensities to the east and west-northwest are more significant as a reasonable percentage of Perryville’s power producing winds blow from these sectors.

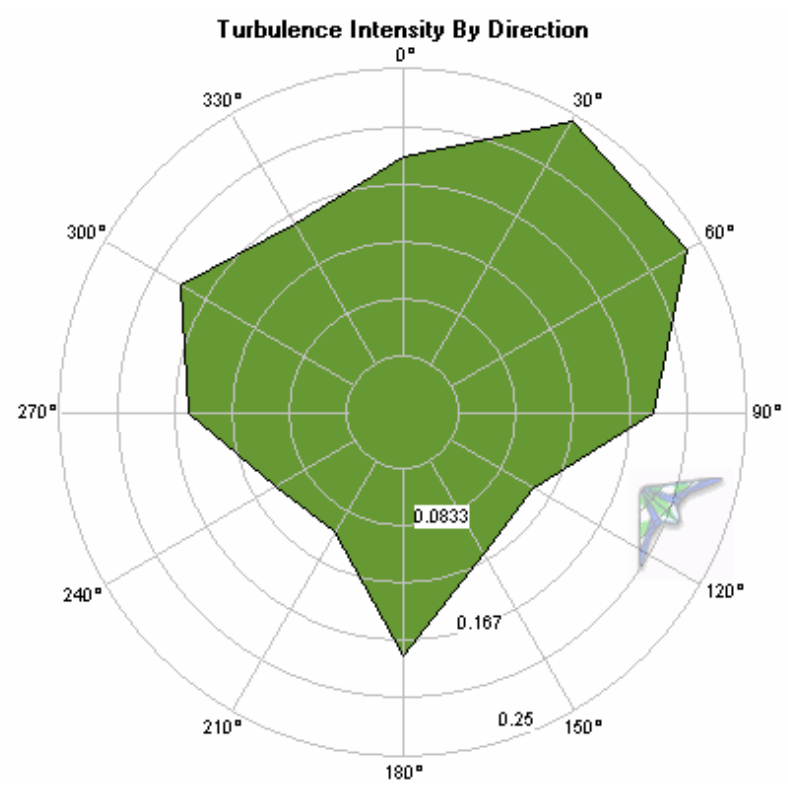

IEC turbulence intensity standards

The turbulence intensities at 30 meters at the Perryville project test site do not meet International Electrotechnical Commission (IEC) standards in southwest to northeast sectors at higher wind speeds. 
Perryville, Alaska Wind Resource Report
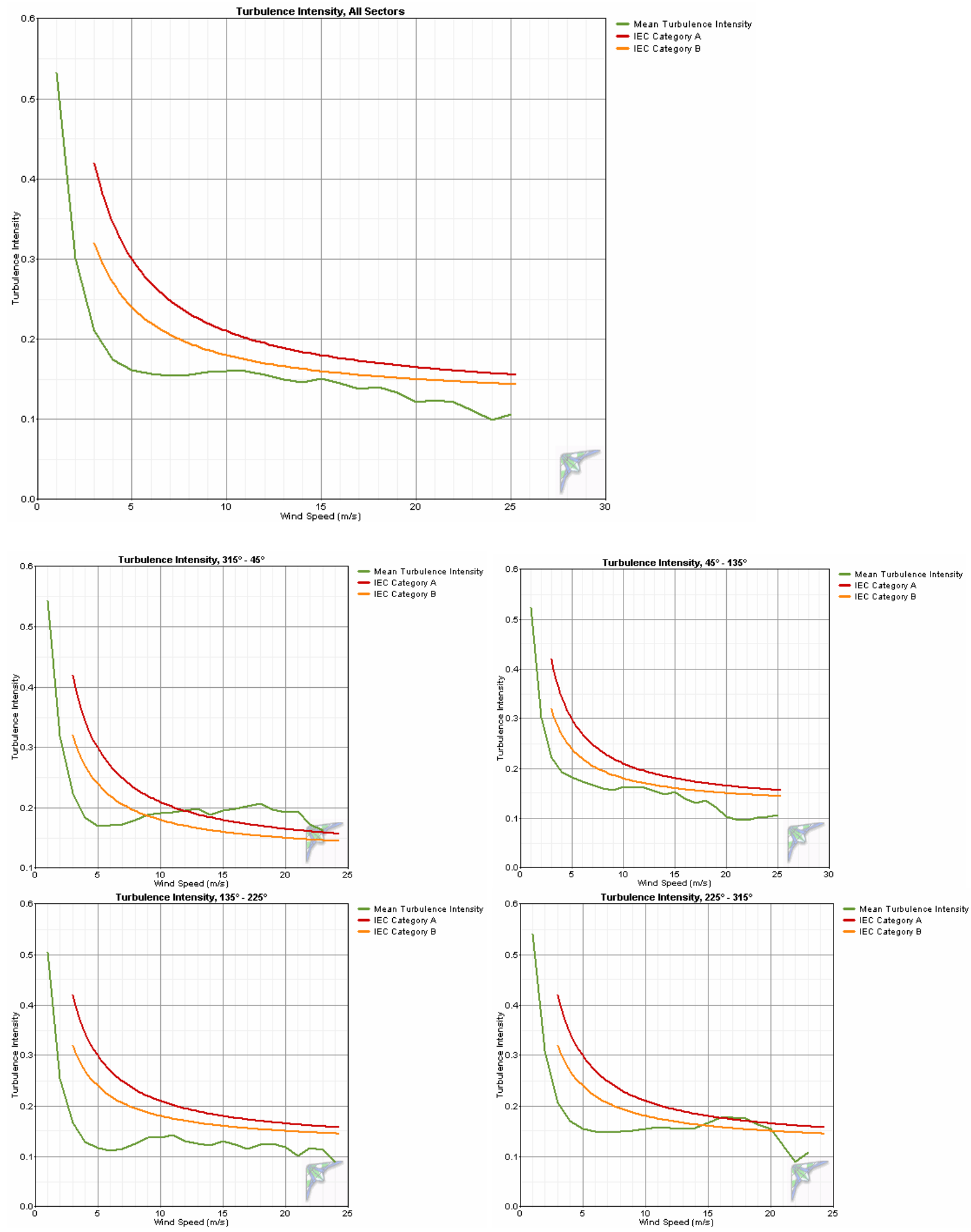
Perryville, Alaska Wind Resource Report

Turbulence Table

\begin{tabular}{cccccccc}
$\begin{array}{c}\text { Bin } \\
\begin{array}{c}\text { Midpoint } \\
(\mathrm{m} / \mathrm{s})\end{array}\end{array}$ & $\begin{array}{c}\text { Bin Endpoints } \\
\text { Lower } \\
(\mathrm{m} / \mathrm{s})\end{array}$ & $\begin{array}{c}\text { Upper } \\
(\mathrm{m} / \mathrm{s})\end{array}$ & $\begin{array}{c}\text { Records } \\
\text { In }\end{array}$ & $\begin{array}{c}\text { Sin } \\
\text { Deviation } \\
\text { of Wind Speed } \\
(\mathrm{m} / \mathrm{s})\end{array}$ & $\begin{array}{c}\text { Mean } \\
\text { Turbulence } \\
\text { Intensity }\end{array}$ & $\begin{array}{c}\text { Standard } \\
\text { Deviation } \\
\text { of Turbulence } \\
\text { Intensity }\end{array}$ & $\begin{array}{c}\text { Characteristic } \\
\text { Turbulence } \\
\text { Intensity }\end{array}$ \\
\hline 1 & 0.5 & 1.5 & 11,379 & 0.473 & 0.533 & 0.168 & 0.700 \\
2 & 1.5 & 2.5 & 11,781 & 0.580 & 0.302 & 0.140 & 0.442 \\
3 & 2.5 & 3.5 & 13,178 & 0.618 & 0.211 & 0.101 & 0.312 \\
4 & 3.5 & 4.5 & 13,025 & 0.686 & 0.175 & 0.083 & 0.258 \\
5 & 4.5 & 5.5 & 11,382 & 0.795 & 0.161 & 0.072 & 0.233 \\
6 & 5.5 & 6.5 & 9,743 & 0.931 & 0.157 & 0.067 & 0.224 \\
7 & 6.5 & 7.5 & 7,630 & 1.071 & 0.154 & 0.064 & 0.218 \\
8 & 7.5 & 8.5 & 5,249 & 1.231 & 0.155 & 0.061 & 0.216 \\
9 & 8.5 & 9.5 & 3,805 & 1.414 & 0.159 & 0.060 & 0.218 \\
10 & 9.5 & 10.5 & 2,695 & 1.591 & 0.161 & 0.059 & 0.219 \\
11 & 10.5 & 11.5 & 1,823 & 1.756 & 0.161 & 0.059 & 0.220 \\
12 & 11.5 & 12.5 & 1,379 & 1.860 & 0.156 & 0.057 & 0.213 \\
13 & 12.5 & 13.5 & 1,011 & 1.941 & 0.150 & 0.053 & 0.203 \\
14 & 13.5 & 14.5 & 737 & 2.031 & 0.146 & 0.050 & 0.196 \\
15 & 14.5 & 15.5 & 505 & 2.257 & 0.151 & 0.047 & 0.198 \\
16 & 15.5 & 16.5 & 313 & 2.300 & 0.145 & 0.046 & 0.191 \\
17 & 16.5 & 17.5 & 224 & 2.341 & 0.138 & 0.046 & 0.184 \\
18 & 17.5 & 18.5 & 153 & 2.514 & 0.140 & 0.044 & 0.185 \\
19 & 18.5 & 19.5 & 75 & 2.507 & 0.133 & 0.037 & 0.169 \\
20 & 19.5 & 20.5 & 44 & 2.409 & 0.121 & 0.037 & 0.158 \\
21 & 20.5 & 21.5 & 18 & 2.589 & 0.124 & 0.044 & 0.168 \\
22 & 21.5 & 22.5 & 16 & 2.669 & 0.122 & 0.037 & 0.159 \\
23 & 22.5 & 23.5 & 12 & 2.550 & 0.111 & 0.020 & 0.131 \\
24 & 23.5 & 24.5 & 4 & 2.375 & 0.100 & 0.012 & 0.112 \\
25 & 24.5 & 25.5 & 1 & 2.600 & 0.106 & 0.000 & 0.106
\end{tabular}


Perryville, Alaska Wind Resource Report

\section{Air Temperature and Density}

Over the reporting period, Perryville had an average temperature of $5.8^{\circ} \mathrm{C}$. The minimum recorded temperature during the measurement period was $-18.1^{\circ} \mathrm{C}$ and the maximum temperature was $26.4^{\circ} \mathrm{C}$, indicating a cool to moderate temperate environment for wind turbine operations. Consequent to Perryville's cool temperatures, the average air density of $1.265 \mathrm{~kg} / \mathrm{m}^{3}$ is 3.2 percent higher than the standard air density of $1.225 \mathrm{~kg} / \mathrm{m}^{3}$ (at $15^{\circ} \mathrm{C}$ ).

\begin{tabular}{|c|c|c|c|c|c|c|c|}
\hline \multirow[b]{2}{*}{ Month } & \multicolumn{4}{|c|}{ Temperature } & \multicolumn{3}{|c|}{ Air Density } \\
\hline & $\begin{array}{l}\text { Mean } \\
\left({ }^{\circ} \mathrm{C}\right)\end{array}$ & $\begin{array}{l}\text { Min } \\
\left({ }^{\circ} \mathrm{C}\right)\end{array}$ & $\begin{array}{l}\operatorname{Max} \\
\left({ }^{\circ} \mathrm{C}\right)\end{array}$ & $\begin{array}{l}\text { Std. } \\
\text { Dev. } \\
\left({ }^{\circ} \mathrm{C}\right)\end{array}$ & $\begin{array}{l}\text { Mean } \\
\left(\mathrm{kg} / \mathrm{m}^{3}\right)\end{array}$ & $\begin{array}{c}\text { Min } \\
\left(\mathrm{kg} / \mathrm{m}^{3}\right)\end{array}$ & $\begin{array}{c}\operatorname{Max} \\
\left(\mathrm{kg} / \mathrm{m}^{3}\right)\end{array}$ \\
\hline Jan & -0.2 & -18.1 & 14.6 & 5.93 & 1.293 & 1.226 & 1.383 \\
\hline Feb & 0.9 & -16.7 & 8.6 & 4.52 & 1.287 & 1.252 & 1.376 \\
\hline Mar & 1.3 & -11.7 & 10.3 & 3.63 & 1.286 & 1.245 & 1.349 \\
\hline Apr & 2.5 & -8.3 & 14.5 & 3.73 & 1.280 & 1.226 & 1.332 \\
\hline May & 7.5 & -3.3 & 26.4 & 3.84 & 1.257 & 1.178 & 1.307 \\
\hline Jun & 10.6 & 2.0 & 26.1 & 3.03 & 1.244 & 1.179 & 1.282 \\
\hline Jul & 12.9 & 4.6 & 21.1 & 2.71 & 1.233 & 1.199 & 1.270 \\
\hline Aug & 13.2 & 4.2 & 22.3 & 2.65 & 1.232 & 1.194 & 1.272 \\
\hline Sep & 10.4 & 0.4 & 18.4 & 2.79 & 1.244 & 1.210 & 1.290 \\
\hline Oct & 6.1 & -4.1 & 13.6 & 3.36 & 1.263 & 1.224 & 1.311 \\
\hline Nov & 1.7 & -11.0 & 9.7 & 4.33 & 1.284 & 1.247 & 1.346 \\
\hline Dec & 2.0 & -8.2 & 9.1 & 3.41 & 1.282 & 1.250 & 1.332 \\
\hline Annual & 5.8 & -18.1 & 26.4 & 6.11 & 1.265 & 1.178 & 1.383 \\
\hline
\end{tabular}

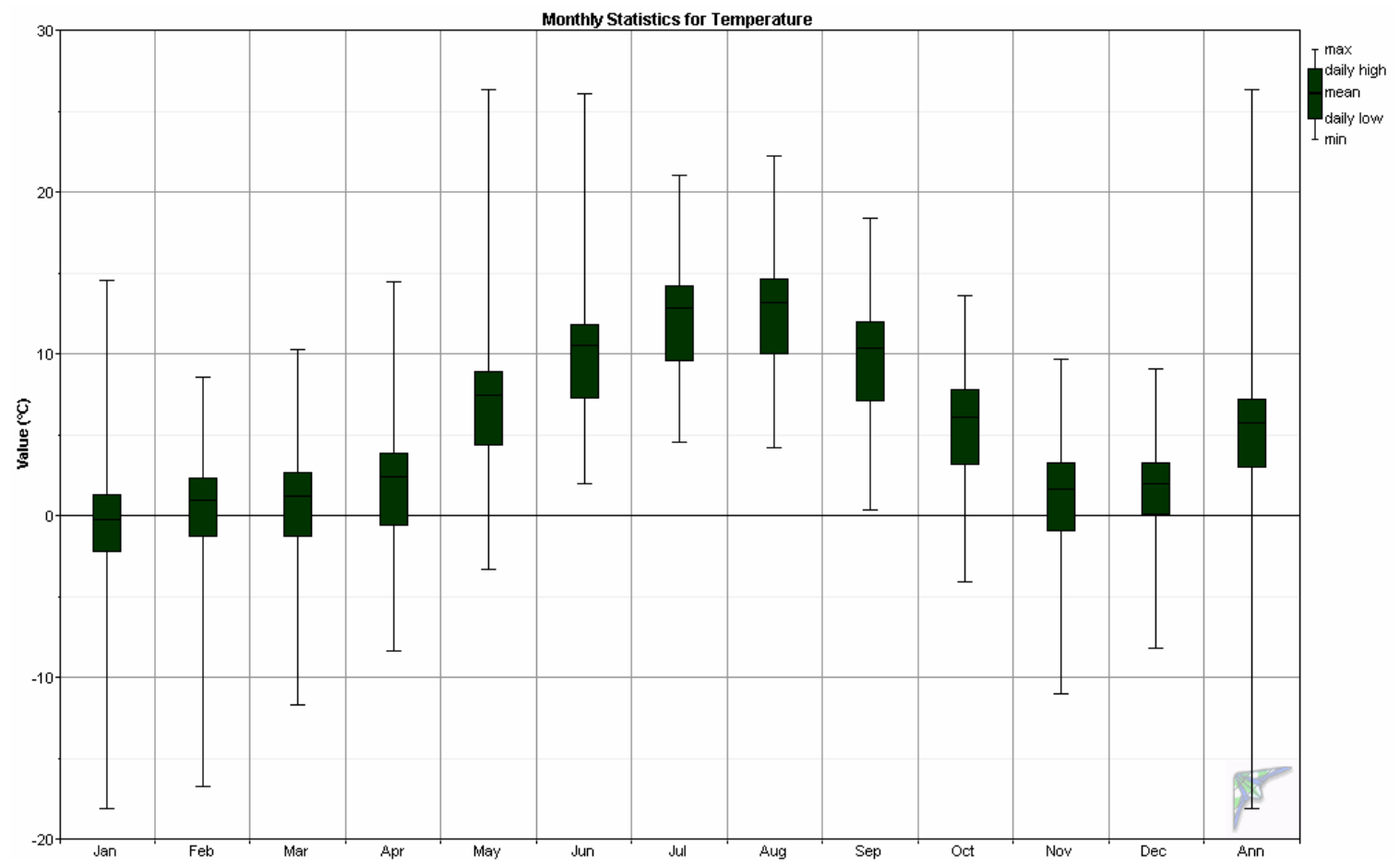




\section{Air Density DMap}

The DMap below is a visual indication of the daily and seasonal variations of air density (and hence temperature). Air densities higher than standard will yield higher turbine power than predicted by the turbine power curve, while densities lower than standard will yield lower turbine power than predicted. Density variance from standard is accounted for in the turbine performance predictions.

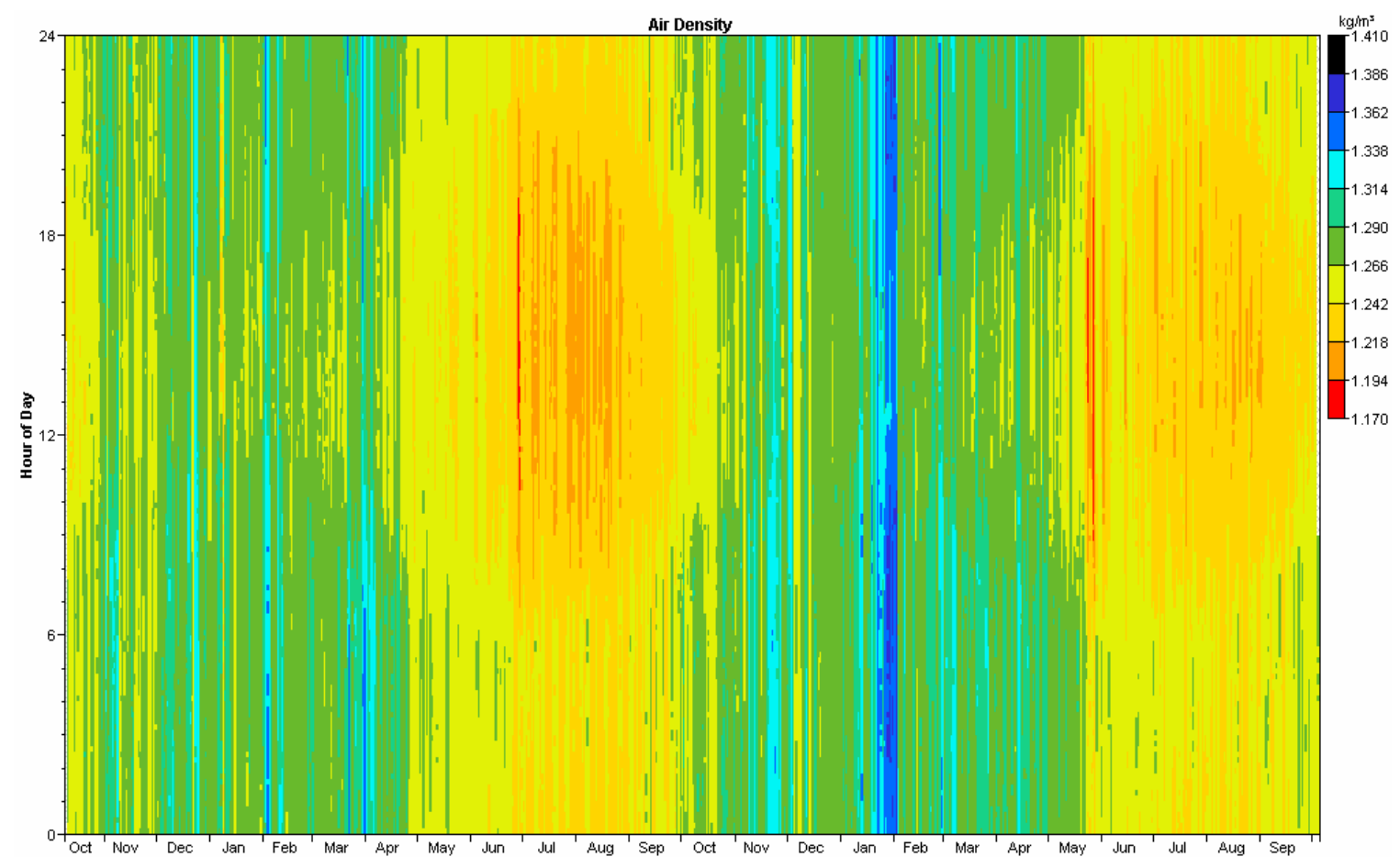




\section{Wind Turbine Performance}

The turbine performance predictions noted below are based on 100 percent and 90 percent turbine availabilities. The 100 percent data is for use as a baseline of comparison, but it is realistic to expect ten percent or more of losses or downtime for wind turbines located in a small, remote community.

Note that these performance estimates were predicted with use of Windographer ${ }^{\circledR}$ wind analysis software; power curves provided by manufacturers are not independently verified and are assumed to be accurate. The power curves are presented for a standard air density of $1.225 \mathrm{~kg} / \mathrm{m}^{3}$ at sea level and $15^{\circ} \mathrm{C}$. However, the predictions of power production are density compensated by multiplying the standard density power output by the ratio of the measured air density to standard air density, accounting for the site elevation.

A number of smaller village-scale grid-connected turbines are profiled in this report for comparison purposes. These turbines were selected because they have market availability and they are deemed to be within a suitable range for consideration of wind power development in a village the size of Perryville.

Southwest Skystream 3.7: $1.8 \mathrm{~kW}$ rated power output, 3.7 meter rotor diameter, stallcontrolled. Available tower heights: 10.7 and 33.5 meters. Additional information is available at www.skystreamenergy.com.

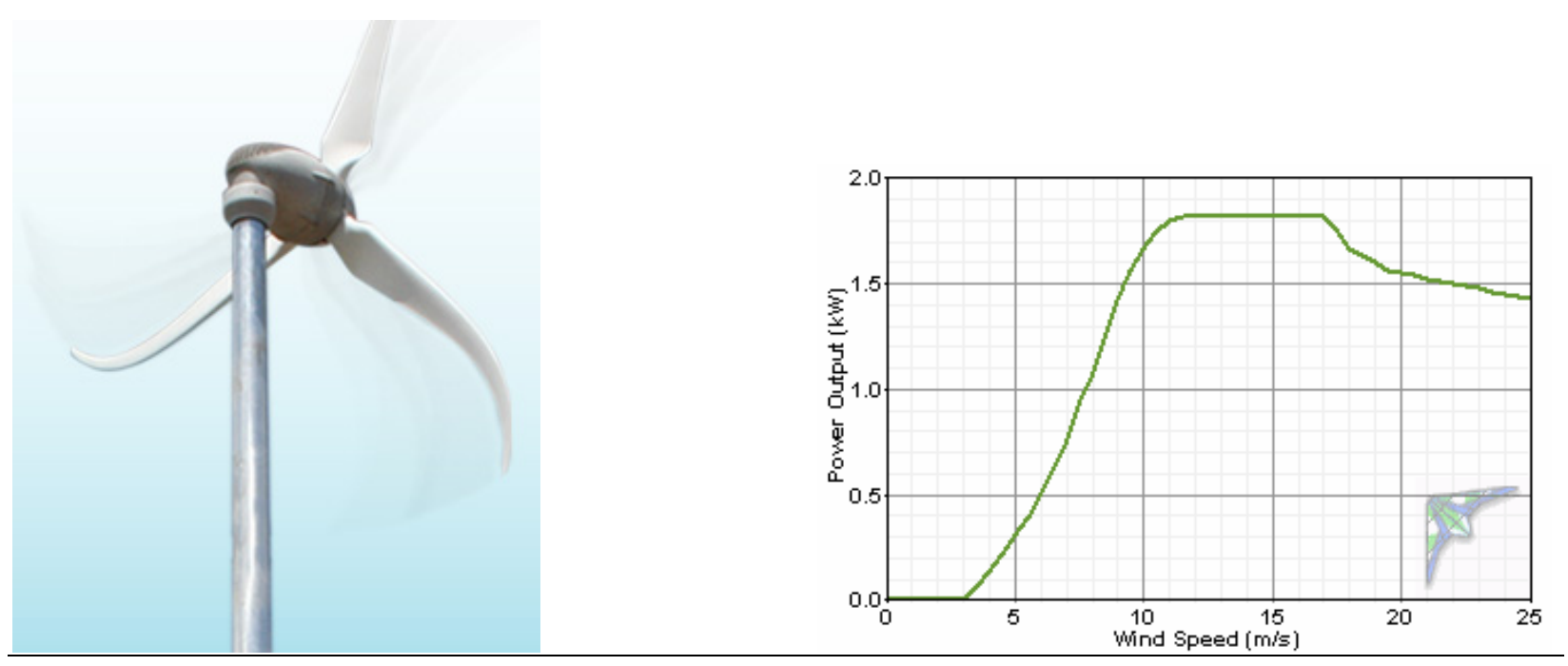

Bergey Excel-S: $10 \mathrm{~kW}$ rated power output, 6.7 meter rotor diameter, stall-controlled. Available tower heights: 18, 24, 30, 37 and 43 meters. Additional information is available at www.bergey.com. 

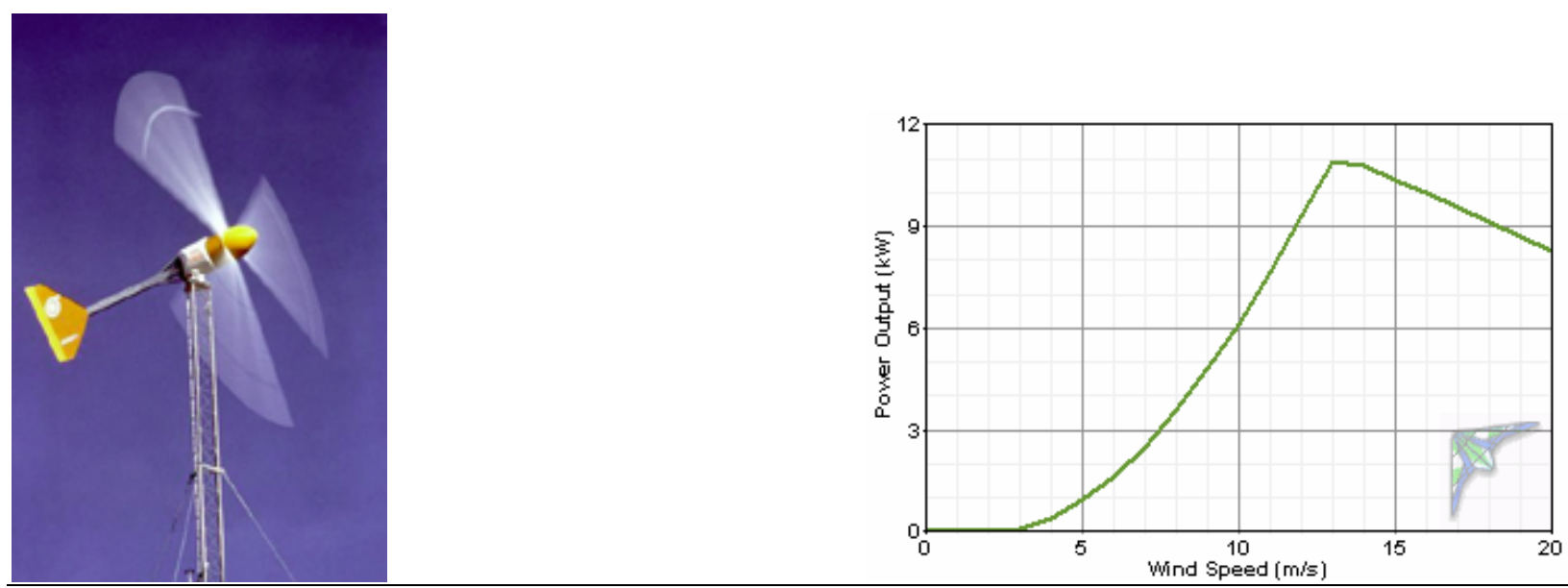

Fuhrländer FL30: $30 \mathrm{~kW}$ rated power output, 13 meter rotor, stall-controlled (power curve provided by Lorax Energy, LLC). Available tower heights: 26 and 30 meters. Additional information is available at http://www.fuhrlaender.de/ and http://www.lorax-energy.com/.
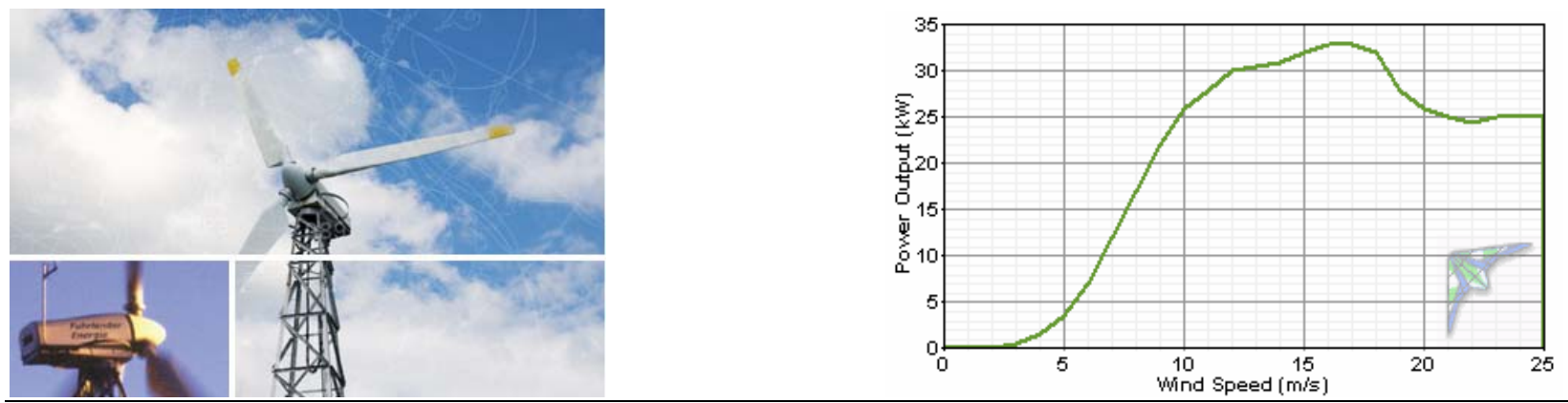

Entegrity eW-15: $65 \mathrm{~kW}$ rated power output, 15 meter rotor, stall-controlled (power curve provided by Entegrity Energy Systems). Available tower heights: 25 and 31 meters. Additional information is available at http://www.entegritywind.com/.
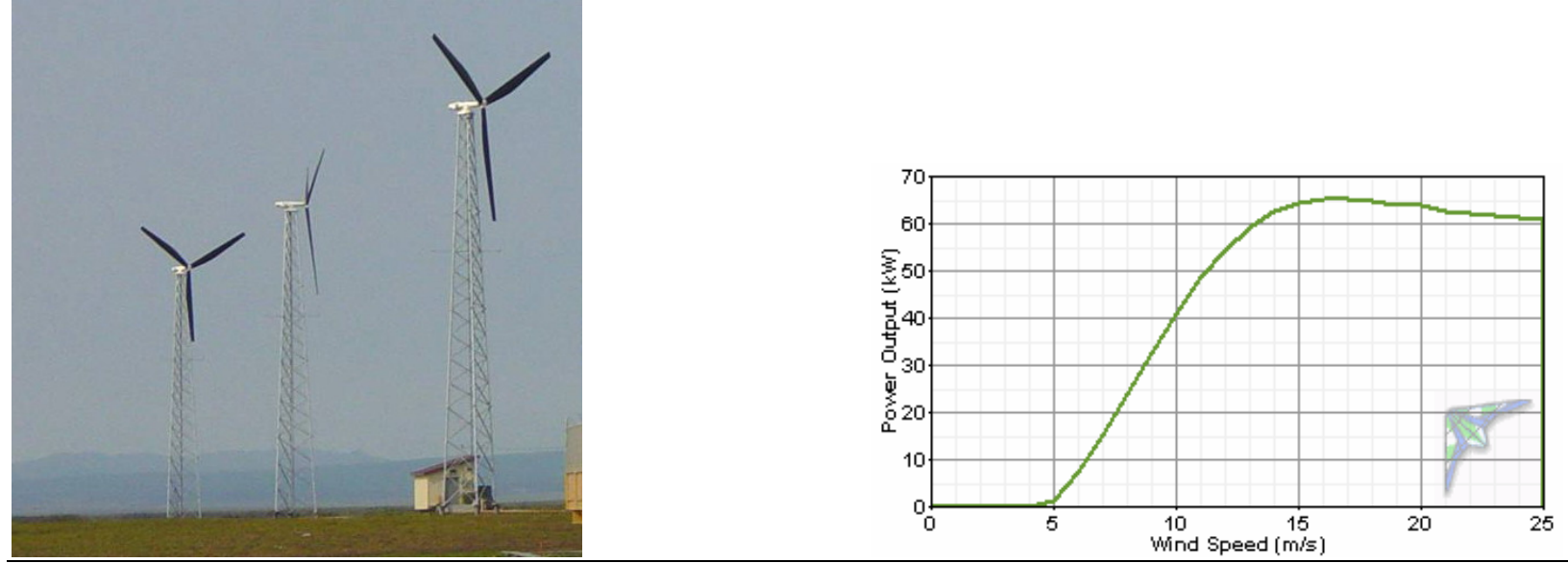
Vestas V15: $75 \mathrm{~kW}$ rated power output, 15 meter rotor, stall-controlled (power curve provided by Powercorp Alaska LLC). Available tower heights: 25, 31 and 34 meters. Additional information is available at http://www.pcorpalaska.com/.
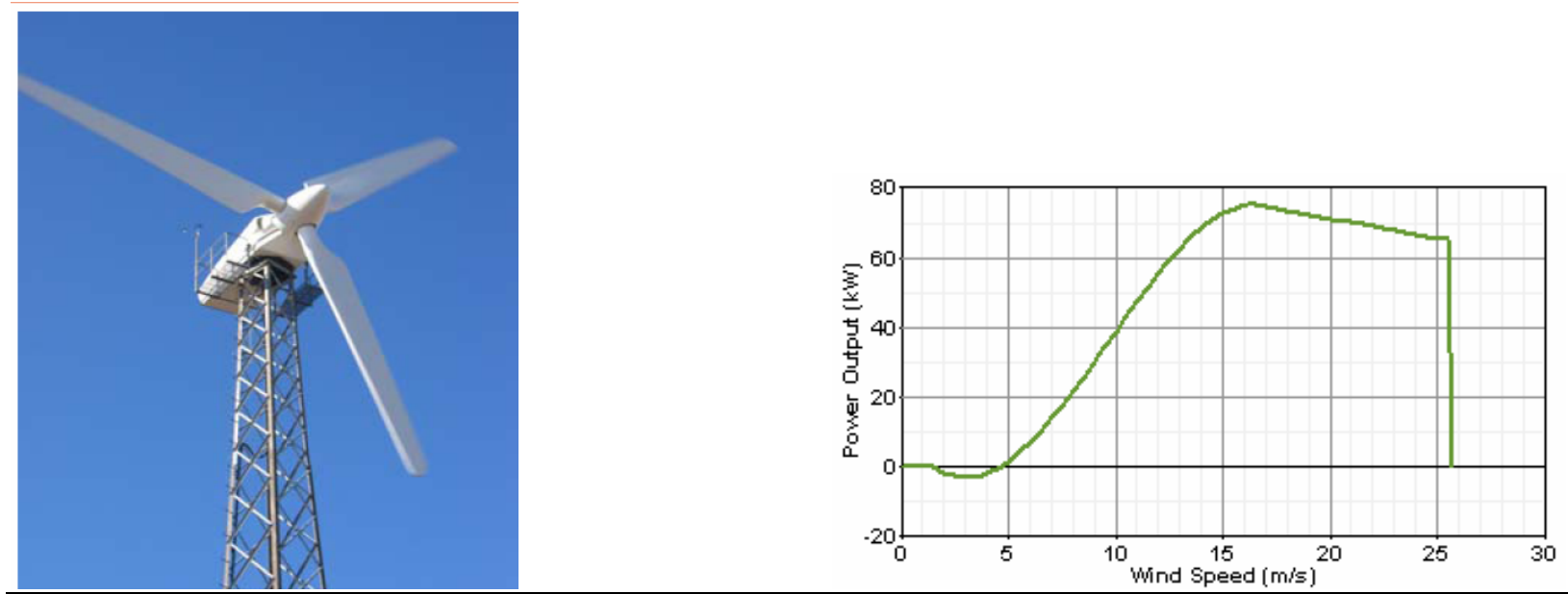

Northwind 100/20: $100 \mathrm{~kW}$ rated power output, 20 meter rotor (19 meter rotor blades with 0.6 meter blade root extensions added), stall-controlled (power curve provided by Northern Power Systems). Available tower heights: 25 and 32 meters. Additional information is available at http://www.northernpower.com/.
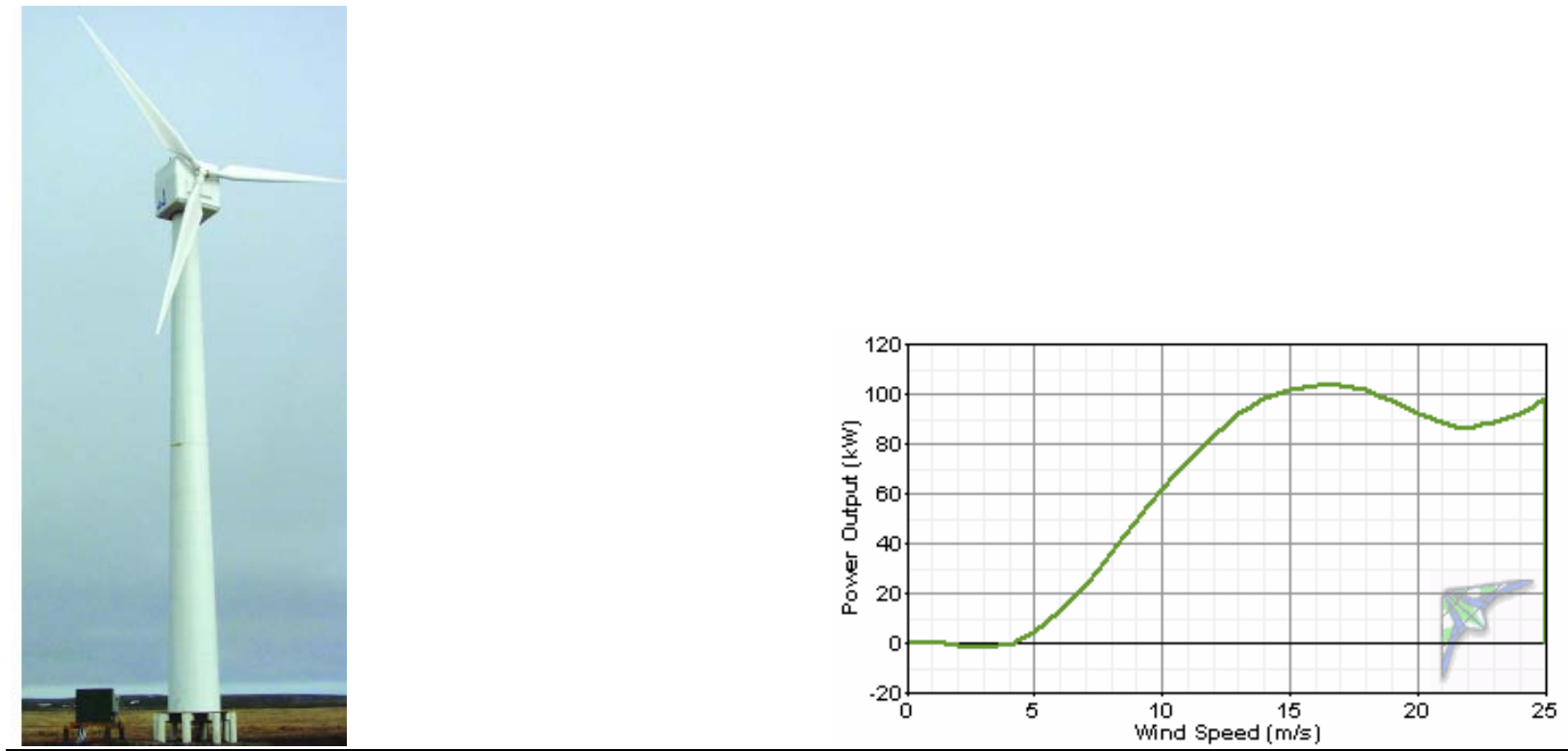
Perryville, Alaska Wind Resource Report

Turbine Power Output Comparison

\begin{tabular}{|c|c|c|c|c|c|c|c|}
\hline Turbine & $\begin{array}{l}\text { Hub } \\
\text { Height } \\
(\mathrm{m})\end{array}$ & $\begin{array}{l}\text { Hub } \\
\text { Height } \\
\text { Wind } \\
\text { Speed } \\
(\mathrm{m} / \mathrm{s})\end{array}$ & $\begin{array}{l}\text { Time At } \\
\text { Zero } \\
\text { Output } \\
(\%)\end{array}$ & $\begin{array}{c}\text { Time At } \\
\text { Rated } \\
\text { Output } \\
(\%)\end{array}$ & $\begin{array}{c}\text { Average Net } \\
\text { Power } \\
\text { Output } \\
(\mathrm{kW})\end{array}$ & $\begin{array}{c}\text { Annual Net } \\
\text { Energy } \\
\text { Output } \\
\text { (kWh/yr) }\end{array}$ & $\begin{array}{c}\text { Average Net } \\
\text { Capacity } \\
\text { Factor } \\
(\%)\end{array}$ \\
\hline Southwest Skystream 3.7 & 10.7 & 3.85 & 46.0 & 3.3 & 0.30 & 2,625 & 16.6 \\
\hline Southwest Skystream 3.7 & 33.5 & 4.68 & 36.2 & 6.1 & 0.44 & 3,847 & 24.4 \\
\hline Bergey Excel-S & 24 & 4.45 & 25.3 & 2.2 & 1.49 & 13,082 & 14.9 \\
\hline Bergey Excel-S & 37 & 4.77 & 23.9 & 2.8 & 1.73 & 15,117 & 17.3 \\
\hline Fuhrländer FL30 & 26 & 4.50 & 25.3 & 0.9 & 6.20 & 54,274 & 18.8 \\
\hline Fuhrländer FL30 & 30 & 4.60 & 25.2 & 1.0 & 6.48 & 56,758 & 19.6 \\
\hline Entegrity eW-15 $60 \mathrm{~Hz}$ & 25 & 4.47 & 51.2 & 1.3 & 8.53 & 74,731 & 13.1 \\
\hline Entegrity eW-15 $60 \mathrm{~Hz}$ & 31 & 4.62 & 49.3 & 1.6 & 9.26 & 81,137 & 14.2 \\
\hline Vestas V15 & 25 & 4.47 & 58.2 & 0.8 & 7.40 & 64,816 & 9.9 \\
\hline Vestas V15 & 34 & 4.70 & 55.2 & 1.1 & 8.57 & 75,036 & 11.4 \\
\hline Northern Power NW 100/20 & 25 & 4.47 & 51.1 & 1.2 & 12.60 & 110,695 & 12.6 \\
\hline Northern Power NW 100/20 & 32 & 4.64 & 48.9 & 1.5 & 13.90 & 121,704 & 13.9 \\
\hline
\end{tabular}

Capacity Factor $<20 \%$

Capacity Factor $>20 \%,<30 \%$

Capacity Factor $>30 \%,<40 \%$

Capacity Factor $>40 \%,<50 \%$

Capacity Factor $>50 \%$

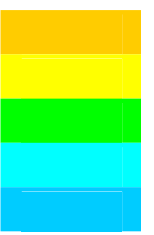

Assumed turbine losses for predictions of average power output, annual energy output, and average capacity factor:

Downtime (\%)

Array (\%)

Icing/soiling (\%)

Other (\%)

Total (\%)

0
0
0
0
0


Perryville, Alaska Wind Resource Report

\begin{tabular}{|c|c|c|c|c|c|c|c|}
\hline Turbine & $\begin{array}{l}\text { Hub } \\
\text { Height } \\
(\mathrm{m})\end{array}$ & $\begin{array}{l}\text { Hub } \\
\text { Height } \\
\text { Wind } \\
\text { Speed } \\
(\mathrm{m} / \mathrm{s})\end{array}$ & $\begin{array}{c}\text { Time At } \\
\text { Zero } \\
\text { Output } \\
(\%) \\
\end{array}$ & $\begin{array}{c}\text { Time At } \\
\text { Rated } \\
\text { Output } \\
(\%) \\
\end{array}$ & $\begin{array}{c}\text { Average Net } \\
\text { Power } \\
\text { Output } \\
(\mathrm{kW})\end{array}$ & $\begin{array}{c}\text { Annual Net } \\
\text { Energy } \\
\text { Output } \\
\text { (kWh/yr) }\end{array}$ & $\begin{array}{c}\text { Average Net } \\
\text { Capacity } \\
\text { Factor } \\
(\%)\end{array}$ \\
\hline Southwest Skystream 3.7 & 10.7 & 3.85 & 46.0 & 3.3 & 0.27 & 2,371 & 15.0 \\
\hline Southwest Skystream 3.7 & 33.5 & 4.68 & 36.2 & 6.1 & 0.40 & 3,474 & 22.0 \\
\hline Bergey Excel-S & 24 & 4.45 & 25.3 & 2.2 & 1.35 & 11,814 & 13.5 \\
\hline Bergey Excel-S & 37 & 4.77 & 23.9 & 2.8 & 1.56 & 13,652 & 15.6 \\
\hline Fuhrländer FL30 & 26 & 4.50 & 25.3 & 0.9 & 5.60 & 49,013 & 17.0 \\
\hline Fuhrländer FL30 & 30 & 4.60 & 25.2 & 1.0 & 5.85 & 51,257 & 17.7 \\
\hline Entegrity eW-15 $60 \mathrm{~Hz}$ & 25 & 4.47 & 51.2 & 1.3 & 7.70 & 67,487 & 11.9 \\
\hline Entegrity eW-15 $60 \mathrm{~Hz}$ & 31 & 4.62 & 49.3 & 1.6 & 8.36 & 73,273 & 12.9 \\
\hline Vestas V15 & 25 & 4.47 & 58.2 & 0.8 & 6.68 & 58,534 & 8.9 \\
\hline Vestas V15 & 34 & 4.70 & 55.2 & 1.1 & 7.74 & 67,763 & 10.3 \\
\hline Northern Power NW 100/20 & 25 & 4.47 & 51.1 & 1.2 & 11.40 & 99,965 & 11.4 \\
\hline Northern Power NW 100/20 & 32 & 4.64 & 48.9 & 1.5 & 12.50 & 109,907 & 12.5 \\
\hline \multicolumn{8}{|l|}{ Capacity Factor $<20 \%$} \\
\hline \multicolumn{8}{|l|}{ Capacity Factor $>20 \%,<30 \%$} \\
\hline \multicolumn{8}{|l|}{ Capacity Factor $>30 \%,<40 \%$} \\
\hline \multicolumn{8}{|l|}{ Capacity Factor $>40 \%,<50 \%$} \\
\hline Capacity Factor $>50 \%$ & & & & & & & \\
\hline
\end{tabular}

Assumed turbine losses for predictions of average power output, annual energy output, and average capacity factor:

Downtime (\%)

Array (\%)

Icing/soiling (\%)

Other (\%)

Total (\%)

$\begin{array}{cl}5 & \\ 0 & \\ 3 & \\ 2 & \\ 9.69 & \text { (factors are multiplicative) }\end{array}$


Perryville, Alaska Wind Resource Report

Annual Fuel Cost Avoided for Energy Generated by Wind Turbine vs. Diesel Generator

\begin{tabular}{|c|c|c|c|c|c|c|c|c|c|c|c|}
\hline \multirow[b]{2}{*}{ Turbine } & \multirow[t]{2}{*}{$\begin{array}{c}\text { Annual } \\
\text { Energy } \\
\text { Output } \\
\text { (kW-hr/yr) }\end{array}$} & \multirow[t]{2}{*}{$\begin{array}{c}\text { Fuel } \\
\text { Quantity } \\
\text { Avoided } \\
\text { (liters) }\end{array}$} & \multirow[t]{2}{*}{$\begin{array}{c}\text { Fuel } \\
\text { Quantity } \\
\text { Avoided } \\
\text { (qallons) }\end{array}$} & \multicolumn{7}{|c|}{ Fuel Price (USD/gallon) } & \multirow[t]{2}{*}{$\begin{array}{c}\text { Turbine } \\
\text { Hub } \\
\text { Height } \\
\text { (m) }\end{array}$} \\
\hline & & & & $\$ 1.75$ & $\$ 2.00$ & $\$ 2.25$ & $\$ 2.50$ & $\$ 2.75$ & $\$ 3.00$ & $\$ 3.25$ & \\
\hline Southwest Skystream 3.7 & 2,371 & 718 & 190 & $\$ 332$ & $\$ 379$ & $\$ 427$ & $\$ 474$ & $\$ 522$ & $\$ 569$ & $\$ 616$ & 10.7 \\
\hline Southwest Skystream 3.7 & 3,474 & 1,052 & 278 & $\$ 486$ & $\$ 556$ & $\$ 625$ & $\$ 695$ & $\$ 764$ & $\$ 834$ & $\$ 903$ & 33.5 \\
\hline Bergey Excel-S & 11,814 & 3,578 & 945 & $\$ 1,654$ & $\$ 1,890$ & $\$ 2,127$ & $\$ 2,363$ & $\$ 2,599$ & $\$ 2,835$ & $\$ 3,072$ & 24 \\
\hline Bergey Excel-S & 13,652 & 4,134 & 1,092 & $\$ 1,911$ & $\$ 2,184$ & $\$ 2,457$ & $\$ 2,730$ & $\$ 3,003$ & $\$ 3,276$ & $\$ 3,550$ & 37 \\
\hline Fuhrländer FL30 & 49,013 & 14,843 & 3,921 & $\$ 6,862$ & $\$ 7,842$ & $\$ 8,822$ & $\$ 9,803$ & $\$ 10,783$ & $\$ 11,763$ & $\$ 12,743$ & 26 \\
\hline Fuhrländer FL30 & 51,257 & 15,522 & 4,101 & $\$ 7,176$ & $\$ 8,201$ & $\$ 9,226$ & $\$ 10,251$ & $\$ 11,277$ & $\$ 12,302$ & $\$ 13,327$ & 30 \\
\hline Entegrity eW-15 $60 \mathrm{~Hz}$ & 67,487 & 20,437 & 5,399 & $\$ 9,448$ & $\$ 10,798$ & $\$ 12,148$ & $\$ 13,497$ & $\$ 14,847$ & $\$ 16,197$ & $\$ 17,547$ & 25 \\
\hline Entegrity eW-15 $60 \mathrm{~Hz}$ & 73,273 & 22,189 & 5,862 & $\$ 10,258$ & $\$ 11,724$ & $\$ 13,189$ & $\$ 14,655$ & $\$ 16,120$ & $\$ 17,586$ & $\$ 19,051$ & 31 \\
\hline Vestas V15 & 58,534 & 17,726 & 4,683 & $\$ 8,195$ & $\$ 9,365$ & $\$ 10,536$ & $\$ 11,707$ & $\$ 12,877$ & $\$ 14,048$ & $\$ 15,219$ & 25 \\
\hline Vestas V15 & 67,763 & 20,521 & 5,421 & $\$ 9,487$ & $\$ 10,842$ & $\$ 12,197$ & $\$ 13,553$ & $\$ 14,908$ & $\$ 16,263$ & $\$ 17,618$ & 34 \\
\hline Northern Power NW 1 & 99,965 & 30,273 & 7,997 & $\$ 13,995$ & $\$ 15,994$ & $\$ 17,994$ & $\$ 19,993$ & $\$ 21,992$ & $\$ 23,992$ & $\$ 25,991$ & 25 \\
\hline Northern Power NW 100/20 & 109,907 & 33,283 & 8,793 & $\$ 15,387$ & $\$ 17,585$ & $\$ 19,783$ & $\$ 21,981$ & $\$ 24,180$ & $\$ 26,378$ & $\$ 28,576$ & 32 \\
\hline
\end{tabular}

Notes:

1. Perryville electrical energy production efficiency assumed to be $12.5 \mathrm{~kW}$-hr/gal

2. Assumes $\mathbf{9 0} \%$ wind turbine availability with no diversion of power to a thermal or other dump load

3. Assumes linear diesel generator fuel efficiency (i.e., 1:1 tradeoff of wind turbine kW-hr to diesel genset kW-hr) 
Perryville, Alaska Wind Resource Report

Temperature Conversion Chart ${ }^{\circ} \mathrm{C}$ to ${ }^{\circ} \mathrm{F}$

\begin{tabular}{|c|c|c|c|c|c|}
\hline${ }^{\circ} \mathrm{C}$ & ${ }^{\circ} \mathrm{F}$ & ${ }^{\circ} \mathrm{C}$ & ${ }^{\circ} \mathrm{F}$ & ${ }^{\circ} \mathrm{C}$ & ${ }^{\circ} \mathrm{F}$ \\
\hline-40 & -40.0 & -10 & 14.0 & 20 & 68.0 \\
\hline-39 & -38.2 & -9 & 15.8 & 21 & 69.8 \\
\hline-38 & -36.4 & -8 & 17.6 & 22 & 71.6 \\
\hline-37 & -34.6 & -7 & 19.4 & 23 & 73.4 \\
\hline-36 & -32.8 & -6 & 21.2 & 24 & 75.2 \\
\hline-35 & -31.0 & -5 & 23.0 & 25 & 77.0 \\
\hline-34 & 29.2 & -4 & 24.8 & 26 & 78.8 \\
\hline-33 & -27.4 & -3 & 26.6 & 27 & 80.6 \\
\hline-32 & -25.6 & -2 & 28.4 & 28 & 82.4 \\
\hline-31 & -23.8 & -1 & 30.2 & 29 & 84.2 \\
\hline-30 & -22.0 & 0 & 32.0 & 30 & 86.0 \\
\hline-29 & -20.2 & 1 & 33.8 & 31 & 87.8 \\
\hline-28 & -18.4 & 2 & 35.6 & 32 & 89.6 \\
\hline-27 & -16.6 & 3 & 37.4 & 33 & 91.4 \\
\hline-26 & -14.8 & 4 & 39.2 & 34 & 93.2 \\
\hline-25 & -13.0 & 5 & 41.0 & 35 & 95.0 \\
\hline-24 & -11.2 & 6 & 42.8 & 36 & 96.8 \\
\hline-23 & -9.4 & 7 & 44.6 & 37 & 98.6 \\
\hline-22 & -7.6 & 8 & 46.4 & 38 & 100.4 \\
\hline-21 & -5.8 & 9 & 48.2 & 39 & 102.2 \\
\hline-20 & -4.0 & 10 & 50.0 & 40 & 104.0 \\
\hline-19 & -2.2 & 11 & 51.8 & 41 & 105.8 \\
\hline-18 & -0.4 & 12 & 53.6 & 42 & 107.6 \\
\hline-17 & 1.4 & 13 & 55.4 & 43 & 109.4 \\
\hline-16 & 3.2 & 14 & 57.2 & 44 & 111.2 \\
\hline-15 & 5.0 & 15 & 59.0 & 45 & 113.0 \\
\hline-14 & 6.8 & 16 & 60.8 & 46 & 114.8 \\
\hline-13 & 8.6 & 17 & 62.6 & 47 & 116.6 \\
\hline-12 & 10.4 & 18 & 64.4 & 48 & 118.4 \\
\hline-11 & 12.2 & 19 & 66.2 & 49 & 120.2 \\
\hline
\end{tabular}


Perryville, Alaska Wind Resource Report

Wind Speed Conversion Chart, $\mathrm{m} / \mathrm{s}$ to $\mathrm{mph}$

\begin{tabular}{|c|c|c|c|c|c|c|c|c|c|}
\hline $\mathbf{m} / \mathbf{s}$ & $\mathbf{m p h}$ & $\mathbf{m} / \mathbf{s}$ & $\mathbf{m p h}$ & $\mathbf{m} / \mathbf{s}$ & $\mathbf{m p h}$ & $\mathbf{m} / \mathbf{s}$ & $\mathbf{m p h}$ & $\mathbf{m} / \mathbf{s}$ & $\mathbf{m p h}$ \\
\hline 0.5 & 1.1 & 10.5 & 23.5 & 20.5 & 45.9 & 30.5 & 68.2 & 40.5 & 90.6 \\
\hline 1.0 & 2.2 & 11.0 & 24.6 & 21.0 & 47.0 & 31.0 & 69.3 & 41.0 & 91.7 \\
\hline 1.5 & 3.4 & 11.5 & 25.7 & 21.5 & 48.1 & 31.5 & 70.5 & 41.5 & 92.8 \\
\hline 2.0 & 4.5 & 12.0 & 26.8 & 22.0 & 49.2 & 32.0 & 71.6 & 42.0 & 93.9 \\
\hline 2.5 & 5.6 & 12.5 & 28.0 & 22.5 & 50.3 & 32.5 & 72.7 & 42.5 & 95.1 \\
\hline 3.0 & 6.7 & 13.0 & 29.1 & 23.0 & 51.4 & 33.0 & 73.8 & 43.0 & 96.2 \\
\hline 3.5 & 7.8 & 13.5 & 30.2 & 23.5 & 52.6 & 33.5 & 74.9 & 43.5 & 97.3 \\
\hline 4.0 & 8.9 & 14.0 & 31.3 & 24.0 & 53.7 & 34.0 & 76.1 & 44.0 & 98.4 \\
\hline 4.5 & 10.1 & 14.5 & 32.4 & 24.5 & 54.8 & 34.5 & 77.2 & 44.5 & 99.5 \\
\hline 5.0 & 11.2 & 15.0 & 33.6 & 25.0 & 55.9 & 35.0 & 78.3 & 45.0 & 100.7 \\
\hline 5.5 & 12.3 & 15.5 & 34.7 & 25.5 & 57.0 & 35.5 & 79.4 & 45.5 & 101.8 \\
\hline 6.0 & 13.4 & 16.0 & 35.8 & 26.0 & 58.2 & 36.0 & 80.5 & 46.0 & 102.9 \\
\hline 6.5 & 14.5 & 16.5 & 36.9 & 26.5 & 59.3 & 36.5 & 81.6 & 46.5 & 104.0 \\
\hline 7.0 & 15.7 & 17.0 & 38.0 & 27.0 & 60.4 & 37.0 & 82.8 & 47.0 & 105.1 \\
\hline 7.5 & 16.8 & 17.5 & 39.1 & 27.5 & 61.5 & 37.5 & 83.9 & 47.5 & 106.3 \\
\hline 8.0 & 17.9 & 18.0 & 40.3 & 28.0 & 62.6 & 38.0 & 85.0 & 48.0 & 107.4 \\
\hline 8.5 & 19.0 & 18.5 & 41.4 & 28.5 & 63.8 & 38.5 & 86.1 & 48.5 & 108.5 \\
\hline 9.0 & 20.1 & 19.0 & 42.5 & 29.0 & 64.9 & 39.0 & 87.2 & 49.0 & 109.6 \\
\hline 9.5 & 21.3 & 19.5 & 43.6 & 29.5 & 66.0 & 39.5 & 88.4 & 49.5 & 110.7 \\
\hline 10.0 & 22.4 & 20.0 & 44.7 & 30.0 & 67.1 & 40.0 & 89.5 & 50.0 & 111.8 \\
\hline
\end{tabular}

Distance Conversion $\mathrm{m}$ to $\mathrm{ft}$

\begin{tabular}{|c|c|c|c|}
\hline $\mathbf{m}$ & $\mathbf{f t}$ & $\mathbf{m}$ & $\mathbf{f t}$ \\
\hline 5 & 16 & 35 & 115 \\
\hline 10 & 33 & 40 & 131 \\
\hline 15 & 49 & 45 & 148 \\
\hline 20 & 66 & 50 & 164 \\
\hline 25 & 82 & 55 & 180 \\
\hline 30 & 98 & 60 & 197 \\
\hline
\end{tabular}


Selected definitions (courtesy of Windographer ${ }^{\circledR}$ software by Mistaya Engineering Inc.)

\section{Wind Power Class}

The wind power class is a number indicating the average energy content of the wind resource. Wind power classes are based on the average wind power density at 50 meters above ground, according to the following table. Source: Wind Energy Resource Atlas of the United States (http://rredc.nrel.gov/wind/pubs/atlas/tables/A-8T.html)

\begin{tabular}{|c|l|c|}
\hline \multicolumn{2}{|c|}{} & \multicolumn{2}{|c|}{} \\
\hline Wind Power Class & Description & Power Density at 50m (W/. $\mathbf{2})$ \\
\hline 1 & Poor & $0-200$ \\
\hline 2 & Marginal & $200-300$ \\
\hline 3 & Fair & $300-400$ \\
\hline 4 & Good & $400-500$ \\
\hline 5 & Excellent & $500-600$ \\
\hline 6 & Outstanding & $600-800$ \\
\hline 7 & Superb & $800-2000$ \\
\hline
\end{tabular}

Windographer classifies any wind resource with an average wind power density above 2000 $\mathrm{W} / \mathrm{m}^{2}$ as class 8 .

\section{Probability Distribution Function}

The probability distribution function $\mathrm{f}(\mathrm{x})$ gives the probability that a variable will take on the value $\mathrm{x}$. It is often expressed using a frequency histogram, which gives the frequency with which the variable falls within certain ranges or bins.

\section{Wind Turbine Power Regulation}

All wind turbines employ some method of limiting power output at high wind speeds to avoid damage to mechanical or electrical subsystems. Most wind turbines employ either stall control or pitch control to regulate power output.

A stall-controlled turbine typically has blades that are fixed in place, and are designed to experience aerodynamic stall at very high wind speeds. Aerodynamic stall dramatically reduces the torque produced by the blades, and therefore the power produced by the turbine.

On a pitch-controlled turbine, a controller adjusts the angle (pitch) of the blades to best match the wind speed. At very high wind speeds the controller increasingly feathers the blades out of the wind to limit the power output. 


\section{Togiak, Alaska Wind Resource Report}

Report written by: Douglas Vaught, P.E., V3 Energy, LLC, Eagle River, AK

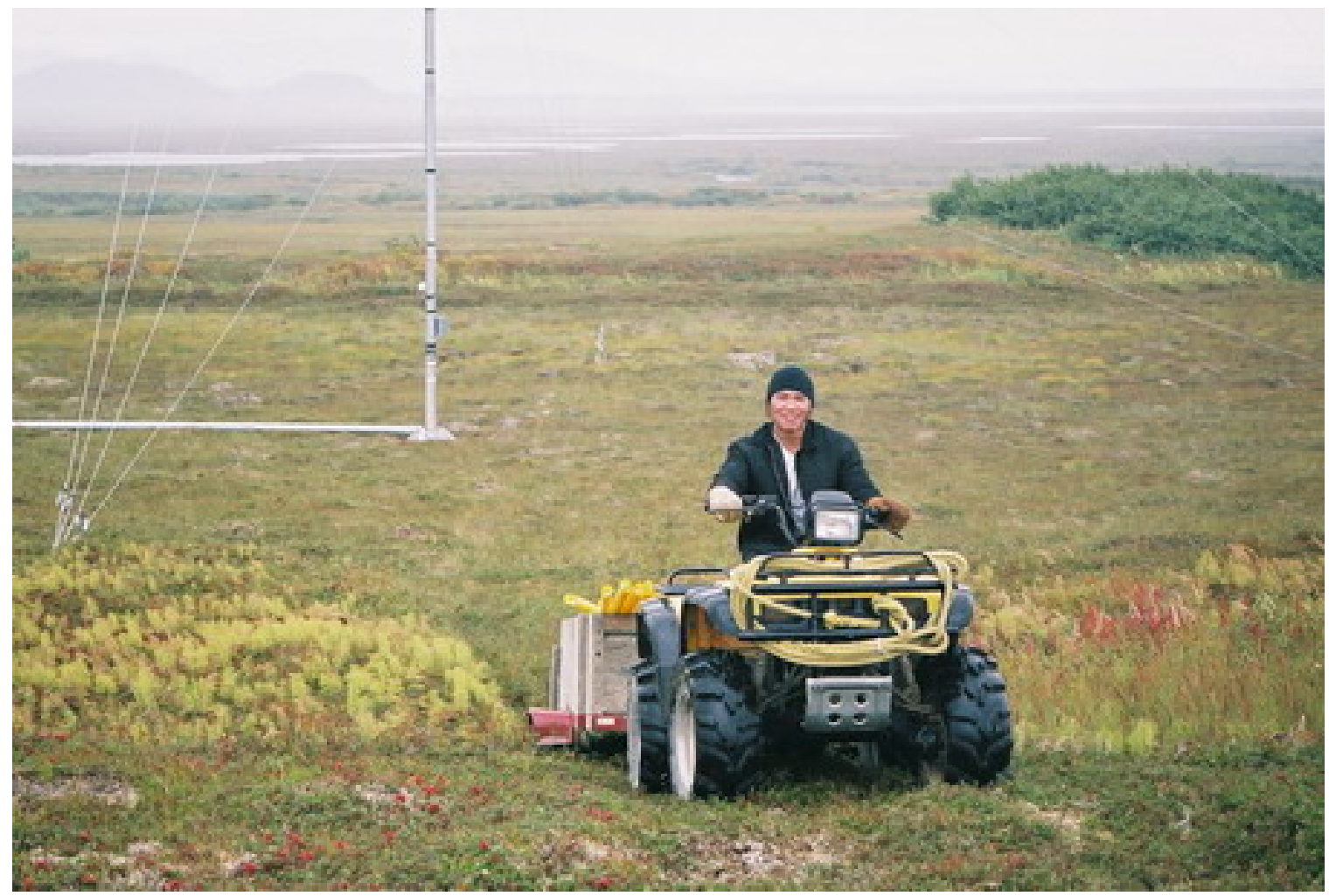

Photo by Doug Vaught

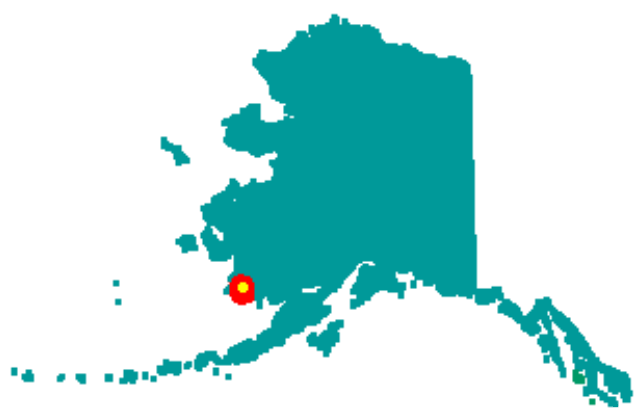

\section{Summary Information}

Togiak's winds are possibly lighter than expected given its geographic location on the Bering Sea coast. This may be due to the site location well down on the northeast side of the hill that comprises the Togiak Heights subdivision. Possibly more exposed locations would experience higher wind speeds. 


\section{Meteorological Tower Data Synopsis}

Wind power class

Wind speed annual average (30 meters)

Maximum wind gust (2 sec avg)

Mean wind power density (50 meters)

Mean wind power density (30 meters)

Weibull distribution parameters

Roughness Class

Power law exponent

Turbulence Intensity

Data start date

Data end date
Class 3 - Fair

$5.68 \mathrm{~m} / \mathrm{s}$

$32.9 \mathrm{~m} / \mathrm{s}$ (April 2005)

$311 \mathrm{~W} / \mathrm{m}^{2}$ (calculated)

$256 \mathrm{~W} / \mathrm{m}^{2}$ (measured)

$\mathrm{k}=1.75, \mathrm{c}=6.40 \mathrm{~m} / \mathrm{s}$

1.11 (fallow field)

0.151 (moderate wind shear)

0.104

September 11, 2004

July 12, 2006

\section{Community Profile}

Current Population: 779 (2005 State Demographer est.)

Pronunciation/Other Names: (TOAG-ee-ack)

Incorporation Type: 2nd Class City

Borough Located In: Unorganized

School District: Southwest Region Schools

Regional Native Corporation: Bristol Bay Native Corporation

\section{Location:}

Togiak is located at the head of Togiak Bay, 67 miles west of Dillingham. It lies in Togiak National Wildlife Refuge, and is the gateway to Walrus Island Game Sanctuary. It lies at approximately $59.061940^{\circ}$ North Latitude and $-160.376390^{\circ}$ West Longitude. (Sec. 12, T013S, R067W, Seward Meridian.) Togiak is located in the Bristol Bay Recording District. The area encompasses 45.2 sq. miles of land and 183.3 sq. miles of water.

\section{History:}

In 1880, "Old Togiak," or "Togiagamute," was located across the Bay, and had a population of 276. Heavy winter snowfalls made wood-gathering difficult at Old Togiak, so gradually people settled at a new site on the opposite shore, where the task was easier. Many residents of the Yukon-Kuskokwim region migrated south to the Togiak area after the devastating influenza epidemic in 1918-19. A school was established in an old church in 1950. A school building and a National Guard Armory were constructed in 1959. Togiak was flooded in 1964, and many fish racks and stores of gas, fuel oil and stove oil were destroyed. Three or four households left Togiak after the flood and developed the village of Twin Hills upriver. The City government was incorporated in 1969.

\section{Culture:}

Togiak is a traditional Yup'ik Eskimo village with a fishing and subsistence lifestyle. The sale, importation or possession of alcohol is banned in the village.

\section{Economy:}

Togiak's economic base is primarily commercial salmon, herring, and herring roe-on-kelp fisheries. Two hundred forty-four residents hold commercial fishing permits; fishermen use flat-bottom boats for the shallow waters of Togiak Bay. There is one on-shore fish processor and several floating processing facilities near Togiak. The entire community depends heavily on subsistence activities. Salmon, herring, 
seal, sea lion, whale and walrus are among the species harvested. A few residents trap.

\section{Facilities:}

Water is derived from a well, is treated and stored in a 500,000-gal. tank. The majority of households (125 residences) are connected to the piped water and sewer system installed in 1976; the remaining homes have new individual wells and septic tanks. Thirty-five new HUD housing units were recently completed in the Togiak Heights Subdivision, with a sewage system. In all, 210 homes are fully plumbed, and 14 are not. The water system is 25 to 30 years old and suffers from broken or corroded pipes, valves and service connections. A new landfill was recently completed.

\section{Transportation:}

A State-owned 4,400' long by $98^{\prime}$ wide lighted gravel airstrip with a 1,200' long by 49' wide crosswind airstrip and navigation aids is available. Scheduled and chartered flights are available from Dillingham. Freight is brought in by air or barge and lightered to shore. There are no docking facilities. Skiffs, autos, ATVs and snowmachines are used for local transportation.

\section{Climate:}

Togiak is located in a climatic transition zone, however the arctic climate also affects this region. Average summer temperatures range from 37 to 66; winter temperatures average 4 to 30 . Precipitation is 20 to 26 inches annually. Fog and high winds are prevalent during the winter. The Bay is ice-free from June through mid-November.

(Above information from State of Alaska Department of Commerce, Community, and Economic Development website, http://www.dced.state.ak.us/)

\section{Tower Sensor Information}

\begin{tabular}{clcrcc} 
Channel & Sensor type & Height & Multiplier & Offset & Orientation \\
\hline 1 & NRG \#40 anemometer & $30 \mathrm{~m}$ & 0.765 & 0.35 & west \\
2 & NRG \#40 anemometer & $22 \mathrm{~m}$ & 0.765 & 0.35 & northeast \\
7 & NRG \#200P wind vane & $30 \mathrm{~m}$ & 0.351 & 280 & east \\
9 & NRG \#110S Temp C & $2 \mathrm{~m}$ & 0.136 & -86.383 & N/A
\end{tabular}

Site Information and Location

Site number

Site Description

Latitude/longitude

Site elevation

Datalogger type

Tower type
0010

Open tundra, northeast side of Togiak Heights subdivision N 59 04.278'; W $160^{\circ} 25.386^{\prime}$

20 meters

NRG Symphonie

NRG 30-meter tall tower, 152 mm (6-in) diameter 
Togiak, Alaska Wind Resource Report

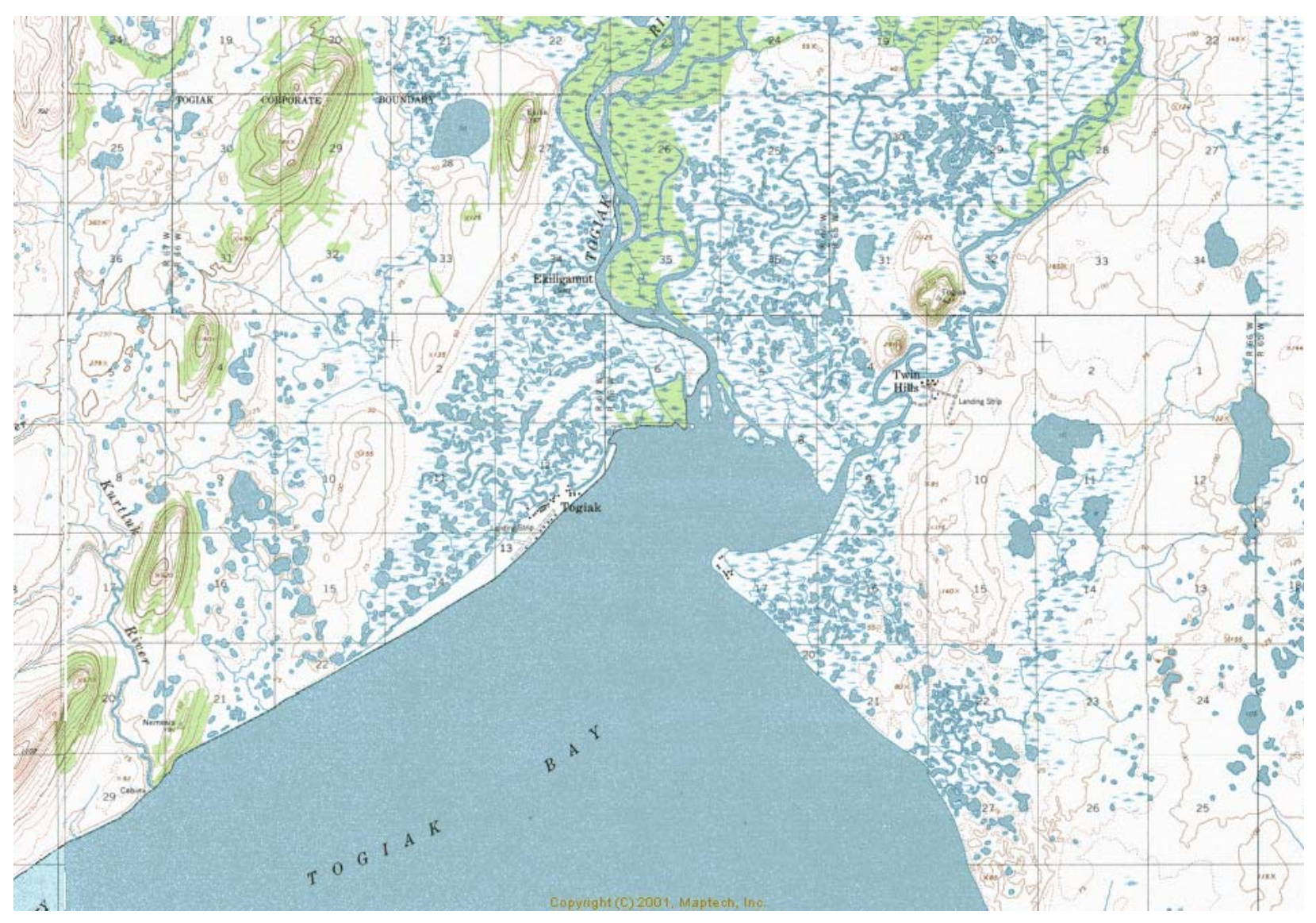


Togiak, Alaska Wind Resource Report

\section{Data Quality Control}

Data was filtered to remove presumed icing events that yield false zero wind speed data. Data that met the following criteria were filtered: wind speed $<1 \mathrm{~m} / \mathrm{s}$, wind speed standard deviation $=0$, and temperature $<2^{\circ} \mathrm{C}$. Note that during the months of March through September little to no data was lost due to icing with some icing loss during the winter months. Because sensor icing was minimal, filtered data was not synthesized and replaced.

\begin{tabular}{|c|c|c|c|c|c|c|c|c|c|}
\hline \multirow[b]{2}{*}{ Year } & \multirow[b]{2}{*}{ Month } & \multicolumn{2}{|c|}{ Ch 1 (30 m speed) } & \multicolumn{2}{|c|}{ Ch 2 (22 m speed) } & \multicolumn{2}{|c|}{ Ch 7 (wind vane) } & \multicolumn{2}{|c|}{ Ch 9 (temperature) } \\
\hline & & Records & $\begin{array}{l}\text { Recovery } \\
\text { Rate (\%) }\end{array}$ & Records & $\begin{array}{l}\text { Recovery } \\
\text { Rate (\%) }\end{array}$ & Records & $\begin{array}{l}\text { Recovery } \\
\text { Rate (\%) }\end{array}$ & Records & $\begin{array}{l}\text { Recovery } \\
\text { Rate (\%) }\end{array}$ \\
\hline 2004 & Sep & 2,820 & 100 & 2,820 & 100 & 2,820 & 100 & 2,820 & 100 \\
\hline 2004 & Oct & 4,464 & 100 & 4,464 & 100 & 4,464 & 100 & 4,464 & 100 \\
\hline 2004 & Nov & 4,182 & 96.8 & 4,182 & 96.8 & 4,227 & 97.8 & 4,320 & 100 \\
\hline 2004 & Dec & 4,266 & 95.6 & 4,182 & 93.7 & 2,802 & 62.8 & 4,464 & 100 \\
\hline 2005 & Jan & 4,210 & 94.3 & 4,233 & 94.8 & 4,002 & 89.7 & 4,464 & 100 \\
\hline 2005 & Feb & 3,910 & 97.0 & 3,910 & 97.0 & 3,846 & 95.4 & 4,032 & 100 \\
\hline 2005 & Mar & 4,446 & 100 & 4,446 & 100 & 4,345 & 97.3 & 4,446 & 100 \\
\hline 2005 & Apr & 4,320 & 100 & 4,320 & 100 & 4,320 & 100 & 4,320 & 100 \\
\hline 2005 & May & 4,464 & 100 & 4,464 & 100 & 4,464 & 100 & 4,464 & 100 \\
\hline 2005 & Jun & 4,320 & 100 & 4,320 & 100 & 4,320 & 100 & 4,320 & 100 \\
\hline 2005 & Jul & 4,464 & 100 & 4,464 & 100 & 4,464 & 100 & 4,464 & 100 \\
\hline 2005 & Aug & 4,464 & 100 & 4,464 & 100 & 4,464 & 100 & 4,464 & 100 \\
\hline 2005 & Sep & 4,320 & 100 & 4,320 & 100 & 4,320 & 100 & 4,320 & 100 \\
\hline 2005 & Oct & 4,382 & 98.2 & 4,464 & 100 & 4,317 & 96.7 & 4,464 & 100 \\
\hline 2005 & Nov & 4,320 & 100 & 4,320 & 100 & 4,320 & 100 & 4,320 & 100 \\
\hline 2005 & Dec & 4,101 & 91.9 & 3,774 & 84.5 & 3,659 & 82.0 & 4,464 & 100 \\
\hline 2006 & Jan & 4,405 & 98.7 & 4,405 & 98.7 & 4,464 & 100 & 4,464 & 100 \\
\hline 2006 & Feb & 3,932 & 97.5 & 3,932 & 97.5 & 4,032 & 100 & 4,032 & 100 \\
\hline 2006 & Mar & 4,382 & 98.2 & 4,464 & 100 & 4,417 & 98.9 & 4,464 & 100 \\
\hline 2006 & Apr & 4,320 & 100 & 4,320 & 100 & 4,320 & 100 & 4,320 & 100 \\
\hline 2006 & May & 4,464 & 100 & 4,464 & 100 & 4,464 & 100 & 4,464 & 100 \\
\hline 2006 & Jun & 4,320 & 100 & 4,320 & 100 & 4,320 & 100 & 4,320 & 100 \\
\hline 2006 & Jul & 1,638 & 100 & 1,638 & 100 & 1,638 & 100 & 1,638 & 100 \\
\hline $\begin{array}{l}\text { All } \\
\text { data }\end{array}$ & & 94,914 & 98.5 & 94,690 & 98.3 & 92,809 & 96.3 & 96,312 & 100 \\
\hline
\end{tabular}


Togiak, Alaska Wind Resource Report

\section{Measured Wind Speeds}

The 30 meter anemometer annual wind speed average for the reporting period is $5.68 \mathrm{~m} / \mathrm{s}$ and the 22 meter anemometer wind speed average is $5.42 \mathrm{~m} / \mathrm{s}$.

\begin{tabular}{ccccccccc} 
& \multicolumn{9}{c}{$30 \mathrm{~m}$ speed (Ch 1) } & \multicolumn{3}{c}{$22 \mathrm{~m}$ speed (Ch 2) } \\
Month & $\begin{array}{c}\text { Mean } \\
(\mathrm{m} / \mathrm{s})\end{array}$ & $\begin{array}{c}\text { Max } \\
(\mathrm{m} / \mathrm{s})\end{array}$ & $\begin{array}{c}\text { Wev. } \\
\text { Dev/s) }\end{array}$ & Weibull k & $\begin{array}{c}\text { Weibull } \\
\mathrm{C} / \mathrm{s})\end{array}$ & $\begin{array}{c}\text { Mean } \\
(\mathrm{m} / \mathrm{s})\end{array}$ & $\begin{array}{c}\text { Max } \\
(\mathrm{m} / \mathrm{s})\end{array}$ & $\begin{array}{c}\text { Std. } \\
\text { Dev. } \\
(\mathrm{m} / \mathrm{s})\end{array}$ \\
\hline Jan & 5.39 & 16.9 & 2.77 & 2.003 & 6.07 & 5.02 & 16.2 & 2.68 \\
Feb & 7.21 & 26.1 & 4.34 & 1.697 & 8.06 & 6.95 & 25.3 & 4.45 \\
Mar & 6.41 & 20.8 & 3.63 & 1.792 & 7.18 & 6.16 & 19.2 & 3.49 \\
Apr & 6.18 & 25.8 & 3.70 & 1.651 & 6.86 & 5.99 & 24.8 & 3.59 \\
May & 5.16 & 17.5 & 2.79 & 1.873 & 5.78 & 5.01 & 17.4 & 2.74 \\
Jun & 4.80 & 17.0 & 2.70 & 1.799 & 5.37 & 4.62 & 16.4 & 2.62 \\
Jul & 4.65 & 12.7 & 2.47 & 1.880 & 5.20 & 4.49 & 12.3 & 2.37 \\
Aug & 4.99 & 19.4 & 2.92 & 1.718 & 5.58 & 4.86 & 18.4 & 2.69 \\
Sep & 6.05 & 16.3 & 3.08 & 2.017 & 6.80 & 5.63 & 15.5 & 2.97 \\
Oct & 5.48 & 19.5 & 3.36 & 1.652 & 6.12 & 5.09 & 18.8 & 3.16 \\
Nov & 5.67 & 18.9 & 3.50 & 1.604 & 6.30 & 5.35 & 18.7 & 3.43 \\
Dec & 6.28 & 19.2 & 3.07 & 2.115 & 7.06 & 5.87 & 18.5 & 3.00 \\
\hline Annual & 5.68 & 26.1 & 3.33 & 1.745 & 6.41 & 5.42 & 25.3 & 3.25
\end{tabular}

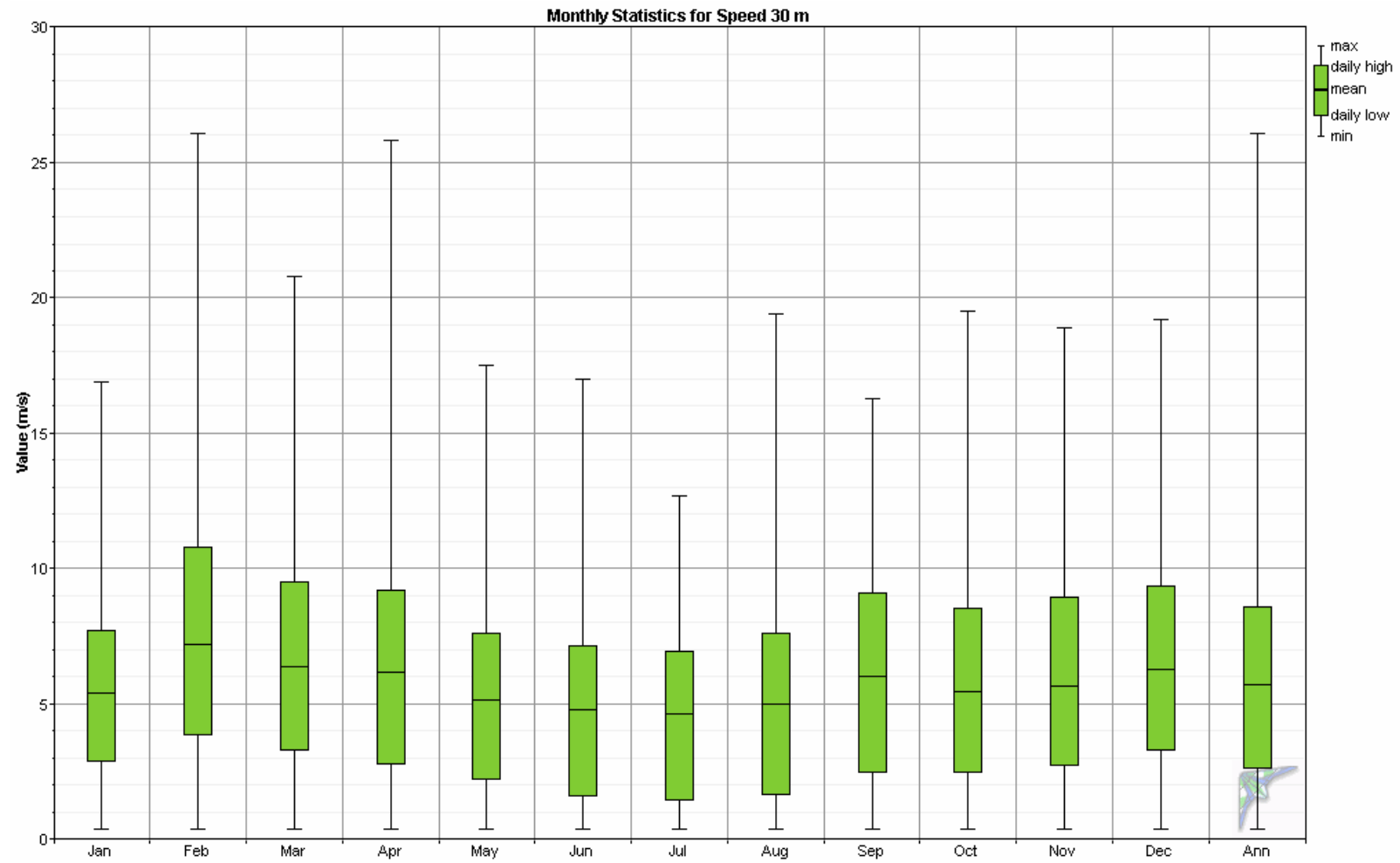


Togiak, Alaska Wind Resource Report

\section{Daily Wind Profile}

The daily wind profile indicates a strong daily variation of wind speeds with the lowest wind speeds occurring in the morning hours of 6 to 8 a.m. and the highest wind speeds of the day occur during the afternoon and early evening hours of 2 to 6 p.m.
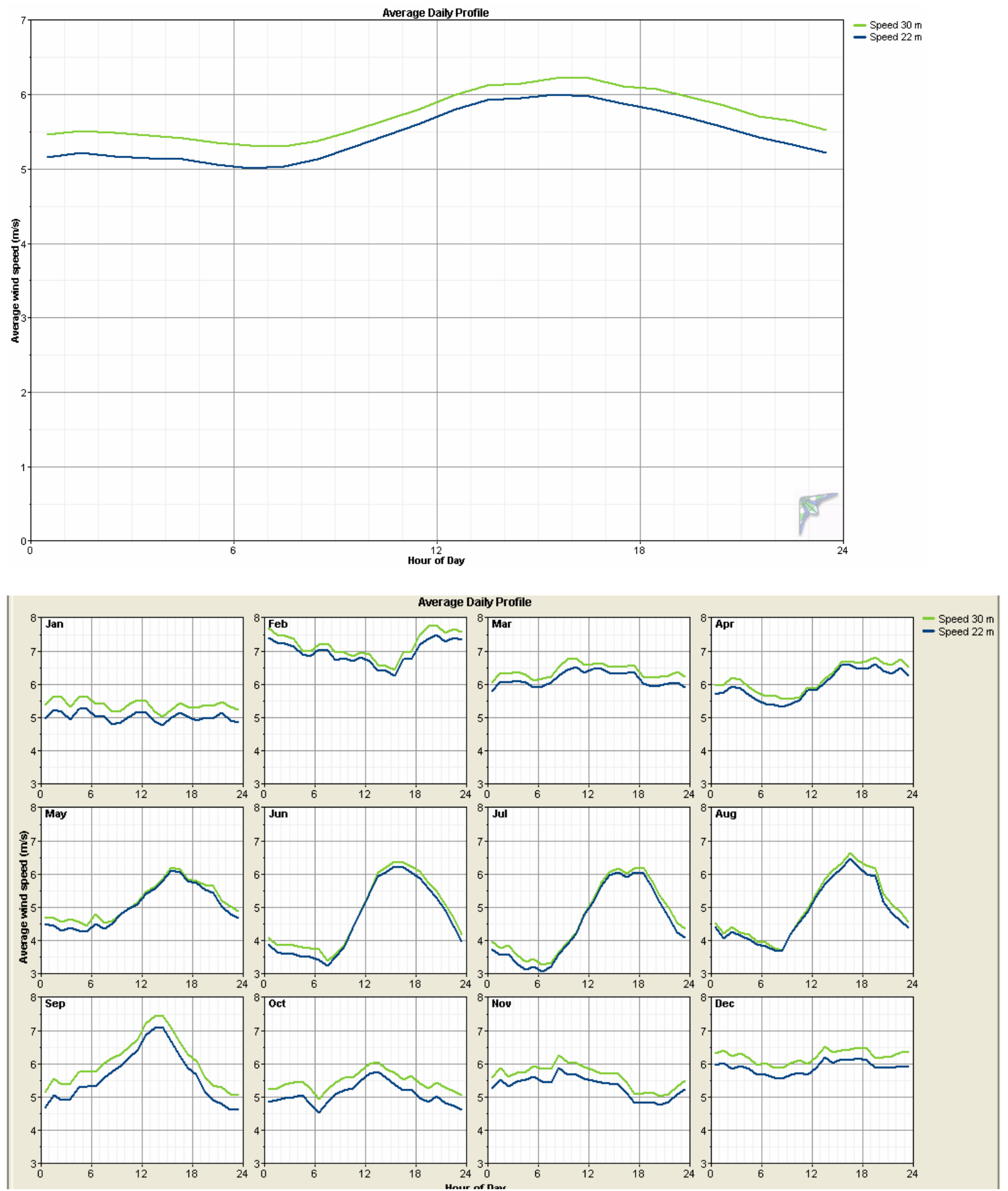
Togiak, Alaska Wind Resource Report

\section{Time Series of Wind Speed Monthly Averages}

As expected, the highest winds occurred during the fall through spring months with relatively light winds during the late spring and summer months of May through August. Note that the measured winds in January 2006 were unusually low. This was due to a high pressure system that brought extremely cold temperatures and low winds throughout much of Alaska during this month.

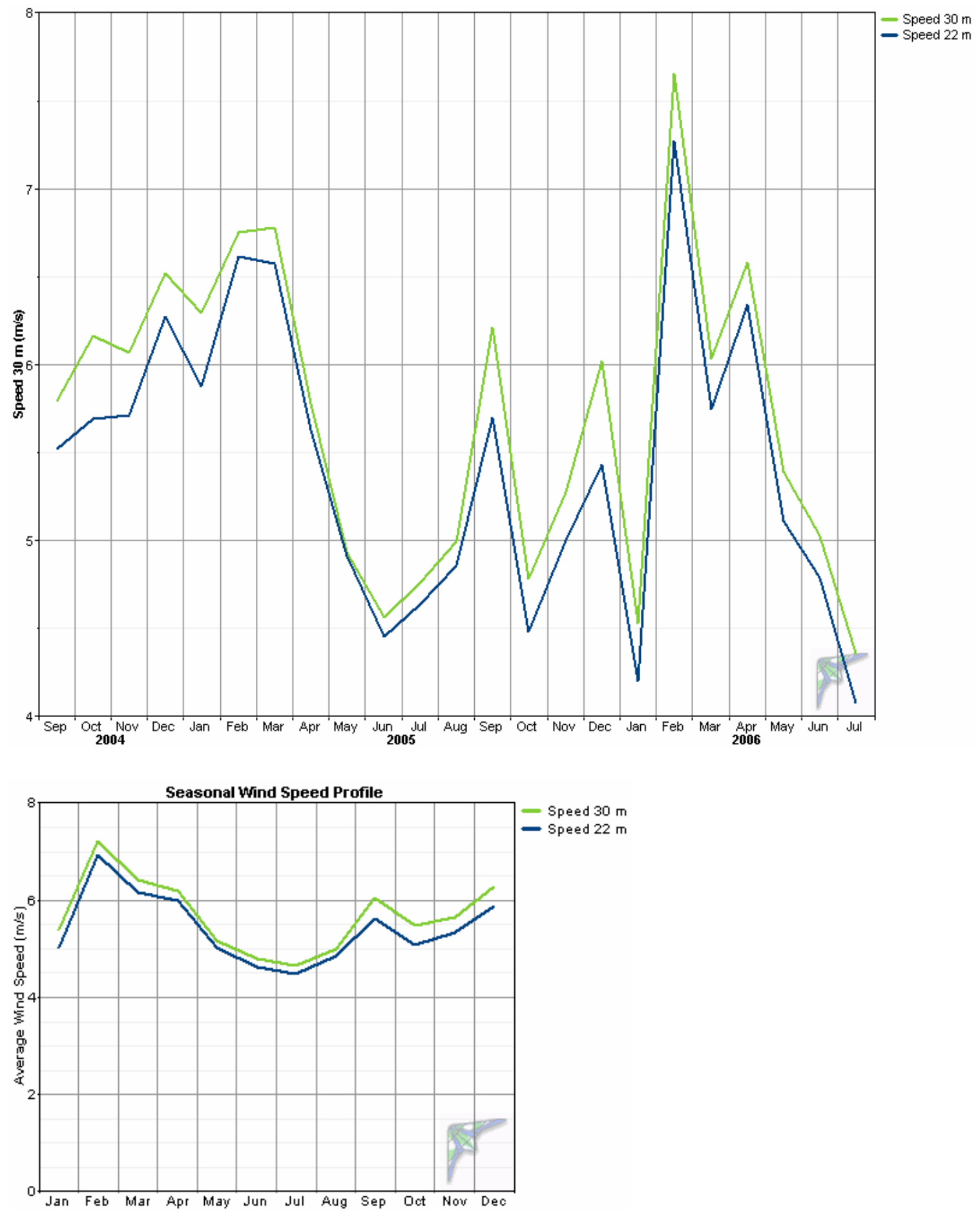




\section{Wind Shear Profile}

The average power law exponent was calculated at 0.154 , indicating moderate wind shear at the Togiak met tower test site, with the seasonal wind shear variation shown below. The practical application of this information is that a higher turbine tower height is advantageous as there is an appreciable marginal gain in average wind speed with height. However, a tower height/power recovery/construction cost tradeoff study would be advisable should a wind power project be initiated.
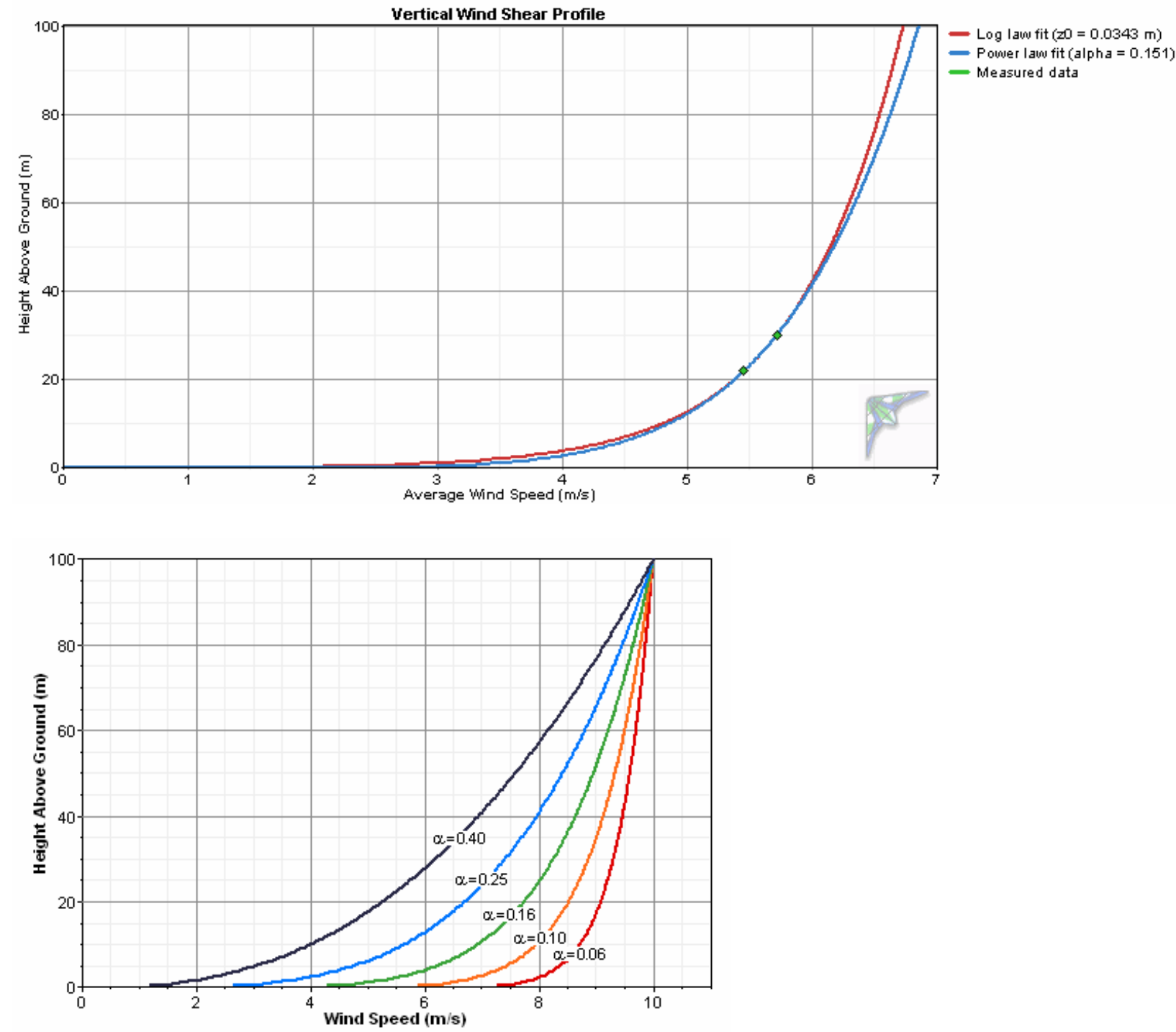
Togiak, Alaska Wind Resource Report
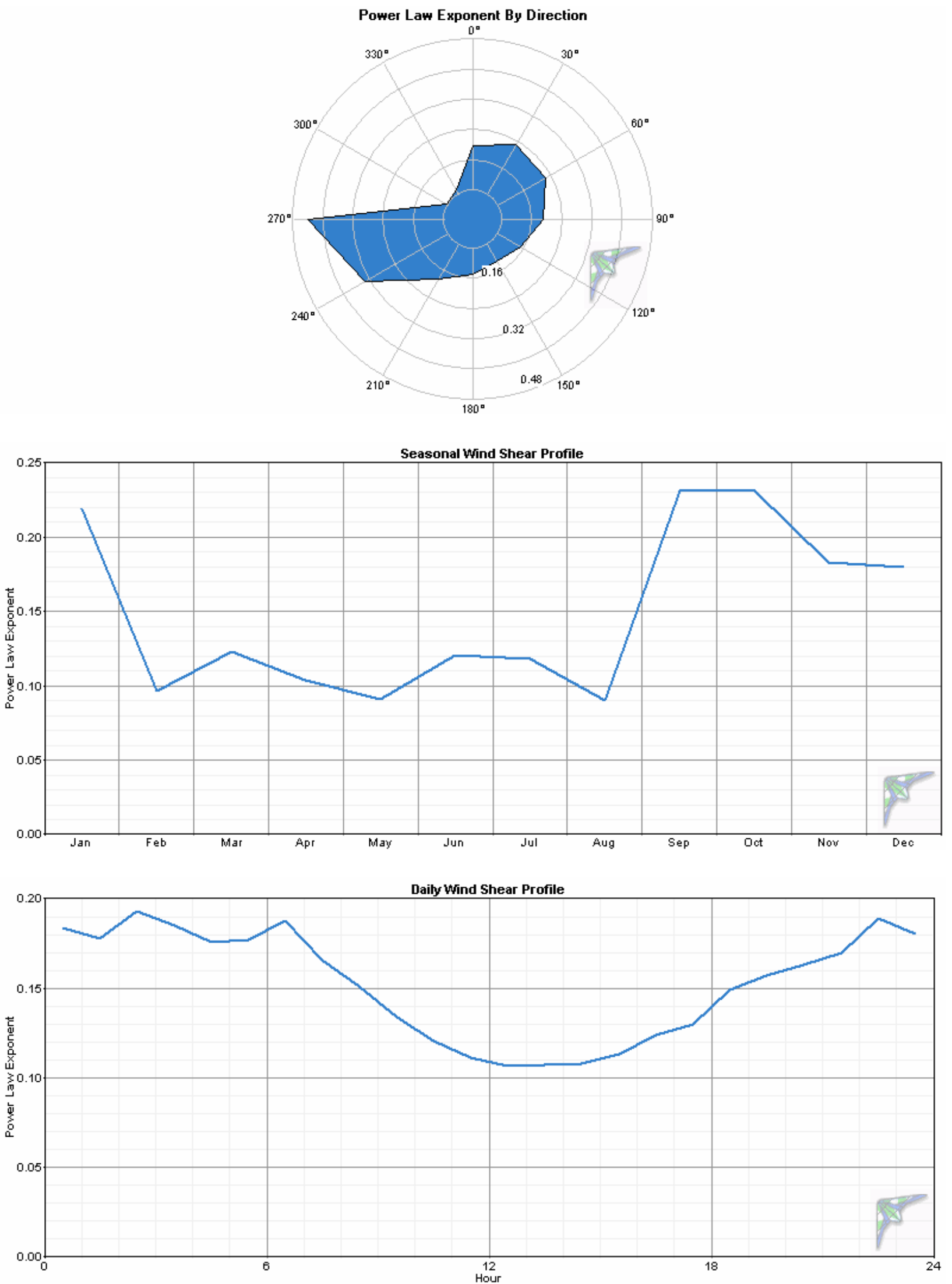


\section{Probability Distribution Function}

The probability distribution function provides a visual indication of measured wind speeds in one meter per second "bins". Note that most wind turbines do not begin to generate power until the wind speed at hub height reaches $4 \mathrm{~m} / \mathrm{s}$, also known as the "cut-in" wind speed. The black line in the graph is a best fit Weibull distribution. At the 30 meter level, Weibull parameters are $\mathrm{k}=$ 1.75 (indicates a low distribution of wind speeds) and $\mathrm{c}=6.40 \mathrm{~m} / \mathrm{s}$ (scale factor for the Weibull distribution).
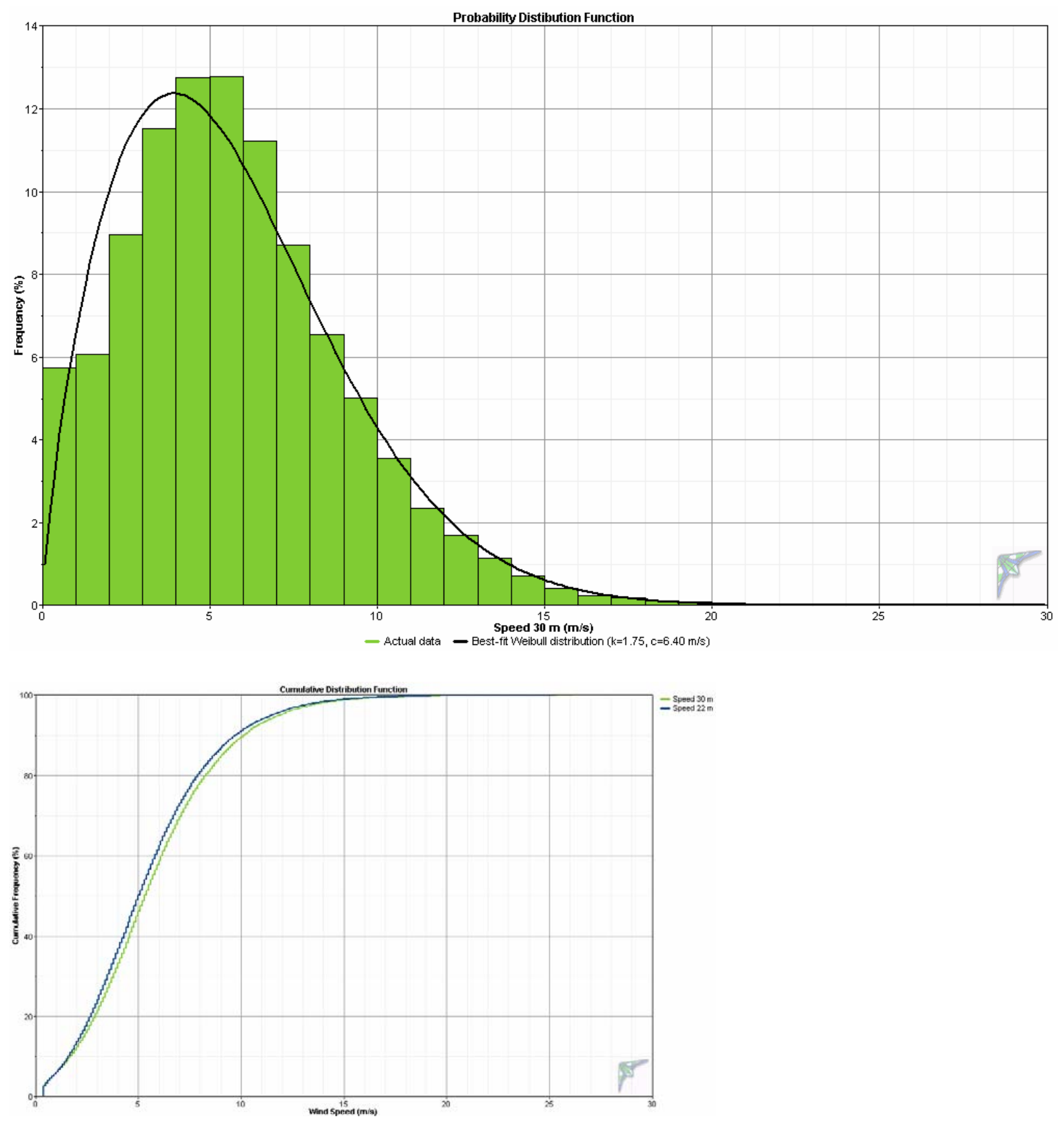


\section{Wind Roses}

Togiak's winds are strongly bi-directional with the most frequent winds from the northnorthwest and north-northeast, and lesser occurring winds from the southeast and southsouthwest. This data observation, however, changes somewhat upon consideration of the power density rose (second wind rose). As one can see, the power producing winds are primarily northnorthwest and southeast. The NNE winds, although, frequent, are primarily low speed and hence low power. The practical application of this information is that multiple turbines must be spaced in a east-to-west alignment to minimize power loss to downwind machines.

Note also that a wind threshold of $4 \mathrm{~m} / \mathrm{s}$ was selected for the definition of calm winds. This wind speed represents the cut-in wind speed of most wind turbines. By this definition Togiak experiences calm conditions thirty-three percent of the time (see wind frequency rose below).

Wind frequency rose (30 meters)

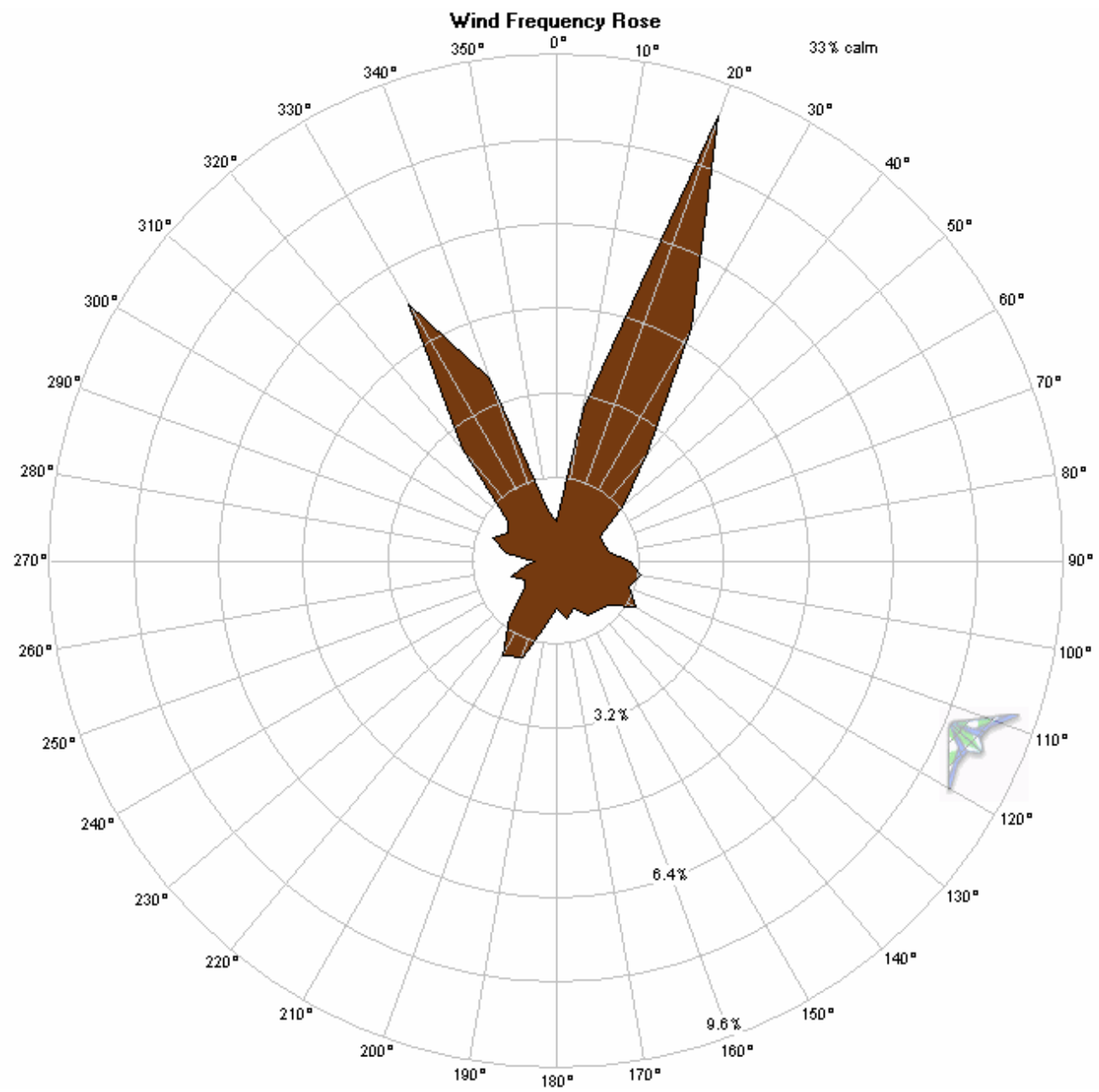


Togiak, Alaska Wind Resource Report

Power Density Rose (30 meters)

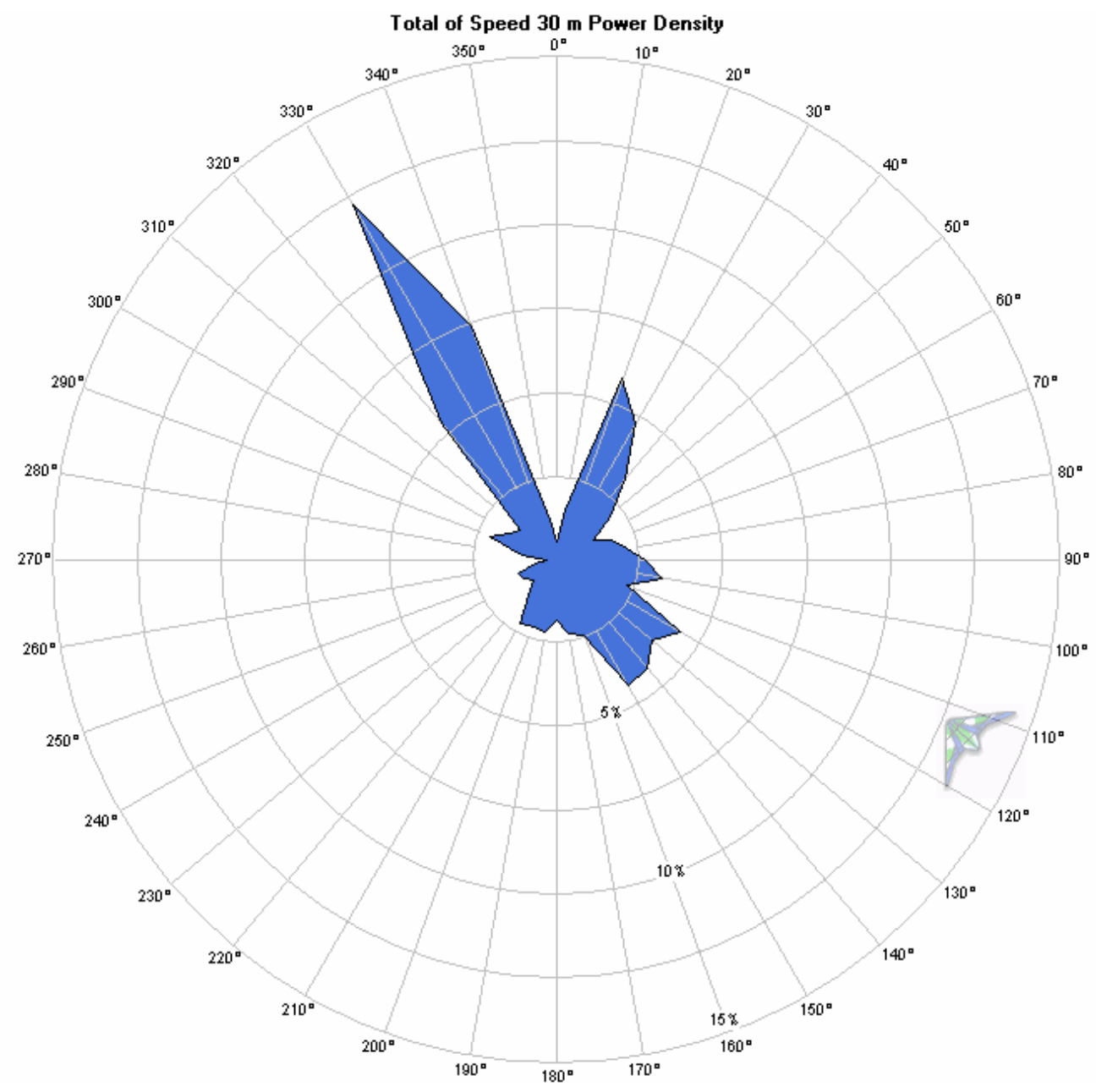

Wind Power Density Rose by Month (30 meters), scale is common

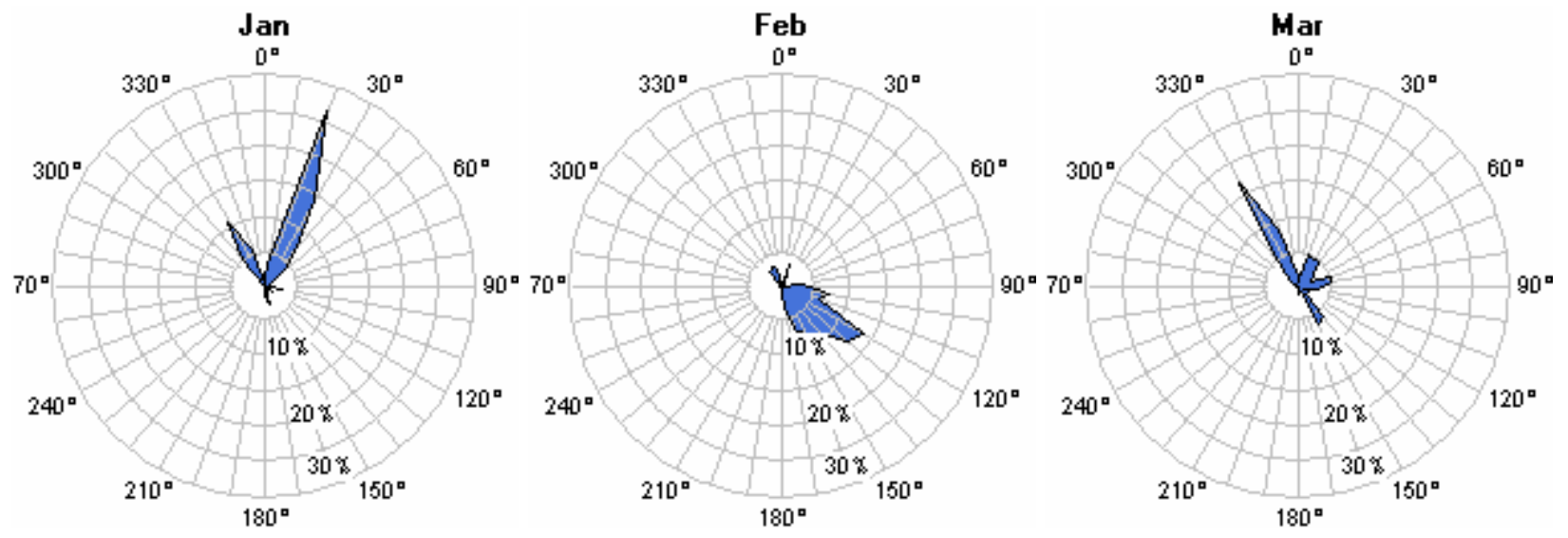


Togiak, Alaska Wind Resource Report

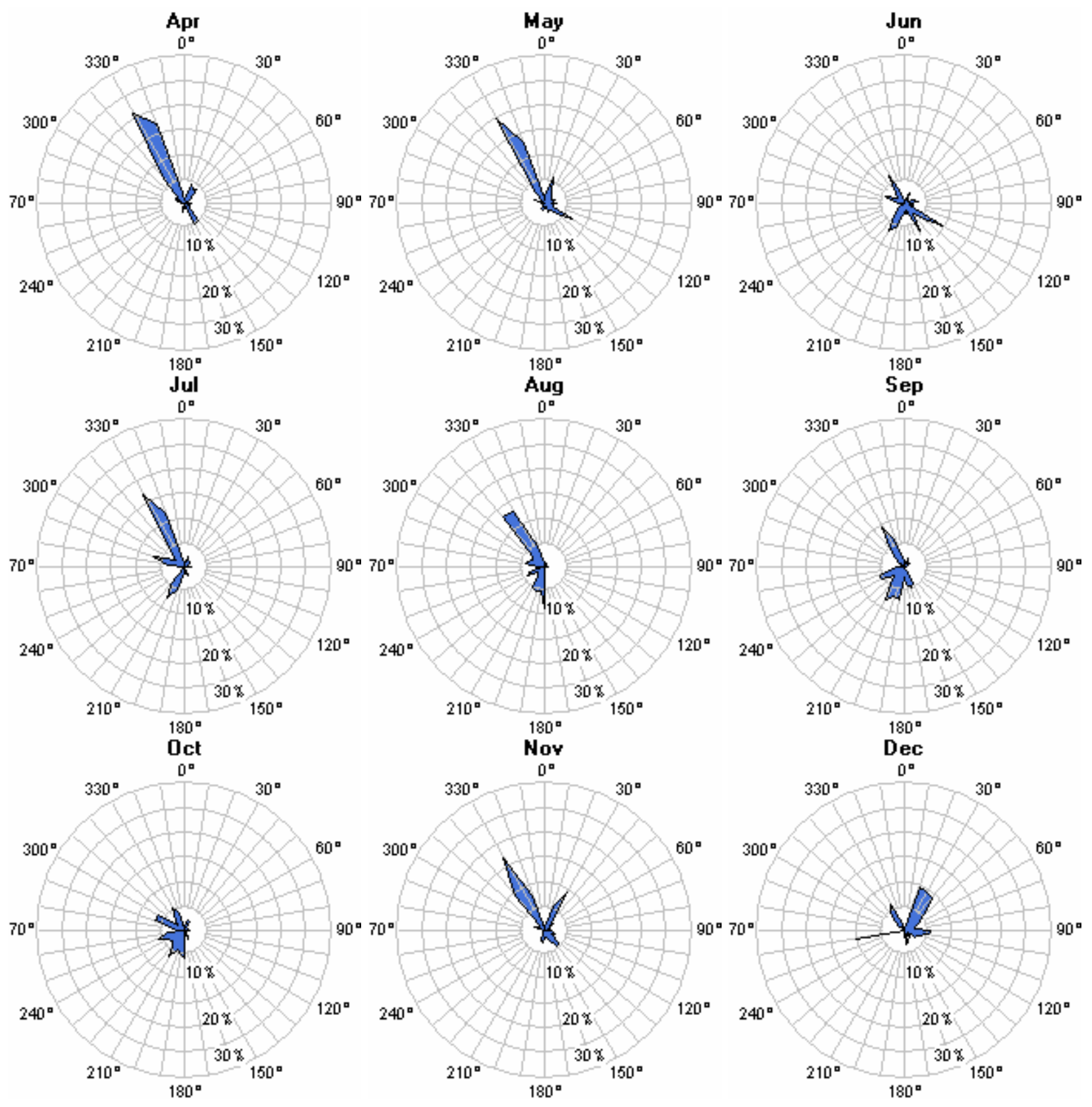




\section{Turbulence Intensity}

The turbulence intensity is acceptable for the most frequent wind directions, with mean turbulence intensity at 30 meters of 0.104 (threshold wind speed is $4 \mathrm{~m} / \mathrm{s}$ ), indicating acceptable turbulence for wind power development. The relatively high turbulence intensity to the southwest is not important as winds rarely blow from this sector, but the relatively high turbulence intensity to the southeast likely is due to gusty storm winds from this sector.

Turbulence Intensity Rose - 30 meter vane, 30 meter anemometer

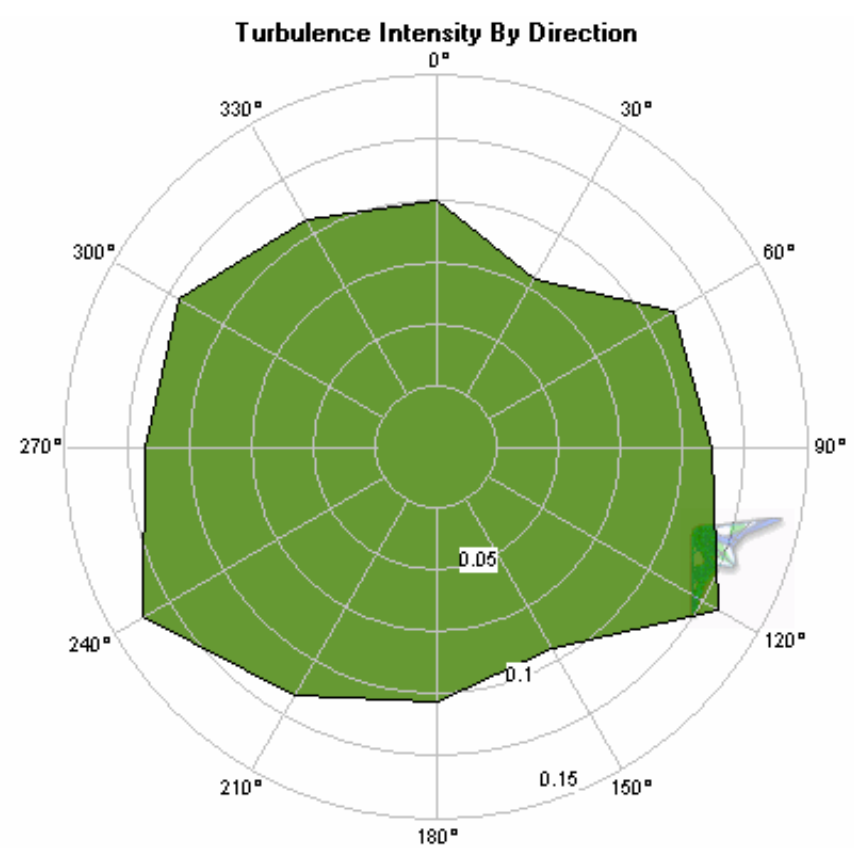

IEC Turbulence Intensity Standards

As shown below, the Togiak project test site meets International Electrotechnical Commission (IEC) turbulence intensity Category A and Category B standards. 
Togiak, Alaska Wind Resource Report
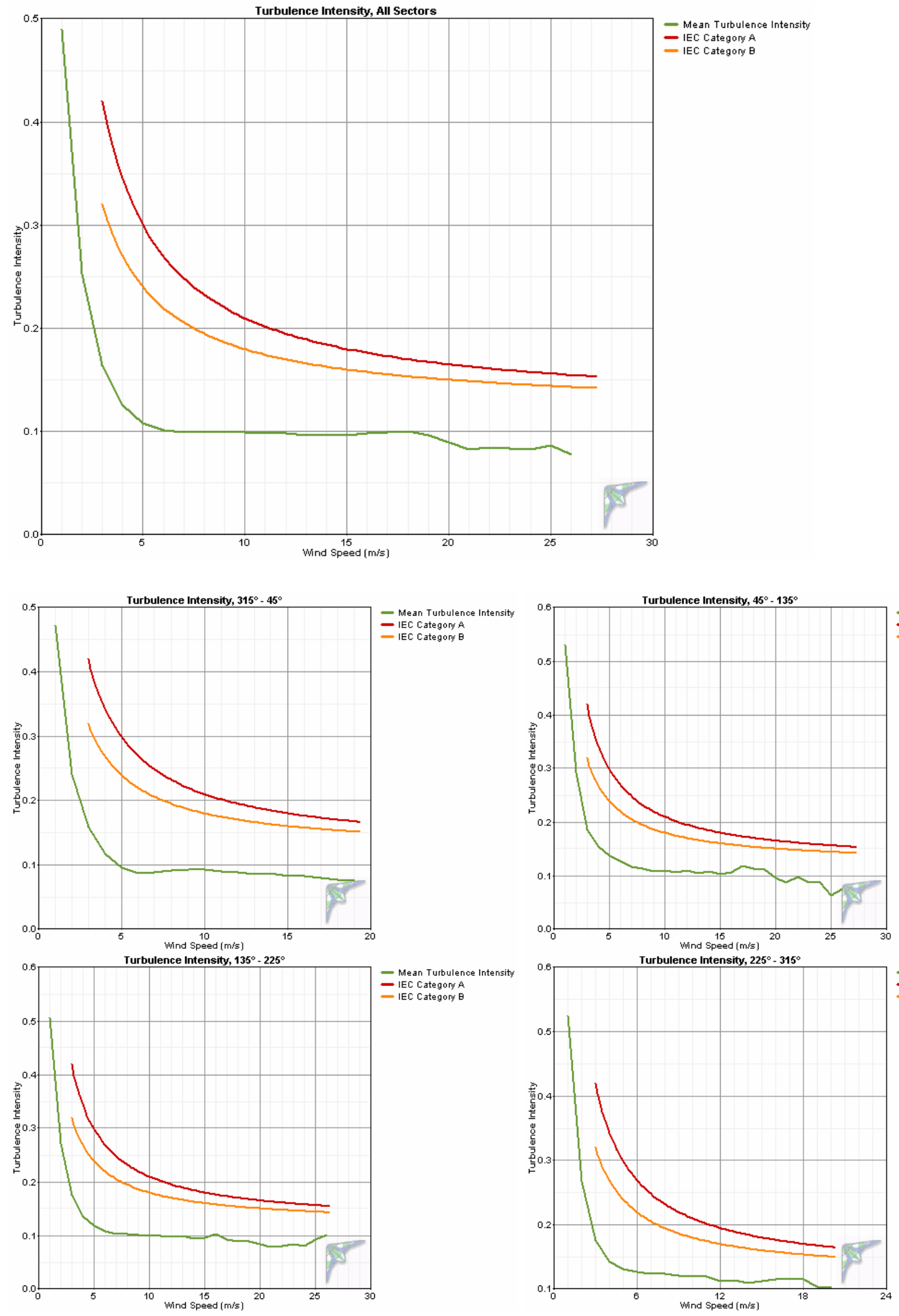

- Mean Turbulence Intensity - IEC Category A
- IEC Category B

- Mean Turbulence Intensity - IEC Category A
- IEC Category B 
Togiak, Alaska Wind Resource Report

Turbulence Table

\begin{tabular}{cccccccc}
$\begin{array}{c}\text { Bin } \\
\text { Midpoint } \\
(\mathrm{m} / \mathrm{s})\end{array}$ & $\begin{array}{c}\text { Bin Endpoints } \\
\text { Lower } \\
(\mathrm{m} / \mathrm{s})\end{array}$ & $\begin{array}{c}\text { Upper } \\
(\mathrm{m} / \mathrm{s})\end{array}$ & $\begin{array}{c}\text { Records } \\
\text { In }\end{array}$ & $\begin{array}{c}\text { Sin } \\
\text { Beviation } \\
\text { of Wind Speed } \\
(\mathrm{m} / \mathrm{s})\end{array}$ & $\begin{array}{c}\text { Mean } \\
\text { Turbulence } \\
\text { Intensity }\end{array}$ & $\begin{array}{c}\text { Standard } \\
\text { Deviation } \\
\text { of Turbulence } \\
\text { Intensity }\end{array}$ & $\begin{array}{c}\text { Characteristic } \\
\text { Turbulence } \\
\text { Intensity }\end{array}$ \\
\hline 1 & 0.5 & 1.5 & 5222 & 0.452 & 0.502 & 0.179 & 0.680 \\
2 & 1.5 & 2.5 & 7029 & 0.502 & 0.259 & 0.138 & 0.397 \\
3 & 2.5 & 3.5 & 9555 & 0.490 & 0.167 & 0.086 & 0.253 \\
4 & 3.5 & 4.5 & 11827 & 0.504 & 0.128 & 0.064 & 0.192 \\
5 & 4.5 & 5.5 & 12450 & 0.540 & 0.109 & 0.054 & 0.163 \\
6 & 5.5 & 6.5 & 11408 & 0.605 & 0.102 & 0.047 & 0.149 \\
7 & 6.5 & 7.5 & 9602 & 0.695 & 0.100 & 0.041 & 0.142 \\
8 & 7.5 & 8.5 & 7100 & 0.807 & 0.102 & 0.037 & 0.139 \\
9 & 8.5 & 9.5 & 5620 & 0.900 & 0.101 & 0.034 & 0.135 \\
10 & 9.5 & 10.5 & 4041 & 1.002 & 0.101 & 0.033 & 0.134 \\
11 & 10.5 & 11.5 & 2711 & 1.083 & 0.099 & 0.032 & 0.131 \\
12 & 11.5 & 12.5 & 1924 & 1.176 & 0.099 & 0.031 & 0.129 \\
13 & 12.5 & 13.5 & 1324 & 1.252 & 0.097 & 0.027 & 0.124 \\
14 & 13.5 & 14.5 & 863 & 1.346 & 0.097 & 0.028 & 0.125 \\
15 & 14.5 & 15.5 & 540 & 1.435 & 0.096 & 0.030 & 0.126 \\
16 & 15.5 & 16.5 & 295 & 1.567 & 0.098 & 0.029 & 0.127 \\
17 & 16.5 & 17.5 & 212 & 1.678 & 0.099 & 0.030 & 0.129 \\
18 & 17.5 & 18.5 & 137 & 1.791 & 0.100 & 0.032 & 0.132 \\
19 & 18.5 & 19.5 & 75 & 1.817 & 0.096 & 0.024 & 0.120 \\
20 & 19.5 & 20.5 & 70 & 1.779 & 0.089 & 0.019 & 0.108 \\
21 & 20.5 & 21.5 & 42 & 1.736 & 0.083 & 0.014 & 0.097 \\
22 & 21.5 & 22.5 & 35 & 1.863 & 0.085 & 0.014 & 0.099 \\
23 & 22.5 & 23.5 & 19 & 1.911 & 0.084 & 0.012 & 0.096 \\
24 & 23.5 & 24.5 & 7 & 1.971 & 0.082 & 0.013 & 0.095 \\
25 & 24.5 & 25.5 & 5 & 2.160 & 0.086 & 0.014 & 0.100 \\
26 & 25.5 & 26.5 & 8 & 2.025 & 0.078 & 0.011 & 0.090 \\
27 & 26.5 & 27.5 & 0 & 2.025 & 0.078 & 0.011 & 0.090
\end{tabular}


Togiak, Alaska Wind Resource Report

\section{Air Temperature and Density}

Over the reporting period, Togiak had an average temperature of $1.6^{\circ} \mathrm{C}$. The minimum recorded temperature during the measurement period was $-29.7^{\circ} \mathrm{C}$ and the maximum temperature was $28.1^{\circ} \mathrm{C}$, indicating a cool temperate environment for wind turbine operations. Consequent to Togiak's cool temperatures, the average air density of $1.283 \mathrm{~kg} / \mathrm{m}^{3}$ is five percent higher than the standard air density of $1.223 \mathrm{~kg} / \mathrm{m}^{3}$ (at $14.8^{\circ} \mathrm{C}$ temperature and $101.1 \mathrm{kPa}$ pressure at 20 meters elevation). Density variance from standard is accounted for in the turbine performance predictions.

\begin{tabular}{crrrrrrr} 
Month & \multicolumn{3}{c}{ Temperature (Ch 9) } & \multicolumn{3}{c}{ Air Density } \\
& $\begin{array}{c}\text { Mean } \\
\left({ }^{\circ} \mathrm{C}\right)\end{array}$ & \multicolumn{1}{c}{$\begin{array}{c}\text { Min } \\
\left({ }^{\circ} \mathrm{C}\right)\end{array}$} & $\begin{array}{c}\text { Max } \\
\left({ }^{\circ} \mathrm{C}\right)\end{array}$ & $\begin{array}{c}\text { Std. } \\
\text { Dev. } \\
\left({ }^{\circ} \mathrm{C}\right)\end{array}$ & $\begin{array}{c}\text { Mean } \\
\left(\mathrm{kg} / \mathrm{m}^{3}\right)\end{array}$ & $\begin{array}{c}\text { Min } \\
\left(\mathrm{kg} / \mathrm{m}^{3}\right)\end{array}$ & $\begin{array}{c}\text { Max } \\
\left(\mathrm{kg} / \mathrm{m}^{3}\right)\end{array}$ \\
\hline Jan & -9.5 & -28.3 & 2.8 & 8.489 & 1.337 & 1.276 & 1.438 \\
Feb & -5.8 & -29.7 & 4.4 & 7.756 & 1.318 & 1.268 & 1.446 \\
Mar & -5.4 & -25.4 & 8.0 & 6.391 & 1.315 & 1.222 & 1.421 \\
Apr & -2.5 & -21.4 & 18.8 & 6.200 & 1.301 & 1.206 & 1.398 \\
May & 6.8 & -7.1 & 25.6 & 5.539 & 1.258 & 1.178 & 1.323 \\
Jun & 10.9 & -0.5 & 28.1 & 4.328 & 1.240 & 1.169 & 1.291 \\
Jul & 13.5 & 2.2 & 23.6 & 3.824 & 1.228 & 1.186 & 1.279 \\
Aug & 13.0 & 4.8 & 23.8 & 3.584 & 1.230 & 1.186 & 1.267 \\
Sep & 7.3 & -5.0 & 17.4 & 3.571 & 1.256 & 1.212 & 1.313 \\
Oct & 2.1 & -13.7 & 12.0 & 4.825 & 1.279 & 1.235 & 1.357 \\
Nov & -6.2 & -24.9 & 4.4 & 6.671 & 1.319 & 1.268 & 1.418 \\
Dec & -4.4 & -27.5 & 4.8 & 6.619 & 1.310 & 1.267 & 1.433 \\
\hline Annual & $\mathbf{1 . 6}$ & -29.7 & 28.1 & 9.680 & 1.283 & 1.169 & 1.446
\end{tabular}

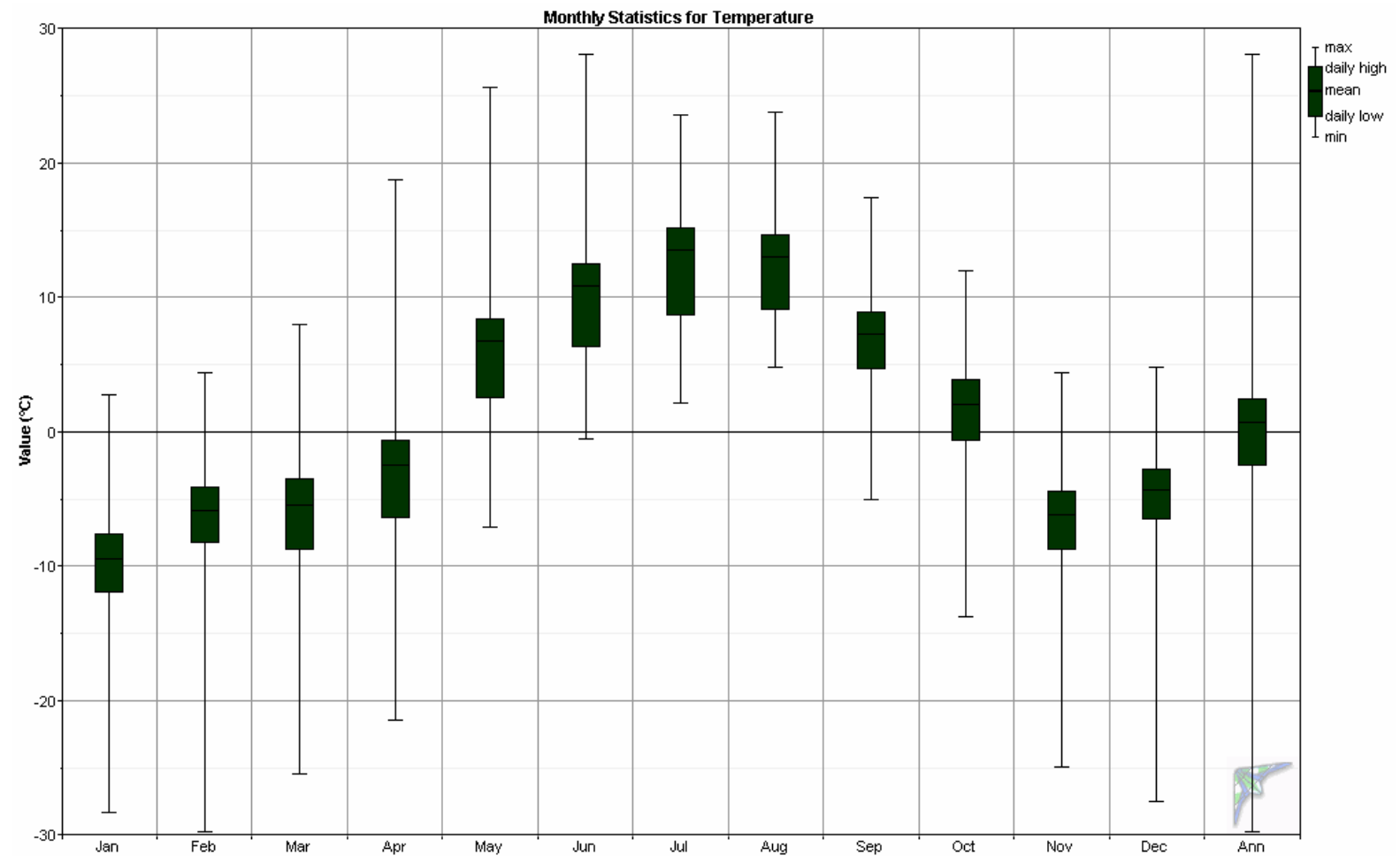




\section{Air Density DMap}

The DMap below is a visual indication of the daily and seasonal variations of air density (and hence temperature). Air densities higher than standard will yield higher turbine power than predicated by the turbine power curves, while densities lower than average will yield lower turbine power than predicted. Density variance from standard is accounted for in the turbine performance predictions.

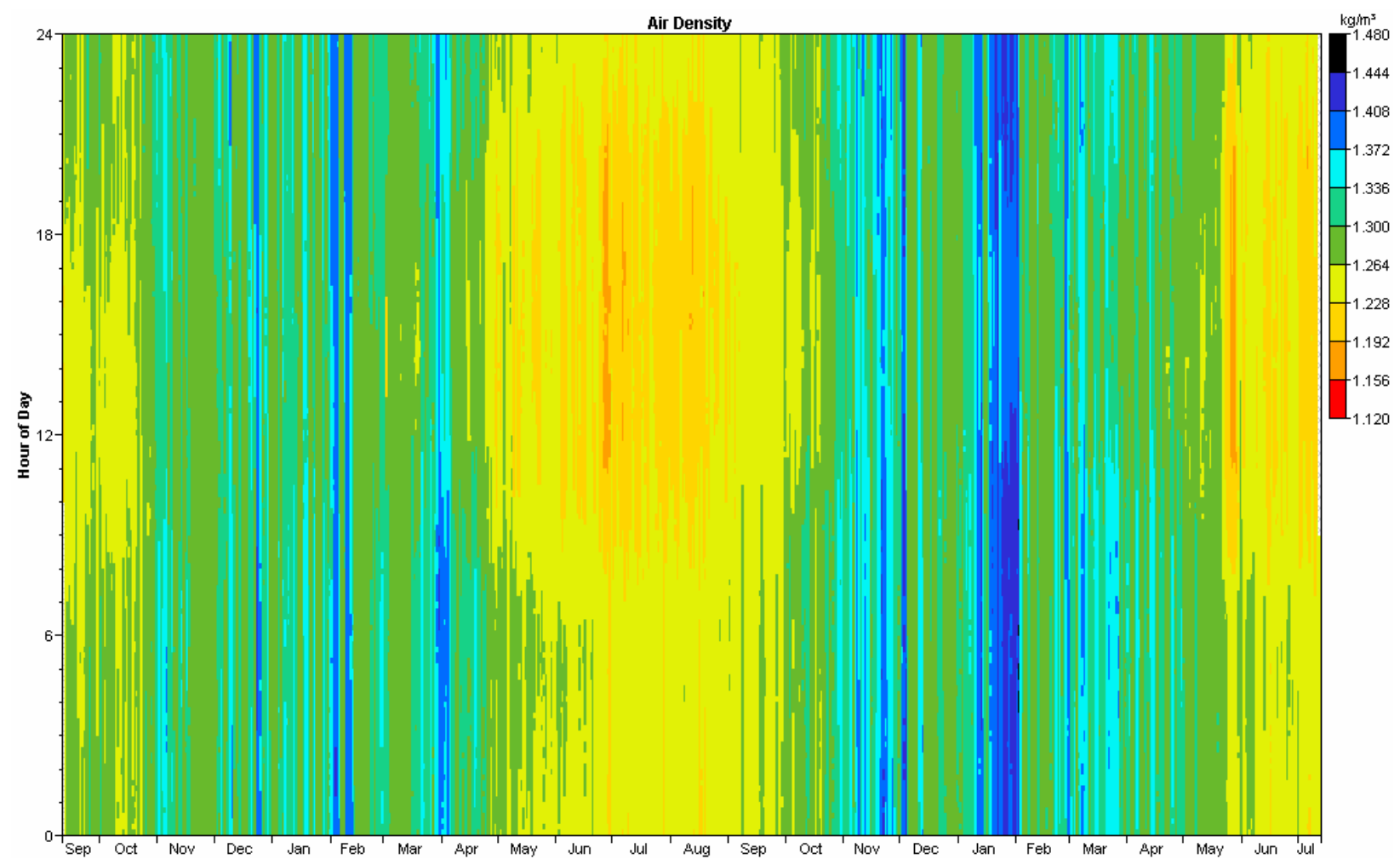




\section{Wind Turbine Performance}

The turbine performance predictions noted below are based on 100\% and 90\% turbine availabilities. It is realistic to expect five to ten percent downtime for maintenance, repairs and/or other outages should be expected.

Note that these performance estimates were predicted with use of Windographer ${ }^{\circledR}$ wind analysis software; power curves provided by manufacturers are not independently verified and are assumed to be accurate. The power curves are presented for a standard air density of $1.225 \mathrm{~kg} / \mathrm{m}^{3}$ at $15^{\circ} \mathrm{C}$ temperature and $101.3 \mathrm{kPa}$ at sea level; however the predictions of power production are density compensated by multiplying the standard density power output by the ratio of the measured air density to standard air density.

A number of smaller village-scale grid-connected turbines are profiled belong for comparison purposes. These turbines were selected because they have market availability and they are deemed to be within a suitable range for consideration of wind power development in a village the size of Togiak.

Entegrity eW-15: $65 \mathrm{~kW}$ rated power output, 15 meter rotor, stall-controlled (power curve provided by Entegrity Energy Systems). Additional information is available at http://www.entegritywind.com/.
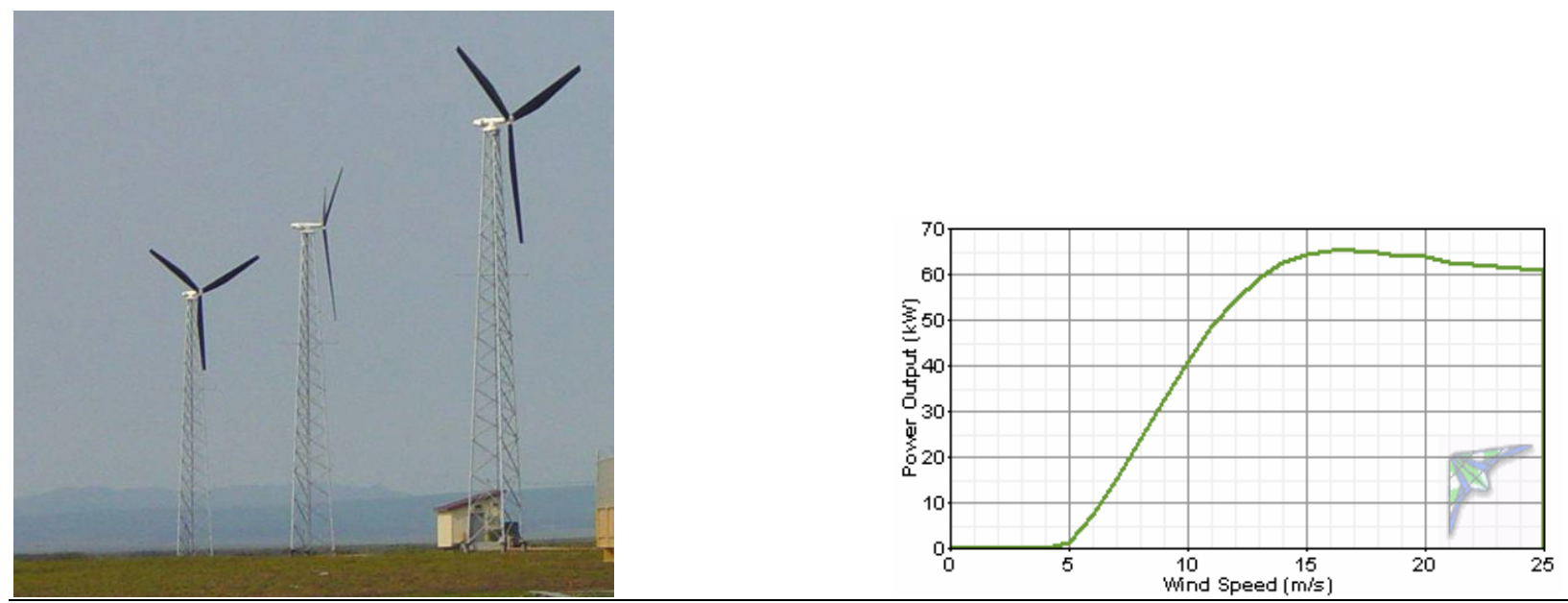

Northwind 100/19 and 100/20: $100 \mathrm{~kW}$ rated power output, 19 meter rotor and 20 meter rotor (19 meter rotor blades with 0.6 meter blade root extensions added) models, stall-controlled (power curve provided by Northern Power Systems). Additional information is available at http://www.northernpower.com/. 

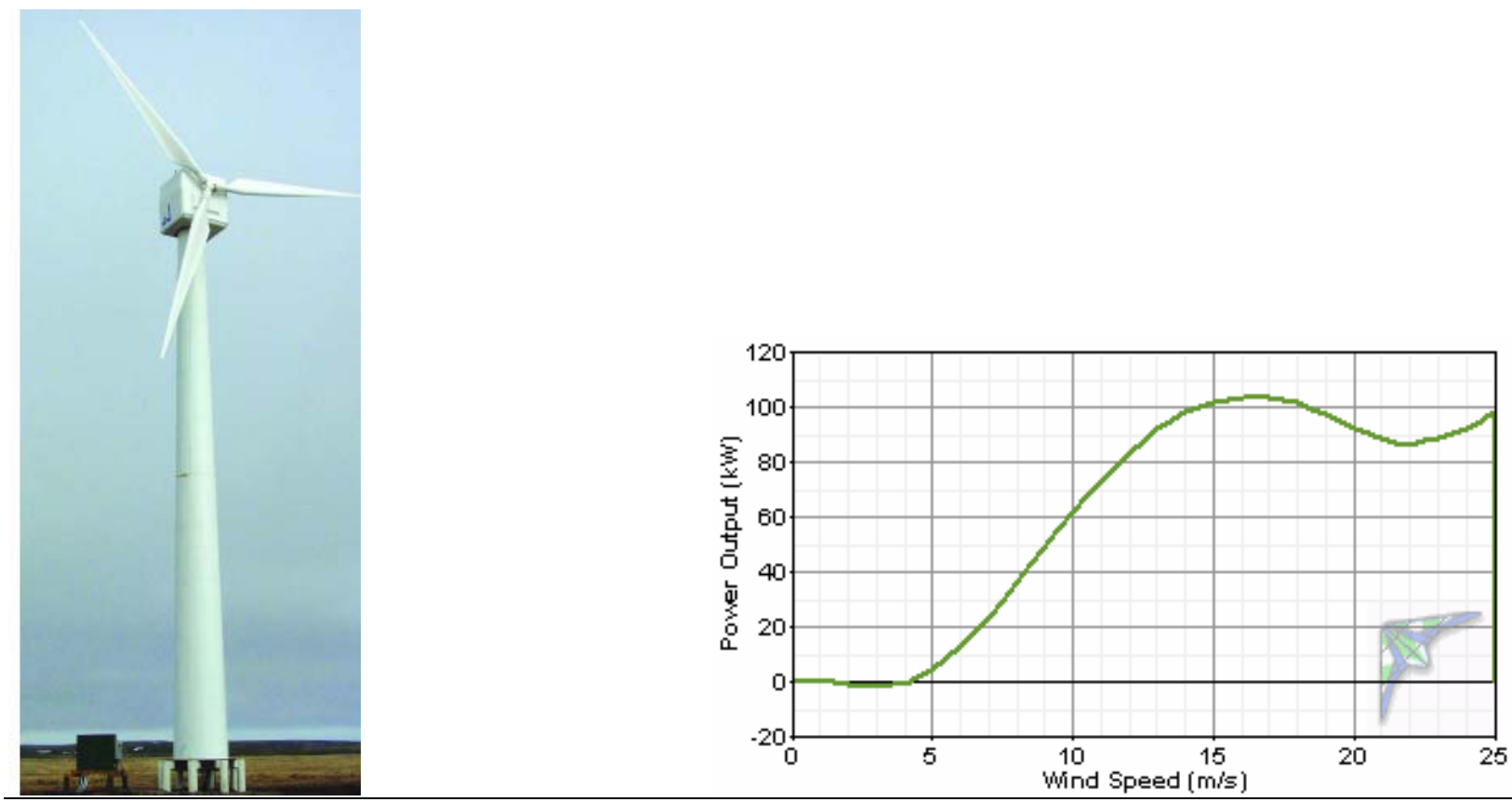

Fuhrländer FL100: 100 kW rated output (125 kW max output), 21 meter rotor, stall-controlled, 35 meter hub height (power curve provided by lorax-energy.com). Additional information is available at http://www.fuhrlaender.de/ and http://www.lorax-energy.com/.
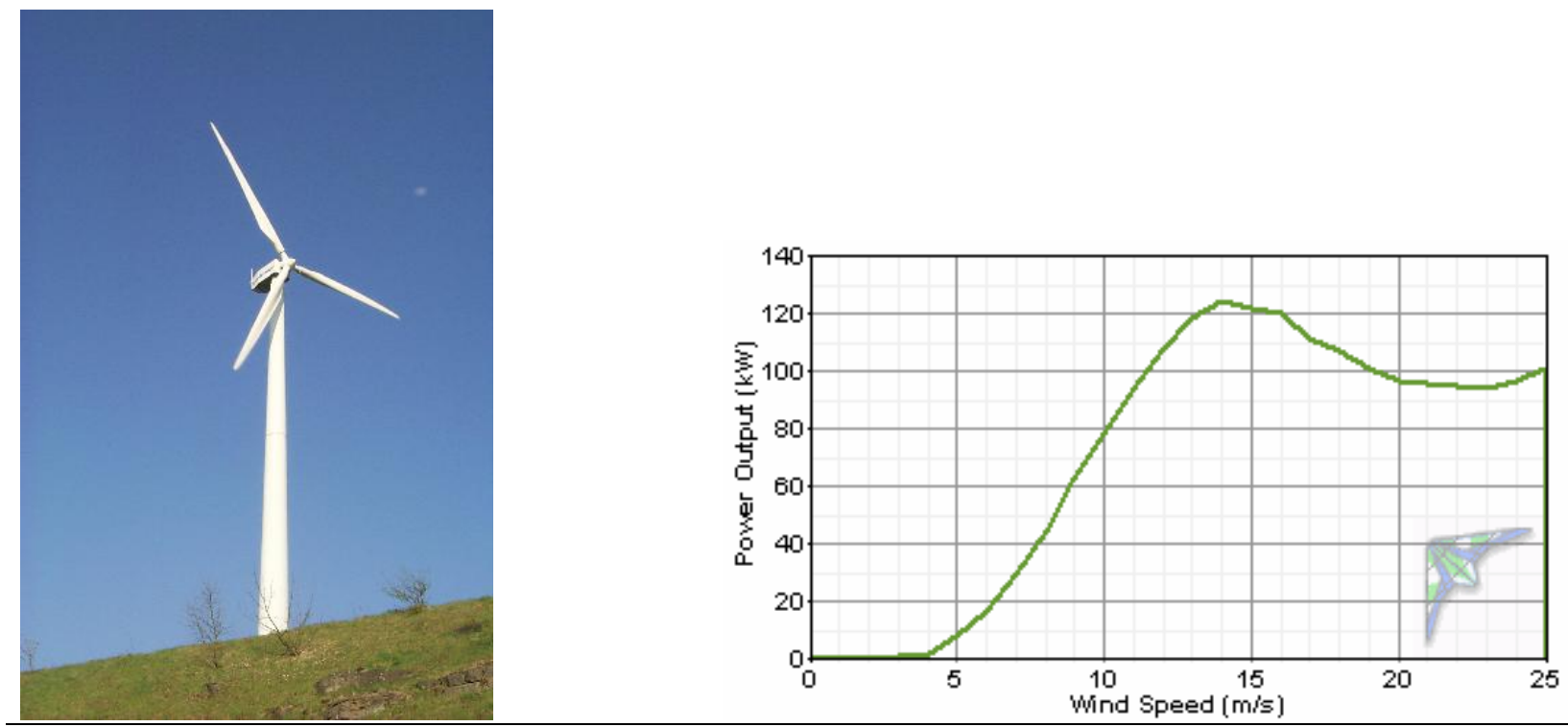

Fuhrländer FL250: 250 kW rated output (300 kW max output), 29.5 meter rotor, stallcontrolled, 42-meter hub height (power curve provided by lorax-energy.com). Additional information is available at http://www.fuhrlaender.de/ and http://www.lorax-energy.com/. 
Togiak, Alaska Wind Resource Report
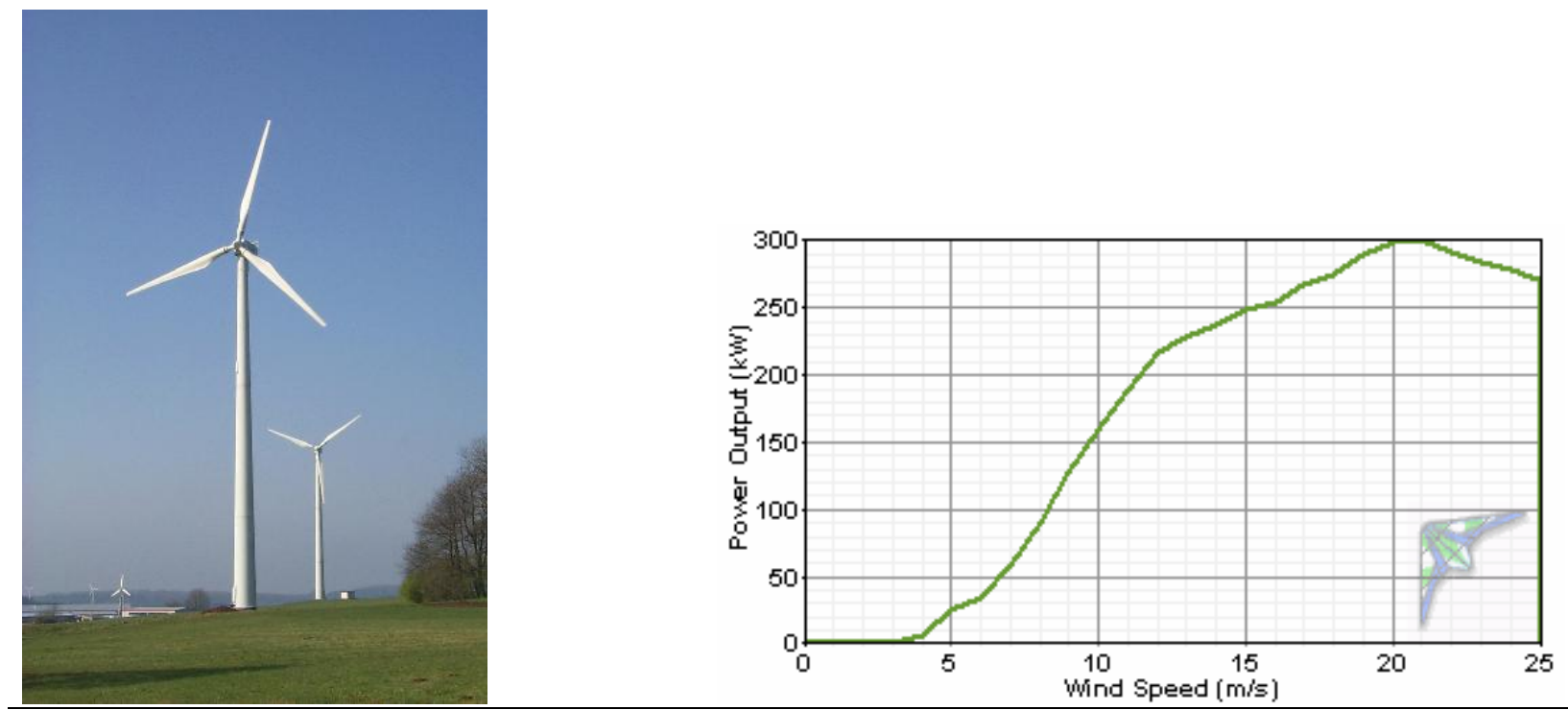

Vestas V27: $225 \mathrm{~kW}$ rated power output, 27 meter rotor, pitch-controlled (power curve provided by Alaska Energy Authority)
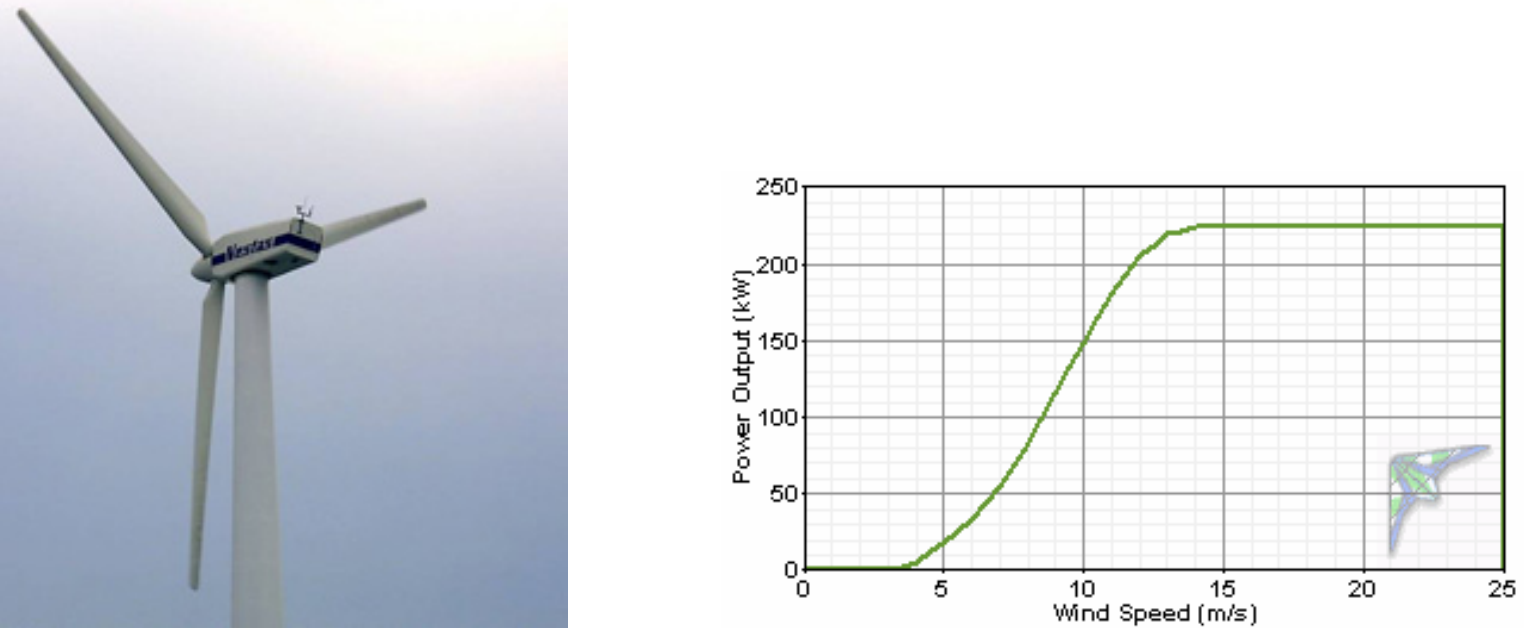
Turbine Power Output Comparison (100\% Turbine Availability)

\begin{tabular}{|c|c|c|c|c|c|c|c|}
\hline Turbine & $\begin{array}{l}\text { Hub } \\
\text { Height } \\
\text { (m) }\end{array}$ & $\begin{array}{l}\text { Hub } \\
\text { Height } \\
\text { Wind } \\
\text { Speed } \\
\text { (m/s) }\end{array}$ & $\begin{array}{c}\text { Time At } \\
\text { Zero } \\
\text { Output } \\
(\%)\end{array}$ & $\begin{array}{c}\text { Time At } \\
\text { Rated } \\
\text { Output } \\
(\%)\end{array}$ & $\begin{array}{c}\text { Average } \\
\text { Power } \\
\text { Output } \\
\text { (kW) }\end{array}$ & $\begin{array}{c}\text { Annual } \\
\text { Energy } \\
\text { Output } \\
\text { (kWh/yr) }\end{array}$ & $\begin{array}{c}\text { Average } \\
\text { Capacity } \\
\text { Factor } \\
(\%)\end{array}$ \\
\hline Entegrity eW-15 $60 \mathrm{~Hz}$ & 25 & 5.57 & 34.84 & 2.0 & 12.7 & 110,956 & 19.5 \\
\hline Entegrity eW-15 $60 \mathrm{~Hz}$ & 31 & 5.71 & 33.14 & 2.3 & 13.6 & 119,008 & 20.9 \\
\hline Northern Power NW 100/19 & 25 & 5.57 & 34.83 & 1.2 & 17.6 & 153,937 & 17.6 \\
\hline Northern Power NW 100/19 & 32 & 5.74 & 33.00 & 1.4 & 19.1 & 166,982 & 19.1 \\
\hline Northern Power NW 100/20 & 25 & 5.57 & 34.82 & 1.8 & 18.6 & 163,255 & 18.6 \\
\hline Northern Power NW 100/20 & 32 & 5.74 & 33.00 & 2.1 & 20.2 & 177,034 & 20.2 \\
\hline Fuhrländer FL100 & 35 & 5.83 & 12.63 & 2.5 & 28.6 & 250,930 & 22.9 \\
\hline Fuhrländer FL250 & 42 & 6.00 & 12.33 & 0.3 & 63.3 & 554,717 & 21.1 \\
\hline Vestas V27 & 32 & 5.74 & 16.56 & 1.4 & 51.6 & 451,821 & 22.9 \\
\hline Vestas V27 & 42 & 6.00 & 15.71 & 1.8 & 56.8 & 497,155 & 25.2 \\
\hline $\begin{array}{l}\text { Capacity Factor }<20 \% \\
\text { Capacity Factor }>20 \%,<30 \% \\
\text { Capacity Factor }>30 \%,<40 \% \\
\text { Capacity Factor }>40 \%,<50 \% \\
\text { Capacity Factor }>50 \%\end{array}$ & & & & & & & \\
\hline
\end{tabular}

Note: Calculated for the data period 9/11/04 to 7/12/06 
Turbine Power Output Comparison (90\% Turbine Availability)

\begin{tabular}{|c|c|c|c|c|c|c|c|}
\hline Turbine & $\begin{array}{c}\text { Hub } \\
\text { Height } \\
(\mathrm{m})\end{array}$ & $\begin{array}{l}\text { Hub } \\
\text { Height } \\
\text { Wind } \\
\text { Speed } \\
(\mathrm{m} / \mathrm{s})\end{array}$ & $\begin{array}{c}\text { Time At } \\
\text { Zero } \\
\text { Output } \\
(\%) \\
\end{array}$ & $\begin{array}{c}\text { Time At } \\
\text { Rated } \\
\text { Output } \\
(\%) \\
\end{array}$ & $\begin{array}{c}\text { Average } \\
\text { Power } \\
\text { Output } \\
\text { (kW) }\end{array}$ & $\begin{array}{l}\text { Annual } \\
\text { Energy } \\
\text { Output } \\
\text { (kWh/yr) }\end{array}$ & $\begin{array}{c}\text { Average } \\
\text { Capacity } \\
\text { Factor } \\
(\%)\end{array}$ \\
\hline Entegrity eW-15 $60 \mathrm{~Hz}$ & 25 & 5.57 & 34.84 & 2.0 & 12.7 & 99,860 & 17.6 \\
\hline Entegrity eW-15 $60 \mathrm{~Hz}$ & 31 & 5.71 & 33.14 & 2.3 & 13.6 & 107,107 & 18.8 \\
\hline Northern Power NW 100/19 & 25 & 5.57 & 34.83 & 1.2 & 17.6 & 138,543 & 15.8 \\
\hline Northern Power NW 100/19 & 32 & 5.74 & 33.00 & 1.4 & 19.1 & 150,284 & 17.2 \\
\hline Northern Power NW 100/20 & 25 & 5.57 & 34.82 & 1.8 & 18.6 & 146,930 & 16.7 \\
\hline Northern Power NW 100/20 & 32 & 5.74 & 33.00 & 2.1 & 20.2 & 159,331 & 18.2 \\
\hline Fuhrländer FL100 & 35 & 5.83 & 12.63 & 2.5 & 28.6 & 225,837 & 20.6 \\
\hline Fuhrländer FL250 & 42 & 6.00 & 12.33 & 0.3 & 63.3 & 499,245 & 19.0 \\
\hline Vestas V27 & 32 & 5.74 & 16.56 & 1.4 & 51.6 & 406,639 & 20.6 \\
\hline Vestas V27 & 42 & 6.00 & 15.71 & 1.8 & 56.8 & 447,440 & 22.7 \\
\hline \multicolumn{8}{|l|}{ Capacity Factor $<20 \%$} \\
\hline \multicolumn{8}{|l|}{ Capacity Factor $>20 \%,<30 \%$} \\
\hline \multicolumn{8}{|l|}{ Capacity Factor $>30 \%,<40 \%$} \\
\hline \multicolumn{8}{|l|}{ Capacity Factor $>40 \%,<50 \%$} \\
\hline Capacity Factor $>50 \%$ & & & & & & & \\
\hline
\end{tabular}

Note: Calculated for the data period 9/11/04 to 7/12/06 
Togiak, Alaska Wind Resource Report

Annual Fuel Cost Avoided for Energy Generated by Wind Turbine vs. Diesel Generator

\begin{tabular}{|c|c|c|c|c|c|c|c|c|c|c|c|}
\hline \multirow[b]{2}{*}{ Turbine } & \multirow[t]{2}{*}{$\begin{array}{c}\text { Annual } \\
\text { Energy } \\
\text { Output } \\
\text { (kW- } \\
\text { hr/yr) }\end{array}$} & \multirow{2}{*}{$\begin{array}{c}\text { Fuel } \\
\text { Quantity } \\
\text { Avoided } \\
\text { (liters) }\end{array}$} & \multirow{2}{*}{$\begin{array}{c}\text { Fuel } \\
\text { Quantity } \\
\text { Avoided } \\
\text { (gallons) }\end{array}$} & \multicolumn{7}{|c|}{ Fuel Price (USD/gallon) } & \multirow{2}{*}{$\begin{array}{c}\text { Turbine } \\
\text { Hub } \\
\text { Height } \\
\text { (m) }\end{array}$} \\
\hline & & & & $\$ 1.75$ & $\$ 2.00$ & $\$ 2.25$ & $\$ 2.50$ & $\$ 2.75$ & $\$ 3.00$ & $\$ 3.25$ & \\
\hline \multicolumn{12}{|c|}{ Entegrity eW-15 } \\
\hline & 99,860 & 28,001 & 7,397 & $\$ 12,945$ & $\$ 14,794$ & $\$ 16,643$ & $\$ 18,493$ & $\$ 20,342$ & $\$ 22,191$ & $\$ 24,040$ & 25 \\
\hline & 107,107 & 30,033 & 7,934 & $\$ 13,884$ & $\$ 15,868$ & $\$ 17,851$ & $\$ 19,835$ & $\$ 21,818$ & $\$ 23,802$ & $\$ 25,785$ & 31 \\
\hline \multicolumn{12}{|c|}{ NPS NW100/19 } \\
\hline & 138,543 & 38,848 & 10,262 & $\$ 17,959$ & $\$ 20,525$ & $\$ 23,091$ & $\$ 25,656$ & $\$ 28,222$ & $\$ 30,787$ & $\$ 33,353$ & 25 \\
\hline & 150,284 & 42,140 & 11,132 & $\$ 19,481$ & $\$ 22,264$ & $\$ 25,047$ & $\$ 27,830$ & $\$ 30,613$ & $\$ 33,396$ & $\$ 36,179$ & 32 \\
\hline \multicolumn{12}{|c|}{ NPS NW100/20 } \\
\hline & 146,930 & 41,199 & 10,884 & $\$ 19,046$ & $\$ 21,767$ & $\$ 24,488$ & $\$ 27,209$ & $\$ 29,930$ & $\$ 32,651$ & $\$ 35,372$ & 25 \\
\hline & 159,331 & 44,676 & 11,802 & $\$ 20,654$ & $\$ 23,605$ & $\$ 26,555$ & $\$ 29,506$ & $\$ 32,456$ & $\$ 35,407$ & $\$ 38,357$ & 32 \\
\hline \multicolumn{12}{|c|}{ Fuhrländer FL100 } \\
\hline & 225,837 & 63,325 & 16,729 & $\$ 29,275$ & $\$ 33,457$ & $\$ 37,640$ & $\$ 41,822$ & $\$ 46,004$ & $\$ 50,186$ & $\$ 54,368$ & 35 \\
\hline \multicolumn{12}{|c|}{ Fuhrländer FL250 } \\
\hline & 499,245 & 139,988 & 36,981 & $\$ 64,717$ & $\$ 73,962$ & $\$ 83,208$ & $\$ 92,453$ & $\$ 101,698$ & $\$ 110,943$ & $\$ 120,189$ & 42 \\
\hline \multicolumn{12}{|c|}{ Vestas V27 } \\
\hline & 406,639 & 114,022 & 30,121 & $\$ 52,712$ & $\$ 60,243$ & $\$ 67,773$ & $\$ 75,304$ & $\$ 82,834$ & $\$ 90,364$ & $\$ 97,895$ & 32 \\
\hline & 447,440 & 125,462 & 33,144 & $\$ 58,001$ & $\$ 66,287$ & $\$ 74,573$ & $\$ 82,859$ & $\$ 91,145$ & $\$ 99,431$ & $\$ 107,717$ & 42 \\
\hline
\end{tabular}

Notes:

1. Togiak electrical energy production efficiency assumed to be $13.5 \mathrm{~kW}$-hr/gal or $3.57 \mathrm{~kW}$-hr/L (AVEC data)

2. Assumes $90 \%$ wind turbine availability with no diversion of power to a thermal or other dump load

3. Assumes linear diesel generator fuel efficiency (i.e., 1:1 tradeoff of wind turbine kW-hr to diesel genset kW-hr)

4. Calculated for the data period 9/11/04 to 7/12/06 
Togiak, Alaska Wind Resource Report

Select Turbine Performance Annual Output Data

\begin{tabular}{|c|c|c|c|c|c|c|c|c|c|c|c|c|}
\hline \multirow[b]{2}{*}{ Month } & \multicolumn{6}{|c|}{ NPS NW100/20 turbine at $32 \mathrm{~m}$ hub height } & \multicolumn{6}{|c|}{ Vestas V27 turbine at $32 \mathrm{~m}$ hub height } \\
\hline & $\begin{array}{l}\text { Hub } \\
\text { Height } \\
\text { Wind } \\
\text { Speed } \\
(\mathrm{m} / \mathrm{s})\end{array}$ & $\begin{array}{c}\text { Time At } \\
\text { Zero } \\
\text { Output } \\
(\%)\end{array}$ & $\begin{array}{c}\text { Time At } \\
\text { Rated } \\
\text { Output } \\
(\%)\end{array}$ & $\begin{array}{c}\text { Average } \\
\text { Power } \\
\text { Output } \\
\text { (kW) }\end{array}$ & $\begin{array}{c}\text { Average } \\
\text { Energy } \\
\text { Output } \\
\text { (kWh) }\end{array}$ & $\begin{array}{c}\text { Average } \\
\text { Capacity } \\
\text { Factor } \\
(\%)\end{array}$ & $\begin{array}{l}\text { Hub } \\
\text { Height } \\
\text { Wind } \\
\text { Speed } \\
(\mathrm{m} / \mathrm{s})\end{array}$ & $\begin{array}{c}\text { Time At } \\
\text { Zero } \\
\text { Output } \\
(\%)\end{array}$ & $\begin{array}{c}\text { Time At } \\
\text { Rated } \\
\text { Output } \\
(\%)\end{array}$ & $\begin{array}{c}\text { Average } \\
\text { Power } \\
\text { Output } \\
(\mathrm{kW})\end{array}$ & $\begin{array}{c}\text { Average } \\
\text { Energy } \\
\text { Output } \\
\text { (kWh) }\end{array}$ & $\begin{array}{c}\text { Average } \\
\text { Capacity } \\
\text { Factor } \\
(\%)\end{array}$ \\
\hline Jan & 5.40 & 34.1 & 0.9 & 17.3 & 12,843 & 17.3 & 5.40 & 15.7 & 0.3 & 45.0 & 33,503 & 20.0 \\
\hline Feb & 7.20 & 25.0 & 6.7 & 32.5 & 21,845 & 32.5 & 7.20 & 11.7 & 5.7 & 79.6 & 53,524 & 35.4 \\
\hline Mar & 6.44 & 27.3 & 4.1 & 27.1 & 20,157 & 27.1 & 6.44 & 13.9 & 2.0 & 67.4 & 50,145 & 30.0 \\
\hline Apr & 6.21 & 29.5 & 3.5 & 24.2 & 17,445 & 24.2 & 6.21 & 14.7 & 2.7 & 60.5 & 43,577 & 26.9 \\
\hline May & 5.18 & 34.5 & 0.6 & 14.4 & 10,730 & 14.4 & 5.18 & 17.4 & 0.4 & 38.1 & 28,354 & 16.9 \\
\hline Jun & 4.81 & 41.0 & 0.3 & 12.1 & 8,704 & 12.1 & 4.81 & 22.1 & 0.2 & 32.3 & 23,279 & 14.4 \\
\hline Jul & 4.67 & 42.1 & 0.0 & 10.6 & 7,856 & 10.6 & 4.67 & 22.5 & 0.0 & 28.6 & 21,267 & 12.7 \\
\hline Aug & 5.02 & 40.3 & 0.5 & 14.0 & 10,386 & 14.0 & 5.02 & 22.3 & 0.6 & 36.9 & 27,464 & 16.4 \\
\hline Sep & 6.07 & 27.8 & 0.6 & 21.8 & 15,710 & 21.8 & 6.07 & 12.4 & 0.4 & 56.4 & 40,638 & 25.1 \\
\hline Oct & 5.48 & 38.4 & 1.9 & 18.6 & 13,838 & 18.6 & 5.48 & 19.5 & 1.5 & 47.9 & 35,611 & 21.3 \\
\hline Nov & 5.68 & 37.1 & 2.5 & 21.8 & 15,679 & 21.8 & 5.68 & 19.8 & 1.4 & 55.1 & 39,682 & 24.5 \\
\hline Dec & 6.29 & 23.3 & 2.0 & 23.9 & 17,773 & 23.9 & 6.29 & 9.9 & 0.9 & 60.9 & 45,304 & 27.1 \\
\hline Overall & 5.74 & 33.0 & 2.1 & 20.2 & 177,034 & 20.2 & 5.74 & 16.6 & 1.4 & 51.6 & 451,821 & 22.9 \\
\hline
\end{tabular}

Notes:

1. Assumes $\underline{100 \%}$ turbine availability

2. Calculated for data period $9 / 11 / 04$ to $7 / 12 / 06$ 
Togiak, Alaska Wind Resource Report

Temperature Conversion Chart ${ }^{\circ} \mathrm{C}$ to ${ }^{\circ} \mathrm{F}$

\begin{tabular}{|c|c|c|c|c|c|}
\hline${ }^{\circ} \mathrm{C}$ & ${ }^{\circ} \mathrm{F}$ & ${ }^{\circ} \mathrm{C}$ & ${ }^{\circ} \mathrm{F}$ & ${ }^{\circ} \mathrm{C}$ & ${ }^{\circ} \mathrm{F}$ \\
\hline-40 & -40.0 & -10 & 14.0 & 20 & 68.0 \\
\hline-39 & -38.2 & -9 & 15.8 & 21 & 69.8 \\
\hline-38 & -36.4 & -8 & 17.6 & 22 & 71.6 \\
\hline-37 & -34.6 & -7 & 19.4 & 23 & 73.4 \\
\hline-36 & -32.8 & -6 & 21.2 & 24 & 75.2 \\
\hline-35 & -31.0 & -5 & 23.0 & 25 & 77.0 \\
\hline-34 & 29.2 & -4 & 24.8 & 26 & 78.8 \\
\hline-33 & -27.4 & -3 & 26.6 & 27 & 80.6 \\
\hline-32 & -25.6 & -2 & 28.4 & 28 & 82.4 \\
\hline-31 & -23.8 & -1 & 30.2 & 29 & 84.2 \\
\hline-30 & -22.0 & 0 & 32.0 & 30 & 86.0 \\
\hline-29 & -20.2 & 1 & 33.8 & 31 & 87.8 \\
\hline-28 & -18.4 & 2 & 35.6 & 32 & 89.6 \\
\hline-27 & -16.6 & 3 & 37.4 & 33 & 91.4 \\
\hline-26 & -14.8 & 4 & 39.2 & 34 & 93.2 \\
\hline-25 & -13.0 & 5 & 41.0 & 35 & 95.0 \\
\hline-24 & -11.2 & 6 & 42.8 & 36 & 96.8 \\
\hline-23 & -9.4 & 7 & 44.6 & 37 & 98.6 \\
\hline-22 & -7.6 & 8 & 46.4 & 38 & 100.4 \\
\hline-21 & -5.8 & 9 & 48.2 & 39 & 102.2 \\
\hline-20 & -4.0 & 10 & 50.0 & 40 & 104.0 \\
\hline-19 & -2.2 & 11 & 51.8 & 41 & 105.8 \\
\hline-18 & -0.4 & 12 & 53.6 & 42 & 107.6 \\
\hline-17 & 1.4 & 13 & 55.4 & 43 & 109.4 \\
\hline-16 & 3.2 & 14 & 57.2 & 44 & 111.2 \\
\hline-15 & 5.0 & 15 & 59.0 & 45 & 113.0 \\
\hline-14 & 6.8 & 16 & 60.8 & 46 & 114.8 \\
\hline-13 & 8.6 & 17 & 62.6 & 47 & 116.6 \\
\hline-12 & 10.4 & 18 & 64.4 & 48 & 118.4 \\
\hline-11 & 12.2 & 19 & 66.2 & 49 & 120.2 \\
\hline
\end{tabular}


Togiak, Alaska Wind Resource Report

Wind Speed Conversion Chart, $\mathrm{m} / \mathrm{s}$ to $\mathrm{mph}$

\begin{tabular}{|c|c|c|c|c|c|c|c|c|c|}
\hline $\mathbf{m} / \mathbf{s}$ & $\mathbf{m p h}$ & $\mathbf{m} / \mathbf{s}$ & $\mathbf{m p h}$ & $\mathbf{~ m / s}$ & $\mathbf{m p h}$ & $\mathbf{~} / \mathbf{s}$ & $\mathbf{~ m p h}$ & $\mathbf{~} / \mathbf{s}$ & $\mathbf{m p h}$ \\
\hline 0.5 & 1.1 & 10.5 & 23.5 & 20.5 & 45.9 & 30.5 & 68.2 & 40.5 & 90.6 \\
\hline 1.0 & 2.2 & 11.0 & 24.6 & 21.0 & 47.0 & 31.0 & 69.3 & 41.0 & 91.7 \\
\hline 1.5 & 3.4 & 11.5 & 25.7 & 21.5 & 48.1 & 31.5 & 70.5 & 41.5 & 92.8 \\
\hline 2.0 & 4.5 & 12.0 & 26.8 & 22.0 & 49.2 & 32.0 & 71.6 & 42.0 & 93.9 \\
\hline 2.5 & 5.6 & 12.5 & 28.0 & 22.5 & 50.3 & 32.5 & 72.7 & 42.5 & 95.1 \\
\hline 3.0 & 6.7 & 13.0 & 29.1 & 23.0 & 51.4 & 33.0 & 73.8 & 43.0 & 96.2 \\
\hline 3.5 & 7.8 & 13.5 & 30.2 & 23.5 & 52.6 & 33.5 & 74.9 & 43.5 & 97.3 \\
\hline 4.0 & 8.9 & 14.0 & 31.3 & 24.0 & 53.7 & 34.0 & 76.1 & 44.0 & 98.4 \\
\hline 4.5 & 10.1 & 14.5 & 32.4 & 24.5 & 54.8 & 34.5 & 77.2 & 44.5 & 99.5 \\
\hline 5.0 & 11.2 & 15.0 & 33.6 & 25.0 & 55.9 & 35.0 & 78.3 & 45.0 & 100.7 \\
\hline 5.5 & 12.3 & 15.5 & 34.7 & 25.5 & 57.0 & 35.5 & 79.4 & 45.5 & 101.8 \\
\hline 6.0 & 13.4 & 16.0 & 35.8 & 26.0 & 58.2 & 36.0 & 80.5 & 46.0 & 102.9 \\
\hline 6.5 & 14.5 & 16.5 & 36.9 & 26.5 & 59.3 & 36.5 & 81.6 & 46.5 & 104.0 \\
\hline 7.0 & 15.7 & 17.0 & 38.0 & 27.0 & 60.4 & 37.0 & 82.8 & 47.0 & 105.1 \\
\hline 7.5 & 16.8 & 17.5 & 39.1 & 27.5 & 61.5 & 37.5 & 83.9 & 47.5 & 106.3 \\
\hline 8.0 & 17.9 & 18.0 & 40.3 & 28.0 & 62.6 & 38.0 & 85.0 & 48.0 & 107.4 \\
\hline 8.5 & 19.0 & 18.5 & 41.4 & 28.5 & 63.8 & 38.5 & 86.1 & 48.5 & 108.5 \\
\hline 9.0 & 20.1 & 19.0 & 42.5 & 29.0 & 64.9 & 39.0 & 87.2 & 49.0 & 109.6 \\
\hline 9.5 & 21.3 & 19.5 & 43.6 & 29.5 & 66.0 & 39.5 & 88.4 & 49.5 & 110.7 \\
\hline 10.0 & 22.4 & 20.0 & 44.7 & 30.0 & 67.1 & 40.0 & 89.5 & 50.0 & 111.8 \\
\hline
\end{tabular}

Distance Conversion $\mathrm{m}$ to $\mathrm{ft}$

\begin{tabular}{|c|c|c|c|}
\hline $\mathbf{m}$ & $\mathbf{f t}$ & $\mathbf{m}$ & $\mathbf{f t}$ \\
\hline 5 & 16 & 35 & 115 \\
\hline 10 & 33 & 40 & 131 \\
\hline 15 & 49 & 45 & 148 \\
\hline 20 & 66 & 50 & 164 \\
\hline 25 & 82 & 55 & 180 \\
\hline 30 & 98 & 60 & 197 \\
\hline
\end{tabular}


Selected definitions (courtesy of Windographer ${ }^{\circledR}$ software by Mistaya Engineering Inc.)

\section{Wind Power Class}

The wind power class is a number indicating the average energy content of the wind resource. Wind power classes are based on the average wind power density at 50 meters above ground, according to the following table. Source: Wind Energy Resource Atlas of the United States (http://rredc.nrel.gov/wind/pubs/atlas/tables/A-8T.html)

\begin{tabular}{|c|l|c|}
\hline \multicolumn{2}{|c|}{} & \multicolumn{2}{|c|}{} \\
\hline Wind Power Class & Description & Power Density at 50m (W/. $\mathbf{2})$ \\
\hline 1 & Poor & $0-200$ \\
\hline 2 & Marginal & $200-300$ \\
\hline 3 & Fair & $300-400$ \\
\hline 4 & Good & $400-500$ \\
\hline 5 & Excellent & $500-600$ \\
\hline 6 & Outstanding & $600-800$ \\
\hline 7 & Superb & $800-2000$ \\
\hline
\end{tabular}

Windographer classifies any wind resource with an average wind power density above 2000 $\mathrm{W} / \mathrm{m}^{2}$ as class 8 .

\section{Probability Distribution Function}

The probability distribution function $\mathrm{f}(\mathrm{x})$ gives the probability that a variable will take on the value $\mathrm{x}$. It is often expressed using a frequency histogram, which gives the frequency with which the variable falls within certain ranges or bins.

\section{Wind Turbine Power Regulation}

All wind turbines employ some method of limiting power output at high wind speeds to avoid damage to mechanical or electrical subsystems. Most wind turbines employ either stall control or pitch control to regulate power output.

A stall-controlled turbine typically has blades that are fixed in place, and are designed to experience aerodynamic stall at very high wind speeds. Aerodynamic stall dramatically reduces the torque produced by the blades, and therefore the power produced by the turbine.

On a pitch-controlled turbine, a controller adjusts the angle (pitch) of the blades to best match the wind speed. At very high wind speeds the controller increasingly feathers the blades out of the wind to limit the power output. 